\title{
THE POLITICAL \\ $\mathrm{F} \equiv$ ORY OF ENGLAND \\ TWELVE VOLUMES
}




\section{log 157 entes}

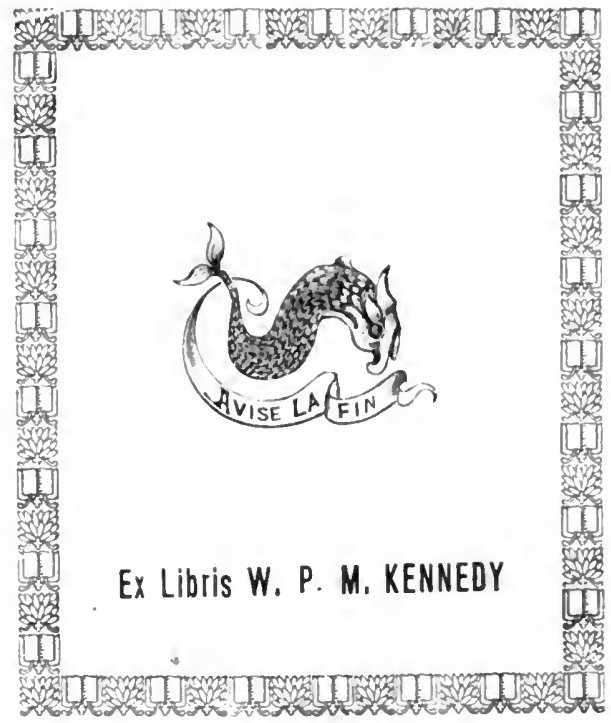


$+7 i^{n}$

to

\section{We}

C. We

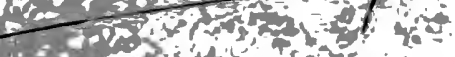
$x=32^{2} x^{2}+y^{2}$

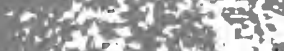

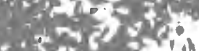

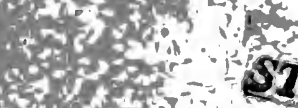

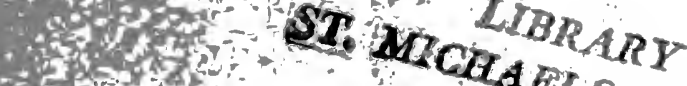

itsinis.

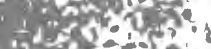

if

r.t.

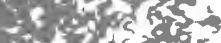

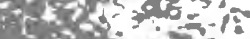

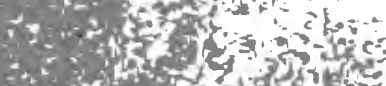

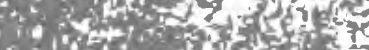

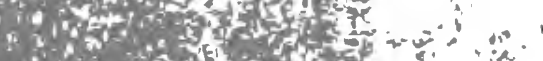

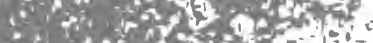

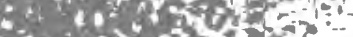

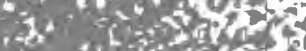

1 *t.

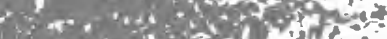

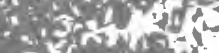

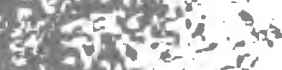

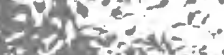

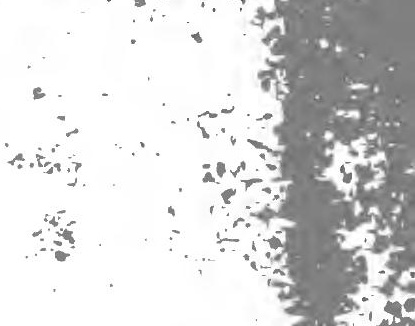

(N) 2 the

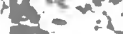
is: B. i. 5 . $=$ $7^{\circ} \rightarrow$ $\because$ 娄<smiles></smiles>

at

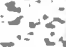
15 $\div \quad=$

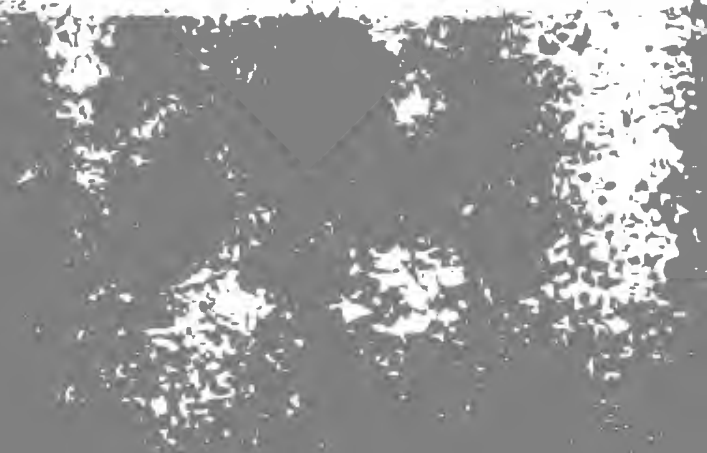





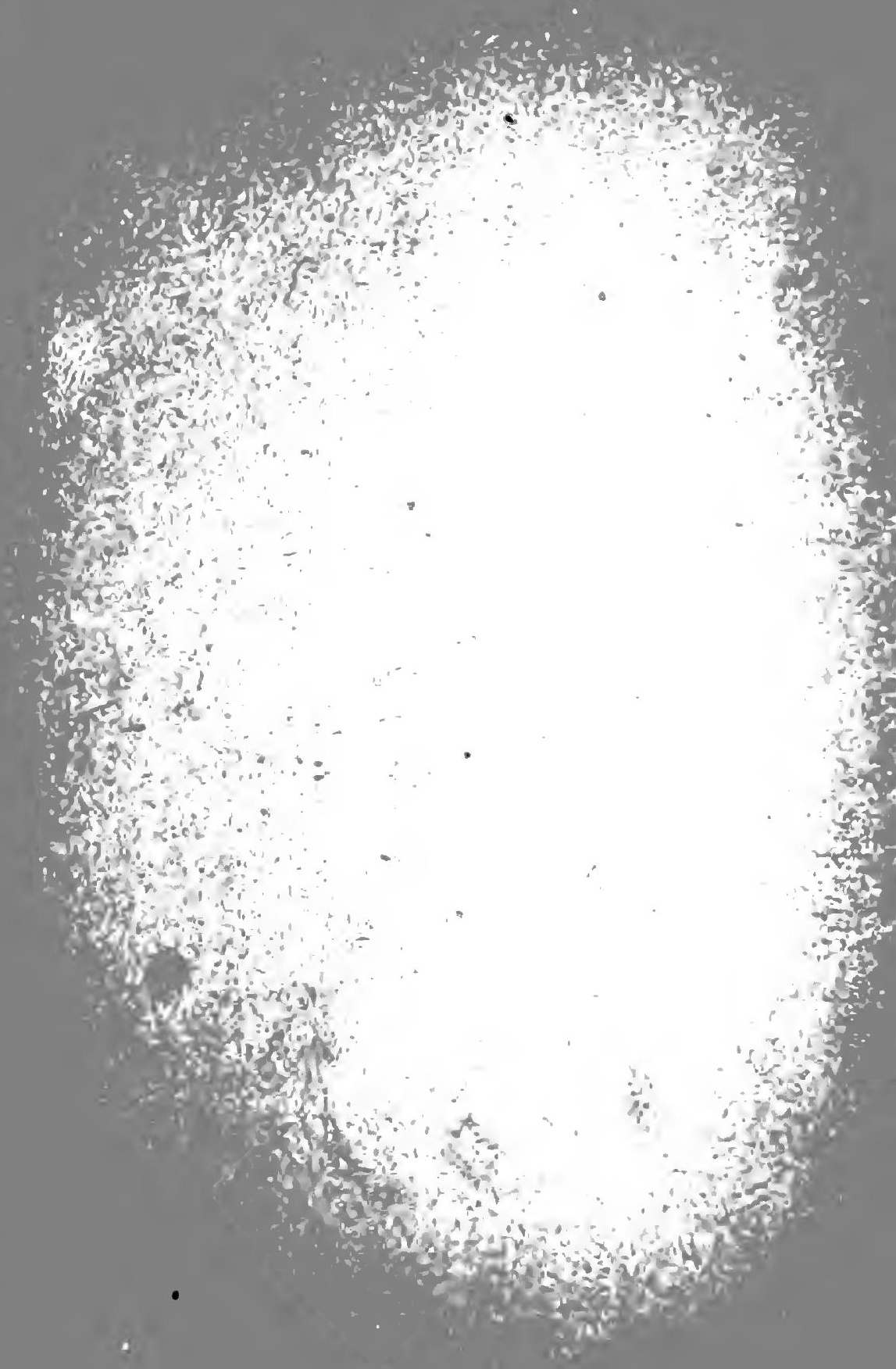




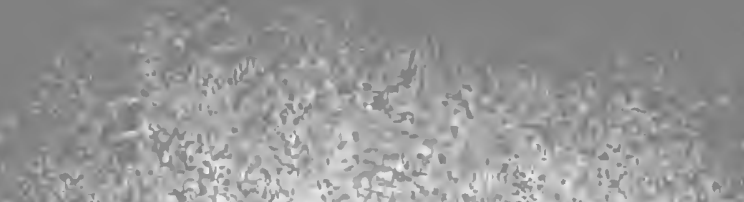

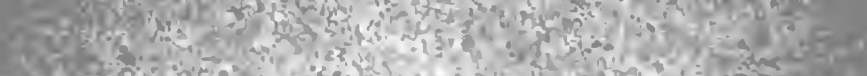

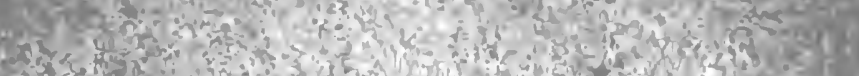

Asens

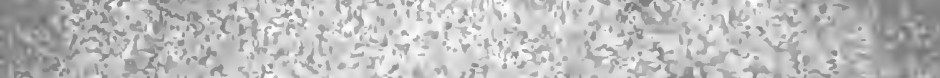

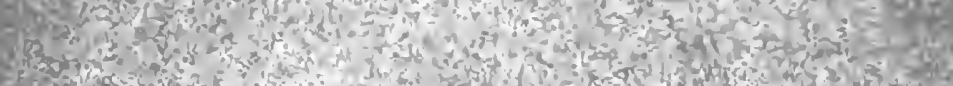

30 (n) Wat

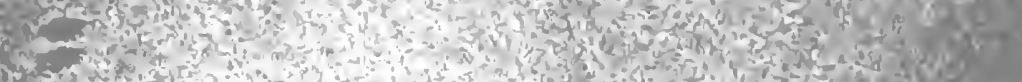
ont SNo cosisina

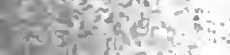
ads and

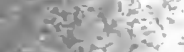
$-\frac{2}{4}$

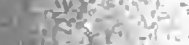
ats aif बैरूे and $20 x^{2}<$ covistoic tons onlite (1) (1) (n) $=$ $-7$

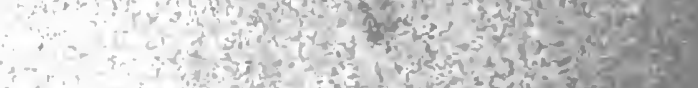
.

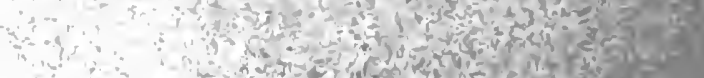

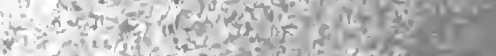




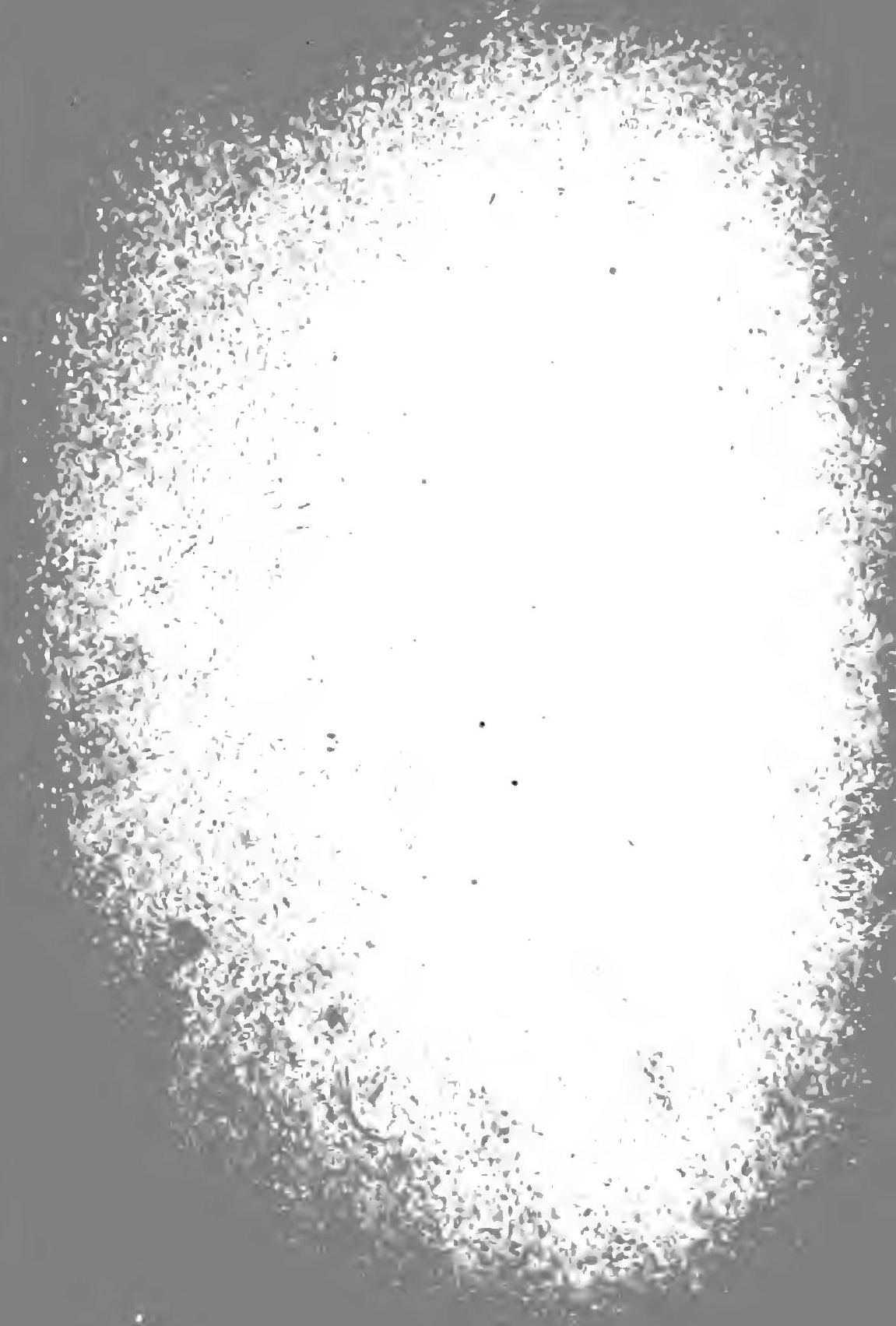



THE POLITICAL HISTORY OF ENGLAND.

Seventy-five years have passed since Lingard completed his History OF England, which ends with the Revolution of 1688 . During that period historical study has made a great advance. Year after year the mass of materials for a new History of England has increased; new lights have been thrown on events and characters, and old errors have been corrected. Many notable works have been written on various periods of our history; some of them at such length as to appial almost exclusively to professed historical students. It is believed that the time has come when the advance which has been made in the knowledge of English history as a whole should be laid before the public in a single work of fairly adequate size. Such a book should be founded on independent thought and research, but should at the same time be written with a full knowledge of the works of the best modern historians and with a desire to take advantage of their teaching wherever it appears sound.

The vast number of authorities, printed and in manuscript, on which a History of England should be based, if it is to represent the existing state of knowledge, renders co-operation almost necessary and certainly advisable. The History, of which this volume is an instalment, is an attempt to set forth in a readable form the results at present attained by research. It consists of twelve volumes by twelve different writers, each 
of them chosen as being specially capable of dealing with the period which he undertakes, and the editors, while leaving to cach author as free a hand as possible, hope to insure a general similarity in method of treatment, so that the twelve volumes may in their contents, as well as in their outward appearance, form one History.

As its title imports, this History will primarily deal with politics, with the History of England and, after the date of the union with Scotland, Great Britain, as a state or body politic; but as the life of a nation is complex, and its condition at any given time cannot be understood without taking into account the various forces acting upon it, notices of religious matters and of intellectual, social, and economic progress will also find place in these volumes. The footnotes are, so far as is possible, confined to references to authorities, and references are appended to statements which appear to be matters of common knowledge and do not call for support. Each volume contains an Appendix giving some account of the chief authorities, original and secondary, which the author has used. This account has been compiled with a view of helping students rather than of making long lists of books without any notes as to their contents or value. That the History will have faults both of its owen and such as will always in some measure attend co-operative work, must be expected, but no pains have been spared to make $i t$, so far as may be, not wholly unworthy of the greatness of its subject.

Each volume, while forming part of a complcte History, is also in itself a separate and complete book, is sold separately, and has its own index, and two or more maps. 
The History is divided as follows :-

Vol. I. From the Earliest Times to the NoRman Conquest (to 1066). By Thomas Hodgkin, D.C.L., Litt.D., Fellow of University College, London; Member of the British Academy. With 2 Maps.

Vol. II. From the Norman Conquest to the Death OF JoHN (I066-I216). By George Burton Adams, Professor of History in Yale University. With 2 Maps.

Vol. III. From the Accession of Henry III. TO the DEATH OF EDWARD III. (1216-1377). By T. F. Tout, M.A., Professor of Mediæval and Modern History in the University of Manchester. With 3 Maps.

Vol. IV. FROM THE ACCESSION OF RICHARD II. TO THE DEATH OF RICHARD III. (1377-1485). By C. Oman, M.A., Chichele Professor of Modern History in the University of Oxford; Member of the British Academy. With 3 Maps.

Vol. V. From the ACCESSION OF HENRY VII. TO THE DeAth OF HenRy VIII. (1485-1547). By H. A. L. Fisher, M.A., Fellow and Tutor of New College, Oxford. With 2 Maps.

Vol. VI. From the Accession of Edward VI. To the Death of Elizabeth (1547-1603). By A. F. Pollard, M.A., Fellow of All Souls' College, Oxford, and Professor of Constitutional History in University College, London. With Maps.

Vol. VII. From the ACCESSION OF JAMES I. TO THE Restoration (1603-1660). By F. C. Montague, M.A., Astor Professor of History in University College, London; formerly Fellow of Oriel College, Oxford. With 3 Maps. 
Vol. Vili. From the Restoration to the Death of WILlIAM III. (I660-1702). By Richard Lodge, M.A., Professor of History in the University of Edinburgh; formerly Fellow of Brasenose College, Oxford. With 2 Maps.

Vol. IX. From the AcCession of AnNe to the DeATH OF GEORGE II. (1702-1760). By I. S. Leadam, M.A., formerly Fellow of Brasenose College, Oxford. With Maps.

Vol. X. From the Accession of George III. to the Close of Pitt's First Administration (I 760-1 801). By the Rev. William Hunt, M.A., D.Litt., Trinity College, Oxford. With 3 Maps.

Vol. XI. From ADDington's Administration to the Close of William IV'S REIGN (I80r-1837). By the Hon. George C. Brodrick, D.C.L., late Warden of Merton College, Oxford, and J. K. Fotheringham, M.A., Magdalen College, Oxford ; Lecturer in Classical Literature at King's College, London. With 3 Maps.

Vol. XII. The ReIGn of QueEn Victoria (I837-IgOI). By Sidney Low, M.A., Balliol College, Oxford; formerly Lecturer on History at King's College, London, and Lloyd C. Sanders, B.A. With 3 Maps. 


\title{
The Dolitical Digtory of England
}

IN TWELVE VOLUMES

\author{
Edited by WILLIAM HUNT, D.LITt., AND \\ REGINALD L. POOLE, M.A., L.L.D.
}

IX.

THE HISTORY OF ENGLAND

FROM THE ACCESSION OF ANNE TO THE

DEATH OF GEORGE II.

$(1702-1760)$ 



\section{THE \\ HISTORY OF ENGLAND}

FROM THE ACCESSION OF ANNE TO THE

DEATH OF GEORGE II.

( I 702-1760)

BY

I. S. LEADAM, M.A.

PORYERLY YELLOW OF BRASENOSE COLLEOE, OXPORD

LONGMANS, GREEN, AND CO.

39 PATERnOSTER ROW, LONDON

NEW YORK, BOMBAY, AND CALCUTTA

1909 
$\theta$ 


\title{
CONTENTS.
}

\author{
CHAPTER 1.
}

The Grand Alliance.

$8 \mathrm{March}, 1702$. Accession of Anne . . . . . . . I

The queen's appearance and character . . . 2 .

April. Influence of the Earl of Rochester . . . . 3

May. Commercial interests and the war . . . . 5

June. The constituents of the grand alliance . . . 7 .

July-Nov. Marlborough's campaign in the Netherlands . . 9

July.Sept. Rooke's expedition against Cadiz . . . $\quad 12$

Oct. Rooke captures the Spanish treasure fleet . . . 14

July-Nov. Benbow's action, and death . . . . . 14

March-Sept., 1703. Marlborough's campaign in the Netherlands . . I5

Feb.-Oct. Operations of the French and Bavarians . . . 16

Nov. 8. Savoy joins the grand alliance . . . . 18

May-Nov. Naval operations . . . . . . . . 18-21

July-Oct. Feeling in Spain . . . . . . . 21

May. Portugal enters the grand alliance . . . $22 \cdot$

Dec. The Methuen treaty . . . . . . 23

\section{CHAPTER II.}

Home Politics.

July, 1702. Election of Anne's first parliament . . . . 25

12 Nov. Thanksgiving for victories of Marlborough, Ormonde,

and Rooke. . . . . . . . . 26

Feb., 1703. Inquiry into Rooke's conduct . . . . $\quad 27$

Dec., 1702. Tory attack on alien peers. . . . . . 29

March, 1703. Nottingham dismisses whig officials . $\quad \cdot \quad \cdot \quad \cdot \quad \cdot \quad 31$

Nov. Second occasional conformity bill ; the tack . . 37

Dec., 1703. The Scottish plot . . . . . . 38

March, 1704. The house of lords and the Aylesbury election . . 41

Harley and St. John. . . . . . . 42

CHAPTER III.

The War and Parties.

1704. The French plan of campaign . . . . . 48

Marlborough's plan of campaign . . . 49 
2 July. Marlborough storms the Schellenberg . . 52

13 Aug. The battle of Blenheim . . . . . . 54

6 Aug. Rooke captures Gibraltar . . . . . . 60

24 Aug. Rooke's action off Malaga . . . . . . 6r

May. The British and Dutch in Portugal . . . : 63

9 Nov. Admiral Sir John Leake relieves Gibraltar . . $\quad 64$

Dec. Parliament and the Aylesbury election . . . 67

5 April, 1705. Dissolution of Anne's first parliament : . . 67

25 Oct. Meeting of Anne's second parliament . . . 69

Nov. Parliament and the Electress Sophia . . . . 69

Ireland $. \quad . \quad . \quad . \quad . \quad$. 7 I

\section{CHAPTER IV.}

The Netherlands and the Peninsula.

17 July, 1705. Marlborough forces the French lines . . . . 76

Aug. Marlborough's difficulties with the Dutch generals . 77

Nov. Marlborough negotiates at Vienna . . . 79

May, 1706. Marlborough's victory at Ramillies . . . . 80

The "Barrier" . . . . . . . . 82

Friction between England and the Dutch . . . 84

June, 1705. The campaign of the British and Dutch in the Peninsula . . . . . . . . 85

The Earl of Peterborough . . . . . 86

Peterborough captures Barcelona . $\quad$. 87

May, 1706. Operations of Lord Galway in the west of Spain . 88

27 June. Galway occupies Madrid . . • • • 89

4 Aug. The allies evacuate Madrid . . . . . 9r

The Marquis de Guiscard . . . . . . 91

Rivalry of Rivers and Galway in Spain . . $\quad$. 92

\section{CHAPTER V.}

The Union with Scotland.

May, 1703. The Scots parliament .

June. The "Act of Security" and the "Act anent Peace and

$$
\text { War". }
$$

July, r704. The Scots parliament again passes the "Act of Security" . . . . . . . . 96

Dec. Retaliatory measures of the English parliament . 98

Oct., 1706. Agitation in Scotland against union . . . . 103

Jan., 1707. The Act of Union passed by the Scots parliament . 106

6 March. The English Act of Union receives the,royal assent . I07

March-May. Discontent in Scotland . . . . . . 107 


\section{CHAPTER VI.}

The Campalons of 1707 and 1708.

Feb., 1707. The allies in the east of Spain . . . PAOE

25 April. Berwick defeats Galway at Almanza . . . . 110

July. Prince Eugene and Admiral Shovell co-operate against

Toulon . . . . . . . - III

April. Marlborough's embassy to Charles XII. of Sweden - Ir3

May-Nov. Marlborough in the Netherlands . . . . II4

April, 1708. Plan of campaign . . . . . . . 115

II July. Marlborough's victory at Oudenarde . . . . I16

27 Sept. Webb's victory at Wynendaele . . . . . I18

Nov.-Dec. Mariborough's relief of Brussels and capture of Lille . 119

Sept. Stanhope captures Port Mahon . . . . . 12 I

\section{CHAPTER VII. \\ Godolphin AND HaRLEY. $\sqrt{ }$}

Aug., 1706. Friction Detween the queen and the Duchess of Marlborough . . . . . . . .

Dec. Displacement of tories from office; Sunderland secretary of state. . . . . . . . 124

The queen appoints two tory bishops . . . . 125

July, 1707. Growing influence of Mrs. Masham . . . . 126

23 Oct. Meeting of the first parliament of Great Britain . 127

Dec. The Earl of Peterborough and the peers . . . 129

Jan., 1708. Debate in the commons on the war in Spain . . 130

Nov., 1707. The treason of William Greg. . . . . . 131

$10 \mathrm{Feb}$., 1708. Resignation of Harley . . . . . . 133

March. Projected invasion of Scotland . . . . . 135

28 Oct. Death of Prince George of Denmark; ascendency of

the whigs . . . . . . . . . 139

May-July, 1709. Immigration of Protestant refugees . . . . I4I

\section{CHAPTER VIII.}

\section{The Barrler Treaty.}

March, 1709. Negotiation of the barrier treaty . . . . I46

28 May. The allies' preliminaries of peace . . . . 147

May. Renewal of the war in the Netherlands . . . 151

II Sept. Marlborough's victory at Malplaquet . . . . 153

May,1708-May,1709. The campaigns in Spain . . . . . 156

April, 1710. The campaigns in the Netherlands . . . . 158

June. Failure of the peace conferences at Gertruydenberg - 159

\section{CHAPTER IX.}

The IMPEACHMENT OF SACHEVERELL.

1709. Friction between Godolphin and the junta. . . 160

Jan., 1710. Friction between Marlborough and the queen . . 162

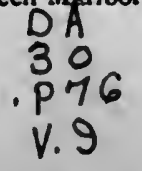


PAOE

The cabinet and Mrs. Masham . . . . . 163

April. Final rupture between the queen and the Duchess of

Marlborough . . . . . . . 163

5 Nov., 1709. Sacheverell's sermon at St. Paul's . . . . $16_{4}$

Dec. Impeachment of Sacheverell . . . . . 166

Feb., 17ro. Trial of Sacheverell . . . . . . . 167

13 June. Dismissal of Sunderland . . . . . . I7I

7 Aug. Dismissal of Godolphin . . . . . . 172

Sept. Harley forms a ministry . . . . . . I73

Oct. Secret negotiations with France. . . . . 175

Harley and the press; Swift . . . . $\quad$. 177

\section{CHAPTER X.}

\section{Harley's Ministry.}

17 Jan., I7II. The Duchess of Marlborough dismissed from office . 179

4 Jan. Lords' inquiry into the Peninsular campaigns . 179

The October club and the ministry . . . . 180

8 March. Harley stabbed by Guiscard . . . . 182

26 April. Harley created Earl of Oxford and Mortimer . . 183

May. Incorporation of the South Sea Company . . . I85

July. Matthew Prior negotiates peace at Paris . . . 186

27 Sept. Preliminaries of peace agreed upon . . . $\quad 187$

5 Aug. Marlborough penetrates the French lines . . 188

4 June. Departure of Sir Hovenden Walker's expedition against Quebec . . . . . . . 189

7 Dec. Defeat of the ministry in the lords . . . . 191

I7 Jan., I712. Robert Walpole sent to the Tower . . . . Ig2

31 Dec., 1711. Dismissal of Marlborough . . . . . . 192

Dec., I7II-Jan.,I712. Twelve tory peers created . . . . . . I93

\section{CHAPTER XI.}

\section{The Peace of Utrecht.}

29 Jan., I712. Opening of the conferences for peace at Utrecht . 196

April. Ormonde captain-general in the Netherlands . $\quad 197$

July. Ormonde proclaims an armistice with France . . 199

The tory ministry and Scottish affairs . . . 201

6 June. Announcement of the preliminaries of peace . 202

7 July. St. John created Viscount Bolingbroke . . . 202

II April, I713. Treaty of peace signed at Utrecht . . . . 205

r8 June. Defeat of Bolingbroke's proposed commercial treaty

with France. . . . . . . . 208

\section{CHAPTER XII.}

\section{The Succession in Danoer.}

3 Aug., I7r3. Dissolution of parliament . . . . . . 210

Intrigues of Bolingbroke . . . . . 211 
Bolingbroke's Irish policy . PACX

April, 1714. Dismissal of Argyll . . . . . . .

28 May. Death of the Electress Sophia . . . . . 217

The queen and the pretender . . . . . 217

Bolingbroke's schism bill . . . . . . 217

27 July. Dismissal of Oxford . . . . . . . 2 .9

I Aug. Death of the queen . . . . . . . 221

\section{CHAPTER XIII.}

\section{The Accrssion of George I.}

1712. Marlborough in retirement abroad . . . . 223

6 Aug., 1714. Marlborough nominated captain-general . . $\quad 224$

31 Aug. Dismissal of Bolingbroke . . . . . . 225

The new king . $\quad . \quad . \quad . \quad . \quad . \quad . \quad 226$

18 Sept. Arrival of George I. at Greenwich . . . . 228

Lord Townshend forms a ministry . . . . 229

General James Stanhope . . . . . . 229

The Hanoverian junta. . . . . . . 230

17 March, 1715. Meeting of a new parliament . . . . 233

28 March. Flight of Bolingbroke . . . . . . 235

June. Impeachment of late ministers . . . . . 236

\section{CHAPTER XIV.}

The ReBellion of 1715 .

1715. The pretender $. \quad . \quad . \quad . \quad . \quad . \quad 239$

Sept.,1714-Jan.,1715. The question of Dunkirk . • . . . . . 240

Jan., 1715. Stair's embassy to France . . . . . . 241

July. Bolingbroke takes service with the pretender $\quad$. 242

- Preparations against invasion . . . . . 243

20 July. Flight of Ormonde . . . . . . . 244

Marlborough and the pretender . . . . . 245

6 Sept. The Earl of Mar proclaims the pretender in Scotland . 246

14 Sept. The rebels occupy Perth . . . . . . 247

21 Sept. Arrest of tory members . . . . . 248

6 Oct. Rising of Forster in Northumberland. . . 250

I Nov. A party of Scottish rebels enters England . . . 252

13 Nov. Surrender of English and Scotish rebels at Preston . 254

13 Nov. Drawn battle at Sheriff Muir . . . . 256

\section{CHAPTER XV.}

The Pretrnder in Scotland. The Septennial Act.

22 Dec., 1715. The pretender lands at Peterhead . . . . 259

29 Jan., 1716. He retreats from Perth . . . . . . 260

4 Feb. He re-embarks for France. . . . . . 261

13/24 Feb. He dismisses Bolingbroke . . . . . . 263

Fate of the rebel prisoners . . . . . . 265 
24 Feb., 17r6. Execution of two rebel lords PAOE 28 Feb. Dismissal of Nottingham . . . . . . 267 7 May. The septennial act . . . . . . . . 267 7 July. George I. embarks for Hanover . . . . . 271

\section{CHAPTER XVI.}

The Quadruple Alliance, Spain, and Sweden.

6 Feb., 1716. Treaty of Westminster between Great Britain and the States-general . . . . . . Dec.,1715-May,1716. Bubb negotiates a new commercial and new Asiento treaty with Spain . . . . . . . 273

May, 1715. Admiral Sir John Norris commissioned to the Baltic . 274 18 Jan., 1717. George I. returns to London . . . . 275

29 Jan. Arrest of the Swedish ambassador, Count Gyllenborg. 275

2 April. Admiral Sir George Byng sails for the Baltic . 277

4 Jan., 1717. Triple alliance concluded between England, France, and Holland . . . . . . 278

15 Dec., 1716. Dismissal of Townshend . . . . . . 279

Io April, 1717. Resignation of Walpole . . . . . 279

22 July-2 Aug., 1718. Stanhope negotiates the quadruple alliance . . 280

I Aug. Sir George Byng destroys the Spanish fleet off Cape

Passaro . . . . . . . . 281

7 March, I719. Ormonde sails from Cadiz for England . . $\quad 283$

13 April. A Spanish force lands in Scotland . . . 284

ro June. General Wightman captures the Spanish troops at

Glen Shiel . $. \quad . \quad . \quad . \quad . \quad 284$

Feb., 1720. Spain accedes to the quadruple alliance . . . 285

14 Aug., 1719. Treaty between Great Britain, Prussia, and Hanover . 286

18 Aug. Treaty between Great Britain and Sweden . . 286

\section{CHAPTER XVII.}

Administration of Stanhope and Sundrrland.

I July, 1717. Acquittal of Oxford . . . . . . . 289

Nov. Quarrels between the king and the Prince of Wales . 289

1718. The ministry and the dissenters . . . . . $29 \mathrm{r}$

- Jan., I719. Stanhope carries a dissenters' relief bill . . . 29 I

The peerage bill . . . . . . . . 291

18 Dec. Defeat of the peerage bill in the commons . . 293

1720. The South Sea bubble . . . . . . 293

22 Jan., 1720. Aislabie introduces the South Sea bill . . . 293

7 April. South Sea act passed . . . . . . . 293

Io Jan., I721. Bill to punish the South Sea directors. . . . 299

Jan.-March. Parliamentary inquiries into the South Sea Company's affairs . . . . . . . 300

5 Feb. Death of Stanhope . . . . . . 300

Feb.-April. Townshend and Walpole again take office . . . 304 


\section{CHAPTER XVIII.}

\section{Admisistration of Townshend and Walpole.}

31 Dec., 1720. Birth of Charles Edward, the young pretender . . 305

1721. Jacobite intrigues . . . . . . . 305

24 Aug., 1722. Arrest of Bishop Atterbury. . . . . . 306

Plans of insurrection . . . . . . . 307

19 Oct., 1721. Announcement of Walpole's new commercial policy . 308

M2y, 1723. Return of Bolingbroke to England . . . . 309

Carteret . . . . . . . . . 309

13 June, 1721. Alliance between Great Britain, France, and Spain . 310

1723. Rivalry of Carteret and Townshend . . . . 3 so

Oct., 1723. The treaty with Prussia for a double marriage . . 311

1709-23. Affairs of Ireland . . . . . . . 312

1722-23. Wood's halfpence . . . . . . . 314

April, 1724. Swift's first "Drapier's Letter" . . . . . 317

1724. The Drapier's letters; agitation in Ireland . . . 317

Aug., 1725. The ministry yield . . . . . . . . . . 319

1725. Discontents in Scotland . . . . . . 319

\section{CHAPTER XIX.}

Treaties of Vienna and Hanover.

1720-21. Elisabeth Farnese, Queen of Spain . . . . 321

Dec., 1722. The Emperor Charles VI. incorporates the Ostend

East India Company . . . . . . 322

April-May, 1725. Treaty of Vienna between Spain and the emperor $\quad 323$

July, 1725. Spain demands the cession of Gibraltar . . . 323

3 Sept. Treaty of Hanover between Great Britain, France, and Prussia. $. \quad . \quad . \quad . \quad . \quad . \quad .324$

5 Nov. Second and secret treaty of Vienna . . . . 325

Aug., 1726. Russia adheres to the treaty of Vienna . . . 326

$26 \mathrm{March}, 1727$. Sweden adheres to the treaty of Hanover . . 326

12 Oct., 1726. Defection of Prussia from the treaty of Hanover . 327

Jan., 1727. England prepares for war . . . . . . 328

Feb. Spain besieges Gibraltar . . . . . . 330

31 May. Preliminaries of peace signed at Paris . . . 330

12 June. Death of George I. . . . . . . . . 332

CHAPTER XX.

Enoland, Spain, and Franck.

1727. Walpole retained in office . . . . . . 334

The opposition . . . . . . . . 335

6 March, N.S., 1728. The convention of the Pardo . . . . . 337

14 June. Congress of Soissons . . . . . . . 337

9 Nov., 1729. Treaty of Seville between Great Britain and Spain - $33^{8}$

16 March, 1731. Second (public) treaty of Vienna between Great

Britain, the emperor, and Holland . . $33^{8}$

1729-30. Growing friction between Great Britain and France • 339 


\section{CHAPTER XXI.}

The Excise Bile.

1725-29. Alienation between Walpole and Townshend . . 340

I5 May, 1730. Retirement of Townshend. . . . . . 34r

1728. Frederick, Prince of Wales, and the opposition . . 342

1729-32. Walpole's domestic policy . . . . . . 342

1733. Walpole's scheme of tariff reform . . . 344

II April, I733. The excise bill dropped . $\quad . \quad$. $\quad . \quad$. 345

Walpole's new maxims of government . . $\quad 346$

Dismissals of leaders of the opposition . . 347

\section{CHAPTER XXII.}

\section{The Fall of Walpole.}

7 Nov., r733. Signature of the family compact between France and Spain

1729-43. Parliament and the liquor trade. 349

7 Sept., 1736. The Porteous riot at Edinburgh . . . . . 352

1736-37. Social reforms; smuggling and stage plays . 353

1736-39. Walpole and the dissenters. . . . . 353

27 April, 1736. Marriage of Frederick, Prince of Wales . . 355

20 Nov., 1737. Death of Queen Caroline; her character . . . 357

March, 1738. Inquiry into complaints against Spain; Jenkins's ear . 358

14 Jan., 1739, N.S. Convention of Madrid . . . . . . 360 William Pitt $. \quad . \quad . \quad . \quad . \quad . \quad .360$

9 March. Secession of the opposition from the house of commons . . . . . . . . . 36r

June. Preparations for war with Spain . . . . . $\quad .362$

23 Oct. Declaration of war with Spain . . . . . 363

21 Nov. Admiral Vernon takes Porto Bello . . . . 363

5 Feb., 1740. Admiral Wager introduces bill for recruiting the navy 365

Oct. Fleet under Sir Chaloner Ogle sails to reinforce Vernon . . . . . . . . 366

18 Sept. Commodore George Anson sails for the Pacific . $\quad 366$

20 Oct. Death of the emperor, Charles VI. . . . 366

Feb., 1741. Walpole defeats the opposition . . . . . 367

I Dec., 1741. Meeting of a new parliament . . . . . 368

I Feb., 1742. Resignation of Walpole . . . . . . 369

The new ministry $\quad . \quad+\quad . \quad+\quad . \quad . \quad .369$

1742. Inquiry into Walpole's conduct fruitless . . 370

\section{CHAPTER XXIII.}

\section{The Carteret administration.}

II June, 1742. Restoration of peace between Prussia and Austria by the treaty of Breslau . . . . . . 371

I Feb., 1742. Charles Emanuel of Sardinia joins Austria against

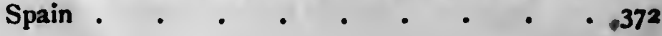


9 Aug. Commodore Martin's squadron threatens to bombard

PAOE

Naples. • • • • • • . 372

March. Lord Stair commander-in-chief of the British army in

the Netherlands . . . . . . . 372

Aug. The case of the Hanoverian troops . . . . 373

18 Nov. Treaty of Westminster with Prussia . . . . 374

27 June, 1743. Battle of Dettingen . . . . . . 374

Rivalry of Carteret and the Pelhams . . . . 377

Irritation of France against England . . . . 378

22 Feb., 1744. Action with French and Spanish fleets off Toulon . 379

Prince Charles Edward, the young pretender . . 380

Failure of French attempt at invasion . . . 381

4/15 March. France formally declares war . . . . . 381

June. Return of Commodore Anson with the Spanish

treasure . . . . . . . $\quad 382$

24 Nov. Resignation of Granville (Carteret) . . . . . 383

1745. William, Duke of Cumberland, captain-general in the

Netherlands. . . . . . . . 385

11 May. Battle of Fontenoy . . . . . . . 386

7 May. Alliance of Genoa with France and Spain . . . 389

27 June. Commodore Peter Warren captures Louisbourg. . 390

\section{CHAPTER XXIV.}

The Rebellion of 1745 .

19 Aug., 1745. Prince Charles Edward, the young pretender, appears

in arms

17 Sept. The Jacobite army occupies Edinburgh . . . 393

21 Sept. Jacobite victory at Preston Pans . . . . 394

Feeling in London . $\quad . \quad$. $\quad . \quad$. 395

Nov. The Jacobite army occupies Carlisle and Manchester. 396

4 Dec. Advance of the rebels to Derby . . . . . 398

20 Dec. Prince Charles recrosses the border . . . . 401

17 Jan., 1746. Defeat of General Hawley at Falkirk . . . 402

16 April. Cumberland's victory at Culloden . . . . 404

Trials and executions of rebel leaders . . . . 108

\section{CHAPTER XXV.}

\section{The Pelham administration.}

Feb., 1746. Attempted change of ministry ; victory of the Pelhams

Sept. Peace conference at Breda . . . . . . 413

2 July. Battle of Laffeldt . . . . . . . 414

3 May, 1747. Admiral Anson's victory off Cape Finisterre . : 415 The English and French in India . . . . 415

30 April, 1748. The peace of Aix-12-Chapelle . . . . . 416

1749. The prince's party . . . . . . . 419 Domestic policy of Pelham . . . . . 420 
3 Oct., 1750. Treaty of Madrid . . . . . . . 421

1751. Parliament and the liquor trade . . . . . 422

Reform of the calendar . . . . . . 423

20 March. Death of Frederick, Prince of Wales . . . . 424

1749-54. Friction between England and Ireland . . . 425

\section{CHAPTER XXVI.}

PitT.

1752. Disputes between Great Britain and Prussia . $\quad 427$

1753. Hardwicke's marriage act . . . . . 428

The naturalisation of the Jews . . . . 428

Domestic reforms . . . . . . 429

6 March, 1754. Death of Henry Pelham . . . . . . 430

1751. The struggle with France in India . . . . 431

1753-54. The struggle with France in North America . 432

9 July, 1755. Defeat of General Braddock . . . . 433

Nov., 1754. Pitt attacks Newcastle . . . • . . 435

7 June, 1755. Admiral Boscawen attacks a French fleet . . . 436

12 March, 1756. The militia bill . . . . . 437

I6 Jan., 1756. Convention of Westminster between Great Britain and Prussia. . . . . . . . 439

The state of the navy . . . . . . 44I

20 May. Admiral Byng engages the French fleet . . 443

28 June. Surrender of Fort St. Philip, Port Mahon . . . 443

Nov. Pitt forms a ministry . . . . . . 445

Pitt and the war. . . . . . . . 447

27 Jan., 1757. Byng condemned to death . . . . . . 449

14 March. Execution of Byng . . . . . . . 450

6 April. Dismissal of Pitt . . . . . . . 450

\section{CHAPTER XXVII.}

\section{DEFEAT AND Victory.}

20 June, 1756. The black hole of Calcutta . . . . . 452

8 Sept., 1757. Convention of Kloster-Zeven . . . . . 453

Retirement of Cumberland . . . . . . 454

June, 1758. Expedition against Cherbourg • . • . . 455

Aug. Dispatch of British troops to Germany . . . 456

27 July. Capture of Louisbourg . . . . . . 457

Supremacy of Pitt . . . . . . . 458

1759. Renewal by French of schemes of invasion . . 459

July-Aug. The British forces in Germany; battle of Minden . 460

Aug. Boscawen destroys the French fleet under De la Clue. 460 Conduct of Lord George Sackville . . . . 462

26 June. Siege of Quebec by Saunders and Wolfe . . . 463

13 Sept. Victory and death of Wolfe . . . . . 466 
Feb. 1760. A French force lands at Carrickfergus 4.469

Pitt rejects overtures from France

28 April. Defeat of General Murray before Quebec . . . 472

8 Sept. Montreal surrenders to Amherst . . . . 473

1756-57. Clive in India . . . . . . . . 473

23 June, 1757. Clive's victory at Plassey . . . . . . 474.

16 Peb., 1759. Admiral Pocock relieves Madras . . . . 475

22 Jan., 1760. Eyre Coote's victory at Wandewash . . . . 477

25 Oct. Death of George the Second . . . . . 477

\section{CHAPTER XXVIII.}

\section{Literature and Manners.}

Effects of the revolution upon literature . . . 479

Locke's philosophy and the inductive period of Newton 479

Systems affiliated to or opposed to Locke . . . 480

Locke's influence on theology; the Bangorian contro-

versy . . . . . . . . . 480

The Deists . . . . . . . . $48 \mathrm{I}$

Introduction of the historic method into theological

speculation . . . . . . . 482

Addison and literary style . . . . . . 482

Pope . . . . . . . . . . . 483

The mock-heroic; Swift . . . . . . 483

Ethical and didactic poetry . . . . . . 484

Translations; lyrical poetry; political ballads . . 485

Epigrams; hymns . . . . . . . 486

Political plays and satires; caricatures . . $\quad 487$

The drama and its censors . . . . . . 488

Opera; actors and actresses . . . . . . 489

Tales of adventure $. \quad . \quad . \quad . \quad . \quad . \quad .490$

Novels . . . . . . . . . 49I

Periodical essays; the coffee-houses . . . . 49 r

Newspapers . . . . . . . . 493

The position of authors $\quad$. $\quad . \quad$. $\quad . \quad$. 494

Letter-writing; the "grand tour" . . . . 495

Italian influence on taste; gardening . . . . 495

Painting . . . . . . . . . 496

Sculpture and architecture . . . . . 497

Scholarship and science . . . . . . 498

The episcopal bench and learning . . . . 499

Commerce and industry . . . . . . 500

Costume . . . . . . . . . . . 501

Criminals; the services; social habits . . . 502

\section{APPENDIX 1.}




\section{APPENDIX II.}

Administrations, $1702-1760$

\section{APPENDIX}

MAPS.

(At the ENd of the Volume.)

Plan of the Battle of Blenheim, August 13,1704 .

Plan of the Battle of Ramillies, May 23, 1706.

Plan of the Battle of Oudenarde, July II, 1708.

Plan of the Battle of Malplaquet, September II, I709.

Plan of the Battle of Dettingen, June 27, 1743.

Plan of the Battle of Fontenoy, May II, 1745.

Eastern and Central America, 1755.

India in the time of Queen Anne.

[Dates of events in England prior to January 1,1752 , are given in the Old Style, eleven days later than the New Style current in Scotland and on the Continent, except Russia; but the year is taken as beginning on January $i$, not on March 25. Dates of events abroad are given either in the New Style or else with the double figures of the Old and New Styles, as July 12/23 (p. 12).] 
CHAPTER I.

THE GRAND ALLIANCE.

ANNE ascended the throne with little schooling in politics CHAP. save that of the nature of backstairs intrigue. During the life of her sister there had been constant friction arising from the hostile attitude to the court of her favourite Lady Marlborough. When Mary died William had the good sense to recognise the impolicy of maintaining an estrangement with the principal personage in the realm after himself. Yet the reconciliation was little more than formal. The king was himself too jealous of power to share even the semblance of it with another, and so far was he from affording Anne an opportunity of education in public policy that no communications were made to her by ministers of the course of affairs. It was enough for her that her favourite's husband, the Earl of Marlborough, whose military talent he appreciated, but whose tortuous politics he had reason to distrust, held the highest commands. A princess of intellectual force, whose succession was assured, could not have submitted to this exclusion from influence. It was assisted by the divided sympathies of the circle of which she was the centre. Lord Godolphin, her friend from early years, was of the party to which the name of tory was beginning to be applied. Marlborough's predilections were in the same direction, but his wife, who outside military affairs exercised an absolute power over him, was steeped in whig principles.

Anne's little court, therefore, while a rendezvous for all who harboured personal discontents, never became a centre of political opposition. It was known, indeed, that her sympathies favoured the tories, but this was not a proof of identity of VOL. IX. 
CHAP. political principle. She generally applied to the tories the

I. name of the Church party, and her ecclesiastical prepossessions formed the link between them. Nevertheless she could not shut her eyes to the fact that the more extreme among the tories would have displaced her for her half-brother, and she was keenly appreciative of the dignity of sovereignty. She was aware that a far greater number were secretly hostile to the acts of succession, and her attachment to the Church was stronger than the tie of blood, as to which she affected incredulity. Her speech to the privy council upon the day of King William's death and her first speech as queen both insisted upon her political detachment, and were at least in part inspired, as a letter of her own tells us, ${ }^{1}$ by whig politicians.

Anne's physical characteristics have been handed down to us by the brush of Kneller. Her face was heavy but not unpleasing, her forehead good, her lower jaw large and sensuous. However facile to her female favourites, she had in matters of state a strong sense of the homage due to her. It was their failure to render this homage which she alleged as her reason for the dismissal of Sunderland and Harley, and even her lifelong friend Godolphin. This feeling led her to resent intrusive criticism and encouraged her at last to throw off the dominance of the Duchess of Marlborough. If considerations of state compelled her tolerance of statesmen distasteful to her, she concealed, though she seldom conquered, her antipathy. As, however, she detested scenes, she was content to await her chance of release. She was popular for the same reason that George III. was popular, as the embodiment of the homely virtues.

By a statute of $1696^{2}$ it was provided that the parliament in existence at the king's death should assemble forthwith and continue for six months. The two houses accordingly met on the third day after the king's death, Wednesday, March II, I 702. Anne went to the house of lords in state and delivered a speech in which she affirmed her intention to stand by the allies and "to reduce the exorbitant power of France". Such a declaration was imperative to check the dismay with which the news of the king's death had been

1 Hist. MSS. Comm., 8th Rep., I88x, App., p. 53.

${ }^{2} 7 \& 8$ W. III., c. 15 . 
received at Vienna and the Hague. Her first public ap- CHAP. pearance as queen was more than a succes destime. She had, at the desire of Charles II., taken lessons in elocution from the actress Mrs. Barry. She possessed, records Burnet. "softness of voice and sweetness in the pronunciation". "I have heard," says Oldmixon, "the queen speak from the throne. I never saw an audience more affected : it was a sort of charm." Her natural bashfulness covered her with blushes, and the jest ran round the coffee-houses that she was like the sign of the Rose and Crown.

Acting doubtless on the advice of the Marlboroughs, the queen, within two days of her accession, dispatched circular letters to foreign powers affirming her resolution "to maintain the alliances against France". Marlborough himself was accredited with the same assurances to the States-general. Anne had assuredly no idea of surrounding herself with purely party advisers. The necessities of foreign policy might well justify a hope on the part of the whigs of enjoying a controlling voice in her councils. The Duke of Devonshire was appointed lord steward, and a number of other whigs continued in their posts. The nominations of Godolphin as lord treasurer, and of the Earl of Marlborough as captain-general, were followed by promises of support by the whig leaders; for Godolphin was notoriously an opportunist, whose party feeling was of the most lukewarm description, and Marlborough was universally recognised as the most competent person for military command. But although Marlborough's mission to Holland lasted only a few days, in that short interval another influence began to make itself felt.

Laurence Hyde, Earl of Rochester, the younger son of the Lord Chancellor Clarendon, uncle of the queen, and the lordlieutenant of Ireland, was at this time in London. He had been an agent of the tyrannies of James II., and was in disposition the counterpart of that king. To the whig pamphleteers he was the type of mischievous. bigotry. He seized the occasion of Marlborough's absence to engross the queen's ear. The effect of his counsels was first made apparent in a number of court appointments announced on April 14. Among these the most obnoxious to the whigs was that of Sir Edward Seymour to the post of comptroller of the household. He 
CHAP. was now sworn of the privy council, and with him, as privy seal,

I. John Sheffield, Marquis of Normanby, next year created Duke of Buckinghamshire, but generally known by the title of Buckingham. The Earls of Nottingham and Jersey and a group of politicians who, in the words of the Duchess of Marlborough, "had all a wonderful zeal for the Church," also received nominations. Nor was this enough. Two leading whig statesmen were not ordered to be sworn on the new privy council: Somers, who represented in the eyes of Rochester, still a Jacobite at heart, the hateful principles of the revolution; and Halifax, who in the previous year had been impeached by the house of commons. Sir Charles Hedges, a dependant of Rochester, was associated with the Earl of Manchester as secretary of state, and a fortnight later the earl was displaced by Nottingham. Nottingham was scarcely the man to whom to entrust the fortunes of continental campaigns. He had, it is true, some culture, but his disposition was towards a narrow clericalism and his temper so gloomy that he went by the nickname of "Dismal". In the council he supported Rochester's inclination for peace. On the side of an energetic prosecution of the war on the continent stood Marlborough and Godolphin, supported by the whigs in council and by the whig majority in the house of lords.

The queen's coronation took place on St. George's day, April 23, Dr. John Sharp, Archbishop of York, who had ousted Tenison as principal clerical adviser, being selected by her as preacher. The ceremony was marked by the introduction of the declaration against transubstantiation, framed with the intention of excluding Roman catholics from the throne, and of a new coronation oath which, instead of expressing a general adhesion to ancient laws and institutions, specifically pledged the sovereign to observe parliamentary statutes and to maintain the "protestant reformed religion established by law". The remaining life of parliament was chiefly spent in a series of duels between the two parties in the house of lords, for which the pamphleteers of the day furnished occasion. The whig majority carried orders for the prosecution of pamphlets, written in the tory interest, suggesting designs on the part of the whigs against the queen's accession. They also avenged themselves on the Church party 
for the recent court appointments by ordering to be burnt by the hangman a sermon preached by Dr. William Binckes, CHAP. proctor for the diocese of Lichfield, before the lower house of convocation on January 30, 170I, the anniversary of the execution of Charles I., in which there was a comparison, declared by their resolution to have given "just scandal and offence to all Christian people," between Charles and the founder of the Christian religion. A favourite whig project emerged from royal speeches into an act of parliament empowering the queen to appoint commissioners to treat with Scotland for a union. On the other hand, the tories were gratified by an act for the examination of the public accounts, out of which they hoped to extract matter incriminating of peculation the whig financiers of the late reign.

But in this expiring parliament the most momentous incident was the declaration of war against France and Spain on May 4. Apart from the obligations entailed by William III., statesmen were confronted with the dangers of both a naval and military supremacy, and the consequences to the trade of the country were plain enough. France under Colbert had become closed against English goods, and English ships visited French ports frequently in ballast. Spain had hitherto remained comparatively open. England and Holland competed with France in supplying her with industrial products, the tariff being in some particulars favourable to the two maritime powers. In accordance with the prevalent economic theory, they believed their trade to be all the more profitable in that Spanish exports were inferior in value, and the differences were consequently met by exports of the precious metals of which the plethora was ruining Spain.

Nor. was the Spanish market the sole concern of the maritime powers. Spain shared to the full the superstition of the colonial system. The colonial ports of Spain were closed to the traders of other nations, though between the Dutch and English West India settlements on the one hand and the Spanish mainland on the other there existed a vigorous system of smuggling which the Spanish navy in its decay was unable to suppress. Both the English and Dutch settlements were productive communities. They furnished the north of Europe with sugar, and had everything to fear from a loss of naval 
CHAP. supremacy by the maritime powers. On the mainland, EngI. lish colonists raised in Virginia and Carolina the tobacco they exported to Europe. New England was already alarmed at the progress of the French arms in Canada. The English government was anxious for the control of the mouth of the St. Lawrence and the safety of its fishing settlements. It was evident to the maritime powers that the supremacy of the united French and Spanish navies would rob them of their most profitable sources of wealth, as well in the New World as in the Mediterranean. Already the French had established control of Spanish politics. French mercantilism, enforced by the joint action of Spain with France, threatening Dutch and English trade at all points, was a menace to their very existence as European powers of the first rank. The queen's speech (May 4, O.S.), announcing the declaration of war, sought to enlist the sympathies of the moneyed interest by insisting upon the commercial importance of the issues. It added the grievance of Louis XIV.'s recognition of the pretender's title to the throne.

While Louis had been prompt to discern that the peace party among the Dutch would demand a reconsideration of the obligations subsisting at William's death, the assurances of Marlborough, whose talents as a diplomatist matched his military skill, served to confirm the general disposition to adhere to the Orange policy of the Grand Alliance. At the helm of foreign affairs was the Grand Pensionary Heinsius. Heinsius had been Dutch ambassador to France, and, formerly . in opposition, had of late supported William III. Heinsius and Marlborough, both William's political pupils, were at one in the view that war was inevitable, and that it was to be prosecuted with energy. Of the two, the horizon within the vision of Heinsius was the more contracted. His absorbing object was the security of his country from invasion. Its traditional safeguard was the occupation by Dutch troops of the imperial fortresses of the Flemish and Belgian frontiers, commonly known as "The Barrier".

The queen's declaration of war recited the "solemn treaties of alliance with the Emperor, the States-general of the United Provinces, and other princes and potentates". Upon the condition of the court of Vienna we have ample in- 
formation from the dispatches of our ambassador, George CHAP. Stepney, who enjoyed the credit of being the only Englishman I. of the period conversant with the ramifications of German politics. The Emperor (Leopold I.) was but the ghost of a great name. As an ally he could supply men, collected at great distances from the theatre of operations, but organisation, leadership, and capacity had long disappeared from the Austrian army. Such was the financial chaos that, in the words of the Venetian envoy, "the officials live without salary, the troops without bread, the workmen without pay".1 The position of the emperor was made worse by the outbreak in I70I of an insurrection in Hungary, provoked by infractions of the Hungarian constitution and by persecution of the protestants. A Hungarian revolt, headed by Francis Rakoczy, and aided by officers and money supplied by Louis XIV., threatened, in combination with the hostility of Bavaria, to strike the empire at the heart.

The numerous states forming the Germanic empire were torn with dissensions and animated only by common jealousy of the emperor. Their forces if united would have been overwhelming; the more considerable among them, such as the Elector of Bavaria or the King of Prussia, might well turn the scale. Prussia had lately emerged from insignificance under the leadership of Frederick William, the "Great Elector". In military strength it now took rank as the first of the secondary powers with a standing army of 43,000 men. There were, indeed, other suitors than the allies at the Prussian court. But Prussia wanted money, and neither Poland nor Sweden could furnish subsidies. The combination of feudal obligation and financial interest proved decisive. On December 30, I 70I, Frederick I. of Prussia had entered the Grand Alliance. Louis XIV.'s patronage of the pretender left Hanover no doubt as to its course. The majority of the other German princes supported the emperor. On the other side were the two brother princes of the house of Wittelsbach, the Electors of Cologne and Bavaria. Max Emanuel, Elector of Bavaria, was the most powerful of the southern German sovereigns. His jealousy of the emperor led him to support Louis XIV. as the

IVan Arneth, Oesterr. Oeschichts Quallon, xxii., "Relation des Daniel Dolfin vom Jahre 8708 ". 
CHAP. friend of the autonomy of the German states, and the French

I. king dangled before his eyes the prospect of an independent crown. In the extreme north the efforts of the French to organise a confederacy had been frustrated. Its centre was to have been the duchy of Brunswick - Wolfenbïttel, but on March 20, I702, a sudden surprise from Hanover compelled the reigning duke to range his forces with the emperor. The northernmost representative of the French interest was the Duke of Holstein-Gottorp, behind whom loomed the dreaded form of his brother-in-law, Charles XII. of Sweden, whose policy was as yet uncertain. The duke was kept in check by his rival, the King of Denmark, who offered to furnish the allies with troops.

The conventions entered into by William III. placed some 232,000 soldiers at the disposal of the Alliance. In the event of a declaration of war by the German diet this number was to be raised to 360,000 men. But no dependence could be placed on the emperor.' He promised I 30,650 men for the Austrian contingent of 1702 . All he could muster was some 40,000 men for Italy and about 20,000 for the Upper Rhine. The French standing army, on the other hand, was estimated at 205,300 men, of whom at least 130,000 could be brought into the field. To this must be added 25,000 men raised in the Spanish Netherlands, 8,000 Spanish troops in Milan, 1 5,000 auxiliaries from the Duke of Savoy, and 25,000 Bavarians under the elector, Max Emanuel. At the outbreak of the war in 1702 the troops at the disposal of France outnumbered the effective forces of the Grand Alliance by about 30,000 men. Of these the greater part, amounting to nearly 90,000 , were in the Netherlands. The French forces stretched from the sea to Bonn on the Rhine. Their most vulnerable points were the sea-coast on one side and the territory of the Elector of Cologne on the other. Brabant was covered by fortifications extending over a wide area; Ostend, Ghent, Bruges, and Mechlin were protected by lines of defence. With the exception of Maestricht, into which Ginkel, Earl of Ath-

IG. Stepney to the Emperor, April 18, 1703: "Il stato delle truppe che vostra Maesta pretendeva havere in Italia per l'imminente campagna; il qua stato parve a prima vista magnifico sopra il foglio ma," etc. Buccleuch (Montagu House) MSS., ii., 2, 655, Hist. MSS. Comm., 1903. 
lone had thrown 12,000 men, the fortresses on the Upper CHAP. Meuse were in French hands.

On July 2 Marlborough, who since the end of May had been at the Hague concerting a plan of campaign, joined the main army, then posted along the Waal between Nimeguen and Fort Schenck. His nomination to the chief command had not passed uncontested. The general sense was that he owed it not to his merits, but to diplomatic necessities. This feeling impaired his authority with the representatives of the Statesgeneral and encouraged a captious jealousy among his disappointed rivals, especially the King of Prussia and several of the Dutch generals. He was further hampered by the presence with the army of a number of Dutch " field-deputies," a body of inexpert civilians whose approval of his plans it was needful to obtain.

With Nimeguen as his headquarters Marlborough found himself at the head of 60,000 men. His intention had been to march into Brabant, but the Dutch generals refused to expose the Rhine and Nimeguen without authority from the States-general, and the States-general indorsed their view. Marlborough was therefore forced to resort to a compromise, and agreed to leave twenty squadrons of horse and eighteen battalions of foot to intrench themselves before Nimeguen. By a series of strategic marches he compelled the French to abandon the course of the Meuse. The river was lined with fortresses which impeded the navigation, injured the commercial interests of the Dutch and threatened their very doors. As the allies, whose military operations had chiefly consisted in sieges, were indisposed to accept Marlborough's advice and attack the enemy in the open field, it was agreed to undertake the siege of Venloo. An outlying fort defending Venloo was captured on September 18, N.S., by an intrepid assault led by Lord Cutts who, for the "joy of battle" that he shewed under fire, had earned the nickname of "the salamander". "But he lost the honour," says Burnet," "that was due to many brave actions of his, by talking too much of them." On the 23rd the town capitulated, the garrison marching out with the honours of war. Stephanswerth and Roermond on the Meuse fell in succession. Marlborough

'Hist. of His Own Time, ed. Oxford, 1833, bl., vii., vol. v., p. 31. 
CHAP. then "extorted the consent of the States" to the reduction of

I. Liege, which commanded the navigation of the Meuse above Maestricht. Liege fell the last week of October and the allies found themselves in possession of the fortresses of the Meuse from Huy to the sea.

With the capture of Liège Marlborough concluded a campaign, satisfactory enough to the Dutch, but falling far short of the programme he had designed and the opportunities he had been compelled to forgo. On November 3, accompanied by the Dutch field-deputies, he left Maestricht for the Hague, descending the Meuse in a boat with a guard of twenty-five men. A French guerrilla force seized the tow rope and captured the boat. The Dutch deputies had taken the precaution to furnish themselves with French passes. Marlborough was without one, but a servant named Gell, happening to have in his pocket a pass which had been granted to the earl's brother, General Churchill, who had left the army on sick furlough, slipped it into his hand. His captors were probably unable to read, and the earl's face being unknown to them, the party were suffered to proceed.

His return was welcomed by the Dutch with enthusiasm. Success had invested him with the moral authority lacking before. "The success of this campaign," the Earl of Athlone acknowledged, "is solely due to this incomparable chief, since I confess that I, serving as second in command, opposed in all circumstances his opinion and proposals." Public opinion at home indorsed this judgement. The queen offered Marlborough a dukedom. With characteristic caution his countess expressed a disinclination to accept the title "until we have a better estate". A promise from the queen to endow it with $£ 5,000$ a year from the post office during her life prevailed upon him to accept it. He was created Marquis of Blandford and Duke of Marlborough. But the general election of August had returned the tory party with a majority of two to one in the house of commons, and the tories were resolved upon retaliation for the inquiry into the conduct of their favourite, Admiral Sir George Rooke. Even an official like Sir Christopher Musgrave, clerk of the ordnance, ${ }^{1}$ and therefore Marlborough's

I This is not mentioned in his biography in Dict. Nat. Biog., but see Record Office, MS., State Papers, Anne, bundle I, no. 52, June 6, 1702. 
subordinate, denounced the proposed grant. The queen, at cHAP. Marlborough's instance, withdrew the message recommending it, and his wife even declined an offer of $£ 2,000$ a year, from the privy purse, though after her disgrace, nine years later, she claimed and received it as a grant actually made.

During the operations in the Netherlands the emperor had not been inactive. He entertained a strong desire to recover for the empire Alsace and the fortress of Landau which had been left in possession of France by the peace of Ryswick. Before Catinat and Villars could concert its relief Landau fell on September 9. The Elector of Bavaria, who had long amused the court of Vienna with futile negotiations, now threw off the mask. On the loth his troops suddenly occupied the imperial city of Ulm on the Danube. The princes of the empire at the diet of Regensburg thereupon declared war against France and her allies.

From the first threatening of hostilities the tories had favoured operations in the peninsula, in which the fleet would necessarily bear a large part, rather than a campaign in the Netherlands. ${ }^{1}$ The nearest base was Portugal, and Portugal was anxious to avoid participation in the quarrel. The English government was conscious that to coerce Portugal into co-operation against Spain would be useless unless a candidate could be found for the Spanish crown. Nevertheless the emperor, whose desires were set upon the acquisition of Naples, had turned a deaf ear to the proposal of Heinsius in the spring of 1702, though supported by the English government, that his second son, the Archduke Charles, should claim in person the crown of Spain. The emperor's dream was to restore in himself the empire of Charles V., acquiring Spain for himself and his eldest son. But Portugal had no notion of assisting to make its neighbour at Madrid the most formidable monarch in Europe. The negotiations with Vienna were protracted till the late autumn of 1702, and England and Holland had already undertaken an expedition to Cadiz, while the preliminary step of the selection of a rival to the French candidate for the throne of Spain was as yet unsettled.

1 Bonet, Jan. 25, 1701, Berlin State Archives, ap. Von Noorden, Ewropaische Geschichte (1870), i., 359. 
CHAP. During the winter of 1701-2 George, Prince of HesseI. Darmstadt, recently Viceroy of Catalonia, was the guest of William III. in London. Deposed by the government of Philip V. in February, 170I, he was accredited by the emperor to William III. as adviser upon the contemplated expedition to Spain. He maintained a correspondence with all the imperialist partisans in that country and generally inspired the allies in their Spanish policy. It was upon his recommendation that, shortly before William III.'s death, it was determined to undertake a joint sea and land expedition against Cadiz, the principal naval arsenal of Spain and the port of its transatlantic colonies. The fleet of the allies, which sailed from Spithead on July I $2 / 23,1702$, consisted of fifty of the line, thirty English and twenty Dutch, ten frigates, fifty transports, and other ships, nearly 200 in all, under Admiral Sir George Rooke. The Duke of Ormonde, a soldier of experience, commanded the troops, consisting of a handful of dragoons, 7,100 foot, 2,400 marines, and 300 engineers and gunners with twenty heavy guns, sixteen mortars, and ten field-pieces. ${ }^{1}$ There was also a Dutch contingent of 4,000 men. The instructions to Rooke were "to reduce and take the town and island of Cadiz," or if this were impracticable, "to proceed to Gibraltar or take on your way home Vigo, Ponte Vedra, Corunna or any other place belonging to Spain or France ". After the capture of Cadiz or Gibraltar he was to dispatch a squadron and 2,000 troops to the West Indies. The real object of the capture of Cadiz was to make it a naval base for operations against Toulon, whereby to obtain command of the Mediterranean. Cadiz was defended by nine regiments of foot, 1,000 horse, and a coast-guard of militia. In the harbour, which was obstructed by a chain boom, were seven French men-of-war and eight galleys. The defence was entrusted to a skilful soldier, the Marquis de Villadarias, who had already earned a reputation by his defence of Charleroi against the French in 1693.

On arriving before Cadiz, Ormonde was for landing the

1 "The Duke of Ormonde told me," writes Burnet, "he had not half the ammunition that was necessary for the taking Cadiz, if they had defended themselves well." This is to some extent corroborated by an official letter from the office of ordnance to Prince George of Denmark, lord high admiral, of June 6, 1702. See R.O., MS., State Papers, Anne, bundle I, no. 52. 
troops under cover of a bombardment by the fleet, and capturing the town by assault. Rooke insisted on the strength CHAP. of the garrison, and the inability of the fleet to render effective aid if it should come on to blow. He proposed instead the capture of Port St. Mary, slightly inland and on the other side of the bay, as well as the coast town of Rota, still more to the west, and the fort of Santa Catalina. The expedition against Cadiz thereupon degenerated into a predatory foray among sea-side villages. Soldiers and sailors plundered Port St. Mary, even robbing the churches, a pastime in which Lord Nugent's Irish " Rapparees," as they were called, specially distinguished themselves." Prince George, whose mission was to conciliate the Andalusians, ${ }^{2}$ dispatched a complaint to Vienna, implicating in this orgy of plunder Sir Henry Bellasis, second in command of the army. At the same time he addressed to Rooke, who was suffering from gout, and from the first had no heart in the expedition, a protest stating in plain terms that "the methods which have been taken hitherto seem not directed to do anything but to find out some pretence, after some unanswerable delays, to go with the first fair wind for England". Nevertheless, Rooke and the other admirals were unanimous in deciding against an attempt upon any other Spanish port, a proposal on which the military opinion was divided, Ormonde and both the Dutch generals recommending a fresh adventure. On September 9, N.S., the expedition sailed for England, Prince George in disgust retiring to Portugal.

In London the street ballads were already besmirching Rooke as an incapable coward. ${ }^{3}$ He owed the rescue of his naval reputation to a fortunate accident. On October 3 Captain Wishart, with a detachment of the fleet, put into Lagos to water, the admiral continuing his homeward course. At Lagos, Wishart heard a report of the arrival at Vigo of the French admiral, Château-Renault, conveying Spanish trea-

1 O'Nija to Ormonde, Lisbon, Oct. 23, 1702, Ormonde MSS., p. 766, Hist. MSS. Comm., 7th Rep., App.

He accompanied the expedition as representative of the emperor to receive such Spaniards as were disposed to declare themselves "as good subjects of the emperor, which might be of good example and influence other places too". Nottingham to Ormonde, June 25. O.S., 1702, ibid., p. 763.

Letter of Bonet, the Prussian Resident, November 21, 1902, Von Noorden, i., 304, n. 2. 
CHAP. sure galleons from the West Indies. At once sailing after

I. Rooke, on the 17 th Wishart overtook him with the intelligence. Rooke knew in July that the treasure ships were on the way. As a matter of fact, the admiralty had already sent him a dispatch, which had not yet reached him, ordering their interception. It had also commissioned Sir Clowdisley Shovell with a fleet, which had left England on October 4, to watch for them off the west coast of France. Rooke was ill and indisposed to attack, but the Dutch admiral, Van Almonde, insisted. On October $11-22$ the fleets came to anchor off Vigo Bay. Rooke being confined to his bed, the attack was in the hands of Vice-Admiral Hopsonn. The seventeen galleons within the harbour were protected by a boom, by two batteries of twenty and forty guns respectively, and by sixteen French and three Spanish ships of the line. The attack was begun on October 23 , N.S., by Ormonde, who, having landed in command of 2,500 troops, took the larger battery by assault. Hopsonn, in his ship, the Torbay, broke the boom, captured or destroyed almost the entire hostile fleets, and secured a booty to the value of about $£ 1,000,000$. The victory eclipsed the failure of Cadiz.

Simultaneously with the expedition to Cadiz, a squadron under Vice-Admiral Benbow was operating in the West Indies. His force consisted of seven ships, and on July I I, 1702, he sailed from Port Royal in Jamaica with the object of intercepting the French admiral Ducasse, who was conveying the Duke of Albuquerque, the new Spanish viceroy of Mexico, to his government. Benbow engaged in a running fight for six days; but four of his captains having given him very inadequate assistance and finally refusing further to support him, he was obliged to draw off, having lost a leg in the action. On his return to Jamaica he ordered the four captains to be tried by court-martial for cowardice, breach of orders, and neglect of duty. Two of them were condemned to death and were shot at Plymouth in the following April; the third was cashiered, the fourth died before trial. Benbow himself died on November 4, 1702, partly of his wounds, partly of disappointment in having been frustrated, as he declared, in the total destruction of the French squadron.

A treaty with the Dutch for the reinforcement of the army 
in the Netherlands by 11,000 men, including four regiments of СнAP. English infantry, having been signed on March 12, 1703, N.S., the enlistment of troops in Germany began forthwith. Boufflers had now been joined by the more enterprising Villeroy, but the instructions of the French commanders were to wage a defensive campaign upon the Lower Rhine. The main action of the French was reserved for the Upper Rhine. Boufflers and Villeroy, therefore, with no more than 37,000 men, intrenched themselves behind the Mehaigne. Antwerp and Bruges were covered by two corps, together 10,000 men, under the Spanish general, the Marquis Bedmar and Count de la Mothe. Marlborough opened his second campaign with a heavy heart, for on February 20 he had lost his only surviving son, Lord Blandford. He outnumbered the French by 30,000 men, and his desire was to attack the French army in the field. The Dutch adhered to their creed that the object of war was the capture of fortresses.

It was apparent to Marlborough that some more energetic action must be taken against the French than a mere succession of sieges in the Netherlands. During some months the emperor had been making urgent representations to the English government that the French army of the Upper Rhine and the Elector of Bavaria were meditating a campaign which should end in Vienna itself. But the nervousness of the Dutch for their own frontier and Marlborough's restricted powers made help for the present impossible. All that could be done was to effect a diversion to the west so menacing that the French would be obliged to reinforce their army from the Upper Rhine. In the event of a marked success Marlborough hoped to be able to spare some reinforcements for the imperialists, and for their aid on the Upper Rhine he at once detached twenty battalions and eight squadrons of horse. During a month after the reduction of Bonn on May I 5, I703, Marlborough, encamped upon the Meuse, was concerting with Heinsius a plan of operations which he cloaked with the phrase, "our great design". Great importance was attached in England to the capture of the seaports held by the French, above all Antwerp and Ostend, and the consequent revival of English trade. Marlborough's plan was to converge upon the French lines in Flanders from three directions. But the "great design" mis- 
CHAP. carried through the disobedience to orders of the Dutch I. commanders. The Dutch general Opdam rashly attacking the French lines was routed at Eckeren on June 26, and Marlborough became the butt of the Dutch pamphleteers. His jealousy of the Dutch generals and his new-fangled and incompetent strategy were believed to have combined to bring about the disaster.

Marlborough soon felt the effects of this state of public opinion. His friend and supporter, the Grand Pensionary Heinsius, dared not incur the responsibility of authorising an attack projected by him upon the French lines before Antwerp. $\mathrm{He}$ reverted, therefore, to his former plan of preparing the way for a campaign on the Moselle in the following year. He marched back to the Meuse and on August 7-16 invested Huy, a fortress important as covering Liège and commanding the navigation of the river. After the capture of Huy, which held out only a few days, Marlborough, again anxious to meet and crush the French army by his superior numbers, proposed an attack on the yet unfinished intrenchments of Villeroy and Boufflers behind the Mehaigne. But the Dutch field-deputies positively forbade the enterprise, and Marlborough was compelled to content himself with a protest to the States-general. The capture of Limburg and Guelders in the autumn ended the campaign of 1703 . It had lacked brilliancy, and had been accompanied by one disaster. Its main success had been the reduction of Spanish Guelderland, which relieved the Dutch from apprehension of an inroad on that side. On the other hand, Villeroy and Boufflers had fulfilled their instructions, and by occupying a series of defensive positions had kept the superior numbers of the allies at bay.

While in the west the French had maintained the defensive throughout the campaign of 1703 , they had laid their plans for a concerted attack by their army of the Upper Rhine and that of the Elector of Bavaria upon Suabia, Franconia, and Austria itself. In this they were to be aided by offensive diversions from Piedmont upon the emperor's possessions in North Italy and in the east by the Hungarian insurgents. At the beginning of the campaign the army of Villars, who had replaced Catinat, numbered 60,000 men and a reinforcement of 30,000 men was promised. The Elector of Bavaria was at the head of 40,000 
regulars and several thousand militia. Opposed to the army CHAP. of Villars was Louis, Margrave of Baden. At the head of no more than 10,000 men the margrave was unable to offer effective resistance to the advance of Villars at the end of February, 1703 , and could only look on from behind his intrenchments when that general took possession of Kehl, the key to Southern Germany. Even in April reinforcements, among them 6,000 Dutch, had only brought up his army to 20,000 troops. Villars, with 70,000 French and Bavarians, proposed to march on Vienna, a daring enterprise that had many prospects of success. But the Elector of Bavaria, like the Dutch, was careful for his own frontier.

After ceaseless recriminations between the two, Villars threw up his command in the middle of October, 1703. His successor was Count Marsin. The French army of the Middle Rhine under Marshal Tallard had lain inactive during the summer, ready to furnish reinforcements as they might be needed, either on the west or east. With the surrender of Landau to the French on November I7, their position on the Middle Rhine greatly improved. The campaign of 1703 closed in this neighbourhood under circumstances of great depression for the allies. Despite the heavy subsidies of the maritime powers, the margrave's army was reported by the English representative, Davenant, to be holding its intrenchments with no more than three rounds a man. ${ }^{1}$ The South German princes shewed signs of wavering; the Duke of Würtemberg began to talk of a reconciliation with victorious France.

The Duchy of Savoy, including Piedmont, occupied a position between two great powers, France on the one side, on the other Austria, in respect to the imperial possessions in North Italy. The policy of the dukes had, therefore, necessarily been a continual balancing. At the opening of the war of the Spanish succession the reigning duke, Victor Amadeus II., appeared doubly committed to France. His eldest daughter, Marie Adelaide, had married the Duke of Burgundy, Louis XIV.'s grandson. His second daughter had recently (1 $70 \mathrm{I}$ ) become the wife of Philip, Duke of Anjou, the Bourbon candidate for the throne of Spain. But though Victor Amadeus

It had been reduced to one round per man. Davenant to the Secretary of State, January 20, 1704, R.O., MS., Von Noorden, i., 45 I.

VOL. IX. 
CHAP. had by treaty strengthened these ties, he had been alienated

I. by the menaces and insolence of the French generals during the Italian campaign of I 70I, which finally drove him into the arms of the allies. By a treaty signed at Turin on October 25, 1703, the duke came into the Grand Alliance on the terms of an extension of territory at the expense of Milan and Mantua, the assistance of 20,000 imperial troops, to be under his command, and the maintenance of the Piedmontese army by the maritime powers. In England the adhesion of the duke was acclaimed both as a blow to Louis XIV. from within his own family circle and because it facilitated projects long under consideration of invading the south of France.

The tories had continued to insist on the doctrine that England should play only a subordinate part by land. They still hoped that their favourite commander, Rooke, might eclipse the struggling fortunes of Marlborough. The country had made great efforts. A total of 256 ships of war had been equipped, among them 94 of the line with 64 to 100 guns. But, with the exception of the affair at Vigo, the performances of the navy had hitherto been ineffective. The most recent failure was that of Vice-Admiral Graydon, who, having at the beginning of 1703 been dispatched with five ships to reduce the French colony of Placentia in Newfoundland, had returned home without attacking either the place or a French squadron of four ships which he had passed on the way.

The unreadiness of the Dutch naval preparations also involved England in difficulties. The emperor's dominant wish was to secure Naples for the house of Habsburg before attempting Spain. ${ }^{1}$ In the spring of 1702 England, to whom the Spanish succession was the paramount interest, had refused a fleet for this purpose. But the importance of effecting a (rdiversion in Italy was presently perceived and the co-operation of a fleet was promised for the following year. ${ }^{2}$ May, 1703, came $^{3}$ and Stepney was still pledging his word to the impatient

1 G. Stepney to Shrewsbury, May I-12, 1703: "We shall never bring these people seriously to think of Spain before we are masters of Naples and Sicily". Buccleuch MSS., ii., 2, 657.

${ }^{2}$ April 19, 1702. Home Office Admiralty, 10. J. S. Corbett, England in the Mediterranean (1904), ii., 201.

'Stepney to the Emperor, April 7-18, 1703: "Verso la fine del mese di Maggio". Buccleuch MSS., ii., 2, 655. These repeated delays must have been 
emperor that the allied fleet should appear in the Mediterranean by the end of June. But the Dutch had again failed to keep their promises, and without reinforcements no sufficient force could be spared for so distant a service. When the Dutch fleet arrived in England at the end of June, Rooke was offered the chief command. On his declining it as "too small for his character," Sir Clowdisley Shovell, an admiral belonging to the whig party, which, since Prince George of Denmark had been at the head of the admiralty, had been largely excluded from promotion, was nominated to the command of the division of the fleet destined for the Mediterranean. Rooke with the main fleet was to clear the Channel. Something, the government felt, must be done to redeem the series of naval miscarriages which had followed Vigo. But there was little time to effect anything. English and Dutch admirals alike were nervous about bringing a first-class fleet into the Channel late in the year. The instructions of the admiralty to Shovell were that he was to be on his way home, westwards of the Straits of Gibraltar, by the end of September. Within that time he was to convoy a number of merchant vessels to Portugal, to induce the Barbary states to commit hostilities upon the French marine, to supply arms and munitions of war to the insurgents in Languedoc, to rouse the east of Spain to declare against the Bourbon claimant, Philip V., to exact satisfaction from the Grand Duke of Tuscany for alleged injuries to English merchants at Leghorn, to excite an insurrection in Sicily, and to protect the communications of Prince Eugene by clearing the Adriatic of a French squadron. He protested, as well he might, that impossibilities were asked of him. Stepney had pledged himself to the emperor that the fleet should spend two months at Naples alone. ' The admiralty, however, refused to vary their orders, and Shovell set sail from St. Helen's in the Isle of Wight on July 1, 1703, with a fleet of thirty-five English and seventeen Dutch men-of-war. The Dutch were commanded by Van Almonde, the hero of Vigo.

the more galling to Stepney after he had roundly taken the emperor to task on the subject of preparations at the end of April. Buccleuch MSS., ii., 657.

$1 \mathrm{G}$. Stepney to the Emperor, April 7-18, 1703: "Per secondare durante due meal intieri li diesegni della vostra Augustissima : Casa sopra quel Regno ". Ibid., p. 655 . 
CHAP. Shovell did his best to fulfil as many of his multifarious inI. structions as he reasonably could hope, but was obliged to put back by storms, and it was the middle of July before he had finally left England. Having discharged his convoy at Lisbon, he sailed to the Barbary coast, where he met with hostility. Thence he made Altea, on the coast of Valencia in Spain, where he was well received by the population. ${ }^{1}$ Here the fleet distributed proclamations in favour of the Archduke Charles, by the title of Charles III., and proceeded to Leghorn, where it arrived on September 26-October 6, 1703. The Dutch were reluctant to go so far, and in a hurry to start homewards. ${ }^{3}$ All that Shovell could do was to deliver an ultimatum ${ }^{4}$ to the Grand Duke of Tuscany, and after a week's stay set sail for home (October 2-I3). On his way westwards he endeavoured to fulfil another item of his instructions, that of supplying arms and munitions to the insurgents of the Cevennes, whose heroic resistance to religious persecution had excited a warm sympathy in Holland and England. By July, 1703, the insurrection had, after twelve months, grown to such proportions that with substantial aid from the maritime powers the southeast of France might have been ablaze. That aid it was impossible to render for want of a naval base.

The importance of the accession of Victor Amadeus to the Grand Alliance lay in this, that the capture of Toulon by the concerted attack of a Piedmontese army on the land side, and an English and Dutch fleet from the sea, would enable the combined fleet to winter in the Mediterranean, would maintain the communications between Vienna and the imperial armies in Italy, would decide Venice in favour of the allies, ${ }^{5}$ and would deprive France of her southern naval arsenal. Lastly, the success of the Cevennois would have had its effect upon the Spanish war. The coast of Languedoc was inhabited by a

1 Sir C. Shovell to Shrewsbury, September 29, O.S., I703: "They seem to be unanimous for the house of Austria, and declared they don't believe that there are 100 men in the whole kingdom of Valencia that are for the Duke of Anjou's being their king". Buccleuch MSS., ii., 681.

${ }^{2}$ Ibid., p. 679.

${ }^{3}$ Sir C. Shovell to Shrewsbury, September 29, O.S., I703, ibid., p. 68 r.

4Sir C. Shovell to the Grand Duke, October 2-13, 1703, ibid., p. 682.

5 G. Stepney to Secretary Sir C. Hedges, October, I6-27, I703, Vienna, ibid., pp. 685-86. 
Catalan population, and Catalonia was traditionally hostile to Castile. For the present, despite all these fair prospects, there was little enough in Shovell's power to do. He detached two frigates "with a good quantity of arms, ammunition, and money". Their signals to the shore were not answered, for the envoys entrusted with the secret had been arrested on crossing the frontier. ${ }^{1}$

Shovell arrived in the Downs a few days before "the Great Storm " of November 26, 1 703, in which four of his ships were driven from their anchors, though none of them was lost. It was a disastrous night for the navy, which sustained a total loss of seventeen ships, 6 I 8 guns and I,500 seamen, including Rear-Admiral Beaumont. On shore many lost their lives, among them Richard Kidder, Bishop of Bath and Wells, and his wife, crushed by the fall of a stack of chimneys at the palace of Wells. Immense devastation was wrought in our woods. John Evelyn in his Sylva, records that the New Forest lost 4,000 large trees and he himself about 2,000.

Observers abroad as well as the English ministry were deceived by the opposition shown by political parties in Spain to the supremacy of French influence. Well-disposed persons plied them with pleasing intelligence. Sir Lambert Blackwell, our minister at Florence, wrote to Shrewsbury that at the Spanish seaports "the people talk of a change, being all ripe for it". The Genoese envoy at Madrid declared that most Spaniards would welcome the intervention of the Portuguese. ${ }^{3}$ The Aragonese and Catalans, reported Blackwell, were demanding confirmation of their privileges and were "ripe for rebellion".4 This last information was true enough, save that they were not for rebellion in the Austrian interest so much as against the pompous misgovernment of Castile. The emperor's correspondents confirmed the delusion. Towards the end of October, 1702, an event occurred which strengthened these prepossessions. The Duke of Riosecco, great admiral of Castile, foremost in rank and wealth among the Spanish

1 Anonymous to Sir Lambert Blackwell, Genoa, November 6-17, 1703 , Buccleuch MSS., ii., 688.

July 13-24, 1703, Florence, ibid., p. 667.

- Blackwell to Shrewsbury, August 10-21, 1703, Florence, ibid., p. 672.

- Blackwell to Shrewsbury, June 22-July 3, 1703, Florence, ibid., p. 66r. 
CHAP. grandees, accredited by Philip V. ambassador to Versailles, I. made his way to Lisbon and declared for the allies. He had been long a friend of Prince George of Hesse-Darmstadt, the most efficient agent of England in Spain. He announced, to the satisfaction of Portugal and the allies, his intention of putting himself at the head of a Portuguese army for the purpose of seating the Archduke Charles, as Charles III., on the throne of Spain.

This declaration settled the policy of the maritime powers. It was no longer a question of the emperor's claims. The maladroitness by which, as the whigs complained, the landing at Cadiz had been made in the name of the emperor, had justly provoked the resistance of the Andalusian nationalists. ${ }^{1}$ It was determined to enter into a treaty with the Portuguese court, to which a French plenipotentiary was already making overtures for a renewal of the alliances with Louis XIV. Courted by all sides Pedro II. raised his terms. On May I6, I703, a treaty was concluded by Paul Methuen, the resident British minister, eminently favourable to Portugal and no less disadvantageous to the maritime powers. Portugal was to supply 28,000 troops, of whom 13,000 were to be maintained and paid by the maritime powers. An auxiliary force of 12,000 Dutch and English veterans was to be landed in Portugal, a squadron was to protect Portuguese harbours and, like the land forces, to be under the command of the king. The object of the alliance was declared to be the acquisition by Charles III. of the whole Spanish monarchy. The emperor, after making some difficulties, inspired by desire for the Spanish dominions in Italy, agreed to renounce in favour of the archduke the kingdom of Spain and "the kingdoms belonging thereto," which he considered involved a reservation of the Milanese and the Spanish Netherlands. Queen Anne in return declared her willingness to bind herself to the exclusion of the house of Bourbon from every portion of the Spanish monarchy; but this pledge was never committed to a formal document, an omission upon which, at a later date, another ministry had reason to congratulate itself.

The Archduke Charles, the emperor's favourite son, was at

'Bonet, October 20, 1702, Prussian State Archives, Von Noorden, i., 389. 
this time eighteen years of age. He is described as of good proportions and of pleasing presence. He was conscientious, temperate, and fond of study. But he had no originative capacity, and was dependent upon his governor, Prince Antony of Liechtenstein, who, both tactless and overbearing, was ready to sacrifice a kingdom to a point of etiquette. So averse was the Emperor Leopold from parting with him that his presence in Portugal was made an article of the treaty, and one which was not signed without a marked reluctance. ${ }^{1}$ Even then the emperor had not abandoned his desire that the archduke's first step should be to establish himself in Naples and Sicily," which were, the court of Vienna was assured, "ready to catch so soon as the fleet arrives," ${ }^{3}$ that is, the expected fleet of Sir Clowdisley Shovell. Stepney was instructed, therefore, to insist that the archduke should at once proceed to Holland and embark there. ${ }^{4}$ Charles arrived at the Hague on November 3. Having landed at Portsmouth on January 7, 1704, he was received with distinction by the queen at Windsor as King of Spain. He left England on the I 7 th, sailing aboard Rooke's flagship to Lisbon, accompanied by an armada amounting in all to 188 ships. At Lisbon the allies discovered that the Portuguese troops were ill-trained, ill-clothed, and ill-armed; that they were short of horses, and their fortresses in neglect.

The English ministry seized the opportunity to indemnify the nation for the additional sacrifices it was now called upon to make. John Methuen, father of the resident and ex-lord chancellor of Ireland, was dispatched to Portugal, and on December 16-27, 1703, concluded the agreement known to fame as "the Methuen treaty". The object of this treaty was twofold-to give England a monopoly for her woollen goods in the Portuguese markets, and to injure the French by granting preferential duties to imported Portuguese wines. These were to be admitted at a third less duty than wines from France. The treaty was agreeable to the governing

IStepney to Shrewsbury, wbi supra; Stepney to the Emperor, July 3-14, Vienna, Bucclewch MSS., ii., 2, 663.

I Ibid.

Stepney to Shrewsbury, July 24-Angust 4, Vienna, ibid., p. 669.

- Stepney to the Emperor, July 3-14, 1703, Vienna; Stepney to Shrewsbury, July to-2t, Vienna, ibid., p. 665. 
CHAP. classes of both countries. The great landowners of Portugal

I. foresaw a rise in the price of their wines; the great landowners of England increased profits from their wool ; the merchants an active exchange; the shippers profitable freights. Nor was the effect of the treaty so complete a revolution in English taste as has generally been supposed. That had already begun to conform to the exigencies of war. Between 1675 and 1696 England had imported from France a yearly average of about I 5,000 tuns of wine, as contrasted with 300 tuns from Portugal. During the war with France in 1689-97 the import from Portugal rose to 9,459 tuns, an evidence that taste was already beginning to change. It must be remembered also that Portuguese wines were cheaper, especially relatively to alcoholic strength, than the wines of France. After the Methuen treaty, from 1704 to 1712 , England consumed I 8,908 tuns of Portuguese wine, while the import from France remained almost at the level of ten years earlier, viz., 16,553 tuns. The treaty, though advantageous while the French market remained closed proved eventually productive of the ill-effects which invariably result from the interference of governments with the course of trade. England found herself hampered for many years to come in the extension of her commercial relations over the far more profitable market of France. . The treaty marked a change in the attitude of English parties to the war. The tories began to open their eyes to the commercial possibilities to be derived from a conflict they deplored. In this spirit they resolved to accept the enlargement of the area of the struggle. 


\section{CHAPTER II.}

HOME POLITICS.

THE last parliament of William III. had been dissolved on July 2, 1702. The general election resulted in a majority for the CHAP. tory party of nearly two to one, the popularity of the queen and the activity of the clergy being powerful in their favour. ${ }^{1}$ To these causes may be added, as Burnet admits, "the conceit, which had been infused and propagated with much industry, that the whigs had charged the nation with great taxes, of which a large share had been devoured by themselves". On the other hand, the whigs issued a "black list" of 167 tory members of the last parliament, whom they denounced as friends of France. The result was that the tories, as a whole, in order to clear themselves from this imputation, emphatically pledged themselves to support the war. Outside this pledge, as Burnet says, the tories were "full of fury against the late king and against those who had been employed by him ". Parliament met on October 2I, and Robert Harley was again chosen speaker. The temper of their house shewed itself in the commons' address. They congratulated the queen that "the wonderful progress of your majesty's arms, under the conduct of the Earl of Marlborough, has signally retrieved the ancient honour and glory of the English nation". The word "retrieved" was, and was intended to be, a reflexion upon William III. As such it was challenged by the whigs, and "maintained" was proposed as an amendment. The strength of parties was tested by the division. A majority of 180 to 80 voted in favour of "retrieved". Among them were "all who

'Lord Keeper Sir Nathan Wright to [Thomas Coke], July 25, 1702 : "The elections hitberto give hopes of a true Church of England parliament ". Cowper MSS., iii., 14, Hist. MSS. Comm., 12th Rep., App., pt. iii. 
CHAP. had any favour at court or hoped for any". The satirist Walsh

II. summed up the controversy in the lines-

Commanders shall be praised at William's cost,

And honour be retrieved before 'tis lost.

The demand by an extraordinary mission from Holland for an increase of the 40,000 men voted for the war in the Netherlands afforded an opportunity for gratifying a resentment of long standing entertained by the commercial classes against the Dutch. Since the beginning of the war England had prohibited all direct trade with France. The emperor and the German princes had agreed to follow her example. But Amsterdam was the financial clearing-house of Europe. The vote for an additional I0,000 men was carried through the house of commons on January 5, I 703, by a majority of 7 , the friends of Marlborough and Godolphin voting with the whig party. But it was coupled with the condition "that there be an immediate stop put to all commerce and correspondence with France and Spain on the part of the States-General ".

The news of the exploit at Vigo, which did not arrive till after the opening of the new parliament on October 21, 1702, supplied the tories, among whom Rooke sat as member for Portsmouth, with a set-off to the success of Marlborough, who, enjoying the support of the whigs as the representative of William's continental policy, was already obnoxious to the majority. On November 12 the queen went in state to St. Paul's to return thanks "for the signal success of her arms under the Earl of Marlborough and the Duke of Ormonde and of her fleet under Sir George Rooke". The three commanders received the thanks of the houses, and Sir George was sworn of the privy council. The Duke of Ormonde, nevertheless, indignant against Rooke as the author of what the commons, in their address to the queen upon the opening of parliament, styled the. "late disappointment at Cadiz," saw an opportunity of inflicting a rebuff on Marlborough's rival in glory. The whig majority in the lords readily agreed to his motion to appoint a committee to examine Rooke's instructions and the conduct of the expedition. Rooke vindicated his conduct with audacity. He censured the plan of the expedition, which, it will be remembered, had been a whig project, and arraigned the instructions with which he was 
furnished. Besides his political supporters in the ministry he СHAP. had many friends. Speaker Onslow describes him as " more II. of a man of fashion and fitter for a court than any one almost of his profession". The lords rejected the adverse report of its own committee, and a resolution was carried "that Sir George Rooke had done his duty, pursuant to the councils of war, like a brave officer, to the honour of the British nation" (February 17, 1 703).

The bitterness of this indirect reprimand to Ormonde was assuaged by his appointment to the lord-lieutenancy of Ireland. The vacancy had been created by the resignation of Rochester, who had displeased the queen by inspiring the opposition in the house of commons to her offer of a pension to Marlborough. Commanded by the queen, on the advice of Godolphin, his opponent in the cabinet, to proceed to Ireland, he refused to obey. His insolence provoked Anne to "order that he should no longer be summoned" to meetings of the council, and his influence at court was for a while eclipsed. Between the queen and the whig leaders friction presently arose on a domestic question. Anne was devoted to her husband, Prince George of Denmark, and was anxious that parliament should make a provision for him in the event of her death suitable to the relict of a sovereign. How, a tory with a caustic wit, who had already irritated the whigs by an adulatory address presented by him from Gloucestershire, reflecting scandalously on the memory of King William, was entrusted with the measure. On November 21, 1 702, he proposed $£ 100,000$ a year which, it was remarked, was double what any Queen of England ever had in jointure. The demand was an example of the mischief of the dependence of ministers upon the will of the sovereign. No one ventured to oppose it on the ground of its extravagance, both parties being alike anxious to conciliate the queen. But the bill offered the tories an opportunity of gratifying their hatred of the foreigners who had been advanced by William III. It was moved that a clause be inserted in the bill excepting the prince from any disabilities imposed on aliens by the Act of Succession. The motion was an ingenious attempt to assign a retrospective interpretation to disabilities which had, in fact, been imposed to prevent the grant of lands or offices to foreigners by future sovereigns. In the upper 
CHAP. house sat a small body of peers of foreign extraction who II. had under William III. rendered meritorious services to their adopted country: William Bentinck, Earl of Portland, whose counsels were still sought by the chiefs of the whigs; Arnold-Joost van Keppel, Earl of Albemarle, who had commanded the Dutch contingent of the allies in 1689-97; William Nassau-Zulestein, Earl of Rochford ; Henry Nassau-Auverquerque, Earl of Grantham, and Meinhart Schomberg, Duke of Schomberg, an English general, son of the Marshal Schomberg who fell at the Boyne, and whose Latin epitaph in St. Patrick's Cathedral, Dublin, is a record of the greatness of the father, of the meanness of the son, and of the mordancy of the pen of Swift.

Against the insidious clause which indirectly threatened their estates and appointments, two constitutional objections were raised. The first was that it was a tack upon a money bill. The subject of "tacks" was already a sore point between the two houses, for it was evident that if tacking became a practice, and the lords had no alternative but the acceptance or rejection of a bill en bloc as a money bill, they would cease to exercise any legislative power. They had, therefore, recently agreed upon a resolution that they would pass no money bill sent up by the commons to which any clause was tacked that was foreign to the bill. And in this case, a clause making no similar provision for other peers similarly circumstanced suggested the interpretation of the act of succession aimed at by the tories. Anne regarded the opposition as a personal slight and pressed the whole bill "with the greatest earnestness that she had ever yet shown in any thing whatever". She was zealously aided by the Marlboroughs and their friends, anxious to prove gratitude for recent favours. But they could not control their son-in-law, the Earl of Sunderland, a whig of impracticable temper. $\mathrm{He}$ became one of the leaders of the opposition to the bill, disliked even by independent peers as establishing a precedent for degradation from the peerage. Nothing could have saved the bill in the lords but the opinion given by the judges that the foreign peers could not be dispossessed of their rights. The bill passed by a narrow majority, but protests against the clause were signed by most of the whig leaders, among them 
Sunderland, Somers, Portland, Manchester, Rivers, Townshend, Wharton, and the Dukes of Somerset, Devonshire, and CHAP. Bolton, as well as by six bishops and the Archbishop of Canterbury (January 19, 1703). Anne's wifely indignation nurtured a resentment against the signatories in general and Sunderland in particular, which at a later time she seized the opportunity to gratify.

While this bill was in debate a proposal still more menacing to the alien peers was made by Sir Edward Seymour, the comptroller of the household. Acts of resumption had been frequent during the middle ages, when for lack of ready money grants of crown lands were lavished upon hungry courtiers. "The exorbitant grants of William III.," as they were called in a popular pamphlet, were especially obnoxious as tending to an increase of the burdens laid upon Englishmen for the benefit of foreigners and for a war in which foreign interests were primarily concerned. On December 23, 1702, Seymour moved for leave to bring in a bill to "resume all the grants made in King William's reign and apply them to the use of the public". The whigs were rescued from an obvious dilemma by the adroitness of Robert Walpole. He moved an amendment, "that all the grants made in the reign of the late king James should also be resumed". The amendment was rejected, but the tories were conscious that their bid for popularity was trumped. Though they carried Seymour's motion by 180 to 78 votes, they judged it wise to drop the bill.

Foiled in their attacks on the favourites of the late king, the managers of the majority hoped for a more favourable issue from an appeal to the theological prejudices of the nation. Zealots for the Church combined with zealots for the supremacy of the tory party to concert a measure which should have the twofold effect of discouraging dissent and depressing the whig interest. The names of its authors disclose the mixed motives that inspired it. They were, on the one hand, William Bromley and Arthur Annesley, who sat for the Universities of Oxford and Cambridge respectively, and were, in effect, the representatives of the clergy, on the other, Henry St. John;-the missionaries of oneness of creed and the rejecter of all creeds alike. The traditional Anglican assumption had been the co-extensiveness of Church and 
CHAP. State. That this conception was still in full vigour in the 11. minds of the tory party is attested by the preamble of the act transferring first-fruits and tenths to the augmentation of small livings in which the parliament of 1703 addressed the queen as "the only supreme head on earth" of the Church of England. ${ }^{1}$ To the disgust of the tories, a breach in this uniformity had been effected in favour of the dissenters by the toleration act of 1689 . But the revolution had not repealed the corporation act of $166 \mathrm{I}$ which made the taking of the sacrament the condition of holding an office in corporations, nor the test act of 1673 extending this condition to all servants of the crown whether civil or military. To those who refused this limited conformity all posts were closed. They were excluded from the government of the Bank, of the East India Company, and of all other corporate bodies.

As it was no longer punishable after 1689 to attend conventicles, and as the dissenters were, in the main, thriving tradesmen who naturally aspired to the distinctions of local government, there arose among them occasional conformists. These having complied with the law by taking the sacrament once and thereby qualified for civic office, thenceforth resumed their customary religious worship. Some there were to whom conformity was by no means repugnant on religious grounds. Occasional conformists, said Burnet, Bishop of Salisbury, on the second reading of the bill of 1703 , were "without number" in his diocese. Between these and the low churchmen, who sought to strengthen protestantism by enlarging its borders, there was a mutual sympathy. ${ }^{2}$ It was cemented by political partisanship. Both maintained the tradition of hostility to absolutism, whether in Church or State. Both, therefore, were to be found in the whig ranks.

On November 17, 1702, a bill to disqualify occasional conformists from office was read a second time in the house of commons. Whereas the corporation act of $166 \mathrm{I}$ had only included persons " having employment relating to or concerning the government" of corporations, the new bill swept into its

12 \& 3 Anne, c. It.

${ }^{2}$ De Foe, writing to Harley on July 30, 1705, speaks of "the exceeding harmony between the dissenters and the low Church" in Dorset. Portland MSS., iv., 213, Hist. MSS. Comm., 1897. 
net all the inferior officers or freemen in corporations, that is, CHAP. a large number of those whose votes determined elections. Whereas hitherto a single act of conformity was sufficient, it was provided by the bill that any persons who, after taking the sacrament and test, attended any religious meeting, where five persons were present besides the family, should be disabled from their employments and fined $£ 100$, and $£ 5$ a day for every day in which they afterwards acted in such employments. They should also be incapacitated from holding any other employment until after a year's conformity to the Church, to be proved at quarter sessions. Upon a relapse, the penalties and the period of incapacity were to be doubled. The bill was carried through the commons by large majorities, composed of the tories and the court party, and reached the lords on December 2.

Meanwhile, High Church fanaticism set the country aflame. The London mob committed outrages on the meeting-houses of the dissenters. The pamphleteers poured forth a stream of incitements to mischief. The preachers, prominent among them Henry Sacheverell, a fellow of Magdalen College, Oxford, denounced those bishops who connived at the defilement of the temple. At the height of the excitement appeared an anonymous pamphlet, The Shortest Way with the Dissenters. The friends of the Church were conjured to seize the opportunity to extirpate the accursed dissenters with fire and sword. There were High Church fanatics, we know from contemporary evidence, who thought the satirical advice really admirable. But though it translated into plain words the inflammatory language of the pulpit and the press, it provoked a reaction in public feeling. The High Church party began to fear for the bill. A search was made by Lord Nottingham, as secretary of state, for the audacious pamphleteer. He proved to be Daniel De Foe, himself a dissenter, who had been employed by William III., had satirised both tories and whigs, and had recently denounced occasional conformity as hypocrisy. $\mathrm{He}$ was tried for seditious libel, fined $£ 200$ and put in the pillory. But his satire had had its effect. The sympathies of those who were not committed to either political party turned against the persecutors. De Foe's pillory was a triumph. The London mob, which had lately howled against dissenters, 
CHAP. protected him from violence. He remained in prison from July, II. I 703, to August, 1704 , when he was released by the intervention of Harley, whose confidential agent he became. ${ }^{1}$

In face of High Church zeal and of the pressure exerted by the queen, the whig majority in the lords lacked courage to throw out the bill directly. Supported by many of the Low Church bishops, at the head of whom was Bishop Burnet, they endeavoured to maim it by amendments. They inserted clauses protecting the members of the French and Walloon protestant congregations ; they cut the heart out of it by excluding from its provisions the officials of corporations, and leaving it applicable only to officers of state, among whom dissent was unknown. But conscious that this vital amendment would not be accepted, they resorted to the artifice of provoking a constitutional struggle upon an incidental point. They amended the fines imposed by the bill. By this amendment the houses were brought to a direct issue on a constitutional question, for the commons "had of late set it up for a maxim that the lords could not alter the fines that they should fix in a bill, this being a meddling with money". To justify their action, therefore, the lords caused a search for precedents to be made in the Rolls of Parliament and conclusively established their right. The commons thereupon contented themselves with simply affirming their disagreement with the lords' amendments.

As neither side would give way upon the constitutional issue, a free conference of both houses met on January 16, 1703. The queen renewed her pressure in favour of the bill in its utmost severity. Her compliant husband, Prince George, had, on his appointment as lord high admiral on May 21, I 702, qualified himself by receiving the sacrament, yet he maintained a Lutheran chapel and was, therefore, himself an occasional conformist. As Duke of Cumberland he came down to the house to vote for the bill, but was reported to have whispered to Wharton, "My heart is vid you". The primate, Tenison, supported Burnet's eloquence in favour of tolerance, but the

1 Portland MSS., iv., 6r, 68, 75. In Nov., 1703 , Harley hinted to De Foe that there was some one of consequence interested in him. This appears to have been the queen herself, who made him a present in money at a time when Harley proposed to employ him as a secret agent at Hanover. De Foe to Harley, May (?), r704, ibid., pp. 87-89. Cf. Blenkeim MSS., p. 43, Hist. MSS. Comm., 8th Rep., App. 
issue of the division which took place in the lords after their CHAP. retirement from the free conference was doubtful to the last. II. "On three questions put on different heads, the adhering (to their amendments) was carried by but one voice in every one of them, and it was a different person that gave it in all three divisions." The bill was therefore lost. It had excited interest in all the courts of Europe. The lords violated precedent by publishing the proceedings, which triumphantly established their vindication as the representatives of toleration and the champions of public liberty. They followed up their success by amending a tory bill for the relief of non-jurors who had not abjured the pretender within the time limited by the statute of $13 \mathrm{~W}$. III. c. 6 , and by inserting a clause extending in favour of the Electress Sophia and her heirs the penalty of high treason against any who should " endeavour to deprive or hinder" their succession.

In the course of the last session of the expiring parliament of 1702 a bill had been passed for the appointment of commissioners for the examination of public accounts. That considerable confusion and public indebtedness had arisen during the last stormy reign was of common knowledge. In this matter the whigs were not forward to act, the administration of the finances having been largely in the hands of their political partisans, and six previous commissions having proved ineffective. Seven commissioners were nominated, all tories, of whom the most eminent was St. John. Their first inquiry was addressed to the accounts of the Earl of Ranelagh, who having been paymaster-general of the army during the reign of James II. had been continued in that office by William III. Ranelagh, an Irish peer of the whig party, a wit and a man of pleasure, had provoked jealousy and suspicion by the sumptuousness of his establishment and the extent of his gardens. Irregularities were proved, but there was no conclusive evidence of peculation. The commons, therefore, unable to order a criminal prosecution, passed a series of resolutions condemnatory of some of his transactions. But the practice of the retention of interest upon public moneys in the bank which had enriched Ranelagh, as it was not condemned by the house, was not discontinued.

VOL. IX.

1 Inne, st. 2, c. $2 x$. 
CHAP. The tory commissioners next flew at higher game. Charles II. Montagu, Lord Halifax, the restorer of the currency, had exchanged the place of first commissioner of the treasury and $a$ seat in the house of commons for the lucrative office of auditor of the exchequer in 1698 and a peerage in 1700 . At the treasury he had been driven to the irregular expedients by which, when revenues were failing and credit was low, resources were found for an exhausting war. The disorder thus introduced into the finances was aggravated by practices like those admitted by Ranelagh. Numerous though the irregularities of his subordinates were proved to be, the commissioners failed to bring home corruption to Halifax himself. Nevertheless, they ordered a prosecution by the attorney-general. The conviction of Halifax, one of their most prominent leaders, would have been disastrous to the whigs. In anticipation of any judicial process, the house of lords had already summoned the commissioners of accounts before them on February I. The commissioners having taken no notice of the summons, Halifax was heard on the following day. On February 5 the Duke of Somerset presented a report, which was agreed to by the lords, acquitting Halifax of the neglect and breach of trust imputed to him. These proceedings they ordered to be published.

Feeling between the two houses was now at fever heat. A war of retaliation was promised. The lords threatened the appointment of a committee to examine the accounts of tory officials. Among the most unpopular of these was Sir Edward Seymour. It was rumoured that he had never rendered an account of the office of treasurer of the navy, held by him from 1673 to $1681 .{ }^{1}$ If this counter-campaign were pressed, no resource would remain to the tories but to influence the queen to dissolve parliament, and the whigs anticipated that the successes of Marlborough would be credited to their own account. Anne was therefore advised to close the session on February 28, I 703. The tories now felt assured of the court. But their ascendency over the queen was of little effect so long as they were exposed to constant defeats in the house of lords, though, as has been seen, on some critical 
issues the majorities against them were extremely narrow. In CHAP. order, therefore, to secure the upper house, the queen was persuaded to create four new tory peers. Yet the influence of the Duchess of Marlborough was sufficiently powerful, despite much opposition, to obtain a fifth peerage for a nominee of her own. John Hervey, a whig, father of the author of the Memoirs of the Court of George II., was created Lord Hervey of Ickworth. The reinforcement of the tories in the lords amounted, therefore, to no more than three votes. The High Church party was gratified, the whigs rebuffed, and the queen's temper exhibited by the preferment to the deanery of Lichfield of the notorious Dr. William Binckes, whose sermon the house of lords had in the previous parliament ordered to be burnt.

The indecisive campaign in the Netherlands and the want of success in the rest of the vast theatre of war which marked the campaign of 1703 sharpened the hostility of the extreme tory party to Marlborough. ${ }^{1}$ His foreign enterprises, they exclaimed, brought neither honour nor profit. In the house of lords Rochester, in the cabinet Nottingham, outside parliament the pamphleteers, were the spokesmen of this opinion. A sense of common interest was thus drawing together the fraction of the cabinet represented by Godolphin and Marlborough and the whig party. Godolphin had been strong enough in January, 1703 , to check a tory crusade against whig officials by refusing his consent to the dismissal of those of the treasury. The conversation in whig circles began to turn upon the prospect of success in an attempt by Marlborough and Godolphin, with whig aid, to oust the extreme tories from the cabinet and to form a new ministerial body, if not whig, at least sympathetic with whig policy in foreign affairs.

Nottingham, Rochester's alter ego in the cabinet, thought, on the other hand, the time propitious for the renewal of Rochester's policy of "Thorough". In March, 1703, during the absence on the continent of Marlborough, who had defeated Rochester's proposal in the previous year, Nottingham induced the queen to dismiss a number of lords-lieutenant, sheriffs, and justices of the peace. These were not officials whom Godolphin was able to screen by an appeal to the exigencies

1 Portland to Heinsius, December 23, 1703, Heinsius' Archives, Von Noorden, i., 353. 
CHAP. of public business. But this reversal of the policy of William

II. III. to exempt local administration from the vicissitudes of party politics provoked a reaction in public opinion and assisted the very object which Godolphin and Marlborough had in view. There was a general feeling expressed by the speaker, Harley, and by Halifax, who of all the whig leaders approached nearest in disposition to Halifax, the "Trimmer," that it was not for a patriotic Englishman to stir up domestic animosities while war was raging. The same sentiment inspired Davenant's Essays on Peace at Home and War Abroad, which, though published in the following year, were composed at this time. The Marlboroughs and Godolphin threatened resignation, and elicited from Anne one of those imploring remonstrances which are among the curiosities of literary correspondence. Nevertheless, in July, she refused to accede to the duchess's instances and to remove Nottingham. In foreign, as well as in domestic policy, his views and those of Godolphin were irreconcilable. Godolphin's correspondence shews the sympathy with which he followed the insurrection of the Camisards, as the Huguenot insurgents in the Cevennes were called, and his desire to aid it with an expedition. Despite Nottingham's opposition, he insisted, in July, I703, on the dispatch of Richard Hill, a "Hanover tory," as the moderates of that party were now styled, to promote with that object the adhesion of the Duke of Savoy to the Grand Alliance. The high churchmen boasted that the opening of the autumn session of parliament would bring their revenge, and that Nottingham would, before many weeks were over, grasp the lord treasurer's staff.

On November 9, 1703, the queen opened parliament. The creation of new peers had emboldened the tories to a fresh bill against occasional conformity. But a change in the attitude of the court threatened them with another disappointment. The queen's speech had expressed an "earnest desire of seeing all my subjects in perfect peace and union among themselves". It was a hint of which the significance was unmistakeable when it became known that upon this occasion Prince George intended to let his heart so far control his head as to withdraw the support he had formerly given. Anne was torn between affection and bigotry. She shared the current anticipation that the indecision of the court would encourage the opposition to 
the bill in the lords, and that, notwithstanding the new crea- СнАP. tions, another conflict between the two houses was likely to ensue. The opposition, as the tory leaders soon came to know, had been strengthened by the dismissals in the spring. The rejection of the bill by the lords became certain, notwithstanding it had been deemed prudent to modify its severity. It passed its third reading in the commons on December 7 by 223 to 140 votes. The high churchmen then proposed to tack it to a money bill. Marlborough knew that the temper of the whig peers was sufficiently roused to imperil the whole budget rather than give way upon a question which, presented to them in this shape, not only vexed their consciences but invited them to assist in the political annihilation of their house. He took care to let it be known that the queen disapproved of the project of a tack.1

The hint was enough. When the bill came up for second

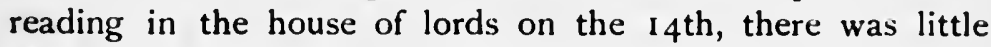
formal criticism of its provisions such as had marked the debate of the previous year. Those who were willing to wound were no longer afraid to strike at the principle which the bill incorporated. The opposition was led by Burnet in an eloquent speech, one of the few examples of the oratory of the period which have come down to us, more nearly approaching the style of our own day than the declamation fashionable a century later. The bill was lost by a majority of twelve. Marlborough and Godolphin, while letting their friends know that they disapproved of the bill, voted for it and signed a protest against its rejection rather than risk loss of office. Their double dealing availed them little. They preserved the queen's favour, but they forfeited the confidence of the stronger men among whigs and tories alike.

Among the English Jacobites there was a general feeling that it would be unwise to attempt an insurrection in favour of the pretender so long as the queen lived. But it was debated whether, even during her lifetime, the pretender might not be able to establish himself in Scotland, where the Jacobites were far more numerous and powerful than in England. The prejudice against a legislative union with England, which was

1 Portland to Heinsius, December 29, 1703, O.S., Heinsius' Archives, Von Noorden, i., 472. 
CHAP. now in contemplation, was likely to operate in favour of this

II. design, and the succession to the crown of Scotland had not, as in the case of England, been determined by statute law. Emissaries began to renew their activity between England and St. Germain's, where Mary of Modena, James II.'s widow, still held court. Not a few of them earned secret service money from the English government for betraying the cause they professed to serve.

Among these intriguers one Simon Fraser of Beaufort, a highland chief, outlawed for abduction, made his way over to France in July, 1702. At interviews with Torcy, the French minister of foreign affairs, and even, as he alleged, with Louis XIV. himself, he concerted a rising in Scotland, to be supported by 5,000 French troops disembarking at Dundee. He himself received a commission as a colonel in the pretender's service. He returned to Scotland entrusted with a letter from the exiled queen, unaddressed, but expressing reliance upon the person for whom it was intended. This letter he himself addressed to the Marquis of Atholl, whose sister he had abducted, and who had been the promoter of his outlawry. He then carried it to the Duke of Queensberry, the queen's commissioner to the Scots parliament. Queensberry zealously reported to London this evidence of the treasonable intrigues of Atholl, his political opponent. The marquis retaliated by hastening to the presence of the queen and reading to her and the council for Scotland a memorial to the effect that Fraser was a confidential agent of Queensberry. Fraser, being denounced at the same time by a political adventurer, known to that generation as "Ferguson the Plotter," fled abroad. The Jacobites and their friends shrieked at the perfidy of a government which employed agents to tempt to treason. The ministry, on the other hand, were embarrassed. They did not wish to sacrifice Queensberry, and determined, therefore, to buy off by a distribution of honours the resentment of the Scottish peers implicated.

A suspicion grew among the English whigs that there was a design on the part of the ministry to hush up the whole intrigue, and Nottingham was thought to have supplied Atholl with information for his defence. Public apprehension having led to the arrest of several Jacobite agents early in December, 
the whig leaders in the lords determined to sift the matter for themselves. They appointed a committee of seven of their CHAP. number to examine Sir John Maclean, a Jacobite agent arrested on November 10, whose case at the time was still being investigated by Nottingham. An order was made that Maclean should be brought before the committee on the following day (December 14). The ministers then had recourse to the queen, who sent a message "that she thought it would be inconvenient to take it out of the method of examination it was now in". The lords were constrained to accept this answer. But their action was felt to have been a censure of Nottingham, and the high churchmen of the commons flew to his aid. An address of the house of commons to the queen on December 23 , declaimed against the lords as guilty of an infringement of the prerogative. The quarrel involved a point of the highest constitutional importance. By their action the commons substituted for the system of conferences, by which the houses had been accustomed to adjust differences, an appeal direct to the crown as arbiter. Upon issues of this sort the lords enjoyed the incomparable advantage of the learning and the pen of Somers. In a masterly "representation to the queen" they vindicated their action on constitutional grounds. They also resumed their examination of Maclean, notwithstanding that Nottingham had put before them, together with the other papers, an abstract of his examination before the privy council, and had taken the further precaution of obtaining from the prisoner an acknowledgement that the abstract contained a full account of all he had said. The lords' committee, however, elicited much that was not contained in Nottingham's abstract which, they complained, "was both short and dark".

It was openly suggested that Nottingham was concealing some evidence, but a motion for the re-examination of Maclean as to what passed between Nottingham and himself was defeated by eleven votes on March 23, I 704. If we may trust a letter of Portland, dated January I, I703/4, there had been a suppression of grave importance. According to this, Maclean declared before the privy council, in presence of Marlborough himself, that both Marlborough and Godolphin had given assurances to the court of St. Germain's. ${ }^{1}$ It is evident that Not-

1 Portland to Heinsius, Heirsius' Archives, Von Noorden, i., 480. 
CHAP. tingham, fearing that revelations of this kind would break up II. the ministry and bring the whigs into power, had, as the lords openly charged him, bought Maclean's silence. Maclean was released from the Tower on March 24, and received a pension of $£ 500$ a year during Anne's life. ${ }^{1}$ The lords concluded their abortive inquiry with the resolution "that there had been dangerous plots between some in Scotland and the courts of France and St. Germain's, and that the encouragement of this plotting came from the not settling the succession to the crown of Scotland in the house of Hanover ". This resolution they embodied in an address to the queen praying for a union between the two kingdoms. The exasperation of the baffled whigs disclosed itself in a second address on March 3 I reflecting on the dismissals from the commission of the peace in the previous year, and expressing an opinion adverse to the nomination of former non-jurors. This the queen received with an unfavourable and evasive reply, pointed by the dismissal of Queensberry from most of his offices.

All these proceedings the lords committed to the press. Their action in taking public opinion into their confidence was a revival of the revolutionary practice of fifty years earlier, discountenanced since the restoration. It was distasteful to the tory majority in the commons, whose supporters were fewer among the reading public of the towns. But the pressure of the constituencies, more active under the system of triennial parliaments than it subsequently became, was so far felt that a proposal in November, I703, to adopt the practice of the lords was only defeated by the casting vote of the speaker, Harley. ${ }^{2}$ A perusal of the addresses and counter-addresses of the two houses reveals that at this time not merely literary ability but discerning and progressive statesmanship were to be found in the house of lords, which contained a considerable number of politicians of eminent service trained in the school of William III. There sat Portland, the late king's wisest counsellor; Somers, the acknowledged master of constitutional law; Godolphin, employed by all governments as the most skilful financier of the age; Halifax, the restorer of

1 Macfarlane's Genealogical Collections (1750-5I), i., I4I, being vol. xxxiii. of the Publications of the Scottish History Society (rgoo).

'L'Hermitage, November 27, 1703, Von Noorden, i., 483. 
the currency; Burnet, a bishop who was also a statesman; and Marlborough, who had already won renown alike by CHAP. his military talent and dexterous diplomacy. By the side of these, the Bromleys, the Hows, the Seymours of the lower house failed to strike public imagination, and St. John had scarcely risen to fame. In the commons the whigs enjoyed social as well as intellectual superiority. They scoffed at the corn-dealers and sheep-breeders who thronged the tory benches, strangers to the classics and ignorant of high politics, but responding with inarticulate docility to the crack of the High Church whip.

The irritation between the two houses resulting from the occasional conformity bill and the Scottish plot next found vent in a question affecting fundamental principles of the representative system. After the general election of 1702, the tory majority had dealt with notorious unfairness in the proceedings before the commons upon controverted elections. While these scandals were fresh in the public mind, the house of lords, in the case of an elector for Aylesbury, Ashby versus White, which came before it upon a writ of error, affirmed its jurisdiction to decide upon the right of the plaintiff to vote at an election to the house of commons. The decision reversed a judgement of the queen's bench, and was declared by the commons to involve a breach of their privileges. The lords in reply passed resolutions on March 27, 1704, against the pretension "to subject the property of Englishmen"is, the franchise- " to the arbitrary votes of the house of commons". To such a pitch had the animosity between the two houses now reached that the Prussian resident, Bonet, reported that an enterprising king had an excellent opportunity of ridding himself of parliament altogether. ${ }^{1}$ It was carried into every detail of parliamentary business. When the tory majority in the commons, in order to screen Rooke, sought to impute to Sir Clowdisley Shovell the futility of the last year's naval expedition, the peers took Shovell under their protection and appointed a committee of inquiry into the administration of the admiralty. They addressed the queen for the removal of the Jacobite Vice-Admiral Graydon for his recent misconduct

1 Bonet, January 21 -February 1, 1704 , Von Noorden, i., 495. 
CHAP. in not engaging Ducasse's squadron and for illegally pressII. ing men from merchant vessels in Jamaica. They vindicated the whig Admiral Russell, Earl of Orford, from a charge of peculation brought against him by the tory commissioners of public accounts.

One more constitutional conflict remained to be fought. The commons, at the close of March, sent up a bill to the lords for the continuance of the commission for the examination of public accounts. But the commission had rendered itself so odious to the whigs that it was determined to wreck it. Sunderland, Marlborough's son-in-law, whose whiggism was of an uncompromising aggressiveness, disinterred a precedent of Charles II.'s time to prove that the peers not only enjoyed the right to reject in such a case the nominees of the commons, but to substitute nominees of their own, which they did accordingly. The commons protested, and on April 3 a stormy conference of the two houses took place. Words were running high when Black Rod knocked at the door with a message from the queen. The ministry in alarm had advised an instant prorogation, and the commission of public accounts ceased to be.

It had become evident to Godolphin and Marlborough that if they hoped to maintain themselves in power they must be secured against treachery from within the ministry. Upon the most urgent questions of foreign and domestic policy Nottingham was at issue with both. Nottingham himself was so far unconscious of the insecurity of his position that he demanded the dismissal from the privy council of the whig Dukes of Somerset and Devonshire, with whom he had come into violent collision in the affair of the Scottish plot. The queen instead of striking the dukes off the list of the privy council, dismissed Lord Jersey, the lord chamberlain, who was under the imputation of Jacobitism, and Sir Edward Seymour, who had been Nottingham's lieutenant in the matter of the dismissal of whig justices of the peace. Seymour had given affront, not only by intemperate attacks on Godolphin, but by an announcement of his intention to renew the attempt at "tacking" the occasional conformity bill in the following session. Nottingham, not unnaturally conceiving the dismissal of Seymour to be a rebuff to himself, sent in his resignation in May, 1704.

Robert Harley, who had first been elected speaker in the 
last parliament of William III., was designated by public CHAP. opinion as the representative in the commons of that middle party which Godolphin and Marlborough were seeking to gather round them. He was acceptable to the Church, and had received an address from the clergy for the part he had taken in the promotion of the act for restoring to them the first-fruits and tenths. While leaning to the side of the tories, he had acted the part of a peacemaker in the quarrels between the houses. He had kept Godolphin constantly acquainted with the cabals of Nottingham. So great was the reliance placed by Godolphin and Marlborough on his management of the commons that it had been arranged by Godolphin, with the assent of Marlborough, ${ }^{1}$ early in November, 1703 , that the three " should meet regularly at least twice a week, if not oftener, to advise upon everything that shall occur". It was not long before the three were known by the nickname of "the triumvirate". Harley, who was at this time forty years of age, was the son of a country gentleman who had sat in parliament for Herefordshire and had fought for it during the civil war. Revolting from the military government of Cromwell, the father had welcomed the restoration, but he had armed for the Prince of Orange. It was his political lot always to find himself between two fires, and while for his conduct in the convention parliament he was denounced as "an enemy to the Church," his opposition to the policy of William III. "drew upon him and his family the implacable rage of the Lord Wharton, Lord Somers, and the other whigs of their party".

This detachment from party ties was improved by his son Robert Harley into a useful talent. When William III. approached the opposition he twice offered Harley a secretaryship of state. Harley's refusal increased his "great reputation among the country party," and his election as speaker in the new parliament of December, I 701, was opposed by the whigs. But his moderation gave so much satisfaction to all parties that in Anne's first parliament he was re-elected without op-

1 Marlborough to Harley, October Ir, N.S., 1703, Bath MSS., i., 56, Hist. MSS. Comm., rgo4.

2 Godolphin to Harley, November 4, 1703, Portland MSS., iv., 75.

- De Foe to Harley, November 2, 17a4, ibid., p. 147.

- See Auditor Harley's Life of the Earl of Oxford, ibid., v., 643.

Ibid., p. 645 . 
CHAP. position. He had the credit, according to the Prussian

II. minister, ${ }^{1}$ of being the most moderate man in the tory party. Brought up in close touch with the dissenters, his father having been an occasional member of Baxter's congregation, he always cultivated friendly relations with them. He was punctilious in religious observances, and, like Pepys, held family prayers, except when overcome by the bottle. ${ }^{2}$ He was an opportunist by temperament, with a natural preference for the backstairs. This disposition had been remarked before his election to the speakership, and had earned him the nickname of "Robin the Trickster". During his tenure of the speakership his disposition to intrigue took the form of management. In this his talents had been so conspicuous that, at the time at which he entered Godolphin's ministry, he had surrounded himself with a group of followers composed from both parties. ${ }^{3}$ The inscrutableness ascribed to him by his friends was sedulously cultivated by Harley. His naturally heavy manner, his involved and oracular utterances were the appropriate equipment of an enigmatic politician whose justly acquired reputation for knowledge of principles and precedents lent substance to mystery. His scheme of politics floated upon the personal favour of the sovereign which should submerge party divisions in a flowing tide of loyalty. By universal consent, he had too much good nature in his disposition to take any pleasure in political animosities. ${ }^{4}$ n. 4 .

${ }^{1}$ Spanheim, May 30, 1704, Prussian State Archives, Von Noorden, i., 501,

${ }^{2}$ That he had a dislike to latitudinarianism appears from the draught of an anonymous letter addressed by him to Archbishop Tenison, at some time between r 701 and 1705, accusing the archbishop of being under the influence of Socinians, Arians, and Deists. Bath MSS., i., 52.

${ }^{3}$ Stanley West to Robert Harley, August 29, 1704, Portland MSS., iv., I18.

4 The tributes to Harley's good nature paid by his correspondents are so frequent, and in one case that we know of so well founded, that it must have been a leading feature of his character. The Earl of Inchiquin, his schoolfellow, wrote to a cousin of his own: "He (Harley) always showed abundance of good nature and affability" (Portland MSS., v., 64). "Your lordship's generosity," wrote a correspondent after Harley had broken with Marlborough, " is much commended at camp for carrying on the building of Blenheim with so much diligence; this is heaping coals of fire on their heads" (July 3-14, 1711, ibid., p. 28). Bolingbroke, apologising for a letter in which he took his chief to task for mismanagement of business, says : "If you forgive the length of this letter and yet think that the worst part of it, you will be that great and that good-natured man I always took you for" (July 27, 1713, ibid., p. 311). 
Such was the man who, on the resignation of Nottinghain, was invited to be secretary of state for the southern department of foreign affairs. As an inducement to his acceptance of office, provision was made for two of his friends. Mansell, member for Merioneth, "the heir of a very considerable family in Wales," was made comptroller of the household in place of Sir Edward Seymour, and Henry St. John, secretary at war, in place of William Blathwayt. The office of lord chamberlain, which had been held by the Jacobite Earl of Jersey, was given to Henry Grey, Earl of Kent, a wealthy peer of a somewhat colourless whiggism.

St. John, then in his twenty-sixth year, had received the usual education of a man of fashion. He had been at Eton and had made the grand tour. Addicted though he was to bouts of drink and debauchery, he had an exceptional capacity for affairs, a sound memory, and remarkable brilliancy of expression. He had acquired some acquaintance with classical authors, appreciated good literature, and was familiar with current philosophical thought. These tastes introduced him to the foremost writers of the day. Destined by training and position to a seat in the house of commons, which he entered for the first time as member for the family borough of Wootton Basset in William III.'s last parliament, he elected to gratify ambition at the cost of such convictions as he had. Upon the tory benches a meagre handful of second-rate speakers struggled feebly against King, the future chancellor, Jekyll, afterwards master of the rolls, and Cowper, who, in the opinion of Burnet, "spoke the best of any in the house of commons". St. John, though a professed freethinker, discerned where lay his opportunity and ranged himself with the High Church party. As leading member of the commission on public accounts he conducted a crusade against one after another of the whig officials. He thundered against the financial proposals of Godolphin and lent eloquent voice to the murmurs of the inarticulate country squires in whose eyes the malt tax and the land tax obscured the glory to be derived from continental wars. They welcomed as their salvation the torrential eloquence and the aggressive wit of their youthful champion which overwhelmed by audacity the more restrained oratory of 
CHAP. the elder parliamentarians. ${ }^{1}$ Not one of his speeches has been II. preserved to us, but as to their effect in the house his contemporaries are unanimous. Every High Church coffee-house rang with his praises. Dissipation, frivolity, scepticism were alike condoned when the talents they marred yoked themselves to the service of orthodoxy.

That a young man of these powers should be left to weld the opposition into an effective fighting force was agreeable neither to Godolphin nor to Marlborough. The duke discerned that at heart St. John was a political adventurer who, like a medieval condottiere, swore fealty to the side that had most to promise. Harley had not failed to establish friendly, indeed affectionate, relations with this rising sun. To St. John, Harley was for long "dear master," and the pupil, Harley's "affectionate Harry". Marlborough, perhaps impressed by St. John's financial talent, perhaps anxious to silence his diatribes against the continental policy, recommended him to Godolphin as secretary at war, despite the warnings of the duchess who saw how slightly the ties of friendship or political alliance would control his ambition. For a while, however, the influence of the duke dominated both Harley and St. John, the master and the pupil. The new secretary at war had not been many days in office" before his former friends perceived with disgust that the muzzle of promotion had moderated his tone. In a few months he was described by the Prussian resident as a warm admirer of the duke and absolutely dependent upon him. Unhappily for Godolphin, the changes in the ministry pleased neither tories nor whigs. The tories were disposed to look upon Harley and St. John as renegades. The extreme whigs were indignant that Marlborough's son-in-law Sunderland, a fighting politician, had not been put in the place of Nottingham. Sunderland, however, had been distasteful to the queen since his opposition to the bill for Prince George's annuity. An attack on the ministry by the whigs, it was thought, ${ }^{3}$ might be supported by the extreme tories. During the anxious weeks of the summer of 1704,

${ }^{1}$ Bonet, April 18, 1704, Prussian State Archives, Von Noorden, i., 507, n.

${ }^{2}$ He kissed hands as secretary, April 4, 1704, Cowper MSS., iii., 32. i., 509 .

${ }^{3}$ L'Hermitage to Heinsius, June 3, 1704, Heinsius' Archives, Von Noorden, 
when the British troops were marching eastwards to the CHAP. succour of the emperor, Rochester and Seymour were deII. claiming against the waste of blood and treasure and threatening the impeachment of the duke. ' The march to Blenheim was the ministry's last card.

'Bonet, June 13 and August 26, L'Hermitage, June 13, 170.4, Heinsius' Archives, Von Noorden, i., 5 ro. 


\section{CHAPTER III.}

THE WAR AND PARTIES.

CHAP. FIVE weeks of the winter session of parliament had been III. spent by Marlborough at the Hague in preparation for the ensuing campaign. The prospect at the beginning of 1704 was by no means encouraging for the Grand Alliance. The empire was in a state of growing disorganisation. In the east the Hungarian insurgents under Rakoczy were raiding Silesia and Moravia, and alarming Vienna itself. On the other side of the frontier of Austria were the 45,000 troops of the Elector of Bavaria, extending along the Danube from Ulm to Linz, and maintaining communication with the Hungarians. To the west of the elector, on the Upper Rhine, was the army of Marshal Tallard. Menacing Austria from the south was the French army of Italy. The French plan of campaign was to unite these forces in co-operation for offensive action. Against them the emperor could only muster three inconsiderable armies, one operating unsuccessfully against the insurgents in Hungary, one of 20,000 men to oppose the Elector of Bavaria, and one ill-equipped force under the Margrave of Baden to hold the fortified lines guarding the passage of the Rhine at Stollhofen, in Baden. It had become clear to Marlborough in I 703 that the empire must be rescued or that the French would dictate peace at Vienna. Determined to disembarrass himself of the interference of the Dutch field-deputies, he had obtained from the States-general the title of commander-in-chief of the two maritime powers. The plan, or absence of plan, by which each power singly defended its own frontiers must, he resolved, be abandoned. The bait of petty advantages which distracted concert must be set aside, and a powerful combined movement, extending from the North Sea to the Danube, must achieve the expulsion of the French from Germany. 
It was not, however, a moment at which Marlborough felt CHAP. it would be wise to approach the Dutch with so vast a plan of campaign. The duke made up his mind, therefore, in the first place to take his measures in concert with Prince Eugene, the Austrian commander-in-chief, and to keep the Dutch ignorant of their full scope until the time came for their execution. Arriving at the Hague in the middle of January, 1704, he suggested a campaign on the Moselle with his own troops and some auxiliaries, while the Dutch under Ouwerkerk maintained the defensive in the Netherlands. These arrangements made, Marlborough returned to England at the close of February. It was necessary, at least, that he should impart his plans to the queen. The first object of the campaign was to crush the army of the Elector of Bavaria upon the Danube. In order to fortify his proposal, he induced the emperor to write a private letter to the queen, asking assistance. On April 2 another private appeal was made by the imperial minister. Marlborough thereupon received from the cabinet general instructions to "concert with the States such measures as should be deemed proper for relieving the emperor and reducing the Elector of Bavaria". Meanwhile, to hoodwink the Dutch, he was affecting to make preparations for the campaign on the Moselle. Not a word was said about a march to the Danube, though, if we are to credit Burnet, Heinsius had unofficial knowledge of the design. Embarking from Harwich about the middle of April, the duke, for the second time that year, arrived at the Hague. The Dutch were wrapped up in their own interests and indifferent to the fate of the emperor. The barrier policy, that is, the occupation of the frontier fortresses, had become the horizon of their vision.

Marlborough's first step on arrival at the Hague was to make formal request to the States-general for permission to detach a part of the combined English and Dutch forces from the Meuse and Schelde to join the army destined for the campaign on the Moselle. There were stormy scenes in the Statesgeneral. He had foreseen refusal, and had armed himself with an authorisation from the queen to march with all the troops in English pay. Not till this was known did the Dutch give way. They were left with 70,000 men under Ouwerkerk to guard their frontiers. With the contingent of 15,000 , the VOL. IX. 
CHAP. detachment of which had provoked so much resistance, the III. troops starting under the immediate command of Marlborough numbered on paper 40,000.1 By the middle of May he was ready to march, and hoped to effect by the middle of June a junction with the Margrave of Baden on the Upper Rhine. On May I 3 Marshal Tallard, in view of the margrave, crossed the Rhine at Breisach, under cover of the fortress captured by him the previous year. He had with him I 3,000 recruits for the Elector of Bavaria and 18,000 regular troops as convoy to a huge train of munitions. Avoiding the German defences by circuitous routes, he delivered the recruits and supplies to the elector and Marshal Marsin at Villingen, and returned with his regulars to rejoin the French army on the Upper Rhine. The Margrave of Baden, whose army now numbered 30,000 men, followed up the elector as he marched back to Ulm. At the beginning of June he was joined by Prince Eugene at Ehingen, on the Upper Danube. At the same time the news was brought that Marlborough with rapid marches was approaching the scene of action.

Marlborough left the Netherlands on May 19, after garrisoning Maestricht with English troops. His army was to be reinforced during his march by troops from Prussia, Lüneburg, and Hesse stationed on the Rhine, and by eleven Dutch battalions at Rothweil, on the borders of the Black Forest. He had advanced no further than Kerpen when Villeroy, to effect a diversion, made a demonstration in force before Huy. Marlborough, foreseeing that Villeroy would probably follow his march, refused the request of Ouwerkerk to halt, and advanced up the Rhine from Bonn, where he heard of Tallard's crossing, to Coblenz. At this point he would have left the Rhine for the expected campaign against the French fortresses on the Moselle; but when, on June 3, he had reached the right bank of the Neckar with the cavalry, his real objective was at last revealed. Meanwhile he had, on May 21 and 23, written dispatches to the States-general justifying his departure from his instructions on the score of the deficiency of the military preparations on the Moselle. He also demanded reinforcements

${ }^{1}$ Alexander Stanhope to Sir Charles Hedges, the Hague, April 25-May 16, I704, R. O., MS., Holland, 226, $f$. 327. 
against Tallard, who was likely to hasten with the French army of the Upper Rhine to the aid of the Bavarian elector.

CHAP.

On June 9, some days in advance of his cannon and infantry, Marlborough met Prince Eugene at Mundelsheim on the Neckar. The Margrave of Baden joined them at Gross Heppach four days later. From this, their first meeting, dated the lifelong friendship of Eugene and Marlborough, both of them alike gifted with the intuition of military genius, and each too highly placed in the confidence of their countrymen for the success of one to eclipse the fame of the other. The Margrave of Baden, who had grown grey in campaigns, had lost the aspiration to initiative. His hungry and ragged troops contrasted ill with the well-clad English, whose appearance had drawn compliments from the Elector of Mainz, and now provoked the admiration of Eugene. Marlborough was already' apprised of the margrave's disposition to find excuses for inactivity: he did not, he boasted, make war "alla Hussara". He now claimed the command in chief, and it was with the utmost difficulty that he was persuaded to allow Marlborough to command on alternate days. On the 22 nd the armies of the margrave and Marlborough effected a junction at Launsheim, about nine English miles north-west of Ulm. They numbered altogether 52,000 men. In Ulm lay 27,000 Bavarians under the elector and 36,000 French under Marshal Marsin; but so many of these were raw recruits that Marlborough was of opinion that, notwithstanding their numerical superiority, he could risk an attack in the open field. To Eugene was assigned the task, with 28,000 troops, of holding the intrenchments of Stollhofen in the west of Baden against the French army of the Upper Rhine, numbering 60,000 men.

The plan of Marlborough and the margrave was to entice the Bavarians from their defences by laying waste the north of their country. The united armies marched in a northnorth-easterly direction behind the range of hills bordering the north bank of the Danube. Donauworrth, on the north bank, a strongly fortified town, was their objective. If it could be taken it would furnish a base from which to operate.

1 Eugene to the Emperor, July 31, 1704, F. Heller, Militärische Korresponden: des Prinsen Eugen (Wien, 1848), ii., 186. 
CHAP. Max Emanuel, perceiving this and anxious for his electorate, III. marched out of Ulm along the north bank of the river and occupied a camp already intrenched between Lauingen and Dillingen. Thence he detached General d'Arco with a force to occupy the Schellenberg, a height on the Danube beyond Donauwörth. On July I Marlborough and the margrave, advancing towards Donauwörth, encamped at Amerdingen, about fourteen miles from the foot of the Schellenberg. The roads were drenched with rain and the army incumbered with heavy artillery. Time was pressing, for the enemy were expecting to be reinforced by Tallard. Moreover, the Schellenberg was being fortified with feverish haste, and Marlborough declared that every hour's delay would cost the loss of 1,000 men.

Availing himself of the fact that on the 2nd he was in supreme command, Marlborough ordered an advance at three in the morning of that day. By midday his advanced guard came upon the enemy, still busy completing the defences of the Schellenberg. As the main body could not come up till the afternoon, the margrave counselled postponement of the attack till next day. Marlborough insisted on an immediate assault. At six in the evening he gave the signal. The enemy made a desperate defence, costing the allies 1,500 killed and 4,000 wounded. But before night set in the Bavarian army was destroyed. Out of 10,000 men only 3,000 rejoined the elector. Donauwörth was occupied by the allies. Max Emanuel hurriedly broke up his intrenched camp and threw himself into Augsburg. Marlborough, having crossed the Danube at Donauwörth on July 5, advanced towards Augsburg from the east. The objects of his march, which was circuitous, were to subsist his army in the enemy's country, if possible to capture Munich, and to employ his cavalry in exhausting and destroying the resources of its environs.

Hearing that Tallard was on the march, Eugene left his lines of defence in Baden under the protection of a handful of troops and advanced along the northern bank of the Danube at the head of 9,000 foot and 6,000 horse. About the time (August 3) that Tallard effected a junction with the elector at Augsburg, Eugene reached the plain of Höchstädt on the Danube. The French and B prarians had now the advantage of position as well as of numbers. They could interrupt the 
communications of Eugene with Franconia and Würtemberg, or could overwhelm both Marlborough and the margrave CHAP. in a hostile country before these could effect a junction with Eugene. Marlborough anticipated this movement, and at once breaking up his camp at Friedberg retraced his steps in a northeasterly direction to Schrobenhausen. To this place, in order to concert operations, Eugene made his way on the 6th across about twenty-eight miles of country, free of the enemy, but intersected with rivers. The two agreed upon the bold step of detaching the margrave with 20,000 men to undertake the siege of Ingolstadt. By this measure, besides the prospect of securing a valuable post, they got rid of a commander who would undoubtedly have opposed their determination to attack the enemy in force. On the 9th they learnt that the French and Bavarian forces were advancing from Augsburg, evidently with the intention of passing the Danube at Lauingen and throwing themselves upon Eugene's troops, whom they outnumbered by nearly four to one. From Augsburg to Horchstädt would be a march of about twenty-seven English miles, with the river Zusam and several smaller watercourses to be crossed before reaching the banks of the Danube. As the whole country was under heavy rains this movement could not be executed with rapidity. The combined French and Bavarians crossed to the north bank of the Danube on the roth. Eugene on the same day, having rejoined his troops in the morning, retired eight miles towards Donauwörth, taking up a position behind the small river Kessel, about eleven miles separating him from the enemy. He now had, some three to four miles in his rear, Donauwörth and the Schellenberg, which had been freshly fortified by the allies. About ten miles intervened between him and Marlborough, crossed, however, by the Lech, the Danube, and, on the northern side of the Danube, the Wernitz. Everything depended upon whether he could hold his ground till Marlborough reached him with his main body.

The reconnaissances of the French were so ineffective that they did not know of Marlborough's line of march, and though they had heard of the diversion of the margrave and his'forces to Ingolstadt, they refused to credit the intelligence. ${ }^{1}$

1"M. Tallard declared that if they durst confide in their intelligence that Prince Lewis was left to besiege Ingoldstadt, they would have fallen upon us in 
CHAP. On the I Ith, therefore, they did nothing more than move some

III. seven miles down the northern bank of the Danube, as far as the neighbourhood of Blindheim or Blenheim, a village about three miles below Höchstädt, and within sight of the encampment of Eugene, whose army during the day was marshalled in expectation of an attack. Meanwhile, on the night of the Ioth, Marlborough at Rain, ten miles distant as the crow flies, received a dispatch from Eugene urging him to hasten his march. $\mathrm{He}$ at once ordered forward twenty battalions under his brother General Charles Churchill, who started at one in the morning, and by three o'clock the main army was in motion. ${ }^{1}$ By ten o'clock the next night the junction of Eugene and Marlborough was complete.

Even as late as the morning of the I 2 th the French still had an advantageous opportunity to attack. It had been necessary to leave the artillery to follow, and after a march of four and twenty miles it and the baggage had only arrived at daybreak. Marlborough's men were worn with fatigue, and he had had no time in which to plan his dispositions. The forces of the Grand Alliance numbered between .52,000 and 54,000 men; those of the combined French and Bavarians some 2,000 to 4,000 more. The Danube here flows in a north-easterly direction. Its valley, in which the battle known to us by the name of Blenheim was fought, stretches seven English miles in length, from the Kessel on the north-east to Dillingen on the south-west, and is of irregular breadth. Northwestwards the valley is skirted by broken and wooded hills, at Dapfheim only half a mile from the river. Midway between the Kessel and Dillingen the little river Nebel runs across the valley and pours itself into the Danube, east of the village of Blenheim which lies on the river bank. Here the valley is at its broadest, being nearly three miles. In the middle of the valley, lying north-eastwards of the Nebel, was the village of Unterglauheim. About 1,200 yards to the north-west, on the

our camp the day before." Metcalfe Graham to James Graham, giving a short account of Blenheim, August 23, 1704, Bagot MSS., p. 338, Hist. MSS. Comm., 1885 .

${ }^{1}$ Dispatch of Marlborough to Harley, giving an account of Blenheim, August 14, 1704, Thirtieth Report of the Deputy-Keeper of the Public Records, cviii., $31 \mathrm{r}$. 
French side of the Nebel, was the village of Oberglauheim, and CHAP. a mile and a quarter west of Oberglauheim was the village of Lutzingen, on the spur of the hills. The soil between Blenheim and Oberglauheim was marshy and the ground was seamed by numerous watercourses.

At two o'clock in the morning of the $13^{\text {th }}$ news was brought into the French camp that the army of the Grand Alliance was stirring. The right wing under Eugene was ordered to advance westwards into the hill country. It consisted of about 18,000 men, of whom nearly half were cavalry. The left wing under Marlborough numbered 34,000 to 36,000 men, the proportion of foot to horse being about three to one. It stretched down to the Danube and consisted of English, Dutch, Danes, Hessians, and Brunswickers. The duke's brother, General Churchill, was at the head of the infantry; the Princes of Würtemberg, Baireuth, and Hesse-Cassel held subordinate commands. Close to the Danube, to attack Blenheim, marched the corps of Lord Cutts. The distance between the two opposed camps was above five English miles. The French and Bavarian camp stretched across the valley at its broadest part, its right resting on Blenheim, its extreme left being in front of Lutzingen and on the spur of the hill beyond. As soon as it was realised that Marlborough and Eugene were marching to attack, a hurried consultation took place between the elector and the two French marshals, Marsin and Tallard. Their armies occupied a position offering distinct advantages for defence. ${ }^{1}$ From the spurs of the hills on their left artillery fire could be directed against the advancing enemy; the three villages of Unterglauheim and Oberglauheim in the middle of the valley, and of Blenheim on their right, could be strongly held, while in the neighbourhood of Blenheim were slight eminences affording positions for artillery.

Between seven and eight o'clock in the morning, the two armies were deploying with bands playing as if on a parade ground. Spectators have described the brilliancy of

1 The Earl of Orkney, who held the rank of major-general, wrote after the battle: "I confess it is intirely owing to my Lord Duke, for I decla ure, had I been to give my opinion, I had been against it, considering the ground wher they were incamped and the strenth of the army". Engl. Hist. Rev. (April, r904), xix., $31 x$. 
CHAP. the scene lit up by the morning sun. Eugene's advance III. through hilly country, overgrown with brushwood, was difficult and slow. Not till after midday did Marlborough receive a dispatch announcing his readiness to take part in a general attack. The duke had drawn up his troops in four lines. Contrary to the usual practice of the day, he had placed his infantry in the first and fourth, his cavalry in the second and third lines instead of on the flank. A slight space separated his left from the ten battalions of infantry, close to the Danube's bank, which had been detailed under Cutts for the assault on Blenheim. The village was defended by barricades and crowded with French infantry. Three assaults were repulsed with great loss. In the centre of the field of battle Marlborough's cavalry were twice routed by the French horse, while the German infantry attacking Oberglauheim were charged by the Irish brigade in the French service, and other regiments, and were cut to pieces. This was a critical moment, for the advance of the French would sever Marlborough from Eugene. Marlborough himself galloped to the spot and, charging at the head of some squadrons of the imperial cavalry which were at hand, drove the French back. Eugene's immediate command fared no better than the German infantry. His cavalry were three times dispersed by the French, and at four o'clock the attack all along the line had proved a failure.

It was at this crisis that the genius of Marlborough asserted itself by a complete change of plan, conceived in the confusion of a losing battle. He withdrew troops from the wings and concentrated on the centre, supported by the reserves. In a quarter of an hour his army was in a new formation, his cavalry in two lines in front, behind them two lines of infantry under General Churchill. His cavalry and the united cavalry of Tallard and Marsin were now face to face. Twice was the English charge repulsed, but the infantry, advancing in support, enabled the cavalry to reform. The fire of the foot threw the French horse into a slight confusion. At this moment the whole English cavalry in a long line extending from Blenheim to Oberglauheim charged for the third time. It broke the French squadrons and their rout revealed Tallard's blunder in denuding 
his centre of infantry in order to overcrowd Blenheim. ${ }^{1}$ The CHAP. French infantry in the centre were surrounded by the superior III. numbers of the English foot; a wedge was driven between the army of Tallard and that of Marsin on his left, and Tallard found himself a prisoner. The French horse dispersed, some making for the Danube, others for the hills. The Bavarians on the left wing of the French retreated in good order. Only the garrison of Blenheim, 9,000 strong, remained. They had missed the moment at which a sally might have given the cavalry time to rally and now vainly endeavoured to break through Churchill's infantry in the direction of Höchstädt. After sustaining a fierce assault by Lord Orkney at the head of eight battalions, they laid down their arms.

On the field of victory Marlborough, tearing a leaf from a commissary's memorandum book, scribbled with a lead pencil on the back of a bill half a dozen lines to the duchess, bidding her let the queen "know her army has had a glorious victory". The day had cost the allies 12,000 men killed and wounded, but the French and Bavarians in killed, wounded and prisoners had lost 28,000 men, besides almost all their artillery. Among the prisoners were a marshal of France and sixteen general officers. ${ }^{2}$ The battle of Blenheim marked the first great defeat of a French army in the field during the reign of Louis XIV., and the first great success which had fallen to the arms of the Grand Alliance. It saved Vienna, it delivered up Bavaria to the conqueror, it enabled the emperor to rally his forces to the defeat of the Hungarian insurgents, the allies of the French, it fortified the resolution of the German princes, it reinvigorated the war party in the Netherlands, and it confirmed the belief of Heinsius in the genius of Marlborough and discredited the former interventions of the field-deputies. In Spain it determined the defection of some influential grandees from Philip V. to the archduke. In Savoy it reanimated the resistance of the duke. But beyond all these effects, it stirred

'See Capt. R. Pope's criticism in Coke MSS., p. 40, Hist. MSS. Comm., 12th Rep., App., pt. iii.

'See letter of Capt. R. Pope, August 16, 1704, in Coke MSS., p. 40, and the list given by Marlborough's chaplain, Dr. Hare, in Hare MSS., p. 201, Hist. MSS. Comm., I4th Rep., App., pt. ix., 1895 . 
CHAP. the English nation to enthusiasm for the war, and depressed III. the high tories correspondingly.

Under the cover of darkness the broken regiments of the French and Bavarians made for Lauingen, about nine miles in their rear, and crossed the Danube. The exertions of the Elector of Bavaria restored some semblance of order to the fugitives. Marlborough and Eugene did not follow up the retreating enemy. They were incumbered with wounded and prisoners, and Marlborough, who had been seventeen hours in the saddle on the day of Blenheim, and had had only three hours' sleep the night after the battle, was incapacitated for further exertion. On the 14th, therefore, he and Eugene marched up the bank of the Danube to Steinheim, little more than four miles. Here they remained four days, resting their troops and dividing the prisoners, who numbered 11,192 men. ${ }^{1}$ It was with difficulty that they succeeded in persuading the margrave to relinquish the siege of Ingolstadt, where he had already made some progress, and from which he hoped for compensation for having failed to share Marlborough's glory. On the 23rd they marched to Sefelingen, within an English mile of Ulm. Here they were joined by the margrave and his army, which, after a halt of five days, they left to undertake the reduction of that city. With the remainder of their forces they marched towards the Rhine. Through the defiles of the Black Forest the French retreat was little better than a flight. Starved for provisions, since their stores had fallen into Marlborough's hands, short of waggons, weakened by desertions, dispersed by attacks of the peasantry, their numbers were reduced when they were met by Marshal Villeroy, who had followed Marlborough's tracks, at the entrances of the passes to the Black Forest, to scarcely 20,000 men.

In the state of discouragement into which so large a part of the French forces was thrown, an invasion of Alsace appeared to Marlborough and Eugene to promise success. But they reckoned without the margrave and the German generals, who preferred the familiar and less hazardous course of an

'Many French soldiers separated from the main body surrendered during some days after the action to escape being murdered by the peasantry. James Brydges to Thomas Coke, August 19, 1704, Coke MSS., p. 42. 
investment. Marlborough accordingly agreed to a siege of CHAP. Landau by the margrave as a step to securing the principal III. fortresses on the Moselle, where he contemplated a campaign in the following year. While covering the siege in concert with Eugene, he strengthened the position of the allies by carrying through negotiations entered into by the Electress of Bavaria. By the convention of Ilbesheim on November 7 , the Bavarian garrisons were surrendered to the emperor, the electress being guaranteed in exchange sufficient revenues and a residence in Munich. As a base for the campaign on the Moselle, Marlborough surprised and captured Treves on October 29. On November 24, when the siege of I andau was approaching a successful conclusion, he visited Berlin, where Frederick I. was wavering between territorial aggrandisement at the expense of Poland and the prospect of subsidies for maintaining the extravagance of his court. Fresh with the glory of Blenheim upon him, he succeeded in persuading the king to sign a treaty promising 8,000 more men for next year's campaign in Italy. On December II Marlborough embarked for England, accompanied by Marshal Tallard and other distinguished prisoners, and with the standards and colours, the trophies of his victory.

Marlborough, before leaving for Holland in April, I704, had concerted with Rooke an attack upon Toulon in cooperation with a land force under the Duke of Savoy. On May 8 Rooke left Lisbon for Nice with thirty English and nineteen Dutch sail of the line, besides frigates and smaller vessels. The troops at his disposal consisted of 1,900 English and 400 Dutch marines. Prince George of Hesse-Darmstadt accompanied him with 5,000 men under his command. In the meanwhile the English government learnt that the Duke of Savoy, unable to maintain himself in the field against the overwhelming numbers of the French, was unequal to assisting in any attempt upon Toulon. It therefore ordered Rooke to watch for and intercept the fleet of the young Count of Toulouse, the son of Louis XIV. and Madame de Montespan, in the event of its evading Sir Clowdisley Shovell, who was cruising in the Channel to prevent its escape from Brest. Rooke put about, and on the 7 th caught sight of the French fleet. Failing to overtake it, he, on June 27, N.S., effected 
CHAP. a junction with Shovell and twenty-three sail of the line at III. Lagos.

At the head of a fleet of seventy-two ships, carrying with troops 30,000 men, Rooke was now in a position to make a fresh attempt upon Cadiz. But four successive dispatches from Methuen, our ambassador in Portugal, urging him to this or, in the alternative, to the capture of Port Mahon, were disregarded by him on the plea that the army was not adequate to the task. Prince George then, it is said at the suggestion of Vice-Admiral Sir John Leake, wrote a formal proposal to Rooke to substitute for an attack on Cadiz an attempt on Gibraltar. It was time something was done. The court of King Pedro and that of the archduke were both irritated at Rooke's supineness and a second Vigo was scarcely likely to follow a second Cadiz. On August I, N.S., Rear-Admiral George Byng with seventeen ships and three bomb vessels, sailing from Tetuan, anchored in the bay of Gibraltar. Rooke followed with the remainder of the fleet on the next day, and landed Prince George with the marines and a body of Spanish troops for the assault of the landport gate. The prince, after repulsing a sally of a few horsemen, sent the governor a summons to surrender. The whole garrison numbered no more than 470 men, and of these only eighty were regulars. French engineers had recently designed some new fortifications, but not one of them had been carried out. A bombardment of about six hours sufficed to compel the garrison to offer terms. By a capitulation of August 6, drawn up by Prince George, they were allowed to march out with arms and baggage, but the inhabitants who should stay were to take the oath of allegiance to Charles III. ${ }^{1}$ The loss of the allies, chiefly the result of the blowing up of a fort, was sixty-one killed and 252 men wounded. This was the first conquest for Charles III. in Spain.

Rooke, leaving Gibraltar in order to winter at Ceuta, dispatched a considerable number of vessels for various services,

1 This was in accordance with the instructions of Nottingham to Ormonde on the occasion of the expedition against Cadiz (June 19, I702): "Her majesty is resolv'd that upon taking or the surrender of that (Cadiz) or any other place, the burghers shall take an oath of fidelity to the Archduke, tho' the garrison to be left by your grace shall be entirely under her majesty's orders and commands". Hist. MSS. Comm., 7 th Rep., App., p. 763. 
and on the IIth worked eastwards in search of the French CHAP. fleet, which had emerged from Toulon. Its nominal comIII. mander was the Count of Toulouse, its real commander was D'Estrées, an admiral then in his eightieth year. The French fleet consisted of fifty sail of the line, six frigates, and twentyeight large galleys, besides fireships and tenders, carrying 3,577 guns and $24,275 \mathrm{men}$. The allies had fifty-one sail of the line and six frigates, two bomb vessels and some tenders and fireships, but only seven of their ships, as contrasted with seventeen of the French, were three-deckers. . On August 24, the allied fleet, having passed the French fleet on the night of the 22nd, was sailing westwards off Malaga, before a light easterly wind, when it came in sight of the enemy. The French on seeing them hove-to in a crescent-shaped line of battle. The allies advanced slowly in échelon, Vice-Admiral Sir John Leake leading the van, under Sir Clowdisley Shovell's command. The centre of twenty-six sail was under Rooke, the rear was made up of twelve Dutch ships under Callenburg. The battle lasted from ten o'clock in the morning till seven at night. Before it was over the ammunition of the English, which had been depleted by the bombardment of Gibraltar and the provision of a magazine there, began to run short and nine ships had to be towed out of action. ${ }^{1}$ The battle was indecisive, except that the Dutch drove the French rear out of action; but there was not a vessel captured, sunk, or burnt on either side. During the night Rooke carefully redistributed his remaining ammunition. The French, however, who had suffered equally, did not renew the fight on the following day, and the two fleets remained within sight of each other. At night, doubling northwards in the darkness, the French fleet made for Toulon. The French had lost heavily, 3,048 of their number being killed and wounded as compared with 2,7 18 of the allies. Rooke left sixteen sail of the line under Leake to winter at Lisbon and himself returned to England (September 10-2 I).

The capture of Gibraltar made little impression upon the English people. It is true that the greater part of the garrison

2 "Five of our biggest in the middle," that is, in Rooke's division. James Brydges to Thomas Coke, September 14, 1704, Cowper MSS., iii., 45. 
CHAP. were English, ${ }^{1}$ but Rooke, before leaving, had written to Pedro III. II. and the archduke, requesting them to supply the whole garrison. Harley, either having a wider outlook or anxious to say the best for a ministry of which he was a member, wrote to the Duke of Newcastle as a parenthesis in a gossipy letter : "The taking of Gibraltar may turn to great account, it being the greatest thoroughfare in the world ".2 The ministry consulted Marlborough. He replied to Hedges that "no cost ought to be spared to maintain it," and a dispatch of October Io from the lord high admiral to Leake at Lisbon acquainted him with the resolution of the government to undertake it. Such were the slow and reluctant steps by which this great possession was finally acquired. The efforts of the Spaniards and French for its recapture were the most potent factors in the education of the public opinion of the country as to its value. With regard to Rooke's battle off Malaga the public exhibited a much more lively concern. Whether the ineptitude of his previous conduct as a naval commander had been due to ill-health or to a fear of responsibility, he had lost credit. But a battle had been fought, and a victory at sea was essential to the glory of the tory party and of their naval hero. The shrewd Godolphin, indeed, was not deceived. "Upon the whole," he sums up, "it seems to have been a sort of drawn battle where both sides had enough of it." 3 The Count of Toulouse returned to Toulon, boasting that he had driven the allies out of the Mediterranean, and Louis, with paternal pride, had a medal struck to commemorate the victory. On the other hand, it was to be said that Toulouse had weighed anchor to retake Gibraltar and that Rooke had baulked his design. It may be added now that the French never again during the war pretended to sweep the Mediterranean with a grand fleet. Naval supremacy remained, though not altogether uncontested, with the allies.

Louis was little disposed to brook the desertion of Portugal to the Grand Alliance. In February, I 704, he dispatched James Duke of Berwick, the son of Jamires'II. by Marlborough's sister,

1 "For its security he (Rooks) hath left 2,000 marines in garrison." James Brydges, M.P., to Thomas Coke, September 14, 1704, Cowper MSS., iii., 45.

2 Portland MSS., ii., 186, September 5, 1704.

3 Godolphin to Harley, September I4, I704, Bath MSS., i., 62. 
Arabella Churchill, to take command of the French and Spanish troops in the peninsula. Berwick had already acquired a high CHAP. reputation as a commander in the French service. He determined to anticipate the allies, and on May 4 at the head of 28,000 men, crossed the frontier of Portugal. To meet him the allies mustered at Lisbon some 5,500 English ${ }^{1}$ under Meinhart, Duke of Schomberg and Leinster, 3,500 Dutch under General Fagel, and 20,000 Portuguese. As the invaders advanced in two divisions, the northern column in the direction of the Douro, the southern towards Lisbon, two armies were organised to meet them. The northern army was under the Marquis das Minas, an expert veteran of seventy years. The English and Dutch were assigned to the southern force.

Early in May the combined English, Dutch, and Portuguese troops took post in the neighbourhood of Elvas with the object of disputing Berwick's advance on Lisbon. Unfortunately Schomberg lacked both the military genius and the conciliatory temper of Marlborough. His disputes with the Dutch general Fagel ran so high that Fagel marched out of the camp at the head of his men with the intention of joining Das Minas. As Berwick advanced, one fortified place fell after another with little or no resistance. But in the north the fortune of war was otherwise. Das Minas drove the Spanish general Ronquillo back across the frontier, baffled the endeavours of Berwick, who hastened to his lieutenant's assistance, to force an action, and finally, aided by the southern army, compelled the entire invading force to retreat. The result of the campaign was that while Berwick could boast the capture of several garrisons, including two English regiments, Stanhope's and Stewart's, surrendered by their Portuguese general, Das Minas was acclaimed as the saviour of Portugal. Schomberg, quarrelsome, sluggish, and incapable, was recalled to England at the request of the court of Lisbon. In his place Marlborough selected a French refugee officer, Henri de Massue de Ruvigny, Earl of Galway. Galway had been raised to the Irish peerage for his distinguished military services, and seems in some respects to have resembled Marlborough himself. $\mathrm{He}$ is, wrote Godolphin, "one of the finest

1 On paper 6,500, but see the Duke of Ormonde to General Earle, May 16, 1704, Ormonde MSS., p. 771, Hist. MSS. Comm., th Rep., App. 
cHAP. gentlemen of the army, with a head fitted for the cabinet as III. well as the camp". He arrived in Lisbon on August 10, with a view to an autumn campaign. But the Portuguese organisation was too defective for an invasion of Spain, and Berwick's intrenchments on the river Agueda too formidable to be taken by storm. At the beginning of October the AngloPortuguese army retired into winter quarters.

Since the return of Rooke to England, Prince George of Hesse-Darmstadt had been left in command at Gibraltar. His garrison numbered 2,442 men of whom nearly 2,000 were English marines and 400 Dutch. At the instance of Louis XIV., whose abortive design for its fortification shewed that he appreciated its value, the Spanish government resolved upon its recapture. With this purpose General Villadarias, at the head of 8,000 Spanish troops, sat down in front of it early in September. He was supported by 4,000 French marines, landed from Toulon on October 4 by the French Rear-Admiral de Pointis, who with his fleet of fourteen sail of the line and seventeen frigates made for the harbour of Cadiz, whence he could issue to intercept relief from Lisbon. The superior artillery of the besiegers made breaches in the fortifications and gradually silenced the guns of the garrison. A plan to deliver a grand assault with 3,000 men on the night of November ro was frustrated by the appearance on the 9 th of Sir John Leake at the head of a squadron bringing munitions and supplies. Leake sailed home on December 13 to hasten reinforcements. By that time the garrison was weakened by sickness, on December 2 only 1,000 men being fit for duty. At the end of the month, 2,500 English and Dutch troops were landed. On the other side, 4,000 men, chiefly French, joined the besiegers as a reinforcement from Marshal de Tessé, who had superseded Berwick as commander-in-chief of the French forces in Spain. On March 21, 1705, Leake, at the head of a fleet of thirty-five ships, eight of them Portuguese and one Dutch, entered the bay with reinforcements, surprising part of a squadron of De Pointis, of which he captured three and destroyed two ships. Tessé, who had arrived in February, now despaired of success. On April 23 he set out for Madrid, and the siege of Gibraltar was at an end. The moral and material importance of the defeat of the Bourbons 
was very great. The result produced sensible effects both in CHAP. England and Spain. It greatly strengthened the Austrian III. party in Catalonia and Aragon. In England it aroused popular interest in the maintenance of the fortress. Towards this end there seemed to be two principal means; the acquisition of a Mediterranean harbour in which an English fleet might winter and the destruction of the arsenal of Toulon.

The political capital sought to be made by the two parties out of affairs abroad was exemplified by the addresses of the two houses upon the opening of parliament. The lords contented themselves with a reference to Blenheim, the commons added to Blenheim a clause congratulating the queen on "the victory obtained by your majesty's fleet under the command and by the courage of Sir George Rooke". "My Lord Marlborough's friends," commented Stepney, "thought that and Blenheim ought not to be mentioned on a day." 1 Nevertheless, the coupling of Blenheim and Malaga became the mot dordre of the High Church party, and even of the Jacobites. ${ }^{2}$ This transparent trick, while it outraged common sense, was repugnant to the queen's sense of gratitude. The resentment she felt was shewn by the promotion of Sir Clowdisley Shovell in Rooke's place as admiral and commander-in-chief of the fleet. Rooke, though on this occasion his conduct had been unexceptionable, was never employed again. Marlborough, on the other hand, was granted the royal manor of Woodstock with the consent of parliament, and received a promise from the queen of the palace now known by the name of Blenheim.

The queen's speech at the opening of parliament, October 29, 1704, expressed, at some length and with unmistakeable significance, her trust that there would be "no contentions" between the houses. But the tory majority in the commons were committed to an irreconcilable position by the fatal inheritance of the occasional conformity bill. To shirk their pledges would have cost its author, Bromley, his seat for the University of Oxford, and the tory party generally the support

'Stepney to Shrewsbury, Vienna, November 11-22, 1704, Buccleuch MSS., ii., 2, 703 .

" His (Rooke's) health is now drunk by those who won't drink the queen's health, nor yours." De Foe to Harley, September 28, 1704, Portland MSS., iv., 136.

VOL. IX. 
CHAP. of the clergy at the coming general election. It was at first

III. resolved, at a private meeting of the party, ${ }^{1}$ not to vote the supplies until the lords had passed the bill. But at, it is said, the insidious suggestion of Harley, ${ }^{2}$ who was still speaker, the more offensive course threatened by Seymour was decided upon. The occasional conformity bill was to be sent to the lords tacked to a money bill. This proposal, as was doubtless foreseen, at once enlisted in the opposition the conservative instincts of the more moderate churchmen, roused in the lords uncommitted to the whig party the instinct of self-preservation, and ranged the influence of the services against the whole measure. Lord Cutts, one of the heroes of Blenheim, warned the party, of which he was himself a member, that the stoppage of the supplies consequent on the tack would break up the Grand Alliance. There was a defection from the middle party to the whig view. The high churchmen were beaten on the question of a tack by 25 I to I 34 votes. The bill was read a third time on December I4, but its sting had been drawn. It was thrown out by the lords the next day, after a perfunctory debate upon the second reading, by $7 \mathrm{I}$ to 50 votes.

By the end of the year two rebuffs had been suffered by the High Church party. They had failed in the tack, and the common sense of parliament and the country had gone against their reckless counsels in a crisis, to be narrated hereafter, which had arisen in England's relations to Scotland. But they were still resolute to get rid of Godolphin, who alone stood in the way of an administration which Rochester and Nottingham would inspire. On Godolphin's side there was no blinking the fact that he and they had broken for ever. "I shall never," he wrote to the Duchess of Marlborough, "think any man fit to continue in his employment who gave his vote for the tack." Godolphin only expressed the feeling of the time that "the Queen's servants" were generally expected to vote against measures discountenanced by the court, very much as members of a ministry are now expected to support their chief. And that the attitude of the court towards political parties had changed

1 Godolphin to Harley, November 8-19, I704, Bath MSS., i., 35.

2 "I hope everybody will do you the justice to attribute the greatest share of it (the defeat of the bill) to your prudent management and zeal for the public." Marlborough to Harley, December 16, 1704, ibid., p. 65 , 
was shewn by a significant warning in the queen's speech at the CHAP. close of the session, March 14, 1705, against "any dangerous III. experiments for the future".

The end of the year 1704 was rendered stormy by the revival under a new form of the Aylesbury election controversy. During the recess, Ashby had obtained execution upon his judgement as delivered in the house of lords. Thereupon five other burgesses of the town of Aylesbury, whose votes had also been rejected by the constables, brought actions for damages. No step was taken by the house of commons against Ashby, but the five who followed his example were committed by the house to Newgate on December 5, for breach of privilege. A majority of the judges of the queen's bench holding that a writ of habeas corpus could not issue against the house of commons, the prisoners petitioned for a writ of error. Their case was then taken up by the house of lords, who passed a resolution that a writ of error was a writ of right, and could not be denied by the crown (March 14, 1705). To an address of the lords in this sense, the queen answered that "there was an absolute necessity of putting an immediate end to this session". The prisoners were thereby released, the house of commons having no jurisdiction to continue an imprisonment beyond its own session. Only the constitutional lawyer is left to regret that by this evasion the important issues raised remain to this day undetermined.

In accordance with the provisions of the triennial act, a proclamation for dissolving Queen Anne's first parliament was issued on April 5, 1705. The increased influence of the whigs had become apparent. The queen had for a year resisted the desire of Godolphin and Marlborough to dismiss the Duke of Buckingham, but on April I the privy seal was transferred to the Duke of Newcastle, ${ }^{1}$ whose house was the social centre of the whig party. It was remarked as significant that on April 8 the queen dined with Lord Orford, who, with Somers, Wharton, Halifax, and Sunderland composed the whig direction which went by the name of "the Junta". The exasperation of the high churchmen at these symptoms of the abandonment of their party by its chief support knew no bounds.

'Godolphin to Harley, Bath MSS., i., 67. 
CHAP. There was a war of pamphlets. Of these, that which played III. the greatest part in the tory interest was a joint production by a physician named Drake and some others with the title The Memorial of the Church of England. This reflected directly on the queen, as giving "comfortable speeches and kind assurances" to those who would destroy the Church. It created great indignation, and on a presentment by the grand jury of Middlesex as " a false, scandalous, and traitorous libel," was ordered to be publicly burnt. The whigs revenged themselves by publishing lists of the tackers, and in The Character of a Tacker and Anti-Tacker, holding them up to public contempt. No sooner was it evident that the elections were a triumph for the whigs than Godolphin shewed his perception that the time had come to repay their services. Both he and Marlborough had long writhed under the annoyance of the cabals of Sir Nathan Wright, the incompetent lord keeper. Wright owed his place to his zeal as a churchman, and now that his party had broken with the queen, "it would have been too ridiculous to have continued it longer in his hands". The new lord keeper, William Cowper, appointed on October II, was a whig who adopted a somewhat independent attitude to the junta, but was of conciliatory address and personally acceptable to all parties. ${ }^{2}$ A few High Church privy councillors were dismissed. Addison was made an under-secretary of state. The satisfaction of the whigs by the admission of their leaders to office was still postponed, but a friendly understanding, it was generally believed, had been established between Godolphin and the junta.

The new parliament met on October 25, 1705. The first trial of strength in the house of commons was a contest for the speakership. The candidate of the ministry was John Smith, a former commissioner of the treasury and, at the end of William III.'s reign, chancellor of the exchequer. On the other side was Bromley, the leader of the tackers. Smith was elected by a majority of forty-three votes, and his victory was interpreted as a sign that the court party was now de-

${ }^{1}$ Godolphin to. Harley, October 1, 1705, Bath MSS., i. 64 (wrongly dated by editor 1704 ; see ibid., p. 78).

" "I am very glad you are so well pleased with Lord Keeper." Marlborough to Harley, June 27-July 3, r706, Bath MSS., i., 82. 
finitely allied with the whigs. ${ }^{1}$ The queen's speech contained two notable passages. The first was an exhortation to parliament to continue the war until France was dispossessed of Spain, the balance of power restored, and the trade of the country preserved from extinction by French monopoly. It was a word in season, for in August the French had opened confidential communications with the Grand Pensionary Heinsius. The pensionary wavered and Marlborough became uneasy. If not sated with glory, he was at least wearied with disappointment, and his letters spoke longingly of retirement. But he was firmly convinced that Engiand could "never consent that the Indies and Spain should remain in the hands of the Duke of Anjou". Godolphin and Harley shared his views. The queen's speech was directed to determine the hesitation of the Dutch. ${ }^{2}$ The other point of the speech was one personal to the queen. The suggestion that she was betraying the interests of the Church, to her zeal for which she had so publicly testified, stung her to the quick. She referred with "warmth" to the malice of the pamphleteers and, after protesting her devotion to the Church, she added a paragraph which shewed how far she had travelled from the High Church party in the course of the past three years-"I will inviolably maintain the toleration".

On November 15 Lord Haversham in the house of lords hurled the tory defiance. The queen herself was present, but such was the recklessness or the exasperation of the tories, that Haversham made no scruple to assail her conduct in taking notice of the disputes between the two houses. After attacking the ministry for the failure of the campaign on the Moselle, he concluded with a motion for an address to the queen to invite the Electress Sophia to reside in England. He was supported by the tory leaders, by Rochester, Nottingham. Anglesey, and Buckingham; their argument being that the proximity of the pretender would enable him to seize the throne in the event of the queen's unexpected death. The whig leaders watched the course of the debate. They saw the

1 Porlland MSS., iv., 250.

2 The Duke of Shrewsbury, then at Frankfort, notes in his diary under November 1, 1705: "The Duke of Marlborough came and drank tea with me. ... His discource was to show how averse the Queen of England was to a pence." Bucclouch MSS., ii., 2, 794. 
CHAP. ministry hostile to the proposal and the annoyance of the III. queen. They seized the opportunity of ingratiating themselves with the court, and defeated the motion. The queen, on her side, made no secret of her change of feeling. "I believe," she wrote to the Duchess of Marlborough, "dear Mrs. Freeman (the duchess) and I shall not disagree as we have formerly done; for I am sensible of the services those people (the whigs) have done me that you have a good opinion of, and will countenance them, and am thoroughly convinced of the malice and insolence of them (the tories) that you have always been speaking against." At the court of Hanover feeling ran in the opposite direction. The Electress Sophia never condoned the whig desertion.

The tory argument that the pretender might find the government unprepared had not been lost on the whigs. It was suggested by Burnet that the most effective mode of proving the attachment of their party to the protestant succession, and at the same time of redeeming their credit with the court of Hanover, was to take timely precautions against the indicated dangers by the constitution of a regency to come into legal existence at the queen's death. The regency bill, introduced by Lord Wharton, nominated seven of the most eminent officers of state, the archbishop of Canterbury, the lord keeper, the lord treasurer, the lord president of the council, the lord privy seal, and the lord chief justice of England, with power reserved to the successor to add to their number. The regents were, upon the queen's death, to proclaim the next sovereign; and the last parliament, even though dissolved, was to be summoned again and to continue sitting for six months. ${ }^{1}$ A bill was passed at the same time for naturalising the electress and her issue. ${ }^{2}$ As a consequence of the regency act, the statute of 1700 as to the tenure of places under the crown by members of the house of commons needed revision. An act followed ${ }^{3}$ by which members accepting a place of profit under the crown ipso facto vacate their seats, but are eligible for re-election. This act survives to our own day, an obsolescent evidence of the jealousy felt by our ancestors of the influence of the sovereign.
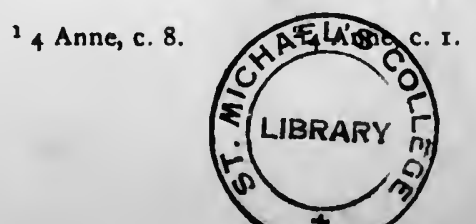

5 Anne, c. 8. 
The junta now made use of the obtuse fanaticism of Rochester to strengthen the unfavourable disposition of the queen CHAP. towards the High Church party. Halifax laid a trap into which Rochester readily walked. He moved an inquiry into the dangers alleged to be threatening the Church. In the queen's presence Rochester paraded once again the propositions which excited her indignation, the necessity of sending for the Hanoverian heir, and of passing the occasional conformity bill. The question whether the Church of England was in danger was negatived by sixty-one to thirty votes, and a resolution was passed by the lords that "whoever goes about to suggest and insinuate that the Church is in danger under her majesty's administration is an enemy to the queen, the Church, and the kingdom". Against this resolution the High Church leaders entered a formal protest. A debate on the same subject in the house of commons resulted, on December 7 , in a concurrence with the lords by 222 to 161 votes. Both houses then agreed on an address to the queen, asking her to take measures for the punishment of the authors and spreaders of these "scandalous and seditious reports". A proclamation to this effect was issued, and the apprehension of the printer of "The Memorial" ordered. Parliament was prorogued on March 19, 1706. For the first time for some years, the session had ended with harmony between the two houses. The triumph of the whigs appeared complete.

Ireland reproduced, though with strong local colouring, the political and religious struggles that divided England. It was reckoned against Rochester that during his shadowy viceroyalty he had done nothing more than add to the divisions already distracting the country. Before his time, it was said, papist and protestant was the only marked line of cleavage: after him divisions were set up among protestants. Churchman and dissenter forgot "the common enemy" to fly each at the other's throat. It is impossible to lay down with any degree of assurance the numbers of the different denominations. Despite the fact that the toleration act of William III. did not obtain in Ireland, the nonconformists boasted in the reign of Anne that they at least equalled the protestant episcopalians, while in Ulster they outnumbered them. They were recruited by a steady stream of Scottish 
CHAP. presbyterians, members of a Church dominant in their own III. country and the suppression of which in Ireland no statesman would venture to undertake. They received a quasi-recognition by the contribution called the Regium Donum to the support of their ministers, amounting to $£ 1,200$. Originally granted by Charles II., but dropped by his successor, it was maintained by Godolphin, despite the protests of the convocation of Ireland and of both houses of the Irish parliament. The governing classes, both lay and clerical, were united against presbyterianism. The "sin of schism," which the bishops saw in it, had a side which obtruded itself upon the lay landowner. "The true point," wrote Archbishop King, "between them and the gentlemen is whether the presbyterians and lay elders in every parish shall have the greatest influence over the people, to lead them as they please, or the landlords over their tenants.".

It was hoped that with the resignation of Rochester in February, 1703, the dissension which he had infused into Irish protestantism would have spent its force. Unhappily, the Duke of Ormonde, who succeeded him, was controlled from England by Rochester's ally Nottingham. ${ }^{1}$ Some mystery, however, still hangs about the origin of the blow dealt at the Irish nonconformists by the hands of the English ministry of 1704. A bill was passed by the Irish house of commons in November, 1703, "to prevent the growth of popery" 2 framed upon the lines of the similar act of $1700 .^{3}$ To the severities of this statute the Irish act added that the old English law of gavelkind should be applied to estates, unless the persons on whom they were

1 The duke has been represented by Tindal (History of England, iii., 523, ed. I763) as animated by the mischievous bigotry of Rochester, but two of Ormonde's letters discredit this view of his disposition. On December 26, 1703, he expresses his disapproval of the occasional conformity bill (Ormonde MSS., p. 768). In another letter he says: "I have gott the Queen to lett me have a summe not exceeding I,200 per annum, to be disposed of amongst those Presbyterian ministers that will behave themselves so as to deserve her Majesty's favour and bounty" (Ormonde to Lord Mount Alexander, January 9, 1704-5, ibid., p. 77r). If this refers to the Regium Donum, it must be remembered that its withdrawal had been demanded by the Irish convocation, and was one of the first acts of the High Cburch ministry which followed Godolphin's fall. That the duke was bostile to the Roman catholics is apparent from the satisfaction implied in bis letter to Lord Coningsby of February 27, I703-4, at the fruitlessness of their protests against the act (Ormonde to Coningsby, ibid., p. 719).

$$
2 \text { Anne, c. 6, Ireland. } 11 \text { \& } 12 \text { W. III., c. 4. }
$$


settled should contorm and take the oaths. The insertion of CHAP. this provision redeems the act from being one of mere religious III. persecution. From the division of estates equally among the children of papists the political result looked for was, that the aggregation of land in the hands of great owners, with an army of dependants and an implacable hatred of constitutional rule, would be prevented. It was an arrangement which for centuries was the law in Kent; and it was introduced into France at the revolution as the equitable ideal which it would require a second revolution to overturn. But when the bill came back from England in 1704 a clause was found to have been added, that no one in Ireland should be capable of any employment or of being in the magistracy in any city who did not qualify by receiving the sacrament in accordance with the provisions of the English test act. This insertion has been imputed to Godolphin. But a recently published document shews that Godolphin was indifferent on the matter ${ }^{2}$ and his behaviour with regard to occasional conformity is evidence that he was not disposed to incur the risk of political collisions for the sake of the dissenters. In England the lay adviser on ecclesiastical affairs was Nottingham.' There need scarcely be doubt as to the parentage of the clause.

Subordinate though it was both to the English privy council and the English parliament, the Irish parliament enjoyed sufficient initiative to give importance and interest to its deliberations and to attract the talent of the educated class, the protestant episcopalians. Notwithstanding the necessity of an ultimate dependence upon England, of which a minority legislating for a nation could not but be sensible, it was not in human nature that the dominant class should view with abject submissiveness the ruin of their country by English interference. There was, indeed, an "English interest," to some of whom, being Englishmen, such an attitude was natural, while others adopted it as profitable to themselves. This party included the officials, with the lord-lieutenant at their head, the greater number of the bishops, who were for the most part

2 Ormonde MSS., p. 776.

2" Lord Nottingham lays his hand on all Church preferment," etc. William Graham, Dean of Carlisle, to his brother, James Graham, Windsor, June 30, 1703, Bagot MSS., p. 337. 
CHAP. Englishmen, and some great landlords whose habitual resid-

III. ence was in England. The "Irish interest," which formed the opposition, was for the most part composed of the smaller landowners who, while they recognised that they were regarded by the Celtic race as intruders, yet looked upon themselves as champions of Irish nationality when it came into conflict with English pretensions. They were supported by the very small number of presbyterians in the house, at no time exceeding twelve, whose interests lay in commercial and industrial freedom, and who had suffered directly by English legislation. They also enjoyed the influential alliance of Trinity College. Their leader was William King, who had been translated in I 703 from Derry to the archbishopric of Dublin. In the house of lords the "English interest" was predominant. It was maintained by the spiritual peers, who as a rule outnumbered the laymen owing to the absenteeism of the great iandlords. The natural disposition of the upper house, therefore, was to support the ascendancy of the protestant episcopalian body as well against the protestant nonconformists as against the Roman catholics.

The spectacle presented by Ireland in I703 rallied the "Irish interest" in the house of commons in favour of a proposal which, if English commercial jealousy had tolerated its realisation, would have restored more than the prosperity of which the country had been robbed. The house addressed to the queen a "representation" of the grievances of the nation. They recapitulated the disastrous consequences to the protestants of the suppression of the woollen manufacture; they dwelt upon the corruption and absenteeism prevalent among the officials, and they made an alternative demand-either for a restoration "of the full enjoyment of their constitution," which meant the abolition of the control of the English privy council under Poynings's act, or free trade and union with England. 


\section{CHAPTER IV.}

THE NETHERLANDS AND THE PENINSULA.

AT the close of the campaign in December, 1704, Marlborough, by his occupation of Trèves, had disclosed his CHAP. intention of an invasion of the Moselle district. It became necessary for the French after their severe losses in men and munitions to redistribute their forces. The imperial army, no longer thrown on the defensive, would be free to take the initiative on the Upper Rhine, and, with Landau as a base, to threaten Alsace. The troops of the maritime powers, with their headquarters at Trèves, were free to co-operate with it ; while on the other side, between Trèves and the Netherlands, the communications were open. The defence of Alsace was entrusted to Marshal Marsin. As the Margrave of Baden would be the general opposed to him, and the marshal's instructions were to act on the defensive, comparatively little anxiety was felt at Versailles. Greater importance attached to the army of Lorraine, which had its headquarters at Thionville and was commanded by Marshal Villars. It formed a link, corresponding to the allied army at Trèves, between Marsin on the Upper Rhine and Villeroy and Max Emanuel in the Netherlands. Upon this army, it was anticipated, would fall the brunt of Marlborough's attack. On the duke's arrival at the Hague on April 3/14 for the campaign of 1705, he found himself confronted with innumerable difficulties. The Dutch had relapsed into their former nervousness. Five weeks were spent in wrangling ere he could extort assent to his plans. He reckoned that after effecting a junction with the Margrave of Baden, he would be at the head of nearly 90,000 men. Against these the army of Villars was estimated at 60,000 . Yet at the end of May the imperialist 
CHAP. forces had not arrived at Trèves, and his whole force conIV. sisted of but 30,000 English and Dutch. To parry his anticipated invasion of the heart of France, the French resolved on a diversion. In June Villeroy captured in succession both Huy and Liege, and at once a clamour arose among the Dutch for Marlborough's return to the Meuse. He had no choice but to comply. Scarcely had he set out when the Palatine general, Aubach, whom he had left in command of Trèves, surrendered to the French with the provisions and munitions stored there. His plan of campaign was wrecked. He himself, broken with disappointment and illness, expressed a longing to retire.

Villeroy, upon Marlborough's approach, withdrew his army of 70,000 men within the French lines, a formidable barrier, the construction of which had occupied three years. It was in shape an arc, of which Namur was at one, Antwerp at the other extremity. Three rivers, the Great and Little Gheet and the Demer, were connected with elaborate earthworks. It was impossible for Marlborough to allow the enemy to occupy a position which threatened his base. On the night of July 17 , having deceived Villeroy by a feint, he forced the lines at the point occupied by the Bavarians, broke their resistance by a cavalry charge headed by himself, and drove the whole French army to retreat upon Louvain. Whether because of Marlborough's weak condition, for he writes on the next day that he could hardly hold his pen, or because the Dutch generals refused to march further, 1 the enemy was not pursued. Had the advantage been hotly pressed, wrote Villeroy to Louis XIV., they must have been destroyed. A number of colours, standards, and cannon and 1,200 prisoners,

1 This is an assertion of Coxe which Von Noorden (ii., r67) disputes as unconfirmed by Marlborough's correspondence; but one of his field officers, Major Cranstoun, in a long account he gives of these events, says: "I believe it is agreed that he (Ouwerkerk) had sent to tell the duke that his troops were wearied and could not march much farther ". Cranstoun also supports the duke's decision to halt by saying that, as Ouwerkerk had not joined him, he might have been attacking the whole French army, the distance of the elector and Villeroy being unknown, with only half his own forces (J. Cranstoun to Robert Cunningham, Herenthals, October x, x705, Portland MSS., iv., 250). Lord Orkney, who was in the affair, wrote on July 20: "You cannot believe how it (the enterprise) was opposed by the Dutch"; and, speaking of the failure to pursue, which he imputes to the Dutch, he says that it was "not of my lord's (Marlborough's) fault" (ibid., p. 314). 
among them D'Alegre, the Bavarian general, were among the CHAP. trophies. By the queen the news was welcomed with a public IV. thanksgiving at St. Paul's on August 23.

Since his return to the Netherlands, Marlborough had been in the nominal command of two armies. Of these the larger consisted of the English and the troops in English pay. These were absolutely at his orders. The Dutch army under Ouwerkerk remained the victim of the paralysing system of field-deputies. Its co-operation in forcing the French lines was nothing more than the execution of a feint, ${ }^{1}$ of the precise object of which even Ouwerkerk was ignorant. Under such a system, Marlborough complained, it was "impossible to act offensively"; yet urgent representations to the States-general failed to extort any substantial concession.

With characteristic determination to make the best of circumstances, Marlborough resolved to resume the offensive. By August 16 he advanced from Meldert to Genappe so as to threaten Brussels from the south-east. On the 18 th the army came in sight of the French forces drawn up in line of battle behind the Yssche to cover Brussels. The allied army was the superior in number. The duke and Ouwerkerk, having reconnoitred the French lines, decided upon four points of attack. To the astonishment of Ouwerkerk and the duke, the field-deputies refused their assent. "They had consulted," wrote the duke's chaplain two days later," "with their other generals, of whom that beast Slangenberg was very noisy and cried out that it was sacrificing their army and an impracticable enterprise." On no previous occasion had Marlborough pressed his purpose so vehemently. From the deputies he addressed an appeal to the Dutch generals and was met by Slangenbourg with insolence. Nothing remained but to withdraw. A war of recrimination ensued. Marlborough wrote an official letter to the States-general, in terms of studious moderation, complaining of his lack of authority over his subordinate generals. The field-deputies issued a counter-manifesto, reflecting upon the duke's concealment of his plans. In England Marlborough's enemies exulted. In France his retreat was

'Cf. Prancis Hare (Marlborough's chaplain) to G. Naylor, July 18, 1705 Tirlemont, Hare MSS., p. 203, Hist. MSS. Comm., 8895.

- F. Hare to G. Naylor, Hare MSS., p. 205. 
CHAP. imputed to incapacity. ${ }^{1}$ But the general feeling in Holland IV. and England was one of indignation." "Had he (Slangenbourg) come to Amsterdam this summer, after he hindered the battle, he would have been De-Witted." 8 Neither the commander-in-chief nor his army was in a condition to renew the campaign that year. "Our army," wrote a field officer in October, "is now very weak, and we have lost this summer in the British troops almost as many men by marauding and desertion, though we have not fought at all, as we lost last summer though we had two bloody battles." 4 Beginning everywhere with promise, the campaign had ended everywhere in disappointment.

During the autumn increasing dissatisfaction with the war had been felt by the Dutch. The stoppage of the exchange robbed them, they urged, of the means of contributing to the cost. Indeed, not even after their undertaking in 1703 was the prohibition faithfully observed, and in 1704 the States-general did not venture to extend it for another year. Unless, wrote the grand pensionary early in 1705, England wished a dissolution of the alliance it must withdraw all obstacles to trade with France. English merchants and shipowners grumbled, tory pamphleteers assailed the ministry, ministers complained at the Hague. But the Hague had its grievances also. England, it was whispered, was cajoling from the Austrian claimant the concession of exclusive trade privileges in Spain and the West Indies. England meditated the annexation of Gibraltar, of the harbour of Cadiz, and of a station on the Balearic Isles which would give her the monopoly of the Mediterranean trade. No wonder, cried the peace party of Amsterdam, that England clamoured for a war which should so richly compensate her sacrifices. But the disclosure of the misconduct of Slangenbourg and the general discredit of the field-deputies had pro-

1 "J'ai obtenu une opinion médiocre de la capacité du duc de Marlborough." Chamillart (minister of war) to Villeroy, September 6, 1705, Von Noorden, ii., I73.

${ }^{2}$ For the remonstrance which it was in contemplation to send to the Statesgeneral by Lord Pembroke, see The Queen to the Earl of Pembroke, August 30, 1705, Portland MSS., iv., 237. 796.

${ }^{3}$ Duke of Shrewsbury's \ournal, December 15, x705, Buccleuch MSS., ii.,

4 Major J. Cranstoun to Robert Cunningham, Herenthals, October I, x705, Portland MSS., iv., 255. Marlborough particularises fatigue and sickness. Murray, Dispatches, ii., 290. 
voked a reaction in Dutch sentiment. Even William Buys, the leader of the peace party, after a visit to London in January, 1706, returned to Amsterdam fervent for the alliance.

Upon the conclusion of the indecisive campaign of 1705 Marlborough again undertook the work of a diplomatist, and as Vienna was now the weak point of the alliance, he determined in November, 1705, there to deal with the emperor personally. He assured him of an English loan, and met his difficulties by agreeing to a reduction of the imperial contingent for the ensuing campaign to 40,000 men, but he insisted that these should be punctually dispatched and adequately equipped. At Vienna he met his son-in-law Sunderland, who, in July, had been appointed envoy-extraordinary to felicitate Joseph I. on his accession, and to act as intermediary between the court of Vienna and the Hungarian insurgents. In Sunderland's company he proceeded from Vienna to Berlin. Frederick was complaining of slights offered by the emperor and threatening to withdraw his 8,000 soldiers from Italy. Not until the States - general paid his arrears would he order his regiments to march to the seat of war on the Rhine. Having effected a continuance of the agreement for the Italian campaign of the ensuing year, which was his main object, Marlborough next proceeded to Hanover. Here his manners, which the electress described as "obliging and polished," reconciled her to the English court. Thence to the Hague, where he arranged for the payment of the States-general's contribution to the supply of Prince Eugene's army, and for his reinforcement with 10,000 men, to be raised from Saxe-Gotha and the Rhenish Palatinate and paid by the maritime powers. On January $/ 7,1706$, he resumed his seat in parliament and received the thanks of the house of commons for his services.

The spring of 1706 was marked by a distraction of counsels among the allies. The States-general peremptorily refused to listen to Marlborough's project of marching/a Dutch force into Italy. If he insisted on an Italian campaign, he must forgo the co-operation of the Dutch troops and resign his position as commander-in-chief of the republic's army. The war in Italy was accordingly reserved for Prince Eugene who, by the defeat of the Duke of Orleans under the walls of Turin on September 7 , dealt the third of the three great blows inflicted that 
CHAP. year on France. The relief of Turin was the loss of Italy to

IV. France. Vast preparations were in the meanwhile being made by Louis XIV. Villars was entrusted with the command of an army on the Upper Rhine ; in the centre of the theatre of war, between the Netherlands and Alsace, lay Marsin; on the Dutch frontier Villeroy and Max Emanuel. The Margrave of Baden, intrenched behind the lines of Hagenau in Alsace, was left with less than 7,000 ill-equipped troops, and on April 30 driven from his position with the loss of all his supplies by a surprise attack of Villars and Marsin. As far as the co-operation of the imperial forces went, the campaign was over before it was begun. At the end of May Marlborough placed himself at the head of the allied forces in Brabant, numbering 60,000 men. His immediate object was to strike a blow before Marsin, who was on the march from Metz, succeeded in effecting a junction with Villeroy. Marsin's advanced detachment of twenty squadrons of cavalry was within two days' march on May 2I, and his infantry some few days' marches behind. Common prudence would have prescribed to Villeroy the avoidance of an engagement, but jealousy prompted him to precipitate one before Marsin's arrival. 1

The two armies met in the neighbourhood of Ramillies, a village eleven miles north of Namur. The field of battle was a convex tract of land between the river Mehaigne on the south and the sources of the Great and Little Gheet. In the morning of May 23, N.S., the advance guards came in contact, Marlborough marching from the east and Villeroy from the north. Villeroy had time to take up the position of his choice. At his centre, Ramillies, he posted his artillery. His left wing was protected by marshy and broken ground. In front of his centre and right was a plain on which his cavalry, now joined by Marsin's detachment, could manœuvre. In advance of his right was the village of Tavier, and beyond it Franquenies, both of which would have to be taken before his position could be turned. Marlborough placed his infantry in the centre, in front of Ramillies, and his cavalry on either flank. A demonstration was made by him against the French

1 "We could hardly fail of meeting, since we marched with a firm resolution to attack them, and I find they did the same out of their line to attack us." Letter of the Earl of Orkney, May 24, x706, Engl. Hist. Rev., xix., 375. 
left, the English infantry wading waist deep in water to the CHAP. attack. But a furious assault on Ramillies ${ }^{1}$ was repulsed, and the Dutch were scattered by the French cavalry on the plain. While rallying the Dutch horse, Marlborough was dismounted ${ }^{2}$ and in danger of being taken prisoner. As at Blenheim, failure inspired him. He executed a change of disposition which determined the battle. Villeroy had been led by the demonstration against his left to withdraw troops from his right. As he did so, Marlborough withdrew half his infantry to his centre, rapidly transferred the cavalry to his left wing and, Franquenies having been already stormed by the Dutch, threw his reserves upon Tavier. The French were outnumbered and their cavalry routed, while at the same time the English and Dutch infantry pierced the French centre. The French right was now turned and the army driven into a retreat which became a rout. With the exception of six guns, the entire French artillery was taken. The victory cost the allies 1,000 killed and some 2,600 wounded; the French and Bavarians lost 12,000 to 1 5,000 men killed, wounded, prisoners, and deserters. Their confidence and discipline were shattered.

After several futile efforts to rally, the defeated army dispersed among the fortresses of the French frontier. Brabant lay at the feet of the victor. Antwerp and Dendermonde were the only places of importance in Brabant which had not surrendered within eleven days of the battle. On June 6 Antwerp, a fortress of such strength that its investment had been proposed by the States-general in 1703 as the sole objective of the campaign, opened its gates, the French garrison being allowed to march out with the honours of war. In the opinion of military experts it would have been feasible for Marlborough at this abysmal crisis of the fortunes of France-for the relief of Barcelona had taken place on May 12 and the French troops had been driven out of Spain-to have marched straight upon Paris. But it would have been idle for him to propose such an enterprise to the Statesgeneral. Now that Flanders and Brabant were assured to

1 "That post was attacked very furiously by chiefly stranger troops, except Churchil's and Mordaunt's regiments, who have suffered greatly." Lord Orkney, Eingl. Hist. Rev., xix., $3 \times 5$.

"My Lord Marlbro' was rid over." Ibid.

VOL. IX. 
CHAP. them, their ambitions travelled no farther than the fortified IV. towns of French Flanders and of Hainault. They fought for safety and profit, not for idle glory.

That the success of Ramillies was to be utilised by the reduction of fortified towns was adopted, therefore, as common ground between the maritime powers. Ouwerkerk undertook the siege of Ostend, while Marlborough with an army at Roselaere, where he could threaten Ypres and Menin, covered the operations. On July 6, after a bombardment by sea and land, Ostend capitulated; and a place which in the preceding century had held out for three years and cost Spinola 80,000 men was acquired at the sacrifice of 500 lives. Leaving Nieuport and Dunkirk, a step by which, if he disappointed his own countrymen, he gratified the Dutch, Marlborough, reinforced by Ouwerkerk, moved eastwards, surprised Courtray and established a fortified camp at Helchen, on the Upper Schelde, whence he could threaten the line of fortresses of the northern frontier of France. Vendôme, who in August had replaced Villeroy, could do no more than intrench his demoralised troops and watch the allies. One after another the fortresses fell, until by November, when the army went into winter quarters, none of the Belgian fortified towns remained to France save Mons, Charleroi, Namur, and Luxembourg.

By a clause in the treaty of the Grand Alliance it was stipulated that the acquisitions made in the Spanish Netherlands should be utilised as a "barrier" between the United Provinces and France. As it was not proposed to withdraw the towns of the barrier from the sovereignty of Spain, which was unable to defend them, a strong barrier was nominally advantageous to that crown as well as to the republic. But while the Dutch were willing to concede to the house of Austria, as succeeding to the rights of Charles II. of Spain, the honour of sovereignty, the burden of judicial responsibility, and a joint scheme of defence, their real object was to make the barrier fortresses dependent on the United Provinces, contributory to their expenditure, and useful to their trade. The wholesale surrenders which followed the battle of Ramillies brought this matter to a crisis. Marlborough was conscious that Dutch annexation on a large scale would excite jealousy in England, and that it "would certainly. set the 
whole country (i.e. the Spanish Netherlands) against them". $\mathrm{He}$ insisted that the occupation of the Belgian provinces CHAP. should be in the name of Charles III. To prevent the change of masters proving merely a substitution of Dutch for French officialism, he encouraged the revival of the States of Flanders and Brabant, proclaiming in the name of Charles III. the restoration of the ancient liberties and privileges suppressed by the French. The policy of this treatment, contrasted with the harsh absolutism of their late masters, so rallied the population to his support that he found himself able to enlist a Belgian army corps in the joint service of the maritime powers. These liberal measures ill accorded with the traditional policy of the court of Vienna; but the emperor's interference having been repudiated by the Dutch, he affected to accept the situation and nominated Marlborough, on behalf of Charles III., governor of the Netherlands. The bait was gilded with a promised salary of $£ 60,000$ a year. Fortunate it was, wrote Heinsius, that Marlborough had subjected his acceptance to the approval of the Dutch. The effect of the proposal upon them was to awaken bitter resentment against Austria, suspicion against England, and a determination to force the allies to a prompt settlement of the barrier. Whatever selection they might make in the Spanish Netherlands of towns to receive their garrisons should be recognised as their barrier, and as such guaranteed to them in possession by England. "By that proposal," wrote Halifax, the British special envoy, to Portland, "the Dutch have desired the whole Spanish Netherlands." $1 \mathrm{He}$ returned indignant to England, and the management of negotiations was entrusted to the calmer diplomacy of Marlborough. The Dutch determined to meet the advent of peace with accomplished facts. Despite Marlborough's protests they endeavoured to obliterate the signs of English condominium in Belgium, and treated the occupied provinces as their own. In September, after repeated expostulations and warnings, the duke insisted that side by side with a Dutch commissioner a special English commissioner should be entrusted with the administration of the Spanish Netherlands. He proposed George Stepney, who, after a quarrel with the imperial minister Count ก. $x$.

1 September 24-October 5, 1706, Heinsius' Archives, Von Noorden, ii., 350, 
cHAP. Wratislaw, had recently been recalled from Vienna. The

IV. States-general had no choice but to accept the nomination.

The French, who were well informed of the course of events in Holland, judged the moment of tension between Marlborough and the Dutch to be favourable to their project of disintegrating the Alliance. In the middle of August, a clearly formulated offer of terms was unofficially put before the leading Dutch politicians by an agent of the war minister Chamiliart. The Dutch could take possession of the entire Spanish Netherlands and enjoy a preferential tariff at the French custom houses. In England the anticipation of a separate accommodation of Holland with France aroused general irritation. The Dutch plea of financial pressure was met by Godolphin with the observation that Holland like England could "borrow money at four or five per cent., whereas the finances of France are so much more exhausted that they are forced to give twenty and twenty-five per cent. for every penny they send out of the kingdom, unless they send it in specie, by which means they have neither money nor credit".1 Whig merchants were jealous that the Dutch should secure a most-favoured-nation treaty. Whig politicians feared that with the cessation of the military successes which had helped them to a majority at the general election of May, 1705 , the tory party would revive and the protestant succession be placed in jeopardy. On September 14, Godolphin sent Buys a dispatch upon the French proposals. He insisted that the Dutch should "specify the particular towns which they propose to have for their barrier". It was not in the power of France to concede them. As England had the power, so she would control the terms of a general peace. Perceiving the failure of his attempt to lure the Dutch from the alliance by golden promises, Louis XIV. next endeavoured to approach Marlborough through the Elector of Bavaria. The elector wrote to the duke and the Dutch field-deputies proposing public conferences on the terms of a peace. The English

1 Godolphin to Marlborough, October 4-15, 1706, Coxe, Memoirs of Marlborough, i., 486. A few days after this letter was written the government received from one of their spies in Paris, Captain John Ogilvie, a report which justifies Godolphin's view. Paris, November 19-30, 1706, Portland MSS., iv., 354 . 
cabinet and the States-general replied through Marlborough that conferences at large were futile until the allies had conIV. certed among themselves the preliminaries of their demands. At the head of these they agreed to set the renunciation by the Duke of Anjou (Philip V.) of the entire Spanish inheritance. That the States-general should have consented to this condition was another Ramillies won by the duke in the field of diplomacy. With a sarcastic comment from Torcy ${ }^{1}$ the French ministers retired discomfited.

During the winter of $1704-5$ Methuen and Galway made preparations for a campaign on the western frontier of Spain. The forces at the disposal of the allies numbered 2,300 Dutch, 1 2,000 Portuguese, and 2,700 English. The evils of a mixed army made themselves apparent from the outset. Galway desired an assault upon the capital fortress of Badajoz before Tessé could march with his troops from Gibraltar. He was overruled by the Portuguese, who preferred the investment of the minor stronghold of Valenza. The allies having captured Valenza and Albuquerque, encamped before Badajoz in June, 1705. By that time Tesse had arrived with reinforcements. Months were spent in futile disputes between the generals. Galway, the most enterprising of them, lost his right arm by a cannon shot. In October the Dutch general, Fagel, having been surprised by Tesse, the allies abandoned the siege.

The ancient kingdoms of Aragon and Valencia and the province of Catalonia had long borne with impatience the Castilian supremacy established by Philip II. For them Madrid was the common enemy. Aware of the prevalence of this feeling, which was greatly exaggerated by the Austrian party in Spain, the English ministry in 1705 resolved on another expedition to its eastern coasts. The commander nominated was Charles Mordaunt, Earl of Peterborough. It was a surprising selection in that age, for he was not a soldier of experience, having for five years enjoyed a sinecure colonelcy of foot as a reward for political services. He had, however, in 1687 held the command of a small Dutch squadron in the West Indies, and had been nominated commander-in-chief of

1 Torcy to Hennequin, a Dutch intermediary, December 5, 1706, G. G. Vreede, Conrespondance diplomatique et militaire de Marlborough, Herinsius, etc., Amsterdam, r850, p. 182 . 
CHAP. a projected Dutch and English expedition to Jamaica in De-

IV. cember, I7O2. This enterprise having been abandoned, owing to the reluctance of the Dutch, his present nomination was in the nature of a compensation to him. He owed it to his adroitness in paying court to the Duchess of Marlborough. Mindful of the mischiefs which had attended the divided command of the naval and military forces by Rooke and the Duke of Ormonde in the Cadiz expedition, Peterborough secured, in addition to his commission as general, a commission with $\mathrm{Sir}$ Clowdisley Shovell as joint admiral of the fleet. Including Leake's squadron at Lisbon, the fleet consisted of sixty-six sail of the line, of which fourteen were Dutch. The land force was made up of three English, three Irish, and four Dutch regiments, and numbered 6,500 men. Prince George of HesseDarmstadt was on board the fleet, together with the candidate of the allies for the crown of Spain, the Archduke Charles. The army disembarked near Barcelona on August 24, I 705, and was joined by I,200 Catalan volunteers locally known as "miquelets".

The influence which Prince George's acquaintance with the country and the people naturally gave him was regarded by Peterborough, a man intoxicated by vanity, with an insane jealousy. He convened a council of English and Dutch generals on August 27, declared that the capture of Barcelona was impracticable, and proposed a march upon Valencia. But the allied expedition now numbered nearly I0,000 soldiers, besides 3,000 miquelets, and a fleet of 24,000 seamen. Barcelona was held by a garrison of Spaniards and Neapolitans, of whom the Spaniards were known to be disaffected to Philip V.; nor had it any prospect of relief. The archduke and Shovell therefore supported Prince George. After many councils of war it was determined that the attempt on Barcelona should be relinquished, and that the army should march on Valencia. But on August 13, the day after this decision was arrived at, Peterborough consented to an attempt by Prince George ${ }^{1}$

${ }^{1}$ According to Lord Stanhope, the credit of the inception of this enterprise belongs to Peterborough. But Stanhope founds his narrative upon Carleton's (as to which, see App. ii.). He has also himself detracted from the probability of his version by the admission that Peterborough was adverse to a stay at Barcelona; and lastly, the journal, which Stanhope does not appear to have seen, of Major-General John Richards, who was at the conferences between Darm- 
to surprise Montjuich, a detached fort on a hill above the sea, about 1,100 yards south of Barcelona. On September 14, CHAP. Prince George selected I,000 men for the enterprise, Peterborough remaining in the rear with the reserves. Montjuich was defended by a garrison of about 200 Neapolitans. The assailants, whose attack was to be delivered from the landward or south-west side, having mistaken their road, did not arrive till broad daylight. They were repulsed with considerable loss, and Prince George was killed. Peterborough rallied them, and they took shelter behind the earthworks whence they could annoy the garrison. Meanwhile a force of miquelets, by the capture of the intermediate work called St. Bertran, cut off the prospects of succour from Barcelona. On the 17 th the powder magazine blew up and the garrison surrendered. As the inaction of Velasco, the governor of Barcelona, shewed that he did not trust his troops, the allies determined to make a serious attack on the city. A breach having been effected, Velasco capitulated and was accorded the honours of war.

The consequences of these successes were quickly seen. The Count of Cifuentes raided Aragon. In the kingdom of Valencia and in Catalonia several strong places sent in their surrenders, and the city of Valencia rose against the Madrid governor. Peterborough, like a knight-errant, rode through Catalonia in January, 1 706, with a handful of horsemen, taking possession of towns. The east had rebelled against the west of Spain. Philip V. was helpless. Tessé, who commanded the bulk of his forces, was confronted at Badajoz by Das Minas and the allies. To march eastwards would be to leave Castile open to the Anglo-Portuguese army. And Castile was wavering. The defection of Portugal and Savoy and the victory of Blenheim, followed by the catastrophe in the east of Spain, had seriously changed the outlook. Louis XIV. awoke to the crisis. He dispatched 9,000 men under General Légal to the northern frontier of Catalonia and ordered Tesse to concentrate the Bourbon troops in Aragon (January, 1706). Meanwhile, Peterborough, having quarrelled with " the wretches of Barcelona," ${ }^{3}$ that is, the Archduke Charles in particular and

stadt and Peterborough, conclusively establishes the secondary part which Peterborough really played.

1 Lord Peterborough to Lord —_, January Ir, 1706, Morrison MSS., p. 467, Hist. MSS. Comm., 1895 . 
CHAP. his German advisers in general, had scattered his troops through

IV. Catalonia and Valencia, leaving a garrison of only 1,400 men in Barcelona. The English fleet having sailed homewards in October, the French next spring seized the opportunity. On April I, I 706, a powerful fleet under the Count of Toulouse anchored before Barcelona, while a land force of 21,000 men, under the nominal command of Philip V., invested the city. Montjuich was taken by storm on the 25 th. Only the arrival of Leake with an English and Dutch fleet of fifty-two line of battle ships, before which the French fleet took to flight, saved Barcelona from recapture. Peterborough had endeavoured to divert Leake's fleet by orders sent to Lisbon to make for the Grao, the harbour of Valencia, adding that he hoped "to march on Madrid". Leake, however, receiving urgent messages from the beleaguered archduke to hasten to his relief, and reflecting that the occupation of Madrid by Peterborough would not countervail the capture by the French of the allies' candidate for the throne, determined, with the concurrence of his officers, to risk disobedience to Peterborough's orders. Peterborough, therefore, adroitly changed his plan, made his way in an open boat to Leake's ship, hoisted his flag as admiral, and posed as the saviour of Barcelona, which, if his orders had been obeyed, would have been lost. Tessé and Philip V. retreated to Roussillon, leaving behind them large stores and munitions of war. The moral effect was immense, for there was now but one king, Charles III., in Spain. Peterborough was glorified as a second Marlborough, and the relief of Barcelona was celebrated with the victory of Ramillies by a public thanksgiving at St. Paul's on June 27 .

The withdrawal at the end of 1705 of the greater part of the French troops from the western frontier of Spain to join Tessé in Aragon offered an opportunity for an advance by the Anglo-Portuguese army under Galway and Das Minas. Their total force amounted to 19,000 men, of whom 2,000 were English and 2,000 Dutch. The English cavalry numbered 200 only, the Portuguese 3,600. Opposed to them was Marshal Berwick with 15,300 Spanish infantry and 4,000 horse. Berwick, a master of retreats, drew back before the allies, who captured the important fortress of Ciudad Rodrigo on May 26. Galway learning on the $27^{\text {th }}$ the defeat of 
Tesse, with great difficulty persuaded the Portuguese to march with him on Madrid. Berwick made no attempt to CHAP. defend the passes of the Guadarrama range, but the population was hostile to the invaders, the roads difficult and provisions scarce, while Das Minas was sulkily threatening to return and the Portuguese soldiers were deserting. Galway himself was ill with gout, and, never having recovered strength since the loss of his arm, had to be lifted on horseback. Had Berwick offered battle, the members of both armies being approximately equal, the issue must have been perilous for the invaders. As he continued to retreat, Galway and Das Minas made a triumphant entry into Madrid on June 27, and proclaimed Charles III. Thence Galway sent dispatches to Charles and Peterborough, urging an immediate advance.

In Madrid the soldiers of the allied army, amid a sullenly hostile population, compensated themselves by excess for the privations of their march. A fourth of their number found their way into the hospitals. On July I I Galway marched out of Madrid, and Berwick, retreating before him, encamped on the 15 th at Guadalaxara. Here he received dispatches announcing the march of Charles and his arrival at Saragossa. On July 28, Berwick was reinforced from Navarre by Légal at the head of a French army of 2,300 horse and 9,000 foot. His entire force now numbered 25,000 men. It was the opinion of Berwick that the delays of Galway and Das Minas at Madrid and in the camp of Guadalaxara ruined the fortunes of the Archduke Charles in Spain. Galway's illness, the want of enterprise of Das Minas, and the quarrels of the two gave Berwick the needed interval in which to form his army. At the beginning of July they could have driven him beyond the Ebro; towards the end of the month he was in a position to open the offensive with a superior force.

A council of war held at Barcelona on May 18 had decided that Peterborough, starting from Valencia, should clear the roads to Madrid, and afterwards, accompanied by the archduke and at the head of 8,000 men, join hands with Galway's army. At the parliamentary inquiry of 1711 , Peterborough bitterly complained that he had received no adequate equipment for his undertaking. But on July 6 , he announced the road to Madrid clear both of hostile walls and of hostile troops, 
CHAP. and urged the archduke by letter to start from Barcelona at IV. once ${ }^{1}$ and join him at Valencia. In the meanwhile, the insurrection in favour of the Austrian candidate had been spreading through Aragon, and, despite the protests of Peterborough and of General Stanhope, his official English adviser, Charles elected to proceed to Saragossa. In this choice, his strained relations with Peterborough were decisive. ${ }^{2}$ Charles knew also of the fall of Madrid and that Galway and Das Minas were expecting him by the route through Saragossa. He could neither anticipate the dilatoriness of those generals nor the rapidity with which Berwick could re-form his army. For six weeks Peterborough remained sulking or pursuing his gallantries at Valencia, until peremptory orders compelled him to join the archduke. On August 5 the two effected a junction with Galway at Guadalaxara at the head of 5,000 men. The camp now contained three generals whose precedence was unsettled and whose powers were indeterminate, each animated by jealousy of the other. Charles and his German' advisers, whom Peterborough hated and ridiculed, treated Peterborough with studied contempt. Perceiving the situation impossible for him, he communicated to Charles a dispatch from Secretary Hedges, of June 19-30, directing him, if it could be done, to proceed to the assistance of the Duke of Savoy, then concerting operations for the relief of Turin. The idea was gratefully seized upon by Charles and the allied generals, who were weary of his arrogance and factiousness. Charles entrusted him with a commission to raise $£ 100,000$ at Genoa, by way of loan upon mortgage of Spanish territory, and suggested that on his return he should attempt the reduction of Minorca. On

${ }^{1}$ In the Memoirs of Lord Walpole, the story is told that when Charles excused his delay in setting out for Saragossa on the plea that his state coach was not ready for his entry into the Aragonese capital, Stanhope replied : "Sir, the Prince of Orange entered London in a coach and four, with a cloak bag behind him, and was made king not many weeks after". This anecdote has been dismissed by Heller in the Oesterr. militär. Zeitschrift (1839) as a fiction, but it finds confirmation in a letter from a person in Peterborough's suite among the Duke of Marlborough's papers at Blenheim Palace, dated Alicant, September 3, 1706: "The king said it was not for his catholic honour to go without his retinue. Mr. Stanhope told him K. William went post in a Hackney coach with a few dragoons to London, or else he had lost the crown. However, folly prevailed," etc. Hist. MSS. Comm., 8th Rep., App., p. I8.

2 Wratislaw to Marlborougb, August 21, 1706, Von Noorden, ii., 412, n. 5 . 
September 15 he left Valencia for Italy. The reinforced French and Castilian army, under Berwick, reoccupied Madrid CHAP. on August 4 amid the applause of the population. Nothing remained for the archduke's army, reduced by disease and desertions at Guadalaxara to 14,000 men, but to beat a retreat. Cut off by Berwick from Portugal, they turned eastwards. Struggling through a country already exhausted by war, enfeebled by sickness and privations, exposed to a sun so fierce "that the barrels of their guns burnt their fingers," " and harassed by the guerrilla warfare of the peasantry of Castile, they re-entered Valencia, a rabble of 10,000 men.

A belief had long been propagated in England that not only in Languedoc was exasperation acute at the religious persecutions and tyrannical suppressions of local self-government by Louis XIV. An ex-abbé of noble French family, preferring the life of adventure to that of seclusion, had quitted his benefices and, being a former friend of Prince Eugene, had made his way to Vienna, where he became a lieutenant-general in the imperial army, assuming the title of Marquis de Guiscard. From Vienna he went to the Hague with an introduction to Heinsius. Thence he issued manifestos calling upon his countrymen to rise against Louis and absolutism, and there he made the acquaintance of Marlborough, and, through Marlborough, of St. John. To St. John, as secretary at war, he presented plans for a descent on the coast of France. It does not appear that Marlborough went further into the matter than to give the idea his general approval, to nominate Earl Rivers as commander of the expedition, and to urge the States-general to contribute some naval and military assistance. He could have no knowledge of the fundamental misconception on which the whole enterprise was based, that the French population of Saintonge and Guienne was ready to rise for their forgotten liberties. ${ }^{2}$

The States-general assented to Marlborough's request.

1 R. Palmer to Lord Fermanagh, Nov. 19, I706, Vermey MSS., p. 507, Hist. MSS. Comm., Tth Rep., App.

'The queen's inatructions to Earl Rivers are printed in the Bath MSS., i., 84, dated July 21, 1706. He is to issue " manifestoes," "taking care to give aseurances to the people, and to make it public that his design is not for conquest, but to restore to all sorts of people their ancient rights and privileges ". The manifestos were prepared in London. H. St. John to Secretary Harley, Portsmouth, July 27, 1706, ibid., p. 85. 
CHAP. Escorted by a guard of horse-grenadiers, Guiscard, in the IV. company of St. John, arrived at Portsmouth at the end of July. But when preparations were completed, a continuance of unfavourable winds prevented the sailing of the fleet. A council of war, held at Torbay under Shovell, on August 13, I 706, concluded that the delay had imperilled the prospects of the enterprise, ${ }^{1}$ and, after consultation with Godolphin, it was determined that the destination of the expedition should be Cadiz. It was not until October that the expedition set sail from Torbay, the destination of the fleet being kept secret. Buffeted by tempestuous weather, in consequence of which no fewer than half the horses were dead or ruined, ${ }^{2}$ the ships were forced to rendezvous at Lisbon. Here Rivers received a dispatch from Secretary Hedges that the extremity to which the allies at Valencia were reduced necessitated his abandonment of the expedition against Cadiz in favour of a junction with the archduke. The correspondence which follows ${ }^{3}$ is a painful exhibition of petty pique on the part of Rivers and infirmity of purpose on that of the ministry. He was instructed to serve under Galway. He not only tendered his resignation on the ground that he had expected an independent command, he brought absurd charges against Galway of clandestine correspondence with the enemy in association with John Methuen, the English ambassador at Lisbon, who had recently died. Galway, foreseeing a second Peterborough, advised the ministry to instruct him to combine with the Portuguese in an invasion of Spain from the west. "The most pernicious advice ever given the queen," wrote Rivers to Halifax on December 31, O.S., "which in my Lord Galway could not be ignorance." In this spirit he determined to go to Valencia.

${ }^{1}$ According to Tindal, a careful collector of facts, Guiscard was sent back to London by Rivers under the discredit of having furnished untrustworthy information as to the prospects of the descent in France. But this is confuted by the publication from the Bath MSS. of the correspondence between Godolphin and Rivers. On August 24, 1706, Godolphin wrote to Rivers: "As for Monsieur de Guiscard, since it is by no fault of his that his project is laid aside, it seems not unreasonable that he should be at liberty to serve upon this expedition, or not, as he shall incline to most" (Bath MSS., i., 93). The letters of Lord Rivers show that he disliked Guiscard, and wished to have nothing to do with him (Rivers to Godolphin, August 21, 1706, ibid., p. 92). And Guiscard was employed again.

Earl Rivers to Sir C. Hedges, Lisbon, October 29, 1706, O.S., ibid., p. 116.

Bath MSS., i., $117-66$. 


\section{CHAPTER V. \\ THE UNION WITH SCOTLAND.}

DURING the hundred years that had passed since the accession of James VI. of Scotland to the English crown, the project of CHAP. constitutional union between the two countries had fitfully occupied men's minds, and with a more constant pressure during the latter years of William III. Among Scottish parties the one best affected to a union was that of the episcopalians who were not Jacobites, and who frequently went by the name of the cavaliers. Their hope was to replace the presbyterian by an episcopal establishment. On this point, the whigs were opposed to them. Those who are familiar with the vituperative pages of the antiquary, Hearne, will remember that presbyterian and whig figure as synonymous terms. A third body of politicians existed, recruited from the left centre of the whigs. The introduction of Italian phrases into the politics of the day was a fashionable taste. It smacked of the grand tour. The squadrone volante of the Scots parliament were zealous for the protestant succession, but they saw in it not an opportunity for a consolidation of the two kingdoms but for the government of Scotland as an independent nation under its noble families, over which an exotic dynasty would be likely to exercise no more than a nominal control. This "flying squadron" naturally rallied the great landowners and held the balance of politics. A number of fractions composed the opposition, obstinately conservative of all the national institutions. On the one hand were the covenanters, whose ideal was a republic and whose horror was an episcopacy; on the other the Jacobites, who after Anne's accession gradually absorbed the episcopalians, ${ }^{1}$ ready

1 "The Jacobite party (in Scotland) whether popish or episcopal it matters little." Daniel De Foe to the Earl of Oxford, Portland MSS., v., 82. 
CHAP. to acquiesce even in a Roman catholic prelacy if imposed by a native hereditary king. ${ }^{1}$

To the statesmen of both countries who were desirous of smoothing the constant friction arising from these relations, the accession of Anne, a sovereign of the ancient Stewart line, seemed an auspicious opportunity. On August 25, 1702, commissioners were appointed to treat on the part of England with commissioners from Scotland with a view to a union. The two commissions met on October 22. The future position/ of the presbyterian establishment, the admission of Scotland to the English colonial trade, the share of Scotland in the liabilities of the two nations, lastly, the extension to Scotland of the internal taxation of England, were all discussed. But the negotiations were wrecked, partly upon the collision of interests between the Scots company trading to Africa and the Indies, partly upon the reluctance shown by Scotland to the adoption of the English system of excise. In the new Scottish parliament summoned for May, I703, the extreme opposition, the Jacobites and the republican covenanters, found themselves more numerous than before. At the head of the Jacobites was the restless Duke of Hamilton. Fletcher of Saltoun, a speculative republican, was spokesman of the other wing of the opposition. Of the Duke of Hamilton no man felt sure. He was suspected of a design to put himself forward as a Scottish pretender, founding himself on the profession of protestantism and his connexion with the Stewarts. ${ }^{2} \mathrm{He}$ was believed to be intriguing with St. Germain's. He was known to be making professions to the government. ${ }^{3}$

At the head of the party for union stood the Duke of Queensberry, a recruit from the tories. Perceiving that the "flying squadron" had been reduced by the elections, he set himself to strengthen it by the customary means by which in the seventeenth century richer countries had acquired political interest with their poorer neighbours." In addition to the V., 186.

${ }^{1}$ Letter of Henrietta, Marchioness of Huntley, June 20, 1712, Portland MSS.,

${ }^{2}$ (G. Lamberty) to Lord Cutts, August 4-15, 1703, Astley MSS., p. 128, Hist. MSS. Comm., Ig00. Cf. Bonet's Correspondence, July 24, 1703, Von Noorden, i., $517,2$.

${ }^{3}$ Bagot MSS., p. 341, Hist. MSS. Comm., r885.

- Earl of Nottingham to James Graham, August 3r, 1703, Whitehall : "I hear that great sums of money have lately been sent into that kingdom ". Ibid., p. 337. 
peers who joined the squadron for substantial considerations paid down, it had the more trustworthy support of the tradiCHAP. tional whigs, of the Duke of Argyll, of the Lords Marchmont and Tweeddale, and of a group of officials who had held office under King William. Nevertheless, the opposition soon shewed that it controlled the majority. The queen's message on May 6 recommended a settlement of the Scottish crown. It was doubtful to no one that this implied a settlement on the precedent of the English Act of Succession. But the consciousness of this was as oil to the fire of the opposition. They were not merely satisfied with taking up the question as if on their own initiative, in jealous independence of the message from St. James's. The "Act for the Security of the Kingdom," currently known as the Act of Security, carried by the opposition through parliament, paid a tribute to national vanity in its provision that on the queen's death the estates should appoint a protestant successor to the crown descended from the old line of sovereigns.

This in itself was a contemptuous disregard of the royal message. Yet the Act of Security went further. It excluded from succession to the crown of Scotland the successor to the crown of England unless "there be such conditions of government settled and enacted as may secure the honour and sovereignty of this crown and kingdom-the freedom, frequency, and power of parliaments, the religion, liberty, and trade of the nation, from the English or any foreign influence". The queen's commissioner, the Duke of Queensberry, refused to give the royal assent by the touch of the sceptre to this audacious defiance. One other act of the same tendency was passed intituled "an Act anent Peace and War". By this it was provided that after the death of Anne the sovereign should be debarred from proclaiming war without the consent of parliament. This measure received the royal assent on September 16, 1703. English parties and the English ministry accepted these messages of defiance with unconcerned indifference. Godolphin regarded the Scots as people of punctilio, ${ }^{1}$ and was of opinion, justified by experience, that punctilio had

2 "I wish there were no such thing upon earth as a punctilio of any kind." Godolphin to Harley on the Scots' demands as to the composition of the commissions for union, April 8, 1705, Bath MSS., i., 67. 
CHAP. its price. It was currently said in English political circles that v. the Scots Estates could be bought for $£ 30,000,1$ and Godolphin had the credit of declaring that he would prorogue them until the bargain and sale were concluded. ${ }^{2}$

The circulation of stories of this sort from the parliament of Edinburgh to the country-side, and the unpopularity which attended the Duke of Queensberry's conduct in the matter of "the Scotch plot," excited popular resentment against England. A universal agitation began. During the winter of $1703-4$ riotous mobs paraded the streets of Edinburgh. The pulpit thundered with declamations against prelacy; the Highlands seethed with disaffection, and the rumour ran round that a force from Dunkirk was ready to support a rising. ${ }^{8}$ The Marquis of Tweeddale, a member of the "flying squadron," had replaced Queensberry as high commissioner. When the estates met on July 6, 1704, they again passed the Act of Security, and notwithstanding the previous refusal of the royal assent, without debate. As if to extort the submission of the English government, they further enacted the calling out of the militia and the general arming of the nation; a measure also supported by those who wished well to the union for the reason that it afforded some security against an invasion from the Highlands in the Jacobite interest. These bills they tacked to a money bill granting six months' supply for the payment of the army, then greatly in arrears.

Ministers in Scotland found themselves in a serious difficulty. The army, 3,000 strong, was unpaid; there was no money in the Scots treasury, and there would be none until either the tack was taken off, for which there was no constitutional device, or the Act of Security was passed. The only remaining alternative-that the English treasury should advance the funds necessary for the army-would have gone near to provoking a civil war. To disband the army at a

${ }^{1}$ Bonet's Correspondence, August 27-September 7, and September 10-21, 1703, Von Noorden, i., 518.

Id., September 24-October 5, r703, ibid.

3 "I have spoke. with the person mentioned ... who says that when he was in Scotland he saw the gentlemen of the country disciplining their men, and that the people were generally armed; that they drank the Prince of Wales's health, and seemed exasperated against England." Duke of Ormonde to Secretary Sir C. Hedges, Dublin, February Ir, 1705, Ommonde MSS., p. 777. 
moment when a hostile movement, as the queen's message had reminded parliament, was expected from France, was out of the question. It was agreed therefore that the Scots ministry should unanimously represent the dangerous condition of affairs to the queen, and recommend her to pass the Act of Security. The moment at which this advice was laid before the disgusted queen 1 was critical in the history of England. It was the end of July, 1704. Marlborough was marching to the Danube, and the existence of the English ministry hung upon his success. His defeat would in all probability be followed by a French invasion of Scotland, and such was the suspicion felt against England across the border that the Scots might decline the aid of English troops to preserve them from the pretender. No resort seemed to be left but to deal with the more immediate danger, to preserve the union of the kingdoms during the queen's life, even at the cost of sacrificing it after her death. On August 6-17, a few days before the news of Blenheim reached England, Godolphin advised the queen to pass the Act of Security. Scarcely was the ink dry on the parchment when a revulsion of feeling set in. The news of Blenheim transformed the English political horizon. A country which had shattered France had nothing to fear from Scotland. The surrender of Godolphin, but a few days before unavoidable, now appeared a gratuitous humiliation. The English parliament met on October 29, O.S., and Lord Haversham, a political stormy petrel, brought on a debate in the house of lords upon Scottish affairs.

The time had arrived for the whigs to decide whether they would continue Godolphin in office, or withdraw their support and watch his downfall. There were comings and goings between the whig leaders and the lord treasurer. The intermediary was Lord Monthermer, afterwards Marlborough's son-in-law, and in 1709 Duke of Montagu. Meanwhile a full-dress debate was fixed for November 29. The queen, anxious to retain Godolphin, now began the practice of attending debates upon important occasions, hoping that her presence might mitigate the severity of the attacks upon him. The opposition was led by Nottingham and Rochester. On the other side, Somers

"A "downright submission," in her opinion, to the cavaliers and Jacobites, Seafield MSS., Pp. 203-4, Hist. MSS. Comm., 14th Rep., App., iii. VOL. IX, 
CHAP. urged counsels of moderation. No good could arise out of v. criticisms of the acts of the Scots parliament, over which the parliament of England could pretend to no sort of jurisdiction. Such proceedings would be futile sources of irritation. It was a wiser course for England to demonstrate that if it came to a war of retaliations, the Scots would be " the greatest losers by it ". That the burning desire of Scotland was admission to free trade with England and her colonies every one knew. The diversions suggested by Somers would set the Scottish instinct for trade against the Scottish instinct for punctilio. A series of resolutions was passed by the lords on December I I, of which the first was once more to empower the crown to nominate commissioners to treat for a union. In the meanwhile, Scotsmen should not enjoy the privileges of Englishmen unless naturalised and permanently resident, or in the sea or land service, "until a union be had or the succession settled as in England". The importation of cattle from Scotland should be prohibited, and the exportation to Scotland of English wool, the raw material of its manufactures. The admiralty were to be instructed to provide cruisers to suppress the trade still surreptitiously carried on between Scotland and France. In short, Scotland, in default of union, should be treated on the footing she had assumed for herself, that of an independent and rival nation.

The tories were not slow to excite their own imaginations and those of their constituents with apprehensions of a Scottish invasion. ${ }^{1}$ As a concession to popular feeling the house of lords voted to address the queen praying for repairs to the fortifications of Newcastle, Carlisle, and Hull, for the raising of the militia of the four northern counties, for the maintenance of "a competent number" of regular troops in the north of England and of Ireland, and for the disarming of papists. Bills were draughted by the judges in conformity with the lords' resolutions The first, for an entire union, was read a third time on December 20 and sent down to the commons. When, however, a bill followed incorporating the other resolutions and inflicting penalties on default, the commons conceived their privilege of exclusively originating money bills to

'See a letter from Edward Repington to Thomas Coke, M.P., Dẹcember I, 1704 , in Coke MSS.; of. Coupper MSS., iii., 53 , 
be assailed. But public opinion would not tolerate a state of suspense which would have been involved in an irreconcilable attitude towards the ministry. Marlborough had returned to England on the 14th-25th, the popular idol. London exulted in the spectacle of a procession bearing from the Tower to Westminster Hall the trophies of victory on January 3, 1705. Three days later another pageant accompanied the duke to his entertainment by the city of London at the Goldsmiths' Hall. It was not a moment to choose for trying a fall with Godolphin with the nation's hero at his back. All that the commons could do was to accept the lords' bills in substance, though, to save their face, they formally redraughted them. They were then sent up to the lords in the form of one original bill. One addition of importance was made. It was resolved to shew Scotland that the more compliant disposition of the Irish legislature was reaping its reward. A clause was inserted prohibiting the importation of Scotch linen into England and Ireland. At the same time an act was passed opening the West Indies to Irish linen carried in English bottoms. All Scotsmen should be reputed as aliens unless the succession of the crown of Scotland followed the English precedent. ${ }^{1}$

These retaliatory measures added to the bitterness already manifested in Scotland. By the nomination of the Marquis of Tweeddale, the leader of the "flying squadron," as high commissioner in 1704 , it had been hoped that a middle party would be formed of sufficient strength to carry the settlement of the succession, which the queen at this time had strongly at heart. ${ }^{2}$ The politics of dilettantism yield in stress to the politics of resolution, and the new "queen's servants" in Scotland only contrived to remain on amicable terms with the opposition by the concession of the Act of Security. It had become even more evident in Scotland, where the pretender's friends were numerous, than in England, that the cause of the protestant succession must be entrusted to the party to whose existence it was vital, to the presbyterians in religion and the whigs in politics. At the head of this party, the most representative of the nation,

3 \& 4 Anne, c. 7.

'See her instructions to the Earl of Seafield, the Scots chancellor, April 5 , I704, Seafield MSS., P. I94. 
CHAP. stood John Campbell, second Duke of Argyll. He was but v. twenty-seven years of age ; but his territorial influence, his wealth, and the eminent services of his family to the whig cause marked him out as its natural leader. He was nominated, in place of Lord Tweeddale, the queen's commissioner for 1705. The Duke of Queensberry, as an astute manager of the place hunters and pensioners to whom the favours of the court were the goal of a political career, regained office as lord privy seal.

Early in the year 1705 an unfortunate incident irritated public feeling in both Scotland and England. In retaliation for the seizure, at the instance of the London East India Company, of a Scottish interloper in the Thames, the Scottish African and East Indian Company arrested an English vessel called the Worcester, which had been driven into the Firth of Forth, and tried the captain and crew for piracy and murder. By English procedure the prosecution would have failed to prove their case, there being no sufficient evidence of the identity of the vessel upon which the piracy was alleged to have been committed, nor that the captain was really murdered. Nevertheless on March 14, the captain and fourteen of the crew were condemned to death and the sentence was applauded in Scotland with passionate enthusiasm. The guilt or innocence of Captain Green became an international question. The ministers in London transmitted to Scotland affidavits showing his innocence, and that the captain, Drummond, supposed to have been murdered by hini, was alive in Madagascar. ${ }^{1}$ The Scottish ministry replied that "there was no possibility of preserying the public peace without allowing some that were thought most guilty to be executed ".2 Three victims were selected to gratify the national thirst for blood, and died protesting their innocence, which was confirmed more than twenty years later.

On February 27, O.S., 1 706, the Scots commissioners were appointed for the treaty of the union. The selections were made with a wise discrimination. Mere irreconcilables, like Lord Belhaven and Fletcher of Saltoun, were excluded ; otherwise the fractions of the Scottish parliament were all represented. Even Lockhart of Carnwath, a Jacobite, was included.

1 Seafield MSS., p. 196.

2 Chancellor Seafield to Godolphin, April II, I705, Burton's, Queen Amre, i., $324, n$. 
Of the thirty-one commissioners seventeen were commoners, some of them small landowners, others officials in the departCHAP. ments of law or finance. Most of the peers held office. The thirty-one English nominations were made by Godolphin and Harley, who were themselves of the number. They consisted largely of whig aristocrats, the two archbishops, Cowper, the new lord keeper, the two chief justices, John Smith, the new speaker, and the law officers. The commissioners sat for the first time on April 16 in the council chamber at the Cockpit, near Whitehall.

The first proposal came from the Scots. It was for a union of a federal nature, in which Scotland, while enjoying the advantages reserved for English subjects, should retain its own parliament. But from the outset the English commissioners were firm that a union meant a union of parliaments. Without that, admission to England's colonial trade, the bait which whetted Scotch appetites, was out of the question. Declining to consider the Scots' proposal, they submitted a counter-proposal for a union of kingdoms and parliaments under the crown as limited by the English Act of Succession. This the Scots accepted with a proviso for their free admission to English trade at home and in the colonies. The constitutional principle having been agreed upon, subsequent proceedings resolved themselves into estimates of the financial consequences to Scotland. Hitherto the burden of expenditure had fallen upon England. Its debt exceeded $£ 17,700, \infty 00$, while that of Scotland was $£ 160,000$. The proportions of revenue raised by taxation were ludicrously unequal, the landowners of England, for example, paying $£ 2,000,000$ land tax, while those of Scotland paid but $£ 3,600$ yearly. If Scotland were to take a share of the English debt, what compensation should she have? If she should come under the burden of English taxation, what proportion should she bear? Upon all these matters the English commissioners exercised a wise generosity. In the matter of taxation they conceded abatements and remissions. As compensation for the liabilities undertaken they fixed a sum called "the equivalent" of $£ 398,085$ to be paid by England at the union. It was agreed that this should be applied towards providing Scotland with a new coinage, paying up in full the shareholders of the bankrupt Scotch African Company, 
CHAP. thereafter to be dissolved, and encouraging manufactures and v. fisheries. In adjusting the representation the English commissioners showed the same liberality. While bearing but a fortieth part of the common burden, Scotland was offered an eleventh part of the legislative representation, regard being had to her proportion of the total population of the two kingdoms. Sixteen peers and forty-five commoners were to sit for Scotland in the common parliament. Her system of law and her ecclesiastical establishment were to remain unchanged. On July 22, 1706, twenty-seven English and twenty-six Scotch commissioners signed the articles.

Upon the eve of the last meeting of the Scots parliament in the autumn of 1706 the government reckoned to have won the majority both of the elected and hereditary members. The "flying squadron" had relaxed its nationalist sympathies. The campaign of 1706, which had dispelled any hope of a French invasion, had tended to make some of the Jacobites reconcilable. In response to addresses to the queen from the Scots parliament against any progress in the treaty of union till the act declaring them aliens was repealed, the English parliament had cheerfully repealed not only that but all clauses hostile to Scotch trade "to the end that the good and friendly disposition of this kingdom towards the kingdom of Scotland may appear". ${ }^{1}$ But there were signs of strong popular hostility to a union. In the wealthy south-eastern counties, the home of presbyterianism and whiggery, the impulse felt by those who were on the path of economic progress was towards England. But here Edinburgh anticipated with dislike its degradation from a capital to a provincial city. On the east coast up to Aberdeen the strong AngloSaxon element was also on the whole friendly. It was otherwise on the west. The western counties of the lowlands and the hill country of mid-Scotland on that side were strongholds of the covenanters. Children of men who had endured under Lauderdale and Dundee, they hated prelacy with a zeal equal to that with which they hated papacy. Those who, in a commission on which sat Anglican prelates, trucked the independence of Scotland and the purity of its gospel were to be withstood as associates of the priests of Baal were with- 
stood by the heroes of Bible history. In the western highlands, CHAP. where many were still Roman catholics, the clans remembered with bitterness the sword of William of Orange. With not a few notable exceptions both chiefs and followers were ready to support the pretender in arms. "There came a scheme from Scotland," wrote in 1705 the Scotch spy employed in Paris, "to the Court of St. Germain's, telling them that on the conclusion of the union was a proper time for the King of France to send in some troops with some money and ammunition and some arms and some officers; and if the Prince of Wales would come himself, the most of the kingdom would join him withal." 1 The Jacobites deceived themselves. Zealous as the fanatics of the covenant were against the union, they were yet more zealous against the Stewarts, the slaughterers of the saints.

Of all Scottish parliamentarians the Duke of Queensberry was incontestably the most capable. In his History of the Union Daniel De Foe, a competent critic, who was entrusted by Harley with the task of watching the progress of the measure, ${ }_{1}^{2}$, has left an eloquent record of his talents as a manager. He enjoyed the confidence of the presbyterians. ${ }^{3}$ Queensberry's ablest lieutenant was John Dalrymple, first Earl of Stair, a name stained with the memory of the massacre of Glencoe, but to whose brilliant parts even the vindictive Jacobite, Lockhart of Carnwath, bears testimony. As secretary of state, John Erskine, the young Earl of Mar, a recruit from the cavalier party, was skilful at unravelling the intrigues of his late associates. The Estates of Scotland met for their last session on October 3, with Queensberry as high commissioner. At once parliament was flooded with addresses against union. Edinburgh was in daily uproar. Mobs, crying "No union," "No union," "English dogs!" and the like, paraded the streets. The Duke of Hamilton, the leader of the opposition, was attended in his chair by shouting crowds. Soldiers were called

1 Memorandum on Scotch affairs by Captain John Ogilvie, Portland MSS., iv., 276.

A memorandum of his duties on this mission, which was secret, is given in a letter to Harley, of September 13, 1706, in Portland MSS., iv., 326-28, 334 . 76.

'Lord Yeater to [the Earl of Oxford], August 28, 1711, Portland MSS., v., 
CHAP. in to disperse the rioters. ${ }^{1}$ When, conformably with Scottish $v$. usage, the d bate on the general question began on November 2-1 3 , an eloquent declamation was uttered by John Hamilton, Lord Belhaven, the principal orator of the opposition, which was received with so much admiration by the public that it found a place in every Scotsman's library. Declamation seldom alters parliamentary votes; and the speech was replied to by the Earl of Marchmont, a leader of the "squadron," in terms of contemptuous sarcasm. By a majority of sixty-four the house decided to proceed to the terms of the treaty of union.

In order to pacify religious apprehensions, the government at an early stage interposed a bill elaborated by the general assembly for the security of the Scots kirk. Upon this Lord Belhaven raised a substantial difficulty. No equality, he argued, was conceded by a union which allowed Englishmen to hold offices in Scotland without a sacramental test, but imposed one on Scotsmen admitted to office in England. That the clause proposing the exemption of Scotsmen from the test should have been rejected by thirty-nine votes was due to the support given to the government by the episcopalians and the Jacobites. It perhaps also indicates that the expectation of seeing Scotsmen in office in England was so remote that the grievance was regarded as fanciful. The act for the security of the Scots kirk was passed on the I 2 th, with a proviso for its repetition in any act adopting the treaty of union. It is in accordance with the provisions of this act that the sovereign takes an oath immediately on his accession to maintain the Scottish establishment. "From this day forwards," wrote Stair to Harley, on November 12, "the ferment will abate." 2 Upon a resumption of the consideration of the articles of union, the second, so hateful to the Jacobites, providing for the succession according to the English precedent, was carried by fifty-nine votes. Upon the third article, that both kingdoms should be represented by

1 De Foe to Harley, Portland MSS., iv., 339-4x, 342-34.

2 Portland MSS., iv., 348. Godolphin treated the turmoil with a discerning contempt. "They are the first people that ever I knew in a fixed intention of going into an open rebellion who thought fit to make so public a declaration of it beforehand." Brit. Mus,, Add. MS., 6420. 
one parliament, there was a formidable resistance upon constitutional grounds. Hobbes, Filmer, and Locl;a had familiCHAP. arised men's mir'ts with theories of sxcial contracts and of consequences. deducible from them. It was urged by the opposition that to agree to the destruction of the Scots parliament, and thereby of the independence of the kingdom, was to usurp a competence never created by the constituencies, nor in the power of the constituencies to create, and that the consent, at least, of every person entitled to be represented was a condition precedent. The government knew that the interval following a dissolution of parliament would be employed, not in political argument, but in preparation for armed violence. Colonel Erskine, provost of Stirling, in front of his regiment of militia "with his sword drawn in one hand and his pen in the other signed" an address against union "and made the rest do so also".1 Edinburgh was full of highlanders armed to the teeth." "All the west is full of tumult. Glasgow is mad," wrote De Foe. ${ }^{3}$ But for the weather, its people boasted, I 5,000 of them would have been at Edinburgh." As soon as they began to carry out their threat, the parliament repealed the Act of Security and made appearing in arms illegal. ${ }^{5}$ It was the only resource left, for the Scotch troops numbered but 2,000 men and these were " not to be depended upon". Stair recommended that troops should be held in readiness in the north of England and in Ireland." "All the interest here would never carry the union without blood." 8

Despite these gloomy forebodings, the opposition in parliament dissolved with unexpected rapidity. Between the Dukes of Hamilton and Atholl there had long been rivalry. Each had outvied the other in zeal against the union. Hamilton, however, had been steadily losing influence. Not he, but Atholl, had been regarded in the affair of the Scottish plot as the representative of the Jacobites. While Atholl now

${ }^{2}$ De Foe to Harley, Edinburgh, November 23, 1706, Portland MSS., iv., 356.

De Foe to Harley, Edinburgh, November 13, ibid., p. 349.

- De Foe to Harley, Edinburgh, November 19, ibid., p. 352.

- De Foe to Harley, November 16, ibid., p. 351; December 27, ibid., p. 374.

- Ibid. De Foe to Hariey, Edinburgh, November 13,1706 , ibid., p. 35a.

' Earl of Stair to Harley, Edinburgh, November 26, 1706, ibid, p. 359

- De Foe to Harley, Edinburgh, November 20, 1706, ibid., p. 361. 
CHAP. ranged himself with the party of violence, Hamilton dissuaded

v. from action, and the dowager-duchess threatened to evict any of her tenants who appeared in arms. ${ }^{1}$ A correspondent of Harley, writing from Edinburgh, reported secret visits paid by Hamilton to the chancellor, Lord Seafield, and the Duke of Queensberry. ${ }^{2}$ The fruit of these interviews was soon culled. The articles conceding freedom of trade to Scotland and settling the respective quotas of taxation, etc., were passed without serious resistance. The opposition was divided, and Hamilton was the leader of a body in favour of passing an act of succession and rejecting a union. Atholl and the Jacobites were resolute against settling the crown on the house of Hanover. ${ }^{3}$ When the final vote upon the question of union was put, Hamilton, to the amazement of his followers, remained motionless in his place, and the government by forty votes carried in the face of a furious but disconcerted opposition the representation agreed on by the commissioners for the union. The union was now assured, but it cost the life of one of its most ardent supporters. Lord Stair "made an extraordinary speech on the debate on the twenty-second article and was found dead in his bed in the morning "(January 8).4 Excitement and exhaustion killed him. The treaty received the touch of the sceptre on January I6, I 707.

On the $28 \mathrm{th}$, the queen in person presented the Scots ratification of the treaty for union to the two houses. As in Scotland, ministers judged it wise to begin by disarming ecclesiastical antipathies. The primate Tenison, on February 3, laid before the house of lords a clause, framed upon the model of the parallel in the Scots Act, for securing the position of the Church of England. The Scotch presbyterians had acted with magnanimity. They had imposed no tests. Episcopalians north of the Tweed were, equally with presbyterians, admissible to office. It would have been well if the English bishops could have followed their example. Certainly if Tenison, who was bold enough to eulogise the Scotch establishment, did not venture to take this course, it was not for

1 De Foe to Harley, Edinburgh, December 7, 1706, Portland MSS., iv., 364.

2 D. Fearns to Harley, ibid., p. 347.

${ }^{3}$ De Foe to Harley, January $4,1706-7$, ibid., p. 378.

'De Foe to Harley, January 9, 1706-7, ibid., p. 380. 
want of tolerance but because the prospects of such a proposal were hopeless. The bill introduced by the primate, which was afterwards incorporated in the Act of Union, provided for the perpetuation of the Act of Uniformity and all other laws "for the establishment and preservation of the Church of England and the doctrine, worship, discipline, and government thereof".

In both houses the proceedings upon the union were the same. The most substantial objections went upon finance and representation. Throughout the divisions in both houses the government had ample majorities. Ministers had resolved to carry the bill substantially as it left the Scots parliament, for amendments would involve endless wrangles and final discomfiture. The knowledge of this fact and the popular feeling in favcur of union knocked the heart out of the opposition. The bill was carried in the commons by 274 to 116 votes on February 28, 1706-7. Taken up to the lords on March 1 it passed rapidly through their house. A final protest was signed on the $4^{\text {th }}$ by Nottingham, and seven tory peers of little note. On the 6 th, the queen attended the house in person and the bill for a union of the two kingdoms of England and Scotland received the royal assent. ${ }^{1}$

The interval of nearly two months before May 1, 1707, when the union was to take effect, furnished occasion for the first quarrel between the two nations. Scottish merchants took advantage of the lower range of customs duties in Scotland to accumulate foreign imports in order to pour them into England. For this purpose vessels were freighted in Holland and even in France. On the other hand, English merchants who had paid an import duty of sixpence a pound on imported tobacco obtained a drawback of fivepence on exporting it to Scotland with a view to a subsequent reimportation free of duty across the border. Those of the commercial classes who could make a profit out of neither operation were exasperated. The English customs officers in June seized the cargoes of a fieet of forty sail, "mostly loaded with wine and brandy," carried from Scotland to the Thames. Only the prudence of Godolphin in waiving the rights of the crown averted a dan- 
CHAP. gerous collision. Eager to catch at grievances, the Scottish V. malcontents next clamoured at the delay in the payment of "the equivalent". Even as early as June 5 a supporter of the union writes that the want of "the equivalent" was contributing with the intrigues of the Jacobites to render the union a failure. ${ }^{1}$ On July 8 twelve waggons were dispatched to Edinburgh with $£ 100,000$ in bullion, under convoy of a troop of horse. The procession was greeted in the High Street with shouts of "Judas money". When it was found that the residue was offered in exchequer bills there was a fresh outburst against English perfidy. Public confidence was only restored through the acceptance of the bills by some large shareholders of the African Company. The distribution of the money involved bitter wrangles and recriminations between the commissioners of union, to whom it was entrusted, and the public, and among the commissioners themselves, for whose indemnification large sums were appropriated. ${ }^{2}$ Nearly twenty years passed before any portion was allotted for the encouragement of the fisheries or manufactures. The introduction of the English system of raising internal revenue excited fresh dissatisfaction. English highwaymen, it was said, in anticipation of Swift's sarcasm on Irish bishops, migrated to Scotland as excise officers. They were pelted in the streets and compelled to walk for protection with the town officials. ${ }^{3} \quad$ The increase of duties at the ports gave a stimulus to smuggling, and the customs officers and riding surveyors of the coast were driven to fulfil their functions under military escort. The fruits of the union in the eyes of the masses were increased cost of living and the influx of a horde of objection- able English officials.

1 Lord Anstruther to the Duke of Montrose, Montrose MSS., p. 368, Hist. MSS. Comm., 3rd Rep., App.

2 Burnet; Seafield MSS., p. 222, John Earl of Mar, Secretary of State for Scotland, to James Earl of Seafield, Lord Chancellor.

3 Earl of Glasgow to Duke of Montrose, June 3, 1707, Montrose MSS., p. 376 . 
CHAPTER VI.

THE CAMPAIGNS OF 1707-1708.

WITH the crushing defeat of the French before Turin by CHAP. Eugene on September 7, the supremacy of Austria in Northern vI. Italy was assured, and this involved a revival of the territorial disputes between the emperor and the Duke of Savoy. The emperor, in order to get possession of Mantua without a conflict, presently ventured on a grave perfidy. Without the knowledge of the allies, he entered into a treaty with France on March I 3, 1707, known as the treaty of Milan, allowing the return home of the isolated French garrisons in Italy. His own troops, now set free, he destined, notwithstanding the protest of the allies, for the conquest of Naples.

With the capture of Madrid in June, 1706, the hopes of the allies rose high. The French, on their side, made extraordinary exertions to reinforce their troops. After the release of their garrisons from Italy by the treaty of Milan, they transferred a strong force to Roussillon for operations against Catalonia from the north. Philip, Duke of Orleans, was appointed to supersede Berwick in the chief command. On February 7, 1707, the belated expeditionary force under Lord Rivers arrived at Alicante. Originally numbering 10,000 men, it had already been reduced through sickness and privation by a fourth. The arrival of Rivers added fresh flames to the heartburnings which during the winter had raged at Valencia. On the one side was Galway, supported by General Stanhope, the English envoy-extraordinary to Charles, on the other the Dutch general, Noyelles, Liechtenstein, the archduke's principal Austrian adviser, and Cardona, the Spanish viceroy of Catalonia. The two English generals were for adopting the advice of Marlborough, who could scarcely have been 
CHAP. accurately informed of the state of the country, and for marchVI. ing at once on Madrid in concert with an advance expected from Portugal. The others were for a defensive war maintained by garrisons dispersed through Valencia and Catalonia. To these last Rivers and Peterborough, who had returned from Genoa on January 6, allied themselves. From divided counsels came divided action. In the middle of March Charles, accompanied by his ministers and escorted by Noyelles with the Spanish and 800 Dutch troops, left Valencia and returned to Barcelona. A partial dispersion of the army among neighbouring garrisons took place. Galway's forces were now reduced by some 10,000 men. Two compensations fell to him; the peremptory recall of Peterborough by Sunderland on the archduke's complaints, and the resignation of his command by Rivers, who also returned home.

Galway's plan was to march through the hilly country of the south of Aragon, where Berwick's superiority in cavalry would be rendered ineffective, and throw himself into Madrid. He began his march on April 10, at the head of about 1 5,500 men, half of them Portuguese, the rest including 4,800 English, besides Dutch, Germans, and Huguenots, but no Spaniards. On April 24 news was brought to the camp of the allies, who were besieging the small fortress of Villena, that Berwick was advancing, presumably to its relief. At a council of war the allied generals unanimously agreed to take the aggressive, before Orleans, who was on the march, could effect a junction with Berwick. Berwick was in command of 25,400 men with a good train of artillery. Of these troops, I 1,900 were French and the remainder Spanish. On the $25^{\text {th }}$, apprised of the approach of the allies, Berwick, who had reached Almanza, had distributed his forces in two lines, with the town at their rear. His cavalry were at the wings. Between his army and that of the allies lay the plain of Almanza, swept by the fire of his artillery. Galway adopted a similar disposition of his men. The attack began with a charge by General Carpenter's cavalry upon the Spanish horse posted at Berwick's right wing. This was followed up by the advance of the English, Dutch, and Huguenot foot, who drove the enemy's infantry towards the walls of the town. But a charge of the French cavalry of Berwick's left wing against the Portuguese horse threw them 
into a panic and exposed the victorious foot to being cut to pieces by an attack on their right flank. Galway having been CHAP. temporarily deprived of sight by two sabre cuts over his right eye, there was no one to give general directions, and each section of the army fought independently. Under cover of a charge by Carpenter at the head of the Huguenot dragoons, Galway drew off the left, over which he had command, numbering 3,500 men. After a retreat of eight miles, the fragments of the centre were compelled next day to lay down their arms. The total loss to the allies was 4,000 killed and wounded and 3,000 prisoners. "I cannot," wrote Galway to Sunderland, "but look upon the affairs of Spain as lost by this bad disaster."

The news of Almanza revived in the minds of Godolphin and Marlborough the policy of a diversion in the south of France. It was still the belief in England that without French troops Philip would be unable to maintain himself on the Spanish throne. Reluctantly yielding to the importunities of the English ministry, Prince Eugene consented to serve in an expedition against Toulon. At the beginning of July the Duke of Savoy and Eugene took the field at the head of 35,000 men. A fleet under Shovell was ready to co-operate. The army arrived before Toulon on the 26th. But the invaders were, as the letters of the English envoy, Chetwynd, disclose, in no condition for a successful campaign. Their march had been through a country bare of provisions, amid a hostile population. Discipline had given way before privations. Desertion was rampant. Nor was it easy to compensate for the ineffectiveness of the land forces by the operations of the fleet. A gauntlet of forts would have to be run before, with its limited range, the fleet could bombard the town, while the space between the fleet and the army was commanded by French fortified posts. Between the allies and the town walls lay Tesse in an intrenched camp, daily receiving reinforcements. It speedily became apparent that the army was inadequate to the task of investing Toulon, perhaps even of defending itself. Time was needed for the siege and time was working on behalf of the enemy. On the 22nd the allies turned their backs upon Toulon. The disorderly retreat was impeded by a revengeful peasantry, but unmolested 
CHAP. by the French army. The failure of the siege was, however, VI. partly redeemed by the success of the operations of the fleet. Fearful lest they should fall into Shovell's hands, the French themselves destroyed ten of their line of battle ships. The French Mediterranean fleet ceased to exist. This was Shovell's last service. On his way home he was wrecked off the Scilly Isles and murdered for his jewelry. In him England lost a naval officer whose courage and enterprise found no equal in the next generation of her seamen.

Early in the year the English ministry had renewed its endeavours to strengthen the Grand Alliance in Italy. The republic of Venice was, however, indisposed to risk a war with France in the Adriatic or the Mediterranean, 1 while that of Genoa, suspicious of the Duke of Savoy, and with nothing to hope from the emperor, was emboldened by the failure at Toulon to turn a deaf ear to the allies. As the misfortune of Toulon affected the disposition of the Italian powers, so Almanza was the cause of a revulsion of feeling in Portugal. The Portuguese complained that their troops had been marched across Spain, and had left their own frontiers without protection. On December 29, Methuen wrote that Portugal could offer no resistance to a French invasion. Between the spirit which prevailed at the court of Lisbon and that at the court of Barcelona there was not much to choose. Galway alone displayed resolution, energetically reforming his army the morrow after Almanza. The Austrian party was torn by dissension and busy with recrimination. Charles himself had lost his hold on the Catalans, who were disgusted with the haughtiness of his German favourites. Nevertheless, they remained animated by their hatred of the Castilians, and reliant upon the difficulties presented by their country to an invading army. At the end of 1707 , when the Bourbon army withdrew to winter quarters, Charles still held the fortresses of Tortosa and Gerona besides Barcelona. In the following spring reinforcements from the maritime powers might restore his fortunes.

In the autumn of 1706 the giant form of Charles XII. of

1 See the letter of Stepney to Hedges relating a discussion of Venetian policy between himself and the Venetian ambassador at Vienna, October 16-27, 1703 , Buccleuch MSS., ii, 2, 685-87. 
Sweden was casting its shadow across the path of the Grand CHAP. Alliance. By a treaty agreed upon at Alt-Ranstädt, near

Leipzig, Frederick Augustus, Elector of Saxony, was compelled to renounce the throne of Poland in favour of Stanislaus, the candidate supported by Charles. In his camp at AltRanstädt, the Swede was the arbiter of Europe. At the head of a disciplined army approaching the number of 60,000 men he had it in his power to turn the scale of fortune as he pleased. Charles conceived himself the successor of Gustavus Adolphus as "the bulwark of the Protestant faith" in Europe. To him Louis XIV. represented a persecuting Catholicism to which he would lend no assistance either by mediation or arms. But against the Emperor Joseph I. he had an accumulation of complaints. Of these the most important were the persecution of Protestants in Silesia and the refusal to surrender $\mathbf{1}, 200$ Russian prisoners who had taken refuge on Austrian territory. Flushed with victory, and confident in the belief that he was entrusted with a divine mission, Charles was already, in the early spring of 1707 , threatening to exact redress by force. A march of the Swedes upon Vienna must have been the ruin of the Grand Alliance.

Dr. John Robinson, the English envoy to Sweden, having failed to pacify Charles's exasperation, the maritime powers agreed, at Marlborough's instance, that the crisis was one demanding his diplomacy. On April 20, N.S., I 707, he left the Hague, arriving at the camp of Alt-Ranstädt six days later. Admitted to the presence of Charles, he addressed the king in a speech of adulation pitched to the tone of his intoxicated 'military vanity. The king through Count Piper, his minister for foreign affairs, returned an answer unusually gracious, professing the utmost regard for the queen and for the interests of the Grand Alliance. He assured Marlborough that he would undertake no mediation unless with the queen's concurrence. Marlborough left Charles with the conviction that his mission had proved a success, and that the court of Vienna would, on its side, follow his counsel and satisfy the Swedish demands. For months the characteristic evasiveness and procrastination of Joseph I. postponed a settlement. But for his conquest of Naples in May, 1707, and the occupation of the Italian duchies, which divided his forces, he would probably VOL. IX. 
CHAP. have challenged a recourse to arms. Those diversions, which

VI. had angered the maritime powers, thus proved the salvation of the Alliance. When the patience of Charles at length gave way, the emperor yielded, and the Swedish army turned its steps towards the Russian frentier.

In January, I707, Louis, Margrave of Baden, whose inactivity and contentiousness had long been a thorn in the side of Marlborough, died. The commander whose co-operation in Germany the duke would have preferred was Prince Eugene, but Eugene was already destined for the expedition against Toulon. The imperial general in Germany chosen, in conformity with Austrian traditions, on account of his age and rank, was Christian, Margrave of Baireuth, as infirm and even less enterprising than his predecessor. On the night of May 22 he allowed himself to be surprised by Villars within the fortified lines of Stollhofen, fled eastwards, and again opened up to the French the prospect of a march upon Vienna in concert with the Hungarian insurgents. Exasperated by the excesses of the French in Würtemberg, the South German princes turned for aid to the maritime powers. Marlborough, who was at this time confronting the army of Vendôme, seized the opportunity to strike a bargain which at once served to get rid of the margrave and to fortify his own influence with the whig party. The maritime powers would send a detachment to threaten the communications of Villars on condition that the emperor would nominate the Elector of Hanover to the command of the army of the Rhine. The negotiations were protracted from May to September, when the Elector George took over the command of the imperial forces. Week after week passed uneventfully, and at the beginning of November Villars withdrew to the left bank of the Rhine. Marlborough, in his intrenched camp at Meldert, was playing a game of diplomacy rather than of war, his gaze directed to Alt-Ranstädt and Vienna, where a new conflagration might at any moment arise. Not until August, when the Swedish war-cloud was driving towards Russia, did he feel free to move. But the autumn proved wet, the army was wasted by sickness, and the French, as Marlborough bitterly complained, had been reinforced by their garrisons from Italy and by their victorious comrades from Toulon. There, as in Germany and Spain, 
the sun of success had shone upon the Bourbon arms. For the allies the campaign of 1707 had proved a gloomy conCHAP. trast to the brilliancy of the year of Ramillies.

Dispiriting as the campaign had proved to be, Marlborough and Godolphin remained resolute for the continuance of the war. But both English and Dutch agreed in indignation at the selfish policy of the emperor, for the benefit of whose family the war was being carried on, at his greed for territory, and at his neglect to perform his pledges as to troops. The German princes were full of grievances and demands. Chief among them the Elector George of Hanover, jealous of Eugene, was threatening rather to resign his command than to suffer a partial eclipse by a comradeship in arms. It needed all the diplomatic skill of Marlborough and Eugene, who visited Hanover together in April, 1708, to soothe his injured vanity. He consented to retain his command on the Rhine with the understanding that his independence would be assured by the formation of a third army on the Moselle under Eugene. The three armies should co-operate together in a general offensive, the elector with 45,000 men against Alsace, Eugene, at the head of 40,000 imperialists on the Moselle, and Marlborough in the Spanish Netherlands. A secret understanding between Eugene and Marlborough provided that, in case of need, either should support the other with his entire force. The French army in Flanders was placed under the nominal command of the Duke of Burgundy, the eldest son of the dauphin. At his side was Vendôme; but between the pupil of the saintly Fénelon and Vendôme, a man notorious for his coarseness and profanity, there existed an incompatibility of temper paralysing the loyal concert indispensable to the success of a divided command.

By the middle of May, the French army was in the field. Its two commanders were involved in incessant wrangles, while Marlborough in his intrenched camp at Terbank, west of Louvain, waited until the movements of Eugene upon the Moselle should compel the French to withdraw reinforcements thither. As usual, the imperialists were unready. Impatient at the prospect of an inglorious campaign, Marlborough at length on May 30, N.S., wrote to Eugene recommending a change of plan. A sudden junction of their armies by a 
CHAP. series of forced marches would enable them to throw themselves VI. in superior numbers upon the troops of Vendôme and Burgundy. A month later Eugene began his march, but at this critical moment an important diversion occurred in favour of the French. The growing discontent aroused in the Netherlands by the oppressive government of the Dutch had taken shape in a conspiracy to replace the great towns in French hands. Ghent and Bruges welcomed French troops; Ostend was in danger. In a few days much of the fruit of Ramillies was lost. On July 6, Eugene with his staff joined Marlborough at the camp of Anderlecht, west of Brussels. To the French army, with its superiority of numbers, time was precious, for the imperialist reinforcements of 30,000 foot were still several days' march behind. Vendôme conceived the plan of crossing the Schelde and storming Oudenarde, the link between Flanders and Brabant. If Oudenarde was to be saved to the allies, there was no leisure to await Eugene's troops. Hastening westwards by night marches Marlborough reached its walls while the French, some eight miles to.the north, were bridging the river, unaware, as at Blenheim, of his movements.

The scene of the battle of Oudenarde on July I I, I 708, may be described as an arc of which the Schelde on the east forms the chord, the arc extending about two miles westwards. The area of ground rising upwards from the Schelde thus inclosed is bisected by the little river Norken, running from west to east into the Schelde. Behind this the main body of the French was posted. From north to south the area known as the plain of Heurne is about three miles. The ground was divided by numerous hedges and ditches, and the banks of the Norken were overgrown with brushwood. It was, therefore, unfavourable to cavalry, in which arm the French were particularly strong. So surprised were the French at the appearance of the allies that they had no time to select their positions. They had not even decided whether they would accept battle. Profiting by their indecision, Marlborough, without waiting for his whole army to cross the Schelde, ${ }^{2}$

${ }^{1}$ According to Francis Hare, the duke's chaplain and friend, "We had scarce a third part (of the foot) over" when Cadogan's attack began. Francis Hare to George Naylor, July I2, I708, Hare MSS., p. 218, Hist. MSS. Comm., I4th Rep., App., ix. 
threw forward General Cadogan, who opened a sudden attack on a body of horse and toot which had advanced to Eyne, char. a village two miles to the north of Oudenarde. A sharp struggle took place; the French were routed and most of them driven across the Norken, while three entire battalions and their general, the Duke de Biron, were taken prisoners. In this charge, the electoral prince George of Hanover, afterwards George II. of England, led a squadron with intrepidity. Cadogan's troops then pressed forward and occupied Heurne, a mile north of Eyne. It was becoming dusk and the French could still have avoided a general engagement, but the Duke of Burgundy, without consulting Vendôme, ordered an advance. After a stubbornly contested fight the issue was determined by the execution, under the direction of Marlborough, of a turning movement of the French right by the veteran Dutch marshal, Ouwerkerk. This threw the French into confusion, and soon after eight o'clock Vendôme ordered a general retreat. But for the darkness, Marlborough repeatedly affirmed, the retreat would have degenerated into a panic-stricken rout and the war have been at an end. The allies lost only 3,000 men; the French 6,000 killed and wounded and 9,000 prisoners, including 700 officers, as well as ninety-eight colours and standards. Including deserters and fugitives who never rejoined, Marlborough computed the diminution of their numbers at 20,000 men. With a modesty characteristic of his dispatches, Marlborough summed up the features of the engagement which exhibit his genius in defying with success the traditional rules of war. "We were obliged," he wrote to the queen in reply to her letter of congratulation, "not only to march five leagues that morning, but to pass a river before the enemy and to engage them before the whole army was passed." The queen ordered a public thanksgiving. The tories were divided in their attitude. To the Jacobites there were the additional vexations that the pretender, under the name of the Chevalier de St. George, had been prominent in the defeated army, and that the protestant heir had won a name for gallantry in the action. ${ }^{1}$ Many of them minimised

1 The interesting metrical account of the battle by John Scot, serving in the Scots Brigade in pay of the States of Holland, narrates that the Elector of Hanover, i.e, Prince George, having had his horse shot under him, was supposed 
CHAP. the success and affected to "look upon the giving of thanks

vi. for a victory at Oudenarde to be a mocking of God".1 The first care of Vendôme after the battle was to protect Ghent and Bruges. With this object he occupied an intrenched camp behind the canal of Bruges. Here he was safe against attack and could await the advance of Berwick, whose army would raise the combined forces to 100,000 men. As after Ramillies, Marlborough proposed to strike a blow at the heart of France, to mask Lille and to advance by forced marches upon Paris. Eugene refused. It was decided, therefore, to lay siege to Lille; its relief would certainly necessitate the advance of the French armies, its capture would pave the way for Marlborough's brilliant project. In the meantime a body of English cavalry was detached to ravage Picardy.

Before the army of Berwick had entered the theatre of operations, the investment of Lille was begun on August I 3 . Though Vendôme and Berwick effected a junction on the 3oth they could agree upon nothing but the interception of the communications of the besiegers. During September the resources of the allies were daily more straitened by the cutting off of convoys from Brussels. The only source of supplies left them was the sea. It happened that during the summer months a military force under General Erle had been cruising in the Channel, with orders to effect a landing in Normandy or Brittany. The expedition proved a failure, and the troops, at Marlborough's instance, were now conveyed to Ostend. There a large convoy was prepared, to conduct which Marlborough detached General Webb, with about 4,000 foot and three squadrons of dragoons. On September 27, when some fifteen miles from Ostend, near the castle of Wynendaele, Webb was attacked by the French general Lamothe, with troops nearly double in numbers. Reinforced, after a brilliant defence, by General Cadogan, he beat the French off. Upon the issue of this action hung the fate of Lille. "If they [Webb and Cadogan] had not succeeded, and our convoy had been lost, the consequence must have been the raising of to have been killed, but afterwards fought on foot with a half-pike. The pretender is said by the same author to have thrice rallied the French and the Irish Brigade. The Remembrance, Scòttish Hist. Soc. (rgor), iii., 412.

1 Erasmus Lewis to Robert Harley, Whitehall, August 19, 1708, Portland MSS., iv,. 5or, 
the siege next day," wrote Marlborough ; "there did not CHAP. remain powder and ball for above four days." "This last VI. action," wrote Petkum, the minister of the Duke of SchleswigHolstein at the Hague to Torcy, "is considered here more important in its consequences than the battle of Oudenarde." 1 Webb justly received for his exploit the thanks of the house of commons.

The progress of the besiegers could no longer be resisted. On October 22 Marshal Boufflers capitulated for the surrender of the city. The citadel held out week after week, the allies' communications were constantly interrupted, and Marlborough received the discouraging information that the enemy was expecting reinforcements. The Elector of Bavaria, who had hitherto lain inactive on the Rhine, suddenly marched to Mons, and on November 22 appeared before the gates of Brussels at the head of 15,000 men. Its inhabitants were well affected to him and its garrison numbered but 7,000 troops. Marlborough and Eugene hurried to the rescue by rapid marches, surprised and routed the French troops guarding the fords of the Schelde, and captured over 1,000 prisoners. While Eugene returned to the army of investment, Marlborough, despite the fatigue of his troops, pushed on. The defective intelligence from which the opposed commanders habitually suffered again came to his help. Scarcely was the elector aware of the passage of the Schelde ere he found Marlborough upon him. "He immediately," wrote the duke in a dispatch of November 28, "quitted the siege in the greatest confusion, leaving all his artillery and ammunition with above 800 wounded officers and soldiers in the camp, and retired towards Mons." In two days Marlborough had won two brilliant successes. Brussels was saved and the fate of Lille sealed. Marlborough stood master of Brabant. On December 9 the citadel of Lille surrendered. Ghent and Bruges speedily followed its example. The campaign of this year illustrates no less than that of 1704 the extraordinary talents of Marlborough as a general. His army was inferior to the united armies of Vendome and Berwick, yet he contrived, after winning a pitched battle in unfavourable circumstances, pt. ix,

${ }^{2}$ October 4, 1708, Round MSS., p. 33x, Hist. MSS. Comm., x th Rep., App., 
CHAP. to maintain the investment of a first-class fortress with its com-

VI. munications threatened on every side, to defeat two auxiliary armies, to harry the enemy's country, to recover the whole of the territory recently occupied by the French, and, in short, to accomplish every object to which he addressed his efforts.

In Spain at the opening of the campaign of 1708 there were three Bourbon armies afoot; one of 22,000 men, under Orleans in north-west Catalonia, a second under General Bay on the Portuguese frontier, and 6,000 Castilians under General d'Asfeldt in occupation of the province of Valencia. On the northern border of Catalonia hovered the Duke de Noailles at the head of a French force. Galway, who since his wounds at Almanza had become blind of one eye and partially deaf, was, in deference to the emperor's repeated solicitations, relieved of his thankless post as commander-in-chief of the British contingent. But so convinced were Marlborough and his whig friends of his skill as a general and his value as a diplomatist, that it was decided to nominate him to the chief command of the British forces in Portugal, and in February to accredit him as ambassador to the court of Lisbon.

While the archduke's cause continued to lose ground on the mainland, the supremacy of the maritime powers was asserting itself in his interest at sea. In August the fleet of Leake, who had succeeded Shovell in the Mediterranean, put in at Cagliari, and after a show of resistance took possession of Sardinia, replacing the Bourbon governor by the Count Cifuentes, the former leader of the Austrian party in Aragon. That island's inexhaustible granaries were now at the disposal of the allies. But the British government was not disposed to forgo all share in the advantages procured by its efforts and expenditure. The fate of Shovell had impressed more strongly than before upon the mind of Marlborough the necessity of a winter harbour in the Mediterranean. In July of this year he wrote to Stanhope: "I am so entirely convinced that nothing can be done effectually without the fleet, that I conjure you if possible to take Port Mahon". At Stanhope's instance, Leake arrived before Port Mahon, the harbour of Minorca, on September 5, and was joined by Stanhope at the head of 2,600 troops nine days later. After a little more than a fortnight's resistance St. Philip's castle, protecting the harbour, and the castle of 
Fornelle were taken, the reduction of the entire island costing CHAP. the allies no more than fifty men. This, the substantial part VI. of the enterprise, was achieved by Stanhope, Leake having, in obedience to orders, returned home, leaving a squadron behind him. Port Mahon was garrisoned by British troops, and for forty-eight years Minorca remained in British hands. "England," wrote Stanhope to Sunderland, "ought never to part with this island, which will give the law to the Mediterranean both in time of war and peace."

In the judgement alike of Louis XIV. and the allies, the throne of Philip V. rested upon French bayonets. A succession of disasters in the Netherlands, culminating in the loss of Lille, provoked reflexion on the part of Louis as to his power to continue his support. Victory had made the allies, on their part, inflexible in their demand that, as a basis of negotiations for peace, France should make "the preliminary concession of Spain and the Indies, and of the Barrier". ${ }^{1}$ But the prospect to the allies of playing in Spain, on behalf of Charles III., the thankless part which Louis XIV. had undertaken for his grandson, suggested to the fertile brain of the Duke of Orleans a possibility of compromise. As grandson of Anne of Austria, he professed some hereditary claim and was remote from succession to the French crown. $\mathrm{He}$ was ambitious and had no scruples in favour of Philip V., by whom he was disliked and distrusted. In October he opened secret negotiations with Stanhope, with whom before the war he had been on terms of friendship, proposing himself for the crown of Spain. Stanhope ventured a counter-proposal which should satisfy the ambition of Orleans for a crown and detach him from Louis XIV. The duke should have carved out for him a kingdom of Navarre and Languedoc. These negotiations were summarily cut short by the recall of the duke to France in the autumn of 1708 . During the autumn and winter of 1708 the position of Philip V. had daily been growing stronger. After the evacuation in April, 1709, of the citadel of Alicante by the English garrison, which had sustained a siege of nearly five months' duration, the kingdom of Charles III. was reduced to the city of Barcelona.

I Peckum to Torcy, December II, 1708, Round MSS., p. 336. 


\section{CHAPTER VII. \\ GODOLPHIN AND HARLEY.}

CHAP. GODOLPHIN, in the autumn of 1706 , occupied a position of

VII. dazzling success. He was the head of an administration which had weathered violent parliamentary storms at home, which enjoyed reflected glory from the victories of Marlborough abroad, which demonstrated that English credit was sound enough to support the armies on the continent as well as the vast expense of its own expeditions, and which was about to add political stability to the constitution by the union with Scotland. Nevertheless, Godolphin was conscious that his ministry existed on sufferance. That the ministry was dependent upon the whigs had long been apparent. There were rumours of bargains by which support had been rendered in exchange for promises during the previous session. And now the whigs were pressing for fulfilment. They had not been satisfied by the preponderance accorded them in the commission for the union, nor with a few minor appointments, nor with the nomination of Cowper as lord keeper. In place of toleration they sought control. The junta must be represented in the inner circle of the queen's advisers. Of their number Halifax was a financial rival to Godolphin, Orford a naval expert, Wharton a party whip of coarse wit and notorious profligacy, and Somers was disliked by the queen as an adviser of William III. There remained Sunderland, and Sunderland was the son-in-law of Marlborough. His personality and hit diplomatic experience had made an impression upon the public and upon his political associates. Born in 1674, he had imbibed the republican atmosphere of the university of Utrecht. His knowledge of foreign affairs and his acquaintance with foreign languages marked him out as 
a fitting co-adjutor for Marlborough. The whigs determined CHAP. to insist on his admission into the cabinet in place of Sir vit. Charles Hedges, a tory, as secretary of state for the southern $\ell$ department.

The native obstinacy inherited by Anne from her father was always evoked by two irritants, latitudinarianism and uncourtly independence. In the person of Sunderland both were united. He was a freethinker. He had led the opposition in the matter of the grant to Prince George. He was vehement in the expression of his opinions, and was little likely to consider either the prerogative or dignity of the queen. The queen met the proposal with passionate resistance. The Duchess of Marlborough, with characteristic impetuosity, plunged into the fray. With invocations fashionable at the period, she begged, in a letter to Anne of August, I 706, that "Mr. and Mrs. Morley (the queen and Prince George) may see their errors as to this notion before it is too late". By "notion" she meant the idea of an administration "with a part of the tories and the whigs disobliged". The queen, however, read " nation"; her dignity was outraged and her obstinacy increased. Nor though Godolphin's explanations effected a temporary reconciliation, and the customary expressions of affection were renewed, did the influence of the duchess survive in full the estrangement provoked by this dispute. Throughout August and September matters were at a deadlock. Godolphin resolved to bring the influence of Marlborough himself to bear upon the queen. A letter from the duke to the queen from Cambron of October 24, N.S., skilfully played upon Anne's idiosyncrasies. Her scheme of government independent of parties "might be practicable if both parties sought your favour, as in reason and duty they ought. But, Madam, the truth is that the heads of one party have declared against you and your government, as far as it is possible without going into open rebellion."

Behind the obstinacy of the queen were the promptings of Harley. It is surprising that, though Cowper suspected his straightforwardness in August, ${ }^{1}$ yet as late as November 9. 1706, N.S., Marlborough, writing from the Hague, believed him to be unacquainted with the struggle that was going

'See two letters from William Cowper, keeper of the great seal, to the Duke [of Newcastle], Auguat 13, 1706, Porlland MSS., ii., 195. 
CHAP. on, and recommended Godolphin to take him into confiVII. dence. The duchess had already warned Godolphin that he and St. John "were underhand endeavouring" to wreck the government. An access of whig influence threatened Harley's position, and it was natural that he should have no sympathy with the overbearing temper of Sunderland. Anne's resistance continued until the arrival of Marlborough in London on November 18, O.S. The persuasiveness of his appeals, the brilliancy of his services, and the popularity of his name at last succeeded in vanquishing her resolution. On December 3 , the day of the opening of parliament, the changes were announced which thenceforth, in the public mind, united the ministry with the whigs. Sunderland became secretary of state in the place of Hedges ; Cowper had already been created a peer; Wharton received the reward of his party management, and Godolphin of his success in achieving the union with Scotland in promotions to earldoms. A defiance was flung at the tory party by the removal from the privy council of the Duke of Buckingham, the Earls of Nottingham, Rochester, and Jersey, and Sir George Rooke. Matthew Prior, the poet, and others of less note were displaced from commissionerships of trade. The only tories of eminence left in office were Harley and St. John.

Upon the opening of parliament the satisfaction of the whig party was made apparent by the compliance of both houses. Within little more than a fortnight all the money bills were passed, and an unauthorised expenditure of $£ 800,000$ on the campaigns in Savoy and Spain approved by an overwhelming majority of 255 to 105 votes in the commons. With the thanks of the houses the Duke of Marlborough received a perpetual pension of $£ 5,000$ a year upon himself, the duchess, and their posterity, together with a settlement of his honours and estates upon his daughters and their issue successively. If the inclusion of Sunderland in the ministry had strengthened the position of Godolphin and Marlborough in parliament it had weakened their influence at court. " Eterna est mulieris ira," and Anne had an exceptional faculty for concealing resentment till the time came that she could gratify it. Nor did the acquisition of a secretaryship of state satisfy the appetite for power of the leaders of the junta. Their ideal was a purely whig administration. They were, therefore, bound to 
Godolphin and Marlborough only so long as their assistance was rewarded by substantial recognitions.

CHAP.

The department of government in which Anne had always asserted her opinions was that of the Church, and it was in this quarter that the first storm arose. At the close of 1706 , without consulting Godolphin, she promised Sir William Dawes and Dr. Blackall the two vacant sees of Chester and Exeter, a step involving political consequences, since the addition of two tory bishops imperilled the ministerial control of the house of lords. The whigs at once suspected that the nominations indicated a desire on the part of Godolphin to emancipate himself from their tutelage. Godolphin and Marlborough attributed Anne's headstrong act to the intrusion of a new influence. General suspicion pointed to Harley as the queen's secret adviser. Harley, writing to Marlborough, denied the imputation in categorical language. His denial was confirmed by the queen: "He [Harley] knew nothing of it till it was the talk of the town: I do assure you [Marlborough] these men were my own choice". This avowal served but to intensify the personal element in the discords now frequent between the queen and her two chief counsellors.

The confidence which Godolphin and Marlborough, notwithstanding their consciousness of his growing influence with the queen, continued to repose in Harley irritated the suspicions of the whigs. There were personal resentments harboured by members of the junta. Marlborough had refused Halifax a diplomatic appointment; Orford was vexed at his exclusion from the administration of the admiralty, which was practically controlled by the duke's brother, Admiral Churchill, the foremost member of Prince George's council. Among the commercial classes complaints were rife of the ineffectiveness of the navy in protecting commerce. A successful attack on the admiral, whom the duke himself described as "a very indiscreet tory," would at once render a public service, vacate another office for the promotion of a meritorious member of the junta, indicate to the queen that Prince George's continuance as lord high admiral might be rendered impossible, and prove to Marlborough and Godolphin that whig patience was at an end, that they must either identify the ministry with the whig party or be prepared for eviction from power. Fore- 
CHAP. seeing the coming storm, Godolphin and Marlborough were in VII. correspondence during the summer of 1707 as to the means of averting it. They had begun to recognise that Harley's influence with the queen was sufficiently strong to render the experiment of demanding his dismissal of doubtful wisdom, and the duke, at any rate, was deceived by his protestations of personal allegiance to them. "I have no attachment," Harley wrote to Godolphin, "to any other person in the world but your lordship and the Duke of Marlborough." I In July, Marlborough wrote to his duchess suggesting with confidence that the mere intimation to the queen that the instalment of Harley in Godolphin's place was the inevitable consequence of preferring Harley's counsel would suffice. "Then everything might go quietly." In October he contemplated the resignation both of Godolphin and himself, though he still doubted the queen's acceptance of it.

These stages in the appreciation of the crisis through which the two ministers were passing were associated with the gradual revelation that there was some one behind Harley. "Somebody or other," wrote the duke to the duchess on July 2 I, N.S., 1 707, "I know not who has got so much credit with the queen that they will be able to persuade her to do more hurt to herself than we can do good." A week later, July 17, O.S., the duchess wrote a scolding letter to "Mrs. Morley," complaining of the influence upon her of a woman of the bedchamber, Abigail Hill. The queen replied, with covert sarcasm on the duchess, that Hill was "never meddling with anything ". Abigail Hill, who, in the summer of 1707 , became Mrs. Masham, was the daughter of a distressed Turkey merchant by a daughter of the duchess's grandfather, Sir John Jennings or Jenyns. Before Anne's accession she had been appointed a woman of the princess's bedchamber through the kind offices of the duchess. Modest in her demeanour and assiduous in her duties, she had conducted herself for a long while to the satisfaction of her patroness without exciting particular attention. On her father's side she was also the same relation to Harley as she was to the duchess, but Harley professed not to have been aware of the relationship tiil about the

${ }^{1}$ September ro, 1707, Bath MSS., i., r80. For Godolphin's answer, see ibid., p. $18_{3}$, September $x 8$. 
beginning of $1708 .^{1}$ It is remarkable that among the Harley papers ${ }^{2}$ no letter is to be found from Mrs. Masham before SepCHAP. tember 20,1707, but a letter from Godolphin of a month earlier discloses his knowledge that Harley was her prompter. At that date the queen was to some extent in political correspondence with Harley, ${ }^{3}$ while her former confidante, the duchess, had become a mere source of irritation. Outwardly submissive, Mrs. Masham made herself the echo of her royal mistress. She flattered her doctrine of government independent of party, especially of the whigs. How far this doctrine was hers, how far Harley's, cannot with certainty be affirmed. The practical outcome of it was that it pointed to Harley as its embodiment. Mrs. Masham foresaw that her future fortunes and those of Harley were linked together, and her letters attest the truth of Swift's description of her that she was a woman of "boldness and courage superior to her sex". The "uneasiness between the queen and the lord treasurer," of which Marlborough wrote in June, 1707, necessarily threw the duke and Godolphin yet more upon the support of the whigs, as their distrust of Harley and his followers increased. There are symptoms of a disposition to detach from them St. John, a man to whom the saying, " alieni appetens, sui profusus," was applicable. In July, Marlborough requested Godolphin, not for the first time, to increase St. John's emoluments as secretary at war. Godolphin was reluctant, but finally gave way, and lived, according to the Duchess of Marlborough, to regret his concession. It is true that St. John and Harley had been, as Godolphin phrased it, "particular friends" of Marlborough, and the assiduous goodwill of the secretary at war was indispensable to the general.

It had been decided upon the passing of the Act of Union, to continue the existing English parliament with the addition of the Scots members. This first parliament of Great Britain met on October 23, 1707. In the English house of commons

1 Addison wrote to the Rarl of Manchester on February 13, 1708, of the " bedchamber woman, whom it seems he (Harley) has found out to be his cousin". Hist. MSS. Comm., 8th Rep., App., ii., 95.

Portland MSS., iii., iv., v., vi.

" "Her Majeaty approved of your letter to the Bishop " (Abigail Masham to Robert Harley, September 29, 1707 , Portland MSS., iv., 454). In January, 1708, Anne, who signed hereelf, "With all sincerity your very affectionate friend," was making apparently secret appointments with Harley (Bath MSS., i., 189). 
CHAP. there had been 450 effective members in March, 1706. Of VII. these the tories numbered 190 , the whigs 160 , and "the queen's servants" 100 , of which last no more than eighty-five could be relied on against the tories. ${ }^{1}$ The elections in Scotland returned forty-five members, the overwhelming majority of them of whig sympathies, though their general attitude was nationalist. They formed, in short, a flying squadron generally at the service of the whigs, except where international questions were concerned. It was hoped to render them an important addition to the influence of Godolphin and Marlborough. But fair words were not enough to pacify the irritated whigs. Their constituents were of the commercial class, neglect of whose interests would involve the loss of their own influence. When, therefore, 200 shipowners and merchants presented to parliament a remonstrance on the failure of the navy to protect trade, the junta could not hesitate to intervene. The facts were notorious. The Channel was harried by privateers from Dunkirk and Calais, ${ }^{2}$ which landed armed parties on the English coast, burnt farmhouses, and plundered hamlets. For long voyages the convoys provided were inadequate, and the rule of the admiralty appeared to be that trade was to adjust itself to the convenience of the convoys rather than that the convoys should facilitate trade. Yet no expense had been grudged by parliament. While the main object of the whigs was to oust the controlling tory influence upon the lord high admiral's council, in the person of Admiral Churchill, the tories began to see their way to the eviction of the ministry. Rochester, Buckingham, and Haversham joined with alacrity in the attack which was led by Wharton in the house of lords on December 3, 1707. The culprits, they argued, were the queen's advisers, and as the council of the lord high admiral had no existence in constitutional law, these were represented by Godolphin and Marlborough. Both parties, in fact, were aware that the responsible person was the lord high admiral. The queen replied to an address by the lords of February 25, 1708, exhorting her that "sea affairs may be your first and most peculiar care" in terms of general assurance, but she laid up against the account of the whigs a fresh resentment.

3 Godolphin to Harley, March 22, 1705-6, Portland MSS., iv., 29 r.

aty Petition, R. O., MS., State Papers, Anne, bundle I2, no. 66. 
Peterborough had arrived home, recalled by a peremptory letter from Sunderland, ${ }^{1}$ on August 7, 1707. He was refused CHAP. audience by the queen until he had furnished an explanation of his conduct in borrowing money at Genoa in the name of the government upon unreasonable terms, and in leaving Spain to embark in a circular tour of negotiations with foreign powers to which he was not accredited. As in the case of Rooke, the tories were in search of a hero by way of a foil to Marlborough and the whig favourite Galway. A literary campaign followed, of which Peterborough was himself the inspirer. His behaviour was extolled in a pamphlet, Conduct of the Earl of Peterborough in Spain, by Dr. Freind, who had been attached to his suite. From a hero he became a martyr. On December 19 Rochester denounced his ill reception by the ministry and suggested a vote of thanks. The proposal involved a censure of Godolphin and a condemnation of Galway. It was therefore doubly gratifying to the Jacobites, who had toasted the brave Englishman, Berwick, by whom the Frenchman, Galway, had been routed. The whigs, reinforced by the Scotch peers, rallied to Godolphin. It would in any case have been difficult to carry a resolution in face of the adverse judgment of Marlborough, and Peterborough, whose exculpations and justifications had exhausted the house, was obliged to go without his vote of thanks.

By way of retaliation, Rochester and Nottingham assailed Marlborough's conduct of the war in Flanders, and recommended the transfer of 15,000 or 20,000 troops from his command to Catalonia. This proposal hit the whigs in a vital spot, the maintenance of a close connexion with the Dutch, and was combated by Marlborough with a warmth unusual in him. The whig leaders dexterously converted the zeal of the tories for the fortunes of the archduke into a fresh support to their own position. In conjunction with the house of commons the lords presented an address to the queen on December 22, that no peace could be "honourable or safe" if Spain, the West Indies, or any part of the Spanish monarchy were suffered to remain under the power of the house of Bourbon. The tories having recently railed at the indifference of the ministry to

1The Earl of Sunderland to the Earl of Peterborough, January 14, 1706-7, Bath MSS., i., 153.

VOL, IX. 
CHAP. the predominance of French commerce in the Mediterranean VII. and the exploitation by French enterprise of Spanish America, had abandoned the right to oppose this declaration of principle which had, indeed, been originally laid down by Nottingham when secretary of state in 1704. Fortified by the arguments of Addison in a pamphlet entituled The Present State of the War and the Necessity of an Augmentation Considered (1708), this principle became thenceforward a leading formula of whig policy.

Five weeks later, January 29, 1707-8, the commons entered into a debate upon the war in Spain. As is usual with ministries, official defenders were found to demonstrate the care of the government for the efficiency of its forces. These apologies were of a sudden shattered by a stroke from an unforeseen quarter. Without communicating with Godolphin, St. John, secretary at war, laid upon the table of the house of commons the muster rolls of the English troops in the Peninsula in the spring of 1707 . From these it appeared that of the 29,595 men voted for service as the English force in Spain and Portugal during the year, there were at the time of the battle of Almanza no more than 8,660 English troops in the whole Peninsula. The effect of this revelation was stunning. Men broke loose from the ties of political party. The extreme whigs united with the extreme tories in denunciations of the ministry. ${ }^{1}$ On February 5 , the house of commons presented an address to the queen demanding an explanation. Explanation there was, a fortnight later, that the English forces really amounted to nearly 14,000 men and that the complement had only been voted a short time previously, but the misrepresentation had the start and proved of damaging consequence. In this blow the hand of Harley was seen. Godolphin had already come to the end of his patience. On the night of the disclosure by St. John, Godolphin , sent the attorney-general, Sir Simon Harcourt, a political frien' of Harley, to announce the rupture of friendly relations. ${ }^{2}$ Go.tolphin and Marlborough were indeed at last aware that Harley was secretly advising their dismissal and the substitution of a moderate tory administration under himself

1 L'Hermitage, February 3-14, 1708 ; Bonet, February 6-17, 1708, Von Noorden, iii., 220.

'January 3̧o, I707-8, ibid., p. I90, 
and St. John. He was admitted to surreptitious audiences with the queen, generally in the evening, at hours he afterwards spoke CHAP. of as "unreasonable," and the first disclosure of their interviews is said to have been due to a complaint by Prince George that the queen would sit up so late at night.1 All that can be said for him is that he began by endeavouring to convert his colleagues, and that, failing in this, he aspired to the treasury for himself. That he deliberately fomented the "uneasiness" between the queen and Godolphin seems to have been the belief of all his contemporaries, of Addison among the whigs, of Swift among the tories, and of the foreign observers, Bonet and L'Hermitage.

Unfortunately for himself, Harley struck at the wrong time. A Scotsman named William Greg had been for some time in his confidential employment. In I $704 \mathrm{Greg}$ had been employed by Harley as a secret agent to report on the proceedings of the Scottish parliament and the temper of Scottish parties. He returned to London in October, I 705, and the letters that he wrote to Harley shew that he was in a necessitous condition. ${ }^{2}$ As he was a good French scholar, a much better one, he tells us, than Harley, he was given employment in the secretary of state's office. Here he was irregularly paid small sums which he seems to have begged from Harley when pressed by creditors. Harley's office was a welter of confusion. Rough draughts of letters of the highest consequence were left lying about in a room to which not only clerks but attendants had access. ${ }^{3}$ There also passed through the office letters to and from French prisoners of war, among them those of Marshal Tallard, who was interned at Nottingham. Opportunity proffered a bait to poverty. Under cover of a letter of Tallard, Greg made overtures to Chamillart, the French minister of war, whom he engaged to furnish with copies of important state documents as they passed through his office. On November 28,1707 , he transcribed a letter from the queen to the emperor,

'Letters signed "Your very affectionate friend, Anne R.," one (January 2r, 1707-8) appointing an interview in the morning, the second another for the next evening (January 27, 1707-8), are in the Bath MSS., i., 189.

W. Greg to R. Harley, April so and 15, 1707. Portland MSS., iv., 400, 401.

That these irregularities were inherited by Harley from the practice of Nottingham appears from a paper of Daniel De Foe censuring them, written about May or June, 1704, and printed in the Engl. Hist. Rev., xxii. (Jan., 1907), 137. 
CHAP. pressing that Prince Eugene should be sent to Spain, which

VII. transcript would, in the course of post, reach Versailles before the original could arrive at Vienna. Greg's letter and inclosure being intercepted, he was arrested on December 30, 1707, and on January 19, 1708, put upon his trial for high treason, when he pleaded guilty.

At the same time two spies employed by Harley, John Bara and Alexander Valiere, alias John Clarke, were arrested for conveying intelligence from England to France. The moment had come, in the judgement of Marlborough and Godolphin, for decisive action. Greg's arrest had produced a public uneasiness. Ill-natured rumour was busy with the name of his patron, Harley. The two ministers wrote to the queen offering her the choice of their resignation or of Harley's dismissal. Moderate though Marlborough habitually was, his letter did not mince language. He denounced "the false and treacherous proceedings" of Harley to his colleagues. The queen shewing no sign of yielding, both ministers sought audience of her immediately before the sitting of the cabinet council on the morning of Sunday, February 9, and formally tendered their resignations. Anne had apparently resolved to part with Godolphin, but endeavoured to dissuade Marlborough from his intention. Marlborough resisted all persuasion and the two left the palace together. Upon the opening of the council Harley began a discussion on the imperial contingent of troops, business with the court of Vienna being in his department. He was interrupted by the Duke of Somerset. How, asked the duke, could they deliberate on such matters since the general was not with them? Both he and Lord Pembroke, the president of the council, offered to withdraw. The queen found no support and broke up the meeting.

Since Greg's plea of guilty precluded knowledge of the circumstances and extent of his crimes, a committee of seven lords was appointed by the house to examine him in Newgate after his condemnation to death. According to common report, party rancour had reached such lengths that the whigs hoped to connect Harley directly with his clerk's treasons. ${ }^{1}$ Even

1 "K. O." to Edward Harley, March 4, 1707-8, Portland MSS., iv., 479; cf. ibid., p. 481 . See also Swift to Archbishop King, February 12, 1707-8, Works, xy., $28 \mathrm{r}-84$. 
the Jacobites appear to have suspected there was something CHAP. behind.1 No such suggestion appears in the formal report of the examination," though Greg was asked, very properly, "by what instigation he was drawn in to correspond with the queen's enemies". Greg, however, constantly declared Harley's innocence, and upon the scaffold begged pardon for "basely betraying" his trust (April 28). Anne still remained obstinately determined to retain Harley, and Harley, according to Swift, had the scheme of a new ministry in his pocket. At this crisis the value to Marlborough of a representative of the Churchills in the tory camp manifested itself. Admiral George Churchill, grateful to his brother for his recent support against the attack on the admiralty, undertook to induce Prince George to exert his influence with the queen. ${ }^{3}$ Harley was acute enough to be aware that, though he might replace Godolphin at the treasury, he could not form a ministry if the prince and his personal following joined the opposition. The queen, the day after the abortive council, consented with tears in her eyes to accept Harley's resignation. St. John had resolved to attach himself to his fortunes. He had gone too far to remain in a ministry controlled by the victorious whigs. Sir Simon Harcourt, the attorney-general, and Sir Thomas Mansell, who had come into office with him, resigned at the same time. Robert Walpole, now a leading whig, became secretary at war. He was intimate with the circle of the Duchess of Marlborough, and upon the admission of the Duke of Newcastle and other whigs to office in March, 1705, had been nominated one of the council of seven who advised the lord high admiral, Prince George. In this position he had commended himself to Marlborough as well as to the queen by his defence of Admiral Churchill. Sir James Montagu, brother of Lord Halifax, became solicitor-general, and Lord Cholmondeley comptroller of the household. Harley's secretaryship was transferred to Henry Boyle, since January 19 chancellor of the exchequer. On April 21 the speaker of the house of commons, John Smith, succeeded Boyle at the exchequer. Both were ardent

1 Edward Harley's Memoirs in Portland MSS., v., 648.

A gossipy letter with second-hand news states that in fact it was otherwise. "Wm. Greg's examination," Portland MSS., iv., 484. March 3r, 1708 . So also Edward Hasley's Memoirs, ibid., v., 647.

Ibid., v., 647. 
CHAP. whigs. By these changes the ministry both gained and lost. viI. It enlisted the hearty support of the rank and file of the whigs; it lost Harley and his personal followers, who henceforth divided with the opposition. With the support of the whigs and the placemen it retained substantial majorities.

During the interval that had elapsed since the Act of Union had been passed by the Scots parliament, government had been aware, by the reports of its secret agents, ${ }^{1}$ of the rising tide of irritation in Scotland. The people resented the introduction of the English system of excise; the commercial classes were feeling the pressure of the new duties at the ports; the Darien shareholders were angry that a large slice of "the equivalent" had been allotted for extravagant allowances to the members of the two Scottish commissions for union; the great families regarded their consideration as impaired through the supersession by an English majority of some of their claims to hereditary jurisdiction, ${ }^{2}$ the leading supporters of the union among the nobility anticipated that the extinction of the privy council for Scotland would involve the loss of honour and profit. "The whole kingdom is disaffected," wrote Harley's spy on October 18, 1707.3 Report after report reached the courts of St. Germain's and Versailles exaggerating every manifestation of hostility to the government. The hopes of the exiles were quick to transmute discontent with the union into enthusiasm for the Jacobite cause. $^{4}$ In the spring of 1707 , one Hooke, an Irish colonel in the French service, was dispatched as an emissary to organise a rebellion in Scotland. The Duke of Atholl authorised his signature to an invitation to the pretender. Thirty thousand men should be raised if 5,000 French troops were landed with arms and ammunition for the entire force. This memorial obtained no more than ten peers' signatures, but with it Hooke returned to France, full of confidence, in the June following.

Ministers were well served with intelligence. Prominent

'See especially the letters of Jean Gassion, alias Ogilvie, and of Daniel De Foe to Harley in Portland MSS., iv.

26 Anne, c. 6. $\quad 3$ Jean Gassion to Robert Harley, Edinburgh, ibid., p. 457.

- Even De Foe reported: "Different interests, differing parties, all join in a universal clamour, and the very whigs declare openly they will join with France or King James or anybody rather than be insulted, as they call it, by the English ". De Foe to Harley, Edinburgh, August 9, I707, ibid., iv., 433. 
among the Jacobites for zeal was Ker of Kersland, an intriguing laird, who transmitted to Godolphin their plan to CHAP. seize " the equivalent" stored at Edinburgh castle, the key to their cipher, and the lurking-places of their secret agents. ${ }^{1}$ His influence with the Cameronians made him valuable to both sides. While in their name he exhorted the pretender to come over, he secretly inflamed them against a popish prince relying on a popish fleet and popish regiments to re-establish arbitrary power in Scotland. The reappearance of "whole nests of priests " lent point to his warnings. ${ }^{2}$ Chamillart, the French war minister, bombarded by letters imploring instant action, was led to appreciate the effect of a successful diversion in Scotland upon the campaign in Flanders. At Dunkirk, in the early spring of 1708, he assembled eight sail of the line, twenty-four frigates, sixty-six long-boats, 1 3,000 stand of arms, and 6,000 French troops. It was a new crusade. The papal blessing, $100, \infty 00$ crowns from the papal treasury, ${ }^{3}$ and public prayers from the French prelates ${ }^{4}$ furnished assurance of its success. A fleet of this importance was not likely to elude the vigilance of Marlborough and the Dutch government. In the middle of February the necessary orders for the concentration of the troops were given by the duke. On March 12 he wrote to Heinsius that all preparations were complete. Before leaving St. Germain's, Prince James put out a proclamation dated March I, N.S., 1708. It promised a general amnesty to those who offered no resistance, and stigmatised the queen as "the usurper". Upon the subject of religion it expressed itself with an ambiguity which, as it relieved its author's conscience, could not have failed to inspire distrust in presbyterian and high churchman alike."

1 Ker's receipts for secret service, signed by his own hand, were $£ 700$ on November 15, 1707; $£ 300$ on February 19, 1708; $£ 100$ on July 21 , and $£ 300$ on October 1, 1709; and $£ 500$ on March 23, 1709-10, which last payment, it is to be noted, was made to him by the agency of the Duke of Roxburghe. R. O., MS., Secret Service, Anne, 1701-10, no. 266.

See a letter from Jean Gassion to Harley, December 25, 1707, Portland MSS., iv., $464-67$.

3 They had been lodged by the pope seven years before at a Paris banker's for this purpose. Louis XIV. to Cardinal Trémoille, March 8, 1708, Paris, Aff. ctrang., Von Noorden, iii., 232, n. 1.

- Mary of Modena to the Archbishop of Arles, April 24, 1708. Stmart Papers, i., 221-22.

Ibid., i., 218. 
CHaP. On March 10, N.S., James himself arrived at Dunkirk. He VII. was in his twentieth year, at times pleasing in address, weak in health, with the training, as Bolingbroke afterwards discovered, rather of a monk than of a statesman, and when not engaged in hunting or correspondence, with a passion for carrying candles in religious processions. Misfortune dogged him from the outset. At Dunkirk he fell ill of a feverish attack which delayed his embarkation a week. Meanwhile the English admiralty, with a promptitude which retrieved much of their former discredit, dispatched Sir George Byng in command of a fleet of twenty-eight sail, afterwards reinforced by some Dutch ships. On the night of March I7, while Byng was sheltering from the rough weather at Nieuport, the French admiral Forbin weighed anchor. His plan was to land the prince at Leith, whence he might march promptly upon Edinburgh. Missing the Firth of Forth in the night of the 22nd, he was two days later sighted by Byng, and made northwards. The Jacobite exiles and the prince himself clamoured to be set on shore, but the weather was tempestuous; one ship had been captured, with the Jacobite Lord Griffin on board ; only four sail of the line protected his transports, and nothing was left but to regain Dunkirk. At the end of three weeks' battle with winds and waves the expedition returned, having lost, from tempest, sickness, and capture, 4,000 men. Shortly before the start from Dunkirk a Jacobite agent named Fleming, brother of the Earl of Wigton, had been commissioned to organise concerted action in Scotland. But the national disposition to caution triumphed. No resistance was offered to a number of arrests of leading Scottish Jacobites, among them the Duke of Hamilton. Five gentlemen were put on their trial for high treason, but released upon a technical point, which led in the next parliament to an act assimilating in such cases the Scottish to the English procedire. ${ }^{1}$ Lord Griffin was tried in London and sentenced to execution, but after two years' imprisonment he died a natural death in the Tower. A crowd of Scottish nobles and gentlemen who had been brought prisoners to London were discharged, among them Sir John Maclean. ${ }^{2}$. Marlborough and

17 Anne, c. 2 r.

${ }^{2}$ Register of the Privy Council, Anne, vol. iv., pp. 105, 106, warrants for transfer of prisoners from military to queen's messengers and lists of prisoners. MS., Privy Council Office. 
Godolphin were not men of blood, and contempt was more CHAP. effective than punishment.

In London there seemed but one sentiment. Party divisions were obliterated by the flow of loyalty. At first, a general sense of security prevailed. Even while the French squadron was on its way to Scotland a new government loan was subscribed before the time had expired for closing the lists. But on March 12, sinister rumours were set afloat. The French had landed in Scotland; there was a general rising; the pretender was on the march to England. The funds fell 14 and 15 per cent. Opportunity was seized by the goldsmiths of London, with the great house of Child at their head, ${ }^{1}$ to gratify their baffled rivalry and concert a run upon the Bank of England. The Jacobites were jubilant. With the credit of the Bank would disappear the credit of the government, and the Grand Alliance be undermined at its base. Godolphin was neither without courage nor resources. On the 16 th he ordered the money in the treasury to be paid into the Bank. The queen, the Dukes of Newcastle, Somerset, and Marlborough, with others of the nobility and of the whig commercial magnates, and the Huguenot, Dutch, and Jewish houses, advanced thousands to its coffers. The shareholders cheerfully responded to a call of 20 per cent. on the capital. These combined exertions defeated the conspiracy. To defeat was added public odium, the house of commons declaring by a unanimous resolution on the 2oth "that whoever designedly endeavoured to destroy or lessen the public credit, especially at a time when the kingdom was threatened by an invasion, was guilty of a high crime and misdemeanour, and was an enemy to her majesty and the kingdom". That the language of the pretender's proclamation had produced its natural effect upon the feelings with which Anne regarded the Jacobites is apparent from her answer to the addresses of the two houses at the close of the session on April I. For the first time she stigmatised her half-brother as "a popish pretender, bred up in the principles of the most arbitrary government ". To the whigs, as

1 Sir Robert Hoare, head of another firm of goldsmiths, was accused of having collected banknotes and suddenly pressed them for payment, but he disclaimed the imputation, giving a detailed account of his proceedings. Harl. MSS., 5996, 153 . 
CHAP. a party, the attempted invasion was a boon. .Its failure raised VII. their credit with the nation, while the dismissal of Harley and the resignation of St. John conveyed the impression that they enjoyed the favour of the queen, a valuable asset for the approaching elections. They now posed as the court party. ${ }^{1}$

With the ejection of Harley from office the alliance was dissolved between his personal following among the moderate tories and the ministry. There was now no half-way house between the whig and tory parties. Henceforth the government was entirely at the mercy of the whig majorities in the two houses. The time, the junta felt, had arrived when the change should be registered in the composition of the ministry. The crumbs of office dispensed to Boyle and Walpole were an inadequate recognition of the services rendered. The Dukes of Newcastle and Devonshire, therefore, as lord privy seal and lord steward, approached the queen in April, with the proposal that the Earl of Pembroke, who was also lord-lieutenant of Ireland, should resign the presidency of the council in favour of Lord Somers, the oracle of the whig party. Anne received the proposal with resentment, nor would she listen to the insidious alternative of calling Somers into the cabinet without office. His principles tended in her eyes "to tear that little prerogative the crown has to pieces". He was personally disliked by her husband, and one of the earliest acts of her reign had been to omit his name from the new privy council. In her dismay at finding that the whig proposal enjoyed the support of Godolphin, she wrote a passionate appeal to Marlborough.

Week after week passed during the spring and summer of I 708 in expostulation and recrimination between Godolphin and Marlborough on the one hand, and the queen, inspired through Mrs. Masham by Harley, on the other. Her obstinacy was encouraged by signs of defection from the junta. The Duke of Somerset, master of the horse, who had been active in procuring the dismissal of Harley, elated by his success, conceived the idea of forming a party on Harley's plan but upon the basis of moderate whiggism. The position of Godolphin after the general election of May became more

1 Erasmus Lewis to Robert Harley, May 22, I708, Portland MSS., iv., 490. Cf. Lord Cowper to the Duke of Newcastle, October 4, I708, ibid., ii., 205. 
insecure than before. In England the whigs, thanks to the CHAP. attempt of the pretender, had secured a considerable inajority. VII. The junta was in a position to dictate terms. Again, therefore, Godolphin and Marlborough offered their resignations (August), Godolphin telling the queen outright that he would not come back from Newmarket. She replied that she hoped they would "both consider better of it," and appealed to Marlborough to keep her "from being thrown into the hands of the five lords".

Behind the scenes Mrs. Masham was fast rising in favour, aided by the splenetic outbursts of her rival. Wrangles by letter and passionate scenes wore out the last remnant of affection between the duchess and the queen. The duchess attacked Harley, the queen complained of Sunderland. In September, the duchess ceased to attend court, and Mrs. Masham was left for six weeks to the undisputed enjoyment of victory. The death of Prince George of Denmark, on October 28, was alike fortunate for the whigs and the ministry. It relieved Godolphin from the burden of defending the admiralty against a fresh attack, and it enabled the whigs to compensate the Earl of Pembroke by restoring him to the place of lord high admiral from which he had been dispossessed by Prince George. The junta secured his lord-lieutenancy for Wharton, who appointed as his secretary the whig poet, pamphleteer, and politician, Joseph Addison. The tories, on the other side, were busy in drawing their party together. "You broke the party," wrote St. John to Harley, "unite it again." Its twin pillars were to be "the Church of England party" and the landed gentry; its rallying cry, "For God's sake, let us get out of Spain "." Harley responded to St. John's exhortation. Rochester, Shrewsbury, Bromley, and Harcourt were invited to share his counsels.

The loss of her husband broke the queen's spirit. "Oh, my" poor aunt" (the queen), wrote Mrs. Masham to Harley, " is in a very deplorable condition, for now her ready money (courage) is all gone." 2 She held out no longer. The junta's victory was

1October 11, 1708, Bath MSS., i., 191, 192. The party " will be in condition whenever the propitious day comes to lodge power where it naturally should be, with property". Ibid., p. I94.

2 November 6, 1708, Portland MSS., iv., 511. 
CHAP. complete. Somers was nominated president of the council and vil. Godolphin remained in office. Parliament met on November I8. By a compromise between the whigs and Godolphin, Sir Richard Onslow, a moderate whig, was elected speaker. The first-fruits of the whig control of the ministry appeared in parliament in a reiteration by the house of lords of their former resolution "that no peace can be safe and honourable until the whole monarchy of Spain be restored to the House of Austria". This at once exculpated the ministry in the eyes of the emperor from suspicion of complicity with the designs of Orleans, ${ }^{1}$ and strengthened Marlborough against the peace party in the Netherlands. The whig majority in return stood by Godolphin against an assault in force for the neglect of preparations to resist the pretender in Scotland.

It was traditional with the opposition, mindful of Cromwell's major-generals, to impute to the whigs a tendency to militarise our national institutions. The drain caused by the war had long been felt. By acts of 1702 and 1703 insolvent debtors under forty years of age willing to serve were discharged from prison. In I 703, 1704, and I705 acts had been passed for recruiting the navy and army by forcible enlistment of able-bodied men without visible means of subsistence. The bounty of 40 . payable to each volunteer for three years' service had been raised by the recruiting act of 1707 to $£ 4$. Proposals began to be discussed among the ministerialists for the introduction of some form of general compulsory service. Walpole, as secretary at war, suggested that the French system should be followed and that every parish should be responsible for raising a fixed quota of men. The tory party fulminated against French despotism, and were supported by a section of the extreme whigs, to whom liberty was genuinely of more account than the embarrassment of a ministry. No resource remained but to draw closer the meshes of the net. A premium was offered to the parishes to co-operate with the constables in securing ablebodied recruits. By a provision of the recruiting act of 1708 the sum of $£ 3$ was granted to the overseers of the poor for each man produced by the parish constable or other official to the recruiting officers, besides 20s., instead of IOs. under the earlier acts, to the constables " for every person they brought 
before the magistrates to be imprisoned," i.e., until taken over by the military. Military service was converted into an agency CHAP. for ratepayers' relief.

A bill introduced by Wortley Montagu, a whig member best known to fame as the husband of the famous letter-writer, Lady Mary, for facilitating the naturalisation of foreign protestants afforded the High Church party an opportunity of reviving the spirit of religious bigotry. The high churchmen disliked the support to latitudinarianism lent by the influx of strangers to the forms and doctrines of the Church of England. They appealed also to economic apprehensions, to the anticipated lowering of wages by competition in the market for labour. On the other side were cited the liberal example of the King of Prussia, the value of the industries introduced into that country by French refugees, the wealth they brought into England, not less than $£ 500,000$ having recently been subscribed by them to the Bank, and their efficient military services. The case in their favour was so clear that the high churchmen were driven to a vain endeavour to exact conformity as the price of naturalisation, but by a large majority no more stringent condition was exacted than that the persons to be naturalised should take the oaths to the government and receive the sacrament in any protestant church. Bishop Burnet, to the scandal of the high churchmen, supported the measure in the lords, where on March 15 the leaders of the tory party, to the number of nine, recorded their protests against it.

In the course of the spring and summer of 1709 some of the forebodings of the tories appeared to be verified. During the two months from May 23 to July 27, 8,418 refugees landed here from Rotterdam alone. ${ }^{2}$ Within a few weeks 2,000 aliens availed themselves of the increased facilities for naturalisation. The squares, the taverns, the refuges of London were crowded with protestants from the Palatinate flying from the persecution of their Roman catholic rulers. Tents were issued by the board of ordnance by order of the queen and an encampment of 6,500 formed on Blackheath. "The case of the Palatines is all

2 Portland MSS., ii., $20 t$.

R. O., MS., Treasury Papers, Anne, 1709, vol. cxix.

3 The Council of Trade to the Earl of Sunderland, June $1,17 \times 9$, Blemhrim MSS., p. 47, Hist. MSS. Comm., 8th Rep., App. Also same to same, May 12, I709, ibid. 
CHAP. our domestic talk," writes a London resident to a nephew in the VII. country. ${ }^{1}$ A royal proclamation invited collections in the churches in their behalf. Circulars were addressed to the county magistrates and municipal authorities all over the country by the lords of the council desiring them to find employment and assistance for the refugees. ${ }^{2}$ Many were thus distributed in the provinces. "Our country has whole loads of them," wrote an inhabitant of Lichfield. ${ }^{3}$ Many more the Quaker apostle, William Penn, selected for emigration to his transatlantic settlement, but his scheme became involved in his financial ruin, and these unfortunate persons, in want of the necessaries of life, fell a burden upon the English poor rates. Three thousand were shipped to New York, over 600 to North Carolina ; 3,000 took military service. A hundred families were ordered to be shipped to the Scilly Isles. Eight hundred and twenty families, with the aid of a small grant from the Irish parliament and private subscriptions, were settled in Limerick and Kerry. ${ }^{5}$ Wharton, as lord-lieutenant, was active in this work, which proved a not unmixed success. Protestant landowners, glad to welcome an influx of co-religionists, provided them with houses and assigned them lands " at easy rates and often at a third part less rents than the like lands were sett to other tenants". Nevertheless, having arrived with the expectation of receiving lands rent free from the crown, and perhaps also because their Irish neighbours laid "hold on any opportunity to abuse them," a large proportion of them soon began to drift away from their holdings, some to Dublin, others to England. A return of February, I 7 I I, states that of $82 \mathrm{I}$ families, numbering 3,073 persons who had been brought to Ireland in I 709 and I 7 IO, only 507 families and 2,05 I persons were remaining. In 17 I 2 there were stated by the commissioners to be only 263 families and 979 persons left in Ireland. Of

1 R. Palmer to Ralph Verney, August 17, 1709, Verney MSS., p. 507, Hist. MSS. Comm., 7th Rep., App.

2 Magistrates of East Riding to Duke of Newcastle, July 29, I709. Magistrates of Notts to same, Portland MSS., ii., 207. Lords of the Council to Mayor of Chester, June 29, 1709, MSS. of Corporation of Chester, p. 395, Hist. MSS. Comm., 8th Rep., App.

${ }^{3}$ Dartmouth MSS., iii., I47, August 23, 1709.

4 R. O., MS., State Papers, Anne, bundle 15, no. 47.

'Stair MSS., p. 231, Hist. MSS. Comm., 2nd Rep., App. (Correspondence of Archbishop King). 
those settlers it is, indeed, added that they were employing themselves industriously in raising flax and hemp. Their CHAP. descendants are still known in some parts of Ireland by the name of "Palatines"..

The energetic temper of Wharton resolved to signalise his lieutenancy by building up the whig party in Ireland. The test, in his eyes, was a mischievous wedge introduced between the two great protestant bodies to the weakening of the entire protestant interest. Wharton's scheme to repeal it revived the movement for a union with England; the threatened monopolists, the prelates, and the great landowners looking to a union for an assurance of their supremacy. But the Irish house of lords was willing, in the meanwhile, to strengthen the protestant interest in another way. An act more irritating than effective was passed ${ }^{2}$ in 1709 having for its object the gradual devolution of land from papists to protestants. Children of Roman catholics, upon conforming to the established Church, were protected from being disinherited and were entitled to claim their share of the inheritance during their fathers' lifetime. Wharton also showed sympathy with the nationalist or Irish party, that is, the industrial and mercantile classes, of whom Archbishop King was the leader. But neither his English colleagues nor the English commercial classes were in a mind to strike off the fetters imposed upon Irish trade. The addresses for a union in 1703 and 1707 had found no encouragement, and Somers and Sunderland now blamed Wharton's headstrong zeal for Irish interests.

Since the middle ages, it had been customary to pass acts of grace relieving the mass of delinquents against the crown of forfeitures or other penalties. No such act had been passed since the accession of Anne. It was, however, much to the interest of distinguished politicians of both parties that a sponge should be passed over relations of a treasonable character with the exiled family. That both Godolphin and Marlborough had maintained a correspondence with St. Germain's had long been common rumour, and none was so sensible as they of the insecurity of their tenure of office and of the possibility

1 Report of "Commissioners for settling the poor distressed Palatines in Ireland". Hardwicke Papers, vol. dl xxxvv., Brit. Mus., Add. MSS., 35,933, f. 12, 88 Anne, c. 3, Ireland. 
CHAP. of impeachment by their successors. Tories, on the other

VII. hand, who had been similarly guilty, were acutely conscious that their impunity depended on the life of the queen, and that the Elector of Hanover was likely to show them no favour. When, therefore, on April 20, Sunderland introduced a bill for a general pardon, including high treason, neither side felt it to be its interest to oppose. Only those who had accompanied the pretender in his descent on Scotland were excepted by the proviso that the treasons pardoned should not comprise those committed on the high seas. 


\section{CHAPTER VIII.}

\section{THE BARRIER TREATY.}

THE successes in the Netherlands of the campaign of 1708 and CHAP. the notorious exhaustion of France once more elated the VIII. Dutch war party, and the States-general responded with an augmentation of 6,000 men to the additional 10,000 voted by the British parliament. The winter of $1708-9$ was spent by Marlborough in the Netherlands and by Eugene at Vienna in organising the allies for the next effort. Jealousies and grievances between the emperor and Savoy, Prussia and Hanover needed all the diplomacy of Marlborough to assuage them. Prolonged persuasion extracted from Frederick I. a promise of 31,200 Prussian troops. A fresh accession of strength to the Grand Alliance from the east was frustrated by a curious incident. In May, 1708, Peter the Great, anxious to be admitted to the comity of nations, made an offer to Heinsius, Marlborough, and Eugene of an auxiliary corps. His conditions were a guarantee of his conquests in the Baltic and support, if necessary, against the Scandinavian kingdoms. To the maritime powers, jealous of an intruder into the European system, the proposal and the conditions were alike embarrassing. In July while negotiations were pending, Peter's ambassador was, in violation of international usage, arrested for debt by one Morton, a London laceman, and some other creditors. The privy council ordered the arrest of seven of the principal persons concerned in the outrage and offered due apology to the ambassador. It was found, however, that, save by indictment for riot, no penalty could be exacted from the offenders. A formal demand by Peter for their capital punishment was refused, and the tsar in offended dignity withdrew his overtures. $^{1}$

vOL. IX.

2 See 7 Anne, c. 12 (1708). 
CHAP. The best prospect of peace was to be found not in the vill. preparations of the allies but in the exhaustion of France. To financial distress was now added the calamity of famine. But the French overtures for peace which had followed Ramillies were not renewed in I 707. Hope had revived. In July of that year a violation of the understanding among the allies not to seek exclusive advantages unknown to the others was committed by the English envoy at Barcelona. General James Stanhope forced upon the reluctant archduke a secret treaty of commerce admitting English ships to trade with the West Indies upon the same terms as Spanish vessels during the war, and after the conclusion of peace granting England the exclusive privilege of sending ten ships yearly, of 500 tons, to Spanish colonies in America. A copy of this treaty, captured at the beginning of 1708 , was transmitted by Louis XIV. to the States-general and might, it was thought, lead to an open rupture. There was the chance, also, of a successful attempt by the pretender upon Scotland, and a hope of the turn of the political wheel in England.' Nevertheless, in 1707 and 1708, Petkum, the Duke of Schleswig-Holstein's envoy at the Hague, a well-meaning political busybody, took upon himself to begin a correspondence with Torcy, as to the probable conditions of peace. $^{2}$ The correspondence did little more than keep alive the impression that France was willing to come to terms, but it demonstrated Torcy's political foresight of the obstacle to a settlement. "The king " (Philip V.), he wrote in I 707, " would rather die than give up Spain and the Indies . . . so even if we accepted your suggestion, he could refuse to do so." 3

In the opinion of the English ministry, a definite arrangement between England and Holland of open questions was the best preliminary to a general peace. Accordingly, in March, I 709, Marlborough was commissioned to negotiate a treaty comprising a settlement of both the barrier and the British succession. Conscious of the difficulty of his position as commander-in-chief of the allied forces, the duke proposed the appointment of a second negotiator. The choice fell upon

1 Torcy to Petkum, October 6, r707, Round MSS., p. 322.

2 The correspondence is among the Round MSS., Hist. MSS. Comm., Itth Rep., App., pt. ix.

3 Torcy to Petkum, October 30, r707, ibid., p. 322. 
Lord Townshend, a young peer who had recently abandoned CHAP. the tory party and attached himself to Somers. He was of an VIII. impulsive temper, but recommended himself to foreign diplomatists by his knowledge and uprightness.

On May 18, Marlborough arrived at the Hague and was joined by Townshend. The principal French plenipotentiary was the Marquis de Torcy, who has left us a picture of the contrast between the two leading figures of Europe. On the one hand, the simple and concise address of the grand pensionary; on the other, the involved sentences, the sympathetic expressions, the regrets for the obstinacy of his countrymen, the appeals to duty and conscience, the invocations to the Almighty, the captivating manners with which Marlborough decked his discourse. The experience of Louis XIV. with the diplomatists of the continent had persuaded him that Marlborough, too, had his price. But, whatever justification there may have been for the imputation of acquisitiveness, Marlborough, judged by the standards of that day, was an honest man. Torcy unfolded to him a table of the concessions asked and the sums offered. For Naples, for the maintenance of Dunkirk, for the reservation of Strasburg to France, he promised 2,000,000 livres apiece. The duke blushed and turned the conversation. The proposals, renewed in various forms, only served to confirm the belief that the French powers of resistance were at an end.

On the 28th, the plenipotentiaries of England, the Statesgeneral, and the emperor signed an ultimatum of forty articles by way of "preliminaries" to a treaty of peace. These they placed in Torcy's hands. For England they demanded acknowledgement of the queen's title and of the protestant succession, the cession of Newfoundland, the dismantlement of Dunkirk, the withdrawal of the pretender from France, and a treaty of commerce between the two countries. To the Dutch the French were to cede seven towns, including Lille. Besides these, all the towns in the Spanish Netherlands which had been taken by the French were to be restored, to be occupied as a barrier so far as might be agreed upon between the allies, and otherwise to revert with the other dominions of the Spanish crown to Charles III. The Dutch were also to have Upper Guelderland and the enjoyment of the low commercial 
CHAP. tariff with France fixed in the year 1664. To these deVIII. mands the preliminaries, when completed, added the exclusion of French trade from the Spanish Indies and reserved additional claims to be made by the allies at their discretion at a general congress. By this provision it was hoped to avert the discontent of the Duke of Savoy and the Kings of Portugal and Prussia. France was to bind herself to secure the surrender of the Spanish monarchy to Charles III. within two months after June 1,1709 . By article 37 , in the event of a refusal on the part of Philip V. to abdicate, French troops were to assist the allies in enforcing the evacuation of Spain.

At the court of Versailles the proposals of the allies were received with indignation. Louis would not be responsible for the abdication of his grandson, still less would he undertake to treat as hostile the Spanish people in return for their attachment to the legitimate heir to the Spanish throne. The unlooked-for rejection of the preliminaries transformed the widely-spread hope of peace into exasperation. On June 7 the States-general declared their resolution "to adhere to the preliminaries and to push the war with all possible vigour". 1 The articles were published that they might serve as a bond between the allies and an unimpeachable standard for the future. The result was other than had been expected. Each minor member of the alliance conceived his claims neglected. Marlborough, who had carried out the instructions of the English ministry, sided with Eugene in declaring that, in his individual opinion, the thirty-seventh article should be reconsidered. Heinsius reopened to Torcy his former proposal of a substantial security that Louis would do his best. But the British cabinet foresaw that if it accepted the surrender of certain cautionary towns, the Dutch would take no further interest in the sovereignty of Spain. Still, the pressure of opinion compelled an attempt at compromise. Marlborough having rejoined the army, Townshend received instructions that the only satisfactory substitute for the thirty-seventh article would be the surrender of such Spanish fortresses as would render the reduction of Castile certain. It was not for one in his position, wrote Marlborough to Heinsius, to gainsay positive directions, but the demand was more than the King of France had it in his 
power to fulfil. Townshend, however, insisted on this as the irreducible minimum, and persuaded the States-general to conCHAP. firm it by a resolution on August 30. Torcy thereupon broke off the renewed negotiations.

While this diplomatic contest was being waged with France, Townshend proceeded with the other part of his commission, the completion of the barrier treaty with the Dutch. The conflict of interests between the English and Dutch turned upon the number of the barrier towns. These Dutch commercial jealousy might close, at least partially, to British trade. The concern of the English, therefore, was to limit their number, and for this they could plead their obligation to conserve the rights of the titular King of Spain. The Dutch, on the other hand, had become anxious to avoid a formal committal to the enforcement of the evacuation of Spain or the dismantlement of Dunkirk. Upon the necessity of the incorporation of these two points in the barrier treaty Marlborough was insistent.

At this crisis an event occurred which heightened the disinclination of the Dutch to commit themselves irrevocably to British policy in Spain. The communication by Louis XIV. to the States-general in 1708 of the secret treaty with the archduke of July, 1707, had excited resentment against England even among its warmest friends. It now became known that a further step in the direction of exclusive advantages for England had recently been taken. In January, I 709, the English ministers, determined not to abandon Port Mahon, proposed to the archduke the formal cession of the whole island of Minorca. The excuse put forward by Charles that his oath to the Cortes of Aragon forbade him to diminish the territory of Spain was parried by the ingenuity of Craggs, Stanhope's deputy as resident at Barcelona, and a treaty was executed in August, 1709, by which England took over the island as a pledge for the expenses it had been put to in the war. The secret was not long oozing out. Heinsius indignantly denounced to Townshend this breach of the Grand Alliance, by the terms of which no contracting party was at liberty to obtain private advantages at the expense of the other. The consequence was that Townshend felt compelled to give way

1 Townshend, The Hague, September 6 and 10,1709 , Von Noorden, iii., 596 . 
CHAP. upon the points at issue in the negotiations for the barrier viII. treaty. Marlborough, however, who during the campaign had left him the sole conduct of the negotiations, protested that he would not sign the concessions demanded by the Dutch. "This treaty," wrote Swift, "was only signed by one of the plenipotentiaries, and I have been told the other was heard to say he would rather lose his right hand than set it to such a treaty."

By the barrier treaty of October 29, the Dutch received an extension of the right of garrisoning the Spanish Netherlands enjoyed by them at the death of Charles II. of Spain, including some twenty fortified, towns. The whole territory of the Schelde and the Meuse was to become tributary. In revival of their rights under the treaty of Münster (I648) they were at liberty to close the Schelde, thereby, as the English merchants of Bruges protested, grievously injuring English trade with the surrendered frontier towns of French Flanders. Further, England was pledged to support the claim of the republic to Upper or Spanish Guelderland and to the occupation of Liège, Huy, and Bonn, towns belonging to princes of the empire. Townshend had both exceeded his instructions and involved his country in disputes with the other allies. The council hesitated to ratify the treaty. ${ }^{1}$ Met by Heinsius with menace of a rupture, it had no alternative but to yield. In exchange for a treaty which established the supremacy of the Dutch republic in North-Western Europe, made it master, under a titular sovereignty, of Flanders and Belgium, and added to its dominions the places conquered from France, the advantages secured by England were hypothetical. It is scarcely fair to exclude, as Swift does in Some Remarks on the Barrier Treaty, the collateral acquisition by England of Minorca to which the ample concessions of the barrier treaty were, in part, a set-off. On the face of the treaty the reciprocity clauses were limited to an undertaking by the republic not to conclude peace except upon the conditions that Louis XIV. should recognise the queen's title and the succession of the house of Hanover. Yet to the Dutch the protestant succession in England was of the first importance and its main-

1 Boyle to Townshend, November 18, 1709, R.O., M.S., State Papers, Foreign Entry Books, Holland, 75. 
tenance must, in any case, have attracted their support. The CHAP. only unquestionable gain was the imposition of a condition VIII. fettering the activities of the Dutch peace party and the prevention of a disastrous quarrel between the two maritime powers. The British cabinet also intimated that the balance must be redressed by concessions in other directions. "The Queen," wrote Boyle to Townshend," "trusts she may get a substantial quid pro quo in the West Indies." Marlborough urged "the renewing of the Grand Alliance upon the footing of the preliminaries". Some antidote was indeed needed for the disintegrating effect produced by the publication of the treaty. The emperor was threatening to withdraw from the alliance. Frederick of Prussia incensed, as the British ministry had foreseen, at being forestalled in the matter of Guelderland, could only be pacified by Marlborough's assurances of compensation elsewhere. The tightening of the bond between the maritime powers had weakened the cohesion of the rest of the alliance.

The negotiations for peace carried on during the first half of 1709 were accompanied by renewed energy in recruiting on the part of the combatants. In May, the army of the allies was estimated to be 25,000 men stronger than in the previous campaign, ${ }^{2}$ and when it finally assembled between Courtray and Menin on June 21 it numbered at least 110,000 troops. Famine furnished recruits to the French, justifying Louis XIV.'s saying that hunger would compel men to follow his bread waggons. Yet no more than 80,000 could be mustered for the army of the Netherlands. Louis now entrusted his army to Marshal Villars, a soldier whose rise had not been due to his assiduity as a courtier, who was popular with the troops and as yet undefeated in the field. France felt that its existence as a nation depended upon the defence which he could offer. It was an age in which Vauban in France and Coehoorn in Holland had impressed upon soldiers the value of defensive works. Villars compensated by the diligence of his engineers for his inferiority in the open. His lines were too formidable to be attacked and he could not afford to

1 November 18, O.S., R.O., MS., State Papers, Foreign, Holland, 233.

- Francis Hare to George Naylor, Hague, May 10-2x, 1709, Hare MSS, p. 223. 
CHAP. risk a pitched battle. Marlborough and Eugene began by vill. laying siege to Tournay. After a month's resistance the city surrendered on July 28 , the network of mines by which it was defended having cost the besiegers 3,000 men; but the citadel continued to hold out till September 3, when "the finest and strongest fortification in Europe " 1 capitulated.

Without waiting for the garrison of 4,000 men to march out, Marlborough on the same afternoon ${ }^{2}$ detached the Prince of Hesse in a south-easterly direction with 10,000 men, and at midnight followed with his main army. Information had reached him that the garrison of Mons was weak, and the prince had instructions to force the intrenched position called "the lines of the Trouille," running south-southeast from Mons to the Sambre. No sooner did Villars perceive the objective of the allies than he crossed the Schelde at Valenciennes, hoping to surprise the prince before the arrival of the main body of the allies, and to be found intrenched with the guns of Mons at his rear. But Marlborough and Eugene had been too quick for him. On the gth Villars, advancing from Bavay, found the army of the allies between his own and Mons. The country in this neighbourhood was covered with woods, clearances in which afforded access to Mons from the west, either along the banks of the river Haine-the route taken by the allies-or to the south by a clearance of which the village of Malplaquet was the centre. By this route, where the open space was wide enough to allow twenty squadrons of horse to ride abreast, Villars advanced so rapidly that the allies had scarcely time enough to draw up their forces to meet him. Their guns had not come up, ${ }^{3}$ and a reconnaissance by the enemy threw them into some confusion. The French, however, not pushing their advantage, the allies succeeded in taking up a position at the north-east end of the clearance, with a gentle rise between themselves and the enemy.

\footnotetext{
I Col. E. Revett to D. Polhill, Tournay, July 2I-August I, 1709, Astley MSS., p. Ig8.

2 So Marlborough to Boyle, September 7, 1709, in Murray's Dispatches, iv., 590, and Dr. Hare in the Hare MSS., p. 228. The Austrian war office's account of the campaign corroborates this date. Von Noorden (iii., 523) gives August 3 r.

'Lord Orkney's letter, September I6, 1709, in Engl. Hist, Rev, xix. (April, I904), 316-2I,
} 
In the opinion of military experts, ${ }^{1}$ had either side ventured an immediate attack, it would probably have been sucCHAP. cessful. A considerable force, roughly estimated at 10,000 men, had been left behind by the allies at Tournay, and this rendered the numbers in both armies approximately equal, the French having been reinforced to 90,000 men. The clearance at the south-west end of which the French army lay, the allies occupying the north-east of it, was skirted on the French right by the wood of Laniere and on their left by that of Taisniere, the end of which nearest the allies was called the wood of Sart. ${ }^{2}$ In the woods on his right Villars stationed two lines of infantry; in the clearance on their left his cavalry, forming the centre of the army, in four lines. His left wing was advanced to within sight of the allies, and lay in the wood of Taisniere. When the allies were drawn up in order of battle on the morning of September 10, Eugene commanded on their right wing with the imperial and Danish troops, Marlborough the centre and left with the English, Prussians, Dutch, and Hanoverians. Opposed to the French right were the Dutch guards, led by the youthful Prince of Orange. Lord Orkney was posted with fifteen British battalions to support the centre. Behind Orkney was the Prince d'Auvergne at the head of the cavalry.

As the allies in order of battle stood to their arms, it was at once seen that Villars had utilised the night to throw up formidable defences, described by Lord Orkney as "three, four, and five retrenchments, one behind another". Neither side being disposed to attack, the French continued this work during the day. Time having been allowed for the march of the force from Tournay under General Withers, the command was given to attack on the following morning. The battle began on the I I th by an endeavour of the German auxiliaries to clear the wood of Sart on their extreme right and that of Taisniere, which lay behind it, so as to turn the barricades,

1 Esterr. Kriegs-Archiv, Prinz Eugen, 1709, with which Lord Orkney appears to agree.

The names given to the various woods differ so much in German and French writers and in the Austrian general staff's history, that I have judged it best for English readers to adopt the nomenclature of Coxe in his excellent plans of the battle. Substantially, the accounts agree. I have mainly followed the Austrian official account and the graphic narrative of the Earl of Orkney, then a lieutenant-general, 
CHAP. which were to be attacked by the English in front. At this vIII. last point, in advance of Malplaquet, Villars commanded in person. While the attack was proceeding, the Prince of Orange, who was on the left and had been instructed not to advance without orders, impatiently hurled the left wing, chiefly composed of the Dutch troops, against the French barricades in front of him. Exposed to a cross-fire, the Dutch lost in a few minutes 2,000 men, and, despite the heroic efforts of the prince, retired in confusion. Instantly the French poured in pursuit through the openings between their retrenchments. The completeness of their defences proved an obstacle, and they could only emerge in small bodies. The delay gave Marlborough, who had hurried to the spot, his opportunity. Ordering the Prince of Hesse's cavalry to check the French advance, he found time to reform his shattered left wing. After two hours' fighting with various vicissitudes, the French right wing was driven out of the woods. The further course of the battle now depended upon whether the French commander could by means of his reserves rally his left wing, then hard pressed by the Prussians. At this critical moment Withers and the reinforcements from Tournay arrived on the scene and attacked the extreme left of the French in the flank. Villars kept his head and withdrew a considerable body of troops from his centre to form front to his fresh assailants, but was wounded in the knee, and carried fainting from the field, the command being then taken over by Marshal Boufflers, who had led the right wing.

The fortunes of the day were still wavering when Marlborough ordered an assault by the fifteen British battalions held in reserve under Orkney against the weakened French centre. It was defended by the troops of the Electors of Bavaria and Cologne, who fled with scarcely any resistance. But the French cavalry again and again charged the British and "had not the foot been there they would have drove our horse out of the field".. By 3 P.M. the French left and centre had been driven from their defences. Boufflers decided on retreat. His army retired in order, part to Valenciennes, part to Le Quesnay. The allies were too exhausted to pursue.

The victory was won, but won at a price which made it 
scarcely more tolerable than a defeat. The attack on the French defences cost the assailants 22,939 men killed and wounded, CHAP. while the French, protected by their intrenchments, lost only I $1, \infty .^{1}$ Nineteen cannon, fifty standards and colours and many prisoners fell into the hands of the allies. Among the enemy's wounded was the pretender.

Marlborough, whose letters to the duchess testify to his longing for peace, at first overestimated the probable consequences of his success. "It is now in our power," he wrote on the evening after the battle, "to have what peace we please." But despite a formal thanksgiving and a revival of confidence in Marlborough's invincibleness, which Godolphin utilised to obtain an advance from the Bank, a disposition to pessimism, sedulously spread by the Jacobites, presently set in. Mons surrendered on October 21. Without further delay the combatant armies sought winter quarters. In the rest of the theatre of war the campaign of the allies proved inglorious. A double invasion of France from Alsace and Savoy had been arranged in combination with that from the north-west. The imperialist army of the Upper Rhine, under the Elector George of Hanover, was to rouse to revolt the discontented inhabitants of Alsace, while the Duke of Savoy, at the head of another force, was to rekindle the smouldering embers of insurrection in the Cevennes. In the event of success, the two were to form a junction at Lyons. Victor Amadeus, however, refused to act with the Austrian general Daun, while the elector's advance force of 6,000 men under Count Mercy, on its march southwards, was driven back across the Rhine. These initial difficulties paralysed both commanders. While the elector remained inactive, Daun recrossed the Alps. The failure revealed once more the weakness inherent in confederate action.

While in England and Holland the feeling expressed itselt that the abandonment of Spain by the French candidate was the indispensable preliminary of peace, Philip V. defiantly declared : "God has placed the crown of Spain on my head and I will maintain it as long as a drop of blood flows in my veins". He threw himself upon the Spanish national feeling and the Spaniards responded to the appeal. Anxious in the first place to insure the protestant succession by strengthening 
CHAP. the Dutch republic against France, the English whigs were

viII. indisposed to unlimited sacrifices in Spain. The queen had already, the emperor's ambassador was told, done more than her share for Charles III. All she would now do was to land 2,400 imperial troops in Catalonia and find their pay. In the west of Spain Galway was in command of 2,800 British, the nucleus of an army of 15,000 men with which he intended again to besiege Badajoz. Owing, however, to the misconduct of the Portuguese, his army was defeated at Gudina by the Spanish general Bay on May 7, 1709, and from thenceforth he refused to take the field with Portuguese troops. In Catalonia the Austrian commander Stahremberg, outnumbered by the combined French and Spanish troops, could do little more than maintain himself in an impregnable position. The sole gleam of good fortune for the archduke was the recall of the French troops, in the course of the autumn, to France.

When in May, I 7 I 0 , Philip V. assembled his troops at Lerida, on the western frontier of Catalonia, they numbered 22,000 men. Against these the allies, under Stahremberg and Stanhope, who had returned from England, mustered 24,500, of whom 4,200 were British, 14,000 German, I,400 Dutch, and the rest Spanish and Portuguese. At the pressing instances of Stanhope, Stahremberg agreed to take the offensive. After surprising Philip at Almenara on July 27 and inflicting on him a loss of nearly 1,000 killed and wounded, the allies pressed forward upon Saragossa. On August 19 a battle was fought under the walls of the city which ended in the complete rout of the Bourbon army. Twenty cannon, sixty-three colours, and 4,000 prisoners were taken, and 3,000 men killed and wounded. The loss of the allies was 2,000, but an oft-expressed wish of Stanhope of "a day to retrieve Almanza" was at length gratified. The inhabitants of Saragossa, who had watched the combat from their walls, acclaimed the re-entry of Charles. As throughout the campaign, Stanhope was for enterprise, Charles and Stahremberg for caution. The occupation of Madrid, urged Stanhope and Wills, the commander of the English foot, would strengthen the position of the allies in the negotiations for peace. Stanhope forced compliance with his views by a declaration that his court was weary of maintaining an indecisive warfare. On September $2 \mathrm{I}$, at the head of 
I,000 horse, the vanguard of the allies, he occupied the CHAP. capital. A week later Charles made his state entry. Houses VIII. and shops were shut and the streets empty. "The city," he exclaimed, "is a desert."

But the reversal of the fortune of war in Aragon was not the conquest of Castile. Vendôme, whose services had previously been refused to Philip, joined him in September at Valladolid, where he assembled 25,000 Spanish and French troops. Once more, with the occupation of Madrid, there had been a turn of the tide. On November II the approach of the enemy, the shortness of supplies, and the hostility of the population compelled an evacuation. The Archduke Charles, at the head of an escort of 2,000 cavalry, made straight for Barcelona, then threatened by the Duke de Noailles from Roussillon. Owing to the difficulty of obtaining provisions, the retreating allies were formed into several columns, marching with considerable intervals between them. Stanhope, in command of 2,500 British, who formed the rearguard, was surprised by Vendôme at Brihuega on December 9, and, after a gallant defence, compelled to surrender. Too late, Stahremberg hurried to his relief, and at Villa Viciosa gained a brilliant but barren victory. He was forced to continue his retreat. In less than four months after the allies' victory of Saragossa, Vendôme had retrieved the fortunes of Philip, while an immense moral impression had been produced by the fidelity of the Castilians in their king's adversity. The article of whig political doctrine that the future of Spain could be settled by a bargain between London and Paris had received a fatal shock. Once more the archduke found himself confined to a strip of seaboard, with impaired resources and darkened prospects.

In the critical state of affairs at home, when a defeat might involve his ruin, Marlborough was disposed to caution. The plan of campaign for 1710 concerted with Eugene had for its object the reduction of the remaining French frontier fortresses, which would clear the way for an advance on Paris at a later date. Marlborough, foreseeing the fruitlessness of the negotiations then being renewed at Gertruydenberg, reached Tournay from the Hague on April 18. The French were expecting reinforcements from the Upper Rhine and were unprepared for the rapidity of Marlborough's advance. They precipitately 
CHAP. abandoned their fortified lines near La Bassée, north-west of vIII. Douay, along the canal running from Douay to Lille. "I bless God," wrote Marlborough, "for putting it into their heads not to defend their lines; for at Pont de Vendin, where I passed, the Mareschal d'Artagnan was with 20,000 men, which, if he had stayed, must have made it very doubtful." On April 23 Marlborough invested Douay. The defence of the town was conducted with skill and vigour, while Villars, accompanied by the pretender and Berwick, assembled an army of relief in the neighbourhood of Cambray. Villars, however, found the lines of the allies unassailable, and seeing no hope of relief, the town capitulated on June 26 . It had cost the allies dear-over 2,000 killed and 5,865 wounded. Villars, who had drawn troops from the Rhine and from Dauphiné, now boasted that 160,000 men were under his command. In face of his superiority in numbers, the allies were unable to do more than reduce a few minor fortresses, ${ }^{1}$ and in November went into winter quarters. The French had, though with the loss of Douay, effected their principal object, namely to cover Arras and prevent the invasion of Picardy and attacks upon Abbeville and Calais.

Both sides had weakened their troops on the Rhine in order to strengthen those in Flanders; nor had the emperor and the German princes redeemed their promises of reinforcements. The elector, George of Hanover, the imperialist commander-in-chief, finding himself short of men and money, after futile remonstrances with the emperor, resigned his command on May 20, I 7 10. For the rest of the summer the imperialist and French armies, each too weak to attack, occupied their fortified lines in watchful inactivity. Again, as in 1709, plans for a flank invasion of France proved failures. While Marshal Daun with the imperial and Piedmontese troops was to rouse the protestants of Dauphiné, a diversion was to be made by the English among those of Languedoc. With this object a force of 700 English soldiers was embarked at Barcelona by Admiral Sir John Norris and landed at Cette on July 19, in

1 The heavy losses incurred in these sieges provoked lively complaints. According to the metrical history, The Remembrance, by John Scot, the official lists shewed the total losses at Douay, Bethune, St. Venant, and Aire to have been 18,901 killed and wounded. Scottish Hist. Soc., vol. xxxviii., P. 558. 
1710 CONFERENCES AT GERTRUYDENBERG. 159

the hope of establishing communications with a body of the Camisards in arms near Montpellier. They were, however,

CHAP.

VIII. speedily overpowered by numbers and driven back to their ships. Dawn and his army, unable to break through the cordon of Berwick's troops, recrossed the Alps a month later. Meanwhile, after eight months of negotiation, the peace conferences at Gertruydenberg had broken down in June, 1710 , over the insoluble question of the evacuation of Spain. Peace was "now farther off than ever".

1 Rouillé, president of the parliament of Paris, to Petkum, August 11, 1710, Round MSS., p. 351. 


\section{CHAPTER IX.}

THE IMPEACHMENT OF SACHEVERELL.

CHAP. THE ministry now in office presented, it will have been IX. apparent, many contrasts to modern usage. Corporate responsibility, whatever place it may have held in the political ideals of Somers or of Sunderland, was practically unrecognised. The name of prime minister, which expresses this, was not in current use. It may be found occasionally in the writings of Swift, but it bore for long after an unpopular association as a term of French origin and of unconstitutional import. While, in fact, the lord treasurer exercised the functions of the leading member of the cabinet, its members did not conceive themselves bound to the alternative of carrying out his policy or resigning office. The tie between them was the sovereign of whom they were alike the "servants". Between Godolphin and the nominees of the junta co-operation was the outcome of necessity, not of choice. There was a sense among the whigs that the treasurer was ready, for the sake of office, to temporise with principle, and, rather than offend the queen, to allow the intrigues of Harley and Mrs. Masham to prepare their overthrow. There were yet unsatisfied ambitions among the junta. Orford desired office, Halifax had been irritated in 1708 by Marlborough's choice of Townshend as plenipotentiary to the States-general. Somers also, with a reputation for political "virtue," as Macaulay insists, second to none, was dissatisfied and talking of resignation. Though president of the council, he and the other ministers were, they complained, treated as nullities. Nothing but the fear of alarming the allies and the appeasement of Somers by the queen with $£ 1,000$ out of the secret service money ${ }^{1}$ induced the whigs to

1 His receipt is signed on April 2, I709. R.O., MS., Secret Service, 266. It should be observed, however, that the next two receipts, dated October I4, 
remain in office. As for Godolphin, sensitive to the friction with the queen on one side and with his whig supporters on CHAP. the other, he wrote to Marlborough in January, 1709: "The life of a slave in the galleys is paradise in comparison of mine".

The services of the Duke of Queensberry in the management of his countrymen were felt by Godolphin to be indispensable. On February 9, I 709, he was appointed a third secretary of state, to take charge of the affairs of Scotland. By this arrangement influential patronage was withdrawn from Sunderland, the most intractable in temper of the junta. Thenceforward undissembled hostility glowered between him and Godolphin. The junta felt that the time had arrived for delivering a counter-attack. Their first attempt to strengthen their position was by recommending Halifax as plenipotentiary to the peace conference in the Netherlands. Against this Marlborough, as before, stood firm, and in such a matter Marlborough's authority was indisputable. Their next effort was to oust Lord Pembroke from the office of lord high admiral. To Orford, the nominee of the junta, both Marlborough and Godolphin were at first opposed. The office was too well paid-Pembroke's salary had been fixed at $£ 7,000$ a year ${ }^{1}$ - and too influential to be bestowed on a politician beyond their control. Their disapproval was fortified by the resentment of the queen against Orford as an inspirer of the attacks upon her husband's administration of the admiralty. His political and family connexions were, however, too strong to be withstood. When Marlborough and Godolphin withdrew an opposition in which they found no support but that of Boyle, and themselves recommended the appointment, the queen's resistance ceased. At the beginning of November, 1709, Orford was nominated head of the admiralty, but, mindful of the contingencies of party government, he preferred the

1709 , and June 24,1710 , respectively, run in the following form :- " $£ 1,000$ for an additional allowance of $£ 2,000$ which her majesty is pleased to make to my salary as president of her most honourable privy council". These payments, however, throw a disagreeable light upon the halting and equivocal attitude of Somers at the time of Godolphin's dismissal, and account for the distrust felt of him by Godolphin (see Lord Coningsby's "Account" in Archacol., xaxviti, I0-24). Only the Duchess of Marlborough seems to have suspected the truth (Correspondence, 1838, ii., 148).

I March 30, 1709, 30th Rept. of Deputy-keoper of Pwblic Records, p. 460.

VOL. IX. 
CHAP. office of lord high admiral to be thrown into commission, being IX. willing rather to reduce his post to the presidency of a board than to incur undivided responsibility. Sir George Byng and Sir John Leake were associated with him as commissioners. The contest over this appointment, into which the Duchess of Marlborough had thrown herself with her accustomed indiscretion, led to a further exchange of letters between herself and the queen, in which recriminations only served to mark the growing extinction of their friendship. The appearance of The New Atlantis, which bespattered the duchess with mud, while it extolled under transparent names the new favourite, Harley, and Peterborough, stirred no displeasure in the queen. No royal congratulations greeted the duchess on the news of Malplaquet. The omission was a symptom that the intriguers had already undermined the influence of the duke himself. The next step of Harley's faction was to prompt the queen to a direct attack upon him.

Marlborough, anticipating a break-up of the ministry and alive to the precarious tenure of his position, judged it opportune to make an attempt to establish himself out of the reach of the vicissitudes of politics. In the autumn of 1709 he sounded the whig leaders as to a proposal for a patent conferring on him the office of captain-general for life. Cowper, whose opinion as chancellor was most important, declared that there was no precedent. Undeterred by this disappointment, the duke made direct application to the queen. Anne's ear had been already filled with suggestions that she was the tool of the ambitions of the Marlboroughs. "She talked," writes Swift, "to a person whom she had taken into confidence as if she apprehended an attempt upon the crown." Her alarm prompted a downright refusal and reconciled her to the duke's threat that he would retire at the end of the war. She followed this up by bestowing the lieutenancy of the Tower, a post in Marlborough's patronage, on Lord Rivers, a friend of Harley's, and in January, 1710 , ordered the duke, despite his energetic protest, to give a regiment to Mrs. Masham's brother, Colonel Hill. On this Marlborough appealed to the whigs. He laid before the leaders a letter addressed to the queen in which he detailed his grievances against Mrs. Masham, and added: "I hope your majesty will either dismiss her or myself". Sunderland, as 
usual, "rode on the whirlwind," and was supported by the CHAP. duchess and Walpole. The united cabinet, they maintained, IX. must demand Mrs. Masham's dismissal and, in the event of refusal, must carry resolutions through the two houses to that effect. Godolphin, Somers, Cowper, and Boyle favoured milder measures. In this conflict of opinions Marlborough took a middle course. He wrote another letter to the queen to take the place of the first, inveighing against the mortifications inflicted upon him through " the malice of a bedchamber woman," but abstaining from insistence on her removal as a condition of his continuance in office.

The queen was becoming alarmed at the public feeling, at the possibility of the adoption by the whigs of Sunderland's resolutions and at hints of suspension of the supplies. Before Marlborough's substituted letter had been placed in her hands she told Godolphin that, upon the representations of Somers, she would not insist on the preferment of Colonel Hill. Marlborough, who had left town, returned accordingly, and, on January 24, was most graciously received by the queen. The command in dispute was given by him to his nominee, Colonel Meredith. But though he had been received back into a sernblance of favour, no movement was made by the queen towards reconciliation with the duchess. Accused of disrespectful expressions towards her mistress, the duchess, who had withdrawn to the country, forced herself into the presence on April 6, and in spite of frequent rebuffs and a command to present her statement in writing, insisted on offering verbal explanations. Tears and protestations proved ineffective. The queen left the room, and, though the duchess retained her offices, they never saw one another again.

A turn in the current of popular favour was all that was needed to sweep away the ministry. Discontent was in the air. Enthusiasm for war could not be rekindled out of the ashes of the negotiations for peace. The country was sated with victories, of which the latest was the most equivocal and the most costly. Financial difficulties were accumulating ; taxation was oppressive ; everywhere the tory squires, resenting the land tax and the rise of interest upon mortgages, which they imputed to the scarcity of money sunk in the loans of the whig financiers, were denouncing the war as a 
CHAP. waste of the national strength. Their murmurs were re-echoed IX. by the inferior clergy, who exclaimed at the growing insolence of the dissenters and at the latitudinarianism of a ministry and a bench of bishops indifferent to the heterodox opinions daily issuing from the press. Against a party predominant in the legislature and successful in the field orthodoxy could still raise its head. Prominent among the High Church clergy was Henry Sacheverell, in 1710 about thirty-six years of age. As an Oxford undergraduate he had been intimate with the gentle Addison, who had in 1694 dedicated a poem to his friend. Nevertheless his contemporaries emphasise insolence as a main trait of his character. Even Hearne, who sympathised with his politics, speaks of him as "conceited, ignorant, impudent, a rascal and a knave". The picture is coloured by personal pique, but it is certain that he was of a temper that delighted in acrimonious controversy. He had a striking presence, studied gestures, a rhetoric dripping with unction. Women hung upon his words; they named their sons after him and invited him to officiate at their children's christenings.

Sacheverell's literary achievements consisted of polemical pamphlets and sermons. A violent attack on nonconformity delivered by him from the pulpit of the university church on June 2, I7O2, was among the publications which had inspired De Foe's Shortest Way with the Dissenters. On December 23, 1705, he had preached from the same place a diatribe against latitudinarianism in Church and State, which had extorted the admiration of the narrow and splenetic Hearne. The text taken by him was St. Paul's recital of his sufferings in 2 Corinthians xi. 26, culminating in the words, "in perils among false brethren ". This text and discourse, with some additions and alterations, served as a sermon preached in St. Paul's Cathedral on November 5, I 709, before Sir Samuel Garrard, lord mayor, and the aldermen of London. A complaint against it was laid before the house of commons on December 13. With it was coupled another sermon preached by him at the assizes at Derby on the previous August 15, and published under the seemingly innocuous title of The Communication of Sin. The title of the St. Paul's sermon was less ambiguous. It was The Perils of False Brethren both in Church and State. The gist of the earlier sermon was that the communicators of 
sin were those, especially of the clergy, who countenanced dis- CHAP. sent. This was notoriously aimed at the Low Church bishops, especially their leader, Burnet, who were favourable to occasional conformists. The later sermon went on to lash politicians in high places who were for comprehension and toleration as politically expedient. He applied to them the language of the Psalmist, speaking of his betrayal by his own familiar friend. "In what moving and lively colour," exclaimed the preacher, "does the holy Psalmist point out the crafty insidiousness of such wily Volpones!" By the use of the word "Volpones," Sacheverell gave his declamation a personal point. Volpone, a name borrowed in the first instance from Ben Jonson's play, "Volpone, or the Foxe," had for some years been in vogue as a nickname for Godolphin. It occurs in a poetic lampoon of 1705 , where Harley figures by the felicitous designation of Janus, and had become a current epithet needing no identification. ${ }^{\prime}$ Its introduction, therefore, by Sacheverell was singularly audacious.

We may well credit the assertion of Somers to Swift, that but for the treasurer's resentment a prosecution of Sacheverell would never have been undertaken. "I knew," wrote Lord Dartmouth, "neither the doctor nor the doctrine had been called in question, if the word Volpone had been left out of his sermon." But there were wider reasons determining the ministry to proceed against Sacheverell. His impeachment, as Burke said, "was carried on for the express purpose of stating the true grounds and principles of the revolution; what the commons emphatically called their foundation. It was carried on for the purpose of condemning the principles on which the revolution was first opposed and afterwards calumniated, in order by a juridical sentence of the highest authority to confirm and fix whig principles as they had operated both in the resistance to King James and in the subsequent settlement." 2 Such is a just description of the method in which the prosecution was conducted. Its inception was due to Godolphin's spleen, the expectation of strengthening the ministry by the queen's support, and the hope cherished

1 Abigail Herley to Edward Harley at Eywood, March 29, 1709, Portland MSS., iv., 522.

" Appeal from the New to the Old Whigh" Works, iv., 430 (ed. 1852). 
CHAP. by Wharton, Sunderland, and Orford, of muzzling the most IX. dangerous and aggressive class of their political adversaries. A conviction, it was thought, should be followed by "an injunction to all the clergy not to meddle with the Toleracion, Administracion, and Politicks".'

On December I 3 Sacheverell, having been summoned to appear before the house of commons, admitted his authorship of the sermons. An impeachment was ordered. The principal manager was John Dolben, who first called the attention of the house of commons to the sermons, "a great stickler for Godolphin," aptly selected as born in the purple of prelacy, the son of an archbishop of York, and a great-nephew of Archbishop Sheldon of Canterbury. The tories in the house of commons were at first undecided as to their course. Of the clergy the majority entertained no doubt, and sermons were preached extolling the persecuted vindicator of orthodoxy. By the time that the articles of impeachment were draughted, a growing body of opinion had come into existence favourable to the defendant. It was resolved by Harley and the other leaders of the party to make common cause with him, and to resist the prosecution with the best talent it could command. On January 12, 17 IO, the articles of impeachment, four in number, were carried up to the lords. Of these the first was that Sacheverell had maintained that the means taken to effect the revolution were "odious and unjustifiable; that his late majesty (William III.), in his declaration, disclaimed the least imputation of resistance; and that to impute resistance to the said revolution is to cast black and odious colours upon his late majesty and the said revolution". The second charged the assertion "that the toleration granted by law is unreasonable" and that its apologists were "false brethren"; the third, "that the Church of England is in a condition of great peril and adversity under her majesty's administration"; the fourth, "that there are men of characters and stations in Church and State who are false brethren," and traitors to the constitution. Seditious suggestions of maladministration and religious incendiarism formed incidental gravamina of this article. The

${ }^{1}$ A. Windham to Lord Townshend, March 15, 1709-10, Townshend MSS., p. 334, Hist. MSS. Comm., IIth Rep., App., 4. 
lords, having read the articles, released Sacheverell on bail from the custody of the serjeant-at-arms.

CHAP.

IX.

The tories had long been in search of a hero. Neither Rooke nor Peterborough had proved a counterpoise for Marlborough. Now a champion had been found in a conflict which could enlist the most violent of all fanaticisms. The mob caught the infection. Harried by press-gangs, starving for lack of employment, weary of a war in which they bore the hardships but did not share the rewards, and with wheat at famine price, the industrial classes had outlived their enthusiasms. Gratitude to the party which had achieved the deliverance of the revolution had worn itself out. A bitter feeling had been left by the whig encouragement of foreign refugees. The invasion of the Palatines the year before, the sums contributed by government or subscribed under the encouragement of the queen's "brief," published throughout the kingdom on June 23, 1709, "filled our own poor with great indignation, who thought those charities, to which they had a better right, were thus intercepted by strangers ". The clergy disliked the intrusion into their parishes of paupers, who were likely to breed "some contagious distemper," who raised the rates and strengthened the nonconformists' numbers. The rural inhabitants received them with hostile tumults. $^{1}$ Priests and people found themselves united by the same interests. The trial in Westminster Hall, begun on February 27, 1710, was clothed with the accessories befitting a solemn occasion. The queen herself was carried thither privately in a chair. "God bless your majesty!" shouted the crowd, as she passed through the streets. "We hope your majesty is for the Church and Dr. Sacheverell!" Sacheverell, who was lodged in the Temple, daily made an ostentatious progress through the Strand to his trial in a coach with large glass windows, escorted by shouting partisans.

For the whig party the capital article of the impeachment was the first. If the revolution were not an example of resistance to arbitrary power approved by parliament, if the present occupant of the throne were there by a title other

1 Archdeacon Edward Tenison to Lord Sunderland, Sundrich (Sundridge), October 13, 1709, R. O., MS., State Papers, Anne, bundle 15, no. 44. For the attitude of the tailors of Southampton to a French protestant refugee a few years earlier, see bundle 11 , no. 138 . 
CHAP. than parliamentary, if it might be successfully contended that

IX. parliament could neither sanction resistance nor confer title, then the protestant succession was a plant without roots. But English history proved, as the whig lawyer Sir John Hawles insisted, that upon resistance sanctioned by a parliamentary vote rested the sovereignty of Henry IV. and Henry VII., as well as of William III. and Queen Anne herself. It was a hazardous argument in presence of a queen bred in the High Church doctrine of non-resistance, one who, clinging to a belief in the divine right of her title, ${ }^{1}$ had revived the ancient practice of touching for the "king's evil ". The story of the supposititious origin of the pretender was widely circulated, and Anne affected to believe it. But the whigs could not afford to hazard their cause upon so doubtful an issue as that of the pretender's parentage. They boldly faced the question. The pretender, they alleged, was the heir to the crown in right of blood. He had been expelled on account of his father. Priceless was the obligation owed by the English people to the queen for her participation in and support of the change. In pressing the minor charges, Sir Thomas Parker, the future chancellor, delivered a speech which secured much commendation. " Who were the "false brethren" unless the promoters of the revolution? The true brethren then must be the Jacobites. The alternative was the right to resistance or submission to the pretender. The defence fell chiefly upon Sir Simon Harcourt, assisted by Constantine Phipps, afterwards lord chancellor of Ireland. Harcourt's main contention was the transparent sophism that the resistance condemned by Sacheverell was resistance to the supreme legislature.

After the speeches of his counsel, Sacheverell was allowed to read two papers in his defence. His language was respectful but uncompromising on the doctrine of non-resistance, and his

1 The arguments at the trial seem to have convinced Anne that "divine right " was a myth. At any rate, in October, I7ro, on the presentation of an address by the city of London, "she immediately took exception to the expression that 'her right was divine,' and this morning told me that having thought often of it, she could by no means like it, and thought it so unfit to be given to anybody that she wished it might be left out" (Duke of Shrewsbury to Robert Harley, October 20, I710, Bath MSS., i., I99). Nevertheless, she continued to touch for the " king's evil".

2 "The best judges say Parker spoke best," Abigail Harley to Edward Harley, London, March 4, I709-10, Portland MSS., iv., 533. 
elocution effective. Contemporaries ascribed the composition to Atterbury, Smalridge, and others of the queen's chaplains IX. who, a significant incident, stood around him. "He made his own defence," wrote an enthusiastic feminine sympathiser, "which they tell you was done in so fine a manner, in such moving terms, with so harmonious a voice, that the poor ladies wet all their clean handkerchiefs, nay, the men could not refrain tears." ' The defendant was voted guilty by sixty-nine to fiftytwo; of the thirteen bishops present seven being for conviction and six for acquittal. In the sentence passed on March 23 , the house was probably influenced by the whisper that the queen desired that it should be mild, and the ministry by the fear that proposals of severity might be defeated, strong pressure having been exerted on waverers by Harley and St. John." A motion to incapacitate the defendant from all preferment during three years was rejected by a majority of one, and a suspension from preaching during that time was the only penalty imposed. The sermons were ordered to be burnt in presence of the lord mayor, who had encouraged the publication, and of the sheriffs, in front of the Royal Exchange.

Throughout the country the lightness of the sentence was regarded by Sacheverell's supporters as a victory to be cele. brated with bonfires and popular rejoicings. In London a mob sacked dissenters' meeting-houses and threatened the mansions of the leading whig peers. During the progress of the trial Sacheverell had been presented by Robert Lloyd of Aston, Salop, one of his former pupils, to the rectory of Selattyn in that county. His journey to take possession of the living resembled a triumphal progress. The University of Oxford assembled its officials to do him honour. $\mathrm{He}$ was escorted into Shrewsbury by 5,000 horsemen, and into Bridgnorth by 7,000 persons. Bells pealed, bonfires blazed, banquets welcomed the Church's champion. ${ }^{3}$ His counsel shared his popularity, while managers of the prosecution were hissed by the crowd.4 The queen restrained any manifestation of her

' [Abigail Harley] to [Edward] Harley, London, March 7, 1709-10, Portlasid MSS., iv., 535.

2 Ibid., iv., 537-39.

- See, for example, ibid., iv., 550, giving an account of his reception at Worcester, where the bishop, William Lloyd, was a strong whig.

- Ibid., p. 339. For disturbances at Wrexham, alleged to have boen fomented by the clergy, see R. O., MS., State Papers, Anne, bundie 16, no. 44 . 
CHAP. sympathy until the completion of his sentence. On April 13,

IX. I 7 I 3, she presented him to the rich benefice of St. Andrew's, Holborn.

It was the policy of Harley to pave the way for a new administration by accustoming the queen to the gradual exercise of her prerogative. The Duke of Shrewsbury, whose winning manners had in his earlier days won him the title of the "king of hearts," had, after a long retirement at Rome, returned to England in I706. Harley perceived his value and determined to utilise it. He sought him out at his country seat in $\mathrm{Ox}$ fordshire ${ }^{1}$ in the summer of I708. Of whig antecedents, but dissociated by absence from close party ties, Shrewsbury might prove a rallying point for ministers in search of neutral support. Marlborough himself, before his conversion to the necessity of relying upon the whigs, had desired Shrewsbury's assistance to resist the mandates of the junta. But Marlborough soon realised that he was a broken reed. The very compliance of temper which had secured him popularity involved him in equivocal positions. His idea of politics was to please. His courtier's temper rendered him a fit tool for Harley's hand, and he was recommended to the queen, that he might "give Mrs. Morley right impressions". On April I 3, I 7 IO, after the prorogation of parliament, while Marlborough at the Hague was watching the progress of the negotiations of Gertruydenberg and Godolphin had retired to his racing stable at Newmarket, the queen, inspired with courage by her manifest popularity, as shewn at the recent trial, resolved to strike. She sent for the lord chamberlain, the Marquis of Kent, requested his resignation, and offered him a dukedom as a solatium. That same evening she invested Shrewsbury with the badges of office as chamberlain.

Godolphin, on receipt of the queen's announcement of what she had done, wrote a long and indignant protest and tendered his resignation. But Shrewsbury's conciliatory address left him in doubt as to his real intentions. Godolphin therefore kept his own counsel about the affront he had suffered, and the political quidnuncs inclined to attribute the promotion to the influence of himself and Marlborough with the object of strengthening themselves against the junta. Having lulled

${ }^{1}$ Buecleuch MSS., ii., 2, 720 (July 27, 1708). 
the distrust of Godolphin, Shrewsbury next made direct ad- CHAP. vances to Marlborough whose opinion of him was conveyed in a letter to the duchess, assuring the junta of his steadfastness; but among those of the junta whose suspicions Shrewsbury's advances disarmed was the impulsive Sunderland. Yet in May the lord chamberlain began to whisper that the queen intended Sunderland's dismissal, which he himself was struggling to avert. This again was not, on the face of it, a tory attack. "The great drivers of it upon Lord Sunderland," wrote Godolphin to the duchess on June I, 1710, "I understood (from Lord Poulett) to be the Duke of Somerset and Lord Rivers most of all." Somerset, whose little following of discontented whigs was nicknamed "the juntilla," was playing a wrecking game, from which he was to emerge at the head of a moderate whig ministry. At the news that Sunderland was threatened, Marlborough wrote on June 15 that he must receive the unanimous support of all the friends of the ministry. Somers was assured by the queen that she did "not intend to make any further alteration," and was tranquillised a few days later with $£ \mathrm{I}, 000$ from the secret service fund. ${ }^{1}$ The Duke of Newcastle, whom Harley obsequiously cultivated, agreed to bring over Boyle. On June 13 Anne took the plunge. Sunderland was dismissed. The queen had spent the interval since the 2nd, when she communicated her intention to Godolphin, in searching for a successor. Lord Dartmouth was at last fixed upon. His antecedents commended him to the queen, for his father had remained a fast friend to James II. But he was a nominee of Harley, and like Harley a Hanover tory, who had paid his court and was personally acceptable to the Electress Sophia."

This success did not relax the intrigues of Harley and his allies. The Harley papers reveal the Duke of Somerset slinking in at Harley's back door, or being admitted in a sedan chair into his hall with the curtains drawn. ${ }^{3}$ Harley, on his side, made nocturnal and secret visits to Somerset, Shrewsbury, and the queen," without whose knowledge he was con-

isee p. 160, n. I.

The Electress to Lord Dartmouth, Herrenhausen, Sept. 2, 1710 , Dartmowth MSS., p. 297, Hist. MSS. Comm., IIth Rep., App., v.

3 Portland MSS., iv., 542, 545, 553.

'Ibid., pp. 548, 553, 557 ; ii., 211 (July 1, 1710). 
CHAP. certing schemes at his own house with Mrs. Masham.1 An IX. entire reconstitution of the ministry was in hand, to be opened with the dismissal of Godolphin. Harley, however, foresaw difficulties in connexion with the money market, which was controlled by the whigs. The dismissal of the lord treasurer might, it was plain, involve consequences so momentous that Anne hesitated. The directors of the Bank, though too late to save Sunderland, sought audience of the queen, to the infinite disgust of Harley at their presumption, and urged the "danger of altering her ministers and dissolving parliament". 2

The allies, no less than the city magnates, had taken the alarm. Immediately, on hearing of the dismissal of Sunderland, the emperor wrote to the queen in the same sense. The retention of Marlborough at the head of the military forces of the allies he declared indispensable. No time was lost in tranquillising the apprehensions of the allies. The remonstrances provoked or the pledges given stayed awhile the progress of Harley's designs. His brother, the auditor of the exchequer, warned him of the danger of taking over the embarrassed finances of the country. ${ }^{3}$ The notorious insecurity of Godolphin's position, and the certainty that his fall would be followed by a depreciation of public securities, tightened the Bank's purse-strings. ${ }^{4}$ It declined to make a further advance of $£ \mathrm{I} 00,000$. Godolphin's last resource was to ask the queen to put pressure upon the directors. It was obvious that this could as well be done on behalf of Harley. The request settled his fate. On August 7 he had a long audience of the queen. Scarcely had he left her presence when she penned his dismissal. Her pretext was the "uneasiness" between them and a want of respect ${ }^{5}$ to her dignity in council. The charge was one which, as previously in the case of Sunderland and afterwards in that of Harley, served in lieu of explanations

${ }^{1}$ [Abigail Masham to R. Harley], April 17, 1710, Portland MSS., iv., 540.

'[R. Harley] to Arthur Moore, June 19, 1710, ibid., iv., 545.

${ }^{8}$ Portland MSS., v., 650; $c f$. Halifax, August 10, 1710, ibid., iv., 560 .

- This was not the earliest symptom that the Bank was becoming cautious. On May 19, 1709, the deputy treasurer of the ordnance reported to the treasury that it declined "to meddle with" certain tallies issued to his department which it was desired to cash. Treasury Papers, Anne, vol. cxiv., no. 26.

s " He [Godolphin] every day grows sourer and indeed ruder to 32 (the queen)." [Robert] Harley to the Duke of Newcastle, August 5, 1710, Portland MSS., ii., 213. 
which would have challenged controversy. He was not even CHAP. granted the compliment of a formal audience. He was ordered IX. to break his staff; but he was promised a pension of $£ 4, \infty 00$ a year, which was never paid. The treasury was put into commission with Earl Poulett, who had been one of the commissioners for the union, at its head. Harley himself took the place of Smith as second lord and chancellor of the exchequer. In Somers the blanoishments and guineas of the queen, alienation from Godolphin and the Duchess of Marlborough and, if we may credit Harley, a belief that he might be made "chief minister," 1 produced a benevolent neutrality. Halifax hastened to salute the rising sun. ${ }^{2}$ Newcastle received a personal message from the queen that she depended upon his assistance. In order to disarm the duke's whiggish apprehensions, Harley expounded to him the new policy. It was to be "directed to the sole aime of making an honorable and safe peace, securing her [the queen's] allys, reserving [preserving ?] the liberty and property of the subject in general and the indulgence to dissenters in particular, and to perpetuate this by really securing the succession of the House of Hanover".

Harley, in fact, was not disposed to drive the entire whig party into opposition. It would have made the management of the house of commons impracticable, while the very whisper of a dissolution was followed by a fall of 2 per cent. in the funds." Cowper records in his diary for September 18 a visit from Harley, urging him, in the name of the queen, to retain office. "All should be easy. A whig game intended at bottom." Upon Walpole, already a power in the house of commons, Harley tried flattery. He was worth, said Harley, half his party. But the disappointed ambition of Somers, the suspicions of the whigs, the advice of Godolphin, and the general doubt whether a tory administration could maintain itself, co-operated adversely to a coalition. A string of resignations followed. Before the end of the year, with the exception of the Dukes of Newcastle and Somerset, scarcely a whig

1 R. Harley to the Duke of Newcastle, September 12, 1710, Portland MSS., ii., 289.

The Earl of Halifax to R. Harley, August 10, 1710, ibid., iv., 560.

2 R. Harley to the Duke of Newcastle, August 5, 1710, ibid., ii., 213.

- R. Harley to the Duke of Newcastle, July 1, 1710, ibid., ii., 211. 
CHAP. was left in any office of importance. While the efforts of IX. Harley to create a ministry of "moderates" were thus frustrated, they provoked lively dissatisfaction among his tory supporters. ${ }^{1}$ In September Atterbury, always for violent courses, was complaining "that the parliament was not yet dissolved, nor so many of the whigs turned out as was expected ".2 A ministry independent of parties, Rochester declared, was impracticable. The tories were ready to serve the queen, but only in concert with men of their own principles. It became necessary to construct the new administration on these lines. Rochester, having declared his adhesion, ${ }^{3}$ displaced Somers as president of the council on September 21 , and St. John was nominated secretary of state in place of Boyle. Ormonde went to Ireland in succession to Wharton, Sir John Leake followed Orford as first lord of the admiralty, Sir Simon Harcourt again became attorney-general, and the great seal was put into commission. A change so complete and a ministry so politically homogeneous had not been constituted since the revolution. What had become of Harley's ideal of "the exercise of power without regard to parties only" ? " In these circumstances no resource remained but immediate dissolution. On September 2 I the royal proclamation was issued. Sacheverell's tour had done its work effectively. The clergy were the busiest of canvassers. As an overturn of parties the result was dramatic. Two hundred and seventy members lost their seats and an imposing tory majority reigned in their stead.

From the time of the battle of Ramillies Harley had sedulously inculcated upon the queen "that nothing could be so fatal to her people as the carrying on of a lingering war which must destroy the trade and exhaust the strength of her kingdom ". ${ }^{5}$ Torcy, on his side, had felt that the deadlock with the whigs compelled recourse to the opposition. On July IO, I7ro, he wrote to his agent in London, the Abbé Gaultier or Gauthier, requesting him to make approaches to

1 See R. Monckton to [R. Harley], August 23, r710, Portland MSS., iv., 574.

Ibid., v., 650.

Joanna Cutts to N., August, 17ro, Astley MSS., p. 202.

4 [Robert] Harley to the Duke of Newcastle, September 14, 1710, Portland MSS., ii., 219.

Buditor Harley's Memoirs, ibid., v., 647; cf. the Earl of Orford to the Duke of Somerset, December I, 17r r, ibid., p. IIg. 
Shrewsbury and Mrs. Masham. Gaultier had access to the houses of some of the Roman catholic aristocracy, amongst CHAP. them the Jacobite Earl of Jersey, whose countess was of that religion. Through him Jersey, as the mouthpiece of the new ministry, entered into communication with Torcy, advising him to reopen negotiations at the close of the campaign. Lest the French should be encouraged to raise their demands, Harley resolved to conciliate Marlborough. The resignation of the duke would, he knew, be followed by alarm among the allies and by a fall in the funds. At the time of Godolphin's dismissal he had taken steps to prevent such consequences. "Vast sums," he wrote on Augusí Io, "are bought, and as soon as any one is ready to sell there are more buyers. Stock is not lower than it was this time twelvemonth." 1 But quotations could not long be supported. ${ }^{2}$ When the result of the elections was known Bank stock fell nearly 30 per cent. and the Bank refused to discount foreign bills.s

The selection of Jersey as the intermediary for the resumption of negotiations had the effect of compromising the ministry. His conversations with Gaultier in October, 1710 , represented Harley and Shrewsbury as ready to restore the pretender after the death of the queen, and the queen herself as favourably disposed to the project. These discussions were not without their immediate uses to Harley and his following. The Jacobites in parliament were ordered to support the government. A change in public opinion had manifested itself since the Sacheverell trial. The illegitimacy of the pretender's birth had been an article of public faith, systematically countenanced by the queen, but the whigs, in order to insist on the supremacy of parliament, had now accepted his legitimacy. Anne was not exempt from this change of sentiment. It gained strength from the death of her husband, who was strongly anti-Jacobite, and was increased by her own sense of isolation. During the trial of Sacheverell she had shed tears in speaking of the misfortunes of her family. She had no fixed intentions; she abstained from discussing the pretender with Harley; but the irresolution of

1 [Robert] Harley to the Duke of Newcastle, Portland MSS., ii., 215.

Earl Rivers to Harley, September I2, N.S., The Hague, ibid., iv., 580.

"[Jobn Drummond] to Harley. November 7, N.S., Amsterdam, ibid., p. 617 ; cf. p. 637. "The public credit is fallen past retrieve," Halifax to Newcastle, October 26 -November 6, 1710 , ibid., ii., 223. 
CHAP. her mind awakened hopes in Rochester and the Jacobites. IX. According to Jersey, she had a motherly tenderness for the pretender. All agreed, however, that conformity to Anglicanism was a condition precedent to a restoration. Mere promises conveyed no sense of security. Certainly there is no indication that Harley, who was the reverse of a bigot, was willing to trust the pretender, though he might be disposed to strengthen his parliamentary position by a sympathetic attitude towards the queen's change of feeling.

Round the queen, as round a sovereign emancipated by their leaders, the tory party rallied with such enthusiasm as threatened to swamp the moderating counsels of Harley. To embarrassments of scrupulosity, to the ideal of a via media, to a taste for nicely balancing between extremes, to a dislike for the mob's plaudits, his followers, especially his lieutenant, St. John, were strangers. St. John was a politician of practical aims, of clear insight, and of no convictions save of the charms of office. "The principal spring of our actions," he wrote in later life of this period, "was to have the government of the state in our hands." To him the fervour of the heated partisan was welcome, for he knew how to use it. St. John had been out of parliament since the dissolution of April, 1708, passing a studious life upon his wife's estate of Bucklebury, in Berkshire. His biographers have spun fine-drawn theories to explain his retirement. The real reason is disclosed by a letter to Harley dated May I, I 708.1 From this it seems that he had quarrelled with his father, apparently over politics, and having no hope of being returned for the family seat was searching in vain for a constituency. Whether or not his conduct had scandalised his High Church supporters in Wiltshire, ${ }^{2}$ he was utilising his retirement at Bucklebury to secure the votes of the freeholders of Berkshire. His appointment as secretary of state for the northern department was welcomed by the pamphleteers of the party. $\mathrm{He}$ had, in fact, forced himself upon Harley by intimating his resolution not to accept the minor office of secretary at war. ${ }^{8}$ His colleague, Dartmouth, was a mere third consul, and Harley and St. John were in every mouth as the inspirers of the new policy.

${ }^{1}$ Bath MSS., i., Igo.

2 See Henry St. John to James Graham, July 18, 1708, Bagot MSS., p. 341.

3 H. St. John to Robert Harley, March 8, I709-10, Portland MSS.piv., 536. 
Both as a man of letters and as a burrower in unseen ways Harley discerned the value of the press and was the first statesman to enlist it in the regular service of a ministry. In the natural course of politics the press would have been associated with the whig party, for, as Dr. Hare affirmed, "the men of letters will, by a great majority, be found to be among the whigs". Prior, the son of an obscure artisan, had climbed, through the patronage of Dorset and Halifax, to the rank of secretary to the Paris embassy. Addison had, on the recommendation of Halifax, been sought by Godolphin in an indifferent lodging, and had earned an under-secretaryship of state by his glorification in The Campaign of Marlborough and the ministry. Rowe and Parnell had also risen to fame under whig patronage. De Foe was a dissenter born. Yet all of these, save Addison, proffered their services to Harley. Literary men were sensitive to the fact that the condescension with which Marlborough and Godolphin dispensed their bounty was not the comradeship proffered by Harley and St. John. Prior had joined the tory party upon the accession of Anne. As whig influence grew, he was deprived of his commissionership of trade (1707), but he obtained through Marlborough a pension of $£ 400$ a year, and until the beginning of 1710 had penned adulation to the duke. When his solicitations to Marlborough did not result in his reinstatement by Godolphin, he vindictively assailed his former patrons in The Examiner. Swift, who, in 1704, had achieved notoriety by the Tale of $a T u b$, had been admitted to the tables of the leading whigs. Dissatisfied with his preferments, he had, he declared, been "used barbarously" by the late ministry. He took advantage of a visit to London in October, 1710 , to obtain audience of Harley, to whom he was introduced as a man "discontented with his position". Harley, a gcod judge of men as well as of letters, at once admitted this invaluable auxiliary to his intimacy. "He told me the measures he would take"; "He charged me to come to him often," wrote Swift to Stella. On February 16,1711 , he records that "at last" St. John and Lord Keeper Harcourt had consented to let him join their regular Saturday dinner at Harley's house. He was thus qualified to prepare the public for the ministers' policy, to vindicate their measures, and to become the historian of their administration.

VOL. IX. 


\section{CHAPTER X.}

\section{HARLEY'S: MINISTRY.}

CHAP. THE queen opened the new parliament in state on November $\mathrm{X}$. 25, I 710 , and the commons gave the first evidence of their political bias by the election as speaker of William Bromley, member for the University of Oxford, whose influence with the clerical party gave him importance to Harley and St. John. ${ }^{1}$ The session began peacefully. Public interest awaited the anticipated return of Marlborough. That the new ministry was hostile to him was notorious. Nevertheless, the responsibility of dismissing him before peace was declared was tremendous, and as the Elector of Hanover was his natural successor, such a step would offend as many tories as it gratified. St. John's policy was to provoke him to resignation. His dispatches at this date breathe the insolence of youth and the venom of ingratitude. Marlborough's secretary, Cardonnel, for whom the duke had procured the appointment of secretary at war, was dismissed. His favourite general, Cadogan, who had been envoy to the United Provinces, was replaced by Richard Hill, a brother of Mrs. Masham. Lieutenant-General Meredith, whose battle Marlborough had fought against the queen, Major-General Maccartney, and Brigadier Honeywood were superseded (December IO), and Meredith deprived of all his other appointments, on the charge that they had drunk "Damnation and Confusion to the New Ministry". In The Examiner, Swift charged the duchess with peculation. Amid such omens Marlborough arrived in London from the Hague on December 28, O.S. In his company travelled Baron Bothmer, accredited by the Elector of Hanover as his envoy-extraordinary to report on the state of parties and to use such efforts

${ }^{1}$ St. John to Harley, October II, 1708, Bath MSS., i., rgr. 
as he discreetly might to assist in maintaining the duke in command. Mortification added to the strain of successive HAP. campaigns began to affect the duke's health. Sir David Hamilton, the court physician, represented this to the queen in terms which moved her to "great tenderness". The duchess seized the occasion to attempt a reconciliation. In an audience on January 17, 17 I , Marlborough himself presented a letter from her to the queen expressing her apprehension that he could not live six months. The overture precipitated the catastrophe. The queen insisted that within three days the gold key of the duchess's office should be surrendered. Although the duke threw himself on his knees to beg a respite, Anne remained inexorable.

The Earl of Peterborough was smarting with the grievances suffered by him at the hands of the late ministry. His recklessness in pecuniary dealings had caused Godolphin to attach his revenues until his accounts should be passed. This, he bitterly complained, ${ }^{1}$ was " the reward he had to expect for all his services and uneasiness". His friends were now in power. The glorification of his exploits would serve to discredit Marlborough and Godolphin through the unfortunate Galway, their nominee. An inquiry was accordingly entered upon by the house of lords, with the support of Argyll ${ }^{2}$ and other enemies of Marlborough, extending retrospectively to the operations preceding the battle of Almanza. The protagonists were Marlborough as the champion of Galway and Argyll as the accuser of the late ministry. "Peterborough, the ramblingest lying rogue on earth," as his friend Swift described him, was the advertiser of his own achievements. To the door of the former ministers were laid not only the disasters in Spain but also the failure of the expedition against Toulon. A vote of censure was carried against the late ministry and the thanks of the house expressed to Peterborough by Sir Simon Harcourt, who, on October 19, 1710, had been appointed lord keeper. . His speech, complimenting Peterborough on his generosity in accepting

1 Trenaury Papers, Anne, 1709 (about March 26).

"In the Dict. Nat. Biog., s.v. "Campbell, John," it is stated that the cause of Argyll's animosity against Marlborough is unascertained. Horace Walpole, however, says that it was because Marlborough was " a gainst his (Argyll's) coming into our (the Engliah) army with the same rank". Letters, i., 340. 
CHAP. this, "unattended with any other reward," was interpreted $\mathrm{X}$. as a reflexion upon Marlborough, who, in The Examiner of November 23, had been held up by Swift to popular odium as the recipient of $£ 540,000$.

But the method of indirect attack was unsatisfying. The more violent spirits among the tories began to chafe. They did not appreciate the difficulties of Harley, whose former exhortations to the queen to become independent of ministers were now rendering her intractable. They saw Marlborough still in command and minor posts occupied by moderate whigs. A club comprising numerous Jacobites, called from its potations of October ale the October club, had existed since King William's time. After the general election it recruited its numbers till they amounted to I 50 members of the house of commons. Their object, wrote Swift to Stella (February I8, I 7 I I), was to "drive things on to extremes against the whigs, to call the old ministry to account, and get off five or six heads". Ministers could not afford to incur the hostility of a phalanx so formidable. At the beginning of January, Walpole, shewing no signs of defection from the whigs, was dismissed from the treasurership of the navy. A fortnight later a bill was introduced "for the taking, examining, and stating the publick accounts of this kingdom". A commission was packed with tories and Jacobites. On April 20 they reported that of $£ 35,302,107$ granted by parliament to Christmas, I 7 IO, a great part had not been accounted for.

The October club had overshot its mark. The report was discredited by a statement of accounts by Arthur Maynwaring, Edward Harley's colleague in the auditorship, and by two pamphlets from the pen of Walpole, The Debts of the Nation Considered and The Thirty-five Millions Accounted for. From these it appeared that, notwithstanding the delays in the accountants' offices, abroad as well as at home, only some $£ 4,000,000$ remained to be passed, "much short of one year's supply," and that there was no evidence of malversation. A revulsion took place in public feeling. The sole person to make capital out of the incident was Walpole. His defence of his own financial administration of the navy and of the accounts of the late ministry earned him the reputation of being "the best master of figures of any man of his time". 
The alliance of the clergy and the squirearchy now began to bear fruit. Though a bill to repeal the foreign protestants' naturalisation act of 1708 was rejected by the lords, which, according to Edward Harley, made " the common people very angry," 1 a bill passed both houses after animated debate, by which a qualification of an estate in land of the annual value of $£ 600$ in the case of knights of the shire and of $£ 300$ for borough representatives was imposed upon members of parliament. ${ }^{2}$ The measure was an embodiment of the central principle of St. John's political conceptions expressed by him in the sentence, written many years later: "The landed men are the true owners of our political vessel ". It so far responded to the general sense of the nation that it maintained its place in the statute book for nearly a century and a half. St. John's own pen has furnished an exposition of his constructive policy: abroad peace, at home "to improve the queen's favour... and to fill the employments of the kingdom down to the meanest with tories". To these may be added the imposition of disabilities upon dissenters and the shifting of the burden of taxation from the landed to the "moneyed interest". Harley's intentions were less intelligibly expressed. According to St. John, he never had any policy save that of founding a family. He humoured all sections in succession, always hoping to detach some to form his own personal following. The outcome of his trimming was that no one trusted him. As early as February, I 7 I I, Harley was conscious of St. John's rivalry. St. John, on his side, was no longer "the faithful Harry" of his "Dear Master". It was a situation that lent itself to intrigue.

At this stage an event occurred which brought Harley into the sunshine of popularity, and by throwing St. John into the shade provoked his jealousy and increased the growing estrangement. On St. John's recommendation the Marquis de Guiscard, the promoter of the intended descent on the west coast of France in 1706 , had obtained from Harley a pension of $£ 500$ a year, which Harley presently reduced to $£ 400$ and refused to guarantee for life. Guiscard thereupon entered into a treacherous correspondence with the French minister, De Croisic, v., 657.

'[Edward Harley] to Abigail Harley, February 6, 1710-11, Portland MSS.,

'9 Anne, c. 5. 
CHAP. through Moreau, a banker at Paris. His letters, betraying $\mathrm{X}$. projects for the invasion of the south of France, ${ }^{1}$ having been intercepted, he was arrested, and on March 8, I7I I, was brought before the lords of the council at St. John's office in the cockpit at Whitehall. While awaiting a hearing, he had contrived to possess himself of a penknife, and at the close of the examination he leant over Harley's shoulder and stabbed him with it in the breast. He was overpowered and conveyed to Newgate, where he died of the wounds he received in resisting arrest. Harley was carried home. The wounded minister, who had been the calmest person in the scene, became the darling of the nation. Swift and Prior wrote verses in his praise; Grub Street deluged him with mendicant adulation. Swift's pen improved the occasion in The Examiner. Harley had been assailed by a French papist who had been in whig employment-proof that he was the terror of France and the scourge of the whigs and papists. Slight though Harley's wound was, he was for weeks upon a sick-bed.

St. John's first feeling, expressed to Swift, was that Harley was "absolutely necessary". But as the weeks passed, his natural self-confidence asserted itself. He busied himself in preparations for an expedition to Canada, to be commanded by Mrs. Masham's brother, Brigadier Hill. According to Auditor Harley, a strong partisan of his brother, St. John's eagerness in this project was to secure, in conjunction with his friend, Arthur Moore, $£ 20,000$ by illicit commissions upon contracts for clothing and equipment. ${ }^{2}$ Moore had recently been appointed a commissioner of trade and plantations. He was an Irishman who had begun his career, according to Burnet, as a footman, and was one of the earliest "self-made men" to force their way to the front in political life. His association with St. John appears, on the face of it, to have been in discharge of his official duties. On the other hand, it cannot be left out of sight that in 1714 he was expelled from his directorship of the South Sea Company for clandestine trading to the detriment of the company. St. John was finding his salary and the income of his own and his wife's estates unequal to his expenditure; indeed in 1714 , he did not scruple to solicit the

1 They are printed in Portland MSS., ii., 227-29.

I Ibid., v., 655. 
treasurer for "half a year's secret service" money, with the CHAP. avowed intention of applying it to the discharge of a mortgage." Harley now sent Rochester " his dying request that he would advise the queen that it (the expedition to Canada) might be laid aside". After his displacement by Bolingbroke, he did not scruple to assert that suspicions which he entertained soon after his promotion to the treasury proved justified, and that "the public was cheated of above $£ 20,000$ ".

On April 26, I 7 I 1, Harley attended the house of commons, and received the formal congratulations of the speaker upon his recovery. He was on May 23 created Baron Harley of Wigmore, Earl of Oxford, and Earl Mortimer. On May 30 he was appointed treasurer of the exchequer. An act, the preamble of which recites the incident which occasioned it, made an attempt upon the life of a privy councillor in the execution of his duty felony, and as such punishable with death. ${ }^{2}$ Fortune at this time conspired in favour of Harley. The October club lost its most dangerous spokesman at court by the death of Rochester on May 2. News arrived at about the same time of the unexpected death of Joseph I. on April $6 / 17$, by which the posture of continental relations was fundamentally changed. The vacant offices were filled from the tory ranks. The Duke of Buckingham became lord president of the council, and Earl Poulett lord steward in the duke's place. Upon the accidental death in July of John Holles, Duke of Newcastle, with the exception of Somerset the last of William III.'s great officers still employed, the Earl of Jersey was nominated lord privy seal. He did not live to take up the office. In his stead Dr. John Robinson, Bishop of Bristol, who had long been envoy to Sweden, was appointed in August. "The whigs," chuckled Swift, "will fret to death to see a civil employment given to a clergyman. . . . It will bind the Church to him (Harley) for ever."

The new ministry had from the outset been solicitous to disarm the suspicions of the Elector of Hanover. In November and December, 1710, St. John was protesting to the English resident at Hanover his loyalty to the succession.

1 Viscount Bolingbroke to the Lord Treasurer, January 6, 1713-14, Portland MSS., v., 379.

9 Anne, c. I6. 
CHAP. But in the following June an event occurred which alienated $x$. the two courts. The Duchess of Gordon, a Roman catholic, presented to the library of advocates of Edinburgh a medal, struck by the pretender at the time of his intended invasion. It bore on the obverse under his effigy the legend "Cujus est?" and on the reverse Great Britain and Ireland with an approaching fleet and the legend "Reddite". The Jacobite advocates, by sixty-three to twelve votes, returned thanks in an address undisguisedly treasonable. This audacious defiance passing unnoticed by the ministry, Kreyenberg, the Hanoverian resident, demanded the prosecution of its author, Dundas of Arniston. Nothing was done, however, except to suppress a still more treasonable vindication by Dundas of his address. Thenceforth the elector's envoy-extraordinary, Bothmer, openly ranged himself with the opponents of the ministry.

Edward Harley, the auditor of the exchequer, has described in a few graphic words the embarrassments to which his brother succeeded on his entrance into office. "When he came into the treasury he found the exchequer almost empty; nothing left for the subsistence of the army but some tallies upon the third general mortgage of the customs; the queen's civil list near $£ 700,000$ in debt; the funds all exhausted and a debt of $£ 9,500,000^{1}$ without provision of parliament, which had brought all the credit of the government to a vast discount. In this condition the nation had to pay $255,689 \mathrm{men}$. ... Besides these difficulties, the Bank, stock-jobbers, and moneyed men of the city were all engaged to sink the credit of the government." ${ }^{2}$ On the other side, the tories bestirred themselves to render the ministry financial aid. Two lotteries, raising $£ 1,500,000$ and $£ 2,000,000$ respectively were subscribed in I III. But it was evident that lotteries could not be permanently relied upon to raise revenue, nor did they check the depreciation of government credit. During Harley's illness, consequent upon Guiscard's attempt, his brother, the auditor, was engaged in formulating a scheme which the treasurer had desired for dealing with the outstanding debts. It is uncertain

1 Recited in the South Sea Company's bill in May, 171 (see next page, n. 2), as $f 8,971,000$. 9 Anne, c. 15,8 I.

2 Portland MSS, v., 650. 
with whom the project of the South Sea Company originated; but De Foe's currespondence and his "frequent and long audiCHAP. $\mathbf{X}$. ences" 1 with Harley while the scheme was maturing, suggest that it may have sprung from his fertile brain. The Bank of England had come into existence as an incorporated public creditor quartered upon the exchequer. The New, or English East India Company represented the assertion of the principle that parliament alone could grant a monopoly of trade. Harley's scheme for the incorporation of a South Sea company ${ }^{2}$ was framed upon these two precedents. It was to be a company with a huge monopoly of trade, comprising the east side of South America and the west of the whole continent. The principal part of its stock was to consist of nearly nine and a half millions of public debt, on which it was to receive 6 per cent. and $£ 8, \infty 00$ a year for charges of management. The funds secured to it were the duties on various commodities in perpetuity. Of securities of this kind the investor had of late had enough, and until the conclusion of a favourable treaty with Spain, the glittering attractions of the El Dorado of the South Seas were remote. Two months after the scheme had been " received with general approbation," South Sea stock stood no higher than $77 \frac{1}{2}$. But as peace approached expectations rose. In the meantime, the public stocks continued to flag. "The moneyed people," wrote John Toland, in December, I 7 II, will never trust this parliament." 3

The disasters with which the Spanish campaign of 1710 had concluded brought home to the ministry the conviction, that the possession of Spain by the Austrian claimant could no longer be insisted upon as a condition of peace. It had, indeed, been a graft upon the terms of the Grand Alliance which by the eighth article, as Swift presently shewed in his Conduct of the Allies, stipulated simply for "a sufficient provision that the kingdoms of France and Spain be never united or come under the government of the same person". Nevertheless, the demand had so long been insisted upon that its immediate surrender, while alienating both the emperor and the archduke,

' Portland MSS., iv., 659, De Foe to R. Harley, London, February 3, 1711.

'The incorporating act ( 9 Anne, c. 13 ) is printed among the statutes of 1710 in the "Statutes of the Realm," but the bill was really brought into the bouse of commons on May 17, 1711. See Boyer, Anmals for 1711, P. 379.

December 7, 1711, Portland MSS., v., 126. 
CHAP. would have provoked an outcry against the weakness of the $\mathrm{X}$. ministry. Oxford preferred the more tortuous course. The best way to damp the obstinacy of the Dutch war party and of the emperor was, to insist upon the fulfilment of the share of the burdens both in men and money undertaken in the treaty of alliance. The earliest communication to the French ministry of the disposition to make concessions as to Spain is a dispatch by Gaultier to Torcy in the French archives, dated December 28, I710. At this time it is probable that Harley contemplated a resumption of the conferences of Gertruydenberg. Louis XIV., however, expressed his willingness to enter into separate negotiations with England, while refusing to resume those with the Dutch. But at this stage the English ministry scrupled at appearing, by an assumption of the initiative, to be unfaithful to the Grand Alliance. It formulated seven propositions as essential conditions of peace for Gaultier to lay before the French ministers. "The first proposals of France dated 22 April, 171 1," 1 accordingly took the form of an overture, whereas they were, in fact, though this was concealed, an answer to an overture from England-a distinction of vital moment to the fate of Harley.

The death of the emperor, Joseph I., completely changed the posture of affairs in favour of the ministry, for it united in the Archduke Charles the crowns of Spain and Austria. If Great Britain and Holland had gone to war to prevent their union in the family of Bourbon, they had certainly, wrote St. John to Lord Orrery, our envoy-extraordinary at the Hague, never intended to annex them to the head of the house of Habsburg. Prior was secretly dispatched to Paris about the middle of July entrusted with the heads of negotiation. The proposals with which he was accredited were divided into two categories-those touching the Grand Alliance as a whole and those relating to Great Britain in particular. The first and fundamental proposition was "That we make no peace but what should be to the satisfaction of all our allies". Even this formula, which was presently lost sight of, fell short of our obligations under the treaty of the alliance, which explicitly prohibited separate negotiation. The rest of the proposals touching the allies were in general terms. In the second 
part of the proposals, in which the interests of Great Britain CHAP. were exclusively considered, the terms were more specific-a satisfactory treaty of trade and commerce to be negotiated; the queen's title and the parliamentary succession to be acknowledged; Gibraltar and Port Mahon to remain in English occupation; Dunkirk to be demolished; the Asiento, or contract enjoyed since 1702 by the French Guinea company to provide negro slaves for the Spanish colonies in America, to be reserved exclusively to Great Britain; Newfoundland to be surrendered; the trade of Hudson's Bay and the position in America to remain in statu quo; Great Britain to enjoy equally all commercial privileges conceded by the Spaniards to the French, and lastly, the secret of this agreement only to be divulged by common consent. To these demands Prior reports Torcy to have declared, that "we asked no less than to be master of the Mediterranean and Spain, to possess ourselves of the Indies, and to take away from France all that appertains to that crown in America ". 1 Especially did Torcy resist the claim to Newfoundland. "It is," he exclaimed, "the nursery of our seamen." To the objection that the possession of Gibraltar and Port Mahon gave England "the domination of Spain and France in the Mediterranean," Prior retorted, "We are a trading nation and as such must secure our traffic".

Prior returned to England on August 3 in company with the Abbe Gaultier and with Mesnager, who had been employed as French agent at Gertruydenberg. On September 27, O.S., at London, three conventions upon these bases were concluded as preliminaries of peace. Of these the first comprised the concessions reserved to England; the second the general provisions affecting the Dutch and the emperor; the third those relating to the Duke of Savoy. The second and third only were communicated to the allies. By the whigs the preliminaries were nicknamed in derision "Mat's Peace".

Not until May 23 did Eugene join Marlborough in his camp at Lewarde, to the east of Douay, only to announce his instructions to march to the Rhine. Five days later the two generals parted. Marlborough, with an army inferior in infantry but comparatively strong in cavalry, was left to confront Villars alone. Since the long-planned invasion of France was for the present 
CHAP. out of the question, nothing more could be attempted than to $X$. continue the reduction of the fortresses still protecting the frontier. Of these Bouchain, at the confluence of the Selle and the Sensée into the Schelde, was important for its control of the waterways. Marlborough, by a march westwards, drew off the French troops on August 5, and, retracing his steps at night by a forced march of thirty-six miles, threw himself between Villars and Bouchain, threatening Cambray at the same time. Villars had been out-mancuvred and his lines, which he had described as Marlborough's "ne plus ultra," penetrated by the allies without loss. In the eyes of military experts the feat was one of the most brilliant in the duke's career. It silenced for a while the cavils of the critics who had asserted that, apart from Eugene, Marlborough's military talent was mediocre.

In their new positions neither side could venture a general assault, and the French, in particular, were protected by marshes and broken ground. Despite energetic efforts by Villars, Marlborough had by the close of August completed the investment of Bouchain, which surrendered on September I 4 with a garrison of more than 3,000 men. This, again, was an achievement upon which none but a general of genius could have ventured, and it had been accomplished notwithstanding the remonstrances of the Dutch generals. ${ }^{1}$ A fortified town had been captured under the eyes of the first commander in France, at the head of an army which reinforcements had made "many thousand men stronger than " the besiegers. This was the last service ever performed by Marlborough in the field. Under his leadership all hope of a successful offensive against the Dutch had been wrested from France. It was enough if Villars could check invasion and exact tolerable terms for his impoverished country. To Marlborough, on the other hand, his task appeared unfinished. Two great fortresses, Le Quesnoy and Maubeuge, remained to bar his way to Paris and to the realisation of his "grand project" of dictating peace in the French capital. But before the opening of another spring his career of glory was at an end.

In the rest of the theatre of war the military operations

1 Francis Hare to George Naylor, September 19, I711, Hare MSS, p. 233. 
were halting and inglorious. On the Rhine the armies of CHAP. Eugene and Marshal Harcourt idly confronted one another, as $\mathbf{X}$. did those of Victor Amadeus and Berwick upon the frontiers of Provence. In Catalonia reinforcements of seven new regiments of English foot from Ireland and Gibraltar raised Stahremberg's army to 15,000 men and enabled him to relieve Cardona, besieged by the Duke de Vendôme. The Duke of Argyll arrived at Barcelona on May 29, I7 II, as plenipotentiary and commander-in-chief, but the want of money and supplies rendered it impossible for him to keep his army effective. Save for the bounty of the Catalans the troops would have starved. Disappointed by the neglect of the ministry, he withdrew most of the British forces to Port Mahon, where they remained until the suspension of hostilities in August, 1712 , "reduced to the greatest misery imaginable". At the end of I7 I I the British army in Portugal was removed to Gibraltar and Minorca. In this tame fashion ended the British intervention in the Peninsula. The first aim of tory policy was achieved-" For God's sake, let us be once out of Spain "." During Harley's illness St. John pushed forward a project of General Francis Nicholson, who in 1710 had occupied Nova Scotia, for driving the French out of Quebec, and 5,000 troops had been put under the command of Brigadier Hill, distinguished by his prowess as "a four-bottle man ". They were embarked upon a fleet under Sir Hovenden Walker on June 4, 1711. Meeting tempestuous weather at the mouth of the St. Lawrence and being ill-furnished with supplies, the expedition returned home on October 9, without having disembarked, but with the loss of eight transports conveying about 800 men. Its failure was justly charged against the ministry which had neglected the preparations necessary to success.

While St. John became increasingly hostile, Oxford, upon recovery from his wound, sought to resume friendly relations with Marlborough. There were those who looked to this combination as a possible means of saving the country from the violence of party. ${ }^{3}$ St. John was not unobservant of the change of

1 October, 1712, Tholen, Duke of Argyll to [the Earl of Oxford], Portland MSS., v., 240. "They will soon be naked," wrote Col. R. Kane on February 25, 1712-13, ibid., p. 269.

H. St. John to R. Harley, November 6, 1708, Bash MSS., i., 194.

3 Lord Stair to Lord Oxford, October S, N.S., 1711 , Portland MSS., V., 92. 
CHAP. relations and of the strength which Marlborough's support would $x$. bring to Oxford. It was his design to supplant the treasurer by recommending himself to the tory party as the minister of their revenge. To this the first step was Marlborough's fall.

The opening of parliament for the December session of I 7 I I promised a conflict between the ministry and the commons on one side and the house of lords, under the whig leaders, on the other. ${ }^{1}$ Marlborough, who, in his recent correspondence with Harley, had shewn indications of supporting the ministerial efforts for peace, was encouraged by the attitude of the Elector of Hanover to advise the queen against the preliminaries. To the surprise of the ministers, Nottingham, who had always counted as a tory, ranged himself on the same side. He had been overlooked at the formation of Harley's government, but his fears for the protestant succession, of which he had always been a supporter, probably determined his desertion. The treasurer endeavoured to buy off his opposition by pandering to his religious prejudices. Twice had Nottingham failed to carry occasional conformity bills; the ministry would bring one in themselves. The temptation was a strong one, and Nottingham wavered. For the whigs at this moment the dominant conviction was that of the necessity of rejecting the preliminaries. Before this national interest sectarian interests were of small account. With an effrontery as unabashed as that of Harley, who was known to be a favourer of the dissenters, they offered Nottingham Harley's price, coupled with the condition that the dissenters' liberties should suffer no prejudice. On December I 5 Bothmer triumphantly reported that the bargain was struck. Nottingham and his friends in both houses would vote against the preliminaries.

Parliament assembled on December 6. "I am glad," ran the queen's speech, "that I can now tell you that, notwithstanding the arts of those who delight in war, both time and place are appointed for opening the treaty of a general peace. Our allies (especially the States-general), whose interest I look upon as inseparable from my own, have, by their ready concurrence, expressed their entire confidence in me." This statement was notoriously untrue, and Nottingham, who led the

1 Sir R. Davers to [the Earl of Oxford], November I, I7II, Portland MSS., v., 106. 
attack, did not hesitate to describe the preliminaries as a violation of our engagements. He concluded by moving the CHAP. amendment of the address by the formula that "no peace could be safe or honourable to Great Britain or Europe if Spain and the West Indies were allotted to any branch of the house of Bourbon". Marlborough, Cowper, Halifax, and Burnet spoke in support, and the clause was carried on December 7 by 62 to 54 votes. In the consternation which followed this defeat, graphically described by the pen of Swift, Oxford and St. John kept their heads. They secured the rejection of a similar clause in the house of commons by 232 to 106 votes. Their next step was to avenge themselves upon the principal author of their defeat, the Duke of Marlborough. A fortnight after the defeat of the government in the lords, the commissioners of public accounts presented a report to the house of commons charging the duke, as commander-in-chief, and Walpole, as secretary at war, with peculation.

It was determined to test the temper of the house by proceeding, in the first instance, against Walpole. He had been the rival of St. John at Eton, and was his most formidable antagonist in the commons. His robust common sense, his capacity for management, his mastery of detail, his lucid expositions of finance, his gift of homely but stinging sarcasm were an effective foil to the florid invective, the passion, and the rhetoric of the tory leader. His expulsion, said Speaker Bromley, St. John's intimate, was the "unum necessarium". He was accused by the commissioners of having, as secretary at war, received from contractors for army forage two sums of 500 guineas each, either by himself or his agent, Robert Mann. Walpole's explanation was that the sums in question had been paid to Mann for the purchase of the share in the contracts which had been assigned to him: no part of them had been applied to his own personal profit. Complete though his vindication was, according to the practice of his contemporaries, it failed to satisfy the nice honour of a minister who, if Harley is to be credited, had himself organised a fraud on the treasury, and who, we know from a letter of Prior, was making surreptitious profits out of the sale of passports. Walpole was declared by a majority of fifty-seven guilty of notorious corruption. The majority was far below the normal ministerial strength, 
CHAP. and upon a motion to expel him the house, it fell to twenty$x$. two. The crowning wrong of committing him to the Tower was carried by twelve votes only on January I 7, I 7 I 2.

A few days later the commons proceeded to the consideration of the commissioners' report as to Marlborough. The foundation of the charges was the deposition of Sir Solomon Medina, contractor for bread to the allied army in the Netherlands, who stated that between 1702 and I 7 I he and his predecessors in the contracts, had paid the duke commissions amounting to $£ 63,319$, besides gratuities to Cardonnel, his secretary. There was a second charge of appropriating $2 \frac{1}{2}$ per cent., amounting to $£ 282,366$, from the pay of the foreign troops in British pay. Upon the last head the duke had a clear defence. The deductions, he proved, had been made in accordance with an agreement between William III. and the allies, to serve in lieu of a sum for secret service during the war. This arrangement had been confirmed to him at the outbreak of the war under the queen's own hand. ${ }^{1}$ A letter from the Elector George subsequently confirmed his assent, and expressed satisfaction that the money had been properly applied. ${ }^{2}$ To a generation in which contract has taken the place of custom, the transactions in the matter of the bread contracts are indefensible. In those days perquisites were recognised as an appanage of every office, and the Dutch commander-in-chief had been accustomed to receive a like commission. Marlborough affirmed that none of the money was applied to his private uses, but to procuring intelligence, in which he was undoubtedly well served. But the ministry were pledged to the gratification of animosities, not to listen to defences. The duke was turned out of all his employments on December 3I, and the queen announced his dismissal in an autograph letter "so very offensive that the duke flung it in the fire, though he was not a man of passion ". As in Walpoie's case, so in Marlborough's, the vindictiveness of his enemies had outraged public feeling. He who had been libelled inio unpopularity was now cheered through the streets.

'July 6, I7oz; copy of the queen's grant, Blenheim MSS., p. 16, Hist. MSS. Comm., 8th Rep., App.

2 March 23, 17I3, ibid.; cf. November 16, 1702, ibid., p. 41.

3 Words indorsed on a copy, dated December 31 , of the duke's reply. Ibid. 
It was the ministry, not the duke, who feared the issue of an impeachment. There were tories, who, like Swift, did "not love to see personal resentment mix with public affairs". Both Walpole and Marlborough utilised their retirement by publishing vindications of their conduct.

Without a majority in the upper house the entire ministerial scheme of a peace would be shipwrecked. To insure success, the queen was advised to exert the prerogative by a wholesale creation of peers. It was a measure of which Bolingbroke himself afterwards wrote that it was "unprecedented and invidious, to be excused by nothing but the necessity and hardly by that". Three eldest sons were called up (December 28-29, I7I I, and January I, I 7 I 2), and nine new peers created (January I, I 7 I2), one of them being Samuel Masham, the husband of the favourite. Before the first trial of strength came on, the ministry, according to Burnet, had recovered the allegiance of the greater number of the Scots peers ${ }^{1}$ by "extraordinary profusion" at the expense of the civil list. On January 2, a message from the queen desiring the adjournment of the house, though it involved a stretch of prerogative, was carried by a majority of thirteen. "If these twelve had not been enough," exclaimed the impetuous secretary, "they (the ministers) would have given them (the whigs) another dozen." The division is remembered by the gibe of Wharton who, when the question was put, asked one of the twelve new peers whether they voted by their foreman?

While the ministry were maturing their plans for Marlborough's disgrace, they were perturbed by the arrival of Prince Eugene upon a special mission from the emperor to propose fresh terms for the renewal of the war. Eugene arrived in the Thames on January 2, 1712 , and there heard the news of Marlborough's fall. No course remained to ministers but to entertain the prince with ceremonious indifference. But sensible that the opposition to their negotiations for peace was strengthened by his presence, the more violent took occasion to prejudice him with the public and with the queen. A spy named Plunkett, a lay pupil of the Jesuits, communi-

'Iord Balmerino refused to return to the house. Letter to Lord Oxford, January 29, 1711-12, Portland MSS., V., 141 .

VOL IX. 
CHAP. cated to Buckingham, president of the council, and Lord $x$. Keeper Harcourt a ridiculous story with which he had failed to impose upon Oxford and St. John. Marlborough and Godolphin, he said, had proposed that the treasurer and secretary should be "De-Witted". Eugene had improved the occasion by suggesting that the Mohocks, a band of drunken debauchees then infesting the streets, should be employed to assassinate Oxford. While Marlborough seized the Tower, London should be fired. Bothmer had approved the plot. At Buckingham's instance, these revelations were produced at a cabinet council. They would be unworthy of mention were it not that Torcy appears to have lent some credit to them, and that Swift who at the time thought there was "no truth, or very little in the whole story of the Mohocks and their designs," unflinchingly stood godfather to it in his History of the Four Last Years of the Queen. Plunkett was dismissed to Holland in search of his pretended informant, and spent the rest of his career as the spy and betrayer of the pretender, of Torcy, and of the Elector George.

At the opening of the session in January, I712, the queen announced to parliament the arrival of the plenipotentiaries for peace at Utrecht. By way of impressing on the allies the determination of the ministry, a series of resolutions was carried through the house of commons denouncing each of them in turn as having failed to carry out their pledges. It was a logical consequence that the obligations of Great Britain should come under review. A vote passed that the Barrier treaty contained "several articles destructive to the trade and interest of Great Britain," and Townshend and the ministers who advised its ratification were declared "enemies to the queen and kingdom ". On March I the commons addressed to the queen a long "representation on the state of the nation," the work of Nir Thomas Hanmer, assisted by St. John and Swift, reiterating their complaints against the allies. By way of further estranging the Dutch, St. John contributed to the Amsterdam Gazette a defence of the "representation," the allegations of which the States-general contested in a formal memorial to the queen, voted by the commons to be a "false, scandalous, and malicious libel ". it is difficult to interpret St. John's proceedings otherwise than as designed, by breaking up the alliance, 
to facilitate negotiations for a separate peace upon terms favour- CHAP. able to England. This was the belief of the Dutch. Upon the ministerial defeat by Nottingham, Buys had been dispatched to London to offer the support of the States-general in exchange for half the Asiento. That the Asiento should be reserved for England was the settled resolve of the ministry. It was, wrote Oxford to Buys, all that the nation had to shew for $£ 100,000,000$ expended in two wars. ${ }^{1}$ He omitted to add that St. John had sent instructions to the plenipotentiaries that Port Mahon and Gibraltar would be garrisoned permanently by English troops.

1March 11-19, 1711-12, Brit. Mus., Add. MSS., 20,985, f. 171. 
THE PEACE OF UTRECHT.

CHAP. THE peace conferences were formally opened at Utrecht on

XI. January 29, I 7 I 2, N.S., by Robinson, Bishop of Bristol, the lord privy seal, and the Earl of Strafford, as representatives of Great Britain, Buys and three others being the Dutch plenipotentiaries. These were shortly after joined by two envoys from the emperor. Business was begun by the presentation by the Marquis d'Huxelles, on behalf of France, of a new series of proposals treating the unconditional retention of Spain and the Indies by Philip as settled. The concessions of the convention to England were, it is true, maintained, but the allies were dealt with as the vanquished. In England, and still more abroad, there was general indignation. Halifax carried an address in the house of lords expressing a determination rather to continue the war than to submit to such terms. The incident, in St. John's view, proved the necessity of again violating the terms of the Grand Alliance by coming to terms with France privately and then dictating the conditions of peace to the other allies. By common consent between the French and English cabinets, the plenipotentiaries at Utrecht were to be left to the dilatory methods of formal discussion. A series of fatalities added to the difficulties of the ministry. On February 18 , the Duke of Burgundy died and was followed on March 8 by his eldest son. Between the union of the crowns of France and Spain under Philip V. there remained but the life of a sickly child of two years of age. The problem of the Spanish succession had increased in complexity. The first solution which occurred to the English ministry was a renunciation by Philip V., on behalf of himself and his successors, of all claims to the crown of France. But here they were met by a declara- 
tion on the part of the French lawyers that such a renunciation would be invalid. St. John and Harley thereupon adopted CHAP. as a solution the renunciation by Philip of the crown of Spain, since no one expected the young Prince Louis to survive. France in that case was to receive compensations in Italy, while Spain was to pass to the Duke of Savoy. However substantial the advantages gained by France, the ministry would, at any rate, have the credit of having jockeyed the French claimant out of Spain. While the courier was on his way to Madrid with the sanction of the French king to the plan, Oxford, on May 28, announced in the house of lords that the conditions of peace would be laid before parliament within a few days.

Startling was the disillusionment of ministers upon the news contained in a letter from Torcy dated June 8, N.S., that Philip elected to remain King of Spain. Their parliamentary credit was threatened with bankruptcy. The transfer of Spain to the Duke of Savoy would have silenced the whigs, but to palm off upon the Grand Alliance as a security against the union of the crowns renunciations which they were warned beforehand could have no validity, would be to juggle with public interests and to run risk of impeachment. It cost them, as Bolingbroke afterwards acknowledged, sleepless nights before they could face the inevitable. While the negotiations were wearing on, the time was arriving for the renewal of military operations. The Duke of Ormonde had been appointed captain-general upon Marlborough's dismissal. Upon the eve of his departure for the Netherlands on April 7/18, 1712, Ormonde received his instructions. ${ }^{1} \mathrm{He}$ was to assure the pensionary of the queen's resolution to push the war with vigour until the conclusion of a peace satisfactory to herself and her allies, and to concert his measures with Prince Eugene, who had been nominated generalissimo of the allied forces. After the junction of Ormonde the whole army amounted to 122,000 effectives with 120 cannon. Opposed to them was Villars with 100,000 men, ill-equipped and scantily supplied with artillery.

A dispatch from St. John, dated May 10, imposed upon Ormonde new and extraordinary instructions. At this time

' Hardwicke Papers, Brit. Mus., Add. MSS., 35,838, f. 37t. 
CHAP. the cabinet had received no formal answer from Torcy XI. accepting the principle of a renunciation, though the letter of St. John shows that they counted upon it. The dispatch, which, being unauthorised by any council, afterwards formed a principal article in the impeachments of the ministers, runs : "It is, therefore, the queen's positive command to your grace that you avoid engaging in any siege or hazarding a battle till you have further orders from her majesty. I am, at the same time, directed to let your grace know that the queen would have you disguise the receipt of this order." A postscript adds: "I had almost forgot to tell your grace that communication is given of this order to the court of France, so that if the Mareschal de Villars takes, in any private way, notice of it to you, your grace will answer accordingly". While Oxford might not have shrunk from perfidy towards the allies, his cautious temperament would have forbidden him to countenance the treason of such instructions. St. John, therefore, kept the dispatch a secret from his colleagues and no council was held to consider its terms, which subsequently became famous in debate and history as "the restraining orders". Though scruples never stood in St. John's way, it is surprising that Ormonde was found ready to act upon his instructions. Eugene's estimate of him, but shortly before, had been that he was "the finest cavalier and most complete gentleman that England bred". 1 This was the man who accepted, though reluctantly, ${ }^{2}$ the infamous rôle of entering into a secret correspondence with the enemy in the field to the detriment of the nation's allies.

Ormonde had not the makings of a conspirator. The secret oozed out, and Eugene, to test him, invited him on May 28 to join in an assault upon the French camp. The duke requested a delay, but he felt unable to resist a proposal that his troops should be present with the allies at the siege of Le Quesnoy. He told Eugene, however, that his instructions were not to take the offensive against the French. At the same time he secretly informed Villars that the movements of his troops need cause him no apprehension. ${ }^{3}$ A protest was

${ }^{1}$ April 4, 1712, Characters by Prince Eugene, Portland MSS., v., 156.

2 On June 8 , N.S., he asked to be resalled " if there be no prospect of action ". Dartmonth MSS., iii., 77, Hist. MSS. Comm., I5th Rep., App., pt. i.

Ibid., pp. 75, 79. 
at once addressed by the States-general to Bishop Robinson, from whom on June 3 they received the answer: "That conCHAP. sidering the conduct of the States towards her majesty, she thought herself disengaged from all alliances and engagements with their high mightinesses ". The whigs lost no time in endeavouring to arouse national indignation. Pulteney in the commons and Halifax in the lords on May 28 moved addresses to the queen for the revocation of the instructions. In both houses the ministry won a majority by assurances that in a few days the terms of peace would be laid before parliament. Oxford's emphatic denial that the negotiations were for a separate peace, contributed to the victory of the ministry. On June 6 , however, the queen announced to parliament the terms agreed on, her speech making the avowal, "I have not taken upon me to determine the interests of our confederates; these must be adjusted in the congress of Utrecht". The commons replied with an address of approval. In the lords a weighty protest was signed by Godolphin, Marlborough, and twenty-two other peers.

In the camp of the allies Ormonde announced that, France having agreed to surrender Dunkirk to England, his government had arranged an armistice for two months, to which he invited them to accede. On July I6, N.S., amid the murmurs and hisses of his own soldiers, he evacuated the camp at Cateau-Cambrésis. It was the dissolution of the Grand Alliance. The indignation of the Dutch, both at Ormonde's desertion and at the surrender of Dunkirk, was difficult of restraint. As the duke marched towards Dunkirk, which he was under orders to occupy, the Dutch governors of Bouchain, Tournay, and Douay refused to open their gates. Ghent having an English garrison, he encamped there and a few days afterwards threw a garrison into Bruges, which met no resistance. Dunkirk had been surrendered on July 19 to a force commanded by Brigadier Hill. Ormonde received orders to reinforce the Dunkirk garrison, and to maintain himself in possession of Ghent and Bruges. The extraordinary spectacle was now presented of the British general arranging with the enemy for the march of his troops to Dunkirk, and holding two important towns belonging to his nominal allies against their will and consent. It was not long before events 
CHAP. proved that the dismissal of Marlborough had restored the XI. balance in favour of the French arms. On July 25, Villars surprised a corps of 8,000 men at Denain. The surrender of a succession of fortresses, including Douay, followed, and the campaign which had opened with the expectation of being closed under the walls of Paris, finished ingloriously on October ro with the loss of Bouchain.

St. John, during the session of I 7 I 2 , enjoyed a scarcely contested supremacy in the house of commons. His conception of the use to be made of it is delineated by De Foe in the Secret History of the White Staff, a pamphlet inspired by Oxford after the queen's death. "They told him (Oxford) that it was time to strike home, as it was called, at the whole party; to make a thorough reformation by displacing every whig or moderate man in the nation," and so forth. In the indulgence of this spirit St. John directed a series of assaults on the opposition. The repeal of the naturalisation act of the last parliament in favour of foreign protestants now passed the lords-a sop to the High Church party and a blow to the whigs who had promoted it. In the queen's speech at the beginning of the session (January I7) war was proclaimed against the opposition press. The future of the tory party was to be secured by strengthening its possession of power with the repressive weapons of the law. Opposition was to be treated like dissent; to be frowned down, even proscribed. In pursuance of this policy, a bill aiming at the impoverishment and humiliation of the great whig families was introduced into the house of commons. While the revolution had advanced and enriched some of the leading whig peers, the largest grants of William. III. had fallen to Dutch favourites, of whom the Earl of Portland had been the most conspicuous. By this bill commissioners were to be nominated to report to parliament upon these grants. On the third reading the whig opposition was reinforced by Nottingham and his friends. Argyll and Wharton suggested that the inquiries of the commissioners stiould be carried back to the grants of James II. and Charles II. The ministerialists were too wise to accept an amendment which would have jeopardised so many interests as would have secured the rejection of the bill. Nevertheless the proposal for the spaliation 
of their whig opponents was only defeated by the rule of the CHAP. house that on an equal division the negative carries it, the votes being seventy-eight on each side.

While this assault upon the whig grandees thus miscarried, measures were being devised for muzzling their pamphleteers. A stamp tax of a penny a sheet was imposed upon newspapers and of two shillings a sheet on pamphlets of more than half a sheet. The tory Swift exulted at the prospect of the check in store for his rivals, but lived to admit that the measure failed of its effect owing to the liberality with which the whigs subsidised their party organs. Nor was the repression of the English whigs a sufficient task for the tory majority in the commons. A group of Scottish difficulties had been gradually ripening and were dealt with in the same overbearing spirit. In the spring of I7II riots and bloodshed had taken place in the north and south-west of Scotland. The occasion was a judgement of the house of lords in favour of an episcopal clergyman, named Greenshields, who had been inhibited by the presbytery of Edinburgh from substituting the English for the Scottish episcopal liturgy. "The gentlemen," the mob cried, "are about to restore the liturgy by force." 1 The Jacobite Lockhart seized the opportunity to carry through the house of commons a bill abolishing the jurisdiction of the ecclesiastical courts of Scotland over dissenting congregations. He followed up this blow with another which was galling to presbyterianism-the restoration of patronage in the Church of Scotland. ${ }^{2}$

As if these aggressions upon religious rights were not enough, the ministry attacked Scottish commercial interests. In the session of 17 I I a bill was passed imposing a duty upon exports of linen cloth, Scotland's staple trade. In the session of 1713 another irritating bill was brought in. The fourteenth article of the Act of Union ran: "Scotland shall not be charged with any imposition on malt during this present war". In the face of this, the ministry proposed to extend the malt duty to Scotland. Peace was, no doubt, in sight, but peace had not been proclaimed. Even if it had been, the Scots justly argued that as the produce of the tax was to be appro-

1 De Foe to Harley, March 2, 271 , Portland MSS., iv., 664.

2 so Anne, c. 13 . 
CHAP. priated to the expenses of the war, the intention of the treaty XI. would be defeated. Neither justice nor argument availed. When the malt bill was on its way to the house of lords the moment seemed ripe for a dissolution of the union. At a meeting of the Scots members, convened by Lockhart, the tories heartily, the whigs with reluctance, approved dissolution as the only expedient for rescuing their country from servitude and impoverishment. Oxford warned Lockhart against persistence in his movement, and a deputation of Scots peers and commoners received a rebuke from the queen. Undeterred by the frown of authority, the Earl of Findlater, who, as Earl of Seafield, had been lord chancellor of Scotland, moved for leave to bring in a bill for repeal. The debate which ensued proved that feeling had broken loose from party principles. Among the English whigs, Sunderland, Townshend, and Halifax declared for the repeal of a measure they had been forward to promote, but expressed apprehensions lest, since it was so ardently favoured by the Jacobites, it would prove disastrous to the protestant succession. The court only succeeded in defeating the motion by a majority of four votes.

On the announcement in the queen's speech of the preliminaries of peace on June 6, I 712 , St. John considered the moment.opportune to claim a reward of his services. His eye was doubtless on the treasurer's staff, and precedent made for the appointment of the treasurer from the peerage. He applied, therefore, to Oxford ${ }^{1}$ for the revival of the earldom of Bolingbroke, recently in the elder branch of his family. As the anticipation of a harvest which might not be reaped, the request was premature and the queen refused it. Promotion might come with a peace, for the present he might have a viscounty. In profound chagrin he wrote again, begging to be allowed to remain in the house of commons. ${ }^{2}$ It was too late. On July 7 he was created Baron St. John and Viscount Bullingbrook ${ }^{3}$ (sic). It is said that his face showed his indignation as he kissed the queen's hand. As a means of allaying his discontent, Oxford fell in with a proposal he had made some months before, and dispatched him on an extraordinary mission to the French court. His business was to come to an agreement as

June 28 (?), Portland MSS., v., r94.

2 July 3, ibid., p. 198.

3 He signed "Bolingbroke"; see facsimiles in Coxe's Memoirs nof Sir $R$. Walpole, vol. ii. 
to the pretensions of the Duke of Savoy and the Elector of CHAP. Bavaria, and to conclude an extension of the armistice pendXI. ing the negotiations for peace. On August 22, O.S., he was back in London, having signed an armistice for four months. Oxford, meanwhile, had been undermining his rival's position at court. Soon after his return Bolingbroke was informed that as the correspondence with France really belonged to Lord Dartmouth's department, it would in future revert to him. It was a twofold mortification. It blocked the prospect of a further step in the peerage as a reward for the negotiation of a successful peace, and it implied that Dartmouth would obtain an earldom on the same ground as that on which he had hoped for one. During his absence Oxford had taken care to fill the queen's ear with rumours of his conduct. His intimacy with the ladies of the French court was misliked. He had attended the opera when the pretender was present, and had not shewn due respect for the queen by withdrawal. Gossip even whispered-though it would seem without foundation-that the two had had a private meeting. The death of Godolphin on September I 5 disclosed the queen's feeling. Six garters were vacant. Oxford received one. Bolingbroke was passed over. "This," as Oxford pithily put it, "created a new disturbance."

The leading whigs were urgent for the presence of the elector in London. The position of affairs, they thought, was highly dangerous. During the last eighteen months, under the inspiration of St. John, there had been numerous "reforms" in the high commands of the army. ${ }^{1}$ Webb, the hero of Wynendaele, a Jacobite, was made commander of the land forces in Great Britain on June 11, 1712, and Bolingbroke's confidant, Sir William Wyndham, secretary at war. Whig naval officers were being dismissed and a squadron was being fitted out on pretext of the complications in the north. What was needed was a rallying point for the well-affected to the succession. But the elector was not to be moved from his attitude of caution. The whigs, he answered, must rely on their own exertions and be prepared. When the crisis arrived, he would not fail them. Oxford, while composing protestations to the electress and elector, was mindful of the possibility

1 Portland MSS., iv., 656. 
CHAP. of Jacobite success. During the negotiations, Bolingbroke XI. tells us, "the pretender was made (by Oxford) through the French minister to expect that measures should be taken for his restoration as soon as peace had rendered them practicable". Undoubtedly this was the impression Oxford wished to convey to the sanguine minds of the exiles, but he committed himself to no direct negotiation, leaving Gaultier to report his conversations at his discretion. Of these the earliest in which Oxford was alleged to have expressed favourable intentions towards the pretender occurred about the middle of March, I 7 I 3. ${ }^{1}$ From that time Oxford amused James with promises of payment of his mother's dowry, in return for which he obtained his orders that the Jacobites should support the ministry at the elections of I7I3. There is no ground for supposing that he ever seriously contemplated assisting a restoration. Bolingbroke, indeed, testifies to the contrary, but there was, nevertheless, an ulterior possibility of which he had to take account. The queen had declared to the Dukes of Buckingham and Hamilton, both men of Jacobite sympathies, that she could do nothing for the pretender unless he changed his religion. To a man of Oxford's temperament it seemed not improbable that this condition would be complied with.

It was within the power of the ministry, after Bolingbroke's return from Paris in August, 1712, to conclude a separate peace, but the French were obviously spinning delays, and public opinion in England was becoming irritated. Dartmouth, conscious of incapacity, ${ }^{2}$ had restored the negotiations into Bolingbroke's hands. At Paris, Prior had been left in charge. $\mathrm{He}$ was at once the secretary's faithful friend and an agent under his control. Nevertheless the prejudices of Anne against his humble origin excluded him from the dignity of an embassy. The Duke of Hamilton was therefore accredited in November, I 7 I 2, as ambassador extraordinary to bring the business to an end. He was a favourite with the queen, who had honoured him with both the Thistle and the Garter, and his selection gratified the Jacobites. While his preparations were being made

1 Berwick to James, March 28, 1713, Stuart Papers, i., Introd., p. xlv., and $i b i d .$, p. 260.

2 Erasmus Lewis to the Eidrl of Oxford, October 13, I4, Portland MSS., v., 234. 
he was killed in Hyde Park on November 1 5, in a duel with Lord Mohun, an active whig. . An outburst of party fury folCHAP. lowed this event. General Maccartney, who had been cashiered by the ministry, had acted as Mohun's second, and was accused of having stabbed the duke after he had fallen. The result of his trial on his return from exile in 1716 , proved that Maccartney was innocent of the charge, but in the then prevalent heat of party passion he thought it prudent to flee the country. Shrewsbury was at once nominated in Hamilton's place. The armistice had been prolonged. Month after month slipped by. Parliament had been eleven times prorogued. At last in February, I7 13, even the patience of Bolingbroke with his French friends was at an end. An ultimatum was drawn up by the secretary, laying down in precise terms the demands insisted on by the queen relative to the outstanding questions-the fishing rights off Nova Scotia, the monopoly claimed on behalf of Portugal of the navigation of the Amazon, and the addition of Tournay to the Dutch barrier. Failing these, a plain threat was held out that war would be resumed in the spring.

The consequences of this firmness were immediately evident. The French negotiators abandoned further delay and on March 3I-April II, I 7 I3, a series of treaties was signed at Utrecht. These were a treaty of peace and a treaty of commerce between England and France and treaties for Holland, Portugal, Prussia, and Savoy. The slave trade treaty called the Asiento had been signed a few days before at Madrid, though the formal treaty with Spain was not completed till July 2-13. With the exception of the empire, it was said, peace was restored among the European powers. But this exception, which included the Elector of Hanover and other German princes, involved the surrender of the principle of the solidarity of the Grand Alliance. By the treaty of Utrecht between England and France, the King of France acknowledged the right and title of the queen; pledged himself to accept the succession in the house of Hanover, to exclude the pretender from France, and to abstain from giving him any assistance. He further solemnly accepted the renunciation by Philip V. of his claims to succession in France and by the French princes of the blood of their claims on the crown of Spain, these renunciations being set out in the text of the 
CHAP. treaty; the special privileges of French traders in Spain and $X I$. the Spanish Indies were surrendered; the fortifications of Dunkirk were to be razed; Hudson's Bay, Nova Scotia, and Newfoundland, saving certain fishing rights, were ceded to Great Britain as well as the island of St. Christopher. A treaty of commerce was signed on the same day. By the treaty with Spain the retention of Minorca and Gibraltar was conceded, and Sicily was erected into a kingdom for the Duke of Savoy.

The whigs complained that at the moment of victory the conquering power had accepted worse terms than France had conceded at Gertruydenberg and that Bolingbroke, eager to ingratiate himself with the French, had surrendered the interests of our allies, Holland and the empire. It may be that the substantial advantages of peace, and especially the acquisitions from Spain, outweighed the problematical gains of a continuance of successful war; but it is difficult to dispute that the means by which they were secured were a blot on the national honour. Two complementary sacrifices of public pledges were exacted of us - the abandonment of the cause of the French protestants, still suffering persecution, and of our faithful allies the Catalans.

The queen's speech, at the opening of the session on April 9, 1713, announced the peace. That the nation, as a whole, welcomed it, is incontestable. "In the churches the bells, in the streets the bonfires, and in the windows the illuminations, proclaimed the joy of the people." ${ }^{1}$ But the treaty of commerce provoked bitter controversies among the trading classes. This treaty, by its eighth article, secured to the subjects of Great Britain and France reciprocally the most-favoured-nation treatment. By the ninth it provided that in the event of a statute being passed within two months of the execution of the treaty, conceding the most-favoured-nation treatment to French goods, France would revert to the more liberal tariff prevailing in 1664. A large step was thereby contemplated in the direction of freedom of trade. Against such proposals the manufacturing interests revolted. These, especially the silk industry, had received a vigorous impetus from the influx of the French Huguenots. The manufacturers were supported by the

1 P. Shakerley, M.P., to the Mayor of Chester, Westminster, April 4, 17r3, MSS. of Corporation of Chester, p. 395, Hist. MSS. Comm., 8th Rep., App, 
whigs, hostile by tradition to any measure likely to promote harmonious policy between the two countries, and by the econoXI. mists, who demonstrated that commercial relations with France had always been proved disadvantageous to England by an adverse balance of trade. Petitions against the treaty rained upon parliament. Somers in the lords and General Stanhope in the commons led the opposition. The champion of the measure was Arthur Moore, then a commissioner of trade, who was credited with being its real parent; but it was supported in debate by Wyndham, Hanmer, and other leaders of the tory party. At the instance of Oxford, De Foe entered the field with a paper published thrice a week, of which the first number appeared on May 26, while the treaty was still under discussion in parliament. Its title was Mercator, or Commerce Retrieved. A rival was presently issued, under the name of The British Merchant, or Commerce Preserved, said to have been subsidised by Halifax and Stanhope. Insistence was laid by politicians and traders alike upon the Methuen treaty with Portugal. To infringe that treaty by concessions in favour of French wines, would be to throw away a rising market and to break faith with a loyal ally, while the English manufactures of silk and woollen would be left defenceless to the competition at home of the underpaid labour of France.

Sir Thomas Hanmer was at this time, in the opinion of Swift, "the most considerable man in the house of commons". He it was who had drawn up the famous "Representation," justifying the conduct of the tories towards Marlborough and the allies: He was intimate with Ormonde, and upon a visit to Paris in the previous November had been courted by Berwick ${ }^{1}$ and the Jacobites. From a politician with such connexions a ministry suspected of leanings towards the pretender anticipated no opposition. But Hanmer's closer acquaintance with the Jacobites had produced unlooked-for results. He returned from France convinced of the necessity of the act of settlement, and sharing with the whigs a dislike of the Francophil policy of Bolingbroke. In the commons he controlled forty to fifty votes, recruited chiefly from those members of the October club who were not Jacobites. In the course of the final

1 The Duke of Berwick to the Pretender, November Ir-20, 1712, Stwart Papers, i., 251. 
CHAP. debate on the treaty of commerce on June 18 , he passed over at $X I$. the head of his group to the opposition, and the confirmation of the eighth and ninth articles of the treaty was defeated by nine votes. The defeat of the capital articles of the treaty of commerce heightened the growing antagonism between Bolingbroke and the treasurer. In pursuance of his policy of controlling parliament by a personal following, independent so far as might be of party lines, Oxford had, since the autumn of I 7 I I, been renewing relations with the whig leaders. ${ }^{1}$ When his advances proved fruitless, he resolved to pay addresses to the Hanover tories-the "whimsicals," as Bolingbroke contemptuously called them. He was ready to pay their price, the sacrifice of Bolingbroke's treaty of commerce. Before the fatal division he had let it be known that he "gave up the point". It was not the least of Bolingbroke's vexations that the Dutch, to whom he entertained an antipathy almost morbid, exulted openly at a blunder in commercial politics which promised to result in advantage to their own trade with France. ${ }^{2}$

The time had now arrived, in Bolingbroke's judgement, to make a stand against a policy of truckling which was ineffective for constructive politics. His conception of a government by a parliamentary majority must take its place. He demanded of Oxford a change of system. A clearance must be made of whigs and weak-kneed officials. Oxford himself must undertake no more than he could effectively perform. He was "too jealous". If we are to believe a report conveyed to Oxford, the treasurer "was to have terms put upon him and a junto".4 Oxford affected to surrender. Atterbury had in June, I 7 I3, been nominated to the see of Rochester as a compliment to the leader of the High Church party in convocation. Wyndham, Bolingbroke's personal friend, became chancellor. of the exchequer in November. But these concessions the treasurer did his best to counterbalance. He reduced Bolingbroke's patronage by nominating the Earl of Mar to the

1 Portland MSS., v., 108 (November 9, I711), 254 (December 6, 1712), and Hist. MSS. Comm., 7th Rep., App., p. 508 (March 24, 1713 ).

[Viscount Bolingbroke to the Earl of Oxford], June, 1713, Portland MSS., v., 299 ; De Foe to the same, October 22, 1713, ibid., p. 351.

3 Viscount Bolingbroke to the Lord Treasurer, July 27, 1713, Portland MSS., v., 311 , and December 17, I713, ibid., p. 373.

I Ibid., p. 467. 
secretaryship for Scotland, the duties of which Bolingbroke CHAP. had hitherto attempted to engross; ${ }^{1}$ Lord Findlater was ap$\mathbf{X I}$. pointed keeper of the great seal of Scotland. This appears to have given umbrage to Bolingbroke's ally Lord Harcourt, who had been made lord chancellor in the previous April. Bromley, a high churchman, displaced Dartmouth as secretary of state. Though this group of appointments had the effect of irritating the Bolingbroke faction, ${ }^{2}$ nevertheless, as a year later Oxford confessed to Swift, his power had departed from him. In fact, his health was breaking. ${ }^{3}$ His natural procrastination grew upon him. His correspondence is full of appeals and remonstrances about his inattention to letters. "He seemed," wrote Bolingbroke, "to be sometimes asleep and sometimes at play. He neglected the thread of business."

1 Portland MSS., v., 467. "These things," wrote Erasmus Lewis, Lord Dartmouth's secretary, " make Lord Bol-_ stare." September 1o, 1713, Dartmouth MSS., p. 3r8, Hist. MSS. Comm., rith Rep., App., pt. v.

2 Portland MSS., v., 466, 468; Edward Harley's Memoirs, ibid., p. $66 \mathrm{r}$.

3Ibid., p. 466. 


\section{CHAPTER XII.}

\section{THE SUCCESSION IN DANGER.}

CHAF. THE life of the parliament was now approaching a close, and XII. the public thanksgiving for peace on July 7, I7 13, suggested to the ministerial party that they could " never go to their elections with more advantage" 1 than at that moment. On August 8 the dissolution was proclaimed. It was useless for the whigs to decry the peace, but they made what they could of the treaty of commerce, wearing wool in their hats as a sign of concern for the staple industries of the country threatened with extinction by French competition. Although the tory majority was reduced, it still remained formidable. Lord Lansdown, active as a ministerial whip, boasted that he had carried ten to one in the numerous and venal Cornish boroughs, ${ }^{2}$ presumably by means which introduced into the political vocabulary of the tory party the term to "cornwallise". 3 The elections for the Scots peers, important in the state of relations between the two countries, also went for the government. The new majority in the commons, inasmuch as it was largely inspired with the temper of Bolingbroke, weakened Oxford's. position in parliament. At court he began to be sensible that the favour of Lady Masham was being transferred to his rival. Bolingbroke enlisted her avarice by promising her a share in the lucrative Asiento business. It is stated by Edward Harley that a "great sum" was also shared by her for procuring the signature of the queen to articles varying the treaty of commerce with Spain."

${ }^{1}$ W. Bromley to [the Earl of Oxford], July 24, Portland MSS., v., 308.

2 Lord Lansdown to [the Earl of Oxford], September II, ibid., p. 330.

"Sir Robert Price, baron of the exchequer, to the Earl of Oxford, September 3: "If he could have cornwallised it by scattering some guineas illegally," etc. 'Ibid., p. 326.

- Portland MSS., v., $66 \mathrm{r}$. 
These intrigues were suspended by the alarming illness of the queen. Her health, which had been poor in the spring CHAP. XII. of 1713 , had much improved during the autumn, but on Christmas eve she was attacked by an aguish fever, of such severity that her death was looked for. The tories, in Oxford's words, were "out of their wits". On the other side, Swirt tells us, there was "a great hurrying of chairs and coaches to and from the Earl of Wharton's house" and "the expressions of joy appeared very frequent and loud among many of that party". Upon her recovery, which took place at the end of January, Bolingbroke artfully painted the impatience of the whigs for her death. Her resentment determined her to abandon Oxford's policy, hitherto favoured by her, of combining both parties in the service of the crown. Henceforth she was prepared to indorse the programme of government by party supremacy advocated by Bolingbroke and his friends.

The ill-dissembled exultation of the whigs had been stimulated by their apprehensions. An atmosphere of Jacobitism pervaded the court. As early as May, 1713, Oxford had expressed to Gaultier his willingness to dispatch a confidential emissary to James. ${ }^{1}$ He had renewed the proposal during the queen's illness, ${ }^{2}$ but dropped it when the fears which had inspired it were allayed. But Bolingbroke was not of a temperament to indulge in empty intrigue. He was intimate with Ormonde who, as captain-general, was active in "discarding the army". In I 7 I 3 Ormonde was nominated lord warden of the Cinque Ports, which gave him command of the defences of the southern coasts. Utterly misled as to the state of public opinion in England, Berwick conceived an absurd scheme for the sudden appearance of James by the side of the queen at the opening of the new parliament. ${ }^{3}$ But the advice of Oxford was all of a negative character. In Bolingbroke's words: " He (James) was to attempt nothing; his partisans were to lie still ; Oxford undertook for all". Ormonde had begun a correspondence with the pretender in September, 1713. When the queen's life was in danger, in the January following, he had pressed Oxford to take measures to insure James's suc-

\footnotetext{
'Duke of Berwick to James, May 12, Stwart Papers, i., 264 .

Same to same, January 9, 17x4, ibid., p. $29 x$.

'Same to same, August 18, 1713, ibid., p. 272.
} 
CHAP. cession $;^{1}$ but he had to be contented with the usual vague XII. promises. The queen's illness, however, did not pass away without leaving a definite impress upon the policy of the ministry. Schütz, then Hanoverian envoy, disclosed plainly, enough the elector's preference for the whigs. What prospect of employment was there for Bolingbroke if George ascended the throne? In the autumn of 1713 Iberville was accredited French envoy-extraordinary to London. Thenceforth he served as the intermediary through whom the secretary discussed plans for a restoration.

Up to this time, it seems to have been assumed that the pretender would make no difficulty about religion. It was scarcely intelligible to Oxford that James should refuse to dissemble his faith or to Bolingbroke that he should hesitate to renounce it. Bolingbroke told Iberville plainly that people would rather accept a Turk than a Catholic. A draught declaration renouncing his Church was dictated by Oxford to Gaultier. James, with a spirit which did him credit, flatly refused to sign it. But he endeavoured to soften his refusal by letters to the queen, to Oxford, to Bolingbroke, and to Poulett. He wrote another letter to Gaultier to be shewn to his friends generally. But he only succeeded in making his position worse. He offered nothing more than "reasonable security" for protestantism. The suspicion caused by this attitude quickly spread. Before many weeks Gaultier announced secessions of the tories. At a meeting convened by Bolingbroke of members of both houses of parliament, it was decided that nothing short of conformity should win their support. Bolingbroke himself lies under no suspicion of indulgence in the luxury of religious antipathy. Personally, he was willing to accept James whether he conformed or not. Yet he was not going to run his head into a noose out of deference to the pretender's conscience. James, on his side, was unconscious of the revulsion of feeling caused by his attitude; but on April ro Iberville reported to Louis XIV. his conviction that the Hanoverian heir would ascend the throne without a voice being raised in the pretender's favour.

In his capacity of secretary of state Bolingbroke was also engaged in shaping a continental policy for the tory party. It had 
become possible, consistently with the interest of the country, to cultivate that good understanding with France which was a CHAP. tory tradition. The whigs viewed this tendency with dismay. They inveighed against the complaisance shewn in the matter of Dunkirk where, a year after the treaty of Utrecht, the demolition of the fortifications had been but imperfectly carried out. Steele in The Guardian (August 7, 1713) had declared, "The British nation expect the immediate demolition of Dunkirk," and he followed the point up by a pamphlet entitled The Importance of Dunkirk Considered. Bolingbroke, always sensitive to attack, had reasons of his own why public attention should not be called to Dunkirk. So long as the harbour and fortifications remained, so long could an English garrison be maintained there to put pressure upon Holland for commercial concessions or, as was believed, ${ }^{1}$ to embark French troops for England. Steele's pamphlet furnished a good opportunity for disgracing a dangerous critic, who in The Englishman and The Crisis had also assailed the Jacobite tendencies of the government. Bolingbroke therefore called into play his favourite doctrine that opposition to the queen's ministry was opposition to the queen. Despite a powerful speech by Walpole, who had been returned to the new parliament as member for Lynn, Steele was expelled the house of commons as guilty of "scandalous and seditious libels" on March 18, I7 I4. While relations were to be cultivated with France, Bolingbroke looked on himself as the peculiar patron of Savoy, the duchess of which, Anne of Orleans, was next by blood in succession to the crown after the children of James II. Regarding the duchy as holding the balance between France and the empire, he had exerted himself to strengthen it by procuring the kingdom of Sicily for the duke. He readily welcomed a proposal from Savoy, between which and Austria lay an unsleeping jealousy, for a defensive alliance with France against imperial aggression. This combination was to be the foundation of tory foreign policy, as the Grand Alliance had been that of the whigs.

The energetic policy of Bolingbroke had been entrusted in Ireland to Sir Constantine Phipps, the defender of Sacheverell,

'See alleged undated communication from Major-General Hill, governor of Dunkirk, in Marpherson's Origimal Papers, ii., 480 , 
CHAP. chancellor and lord justice in the absence of Ormonde, the lordXII. lieutenant. The attempts of Phipps to force tories into the corporations provoked riots, and were disapproved by Shrewsbury, who arrived as successor to Ormonde in October, I 73. When the parliament met in Dublin in November, it threw itself into the fray. It offered a reward for the pretender alive or dead. It refused to vote supplies for more than three months. ${ }^{1}$ Its action was recognised as a challenge to the English ministry. Bolingbroke, as usual, was for high-handed reprisals, and Shrewsbury felt himself constrained to warn the English ministers against any project of taxing Ireland from England. ${ }^{2}$ Bolingbroke had in his mind a stronger measure. "Should they" (the parliament), he wrote to Oxford, "ever meet again?" 3 The only way to prevent their doing so, otherwise than by passing an act of union, was to ask no more supplies. To effect this, a scheme was considered by Phipps for the suppression of the Irish establishments and the defrayal of the indispensable expenditure out of the hereditary revenues of the crown.

The failure of various attempts to ingratiate himself with the elector and of the negotiations with the pretender relegated Oxford to his congenial policy of drift. The whigs, on the other hand, entered into negotiations through the Duke of Argyll with Nottingham and Anglesey, the leaders of the Hanover tories, offering their support in the event of the displacement of the existing ministry, without advancing any claims to office. On March 17, 1714, in alliance with Nottingham, they delivered an attack on the ministry, especially with regard to its treatment of the Catalans. The case of the Catalans is the most discreditable incident in the peace of Utrecht. After the failure of the attempt on Cadiz in 1702, Mitford Crowe, the queen's minister at Genoa, had negotiated for their support of the Archduke Charles, promising in return to secure them in their ancient privileges. These promises were renewed by Peterborough and Shovell in 1705 . Nevertheless, Bolingbroke wrote to the plenipotentiaries at Utrecht: i., 244 .

${ }^{1}$ Duke of Shrewsbury to [the Earl of Oxford], December 22, 1713, Bath MSS.,

'Same to same, ibid., p.'245.

${ }^{3}$ December 31, I 713, Portland MSS., v., 377. 
"It is not for the interest of England to preserve the Catalan CHAP. liberties". He even went so far as to instruct Admiral Wishart XII. to assist Philip V. in reducing Barcelona. Against this coldblooded treachery the public conscience rose in revolt. The whigs carried a unanimous address in the lords, praying the queen to "continue her interposition in the most pressing manner in the Catalans' behalf". The only defence offered by Bolingbroke was that the queen's engagements to the Catalans ceased when the archduke left Spain. Yet even Bolingbroke flinched before the outburst of feeling. The queen undertook to endeavour to obtain "the full enjoyment of their ancient privileges and liberties," and Lord Bingley, who as Robert Benson had followed Oxford in the chancellorship of the exchequer, had already been dispatched to Spain upon this errand. At the same time Wishart's instructions were cancelled. But Philip was inexorable. The Catalans, after a vain appeal to the honour of England, hung up at the high altar of Barcelona cathedral the queen's assurance of her protection, and met the fate of the sword, the gibbet, and the dungeon.

The debate on the Catalans was followed by debates in the lords and commons upon the question whether the protestant succession was in danger. The omission of the ministry to secure the expulsion of the pretender from Lorraine, their reception of Lawless, a Jacobite exile accredited as envoy by Philip V., a charge brought by the Duke of Argyll against the lord treasurer of remitting subsidies of $£ 4,000$ a year to the Jacobite clans of the highlands, and the "reform" of whig officers from the army, were the evidences adduced by the opposition. Upon these last two points the Duke of Argyll led the attack. The ministry had its revenge. At the beginning of April the announcement was made that the duke had been removed from all his preferments, and a number of other officers were cashiered. Nevertheless, the weakness of the government, as Bolingbroke afterwards acknowledged, increased every day. In both houses the Hanover tories voted with the opposition. The vote that the protestant succession was not in danger was only carried in the lords by the narrow majority of twelve on April 3. A defeat would have implied a charge of treason against the ministry. Attributing this pre- 
CHAP. carious situation to the half-heartedness of Oxford, Bolingbroke XII. made a bold bid for his place. To Lady Masham, whose avarice he had declined to gratify, the lord treasurer was now become odious. His intervention had lately deprived her of the share in the profits of the Asiento which Bolingbroke had promised. From the house of Hanover she had nothing to expect. She, therefore, threw her influence into the Jacobite scale. But the queen could not in a moment cast off her dependence upon Oxford. With tears she implored the two ministers to be reconciled, and begged Ormonde to act as peacemaker. Oxford weakly acquiesced. He promised everything, even the measure of which he had hitherto disapproved, the further purging of the army from its whig elements, upon which the queen and Ormonde were agreed. ${ }^{1}$

In order to tranquillise the suspicions of the court of Hanover and avert action by the whigs, Thomas Harley, the treasurer's cousin, was dispatched in February, I7I4, with assurances to the electress, his real task being to dissuade the court from accepting an invitation to the electoral prince on the part of the whigs. The invitation, however, took the form of a demand by Schütz, the Hanoverian envoy (April 12), for a writ to the electoral prince as Duke of Cambridge, summoning him to the house of lords. "I never saw her majesty," wrote Oxford, "so much moved in my life." ${ }^{2}$ The writ could not be refused, ${ }^{3}$ but the elector, being made acquainted with the queen's feelings, prudently refused Schütz an audience on his arrival with it at Hanover. Nevertheless, when in May Thomas Harley brought back a suggestion that one of the electoral house should pay a complimentary visit to England, the queen again fell into a state of alarm and indignation. On the 19th, she dispatched three letters, one to the electress, one to the elector, and one to the electoral prince. A fourth letter to the elector was written by Oxford. All the letters emphatically protested against the projected visit. It was, however, decided to soften the rebuff by entrusting the Earl of Clarendon with a conciliatory mission to Hanover. In the meanwhile, the receipt of the letters had been marked by a tragic event. The

1 The Duke of Berwick to James III., April 20, 1714, Stuart Papers, i., 317.

2 To Thomas Harley, at Hanover, April 13-24, 1714, Portland MSS., v., 418,

${ }^{3}$ Lord Harcourt to Baron Schutz, April $x_{3}, x_{4}, 17$, ibid., p. 416, . 
Electress Sophia had attained the age of eighty-four, but so excellent was her health and so lively her energy that she CHAP. looked forward to outliving the queen. If, she said, she could but live to have "Sophia, Queen of England," engraved on her tomb, she should die content. The queen's letters threw her into a chagrin which, after three days, ended with her death on May 28, O.S. The elector thereby became heir to the English crown, and the policy of the court of Hanover was thenceforth directed by a single mind. Oxford seized the occasion of the incident of the writ to assert himself anew. Mere passive obstruction, he felt, was unequal to the task of baffling Bolingbroke. He now set himself to reconcile the queen to the prospect of the Hanoverian succession.

The impracticability of the pretender on the subject of religion had radically affected the queen's disposition towards him. The maintenance of the Church of England was the dominant preoccupation of her statecraft. To expose the Church to a renewal of her father's assaults upon it would have been to betray a sacred trust. She took counsel of a number of High Church bishops as to her duty. The result presently appeared. In the previous December she had connived at an intimation to her brother, through Gaultier, that he need not leave Lorraine. On April-30, she herself dispatched a letter to the duke requesting his expulsion. At the same time she shewed signs of lapsing into her former dislike of Bolingbroke. The secretary's last resource remained. He had failed to establish a permanent influence over the queen. He must find his support in parliament. He would inspire the tory party with a common rallying cry, and one embarrassing to Oxford, by hounding on the churchmen against the nonconformists. Nottingham's occasional conformity act of $17 \mathrm{I}$ had conceded facilities for the education of dissenters by allowing teachers and preachers to exercise their callings, upon conditions, elsewhere than in the counties where they were originally qualified. Shut out as they were from the public schools and universities, the dissenters had multiplied educational institutions of their own. Bolingbroke's idea was to poison dissent at the roots by taking the education of dissenters' children out of the hands of their parents, and handing it over to schoolmasters licensed by the bishops. The bill commonly known as the schism bill, was 
CHAP. brought before the house of commons by Bolingbroke's friend, XII. Sir William Wyndham. It was opposed by the whig leaders, Walpole, Stanhope, Lechmere, Jekyll, and King, but triumphantly carried by 237 to 126 votes. In the house of lords Bolingbroke himself took charge of the measure. The bill passed the lords on June 15 by the narrow majority of seventy-seven to seventy-two votes. Five bishops and twentyeight lay peers signed a protest against this act of persecution, among the bishops being William Wake, Bishop of Lincoln, the future Archbishop of Canterbury.

The position of Oxford during the progress of the bill was embarrassing enough. He had never repudiated his connexion with the dissenters; his wife and children attended a presbyterian meeting-house; he had posed as the dissenters' friend and employed De Foe as a pamphleteer to disarm their suspicions and reconcile them to his ministry. In De Foe's Secret History of the White Staff, written under his inspiration, and in the Considerations upon the Secret History of the White Staff, ascribed to the pen of Bolingbroke, the picture of the situation is sketched from both points of view. Each writer agrees that, as De Foe puts it, "the schism bill was a mine dug to blow up the White Staff". The design was effectual. Oxford had neither the courage to oppose the second reading nor the address to become an advocate of the bill. "He had not yet considered of it," he said; yet he laid claim afterwards to having taken "out all the malicious and persecuting part". "Your lordship," retorted the rival pamphleteer, "did not speak one word through the whole debate: you sat dumb and swelling with a discontent that visibly spake your affections to the bill." In the game of countercheck it was now Oxford's turn to move. The whig leaders in the house of lords, in conjunction with Nottingham, upon the representations of a considerable body of merchants, addressed themselves to a scrutiny of the circumstances under which the court of Madrid had substituted three explanatory articles in the Spanish treaty of commerce, injurious to British trade and practically nullifying those agreed upon at Utrecht. This inquiry was resisted by Bolingbroke, but supported by the treasurer, who threw out dark hints as to hidden motives. An address of the house of lords requested the queen to fur- 
nish the papers relating to the negotiation of the treaty of CHAP. commerce with Spain and the names of the persons advising it. These, it was notorious, were Bolingbroke and Arthur Moore. The lords ordered the appearance of the comınissioners of trade and plantations, of whom Moore was one, and of the directors of the South Sea Company. Evidence was extracted that in the original Asiento contract a share of profits was reserved by the Spanish court; and that this share had not been made over with the rest to the South Sea Company but retained nominally in the hands of the "treasury". The treasury, as was admitted by the secretary, William Lowndes, was ignorant of the matter, and scandal was loud that the money had been reserved for the pockets of Bolingbroke, Moore, and Lady Masham. The two allies, the secretary and the favourite, felt that it was time the inquiry should cease. On the day after the revelations of Lowndes, July 9, 1714 , the queen came down in person to prorogue parliament. Public opinion, however, had formed its own conclusions. Arthur Moore was expelled without a hearing from the South Sea Company, and observers noted that "the dragon," as Oxford was nicknamed, was "more cheerful than usual".

With Oxford at the head of affairs neither the secretary nor the favourite could venture to face another session of parliament. Only the queen's presence had saved Bolingbroke from plain language in the house of lords. The Hanover tory Anglesey had vowed a prosecution. For more than three weeks Anne was hesitating, while each section of the cabinet was predicting its own victory. On July 27 Oxford received his dismissal at the council table. The scene is described in the Secret History of the White Staff. He made the queen a long speech, warning her against his supplanters. He then turned upon them and fiercely accused them of corruption and embezzlement. It was suggested by his enemies that the queen never recovered the shock of this outburst. She herself, it was said, declared she should "not outlive it". Her resentment was feminine in its spite. She indulged it in a tirade to the lords, apparently after his withdrawal, against his idleness, his unintelligibleness, his untruthfulness, his unpunctualityall of which was probably true enough. "He often," she said, "came drunk. He behaved himself towards her with bad 
CHAP. manners, indecency, and disrespect." A council was held on XII. the spot for the reconstruction of the ministry, and sat, with no definite result, till two in the morning, the queen remaining to the end. Bolingbroke in his hour of triumph was yet foiled of his full reward. Oxford had some weeks previously in "a brief account," placed by him in the hands of the queen, charged him plainly with corruption. It was not possible that a politician sneered at as the "sharper secretary," whose name had been thrice associated with pecuniary scandals, -in the matter of the Quebec expedition, in that of the passports, and in the yet unsifted charges arising out of the Asiento,-should be placed in command of the treasury. But by putting the treasury in commission he could, as secretary, retain the general control of affairs and trust that time might rehabilitate him with the queen, or service done find its reward from her successor. Wyndham, as chancellor of the exchequer, was an appropriate head for this commission. As for the rest of the cabinet, Harcourt was to remain chancellor. The other names in men's mouths, Bromley, Mar, Ormonde, Buckingham, and Atterbury, were suspected Jacobites.

The health of the queen had never really recovered the attack of the winter. It had grown sensibly worse since the spring. She could no longer either walk or stand, yet she had eagerly watched every phase of the struggle in the cabinet. The final scene had been followed by a lethargy. The gout from which she was suffering was said to have attacked her brain. On the morning of Friday, July 30, she became sensible, but upon another relapse the council, which was sitting at their usual place of meeting, the cockpit at Whitehall, adjourned to Kensington. There the Dukes of Somerset and Argyll, who had received no summons and had long ceased to attend, presented themselves at the board and claimed their right as privy councillors to assist with their advice in the crisis. Bolingbroke was unprepared. His friends, Buckingham, the lord president, and Wyndham were not present. Shrewsbury, who was presiding, welcomed the two dukes whose appearance had probably been arranged with him, for his attitude during the recent conflict had been regarded with suspicion by Bolingbroke. Bolingbroke was conscious of defeat; but as, in the event of the queen's death without, a new 
appointment, Oxford would be the acting treasurer, he proposed recommending the nomination of Shrewsbury. Anne CHAP. had for an interval regained consciousness, and the council being admitted to her bedside, she gave Shrewsbury the white staff, bidding him use it for the good of her people. It was her last act as queen. On Sunday, August I, soon after seven in the morning, she passed away.

Meanwhile the council, now joined by Somers and other whigs, was dominated by the friends of the protestant succession, who began taking energetic steps to secure it. The heralds with a troop of the life-guards were held in readiness to proclaim the new king; the younger Craggs was dispatched to summon him; the Earl of Berkeley, a whig, was ordered to sea with a fleet; ten battalions were recalled from Flanders; the States-general were called upon to fulfil their guarantee of the succession; orders were sent to the lords-lieutenant of the counties to disarm all papists and non-jurors. The whigs had long been prepared to resist the pretender, should the ministry attempt a restoration. They had formed an association, collected arms, enlisted troops, and planned to seize the fortresses and outposts of the kingdom. They had badges of fusees in brass ready to distinguish their men. By this sudden change of fortune they were now able to control, in addition, the resources of the government itself. That Bolingbroke's desire was for a restoration his measures sufficiently indicate. The steadfastness of the pretender to the Roman faith had cooled him ; but, if we are to trust the reports of Iberville as to his confidential communications, in June he reverted to schemes for bringing him in without conditions. The murmurs of the dissenters over the schism act might break out into civil war. ${ }^{1}$ In that case, he believed that the friends of the Church, that is, the great majority of the nation, would welcome French troops and the pretender at their head. The officers of the army, who were chiefly whigs, were to be weeded out, and to paralyse their authority the mutiny act of 1712 abolished the penalty of death for disobedience. ${ }^{2}$ As it was, Bolingbroke bowed to necessity with an appearance of good v., 46x.

1 Daniel De Foe to the Earl of Oxford, June 23, 1714, Portland MSS.,

'See the Duke of Newenatle's speech on the mutiny bill of 1749, in Parl. Hist., xiv., $44^{2}$. 
CHAP. grace. He at times cherished a lingering hope, as did OxXII. ford, that the elector was not irreconcilable. At other times he was sunk in despair. "The grief of my soul," he said to Atterbury, "is this ; I see plainly that the tory party is gone."

Little needs to be added to what has already been said of the character of the queen. Attempts have recently been made to portray her as a woman of political independence and initiative. This was not the opinion of foreign observers, such as the Prussian resident Spanheim, of the English statesmen of the day, or of the women who knew her in private life. Mrs. Masham frequently deplored her want of "ready money," her slang term for independence. She had been brought up in High Church principles and she clung to them with the doggedness natural to her. But the Duchess of Marlborough, who was certainly a judge, if a severe one, of character, gauged her accurately when she told Lord Cowper, as he records in his diary, that the queen "has no original thoughts on any subject; is neither good nor bad but as put into; that she has much love and passion while pleased, with those who please". The question never was as to the queen's judgement of a situation but as to the person who had her ear. Her predilections were personal rather than political. Her dislike of the Hanover family was believed by Spanheim to date from a visit of the then electoral prince George Lewis, in 1680, which was not followed, as had been anticipated, by an offer of marriage. She entertained, before the rise of Mrs. Masham, a personal affection for the Marlboroughs and for Godolphin. At first she distrusted Somers because he was a whig, but he became a favourite with her because he was ceremonious. Sunderland, had he been a tory, would not have reconciled her to his overbearing manner. She disliked St. John because he was a profligate, and Wharton and Swift because she thought them profane. Cowper was a whig, yet he won her heart. Lastly, the reasons alleged by her for the dismissal of Sunderland, Godolphin, and Oxford were the same-they had been guilty of personal disrespect. In the indulgence of personal preferences she had overthrown the most brilliantly successful administration the country had ever seen. But her political sympathies, dependent though they were upon such predilections, were those of the bulk of the nation, and the sense of this brought her a popularity which has outlived the memory of her mistakes. 


\section{CHAPTER XIII.}

THE ACCESSION OF GEORGE I.

IMMEDIATELY after the queen's decease the council met. cHAP. Kreienberg, the new Hanoverian resident, produced a document XIII. signed by the elector in accordance with the regency act ${ }^{1}$ nominating the lords justices, who, with the great officers of state, were to act as regents till his arrival. Shrewsbury was the only minister upon the list, which contained the names of eighteen peers, most of them belonging to the whig party. The Hanover tories were represented by Anglesey, Abingdon, Nottingham, and Nottingham's son-in-law, the Duke of Roxburghe. Two omissions excited surprise. They were the names of Somers and Marlborough. Whether Somers was excepted on account of his health, or whether his receipt of secret service money was known to and misliked by the elector, remains a mystery. The exclusion of Marlborough provoked, as may be supposed, lively comment. Among the excluded, too, was his son-in-law, Sunderland.

Marlborough after the death of Godolphin on September 15 , 1712, had retired abroad. There were pending against him two actions-one for the $2 \frac{1}{2}$ per cent. which had been condemned by the house of commons; the other for loans to the amount of $£ 30,000$ advanced to workmen engaged upon Blenheim and really due from the treasury. It is said by Burnet ? that these prosecutions were set on foot to get him out of the country, and by Lockhart that Oxford agreed that they should be suspended if he would go. His actions shew that he was in grave doubts as to the future. In December, 1713, he, a

14 \& 5 Anne, co 20.

- Hanmer agreed with Burnet. Torcy's information was that his retirement was due to diagust at his treatment in England. Duke of Berwick to James, November 27, 1712, Stwart Papers, i., 254. 
CHAP. notorious niggard, offered the elector $£ 20,000$ as a loan to be XIII. used for political purposes in England. Such an offer from such a man is eloquent of his real wishes. Nevertheless, in the previous October he had dispatched a secret envoy to the exQueen Mary and his nephew Berwick to solicit through them the intervention in his favour of Louis XIV. with Oxford and the queen, "for he apprehends that young Puisieux (the new parliament) will sue him for an old debt which would quite beggar him ". 1 When in March, 1714 , the restoration of the pretender seemed probable, Marlborough went a step further. To insure against the contingency he applied to his nephew to obtain a free pardon. ${ }^{2}$ A fortnight before, the duke had received a commission from the elector and had written protesting that for his service he was "always ready to hazard both life and fortune". It is clear from the references to Oxford in Berwick's letters that the ministry in England were acquainted with the duke's correspondence with the pretender. Oxford is said by Bothmer to have acquired Marlborough's original letters and to have sent them to Hanover by Thomas Harley. But that the duke had not lost George's confidence is proved by the fact that the first document signed by George I. as king was his commission as captain-general of the forces, dated August 6-17, the day on which the news of the queen's death reached Hanover. Marlborough reached London on August 5 amid the plaudits of crowds. He retired to his mansion of Holywell House, near St. Alban's, and, perhaps doubtful of the intentions of George, announced his resolution to accept no place in the government.

The proclamation of the new king nowhere met with resistance. Politicians under suspicion of Jacobite leanings hastened to protest their loyalty. Oxford wrote professing his "zeal and devotion" as the promoter of the king's succession, ${ }^{3}$ and, in his own anticipation as in that of Swift," stood fair for a return to office. Pending the arrival of the new

1 Duke of Berwick to James III., October ro, 17ro, Stuart Papers, i., 278.

'Same to same, March $\times 3$, I7 I4, ibid., p. 308.

[The Earl of Oxford] to the King, August 6-17, x71 4 , Portland MSS., v., $4^{8} 4$. The Earl of Mar indulged like expectations. MSS. of Earl of Mar and Kellie, p. 505, Hist. MSS. Comm., rno4.

- [Jonathan Swift to the Farl of Oxford], August 15, 17 4 , Portland MSS., v., 488. 
king, Bothmer was the virtual ruler. The royal orders to the lords justices were communicated through him. It was known CHAP. that he had the king's ear, and aristocratic place-hunters crowded his house. A search was made for the late queen's will and for directions as to her burial; but, above all, the sealed packet, always carried about her, the existence of which was well known at court, excited the hopeful anticipations of Bolingbroke and the apprehension of the whigs. No will was discovered; only a few lines directing her body to be laid by the side of her husband's in Westminster Abbey. On the cover of the sealed packet was an order, written and signed by the queen, that it should be burnt unopened after her death. In the presence of Bothmer, Kreienberg, and a group of the regents, the Duke of Somerset threw the packet into the flames.

Neither at home nor abroad did circumstances seem to render necessary any haste on the part of the new king. Louis XIV. volunteered to Prior, the British envoy at Paris, his determination to maintain the conditions of the treaty of Utrecht. He promptly recognised the accession, and he stopped the pretender on his way from Bar-le-Duc to Paris. The pretender returned despondent to Lorraine and contented himself with issuing a manifesto protesting against the usurper and proving, with the aid of genealogical trees, that there were fifty-seven other persons with a better title to the throne. ${ }^{1}$

Bolingbroke's new tory foreign policy, an alliance with France, Spain, and Savoy, was, at the moment of the queen's death, being embodied in a treaty under negotiation by Prior at Paris. On a report to Hanover by the regents, a summary end was put to Prior's diplomacy. Dispatches addressed to Bolingbroke were ordered to be delivered by him to the regents, and the minister was compelled to wait outside the door of their council chamber with his papers. There, on August 3I, his dismissal was announced to him. The doors of his office were sealed up, that his papers might be examined at leisure. Pursuant to the provisions of the act of regency, parliament met in the afternoon of the day of the queen's death, but, Hanmer, the speaker, being in Wales, adjourned till August 5. With wise foresight the whigs defeated a tory proposal to increase the

'August 29, N.S., 1784, R. O., MS., State Papers, Domestic, George I., bundle $\mathrm{I}$, no. 37 . VOL. IX. 
CHAP. civil list from $£ 700,000$ to $£ \mathrm{I}, 000,000$, a step calculated to XIII. provoke public dissatisfaction. A juster propitiatory offering was made to the new sovereign. The arrears of $£ 65,022$ due to the Hanoverian troops in English pay had been withheld after the elector's refusal to allow them to follow the secession of the Duke of Ormonde. So potent was the fact of the succession, or so lively the hopes of the tories, that those who, like the Jacobite Shippen, had shortly before successfully opposed, now voted for the discharge of the debt. On the 3 Ist the king, accompanied by his son George, set out for England. With him were his ministers, Bernstorff and Görz, and a crowd of more than 100 courtiers and attendants. At fifty-four years of age his habits were formed. He lacked the cosmopolitan sympathies of his accomplished mother, the Electress Sophia, and desired to surround himself in his new country with his old associations.

George I., known in his electorate as George Lewis, had from early years been intimately associated with the group of statesmen, of whom William III. was the leading figure, hostile to the supremacy of France in Europe. Loyalty to the empire had been bequeathed to him by his father Ernest Augustus as the guiding principle of his continental policy. He had fought with distinction at the head of the Hanoverian life-guards under the imperial standards at the relief of Vienna and in the campaigns in Hungary that followed. In 1698 he succeeded his father, and as a soldier and a statesman held a leading place among the German princes. While his mother, the Electress Sophia, lived, the court at Herrenhausen, his favourite residence, maintained a dignified splendour relieved by the wits and philosophers whom her taste for literature and science assembled round her. He himself had no share in these pursuits. So deficient was he in intellectual curiosity that he never put himself to the trouble of acquiring the English language, which the old electress spoke to perfection. His interests lay in the business of administration and in the camp. His reputation as a soldier combined with his rank to place him at the head of the imperial forces in 1707-10, and the ineffectiveness of his campaigns, was imputed not to any incapacity on his part but to the defective organisation of the empire for war. A dark shadow was thrown upon his reputa- 
tion by his treatment of his wife Sophia Dorothea of Celle. CHAP. It was a mariage de convenance, reluctantly acquiesced in to inXIII. sure the succession to the patrimony of his father's elder brother, Duke George William of Celle. The liveliness of his wife's disposition, or the looseness of her morals, and her husband's neglect exposed her to compromising situations. The disappearance, as was afterwards known by assassination, though in the prince's absence and probably without his connivance, of her reputed lover, Count Königsmarck, was followed by her divorce in 1694. Thenceforth her life was passed in an enforced seclusion at Ahlden, in the duchy of Celle, where she lived until 1726. Two children had been the offspring of the marriage-George Augustus, the future King George II., born in 1683 , and Sophia Dorothea, afterwards married to Frederick William I. of Prussia. For George one experiment in matrimony had been enough. Thenceforth he was satisfied with the companionship of his mistresses, chief among them being the Baroness Kielmansegg, whom, in 1722, he created Countess of Darlington, and the Baroness von der Schulenburg, who, after being raised to the Irish peerage in 1716 as Duchess of Munster, was advanced in 1719 to be Duchess of Kendal. The latter became a political intermediary, attached by golden chains to Walpole's administration. Her rival drove a lucrative trade in vending small court favours.

In person George was of middle stature with a wide and somewhat heavy face and dull eyes. His nose was large and broad, his mouth coarse, the lines strongly marked. He was reserved in demeanour and awkward in bearing. Penetrated with pride of family, rather than with that of kingship, he hated ceremonial, in which he was conscious of his inability to shine, but cultivated the minor formalities. His understanding was plain but capable, and, if he was slow in decision, he was careful to master the materials put before him. For the fine arts, with the exception of music, he had no taste, and despair of royal patronage drove wits and men of letters into opposition. It is to his credit that his administration of the electorate had been enlightened and liberal. When Bolingbroke forecast a rising against the absolutist tendencies of the new monarch, he reckoned without taking into account the sterling common sense and natural moderation of George $\mathrm{I}$. 
CHAP. His only son, George Augustus, whom, on September 27, XIII. I 7 14, he created Prince of Wales, had, like his father, received a military training and his prowess at the battle of Oudenarde had been sung in Congreve's verse. His face bore none of the father's heavy look. He had a high forehead, quick and prominent blue eyes, and an aquiline nose, which gave him a commanding aspect. But his stature was low and his movements too lively to comport with English notions of dignity. Like his father, he was indifferent to the fine arts. But he had warmer feelings. He cherished the memory of his mother, and, perhaps on her account, was on bad terms with his father. Tenderly attached to his wife, he was yet not insensible to the charms of mistresses. The princess, who preferred the reality to the semblance of power, shut her eyes that she might retain her influence.

Caroline of Anspach, the Princess of Wales, was the most engaging personality of the new court. She had shared the literary and speculative tastes of the old electress, had corresponded with the German philosopher Leibniz and with the English philosopher Clarke. Her mind had travelled on the road of the low churchmen, but to a latitudinarianism beyond its terminus. Handsome in person, unaffected and conciliatory in manner, she did much to soften the asperity between the king and his son, whom she governed with an absolute, if unfelt, sway. She did what she could towards compensating for the dulness of a court in which the sovereign maintained, as far as possible, the simple habits of the Elector of Hanover. If the king remained a German, it was the cue of the prince and princess to be English. Conformable as George I. shewed himself to the spirit of the limited monarchy, in his own family he was a despot. After taking his seat in the house of lords, the prince remained excluded from business. $\mathrm{He}$ was not even allowed to bring up his son Frederick in English ways. While the prince's three daughters accompanied their mother, Frederick, then seven years of age, was left behind to be edu. cated at Hanover. Not until two years later did he receive an English tutor. Only after the accession of his father was he permitted to set foot in England.

On September 18, 1714, George landed at Greenwich. At the reception held by him on the following day, Sunday, 
in the ancient palace, Oxford, among others of the nobility, was admitted to kiss his hand. The king soon dashed his CHAP. hopes. The hand-kissing over, he regarded the earl with a glance of contempt and turned his back upon him without a word. Marlborough was graciously received in an audience of an hour's duration. Ormonde, having received the news of his dismissal, made no attempt to present himself. On Monday, October 1, George 1. made his state entry into the capital. The ministry, the formation of which the king entrusted to Townshend, belonged with the exception of Shrewsbury, who was retained as lord chamberlain, and Nottingham, who remained president of the council, to the militant whigs. Robert Walpole, whose sister Townshend had married, received the lucrative office of paymaster of the forces. General Stanhope was nominated with Townshend 'secretary of state, and led the house of commons; Cowper replaced Harcourt as chancellor; Wharton became a marquis and lord privy seal; the Duke of Somerset master of the horse, and the Duke of Devonshire lord steward. There was an end of the lords treasurers. The office had long been the ambition of the restless Halifax, who was, in his own estimate, scurvily rewarded for his constancy to the new dynasty by being placed at the head of a commission of the treasury and honoured with an earldom and the garter. Orford was reinstated first commissioner of the admiralty. Sunderland was nominated lord-lieutenant of Ireland. In Scotland the same policy was pursued. Mar was displaced by Montrose as secretary of state ; Argyll became commander-in-chief. Sir Constantine Phipps was removed from the Irish chancellorship and his place was taken by Alan Brodrick, an active whig, afterwards Viscount Midleton.

In talents and experience Stanhope stood foremost among the new men of the ministry. Townshend, the nominal chief, had by common agreement bungled the Barrier treaty. But his straightforward character and zeal for the protestant succession had commended him to Robethon, the king's confidential secretary, who introduced him to the notice of Bernstorff, the head of the king's Hanoverian councillors, and of Bothmer, the Hanoverian agent in London. His appointment was an example of the supremacy of Hanoverian over English opinion. 
CHAP. In matters of finance he leant upon Walpole, in foreign affairs XIII. upon Stanhope, to whom was allotted the southern department as secretary of state. Stanhope was one of the few soldiers who, like Marlborough, possessed the qualities of a statesman. He was described by Bonet, the Prussian resident, as the only Englishman whose talent was universal. He was a ready and incisive debater, an adroit diplomatist, an accomplished scholar, a linguist, a historical student, and, as the impeachment of Sacheverell proved, something of a constitutional lawyer. His intimacy with Charles VI., arising out of his campaigns in Spain, had given him a wider outlook upon continental politics than was possessed by any other Englishman, with the exception of Marlborough. He was the originator of the framework of alliances which insured Great Britain a leading part in the politics of Europe and received its complete expression in the Quadruple alliance of I7 I8. Whenever negotiations were vainly protracted and the end remained apparently remote, Stanhope became his own ambassador and transacted the business in person at Vienna, Paris, or Madrid. The accession of Nottingham to the new government was not without importance. With Nottingham in the cabinet, the useful election cry "the Church in danger" lost much of its point. With the exception of Nottingham, the tories stood aloof. Hanmer and Bromley both refused office in the treasury. Their party, they foresaw, would be reunited in opposition.

Behind the English ministry responsible to parliament worked a small group of advisers known as "the Hanoverian junta ". Of these the foremost was Bernstorff. His political sagacity and his knowledge of continental affairs were highly esteemed by the whig leaders, of whose party he was a consistent supporter. But his position as an irresponsible and unofficial adviser to the king necessarily induced a friction with the English system, which eventually resulted in his overthrow. Next to Bernstorff came Bothmer, since 1710 the elector's envoy in London. After the settlement of the government he devoted his attention to foreign affairs. Between him and Bernstorff there was a general co-operation; but Bernstorff represented the jealousy of Prussia which was traditional in the house of Hanover. This sentiment was naturally not shared by Stanhope, and at the time of the negotiation of an alliance 
with Prussia in 1719 a collision of policies took place, in which Bothmer, supporting Stanhope against Bernstorff, proved victorious. Behind these foremost figures stood that of Jean de Robethon, the king's private secretary, "among all the politicians of the day . . . the most closely trusted by both Hanoverian statesmen and English and foreign diplomatists". A refugee from France for religion, he had acquired his diplomatic training at the court of William III. He had kept alive the elector's languid interest in the prospect of a dignity which would certainly be burdensome and not improbably hazardous. But for Robethon, it has been said, the Elector of Hanover would never have become King of England.

It was inevitable that foreigners, who from long habit and the use of the same language had the ear of the king, should be exposed to the solicitations of aspirants for place and to the abuse of those of them who were unsuccessful. The act of settlement precluded the king from following the precedent of William III. and enriching his favourites with grants of crown lands. There was, therefore, the stronger temptation for them to acquire fortunes by the sale of their interest. Walpole, who is not credited with squeamishness, felt called upon to remonstrate with the king and was answered with the retort, "I suppose you are also paid for your recommendations!" Even Mustapha and Mahomet, the two pages of the backstairs, whom the king had brought with him as prisoners from his campaign against the Turks, were believed to share in the pickings of venality. The king himself, surrounded by his English ministers, was often like a man in a fog. Not one of them spoke German; not all of them spoke French. Walpole was reduced to Latin. To sit in council with them, as Queen Anne had done, was mere wearisomeness. He speedily came to prefer leaving them to discuss affairs without him, and receiving reports from one or other of them as to their conclusions. Such deliberations unattended by the sovereign had been common enough, and had gone by the name of sittings of the committee of council as distinguished from the sittings of the cabinet council itself. When the absence of the monarch became normal this distinction gradually disappeared, and the committee of council and the cabinet became a separate entity playing an increasingly important part in poli- 
CHAP. tical life. With this developement was associated that of the XIII. minister who replaced the sovereign as chairman. The term "prime minister" had, in the earlier arrangement, little significance, and occurs but rarely in the writings of Swift and his contemporary pamphleteers. But the necessity out of which it arose remained, and an office unknown to the written law has become an established pillar of the constitution. Ignorant alike of the usages and language of his new country, the king was often content to affix his signature to documents touching domestic affairs on which his mind was little more than a blank. In foreign questions, on the other hand, he took a lively interest. The dispatches of our ambassadors were ordered to be translated into French, the king tempering his command with the merciful concession that the French need not be of the best.

The coronation took place with the customary ceremonial, save for the absence of a queen, on October 20; Tenison, the Archbishop of Canterbury, officiating. Oxford, Bolingbroke, and Atterbury were present among the peers and did homage. In Bristol a High Church mob rioted in honour of Ormonde and Sacheverell, ${ }^{1}$ and the Jacobites excited insignificant disturbances in a few other towns. In Edinburgh, on the other hand, there were general expressions of loyalty. By the act of settlement the parliament in existence at the demise of the crown was to continue six months, unless first prorogued or dissolved by the new sovereign. On January 5, I 7 I 5, a proclamation of dissolution was issued, and ten days later a proclamation summoning a new one. This document was, in fact, a manifesto against the late ministers. Upon the suggestion, as was said, of Walpole, the catalogue of their misdeeds was supplemented by an exhortation to the electors to "have a particular regard to such as shewed a firmness to the protestant succession, when it was in danger". The reality of that danger had but recently been brought home to the minds of the electors by the pretender himself. His declaration of August 29, 17 14, had, in November, been distributed by him to the leading nobility. In this he had the imprudence to boast of the "good intentions towards us of the princess our.

${ }^{1}$ R. K. to Mademoiselle Dufresnoy, October 30, 1714, Stuart Papers, i., 335. 
sister" which "we could not for some time past well doubt". СHAP. The allusion to Oxford's ministry was unmistakeable, and the XIII. effect upon the public mind was to identify the tory party generally with the Jacobites. A fresh declaration by the pretender, dated January 3-14, claiming credit for constancy to Roman catholicism and giving the usual vague assurances as to the Church of England, shewed the only alternative to the reigning sovereign to be impracticable. The tide had turned. The whigs began the parliament of 1715 with a majority of 150 votes in the house of commons. Spencer Compton, a whig, and treasurer to the Prince of Wales, succeeded Hanmer as speaker. In Scotland the sixteen representative peers elected were all whigs but one.

In the debate on the address in the lords on March 22, the voice of Bolingbroke was heard for the last time. The whig Duke of Bolton had moved the address anticipating that, among other benefits to the nation, the king would "recover the reputation of this kingdom in foreign parts ". Bolingbroke took exception to the word "recover" as involving an aspersion on the memory of the late queen, and proposed "maintain" as an amendment. But the house of lords could no longer be reckoned upon for a tory majority. At the coronation, according to custom, some half-dozen supporters of the government had been created peers. Others turned their faces towards the rising sun, and Bolingbroke noted, to his disgust, that peers who had supported him when in power were now turned censors of his policy. The whigs mustered a majority of thirty-three. To Bolingbroke it was a warning of worse to come. What this was the address of the commons, draughted by Walpole, set forth in clear words. After deploring the terms of the peace, and the presumption of the pretender's declaration as to the intentions of the queen, it added: "It shall be our business to trace out those measures whereon he placed his hopes and to bring the authors of them to condign punishment ". The ministry, added Stanhope, had evidence, despite the disappearance of papers from the secretaries' offices, "that a certain English general had acted in concert with, if not received orders from, Marshal Villars". All the world knew the general to be Ormonde, and Bolingbroke to be the secretary who authorised his actions. Bolingbroke had enjoyed 
CHAP. the interval of a month in which to make away with incriminatXIII. ing documents before his dismissal on August $3 \mathrm{I}$.

On January 12/23, 17 15, the Earl of Stair arrived in Paris as envoy in succession to Prior. His mission was to insist on the strict execution of the ninth article of the treaty of Utrecht, providing for the demolition of Dunkirk. He was, at the same time, instructed by Stanhope to demand the surrender of all Prior's official papers. Prior made no resistance and his correspondence was found in apparently regular order. Lord Strafford, Bishop Robinson's colleague at Utrecht, who had returned to England, was summoned on the I Ith, without previous warning, before the privy council.1 Strafford's temper was arrogant and self-satisfied. A demand by the privy council in presence of the king that he should forthwith deliver his papers to the secretaries of state to be sealed up prior to examination, took him by surprise. He blustered and protested against being "so treated, like a criminal". But Townshend and Stanhope, allowing him no delay, he proceeded to his house and took possession of the documents. ${ }^{2}$ Bolingbroke had till now been playing the part of a man unconcerned. Up to the moment of his dismissal he had entertained the hope that the king might continue him in employment. The court of St. Germain's, however, was hoping to persuade him, through the mediation of the restless intriguer, Lady Jersey, to head the English Jacobites. ${ }^{3}$ But, after the seizure of Strafford's papers, he shewed himself seriously alarmed. ${ }^{4}$ He raved to Iberville of prison and the axe. He begged Torcy to warn Prior, who had been ordered home, to bring back to England nothing beyond formal dispatches, above all none of his private correspondence on the negotiations for peace. $\mathrm{He}$ was, as will have been seen, too late. Prior returned to London on March 25 and it was currently reported that he intended to reveal all he knew. The behaviour of the court party gave colour to this impression. He was "very graciously" received by the king. On the 26 th he was entertained at dinner by Town-

1 Portland MSS., v., 503, January Ir, I714-15.

2 The scene is graphically described by the Marquis of Wharton, ibid.

${ }^{3}$ The Duke of Berwick to James III., January 6, 1715, Stuart Papers, i., 342. 508.

- J[ohn] D[rummond] to the Earl of Oxford, March, 1715, Portland MSS., v., 
shend, Stanhope, and others of the ministry, and afterwards examined before a committee of the privy council. This was CHAP. enough for Bolingbroke. His nerves could not face danger. When Guiscard attacked Harley he was said to have lost his head and to have fled from the council-room in terror. ${ }^{1}$ On the 28th, he fled to France, disguised as courier to La Vigne, the official French messenger. A letter was shortly afterwards circulated, said to have been written by him to Lord Lansdown, justifying his flight on the ground that he had already been "prejudged, unheard, by the two houses of parliament".

On April 9 Stanhope moved for the appointment of a committee to inquire into the circumstances of the peace. A committee of secrecy, numbering twenty-one, was packed by the majority. Walpole was elected chairman, but being taken seriously ill on the following day, was replaced by Stanhope. He recovered, however, sufficiently to draught the committee's report, which he presented to the house of commons on June 9. The proceedings of the late ministers were incriminated, as involving betrayal of the nation's allies, a secret correspondence with the queen's enemies, among them the pretender, and a sacrifice to France of the interests and honour of their country. Fortunate it was for Oxford that the discovery was not made that the original overtures had been prompted by him." Behind the offers from France of April 22, 1711 , the committee had been unable to penetrate. At the conclusion of the second reading of the report, on the Ioth Walpole formally impeached Bolingbroke of high treason. The impeachment of Bolingbroke was at once followed by that of Oxford. Although the dependence of a secretary of state upon the chief of the ministry was less complete than at the present day, the lord treasurer had, as the committee of secrecy observed, "never failed to exert himself when he found it absolutely necessary ". On the other hand, mere acquiescence in the proceedings of Bolingbroke on the part of a man frequently subject to illness and known to be in no friendly intimacy with him would, it was obvious, render the charge of high treason difficult to prove. Only on the assurance of a

\footnotetext{
MSS., iv., 670.

'See — Harley's letter to [Abigail Harley], March 22, 1710-11, Portland

See above, p. 186.
} 
CHAP. member of the committee that there was also vivd voce eviXIII. dence to be produced against the earl, did the house unanimously agree to the impeachment. Still more difficult was it, but still more necessary, to frame a case against the Duke of Ormonde. The mob of London idolised him as a hero. "Ormonde and High Church" had become the cry in every tumult. He had lived in and near London since his dismissal in a style of ostentatious magnificence, had refused the favour of a private audience with the king, and had held meetings of tory peers, "especially the young people". What the purport of these meetings was may be inferred from a letter of the pretender to the Duke of Berwick of April 16, I7 I 5: "Orbec (Ormonde) is at the head of my affairs".2 He was at this very time advising on a rising in concert with the Scots." Ormonde was notoriously incautious, ${ }^{4}$ but an impeachment would be difficult to sustain.

There can be little doubt that, as was currently reported, ${ }^{5}$ ministers anticipated that both Oxford and Ormonde would relieve them from further trouble by following the example of Bolingbroke. The Jacobites in France expected nothing less of Oxford. ${ }^{6}$ But Oxford enjoyed that presence of mind which deserted Bolingbroke in emergencies. During the interval of a month between the vote for his impeachment on June Io and the exhibition of the articles against him in the lords on July 9 he led a tranquil life, occupying himself in the collection of precedents to prove that an absplute prerogative for making peace resided in the crown, and that in this matter ministers were not advisers but servants 7 The fourth impeachment was of Strafford. Bishop Robinson, who had since succeeded Compton in the see of London, had at Utrecht enjoyed the

1 Portland MSS., v., 508.

2 Stuart Papers, i., 358.

${ }^{3}$ Duke of Berwick to James, May 21, 17 5 , ibid., p. 365; cf. ibid., pp. 37r, $373,518$.

¿ See James to the Duke of Berwick, March I9, I715, ibid., i., 354; cf. ibid., pp. 355, 358. Same to same, November 24, 1715, ibid., p. 464 .

s "I believe it is the first instance of a vote to impeach a man of high treason and letting him have so much time before the charge is carried up to the house of lords. People say that it is that he may have time to run away, but knowing his innocence he is resolved to stand it." Viscountess Dupplin, Oxford's daughter, to her aunt, Abigail Harley, June 14, 1715, Portland MSS., v., 5 ro.

'The Duke of Barwick to James, April 14, 1715, Stuart Papers, i., 357. v., $5 \mathrm{Ir}$.

${ }^{7}$ See John Austin to the Earl of Oxford, June 20, 1715, Portland MSS., 
precedence in his capacity of lord privy seal. But Robinson CHAP. had acted with discretion and caution, and had not shared XIII. Bolingbroke's confidences with his colleague. Strafford, it was alleged, had advised the suspension of arms and the seizure by Ormonde of Ghent and Bruges. He had the faculty of provoking animosities. The argument in his favour, which was a just one and applied to the other defendants, that two successive parliaments had approved their action, was held insufficient to protect him. By the great majority of 268 to 100 the house of commons voted to impeach him, not of high treason but of the minor offence of high crimes and misdemeanours. Sixteen articles of impeachment were exhibited at the bar of the house of lords against Oxford. Before the vote passed for his committal to the Tower, he made a short speech in his own defence, throwing the responsibility for the peace upon the queen, and for the surrender to the French of Tournay, which had been agreed upon as one of the barrier towns, upon Bolingbroke. After the concession of some days' delay, on account of his health, the earl proceeded to the Tower on the 16 th, escorted by a crowd shouting "High Church and down with the Whigs," though a minority cried "Down with the Pretender".

If it was difficult to justify these proceedings in law, still less can be said for them as instances of political wisdom. It was at the existing juncture impolitic to increase by action savouring of persecution the growing antipathy to the new king. In no case could it have been easy for a foreigner to popularise himself in England. The personal disqualifications of George I. were partly natural, partly due to his habits, and to tradition. Reserved in his disposition, he rarely shewed himself to the people. Unacquainted with the language, he could not, like Charles II., chat with all comers. He made no progresses. He was thrifty in expenditure. And yet the personal loyalty of the people to the sovereign was ready, had it been encouraged, to manifest itself. Addison, in a graphic letter, ${ }^{1}$ describes the enthusiasm when in June, 1715, the king, by the advice of his ministers, shewed himself at a review. By the clergy in particular he was looked at askance. Conformity to Anglicanism being a condition of his accession, he was

'Blonheim MSS., p. 49, Hist. MSS. Comm., 8th Rep., App. 
CHAP. obliged every Sunday morning to attend a service of which he

XIII. did not understand a word, and at which his demeanour was censoriously scrutinised. The Prince of Wales was not more popular than the king, and the endeavour of the tories in the house of commons to appropriate $£ 100,000$ to the prince's use of the $£ 700,000$ voted for the civil list was but intended, by increasing his independence, to foment the notorious scandal of the dissension between father and son.

Behind the clergy and the populace stood the chiefs of the tory party, deeply irritated as well by their exclusion from office as by the impeachments of the late ministers. A general disquiet began to succeed the calm which had accepted the succession. During the summer of 17 I 5 riots were reported in Worcestershire and Staffordshire, and at Birmingham, Oxford, and London. They were promoted, declared the tories, by the whigs to complete the ruin of the tory party. ${ }^{1}$ The mob, at any rate, put into practice the tory ideals by pulling down the meeting-houses of the dissenters. The government met the disturbances by reviving the riot act of $1553,{ }^{2}$ and making the wrecking of registered places of worship a capital offence. ${ }^{3}$ The healths of Oxford and Ormonde were everywhere drunk. At Edinburgh juries refused to convict for toasting the pretender. Persons pilloried in London for disrespectful words of the king were protected from ill-usage by Jacobite mobs. In eight months, wrote Hoffmann, the Prussian resident, the cause of the Jacobites had made more advance than in the whole four years of the tory ministry. In this state of popular feeling, the whigs were unfortunate in losing in succession three of their leaders : Burnet, the champion of the whig Church militant, died on March 17 ; the Marquis of Wharton, their energetic whip, on April I2, and Halifax, the head of the treasury, who, despite his intriguing disposition, had retained the allegiance of the city financiers to the service of his party, on May 15. Somers, who was a member of the cabinet without office, had for some time past survived his strength and intellectual powers. In contrast with those who had so long engaged the public eye, the new men, Townshend, Walpole, and Stanhope, naturally appeared insignificant.

1 George Berkeley to Lord Percival, July 23, 1715, Egmont MSS., pp. 239, 247, Hist. MSS. Comm., 7th Rep., App.

I Mar., st. 2, c. $12 . \quad{ }^{3}$ I G. I., st. 2, c. 5. 


\section{CHAPTER XIV.}

THE REBELLION OF 1715.

THE pretender, meanwhile, remained in Lorraine, whence neither the addresses of parliament nor the rupture by TownsCHAP. hend of diplomatic relations with the duke succeeded in dislodging him. There he maintained a busy correspondence in view of approaching action in concert with his supporters in England and Scotland. A description of him has been left us by a devoted adherent, George Camocke, a cashiered English naval captain. He was "slender, tall, and comely ; the upper part of his face very much like Charles II.; the lower part very much like the late Queen Mother; sharp, quick, eye very perceptable (sic)". He cherished a belief in his divine right to the throne and shared with his followers the sanguine credulity which is the characteristic of exiles. As to his intentions in the event of his restoration, his education, his creed-" all the superstition of a Capuchin, no tincture of the religion of a prince," as Bolingbroke described it-his refusal to Bolingbroke to give "a direct promise of securing the Churches of England and Ireland," his substitution in Bolingbroke's draught proclamation of October 25, 1715, of "very ambiguous" terms in his pledges regarding the Church of England, and his deliberate excision of a pledge for the security of the Church of Ireland, all point to the same inference. His design was to follow in the footsteps of his father and by armed violence of foreign soldiers to extirpate protestantism from Great Britain. The Román catholic Jacobites looked for nothing less. In the palmy days of Bolingbroke's negotiations a large private meeting was held by them in London, admission to which was by tickets depicting a pope trampling down heresy. But we are not left to inferences. The appeals to the pope of the 
CHAP. queen mother, who had superintended her son's education, were XIV. in the name of " the re-establishment of both the catholic faith and our royal house"." In December, 1709, James himself wrote to Clement XI. begging him "to aid, with the other assistance his most Christian majesty will give us, in restoring us and with us restoring religion in our states".2 "The prosperity of the Roman Church," he declared to the pope, when actually in Scotland, "is inseparable from mine." 3

Between the courts of St. James and Versailles, despite official politeness, relations had become less friendly since the king's accession. There was an end of negotiations for alliance with England, defensive or otherwise. The attitude of the French in the matter of Dunkirk, which Steele had made notorious, was felt by the whigs as a galling grievance. The article of the treaty of Utrecht by which Louis XIV. pledged himself to fill up the harbour and demolish the fortifications was esteemed by the shipowners of London to be of capital importance. When the regency learnt in September, 17 I 4, that a fresh harbour was being made at Mardyck, connected by a canal with the town of Dunkirk and capable of sheltering ships in greater number and of larger tonnage than the harbour of Dunkirk, they ordered Prior to demand an explanation. The only answer vouchsafed was that the new works were for the drainage of the country, and that the king's pledges with regard to Dunkirk had been fulfilled. The Earl of Stair, who followed Prior in January, I 715 , had as major-general covered himself with glory at Malplaquet and was neither of rank nor temper to be browbeaten. He carried his protest direct to the king. Louis was able to reply with some truth, as has been seen, that "the delay used in the demolition of Dunkirk is to be attributed to Great Britain only"; but he promised its speedy completion and offered a voluntary pledge not to make any work of fortification upon the new canal.

Stair conceived his duties as ambassador to consist in something more than the dilatory exchange of ceremonious negotiations. He created a system of intelligence. He held open

1 Queen Mary to Pope Innocent XI., Feb. (?), 1689, Stuart Papers, i., 37.

2 December, 1709, ibid., p. 235 ; $c f$. letter to Don Annibal Albani of September 14, I709, ibid., p. 233.

${ }^{3}$ December 31, O.S., 1715, ibid., p. 484. 
house. He made himself intimate with the leaders of French CHAP. society, and even with some of the middle class. He disXIV. patched to England information as to the resources, political condition, and prospects of France, which vied in painstaking accuracy with the relazione of a medieval Venetian ambassador. When Ormonde and the pretender were about to start on their attempts against England and Scotland, Bolingbroke wrote: "Stair has his spyes in every quarter, and even att the first posts on the several roads "." Stair's spies became as great a nightmare to the Jacobites as Pitt's gold to the French of another generation. No sooner had Bolingbroke, early in April, set foot in Paris than Stair had him under observation. ${ }^{2}$ Bolingbroke had intended to write to the pretender, but his friends in England advised him to be quiet for their sake: he called upon Stair and protested his loyalty to King George. He even addressed a letter to Stanhope, to be transmitted by Stair, to the same purport. Nevertheless on April 29 he had an interview with Berwick, at which he "made very great protestations of true zeal for" James. He appears even to have imagined that the home government would accept his assurances, for he suggested "that the best way for him to doe essential service would be his returning to Alençon (England), by reason he could then not only advise but act ". It must be remembered that at this time the committee of secrecy was sitting and there was a belief among the tories, to which Shippen on June I gave utterance, that the "secret committee would end in smoke". He thought it prudent, therefore, to avoid the pretender, notwithstanding the prince's desire for an interview."

There was yet time for him to reconsider his position. Three months were to elapse before the articles of impeachment were carried to the lords on August 6. But the news from England and Scotland was of a general irritation against the government, and he saw that he had already gone so

1 October 24, 1715, Stuart Papers, i., 447. So also ibid., pp. 440, 44I, 502.

" Mr. Raucourt [the Chevalier] cannot be absent himself nor Sably [Bolingbroke] travel without the knowledge of Lord Stairs," Duke of Berwick to James III., May 6, 1715, ibid., p. 364.

Ibid., p. 362.

- James III. to the Duke of Berwick, May 3, 1715, ibid., pp. 361, 363 : James III. to Lord Bolingbroke, May 1, 17x5, ibid.. p. 36r.

VOL. IX. 
CHAP. far that, even if he were acquitted on the impeachment, he XIV. had no hope of office under George I. According to his own subsequent account in his letter to Wyndham, the news of his attainder was felt by him as a smart tingling in every vein. Whatever his anticipations may have been, the dates shew that it was not the passing of the act of attainder that drove him to take service with the pretender. His first interview with the pretender took place at Commercy about the second week of July.1 On July 12-23 he wrote his first letter as the Jacobite secretary of state. The articles of impeachment were exhibited on August 6-17 and the bill of attainder brought in on the same date.

Alike in England and France there was among the Jacobites an entire incapacity for organisation. Bolingbroke graphically describes the chaos reigning at Paris. It was an opera bouffe conspiracy in which, as he complained, the most secret arrangements were common gossip "among women over their tea". Between fear of Stair and friendliness towards the pretender the French ministers were tormented with indecision. They did what they dared. While they refused troops and officers, they winked at the equipment of a few vessels at Havre under a fictitious name and they promised a surreptitious provision of 10,000 stand of arms. Money they had none to give. ${ }^{2}$ But Louis XIV. wrote with his own hand to his grandson of Spain, in consequence of which Philip V. promised 400,000 crowns. These did not arrive until early in December. Alarmed by the dispatches of Stair and the prospect of an imminent attempt, the British ministry determined to appeal to parliament and through parliament to the country. On July 20 the king himself came down to the house of lords. In a speech read by the chancellor he exhorted the commons to take measures for the defence of the nation, "under a rebellion actually begun at home, and threatened with an invasion from abroad". The first half of this paragraph referred to armed Jacobite mobs which were then terrorising Staffordshire. Both commons and lords declared that "their lives and fortunes" were at the king's service. The commons unanimously

${ }^{1}$ See James III. to Lord Bolingbroke, July 2, 1715, Stuart Papers, i., 372, and July 19, ibid., p. 375 .

2 Ibid., i., 529, Bolingbroke's marginal note. 
requested the king to commission an additional number of CHAP. men-of-war and to augment his land forces for the defence of XIV. the country against the designs of "a popish pretender". This last recommendation was not only a blow to the Jacobites-it was a defiance of tory prejudices. The land forces had been a subject of fierce contention. The maintenance of a standing army at the command of the sovereign had, since the revolution, been declaimed against by tories as a constant menace to English liberty.

The process of "discarding" the army, introduced by St. John, was now reversed. Tory officers were dismissed, and all whigs who had been cashiered or placed on half pay were reinstated. Thirteen new regiments of dragoons and eight of foot, in all seven thousand men, were ordered to be raised, the selection of the officers to be left to the Dukes of Marlborough and Argyll, and Generals Stanhope and Cadogan. The militia was also embodied, and those half-pay officers for whom no employment could be found in the army were appointed to commands in it. These military preparations were supplemented by other vigorous measures. A bill was rapidly passed suspending for six months the Habeas Corpus act. A novel precaution was devised by Stanhope for Scotland. The crown officials were authorised by statute to call upon any persons having estates or residences in Scotland to appear at Edinburgh and to give bail for their good behaviour. This power subsequently exercised some effect in paralysing the recruitment of the rebel forces from the ranks of the Scottish country gentry, ${ }^{1}$ though it is said to have frightened many who knew that they were already compromised into secret rebellion. An act was also passed for "extinguishing the hopes of the pretended Prince of Wales and his open and secret abettors" by exacting from all persons in positions of authority, civil or military, three oaths, the first of allegiance to King George ; the second, of abjuration of papal authority; the third, of abjuration of the pretender, for whose seizure within the king's dominions $£ 100,000$ reward was offered." Addresses poured in upon

1 Hope-Fohnstone MSS., pp. 129, 130, 132, Hist. MSS. Comm., 15th Rep., pt. ix. Tindal's statement (Continuation of Rapin, 1763, vi., 431 n.) that only two persons out of sixty-two summoned sursendered themselves appears therefrom to be inaccurate.

I G. 1., st. 2, c. 13. 
CHAP. the king. The two houses of convocation invoked on behalf XIV. of the new dynasty "those principles of obedience and loyalty which the Church of England has always thought it her duty to profess". From the University of Oxford, where the enlistment of dragoons had been obstructed by the undergraduates, a proposed address was refused. ${ }^{1}$ The Bank of England and the City of London offered financial assistance.

Ormonde, meanwhile, had left London for a house near Richmond, where he busied himself in maturing preparations for risings in the north and west. His impeachment had been voted on June I 7 , yet a month later no further steps had been taken against him, and he seems to have fancied that his popularity might deter the government from carrying on the prosecution. $^{2}$ But the proceedings in parliament of July 20 convinced him that he would not be left at large. On that night he rode to the coast of Kent whence he embarked for France. His appearance in Paris not only created profound discouragement among the Jacobites; it sensibly damped the benevolent interest of the French government in their enterprises. He had been painted to them as a popular hero about to head a national uprising supported by, at least, a large part of the army. He arrived a fugitive, "accompanied only," as the whig papers maliciously recorded, "by one Renauld, a French papist, his confectioner". A month later, on September I, a still more stunning blow struck the Jacobites-the death of Louis XIV. The position of Philip, Duke of Orleans, the regent, was threatened by the ambition of Philip V. and by the Spanish party at the French court. He could not afford gratuitously to embark on a policy of adventure, and he shared the general belief that the whigs would gladly renew the war. As Duke of Orleans, he had written to his cousin King George congratulating him on his accession, and had followed up the overture by a friendly visit to London. In the event of the death of Louis XV. the struggle for the throne would come between him and Philip V., the next in blood. Stair

1 This was the official version and is published with the words of refusal by Boyer, Pol. State, August, I715, p. 121. Apparently the government, aware that the vote could not be carried in convocation, anticipated a defeat by refusing to receive any address. Joseph Addison to Abp. King, Oct. 4, 1715, Hist. MSS. Comm., and Rep., App., p. 249.

Earl of Mar to Charles Kinnaird, July 6, 1715, Stuart Papers, i., 525. 
received from his government instructions to convey to him its positive assurances that in that case it would insist on the CHAP. fulfilment of the renunciations which Philip V. had signed at the peace of Utrecht.

In the midst of these rebuffs of fate the only consolation of the Jacobites was in the occasional adhesion of important personages in England. Besides Shrewsbury and Peterborough, the Duke of Leeds, a vice-admiral, addressed " a loyall letter in general terms" to the pretender, which he followed up by a visit to Paris and by an interview with Bolingbroke, who summarily set him down as "a madman". Marlborough had early resumed an important part in the cabinet; but Bothmer's distrust appears to have rapidly extinguished his influence. The chagrin of disappointed ambition or a disbelief in the stability of the new dynasty, made him turn again to the pretender. In November, 1714, the duke intimated to his nephew Berwick his disgust with his position, and offered to resign if the pretender should approve. Berwick advised that he should do so, reconcile himself to the Duke of Ormonde, and influence the army. ${ }^{2}$ Marlborough then dropped the subject, but in April, I715, sent Berwick $£ 2,000$ for James's service. During the summer his correspondence with Berwick continued and towards the end of August he remitted a further contribution of $£ 2,000$. But he warily abstained from any plain declaration as to his intended course of action in the event of an attempted landing. ${ }^{3}$

After months of expectancy the rebellion first broke out in Scotland. John Erskine, sixth Earl of Mar, in 1705 had, as a whig, been a commissioner for the union with England and secretary of state for Scotland; in I 7 I I, as a tory, he had been secretary again; in 1714 he had been willing to continue in office as a whig. His services being dispensed with, he became a Jacobite. These tergiversations earned him with his country-

1 Bolingbroke to James III., August 7, N.S., 1715, Stwart Papers, i., 387; James III. to Bolingbroke, August 23, N.S., ibid., p. 400 ; James III. to Boling broke, August 28, ibid., p. 407 ; Bolingbroke to James III., August 30, ibid., p. 409.

2 Berwick to James III., November 25, I714, ibid., i., 335 ; same to same, December 30, 1714, ibid., p. 340: M. Belley [Berwick] to Mr. Trevers [Tunstall], ibid., p. 34I.

Berwick to James III., April 14,1715 , ibid., Pp. 357, 364, 365, 372, 383, 385 , $387,396,399,407,428$. 
CHAP. men the nickname of "Bobbing John". It is probable that his XIV. displacement from office was not without reason, for in 1713, when the pretender's prospects were brightest, he apparently indicated his adhesion. ${ }^{1}$ But he remained in London and his house became a meeting-place for Jacobite peers in which plans of insurrection were discussed. ${ }^{2}$ In August, 1715, he sent letters to the leading Jacobites inviting them to a hunting party at his castle of Kildrummy. Eight earls and a number of other noblemen re. Jonded to his summons on the 26th. The Dukes of Gordon and Atholl were represented by their sons. Mar unfolded a commission appointing him commanderin-chief of King James's forces. The assembled lords promised their support and on September 6, Mar, at the head of no more than sixty men, unfurled the pretender's flag at Braemar. It was noted by the highlanders as an ominous sign that the gilt ball on the flagstaff fell to the ground.

The moment was, indeed, discouraging. News had just arrived of the death of Louis XIV., and Mar was compelled to raise his followers' spirits by assurances of the regent's active intervention. At the pretender's court it had not yet been determined where Ormonde should land, and James himself was contemplating an attempt on Devonshire. That Mar's action was premature events clearly shewed. Berwick asserts in his Memoirs that it was due to a secret order from James, unknown to his advisers. ${ }^{3}$ At the disposal of the government there were some 8,000 veteran troops in Great Britain. Few of these were in Scotland, for an attempt by Ormonde was looked for in the west. The progress of the rebels was, therefore, easy. The clan MacIntosh was the first to respond to the summons. They occupied Inverness without resistance. James III. was proclaimed by the Earl of Panmure at. Brechin, by the Earl Marischal at Aberdeen, by the Marquis of Huntly at Gordon, by Claverhouse's brother at Dundee. An attack upon Fort William failed. An attempt upon the castle of Edinburgh, a daring project, the

${ }^{1}$ Stuart Papers, i., 278, October ro, 1713. IIbid., p. 525, July 6-17, 1715.

'The probabilities of this are discussed by Professor Michael (Englische Geschichte im 18. Fahrhundert, i., 525 n.) and decided in the affirmative. C $f$. also Stuart Papers, i., 379 and 442. Mar's emphatic assertion in January, I7 I7, written at Avignon when at the pretender's court, that he followed "instructions" in rising confirms Professor Michael's view. Stuart Papers, iii., 487. - 
success of which would have given an immense impetus to the rebellion, was betrayed (September 9). The government, CHAP. embarrassed for want of troops, could do no more than send General Whetham with 1,300 men to occupy Stirling, and thence watch the fords of the Forth. But it availed itself of ' the suspension of Habeas Corpus to effect numerous arrests of leading Jacobites, among them the Earls of Hume, Wigtoun, and Kinnoull, and the yet better-known Lockhart of Carnwath, the historian of Jacobite intrigue. On the other hand, many lowland peers offered their services to King George. In the extreme north, the loyal clans were preparing a diversion. The Duke of Argyll, commander-in-chief in Scotland, the Earl of Sutherland and Lord Lovat ${ }^{1}$ left London in the second week of September to summon their vassals. The Duke of Atholl's attitude was doubtful. His action was of the first importance. He could have "done more in one day in raising the highlands than Mar in two months". It had been proposed to commission him as the pretender's generalissimo; but as he was jealous of his neighbour Mar, and Mar of him, the earl had stipulated that the duke should not be allowed to act independently of himself. ${ }^{2}$ Atholl elected to supply the government with information as to the rebels' movements, and though his son, the Marquis of Tullibardine, joined Mar, he himself declared for the king and offered to co-operate with Sutherland. ${ }^{3}$

The first success of the rebels was the occupation of Perth on September 14. This was a gain of considerable strategic importance. With Perth in his hands Mar was encamped in the heart of Scotland within reach of reinforcements from the highlands. On the other hand, no advance south of the Forth could be made by the rebels while Stirling held out against them. Mar himself entered Perth on September 28, with a force variously estimated at from 3,000 to 5,000 men. On the following day Argyll took over the command at Stirling with no more than 1,300 men under him. His clan, the Campbells, dared not march to his support for fear of invasion by their

'Sutherland to Lovat, November 11-22, 1715, Stwart Papers, i., 461.

Mar to Charlea Kinnaird, July 6, x715, ibid., p. 525.

September 7, 1725, Atholl MSS., Pp. 67, 68; the Duke of Atholl to the Earl of Sutherland, October 9, 1715, ibid., p. 68. 
CHAP. hostile neighbours, and some time must elapse before reinforceXIV. ments could reach him from England or Ireland. Yet Mar, though at the head of men who, he knew, would not long keep the field, remained week after week inactive.

In London the soul of the government was Stanhope. He, rather than Marlborough, decided upon the military measures to be taken. By his side were Townshend, who toiled with indefatigable energy, William Pulteney, as secretary at war, and Walpole who, during Stanhope's absence at Vienna, had so rapidly improved his position that at the opening of the parliamentary session in March, 1715, Lady Mary Wortley Montagu wrote that he was "already looked upon as chief minister". On October I $\mathrm{I}$, in place of the Earl of Carlisle, who had succeeded Halifax, he was appointed first lord of the treasury and chancellor of the exchequer, the latter a post increased in importance by the suppression of the treasurership. He now took a seat in the cabinet. His family connexion with Townshend, his knowledge of affairs, and his mastery of finance all contributed to his influence. ${ }^{1}$

Towards the end of September, Stair sent news from Paris that a rising had been planned for the west of England. Bristol was to be seized. Sir John Maclean, who had disclosed to Nottingham the Scottish plot of 1706 , was now an active agent of Ormonde, the intended head of the insurgents. He betrayed all their designs. ${ }^{2}$. On September 2 I Lord Lansdown, a tory poet, who, as George Granville, had displaced Walpole as secretary at war, and Lord Dupplin, Harley's son-in-law, were arrested, and a warrant was issued for the apprehension of the Earl of Jersey. On the same day Stanhope obtained the leave of the house of commons to arrest six of its members, of whom Sir William Wyndham and Thomas Forster, junior, were well-

1 "The greatest parliament man and statesman on the court side," J. Menzies to [L. Inese], April 2, 1716, Stuart Papers, ii., 83.

2 This was probably not the head of the clan Maclean of the same name and title. That he was a considerable person appears from the circumstance that his return to Scotland was a question discussed by the queen and the secretary of state, Lord Mar (Mar MSS., p. 320, November 14, I706). Sir John Maclean, head of that clan, signed the letter of adhesion to Mar (ibid., p. 509, September 2, 1714), fought for James at the battle of Sheriffmuir on November 13, 1715, and died at Gordon Castle on March 12, 17 I6 (W. Macfarlane, Genealogical Collections, i., I4I, Scottish History Society, vol. xxxiii., 1900). But the treachery of Maclean, Ormonde's agent or secretary, was known to Bolingbroke as early as October 24-November 4 (Stuart Papers, i., 452). 
known as Jacobites. Wyndham escaped from custody, but a reward of $£_{1,000}$ having been offered for his capture, he surCHAP. rendered a few days later. After eight months' confinement in the Tower, he was liberated without being brought to trial. With the information in its possession the government was able to check the conspirators at every point. Bristol was securely garrisoned. Troops were transported from the Channel and Scilly islands to Southampton and Plymouth. Oxford was a notorious nest of disloyalty. The university had flung down a defiance to the government by the election, after Ormonde's flight, of his brother, the Earl of Arran, as chancellor on September 10. A number of dismissed Jacobite officers had sought a haven in society so congenial, and from Oxford maintained a correspondence with their confederates in Bath and Bristol. On October 5 General Pepper, a comrade-in-arms of Stanhope at Brihuega, at the head of a couple of dragoon regiments, occupied Oxford by a surprise march, arrested ten of the conspirators and secured further information of their plans. At Bath three cannon and other warlike stores were seized. So completely were the conspirators' plans frustrated that at the end of October Stanhope wrote to Stair that an attempt upon England by Ormonde and his new master would be welcome to the government.

The events in England filled both Bolingbroke and the pretender with dejection. In France the prospect was not more cheering. When, at the close of September, Byng, at the head of a squadron, appeared before Havre, and pointed out, upon Stair's information, the vessels filled with munitions for the pretender, the regent ordered them to be unloaded into the royal magazines. The letter of September 9-20, in which Bolingbroke conveyed this information to Mar, also contained other bad news. The hostility of Charles XII. to George I., on account of their conflicting claims to Bremen and Verden, had led to negotiations for the support of Swedish troops. Twelve battalions, under a Scottish major-general, Hamilton, were in August in the neighbourhood of Gothenburg ready for transport to Newcastle. ${ }^{1}$ Charles now refused his assistance. In the belief of James and Bolingbroke the time had now arrived for action in unison with the expected rising in the 
CHAP. west. On October 17-28, James left Lorraine and, travelling XIV. secretly, reached St. Malo on the night of October 28 - November 8. There he met Ormonde. The duke had sailed a few days before with fifty men and officers of Lord Nugent's Irish regiment of cavalry in the French service, had anchored in Torbay, had fired signal guns which met with no response, and together with a refugee from the shore had made his way back without attempting a landing. Dispatches which arrived about the same time from Mar, giving a favourable account of the progress of the rebellion in Scotland, and the news of risings in the north of England and the south-west of Scotland, decided James not to court in person another rebuff in Devonshire. Ormonde, whose presence in Scotland would have excited the jealousy of Mar, might try again in Lancashire, unless the wind should compel him to put into Cornwall. James did not conceal the poor opinion he entertained of Ormonde's capacity and spirit, ${ }^{1}$ and was plainly glad to be rid of him.

Among the members of parliament whose arrest had been ordered on September 21 was Thomas Forster, junior, of Adderstone, Northumberland. $\mathrm{He}$ was the eldest son of a considerable landowner and sat for the county. Resolving to anticipate arrest, Forster on October 6 appeared in arms at Greenrig, near Rothbury, in company with the young Earl of Derwentwater, against whom a warrant was also out. Marching through Rothbury they were joined by Lord Widdrington, and then numbered ninety horse. Forster was proclaimed ${ }^{2}$ general, not because he had the least military experience, but because he was the only protestant among the leaders. After spending some days in enlisting recruits, they marched with 300 horse upon Newcastle, where the colliers were reputed to be of Jacobite sympathies. The walls were in disrepair, but the government had thrown a small body of troops into the town. The rebels, therefore, prudently determined to effect a junction with Lord Kenmure, who on October I2, at the head of 200 horsemen, and in company of the Earls of Nithsdale, Wintoun, and Carnwath, had proclaimed the pretender at Moffat.

${ }^{2}$ James III. to Lord [Bolingbroke], November 24, 1715, N.S., Stuart Papers, i., $46 \mathrm{r}, 464,467$.

2 His commission from the pretender is dated "Commercy, October, 24, 1715 ". Ibid., p. 448. 
Mar, instead of marching upon Stirling, where he could have overwhelmed the forces of Argyll, detached a force to the CHAP. west to seize the duke's castle of Inverary, and sent 2,000 men across the Firth of Forth with the object, to use his own expression, to enclose the duke " in a hose net". This latter force, under Brigadier MacIntosh, a veteran officer, succeeded for the most part in evading three English men-of-war which were guarding the channel, and, to the number of 1,600 , reached the mainland at Aberlady and North Berwick. Edinburgh appeared within their grasp. But MacIntosh, judging his force insufficient for a successful assault, first occupied the citadel of Leith. This he presently evacuated and took upan intrenched position at Seton Palace, seven miles from the capital, to resist the reported advance of Argyll. Argyll's march from Stirling and the subtraction of 600 men from its slender garrison offered Mar his opportunity. He advanced at the head of 4,000 men and reached Dunblane. Argyll promptly turned back to the support of General Whetham, whom he had left in command. Within striking distance of the royalist camp and with Edinburgh as the prize of a successful action, Mar retired to his old position at Perth. MacIntosh was then free to advance southwards. On October 22 he effected a junction at Kelso with the rebels of Northumberland and south-west Scotland, who had united their forces at Rothbury. The total body numbered 1,400 horse and 600 foot.

It is remarkable that when England became the scene of rebellion Marlborough, as captain-general, was not entrusted with the command. It may be that the omniscient Stair had detected his correspondence with Berwick. The arrest on September 2 of Captain Paul of his own regiment, the first foot guards (the grenadiers)-which had but recently shewn signs of disaffection-on a charge, subsequently disproved, of enlisting men in the pretender's service, can scarcely have added to the confidence of the government in the duke. The commander to whom Stanhope entrusted the safety of England was General George Carpenter, who had been his second in command at the battles of Almenara and Saragossa and at the defence of Brihuega. Among the Northumbrian rebels there was a conflict of counsels. The English disliked the prospect of advancing into the interior of Scotland, and the 
CHAP. Scots refused to commit themselves to indefinite adventures XIV. in England. After much wrangling, they decided by way of compromise to march south-westwards upon Dumfries. On their way from Jedburgh they were overtaken by Carpenter at the head of 900 dragoons ; but two of his regiments were raw levies and "his horses and men were so fatigued and harrast," says an anonymous writer in the Scottish army, "that we could not well have failed of routing them ". The opportunity was lost, and, Carpenter being in no condition to attack, they continued their march. At Langholm news was brought that Dumfries had been garrisoned by 1,300 men, rendering an assault upon it impracticable. Upon this fresh altercations broke out. Widdrington produced letters assuring them that, in the event of their appearing in Lancashire, 20,000 men would take arms. Five hundred highlanders ${ }^{2}$ flatly refused to accompany them and marched away to the north.

On November 1 the rebels entered England, and at Brampton, in Cumberland, Forster produced commissions which had been dispatched by the pretender to Mar, nominating him major-general commanding in chief, pending the arrival of Ormonde. At this time they were reported to number " $1, \infty 00$ or 1,200 foot and 600 horse ".3 At Penrith they found themselves opposed by a body of militia under Lord Lonsdale, variously estimated at from 6,000 to 10,000 men. ${ }^{4}$ These, says the writer already quoted, "fled like sheep before us, and by their expressions did not seem to wish ill to our cause". If this be so there may have been good reason, not mere remissness on the part of the war office, for the fact that they were mostly armed only with pikes. ${ }^{5}$ The advance of the rebels through Westmorland was slow, and so far were the people from flocking to their colours that they found themselves "not joyned by above five or six gentlemen and these papists, which

1 R. O., MS., State Papers, George I., Domestic, bundle 4, no. 47.

2 "Three hundred of our best highlanders left us" (ibid.). They went off in detached parties, so that the number adopted in the text from Tindal is perhaps accurate. Boyer gives 300.

s Lord Lonsdale to [Lord Carlisle], October 29, 1715, Carlisle MSS., p. 18, Hist. MSS. Comm., Ir97.

4 Lord Stanhope (i., 250) says 10,000; but the Scottish writer already quoted, who was present and apparently a military man, says $6,000-7,000$. Tindal says 12,000 (Cont., r763, vi., 457).

- Lord Lonsdale to [Lord Carlisle], cited above. 
did us no great service". At Preston they received their first important accession of strength, being reinforced by 200 Roman CHAP. catholic gentlemen with their tenantry.1. The movement was beginning to wear the ominous aspect of a religious crusade. Carpenter had, in the meanwhile, by the ruse of a letter written to be intercepted, been diverted to relieve an imaginary attack upon Newcastle. ${ }^{2}$ Owing, however, to the riots of the previous year, a number of troops had been distributed through Lancashire, which on November II were assembled by General Wills, another of Stanhope's officers, at a rendezvous at Wigan.

The next morning Wills, with six regiments of cavalry and a regiment of foot, advanced upon Preston. Upon the Wigan side Preston was protected by the Ribble, across which was a bridge affording an easy defence. But the 200 or 300 men posted here retired without resistance. ${ }^{3}$ Defensible though the approaches to the town were, they had not been fortified. Only four barricades, three of them furnished each with two pieces of cannon, had been construicted at the ends of the streets. Unsuccessful assaults were delivered against these and at nightfall the assailants retired after a skirmish of cavalry, in which the rebels claimed the advantage. But early on the 13 th Carpenter arrived on the north side of the town with three regiments of dragoons. Forster, disheartened, without consulting any of his principal officers except Widdrington, sent Colonel Oxburgh to treat for an armistice. The news infuriated many of the insurgents. They begged to be allowed to attack the enemy whom they believed to have no heart to resist, "being mostly raw and new levied troops". Forster's life was threatened. "The poor man had little to say but that he was not fit for the post he was in,

I R. O., MS., State Papers, Dom., George I., bundle 4, no. 47. "Two hundred well armed but all papists joined us." Lord Stanhope says 1,200 (i., 251), but admits on p. 255 that only 1,400 prisoners were taken at Preston altogether, and no more than seventeen bad been killed.

Hoffmann, November 19, 1715; Michael, p. 550. I have nowhere else found an explanation of the desistance of Carpenter from the pursuit.

${ }^{3}$ The anonymous writer, who believes that Forster betrayed them, says upon orders from bim.

- Carpenter, who was jealous of Wills and quarrelled with him, censured him for "I rash attack, bighly blameable," made to anticipate his superior's arrival. Carpenter to - November 23, 1715, Townshend MSS., p. 170, Hist. MSS. Comm., 1887. 
CHAP. was sorry for what he had done, and wept like a child." 1 XIV. Wills at first refused to treat with rebels, but under pressure consented to hold his prisoners at the disposal of the government. $^{2}$ It was an ignominious surrender. Seven peers and I,489 men yielded to a force not much superior to themselves and as fighting units probably of inferior value. ${ }^{3} \mathrm{~A}$ number of ill-armed Lancashire peasants, who had crowded to join them, are generally supposed to have escaped. The event of Preston was a revelation of the absence of enthusiasm for the pretender in England. In the most disaffected county there had been no general rising and a significant aloofness on the part of the protestants. The prisoners were distributed, to the number of $1,292,4$ among the jails of Lancaster, Wigan, Chester, Preston, and Liverpool. ${ }^{5}$ Four officers in receipt of half-pay were tried by court-martial and shot as deserters. On December 9 a procession of about I 50 of those foremost in rank, with seventy of their attendants, entered London, each man on horseback, his arms tied with

1 State Papers, cited above, p. 253, n. I.

2 Ibid. According to this paper the rebels were surprised at break of day of November $\mathrm{r}_{4}$, after Lord Derwentwater and Colonel MacIntosh had been delivered up as hostages for the completion of the capitulation. The official version has it that the armistice ended, as agreed, at break of day and that the rebels then voluntarily submitted. The terms of surrender subsequently had a controversial importance.

3 According to Berwick the joint forces of Wills and Carpenter numbered no more than 1,000 men, and the official account published by Boyer speaks of "so great a body of desperate men ... reduced by such a'handful of troops ". But Professor Michael has shewn that, estimated by the regiments present and the average strength of regiments at that date, they were probably about 2,000 men. The plan of the action given in Boyer also represents horse and foot militia on the south and foot militia intrenched outside the Ribble bridge, but these were probably little to be depended upon, or perhaps they came up after the action, for no mention is made of them. On the other hand, Forster had six cannon, though no expert gunners, and the royal forces none.

Fifth Report of the Deputy Keeper of Public Records (1844), App., ii., r67. Professor Michael, without citing his authority, says (p. 554) that Wills released a number of the common prisoners. If so, the discrepancies in the estimates of the numbers of the rebel forces, which were reported before the action at 4,000 to 5,000-beyond question an exaggeration-may be partly accounted for. The 1,400 odd reported as captured were those held prisoners only. It is likely enough that, as Professor Michael states, Wills had not force enough to guard all and took upon himself to release many; but as this was without orders, and a release of rebels taken with arms in their hands, he perhaps refrained from reporting it.

R. O., MS., Domestic Entry Books, George I., vii., 132-34. 
ropes, the horses led by soldiers. ${ }^{1}$ In the hour of whig triumph CHAP. the Jacobite mob had disappeared. The prisoners were reXIV. ceived by the populace with shouts of derision, and in mockery of the pretender the file was preceded by a man with a warmingpan. Forster was committed to Newgate : ten of the first in rank to the Tower.

On November 13, the day of Forster's capitulation at Preston, a less decisive action was fought between Mar and Argyll. Mar had remained inactive at Perth, awaiting the reinforcements which continued to filter in. By the early part of November he had drawn together about 10,000 men. Argyll, on the other hand, had been very inadequately reinforced by three additional dragoon regiments and four regiments of foot. By the middle of the month he mustered at Stirling no more than 3,300 men. On the roth Mar left Perth with the intention of advancing directly upon Stirling and forcing his way past Argyll to join the rebels in Lancashire. On the I 2 th he dispatched General Gordon with a detachment to occupy the strategically important position of Dunblane, four miles north of Stirling. Argyll, however, who had learnt the art of war in Marlborough's school, had been too quick for him. Hearing on the I I th of Mar's advance, he strengthened himself by withdrawing the garrisons from the neighbouring towns of Glasgow, Kilsyth, Falkirk, and Linlithgow, and, instead of waiting to be attacked, marched on the following day with his whole force to Dunblane. He selected as the place to give battle an undulating highland, a mile and a half to the north-east of Dunblane, called Sheriff Muir, well adapted by the hardness of the frost for the movements of cavalry, in which arm he was far superior. Both armies bivouacked on the night of the 12 th in the open fields within two miles of one another. Early on the morning of Sunday, the 13th, Mar drew up his forces in two lines-in the centre the infantry, on the wings the horse. A group of nobles were in the middle of the second line-the Earls of Seaforth and Panmure, Lord Drummond, eldest son of the titular Duke of Perth, the author of the attempt on the castle of Edinburgh, and the Marquises of Huntly and Tullibardine, eldest sons of the Dukes of Gordon and Atholl, and others.

A movement of Mar towards the higher ground, before the

'John Drummond to [Lord Hariey], Porlland MSS., v., 520, 521. 
CHAP. royal army was fully deployed, led Argyll, who had planned to XIV. meet a frontal attack, to believe that the main onset of the enemy was to be directed against his right flank. He accordingly began to alter the disposition of his forces. Like Mar's, they were ordered to form in two lines. In the centre were six battalions of veteran infantry under General Wightman; behind them two more battalions, supported by two regiments of dragoons; on each wing were three squadrons. Argyll was on the right; Whetham, the second in command, on the left wing. ${ }^{1}$ The royal forces numbered 3,300 men, of whom some were militia, and 150 gentlemen volunteers who were mounted. ${ }^{2}$ Argyll, in his dispatch, estimated the rebels at about 9,000 men, which appears to have been a fairly accurate computation. The duke, as he advanced towards the rebels, extended his right wing beyond their left, which was weak in cavalry, by throwing out his "grey dragoons" (the "Scots Greys") so as to threaten a turning movement. The rebel right wing was similarly extended beyond the royalist left, the configuration of the ground having hidden the movements of either from the other.

The higher ground towards which the rebel left was advancing was first occupied by the duke, and before the rebel ranks, somewhat disordered by their haste, could be reformed, the battle opened with a discharge of musketry from their centre. This being shortly afterwards followed by a charge of the highlanders upon the duke's right, Evans's dragoons, ${ }^{3}$ which were posted here, were thrown into a momentary confusion. The position was, however, retrieved by a flank attack by the Scots Greys, who rode down the lighter Scottish cavalry and hurled themselves upon the infantry, whom they threw into a confusion which speedily became a rout. For three miles the dragoons, under Argyll's lead, maintained a close pursuit. The duke, whom the intervening rise had from the outset cut off from the sight of his left wing, was persuaded that he was dispersing the main body of the enemy. $\mathrm{He}$ refused for a while to pay attention to warnings from Wight-

1 R. O., MS., State Paper, Dom., G. I., Scotland, bundle ro, no. 48.

"Ibid., no. 46a, "Account of the battle of Dunblain from a gentleman of Stirling" (apparently one of the volunteers), November 15, 1715.

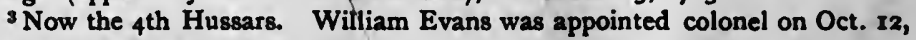
1713, English Army Lists, vi., 3. 
man, who was following him with three of the battalions CHAP. of foot under his command, that his left wing had vanished. XIV.

When, at last, he was prevailed upon to retrace his steps, he found a body of the enemy in possession of the top of the hill in his rear, shewing signs of a disposition to attack. His own force, probably numbered no more than 1,500 , while that of the Scots was, by his estimate, 4,000 men. His troops were too fatigued to attack. He had as yet no knowledge of the fate of the rest of his army, and he encamped for the night on the ground held by him in the morning. Had Mar seized his opportunity, he might, in Wightman's opinion, have annihilated the small force. His characteristic irresolution prevailed. He rested on his arms and during the night, on pretext of want of provisions, tamely marched his troops back to Ardoch, their former camping ground.

The left wing of the royal army was still in the act of changing its disposition to meet the anticipated turning movement of the enemy when the main body of the Scots advanced to the attack. The king's troops received the charge with a volley of musketry, but were greatly outnumbered and were borne down by the masses of the enemy. Many of the militia also, whether from disaffection or want of discipline, dropped their arms. Falling hastily back, they threw the supporting dragoons into confusion, and in seven or eight minutes, according to Mar's boast, " neither the form of a squadron nor battalion" remained. The rout, however, was to some degree checked by the courageous conduct of the cavalry under the immediate command of Whetham.1 They stopped the fugitives at a pass on the road to Stirling and afforded them a cover for reforming their ranks. The artillery was thereby saved, and

'Lord Stanhope speaks of Whetham as a "terrified general," and is justified by the account of Tindal, perhaps founded upon Campbell's Life of Argyll (1745). But Campbell was anxious to extenuate his hero's blunders, and in other particulars is at variance with eye-witnesses of the battle (see C. S. Terry. Chevalier de St. George, 1901, p. 290, n. 2). Argyll, in his first official dispatch, attached no blame to Whetbam; but stories to Whetham's discredit had reached the duke, and on November 15 be writes to the ministry: "I have enquired exactly into this matter that I might be able to do justice to Mr. Whetham, who by experience $I$ know to be ... a good officer and 28 brave a man as any serves His Majesty". R. O., MS., State Papers, Dom., G. I., Scotld., bundle ro, no. 51. On December 6 he repeats, in a dispatch to Townshend, who had heard similar rumours : "I do most aincerely think that what happened was Mr. VOL. IX. 
CHAP. Whetham began to prepare for the defence of the pass against XIV. the main army, in the belief that the whole of Argyll's command had been annihilated, as he heard from a number of professing eye-witnesses. The successful right wing of the rebels, however, had been drawn off from the pursuit and an aide-de-camp from the duke arrived in the afternoon to acquaint Whetham with the real position, and to order his return to Dunblane, about three miles distant. At seven in the evening the royal army was reunited on the field of battle. Both sides claimed a victory. Argyll lost 600 killed, wounded, and prisoners ; the rebels considerably more. ${ }^{1}$ The substantial results remained with the royal army. The advance of the rebels southwards was checked. The indecision of many a highland chief ripened, as in the case of Lords Huntly and Seaforth, into a prudent resolve to submit on terms, or, as in the case of Sinclair and Lord Rollo, to go over to the winning side.

Whetham's misfortune and not his fault". R. O., MS., State Papers, Dom., G. I., Scotld, bundle Io, no. Ir5. Lord Torphichen, who commanded a squadron of cavalry, says that at the pass "dragoons and foot rallied under my cover," and that he acted under Whetham's orders (ibid., no. 95). So far was Whetham from being court-martialled and shot, as he would have been had Stanhope's account been accurate, that he was in command of the cavalry of the left wing during the advance from Stirling to Perth on January 29 following. The account of Campbell and Tindal, upon whom Stanhope probably relied, is also inconsistent with the Jacobite description of what took place on the rebels' right wing printed by Boyer (Pol. State, I715, p. 518), which says that they only pursued half a mile. Colonel Harrison (Royalist) says that the left "retired beyond Dumblain to possess themselves of the passes leading there" (to Stirling).

'Stanhope says 700, but Argyll's dispatch runs: "I count their dead to be 500 and I believe the number of their wounded to be considerable ". R. O., MS., State Papers, G. I., Scotld., bundle ro, no. 485 . 


\section{CHAPTER XV.}

THE PRETENDER IN SCOTLAND. THE SEPTENNIAL ACT.

UpON the arrival of James at St. Malo on November 8, N.S., CHAP.

1715, he found everything, to use his own language, "in a XV. strange confused chaos".' Out of this emerged the decision that Ormonde should make another venture on England, whilst he himself attempted to gain the east coast of Scotland. As the Channel was patrolled by English cruisers, St. Malo was a dangerous port at which to embark. It was agreed, therefore, that he should travel to Dunkirk on horseback by unfrequented roads and in disguise. On his arrival there on December $\mathrm{I}-\mathrm{I} 2$ he was greeted by the news that Ormonde's second attempt to land, on this occasion in Cornwall, had been prevented by tempestuous weather and that he had returned to France. Having embarked at Dunkirk in a small vessel, James on January 2, 1716 , wrote to Bolingbroke from Peterhead: "I am at last, thank God, in my own ancient kingdom". His first act was to issue a proclamation, dated October 25 , the original draught of which had been prepared by Bolingbroke, but altered by himself. ${ }^{2}$ It promised the restoration of the Scottish parliament and, in the equivocal terms which Bolingbroke denounced, security for the two established Churches of England and Scotland only, that of Ireland being deliberately

'James III. to Lord Bolingbroke, November 15, 1715, Stuart Papers, i., 458.

"He" (James), in conversation with Bolingbroke, " took exception against several passages (of Bolingbroke's draught) and particularly against those wherein a direct promise of securing the churches of England and Ireland was made" (Bolingbroke's letter to Sir William Wyndham). Bolingbroke believed that the draught had been "sent to the queen to be corrected by her confessor," and the dates shew that an interval elapsed sufficient for this to be done (see Stwart Papers, i., 1xoxiii.). "The whole tenour of the amendments was one continued instance of the grossest bigotry, and the most material passages were turned with all the Jesuitical prevarication possible" (Letter to Wyndham, see Stwart Papers, i., 448-49). 
CHAP. excluded. After a short stay at the seat of the Earl Marischal XV. at Fetteresso, where he conferred on Mar the title of duke, James, on the 4 th, made his public entry into Dundee. The people flocked to see him, but only to meet with disappointment. He had none of the glamour of the first nor the bonhomie of the second Charles. He recalled rather the gloomy visage of his father. "His countenance," wrote a supporter, "looked extremely heavy. . . . Some said the circumstances he found us in dejected him ; I am sure the figure he made dejected us." After a stay at the royal palace of Scone, where he fixed January 23 for his coronation, James advanced to Perth. There the first revelation awaited him. Mar had led him, while abroad, to expect an army of 16,000 men; but numbers of the highlanders had made their way home, leaving no more than 4,000 men in camp. The Earl of Sutherland, assisted by Lord Lovat, ${ }^{1}$ who was anxious to make his peace with the government, ${ }^{2}$ had on the day before Sheriff Muir recaptured the town and castle of Inverness. The pretender's army was therefore threatened at the same time from the north and from the south.

In the middle of November General Cadogan, Marlborough's favourite officer, who had been in Holland negotiating the Barrier treaty between the emperor and the States-general, arrived in the Thames with 3,000 Dutch troops. Another 3,000 were already embarked for England, the whole 6,000 being the number stipulated for by the treaty of Utrecht. By the close of December the army had assembled at Stirling, Argyll in chief command with Cadogan as next in rank. On January 29, Argyll and Cadogan began their advance. That night a council of war, held at Perth, decided on a retreat towards Dundee. Twelve hours after the evacuation of Perth, Argyll with the vanguard entered the town. The restiveness of the highlanders at the order to retreat was soothed by smooth words. They were marching for Aberdeen, a district notoriously well-affected towards them. ${ }^{3} \quad$ If they were pursued to the highlands, where the enemy's cavalry would be useless, victory would be assured. But when they found themselves making direct for the coast, and at Montrose saw two French

1 Stuart Papers, i., 460, 482.

2 He obtained a pardon for theșe services. Ibid., p. 514 .

'Montrose MSS., p. 373, Hist. MSS. Comm., 3rd Rep., App. 
vessels riding at anchor, they began to harbour suspicions that their prince might be contemplating desertion. In fact, no CHAP. resolution had been come to, and on February 3 James wrote imploring the regent for prompt succour.' But the ships, one of which had been ordered to convey an envoy to the continent, offered an opportunity which might not recur. To divert suspicion, the prince's baggage was sent on with the advance party, while his bodyguard was stationed outside his house, as if he were about to march. He himself, in company of Mar, escaped after dark by a back door on February 4 , and found refuge on board. Before his departure, he signed a commission to Lieutenant-General Alexander Gordon, nominating him commander-in-chief in Scotland.

It is due to James to say that, notwithstanding the equivocal manner of his withdrawal, which gave it the aspect of desertion, he was in fact only prevailed upon by the representation that his presence would make it more difficult for his followers to obtain terms. In a letter written for circulation among them, but not disclosed till they reached Aberdeen, where the new's of his escape was communicated, he recommended them to provide for their own safety until his return with succours might justify a renewal of the attempt. The reading of this letter at a crowded meeting evoked lively. expressions of indignation." Argyll affected to pursue the dispersing rebels to Aberdeen and Peterhead, but with a humane tardiness that provoked the wrath of Cadogan, who accused him of conniving at their escape. ${ }^{3}$ The rebel remnant, consisting of 400 horse and 200 foot, rendezvoused for the last time at Badenoch on February 14, whence General Gordon and the other chiefs wrote to Argyll asking for terms. Argyll, having had reiterated orders to give no answer to such requests, their letter remained unnoticed and they decided to

I Stuart Papers, i., 504.

I February 4, 1716, ibid., i., s05; ii., 110, 150.

3 This seems to have been true; see the detailed accounts of the marches as narrated by Clanranald. Ibid., ii., IIr.

- General Alexander Gordon, the Earls of Linlithgow and Southesk, and seven others to the Duke of Argyll, February 15, ibid., i., 512. The clansmen forced the leaders to sign it. Ibid., ii., I49.

- Lord Townshend to the Duke of Argyll, November 8, 1715, Townshend MSS., p. 177 ; if. pp. 180,18 ז. 
CHAP. shift for themselves as best they could.1 A number escaped to XV. the Orkneys and other islands and thence to Holland, Norway, Sweden, and France. Small ships were dispatched by the pretender during February, March, April, and May to patrol the islands and western coasts and collect and transport the fugitives. ${ }^{2}$ At the close of February Argyll, whose indisposition to press hardly on his countrymen had called forth repeated expressions of dissatisfaction from Townshend, was recalled, and Cadogan, who had censured his remissness, was appointed commander-in-chief in Scotland. Cadogan was indefatigable in hunting down the fugitives. "The Dutch troops," according to a Jacobite, "left nothing earthly undestroyed" between Stirling and Inverness, and " the English troops were very little more merciful". ${ }^{3}$ By April the country was entirely tranquil.

Thus ingloriously ended the pretender's hopes. The rebellion in Scotland had revealed the weakness of the clan system when opposed to an organised government. Political animosities, local jealousies, and blood feuds hindered the co-operation of the clans. The sentiment of personal loyalty rendered the action of the tribesmen dependent, not upon general political views, but upon the interest or the caprice of the individual chief. Lovat was able to attach to either side the Frasers and the Grants, ${ }^{4}$ and to offer to lend his vassals for the extirpation of rival clans. ${ }^{5}$ That the largest of the clans should be hostile to the rebellion and its chief, Argyll, at the head of the royal troops, deprived the movement of national significance. Against the command of his chief it was in vain for the pretender to expect that a proclamation would bring a highlander to the battlefield. Ormonde, Berwick, Marlborough alike had failed him. With Marlborough a despairing effort was made on the very day of his escape. Captain David Floyd "downright forced his way" into the duke's presence, presenting him with a letter probably from James himself. ${ }^{6}$ But the duke's capacity for good or ill was approaching its end. A

1 Stuart Papers, ii., 112, 143.

2 Ibid., ii., $57,74,81,160$.

3 The rebels contributed to the destruction by themselves burning houses to "prevent the enemy subsisting". Ibid., p. I16.

Ibid., i., 499, 501 .

'Lord Lovat to General Cadogan, March ro, 17r6, ibid., ii., 36.

' Jo. Menize (Menzies) to Lord Mar, February 4, 17 16, ibid., i., 587. 
stroke of paralysis on May 28 was the precursor of disabling CHAP. infirmities.

Bolingbroke had remained in France, untiringly exerting himself to persuade the regent to furnish assistance. When James, who landed safely at Gravelines on February IO-2 I, reached St. Germain's the secretary waited upon him. Three days later, Ormonde called upon Bolingbroke with two laconic orders in James's hand--the one dismissing him from his post as secretary, the other requiring the surrender to the duke of his official papers. The ostensible reason assigned to him was that the duke and he were on such bad terms that "they could not be both employed "." The real cause lay deeper. Neither Bolingbroke nor James had forgotten the alterations in the declarations printed in view of the invasion to which the secretary refused his signature. To these radical causes of dissatisfaction between James and the secretary were added such as naturally arise from disappointed hopes. A buzz of calumny circulated. Bolingbroke had betrayed secrets to Stair ; he had been remiss in forwarding munitions of war; he had been inattentive to business. Wearied though he was of a thankless office, he employed his secretary, Brinsdon, to refute these aspersions. To a message from the queen-dowager, offering to adjust matters, he returned answer that he wished his arm might rot off if he ever drew his sword or employed his pen in their service. Bolingbroke's dismissal was an ungracious return for services which, on Berwick's testimony, had been ungrudgingly rendered. James pretended to the regent that it was in consequence of information from Scotland." Berwick's judgement was just. His brother had made an "enormous blunder in dismissing the only Englishman he had able to manage his affairs".

As the cause of the pretender became manifestly more unpromising, the anxiety of the regent to atone for the breaches of friendship shewn by French officials in permitting the equipment and dispatch of his expedition began to shew itself.

1 Mar to Colonel John Hay, Stuart Papers, ii., 85, April 13, 1716.

2 March 6, 1716, Stwart Papers, ii., 5. Bolingbroke declared that the memorial against him had been concocted in France and sent to England. Ibid., p. Io6. In a letter to the Bishop of Rochester (Atterbury), of August 28, 1716, Mar implies that the initial suggestion of his dismissal came from the bishop and his friends. Ibid., p. 386 ; $f$. also ibid., p. 74. 
CHAP. Before the negotiations for the peace of Utrecht the sympaXV. thy of the British government had been repeatedly invoked on behalf of suffering French protestants condemned to the galleys for their faith. Both in England and Holland their representatives had pleaded that no treaty should be concluded without a provision for their release. Queen Anne herself had expressed an interest in them and had received assurances from Louis XIV. But Bolingbroke had no sympathy with religious convictions and had not been disposed either to hazard his favour at the court of Versailles or to retard a peace by insisting upon a condition distasteful to Louis and Madame de Maintenon. The French protestants were sacrificed to bigotry and indifference. It was a timely and gracious concession on the part of the regent to redeem the promises that had been given by ordering them to be set at liberty. The British government was now resolved to insist on the removal of the pretender from Lorraine, whither, after a short stay at St. Germain's, he had once more repaired. The duke, nervous lest the regent should exert pressure, met James at Commercy (March 10-14), and explained his inability to remain his host. No practicable resource remained but the papal territory of Avignon, which he reached about April I. Pope Clement XI. wrote him a letter of welcome and assigned him a pension. ${ }^{1}$ The whigs remained unappeased. They were determined to discredit him by driving him to Rome. A memorial handed in by Stair to the regent declared that his government would not be satisfied till the pretender was beyond the Alps.

Despite occasional disturbances, of which Jacobite correspondence made the most, the population as a whole shewed no sympathy with the rising. The evacuation of Perth by the pretender was acclaimed with cheers in the London theatres. While the dissenters were especially zealous for the government-a dissenting congregation headed by its preacher taking arms to assist the troops at Preston-thirteen of the prelates of the Church of England published a declaration of "abhorrence of the present rebellion". In Ireland the parliament voted $£ 50,000$ for the apprehension of the pretender and $£ 10, \infty 00$ for that of the Duke of Ormonde, in the event of their landing. The speech with which King George opened

'James 111. to Cardinal Imperiali, May 12, 1716, Stuart Papers, ̈̈., 147. 
the session on January 9, 1716, expressed the confidence of CHAP. the ministry in the future, since it conveyed an indirect warnXV. ing to France against " endeavouring to support this desperate undertaking". When reports came to hand that numbers of Irish and Scottish officers were ready to embark from France, I0,000 additional troops were promptly voted for England and 6,000 for Ireland. " Had they " (the king's servants), wrote Stanhope to Stair on January 23, "encouraged the temper which appeared, I do verily believe a war would have been voted before the rising of the house." This was not the attitude of an administration in difficulties, and the news of the pretender's flight a fortnight later completed the effect on the regent's mind. No event, as Prince Eugene declared, could have contributed to the stability of the new dynasty so effectually as the Scottish rebellion.

In the infliction of penalties the government, as compared with the Stewart sovereigns, acted with moderation and lenity. By the rigour of the law all the prisoners were liable to death. But there was no "bloody assize". From among the hundreds of undistinguished prisoners taken at Preston, one in every twenty was selected by lot to take his trial; the rest were respited.1 Less than a hundred of those taken in Scotland were, under a power given by statute, ${ }^{2}$ sent for trial to Carlisle, despite the execrations of the Jacobites and the disapproval of Scottish lawyers. ${ }^{3}$ Though most of them pleaded guilty, not one was executed. A number escaped, 4 so large as to suggest the complicity of jailers. Among them were Forster and Brigadier MacIntosh, who in April broke out of Newgate and, notwithstanding the offer of $£ 1,000$ for Forster, made their way safely to Avignon. Only twenty-two prisoners were hanged in Lancashire and four in London. Some hundreds were transported for terms to the American colonies. ${ }^{5}$ In the

'R. O., MS., State Papers, Dom., G. I., bundle 2, no. 95, Dec. 13, 1715.

2, G. I., st. 2, c. 33 .

Duncan Forbes, then depute-advocate, to Walpole, in August, 1716, Cwlloden Papers, p. 6r.

- Eighteen from Edinburgh Castle, " about as many from Stirling ". Stmart Papers, ii., 432, September 12, 1716; cf. ibid., p. 432.

- See R. O., MS., Board of Trade, Carolina (Proprietary), vol. v., n. 97. They had pleaded guilty, as is acknowledged by the young Lord Wharton in his attack upon the proceedings of the government, October to, 1716, Stwart Papers, iii., 547. 
CHAP. case, however, of the rebel lords it was determined that an xv. example should be made. With a view to diverting unpopularity from the court, the procedure adopted was not that of indictment but of impeachment by the house of commons of high treason. On January II, I 16 , resolutions passed for the impeachment of Lords Derwentwater, Widdrington, Nithsdale, Wintoun, Carnwath, Kenmure, and Nairne. Brought up before the house of lords on the Igth, all of them pleaded guilty and threw themselves on the king's mercy, with the exception of the Earl of Wintoun, who asked for further time to prepare his defence. Sentence upon the other six was delivered with solemn ceremony in Westminster Hall by Lord Chancellor Cowper, sitting as lord high steward. The executions were fixed to take place on February 24.

Among the numerous friends of the condemned there were lively hopes of obtaining a remission of the sentences. Personal appeals to the king proving inefficacious, the friends of the culprits sought to stir public sentiment and, in particular, that of the two houses of parliament. The advocates of clemency, currently called "the mercy men," 1 were in a painful dilemma. If the leaders of the rebellion were spared, their followers ought not to have been executed. On the other hand, the suppression of the rebellion and the flight of the pretender seemed to render further bloodshed needless. They also found themselves confronted with a constitutional difficulty. By a section of the act of settlement it was provided "that no pardon under the great seal of England be pleadable to an impeachment by the commons in parliament". The house of lords, however, agreed that the prerogative of pardon after conviction was not abolished and, on February 22, under the influence of Nottingham who seceded from his colleagues, carried an address for mercy, though by five votes only. After a vehement discussion in council, it was decided that four of the six convicted lords should be reprieved. The three most guilty, Nithsdale, Derwentwater, and Kenmure, were left for execution. Derwentwater and Kenmure were beheaded upon Tower Hill on the 24th, both professing to the last their adherence to the pretender. The escape of

${ }^{1}$ Stuart Papers, ii., 10. 
Nithsdale from prison in a woman's clothes by the contrivance of his countess on the evening before is one of the dramatic CHAP. episodes of history. All England applauded her heroism and, though her act was treason, the government was generous enough to let her go free. The trial of the Earl of Wintoun began on March I5. There was some doubt as to his sanity, but his part in the rebellion was clearly proved. Like the other prisoners he pretended that he had surrendered on the promise of mercy. As this plea reflected upon the king, the government took this, the first opportunity they had had, of rebutting it by the testimony of Generals Carpenter and Wills. Being unanimously found guilty he was sentenced to death on March 19, a sentence commuted for imprisonment for life in the Tower, whence on August 4 he effected his escape to the continent. The opposition offered by Nottingham to the executions brought to the surface the latent differences between him and the rest of the ministry. While his vote in the house of lords in opposition to his colleagues had abundant justification in precedent, public opinion was rapidly maturing in favour of party government. Four days after the executions, Nottingham, his son Lord Finch, his brother Lord Aylesford, and his first cousin Lord Guernsey, were all dismissed from their posts. Henceforth the government was purely whig.

In the days of their domination the tories had conceived the idea of conserving their power from the vicissitudes of popular election by a repeal of the triennial act of 1694 . But the end had come with unexpected suddenness and the opportunity was now transferred to the hands of their opponents. A continuance of the existing parliament for six years longer would probably make in favour of the peaceable establishment of the dynasty. The question was, indeed, raised ' and yet remains one of the controversies of constitutional law, whether a parliament summoned for three years was competent to extend its existence to seven without a reference to the electorate from whom it derived its powers. But time had disclosed practical objections to the continuance of the triennial act which were incontestable. They were admirably sketched by Steele in his speech for the bill in the commons, anci may

'See the Marquis of Wharton's circular letter to the freeholders, October to, 1716, Stwart Papers, iii., 547. 
CHAP. be summarised by saying that election petitions, business and $\mathrm{XV}$. electioneering manœuvres successively engrossed the three years of a parliament's life. Outside parliament it was said that triennial elections had increased bribery. Constituencies and agents preyed upon their representatives. Party passions were heightened, domestic peace was disturbed. In foreign affairs an absence of continuity had made itself felt in English policy and the government of the day had been regarded abroad as an ephemeral power. The triennial act had made, said the old Earl of Sunderland, "a triennial king, a triennial ministry, and a triennial alliance".

Upon these considerations the government determined to repeal the act and substitute a term of seven years as the limit of a parliament's duration. Yet so many interests were involved in the maintenance of the existing system, that doubts were entertained of the reception a septennial bill would meet with in the house of commons. It was determined, therefore, following the precedent of the triennial act, to introduce the bill in the first place into the house of lords. In the debate on the second reading, Nottingham and his friends ranged themselves with the opposition. Bishop Atterbury "complimented, bantered, and lashed the ministry ... with an infinite deal of wit. An essential part of it (the speech) was to admire the happiness of this free nation that was now to be governed by a standing parliament and a standing army." ${ }^{1}$ Shrewsbury, like Atterbury in correspondence with the pretender, caustically observed that, "as to the saving of money, he could not see that, for he believed everybody knew that an annuity of seven years costs dearer than an annuity of three". The division was not wholly upon party lines. The Duke of Somerset, at the head of a group of whigs, voted against the bill ; a group of tory peers in its favour. "A new strange jumble," commented an onlooker. ${ }^{3}$ The second reading was carried on April 16 by seventy-seven to forty-three votes, thirty peers subsequently recording a protest against it. In the house of commons, although there was the same conflict of feeling, the government were more sure of a majority. Whigs who had inveighed against the intentions of the tories in the last par-

'Stuart Papers, ii., 131, April 19, 1716.

I Ibid., p. 123, April 16, 1716.

Ibid., p. 122, April 16, 1716. 
liament felt, in their turn, some scruples at defending the CHAP. measure, but were converted to its necessity by the zealous XV. opposition of the Jacobites. The government carried the second reading by 284 to 162 votes on the 24 th.

Addresses, largely, no doubt, inspired by mercenary motives, now poured in against the bill. ${ }^{3}$ They served but to inspire the government to quicken its pace.2 Lechmere, who had been dismissed from the post of solicitor-general, probably ${ }^{3}$ for his opposition to the impeachment of Oxford for treason, endeavoured to involve the house in a controversy with the peers by the insertion of a clause to disable from sitting in either house all persons having pensions during pleasure. Stanhope promptly undertook to embody such a proposal, so far as regarded the house of commons, in a separate act. ${ }^{4}$ The septennial act itself received the royal assent on May $7 .^{5}$ The predictions which darkened the birth of this measure were never fulfilled. There was no enhancement of the prerogative, there was no "standing parliament". But one consequence resulted which none had foretold. It was said by Speaker Onslow that the passing of the septennial bill marked the emancipation of the house of commons from its former dependence on the crown and the house of lords. The anticipated advantage that it would strengthen the stability of an administration in the eyes of foreign powers was immediately realised. "The present parliament in England that is to last seven years," wrote the Jacobite General Dillon from Paris to Mar at Avignon, "scares them all here and makes them very apprehensive of doing or giving any advice that may disoblige them (the English govern-

1." Addresses are coming up against it from all the boroughs of the kingdom," [Hugh Thomas] to Jean Johnson [L. Inese], April 26, 1716, Stwart Papers, ii., 140. Earl Stanhope kays that "the people at large shewed no disapprobation of the intended change," citing in support the fact that the petitions against it entered in the journals of the house of commons numbered only ten. An explanation may be found in a letter of April 30 from Hugh Thomas to Jean Johnson (L. Inese): "It is said above two hundred addresses on that subject (the septennial bill) have been burnt at the post office as coming too late, so that new addresses are coming up from all parts to his majesty against it ". Ibid., p. 145.

Ibid.

- Stanhope (i., 289) was unable to discover the reason, but see Portland MSS., v., 508, Lady Oxford's letter, ibid., p. $5 \mathrm{Ir}$, written in June, 1715 (where for "attorney" should probably be read "solicitor"), though Lechmere did not retire till December.

I G. I., st. 2, c. 56.

I G. I., st. 2, c. 38 . 
CHAP. ment)." 1 No sooner was the bill safe than Stair vigorously $\mathrm{XV}$. pressed the expulsion of the pretender from Avignon. ${ }^{2}$ From this time the correspondence in the Stuart Papers teems with lamentations over the subserviency of the regent, the adverse bias of Alberoni, and the general disposition of the Roman catholic princes of Europe to leave the pretender to shift for himself. The rise in the funds which greeted the enactment indicated prevision of these effects.

Since the spring of 1715 the king had been hankering to revisit his native country. By a clause of the act of settlement the sovereign was restrained from leaving the realm without the consent of parliament. Both parties, however, concurred in supporting a bill for the repeal of this condition. ${ }^{3}$ The Jacobites, as the Stuart Papers shew, looked forward to the absence of the king as a favourable opportunity for a renewal of their designs. ${ }^{4}$ The Hanover tories, perhaps, hoped for a future reward for complaisance. The question of the regency during the king's absence excited to a high pitch the ill-feeling between father and son. The king found himself compelled to yield to the precedents for constituting the prince sole regent, but insisted on shearing his son's authority of some of its outward importance by styling him "guardian and lieutenant of the realm," a title borne, indeed, by the Black Prince, but less significant of power than events in France had rendered the title of regent. Conformably to this title, the more important appointments in the army and civil service were reserved to the king. The resentment shewn by the prince at these restrictions was visited upon his adviser, Argyll, whom the king ordered to be dismissed, ${ }^{5}$ not only from the post of groom of the stole to the prince, but from all his commands and preferments in the army and elsewhere. His brother, the Earl of Ilay, shared his fall. This burst of ill-temper caused a public scandal. The probabilities of the duke's defection or that of Lord Ilay were

1 Stuart Papers, ii., I54, May 15, N.S., 1716.

3 I G. I., st. 2, c. 5 I (I7 I5).

2 Ibid., p. 155.

- Stuart Papers, ii., 353, 364 .

- Argyll's biographer, Robert Campbell, while admitting ignorance of the cause of his dismissal, suggests that it may have been due to his remissness in the pursuit of the rebels or to his opposition to the removal of the Scotch prisoners to Carlisle for trial. But the Jacobite correspondence in the Stuart Papers attributes it to the cause assigned in the text. See especially John Walkinshaw to the Duke of Mar, July 29, 1716, ii., 315. 
eagerly discussed in the councils of the pretender.' But Argyll continued his attendance at court, cultivated his influence with CHAP. the prince, and had the credit of inspiring him with acts of petty hostility to the cabinet.?

On the eve of the king's departure a partial redistribution of offices was effected. In reward for his services as the introducer of the septennial bill into the house of lords, the Duke of Devonshire was appointed to succeed Nottingham as president of the council, while Stanhope's friend, General Carpenter, followed Argyll as commander-in-chief in Scotland. As a compensation for the attainder of his son, and by way of recognition of his steady adherence to the whig party, Sir Henry St. John, the father of Lord Bolingbroke, received the title of Viscount St. John. In the place of Stanhope, who was selected to accompany the king abroad, Paul Methuen, a lord of the treasury and lately ambassador to Spain, became acting secretary of state. Stanhope was to be the intermediary between the king and the ministry in London. Before starting upon his journey on July 7 , George endeavoured to mollify public opinion by demonstrations of reconciliation with his son. This was the first of a long series of visits to Hanover which in the reign of George II. proved a sensible irritation to the English. For six months the king remained abroad, viewing English affairs through Hanoverian spectacles, with the result that this country was involved in continental combinations embarrassing to the ministry and generally unpopular with the nation at large.

'Stwart Papers, ii., 288, 291, 316, 332.

Ibid., Pp. 297, 304, 316, 378. 


\section{CHAPTER XVI.}

THE QUADRUPLE ALLIANCE, SPAIN AND SWEDEN.

CHAP. IN October, I7I4, Stanhope, rendered distrustful of the intenXVI. tions of Louis XIV. by his failure to fulfil his obligations in the matter of Dunkirk and Mardyck, had visited the Hague and Vienna with the object of reconstituting the Grand Alliance for a renewal of the war. Although unable to secure a definite engagement from the emperor Charles VI., he paved the way to his adhesion by holding out the prospect of the annexation of Sicily with the aid of the English fleet. The first step to what afterwards became the Quadruple alliance of 1718 was the treaty between Great Britain and the States-general, signed on February 6, 1716 , at Westminster, renewing former treaties, but adding a secret article that warlike preparations against either power should bind the other to intervene. The eagerness of England for an Austrian alliance was not entirely a homage to the tradition of whig foreign policy. In June, I 7 I 5 , George I., as Elector of Hanover, had obtained by purchase from Frederick IV. of Denmark the cession of the captured Swedish possessions, the duchy of Bremen, and the secularised bishopric or duchy of Verden, acquisitions which commanded the course of the Weser from twenty miles above Bremen to the mouth of the river, and that of the Elbe to its mouth from the neighbourhood of Hamburg. In an interview of Volkra, the imperial ambassador, with Townshend, Bernstorff, and Bothmer, on February 24, I7 I6, the Hanoverian ministers particularly insisted that a guarantee of the duchies in favour of the Electors of Hanover should, as far as was competent to the emperor, be given in the name of the em-

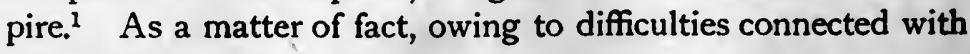

Dr. A. W. Ward in Great Britain and Hanover (p. 97) dates this demand as having been first made in November, 1718, apparently overlook- 
the constitution of the empire, this guarantee was not given, but CHAP. a treaty, signed at Westminster on May 25, pledged the emxVI. peror and the king to assist each other in the maintenance of their existing possessions. So far as Hanoverian interests were concerned this was a valuable result, for Hanover was at this moment nervous as to the intentions of the Russian army which had recently occupied Mecklenburg.

The accession to the crown of England of a sovereign traditionally bound to the imperial house was naturally viewed with distrust by Philip V. Under colour of the three clauses affecting to explain three of the articles of the treaty of commerce of November 28, 17 I 3, which Bolingbroke was suspected of having corruptly accepted, vexations were multiplied upon English merchants. On May 20, 1715, Paul Methuen, then envoy at Madrid, wrote to Stanhope that he saw no redress but in war. The consequences of the death of Louis XIV. were a signal justification of Bolingbroke's prevision as to the effect of the renunciations. Philip V. was eager to assert his claim to the regency, but he found himself forestalled by the Duke of Orleans, and the existence of a "Spanish party" only served to shew that the duke had France as a whole behind him. In the autumn, however, under the inspiration of Alberoni, who was then rising into power at the Spanish court, Philip made a shew of changing his policy for one of friendliness to Great Britain as the holder of the balance between himself and Orleans. George Bubb, afterwards celebrated as Bubb Dodington, Methuen's successor at Madrid, negotiated a new commercial treaty on December 14,17 1 5 , to the lively satisfaction of the English trading classes. By it duties on commerce between the two countries were reduced to the status quo of the reign of Charles II. (of Spain), and each contracting party conceded to the other the privileges of the most favoured nation, a clause highly injurious to the French woollen manufacture. Bubb also obtained a new Asiento treaty (May 26, 1716), which satisfied all the demands advanced by the South Sea Company. Yet, despite the new treaty, the ill-usage of English merchants continued.

Upon the return of Charles XII. of Sweden from his refuge in Turkey in November, 1714 , he found the Northern powers

ing Volkra's report of Pebruary 24-March 6, 17x6, cited by Michael, i., 667 , n. 2.

VOL. IX. 
CHAP. scrambling for the last relics of the Swedish possessions on the XVI. continent. Russia, Denmark, and Poland were already at war with him ; Frederick William I. of Prussia was in occupation of Stettin and had just concluded a "punctation " or preliminary convention with George I., as Elector of Hanover, guaranteeing him the duchies of Bremen and Verden. It was certain that Sweden would do her best to recover them, and Charles declared war with Hanover on October I 5, I7 I 5. George was now involved in the paradoxes inseparable from a dual personality. As Elector of Hanover he was at war, as King of England he was at peace with Sweden. It was just such a situation as had been foreseen by the framers of the act of settlement when they provided that the sovereign should not go to war for his continental possessions without the consent of parliament. But England since I7 I I had had grievances of its own against Sweden. Swedish privateers, under pretext of a blockade of Russian ports, had made prize of fourteen British merchantmen, valued with their cargoes at nearly $£ 66,000 .^{1}$ Six days after Queen Anne's death the lords justices had notified to the new king that men-of-war had been ordered for the Baltic to protect British shipping. It was natural that George I., on his side, should, in the interests of Hanover, be disposed to take advantage of this precarious state of relations. On the other hand, there was no reason why an English ministry should forgo its duty of protecting the English mercantile marine because an incidental advantage might result to Hanover. Further, the English admiralty was largely dependent on Russia for supplies of naval stores. ${ }^{2}$ It was determined, therefore, upon the solicitation of Bernstorff, that a fleet should sail to the Baltic in the summer of 17 I 5 by way of convoy to merchantmen.

The instructions given in May to Sir John Norris, the admiral appointed to command, were likely to lead to a collision. Failing prompt redress, he was directed to stop all Swedish ships, whether men-of-war or merchantmen, and to detain them pending compliance with his demands. While, therefore, his expedition on the face of it professed to be for the protection of merchant shipping, it really involved the cooperation of 'a neutral in an offensive action against a power with which it was ostensibly at peace, although the admiral

1 Toronshend MSS., p. 91.

Ibid., pp. 9r, 93. • 
was forbidden overtly to join the Danish fleet. Norris acted strictly within the lines of his official instructions. He conCHAP. voyed the merchantmen; he refused a request of Frederick William of Prussia to assist the Danes in the blockade of Stralsund, which was defended by Charles XII. in person; he vainly endeavoured to induce the auxiliary Dutch squarlon to assist him to attack the Swedes, ${ }^{1}$ and at the end of August, having collected his convoy, he set sail for home. In deference, however, to the protests of George, eight ships were left, under pretext of exacting reprisals from privateers, to act with the Danish fleet. The amicable relations between the tsar and George, from which Peter hoped for effective action against Sweden, came to an end in the spring of 1716 . The apprehensions of George, as Elector of Hanover, being aroused for the safety of his dominions, by the occupation of Mecklenburg by Russian troops, he sent Bernstorff to Stanhope on September 25 with a proposal " to crush the czar immediately, to secure his ships, and even to seize his person". Though Stanhope at Hanover leant to strong measures, Townshend was aghast. "This northern war," he wrote, "will be our ruin." Seeing the indecision of the English ministry, the Hanoverian statesmen induced the emperor in January, 1717 , to threaten force for the removal of the Russian troops from German soil. It was not Peter's policy idly to provoke central Europe, still less England, without whose support his fleet could not face the Swedes. He therefore agreed in March to dispatch his troops eastwards. But towards George, as the inspirer of the empire against him, he did not hesitate to express his resentment. ${ }^{2}$ It was George's sense of the Russian peril which urged him to enter into a closer alliance with the emperor by the treaty of Westminster.

On January I 8, I 7 I 7, the king returned to London. Eleven days later the world was startled by the news that a breach of the law of nations had been committed by the ministry: Count Gyllenborg, the Swedish ambassador, had been apprehended in his own house and his papers seized. On February 19, O.S., Baron Görz, Swedish ambassador in

${ }^{1}$ Sir John Norris to Lord Townshend, July 8, 1715, Townshend MSS., p. 91.

'See the communication of the tsar's physician, Dr. Erskine, to Sir J. Erskine, Septemter 22, 1716, Stwart Papers, ii., 495. 
CHAP. Holland and adviser of Charles XII., was arrested on his way XVI. to London by the States-general, at the instance of George, and his papers also seized.1 The correspondence of Gyllenborg disclosed that he, Sparre, the Swedish ambassador in Paris, and Görz were concerting with the Jacobites a fresh insurrection to be supported by 12,000 Swedish troops. It was to frustrate this plot that the ministry, conscious that it could not appeal to the revelations of opened letters, had resolved to commit an unprecedented act of violence. Gyllenborg remained in custody until August, when he was put on board a frigate and conveyed to Sweden for exchange with Jackson, the English resident, who was detained there. ${ }^{2}$ The revelation of the plot thus dramatically made strengthened, as was perhaps intended, the hands of Stanhope and Sunderland. Upon the meeting of parliament on February 20, the king's speech adverted to this incident, and the captured correspondence was laid before it. ${ }^{3}$ English liberty, it was felt, had been at stake. The houses voted loyal addresses and the estimates for the land forces were carried in the commons by 222 against 57 votes. It was forgotten by all but those who could not venture to make their voices heard that the peril had arisen out of ambition for the aggrandisement of Hanover. "Pray sir," Görz had written to Gyllenborg, "which way can the King of Sweden better secure himself the recovery and possession of his said duchy (Bremen) than by reducing King George to be nothing more than an elector of the empire?" News presently came from Lord Polwarth, our envoy at Copenhagen, that Charles was equipping ships, it was rumoured for

"The meeting of the cabinet which decided "to require of the states" that Görz should be arrested was held on January 30, 1717, and instructions were given for all outgoing mail-boats to be stopped till twenty-four hours should have elapsed after the messenger's departure. R. O., MS., State Papers, Dom., G. I., bundle 9, no. 9 . On February 3 ships and troops were ordered to be made ready " until the business of Sweden be over". Ibid., no. 12. Görz's papers were not handed over by.the States-general, notwithstanding the pressure of the British government. Engl. Hist. Rev., xviii., ro4.

2 R. O., MS., State Papers, Dom., G. I., bundle ro, no. 12.

s A letter is said to have been taken from the Stuart Papers by Mr. Brougham (afterwards Lord Brougham) in 1817 in which Charles XII. promised the pretender that be would conclude peace with the tsar and land in Scotland with 30,000 men to support his claims. Stuart Papers, i., xi. On the other hand, Charles, who prided himself on bis truthfulness, declared that he was not privy to any plan of invasion. See Engl. Hist. Rev., xviii., 93, n. 5 t 
an invasion of Scotland. On April 2, Sir George Byng, in command of a fleet of over thirty ships, sailed from the Thames. CHAP. The admiral's orders were no longer directed to the protection of merchantmen. He was to blockade or attack the Swedish ships at Karlskrona and at Gothenburg. He found, however, that the project of an invasion of Scotland had been abandoned, and that the Swedish fleet had retired to the defence of the fortifications of Karlskrona. In November he returned home, leaving six ships to co-operate with the Danes. In August, I 7 I 8, a similarly fruitless cruise was undertaken in consequence of a rumour of a junction of the Swedish and Russian fleets for the invasion of Scotland. These costly expeditions naturally provided the opposition in parliament with material for attacks on the administration, but the critics were hampered by the adroitness of the ministers in placing the protection of tracle in the forefront of their policy, inspired though it largely was by consideration for the interests of Hanover. The threat of foreign invasion also never failed to rally the country to the support of the government. In the face of such a danger, declamations from Jacobite lips against a standing army fell flat upon the public ear.

The easy suppression of the Scottish rebellion having demonstrated the stability of the Hanoverian dynasty, the Regent Duke of Orleans, apprehensive of the designs of Philip V. upon the succession to the crown of France, determined upon a closer understanding with Great Britain. His confidential agent, the Abbé Dubois, negotiated with Stanhope at Hanover in the summer of 1716 a reciprocal guarantee of the succession to the crowns of France and Great Britain. In return the regent agreed to give satisfaction in the vexed question of Dunkirk and Mardyck, and to expel the pretender from France. But in October the progress of the negotiations met with unexpected checks. One of the British plenipotentiaries, Horatio Walpole, flatly refused to sign the treaty without the concurrence of the States-general. Objection was taken by Dubois to the insufficiency of the powers with which Townshend had furnished Cadogan, the other plenipotentiary, and the king, fearing the designs of the Russians against his electorate, suspected, as did Stanhope, that Townshend had adopted dilatory manceuvres to prevent a treaty of which he disapproved. A letter 
CHAP. from Stanhope to Townshend written in French for the king's XVI.

perusal, made the accusation in round terms. Townshend was cut to the quick. To a man of his blunt and upright character an accusation of trickery was particularly mordant. To Stanhope he wrote four lines ending, "I pray God forgive you ; I do," and inclosing his letter to the king, in which he vindicated himself as well from the personal imputations as from the charge of hostility to a treaty with France. At last, on November 28, 1716 , the treaty was signed upon the basis of the preliminary convention of Stanhope with Dubois. On January 4 following, the Dutch came in as parties, and the treaty was then known as the Triple alliance of 1717 .

A convergence of circumstances, of which the obstacles to the signature of the treaty were the most operative, rendered a reconstruction of the ministry inevitable. During the absence of the king his jealousy of the Prince of Wales was constantly fed with reports from Bothmer and others, in which Townshend figured as enjoying the prince's "particular confidence," and the prince as sharing Townshend's distrust of an aggressive policy in the Baltic. The prince, by the splendour of his entertainments at Hampton Court, presented, it would seem of settled policy, a contrast to his father which more than reconciled the public to the king's absence. Like Townshend, Walpole was odious to the Hanoverian junta ; the more so that, as chancellor of the exchequer, he controlled the public purse, while Bothmer, as Townshend bitterly complained to Stanhope, had "every day some infamous project on foot to get money". A personal dispute had also arisen between Walpole and the king. At the time of the Jacobite insurrections a contingent of troops from Münster and Saxe-Gotha was hired, upon the advice of the cabinet, under the unlimited authority granted by parliament for the emergency; but the flight of the pretender had made it unnecessary to bring the force over. As some time would elapse before parliament reassembled, George desired Walpole to advance the money for its pay. The interview took place before the king's departure for Hanover, and George told Stanhope "that Mr. Walpole had told him a way would be found to pay that money". Walpole had an emphatic style, and answered this statement characteristically. In truth, as Stanhope] suggested, 
it was "very possible the king and Mr. Walpole might mistake one another". The discussion of business by a minister upon CHAP. his knee in a dead language, spoken by the interlocutors with dissimilar pronunciations, was likely enough to lead to misunderstandings.

The king's irritation with Townshend was not so quickly calmed. On December 1 5, 1716, Stanhope wrote conveying his dismissal from the secretaryship of state. His place was provisionally filled by Paul Methuen, who had been acting secretary during Stanhope's absence from England in the previous summer. Walpole, who lay under the same imputations, made common cause with his brother-in-law. Although with much difficulty, Townshend was induced to accept the lieutenancy of Ireland, retaining his seat in the cabinet. Stanhope remained secretary of state for the southern department. But harmony had passed away. The ministry was rent between Stanhope, and Sunderland, who had fomented Stanhope's dissatisfaction with his colleagues, and Townshend and Walpole on the other side. TThe first two were for an adventurous foreign policy; the others were solicitous for national, and suspicious of dynastic interests.] When, as a sequel to the Gyllenborg incident, Stanhope moved for a supply to counteract the apprehended designs of Sweden, Walpole supported the motion with ill-disguised reluctance, while the whole of his personal following and that of Townshend voted against it, together with the Jacobite and tory opposition. The supply was carried, in consequence, by a majority of no more than four votes. It was evident that in relation to foreign powers the ministry was discredited by its internal weakness. Stanhope was resolute. On the same evening, April 9, 1717, he wrote in the king's name dismissing Townshend from his lieutenancy. [Walpole resigned the treasury and exchequer on the following day.) His offices were taken by Stanhope, who appointed Joseph Addison to succeed himself as secretary for the southern, while Sunderland who since August, 1715, had been lord privy seal, took over the northern department. William Pulteney, at this time a close ally of Walpole, was succeeded as secretary at war by James Craggs, the younger. Vice-Admiral the Earl of Berkeley displaced Orford as first lord of the admiralty. The Irish lieutenancy fell to the Duke of Bolton. Cowper remained on the 
CHAP. woolsack. Thc strength of the whig ascendancy was shewn XVI. by the fact that the party could furnish this strong alternative administration.

It was now the ambition of Stanhope, as the unquestioned head of a united ministry, to extend the network of alliances by which he aspired at the same time to assure the peace of Europe and the stability of the Hanoverian dynasty. A storm was threatening from Spain. Philip V., already irritated by the British guarantee to the emperor of the formerly Spanish provinces of Italy under the treaty of Westminster, was exasperated by the Triple alliance, which aimed at shutting his house out from the succession to the crown of France. Alberoni and the Spanish queen, the restless and ambitious Elisabeth Farnese, were at one in a resolution to regain the lost Italian territories. Since 1713 Spain had been creating a navy and preparing for war. Stanhope, created a viscount in July; 1717 , determined to form a combination to enforce peace upon Spain. His idea was a Quadruple alliance of the maritime powers with France and the empire. The regent required no great persuasion. The emperor hesitated, but acceded upon a promise of the dispatch of an English fleet to the Mediterranean. Negotiations were spun out till July 22August 2, I7 18, when the representatives of Great Britain, France, and the empire signed in London the treaty which, on the accession of the Dutch in December, became known as the Quadruple alliance. [Its main terms were the renunciation of Spain by the emperor, in consideration of which he received Sicily, whilst Victor Amadeus unwillingly accepted Sardinia in exchange, retaining the title of king. This bargain on behalf of the emperor, Lord Hervey tells us, was prompted by the desire of George I. to obtain an imperial investiture of the duchies of Bremen and Verden. The emperor also undertook to grant investiture within two months of the signature of the treaty of the duchies of Tuscany, Parma, and Piacenza to Don Carlos or other sons of Elisabeth, Queen of Spain, to take effect on the death of the present rulers, who were without direct male heirs.

The question was whether Spain would defy the Quadruple alliance. During the progress of these negotiations Alberoni had not been inactive. In August, 1717, he had occupied 
Sardinia. In the north of Europe he entered into correspondence with Charles XII. with a view of promoting a peace CHAP. between Sweden and Russia as a preparatory step to an invasion of England on behalf of the, pretender. In addition to the northern combination he prepared the plan of a Spanish attempt under Ormonde or the pretender himself. The scheme of a Quadruple alliance was formally communicated to Spain in March, 1718. The clause which it was hoped might make it acceptable was that by which the succession to the Italian duchies was to be guaranteed, in default of male issue, to the queen's eldest son. Alberoni, however, declared that Philip would never give up Sardinia. In November, 1717, Bubb had warned Stanhope of the extensive naval preparations on foot. It was evident that Spain no longer contemplated abiding by its promise to stop short at the occupation of Sardinia, but was meditating an attack on Sicily or the imperial possessions in Italy, if not on England itself.

On June 15, 1718, Admiral Sir George Byng set sail from Spithead with a fleet of twenty ships of the line. His orders were to compel the Spaniards to abandon hostilities, but he was not directly instructed to attack them. Stanhope was, in fact, ready to purchase peace with the surrender of Gibraltar which, as we learn from a letter of James Craggs the younger, who had succeeded Addison as secretary of state for the southern department in March, he held "of no great consequence". Neither this offer nor other concessions agreed upon by the allies availed to bring Alberoni to terms. Although the instructions given to Byng were not distinctly aggressive, he had received verbal hints from the ministers that he need not be afraid of doing too much. The king even expressed to Penterriedter, the imperial ambassador, the hope that he would destroy the Spanish fleet. When Byng arrived at Naples on August I, he heard that a large part of Sicily was already occupied by Spanish troops. He offered an armistice which was refused, and then resolved to attack their fleet, at that time engaged in the siege of the citadel of Messina. Upon learning his approach, the Spanish admiral called a council of war. The ex-captain George Camocke, then a rear-admiral in the service of Spain, advised that the Spanish ships should remain at anchor in the roads of Messina in line of battle, supported by the bat- 
CHAP. teries and troops on shore. This proposal was outvoted, and XVI. the fleet put to sea without any definite plan, either of action or retreat. On the morning of the IIth, Byng came up with it off Cape Passaro, on the south-east of Sicily. The Spaniards without any ordered formation were overtaken ship after ship. Camocke with ten ships of war contrived to escape, but the English fleet destroyed eighteen Spanish ships of the line, besides smaller vessels. The defeat paralysed the designs of Alberoni. Byng was rewarded with a congratulatory letter from the king, and on September 9, I 721 , after his return to England, was created Viscount Torrington.

Unless England was to take upon itself the main burden of preserving a peace, in which the emperor was more immediately interested, it was evidently desirable that the Turkish war, which was exhausting his resources, should be brought to an end. The treaty of Passarovits was signed on July $2 \mathrm{I}$, 1718. The credit of effecting peace was ascribed in the main to the British plenipotentiary, Sir Robert Sutton, who opened the congress at Passarovits. In the course of a few weeks three great successes had been achieved by Stanhope's ministry : the conclusion of the Quadruple alliance, the termination of the Turkish war, and the victory of Cape Passaro. The hands of the emperor were now free to grapple with Alberoni, and Great Britain was established as the directing head of the international league of peace. But the action of Byng naturally provoked criticism. At the opening of parliament on November II, the most effective attack on the ministry was delivered by Walpole.f "Ministers," he said, "were conscious of having begun a war against Spain and would now make it the parliament's war." The government, however, had substantial majorities in both houses. Being thus assured of the support of parliament, the king declared war against Spain on December 17 , on the ground that no redress could be obtained for the injuries inflicted on British commerce.

Alberoni, aware that he would be unable to resist a combination in which France bore part, conceived the idea of substituting for the regent the Duke of Maine, who was at the head of the Spanish party. Maine assented to a plan to seize the Duke of Orleans when on a party of pleasure near Paris, to secure the person of the king, and in his name to summon 
the States-general and proclaim Philip V. as the next heir to the throne, with himself as his deputy. But the plot was discovCHAP. ered and the Duke and Duchess of Maine were imprisoned. After this provocation, the regent, in conformity with the terms of the Quadruple alliance, declared war against Spain on January 9 , N.S., 1719.

The combination between Sweden and Russia against England, which Alberoni, in concert with Görz, was planning during the autumn of 1718 , was equally unfortunate. The conquest of Norway and the recovery of Bremen and Verden were to be antecedent steps. With the death of Charles XII., on December II, N.S., this combination fell to the ground. There remained another chance of success, the invasion of England under Ormonde and the pretender, which had been planned to synchronise with the descent of Charles. In December Ormonde secretly left France, and arrived at Madrid. Alberoni, who was equipping a formidable armament, offered him the command of the expedition destined for an attempt upon the west of England. The pretender, who was then living at Rome, embarked at Nettuno on a ship of Admiral Camocke for Cagliari in February, 1719 , and on March 9 reached Rosas, in Catalonia, and proceeded to Madrid where he was received with the honours of royalty. Two days before his landing Ormonde's expedition had sailed from Cadiz. It was intended that in the event of a successful attempt, the pretender should follow in person. The armament consisted of five men-of-war and about twenty transports, 5,000 regular troops, mostly Irish, and arms for 30,000 more. With these Ormonde was to land in the west of England, while the earl marischal with a small body of Spanish troops was to make a diversion in the highlands of Scotland. Ormonde himself was to embark at Corunna. The regent, Orleans, had sent warning of the expedition by a letter from Dubois to Craggs (January 16, 1719), and an offer of eighteen battalions of infantry and ten squadrons of cavalry, ${ }^{1}$ which, however, were declined. In March and April the States-general dispatched 2,000 men, and the Marquis de Prié, governor of the Austrian Netherlands, six battalions of imperialists.

I R. O., MS., State Papers, Foreign, France, 353. 
CHAP. The effectiveness of the Quadruple alliance was now deXVI. monstrated. At home, the troops in the north and west of England were reinforced, and naval preparations hurried on. On March to the king acquainted parliament with the intended invasion, and received loyal assurances from both houses. A fleet of seven ships under Sir John Norris sailed from Spithead to watch the coast of Cornwall. The Spanish fleet, off Cape Finisterre, met with a storm on March 29 which lasted for two days and entirely dispersed it. Only the two frigates with the earl marischal and his party which sailed from the bay of Passajes, the harbour of San Sebastian, succeeded in making their way to the neighbourhood of Kintail in Ross-shire (April 13) having on board 300 Spanish soldiers. They brought arms, also, for 2,000 men, but were only joined by about I,000 highlanders and by Lords Seaforth and Tullibardine, who had landed in a small ship from France. They took possession of Donan Castle and garrisoned it with forty-five Spaniards. After a slight resistance to three English men-of-war, the garrison surrendered on May 10. On June 5, General Wightman marched from Inverness against the main body, which now numbered about 2,000 strong. He found them on the Ioth encamped in an advantageous position, strengthened by hasty fortifications, in a pass in Glen Shiel. His own force consisted of no more than I, IOO men, composed of Dutch and highlanders, one English regiment of infantry, and detachments of grenadiers and dragoons. Nevertheless, he delivered his attack on the evening on which he came up with the rebels, drove them from rock to rock, and after bivouacking for the night, received on the following day the surrender of the whole body of 274 Spaniards. The highlanders dispersed to their homes and the three lords took refuge in the western isles, whence, at a later date, they succeeded in escaping to Spain. Alberoni's invasion was at an end.

The continuance of the pretender at the court of Madrid was felt by the King of Spain to be an irksome expense. The Princess Clementina, grand-daughter of John Sobieski, late King of Poland, to whom James was contracted, contrived in April to escape from the convent at Innsbruck, where she had been detained at the instance of the British government. Upon May 28, while still at Madrid, James was married to 
her by proxy at Bologna. This afforded him a pretext for CHAP. returning to Italy. During the summer and autumn of 1719 XVI. English and French expeditions destroyed a number of Spanish naval stations, while Byng's ships swept the Italian coast, preventing the supply of troops and munitions to the Spanish army in Sicily. To Byng's effective action it was mainly owing that Philip realised the futility of Alberoni's schemes of conquest. In the summer of 1719 the cardinal opened negotiations for peace. The events of the year had not been such as to dispose the allies to concessions. Stanhope was determined that the prime cause of disturbance in Europe should be driven from Spain. Alberoni's enemies at the court of Madrid were also intriguing against him. On December 5 , 1719, the cardinal was dismissed from all his employments and ordered to quit Spanish territory within twenty-one days. Stanhope visited Paris, in order to insist on his demands in concert with the French and imperial ministers. On January 19,1720 , these three signed a joint declaration, binding themselves to enforce the accession of Spain to the Quadruple alliance. In February Philip yielded. He repeated the renunciation of the French succession imposed on him by the treaty of Utrecht, and he undertook to evacuate Sicily and Sardinia within six months. Stanhope's organisation of alliances had borne its first fruits, and Europe enjoyed peace for twelve years.

The death of Charles XII. had already revolutionised the situation in the north of Europe. The combinations of Görz and Alberoni, by which Sweden, Russia, and Spain were to cooperate against England, instantly fell to pieces. On the other hand, the exhaustion of Sweden by Charles XII.'s campaigns removed a possible counterpoise to the growing power of the tsar in the Baltic. The friendly relations which Peter cultivated with Prussia, a power whose policy was always capricious and incalculable, and the animosity, sometimes latent sometimes undisguised, subsisting between him and George I., involved a constant apprehension for the safety of the electoral dominions. George, therefore, as elector, without consulting his English ministry, at once effected a combination against the two powers he dreaded. On January 5, 1719, a treaty of mutual defence was signed at Vienna between Hanover, Saxony, and the emperor. This treaty, though a relief to George's most 
CHAP. pressing anxiety, still left unsettled the affairs of northern XVI. Europe, out of which the apprehended difficulties were likely to arise. The first steps taken by George towards a pacification were the adjustment of the claims of the belligerents other than Russia, and the detachment of Prussia from the tsar. Whitworth, who had been British envoy to Berlin in 1716-17, was sent back there in April, I 7 I9, with instructions to propose a treaty. As Frederick William's indecision between England and Russia was long protracted, Whitworth advised that it should be hastened by the inception of negotiations with Sweden. Lord Carteret, a young peer whose abilities had already attracted attention, arrived in July as ambassador at Stockholm. At this time the Tsar Peter was ravaging the Swedish islands and plundering and burning almost within sight of the capital, while his allies the Danes were invading the south of the country. The alternative appeared to be either the immediate intervention of England or the submission of Sweden to the tsar on his own terms. Norris was lying off Copenhagen with eleven ships of the line and a frigate, and the Swedes begged that he might be ordered to their capital. Upon a promise to this effect Carteret secured the signature of a preliminary convention between Hanover and Sweden, by which a complete cession was made of Bremen and Verden for $1,000,000$ crowns. British mediation was promised in arranging a peace for Sweden with the Kings of Denmark and Poland.

Whitworth's anticipations were justified. Frederick William began to apprehend an arrangement between Great Britain and Sweden, in which his interests would be neglected. On August 14 he signed treaties with both Great Britain and Hanover. The treaty with Great Britain contained a separate secret article pledging the two powers to mutual defence. Encouraged by the proximity of the English fleet, and also by the sum of $£$ I 0,000 distributed by Carteret among the senators, the Swedes concluded a preliminary treaty with Great Britain on August I 8, O.S. This treaty established an inviolable friendship with a view to the maintenance of the protestant religion ; provided for the free navigation of the Baltic by British ships, and for the assessment of damages to trade on either side ; and promised, while war continued, subsidies to Sweden in lieu of the succours to which England was pledged under the treaty of Travendal $(1700)$, and the good offices of King George in the conclusion 
of a peace. By one separate article the preliminary convention CHAP. between Hanover and Sweden, particularly the cession of XV1. Bremen and Verden, was confirmed; by another Great Britain undertook to unite her forces to those of Sweden against the tsar in the event of his continuance of hostilities. On September 5 Norris joined the Swedish fleet, but Peter had no wish to court the destruction of his ships, and they were prudently withdrawn to Reval. On December 9 Norris was back at the Nore.

The Danes having on October 30 accepted King George's mediation, the signature of the British treaty with Sweden, based upon the preliminary treaty of August, took place at Stockholm on January 21 , O.S., 1720 . A treaty between Sweden and Prussia, in the negotiation of which Carteret played an active part, was also signed. To the treaty with Great Britain an article was added binding Sweden to afford no asylum to the pretender and to guarantee the protestant succession. Mutual succours for defence were fixed at 6,000 infantry or their equivalents in munitions of war, ships, etc. The final treaty of Fredericksborg on July 3 between Sweden and Denmark succeeded a protracted wrangle, in which Carteret again took a leading part. There now remained Russia, but Peter withstood the offers of mediation jointly made by George and Frederick William. British fleets appeared in the Baltic in 1720 and 1721 , but as the Russians sought the shelter of their fortifications, these demonstrations were ineffective. At the close of 1720 both Stanhope and Carteret began to see that Sweden had no resource but to accept the Russian terms. The Mississippi scheme and the South Sea bubble had crippled France and England alike. The death of Stanhope on February 5, 1721, suddenly deprived England of the mind which since 1716 had held the direction of public affairs. By the treaty of Nystad of August 30, I 721, peace was re-established between Sweden and Russia, with Russia as the dominant power in the north of Europe. Unwelcome as this result was to King George, there had emerged to him from the tangle of negotiations two substantial compensations, the acknowledgement by Sweden of his claim to the disputed duchies and the security of British trade in the Baltic.1

' For a detailed account of the relations of Great Britain to Russia, Sweden, and Denmark during this period, see a long series of articles by Mr. J. F. Chance in the English Historical Revirw, 1900-08. 


\section{CHAPTER XVII.}

ADMINISTRATION OF STANHOPE AND SUNDERLAND (1717-1721).

CHAP. WALPOLE at the moment of his resignation on April 10, I I 7 ,

XVII. had matured a scheme for the reduction of the interest on the national debt, which, "as a country gentleman," he, at the instance of the king, consented to pilot through the house of commons. The debt stood at $£ 47,000,000$, the interest being seven, eight, and nine per cent. To effect his object he borrowed $£ 2,500,000$ and $£ 2,000,000$ from the Bank of England and the South Sea Company respectively for the purpose of paying off such fundholders as might refuse a reduction of interest to five per cent. The surplus arising out of the taxes which had been appropriated for the payment of the higher interest constituted a sinking fund. These financial arrangements were embodied in three bills, which all became law, the General Fund act, the Bank act, and the South Sea act. But though Walpole came to the help of the government, the friction between him and Stanhope, which had arisen in connexion with the dismissal of Townshend, continued to manifest itself. "The parties of Walpole and Stanhope," wrote Pope in June, I 7 I 7, " are as violent as whig and tory."

The Earl of Oxford had in May, 1717 , been confined in the Tower almost two years without trial. In the opinion of some of the more moderate whigs, it was time that he should be set at liberty. ${ }^{1}$, On June 24 he was brought from the Tower to Westminster Hall. After the opening of proceedings by the reading of the articles of impeachment and of the earl's answer, Lord Harcourt carried a resolution that the lords should receive no evidence on the charges of misdemeanour until those of high treason had been tried. The house of commons was nettled

${ }^{1}$ Lord Carleton to Oxford, May 25, 1717, Portland MSS., v., 526. 
at what it regarded as an unprecedented attempt to dictate its procedure. The commons demanded a free conference, CHAP. which the lords refused, and July I was fixed for the continuance of the trial. Upon that day the lords assembled in Westminster Hall, and the managers of the impeachment making no appearance, the lords acquitted the prisoner of all charges. By way of retort the commons addressed the king to except the earl from the act of grace. To this futile exhibition of impotent malice the king assented. It was well for Oxford that the prosecutors did not know what the Stuart Papers have since revealed, that for a year past he, in conjunction with Shrewsbury and Atterbury, had been in active correspondence with the pretender. Amongst other persons by an empty formality excepted from the act were Lord Harcourt, Prior, Thomas Harley, and Arthur Moore. Strafford, on the other hand, whose impeachment had been dropped, was included, and its large clemency reached to the lords under sentence of death in the Tower, and threw open the prison doors all over England and Scotland. Nevertheless the attainders were not annulled nor the forfeited estates restored. Provision was, however, made for the subsistence of those dependent upon the convicted offenders.

At the close of the spring session of 1717 Stanhope had been raised to the peerage, with the title of Viscount Stanhope of Mahon. That the directing head of the government should think it desirable to quit the commons for the lords, was consonant with the traditional practice, as exemplified in the cases of Harley and St. John. It is evidence of the fact that men still looked to the upper house as paramount in the legislature, as indeed it was. The ministers in the commons, Addison, James Craggs the younger, and Aislabie, who was appointed chancellor of the exchequer in March, 1718 , had to struggle against an opposition by Walpole and his following in alliance with the tories, which at times descended to factiousness. In addition to the animosities ordinarily dividing politicians was the friction between the king and the prince, and the adherents of either side. At the close of November, I717, these quarrels assumed the dimensions of a European scandal. In retaliation for an affront offered by the Prince of IVales to the Duke of Newcastle at the christening of the prince's fifth child in St. VOL. IX. 
CHAP. James's Palace, the king ordered his son to quit the palace XVII. but to leave his children behind him. Circular letters were addressed to the ambassadors abroad giving the king's version of the quarrel.1 So far did the king carry his resentment as in 1718 to conceive a plan of severing his possessions in Germany from the English crown after his own death. He is said only to have desisted from endeavouring to carry this into effect owing to the opposition of Parker, Cowper's successor in the chancellorship. ${ }^{2}$

The Prince and Princess of Wales took up their residence at Leicester House, where they openly set up a court in opposition to the king. The fruits of their hostility soon became evident in parliamentary life. Their party, in concert with Walpole, unsuccessfully opposed a vote of more than I 2,000 men for the army; on which occasion the Jacobite Shippen was committed to the Tower for saying that the king was a stranger to our language and constitution (December 4, I 7 I 7). But they were not content to acquiesce in their defeat. On February 4, 1718, in the debate on the mutiny bill, opinions ran high as to the constitutional propriety of granting courts-martial the power to punish mutiny and desertion with death. Walpole expressed himself in favour of leaving these offences to the civil magistrate; but he saved the government from defeat by declaring his intention to vote for the bill, on the ground that he had rather mutiny and desertion "should be punished by martial law than not at all". In the lords the opposition was headed by Oxford, supported also by the prince's party, led by the Duke of Argyll, who, distinguished soldier though he was, did not hesitate to echo the tory declamations against a standing army. Government, however, carried the third reading by a majority of eighty-eight to sixty-one. A protest was entered by Argyll and twenty-nine peers, comprising most of the leaders of the tory party.

The enlightened temper of Stanhope had for some time past contemplated the repeal of the acts for the depression of dissent. Such a policy enlisted the sympathy of the king who, while desirous to remain on terms with the Church, was latitudinarian in his theological views. It enjoyed the

\footnotetext{
ISee draught letter to Whitwoik, November 29, R. O., MS., State Papers, Dom., G. I., bundle 10, nos. 186, 193.

See note at end of chapter.
} 
support also of a small minority of bishops, of whom Hoadly, now Bishop of Bangor, was the most distinguished. These tolerant prelates were not only willing to dispense with the fancied support lent to the Church by the test act, the occasional conformity act, and the schism act, but were disposed to some scheme of comprehension, which should bring the dissenters back upon favourable terms to the Anglican fold. Conferences with these objects were held in London at the beginning of $1718 .^{1}$ On December 13 of that year Stanhope, who had been promoted to an earldom on April 14, proposed the repeal of the last two acts and of some of the clauses of the test and corporation acts. Considering the general tendency of whig opinion, the strength of the opposition is surprising. Even Sunderland is said to have declared that he would go no further than the repeal of the occasional conformity act. ${ }^{2}$ The bishops were divided, but against the combination opposed to the bill the ministry felt it hopeless to struggle. Ministers, therefore, contented themselves with moving the repeal of the occasional conformity and schism acts, which they carried on December 19, by eighty-six to sixty-six votes. Upon the introduction of the bill into the house of commons, similar surprises occurred. Above all, Walpole, who had formerly denounced the schism act, now ranged himself with Sir William Wyndham, Sir Thomas Hanmer, and Shippen in its defence. Ministers, however, carried the bill by 243 to 202 votes on January $7,1719 .^{3}$ The debate left its mark, by increasing the virulence between the parties of the king and of the prince, who ranged himself with the opposition.

The exacerbation of feeling arising from these party mancuvres played an important part in the history of a measure introduced by Stanhope, which, had it become law, would have revolutionised the British constitution. The whigs had constantly denounced the creation, during the administration of Oxford, of a batch of twelve peers, to serve a party purpose. Ministers were apprehensive that the Prince of Wales, in the event of his succession, might avenge the affronts offered him and rid himself of their control by a similar act.

1 Portland MSS., V., 554

${ }_{5}$ G. I., c. 4 . 
CHAP. Stanhope and Sunderland accordingly recommended to the king XVII. the surrender by the crown of the unrestricted right to create peers. George, disappointed in his hope of punishing the prince with the loss of his German dominions, eagerly accepted the proposal. A bill was accordingly brought in, limiting the house of lords, after the creation of six more peers, to its existing numbers, provided that for every extinction there might be a new creation. The opposition of Scotland was sought to be bought off by the exchange of the sixteen elective of the act of union for twenty-five hereditary peerages. Had such a measure been carried the constitution would have tended to an oligarchy, perhaps to be subsequently recast in a revolution. But the only serious opposition came from Oxford, who henceforth rarely emerged from learned leisure till his death in 1724, and from Cowper, for the peers naturally acquiesced in a proposal which tended to increase their individual and collective consequence. By a majority of eighty-three to thirty votes eleven resolutions were passed as the basis of the scheme. The bill founded on them was twice read. But the increasing disfavour with which it was discussed by the public caused Stanhope, on April 14, I719, to drop it, as likely "to meet with great opposition in the other house".

The dropping of the bill by no means implied a surrender of the project. Stanhope engaged Addison to defend the scheme in a paper called The Old Whig. Steele published a counterblast in The Plebeian. But the most effective arguments against it were those of Walpole, in a pamphlet entitled, The Thoughts of a Member of the Lower House in relation to a Project for restraining and limiting the Power of the Crown in the future Creation of Peers. Nor did Walpole stop short at pamphleteering. He attended a meeting of the discontented whigs at Devonshire House. The whig principle of limitation of prerogative had disarmed, he found, other obvious objections. The general opinion ws that the bill, which it was known was to be reintroduced, shouid be permitted to pass. Walpole stood firm. It was an opportunity, he urged, for defeating the government, since the country squires on the whig side were indisposed to acquiesce in their permanent exclusion from promotion. After much debate, the majority came round to his opinion and resolved to oppose it in the commons. 
On the opening of the autumn session on November 23 the CHAP. bill was introduced by the Duke of Buckingham, whose supXVII. port was judged likely to render it palatable to the tory opposition. Resisted only by Cowper, it passed on the 3oth and was sent down to the house of commons. The bill was read a second time on December 8. In the debate Walpole, wrote Speaker Onslow, "bore down everything before him". The division resulted in the triumphant defeat of the bill by 269 to 177 votes. The controversy left behind it a memorable consequence, the dissolution of the old friendship between Steele and Addison.

In the midst of the confidence engendered by the general success of the government at home and abroad, the world was startled by a crash which shook England. The South Sea Company, as the holders of $£ 10,000,000$ of the government debt, had for some years enjoyed credit and stability, the ordinary price of the stock ranging from 105 to $I$ IO. It is true that the commercial prospectus, originally put before the public by Oxford and his pamphleteers, to which fresh advantages were alleged to have accrued by the peace of Utrecht and the new Asiento treaty of 1716 , had not been realised. (As the Bank had been founded by whigs and had remained under whig control, so the South Sea Company had been the toast of the tory party) It had elected the prince a governor, but on February 3,1718 , the king was requested to accept the place in his stead. An act accordingly passed both houses, enabling him to do so and exempting him from taking the usual oaths.

In March, 1718, Stanhope had taken over Sunderland's secretaryship of state for the northern department, vacating the offices of first lord of the treasury and chancellor of the exchequer. Of these, the first, with the presidency of the council, had been transferred to Sunderland, the second to John Aislabie, since 1714 treasurer of the navy. At the close of 1719 a project was laid before Sunderland and Aislabie for paying off the national debt by incorporating it with the stock of the South Sea Company. At this time the national debt stood at

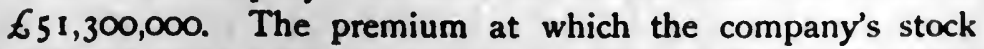
was quoted and the golden anticipations of its future would enable it to acquire the annuities of the national creditors for a comparatively low number of years' purchase. The govern- 
CHAP. ment offered 5 per cent. on the debt, to be reduced after XVII. 1727 to 4 per cent. Out of the savings a sinking fund would be formed, which at that date would amount to $£ 1,200,000$ a year. For the privilege of taking over the national debt the company offered $£ 3,500,000$ to be forthwith applied to reducing it to $£ 47,800,000$. This proposal was introduced to the house of commons by Aislabie on January 22, 1720, with the assurance that, if accepted, it would extinguish the debt in twenty-five years. There were already whispers that Aislabie had been a recent purchaser of South Sea stock, it was said to the amount of $£ 27,000$. Thomas Brodrick, one of the discontented whigs, who had voted against the ministry on the peerage bill, intervened with the suggestion that a transaction so beneficial to the undertakers should be thrown open to public competition. As the general sense of the house was in its favour, Aislabie found himself compelled to agree to receive further proposals. The Bank authorities then offered $£ 5,000,000$ for the same privileges as the company, whereupon the South Sea directors advanced upon the Bank's proposal and bid $£ 7,567,000$, which was accepted.

The act received the royal assent on April 7, 1720.1 lt may well be asked what equivalents the South Sea Company expected to obtain for this prodigious sum? The company's prospective resources may be classified under four heads. First, the profits of the Asiento, though experience had shewn their uncertainty, were reckoned by anticipation at $£ 200,000$ per annum, and wild tales were afloat of inestimable acquisitions to be made in the South Seas. Secondly, the allowance from the treasury for the charge of management was fixed at roughly $£ 10,000$ a year. Thirdly, so long as the company received from the government 5 per cent. instead of employing capital at 4 per cent., they enjoyed a margin of profit. But, lastly, the gain was really looked for in the increased market value of their stock. The infection of the French Mississippi mania which arose from a scheme projected by Law, a Scottish adventurer, was already in the air of London, and the South Sea Company was acclaimed as "the English Mississippi". . The failure of the Bank of England to obtain 
the concession was followed by a fall of Bank stock, while the CHAP. stock of the South Sea Company advanced with astonishing XVII. rapidity pending the passage of the bill through parliament. Quoted at $128 \frac{1}{2}$ on January 1, 1720, before the end of March the shares had reached over 330 . Two and a quarter millions were subscribed on April 14 at the price of 300 per cent. fixed by the directors. By the end of May the company had purchased two-thirds of the annuities.

During the months of the company's feverish prosperity the rage for stock-jobbing, which had for some years been noticeably growing, transformed English society. The spectacles witnessed by Paris while the Mississippi scheme was popular were re-enacted here. "There are few in London," wrote Edward Harley, the younger, on February 25, "that mind anything but the rising and falling of the stocks." 1 Regardless of the severe restrictions imposed by the law upon the formation of companies, new joint-stock schemes sprang up every day. Despite the advice of Walpole, the Prince of Wales allowed himself to be constituted governor of the Welsh Copper Company. The Duke of Bridgewater formed a company for building houses in London and Westminster, and the Duke of Chandos became head of the York Buildings Company. Two important corporations owe their origin to this period, the Royal Exchange and London Assurance Companies; but they had to pay $£ 600, \infty 00$ towards the liquidation of the arrears of the civil list as a condition of obtaining their charters. In the wake of these genuine schemes there rose to the surface a countless number of bubbles. Some of them, indeed, appear to have had rational industrial objects. There were, however, others which had lunacy written upon their faces, such as a scheme of $£ 1, \infty 00,000$ " for a wheel for perpetual motion," and others again which in sane times would be stamped as obviously fraudulent. Such was a prospectus for the formation of a "company for carrying on an undertaking of great advantage, but nobody to know what it is. Every subscriber who deposits $£_{2}$ per share to be entitled to $£ 100$ per annum." Even this prospectus attracted in five hours to its office in Cornhill deposits to the amount of $£ 2,000$, with which the projector decamped. The craze gave occasion to countless caricatures and pasquin-

1 Portland MSS., v., 393 : of. ibid., p. 597. 
CHAP. ades, of which last "A South Sea Ballad," printed in the seventh XVII. volume of the Parliamentary History, is a witty specimen.

It was computed that the sums sought to be raised by speculative undertakings amounted to as much as $£ 300,000,000$ sterling. A check was attempted in the spring session of 1720 by a statute making illegal bubble companies affecting to act in a corporate capacity, or, where chartered, abusing their charters by embarking ultra vires in speculative projects.1 The ministry had before their eyes the recent fall of Law, and the public indignation which was pursuing his patron, the regent. On the day that parliament rose, June I I, the king published a proclamation in conformity with the tenor of the new act, which was to take effect on the 20th, declaring all unlawful projects a public nuisance, threatening the promoters with prosecution, and forbidding any broker, under a penalty of $£ 500$, from buying or selling any shares in them. The warning proved ineffective, and the South Sea directors, thinking that a limitation of the channels of speculation was likely to improve the market price of their shares, induced the lords justices, appointed regents during the absence of the king in Hanover, instead of the prince, then in disgrace with his father, to proclaim no fewer than eighty-six bubble companies illegal and abolished accordingly. For a few days after the proclamation the anticipations of the directors were realised, and on July 16 the South Sea shares rose, for the last time, to 1,000 .

A general panic ensued among the threatened companies. The York Buildings Company's shares fell at once roo per cent., and in a few days the shares of this and other companies ordered to be prosecuted found no buyers at any price. As always happens at such crises, other shares declined in sympathy. But the heavy falls of South Sea stock soon after the middle of August were due to the action of the directors themselves. While in May annuities had been bought up at 375 per cent., in August the directors raised their terms. The stock was computed at 800 per cent., and the outstanding annuitants, who had deposited their securities, received, as compared with those who sold their annuities in May, a correspondent diminution. When this allotment became known some of the dissatisfied annuitants demanded a rescission of their contracts. They

$$
16 \text { G. I., c. } 18 .
$$


complained that they had signed the books without reading the short letter of attorney heading each page empowering three CHAP. nominees of the company to make terms on their behalf. Redress being refused, the quotations began to fall. The directors endeavoured to check the decline by declaring a dividend of 30 per cent., payable at Christmas, and not less than 50 per cent. in subsequent years. But the sales continued, and by the middle of September quotations had fallen below 400. Trhe directors were now sufficiently humbled to consider an application to the Bank of England for help, and Walpole was invited to come forward as intermediary.l He drew up a memorandum on September 19 as the foundation of a future agreement, called "the Bank contract". Reluctant at the outset to come into the agreement, the Bank, seeing the progressive depreciation of South Sea stock, refrained from completing the contract, and on November Io, when the quotation had fallen to 210 , repudiated it altogether. Nor, though it instituted legal proceedings, did the company venture to expose its affairs in a court of law.

In the course of the debate on the South Sea Company's proposal Walpole had eloquently predicted a danger to the constitution as likely to arise from making its directors masters of the public credit. As the company rose on a tide of prosperity, these anticipations, pressed upon the king, gave him some alarm. Sunderland, a speculative republican, Craggs, his creature, and Aislabie, were deeply involved in the company's affairs. The king and Bernstorff began to feel distrust. "The cabal," as the ministers were called, would, it was suggested, " be able for the future to give laws to the king and his son, and even remove them when they shall think proper." " "There is," wrote Bernstorff, "a necessity to change hands." It was evident to Stanhope and Sunderland that, unless the ministry were to be dismissed, there must be a reconciliation both with the prince and with the prince's following. The result of a consultation with Townshend, Walpole, and Devonshire was the sudden reappearance of the prince at court on April 23.

2 "Count Bernsdorfs Project," May 7, 1720, Portland MSS., v., 595, where Oxford appears by mistake for Orford (p. 596), and where the date must be the date of the copy. See also an undated and variant version in Towmshond MSS., p. 106. 
CHAP., On June $4 \mathrm{Walpole}$ received the appointment of paymaster XVII. of the forces, more lucrative, though less dignified, than the chancellorship of the exchequer. The probable secret of his acceptance was that it involved little chance of collision with Sunderland, who resigned the presidency of the council in favour of Townshend. "His [Sunderland's] temper was so violent," as Walpole afterwards explained, "that he would have done his best to throw me out of window." Stanhope and James Craggs the younger, who had succeeded to Addison in March, 1718, remained secretaries of state. Even Argyll, about whom the quarrel between king and prince had raged so furiously, was made lord steward. His enemy Marlborough continued to hold office as captain-general.

The continuous fall of South Sea stock during the autumn involved the whole system of credit. On June 24 Bank stock had stood at 263 ; on October 24 it was 145 . Minor commercial ventures strewed the City with wreckage. Ruin was widespread. While a few made large profits, hundreds of families were crippled or beggared, and the losers were more vociferous than the winners. Sunderland was a heavy sufferer. The Duke of Portland and Lords Lonsdale and Irwin were constrained to apply for governorships in the West Indies. To the chagrin of the losers was added the resentment of those who attributed their losses to the nefarious practices of the directors. Their anger reached even to the king himself, as governor of the company. He had left for Hanover on June I 4 and, during the autumn, dispatch after dispatch urged his return. It was hoped that his presence would have an encouraging effect and check the fall of quotations. It was feared that a panic might encourage the pretender to a fresh attempt. ${ }^{1}$ On November 9 George landed at Margate, but so far was the hoped-for effect from being realised that a week later South Sea stock had fallen from 211 to 135 .

Parliament met on December 8. In the house of commons the desire for vengeance was dominant. The South Sea directors were ordered to produce an account of their proceedings, and the commons in their address undertook " to punish the authors of our present misfortunes". While Bolingbroke

1 The Lords Justices to the King, September 2I, R. O., MS., State Papers, Dom., G. I., bundle 25, no. 193. 
excelled in exciting political passion, the art of Walpole was/chAP. to govern it. A passing lull in the storm of invective against XVII. the directors was produced by the reminder that the application of a remedy was more helpful than the search for a victim. The operation which Walpole proposed on the 21 st, and to which he succeeded in extorting the reluctant consent of the Bank and the East India Company, was to engraft nine millions of South Sea stock into each of those corporations. ${ }^{1}$ Though this scheme became law, ${ }^{2}$ yet being permissive, it never became operative and was superseded by an $a^{3}{ }^{3}$ of the following session.

The members of whom Sir Joseph Jekyll, regardless of party ties, was the spokesman, had no belief in Walpole's scheme, and were not disposed to allow it to be offered as a substitute for a searching inquiry. The accounts of the South Sea Company were ordered to be furnished to the house and, on January 10, 1721, Jekyll brought in a bill, which passed into an act without opposition, ${ }^{5}$ to restrain the directors from going out of the kingdom and compelling them to declare the value of their estates. A committee of secrecy was appointed, of which Thomas Brodrick was the chairman, consisting for the most part of notorious enemies of the company, Jekyll among them. In the lords the same spirit was manifested. Stanhope who, with Argyll and Roxburghe, was distinguished as having stood outside speculation, declared outright for a confiscation of the directors' estates. The young Duke of Wharton, already committed to the pretender, ${ }^{6}$ was loud for the discovery of the offenders in the hope of implicating the ministry. The bill introduced by Jekyll ordered an inquiry into the stock bought or sold by, or on behalf of, any of the officers of the treasury or exchequer since Michaelmas, 1719. On the 24th, the two houses learnt that on the preceding day Knight, the cashier of the company, who had already once appeared before the commons' committee, had fled with the company's register. His flight was, it was felt, an audacious v., 606.

'See [Thomas Harley] to Lord Harley, November 19-29, Portland MSS.,

7 G. I., st. 1 , c. 5 . 7 G. I., st. 2, c. I.

'[Thomas Harley] to Lord Harley, December 24, Portland MSS., v., $6 t 1$.

7 G. I., st. I, c. I.

- August 21, 1716, Stwart Papers, ii., 360. 
CHAP. trick to paralyse investigation. The four directors who were XVII. members of the house of commons were ordered into custody. Five who held posts under government were dismissed; Aislabie was permitted to resign the chancellorship of the exchequer which was transferred provisionally to Sir John Pratt, lord chief justice of the king's bench, though the business was supervised by Walpole. ${ }^{1}$

Both houses pursued their inquiries concurrently. On February 4 Sir John Blunt, having been cited for examination at the bar of the house of lords, refused to answer, on the ground that he had already given evidence before the secret committee of the commons. There being no precedent for a solution of this deadlock, a debate arose in which the Duke of Wharton, who had opposed the South Sea bill at its introduction, delivered a vehement philippic against Stanhope, assailing him as a second Sejanus who throve by fomenting divisions in the imperial family. Stanhope, pronounced by Speaker Onslow to have been "the best scholar, perhaps, of any gentleman of his time," was at no loss for a classical retort. Stung to indignation, he compared the duke, in heated rhetoric, to the degenerate and worthless son of the patriot Brutus. The effort was his last. He was seized in the house with an effusion of blood on the brain and died on the following day, February 5, one of the most accomplished and successful statesmen who ever presided over an administration. Already sensible of the fatigues of his office, he had contemplated exchanging it for that of captain-general, the resignation of which by Marlborough, now wrecked in health, had, a few days previously, been demanded by the king. ${ }^{2}$

The first report of the committee of secrecy was read to the house of commons on February 16 , and was followed by another nine days later. It was made apparent that the act embodying the South Sea Company's offer had been procured by lavish corruption, of which the chief agents outside the company had been the two Craggs, father and son, respectively postmaster-general and secretary of state. The elder Craggs was a dependant of Sunderland: the handsome face

1 Sir J. Vanbrugh to Lord Carlisle, February 7, 1721, Carlisle MSS., p. 29, Hist. MSS. Comm., 1897.

Ibid., p. 28. 
and captivating manners of the son had, it was said, won at Hanover the favour of one of the king's mistresses, the CHAP. beautiful Countess Platen. The committee reported that before the passing of the bill, and with the view of promoting it, fictitious stock had been created in the books of the company to the amount of $£ 574,000$, which had been noted as sold at $£ 1,259,325$. The elder Craggs had secured allotments of $£ 40,000$ of this stock to himself and $£ 50,000$ to Sunderland; the younger had made the ladies his care. In addition to $£ 10,000$ for the countess and the same sum for the Duchess of Kendal, he procured a third allotment to the same amount in favour of the countess's two nieces. Charles Stanhope, a commissioner of the treasury and a cousin of the minister, received an allotment of $£ 10,000$ stock. On the day of the presentation of the first report the younger Craggs died of small-pox, an epidemic of which was at the time scourging London. Even in this hour of downfall his body was thought not unworthy of the abbey; Compton, the speaker, bore his pall and Pope wrote his epitaph. His father, James Craggs the elder, the founder of his own and his son's fortunes, summoned to appear before the commons on March 17, died on the previous day under, suspicion of poison.

The first to ask for an opportunity to be heard was Charles Stanhope. The circumstances of the allotment to him of $£ 10,000$ stock were highly suspicious, but Walpole, who had resolved to stand by the ministry, exerted all his powers of management to secure his acquittal. By dint of pathetic appeals and influential pressure, a majority of three ( 180 to 177) was obtained in Stanhope's favour. This acquittal, wrote Thomas Brodrick to his brother Lord Midleton, "has put the town in a flame". Public indignation against the South Sea financiers resented being baulked of its first expected victim. Aislabie's case followed. His conduct had, indeed, been flagrantly corrupt. He had speculated for a rise during the progress of the bill of which he had the charge; he had accepted stock without consideration as a bribe for his services; he had burnt his account books; he had advised the directors in some of their nefarious transactions. By such devices he had accumulated, in addition to his former estate, $£ 794,000$. The house on March 8 unanimously voted him guilty of "most notorious, 
CHAP. dangerous, and infamous corruption," expelled him, and ordered XVII. him to the Tower. His conviction evoked general rejoicing. Bonfires blazed in the city and an exulting crowd welcomed him to Tower Hill. Sir George Caswall, sheriff of London and member for Leominster, followed the same fate. The case of the Earl of Sunderland came next. He had, as head of the treasury, stood sponsor to the South Sea bill. Had his conviction followed that of Aislabie it would have been impossible for the ministry to remain in office, weakened as it had been by the death of Stanhope. Walpole, it was well known, would exert himself to the utmost on his colleague's behalf. ${ }^{1}$ The evidence against Sunderland would certainly have been insufficient for a conviction in a court of law, and the earl denied the charges against him, which were founded on statements of the defaulting cashier Knight. In the passion of prejudice which, as Brodrick's letters shew, was raging in the house, Walpole felt that a mere appeal to justice was likely to be ineffective. ${ }^{2}$ He preferred to rely upon his skill in parliamentary management. He represented to the hostile whigs that the conviction of Sunderland must be followed by the incoming of a tory ministry. The argument was decisive: Sunderland was acquitted by a majority of $61 ; 233$ against 172 votes.

By March 25, in accordance with the act passed at the opening of the session, details of the fortunes of the directors were laid before parliament. A bill was introduced to sell their property and apply the proceeds, after some deductions for the maintenance of the owners, to the liabilities of the company. Despite opposition from Harcourt and Trevor, the leaders of the tory party in the lords, this proposal was, after Aislabie's defence had been heard, carried unanimously. The same course was taken, after his executors had appeared by counsel, with the estate of James Craggs the elder, acquired since December I, I 7 19. The total value of the estates confiscated under this act ${ }^{3}$ was $£ 2,014,123$, and the allowances amounting to $£ 354,600$, the balance appropriated for the relief of sufferers was

${ }^{1}$ [Thomas Harley to the Earl of Oxford], February 17, 1720-2I, Portland MSS., v., 6rg.

[W. Thomas to the Earl of Oxford], March Io, 1720-21, ibid., p. 6r7.

37 G. I., st. 1 , c. 28. 
$61,659,523$. A committee was appointed with Walpole as chairman, which drew up a series of resolutions on the best CHAP. XVII. way of dealing with the wreckage of the company. These resolutions took the form of an address to the king and afterwards of a bill.

Of this complicated measure ${ }^{1}$ but one or two characteristics can be noted here. It introduced a principle, ${ }^{2}$ which remains to the present day without a parallel in the history of our public finance. With the hope of maintaining the quotations, the directors had lent $£ 11, \infty 00,000$ on the unsound security of their own stock. By this act the debtor was to stand acquitted upon the surrender of his title to the company's stock pledged with the company and the payment of 10 per cent. of the sum borrowed. Even this fraction was by no means universally paid. By an act of the next session ${ }^{3}$ it was reduced to 5 per cent., and the company lost nearly $£ 7,000,000$ on the transaction. The comment of Erasmus Lewis, Oxford's former secretary, upon these proceedings is not without point : "I am assured there are a hundred and thirty-eight members of the house of commons who have borrowed money of the South Sea Company":4 Of the $£ 7,567,000$ which the company had offered to pay to the public, $£ 5,000,000$ was at once remitted and of the remainder $£ 2,000,000$ by an act of $1723 .^{5}$ The annuitants who had changed their annuities for South Sea stock, after a revaluation of the stock, received roughly rather more than half their former incomes. This compulsory sacrifice was keenly resented. On the day of the second reading of the bill " for the re-establishment of public credit," 1 August 3, 1721 , the lobby and passages of the house of commons were thronged with a tumultuous crowd of both sexes, crying "Justice, justice," and thrusting into the hands of members as they made their way into the house a paper inscribed: "Pray do justice to the annuitants who lent their money on parliamentary security". The justices for Westminster were sent for and the riot act read before the throng was dispersed.

Walpole's intervention in favour of the incriminated gave rise to the nickname of "the Screen," applied to him in the

17 G. I., st. 2 , c. I.

38 G. I., c. 21,818 .

That of the Greek reiodx vecia.

g G. J., c. 6. 
CHAP. numerous lampoons of the time. Mist's weekly journal pubXVII. lished attacks on the king and his mistresses, on Marlborough, and on the ministry. Mist was committed to Newgate by the house of commons for seditious libel in May, I72I. Sunderland's retention of the treasury was impossible. On April 3, I721, Walpole was appointed chancellor of the exchequer and first lord of the treasury. His brother-in-law, Townshend, had on February Io taken the place of Stanhope as secretary of state. Carteret, who at the age of thirty-one had already achieved diplomatic fame, followed the younger Craggs as secretary for the southern department. His promotion was due to the friendship of Sunderland who, notwithstanding his loss of office, still retained place and influence at court. During the brief remainder of his life Sunderland, chafing at exclusion from power, and jealous of Walpole's growing ascendancy, was engaged in constant intrigues against the ministry, with the hope of placing himself at the head of a coalition party. It is probable that his sudden death on April 19,1722 , prevented a fresh schism in the ranks of the whigs. He was followed on June 16 by his father-in-law, the Duke of Marlborough. Marlborough's combative duchess survived him till I 744 .

\section{The Will of George I. See p. 290.}

George I. conceived a plan of alienating the Electorate by will to bis cousin, the Duke of Brunswick-Wolfenbuttel. This will was in triplicate, one copy being lodged with Wake, Archbishop of Canterbury, one in the chancellery of the duke, the third in the hands of some person unknown. The archbishop produced his copy at the first council meeting after the king's death, when it was taken possession of by George II. without being read and was never heard of again by the public. Horace Walpole imputed its suppression to reluctance on the part of George II. to pay legacies bequeathed by it to the Queen of Prussia and the Duchess of Kendal's daughter, afterwards Lady Chesterfield, of whom George I. was believed to be the father. It appears, however, from the Newcastle Papers that the will was at once submitted to the electoral ministers at Hanover, and was pronounced by them to be "illegal and invalid," and likely to lead to the intervention of the imperial court. The duke's copy of the will was, in effect, bought from him in December, x $^{27}$, by a subsidy treaty of which a condition was that it should be returned unopened. See Horace Walpole's Letters (ed. 1904), x., 336-37; Newcastle Papers, Brit. Mus, Add. MSS., 32,75I, ff. 24, 59, 121, 153, and 32,753, ff. 267, 269, and a letter to the Times of January 2r, 1909, by the Hon. Evan Charteris. 


\section{CHAPTER XVIII.}

ADMINISTRATION OF TOWNSHEND AND WALPOLE.

$1721-1725$.

THE public irritation excited by the collapse of the South Sea speculation did not come to an end with the passing of reCHAP. medial statutes. "If," wrote Speaker Onslow, "some bold men had taken advantage of the general disorder men's minds were in to provoke them to insurrection, the rage against the government was such for having, as they thought, drawn them into this ruin that I am almost persuaded, the king being at that time abroad, that could the pretender then have landed at the Tower, he might have rode to St. James's with very few hands held up against him." 1 - The Jacobites generally entertained the same anticipations. Their hopes had been raised by the birth of a son to the pretender on December 31, I 720. Correspondence with the exiled court revived. The principal agents in this were John Plunkett, the inventor of the imaginary conspiracy of March, 1712, George Kelly, a non-juring clergyman, and Francis Atterbury, Bishop of Rochester and Dean of Westminster. In a general way their correspondence went by the regular mails upon which the government maintained a vigilant eye. From the letters ministers learnt that a conspiracy was being organised. They were, however, in some doubt about the identity of the London agents, to whom reference was always made under fictitious names. The persons abroad with whom the conspirators were in correspondence were General Dillon, an Irish Jacobite in the French service, Ormonde, then in Spain, and the pretender himself, correspondence with whom was high treason by statute. The 
CHAP. first blow struck by the ministry was the arrest of Kelly on XVIII. May 19, I722. Keeping the messenger at bay with a drawn sword, he burnt some documents and, no sufficient evidence being forthcoming against him, he was released on bail on June 7. Emboldened by his impunity, he at once resumed his correspondence with Dillon and by a change of pseudonyms enabled the government to complete the chain of identifications.

Atterbury as a theologian and a scholar stood at this time at the head of the tory high churchmen. For his services to high orthodoxy he had been promoted by the presbyterian Harley to the see of Rochester, with which, as being worth no more than $£ 500$ a year, he was allowed to hold the deanery of Westminster. Whether or not he had at the queen's death offered to Bolingbroke to proclaim the pretender in his lawn sleeves at Charing Cross, a more than doubtful story, his disaffection to the new dynasty had been made notorious by his refusal to sign the loyal declaration of the bishops after the rebellion of I7 I5, on the pretext that it contained reflexions on the High Church party. At the same time he was in close relations with the Jacobites, and was recognised by the pretender as a friend of such importance that, by an instrument dated September 23, 1716, he constituted the bishop his "resident" or principal agent in England. 'While it was well known to the government that he was intimate with Kelly, his name never appeared in the correspondence, nor were any letters intercepted in his handwriting, but three intercepted letters, in that of Kelly, were suspected to be his. On August 24, 1722, Atterbury was arrested and sent to the Tower. ${ }^{2}$ A number of arrests followed in September. Lord North and Grey was seized in attempting to escape from the Isle of Wight. Charles Boyle, Earl of Orrery, and a disreputable barrister named Christopher Layer, were taken in London, and a young Irish priest named Philip Neynoe at Deal. The new parliament, which had a large whig majority, was called together on October 9. The king's speech acquainted the houses with the discovery of a con-

\section{${ }^{1}$ Stuart Papers, ii., 466.}

2 The assignment of August 22 to a letter in the Portland MSS., vii., 332, giving an account of his arrest is evidently a mistake, since the original warrant, dated August 24, is in the R. O., MS., State Papers, Dom., G. I., bundle 38. 
spiracy and a bill was brought into the house of lords by CHAP. the Duke of Grafton, lord-lieutenant of Ireland, to suspend the XVIII. Habeas Corpus act for a year. Since no precedent could be shown for a suspension extending over six months, considerable opposition, headed by Cowper, was made to this proposal and was renewed in the commons. The bill only passed the commons by a majority of fifty-three on the 16 th.

The first prisoner put on his trial was Layer, who was brought before the court of king's bench on November 21 . He had visited the pretender at Rome in the company of Plunkett, and returned with credentials to the leading Jaccbites at home. Among his papers was found one which, under the name of "The Scheme," revealed the details of the plot. The Tower, the Bank, the persons of the king, the Prince of Wales, and Earl Cadogan, the commander-in-chief, were to be seized; Lord North and Grey, a lieutenant-general under Marlborough, who had lost a hand at Blenheim, was to take command of the disaffected soldiers; Ormonde and Dillon were to bring over arms and, if possible, troops; General Webb, who since the affair of Wynendaele had cherished an implacable resentment against Cadogan, and in 1715 had been forced to sell out, was also to hold a command, ${ }^{1}$ as was another dismissed general officer, Atterbury's old pupil, the Earl of Orrery. In the case of the bishop, Kelly, and Plunkett, the evidence was insufficient to obtain a conviction in a court of law. It was determined, therefore, in the interest of public safety, to banish them from the kingdom by a bill of pains and penalties. The bishop delivered impassioned protestations of innocence, which at the time failed to carry credit, and are now conclusively proved by the Stuart Papers to have been false. He was defended by Sir Constantine Phipps and other counsel, but the bill against him passed the lords by eighty-three to forty-three, depriving him of all preferments and banishing him the realm on pain of death. Similar bills passed against Kelly and Plunkett. As for the other leaders of the conspiracy, Neynoe was drowned in the Thames in an attempt at escape, and Layer, respited from time to time with the object of extracting

I Cf. Stwart Papers, ii., 67-69, Ap. 7, 1716. Webb and others thought 6,000 regular troops sufticient. R. O., MS., State Papers, Dom., G. I., bundle 53, no. 14, February 12, 1722-22. 
CHAP. information, was executed at Tyburn on May I7, 1723, and XVIII. his head set on Temple Bar. But the characteristic clemency of George I. asserted itself. Orrery was released from the Tower on bail, after a six months' confinement, on a certificate from the celebrated physician Dr. Mead that his life was endangered. No proceedings were taken against Webb, who, as the Stuart Papers shew, had plunged deep in treason in 1716 , for his valour at Oudenarde had not been forgotten by the king, who witnessed it. Even Lord North and Grey, who was most deeply involved, was admitted to bail on the king's departure for Hanover in June, 1723, and suffered to retire abroad. An absurd declaration by the pretender which had been put into circulation, inviting George to retire to Hanover with the title of king, was ordered by the lords to be burnt by the common hangman. A secret letter from him to the Archbishop of Canterbury, with the usual assurances as to the Church of England, fell into the hands of the government.1

While Townshend controlled foreign affairs, Walpole was left sole master of domestic policy. His earliest action after resuming office was to revolutionise the traditional official attitude towards international commerce. He saw that the removal and reduction of export duties on manufactures and of import duties on raw material was a natural course by which to encourage exports. This was the policy announced in the speech from the throne of October 19, 1721. The attention of the statesmen of Anne had been attracted to the danger of remaining dependent on the Baltic trade for naval supplies, and premiums had been put upon tar, pitch, masts, etc., imported from the American colonies and from Scotland. These were now continued and export duties on colonial naval stores abolished. In 1722 a less judicious measure, since it carried with it a semblance of religious persecution, was a consequence of the discovery of the recent conspiracy. This was a proposal suggested by Walpole for raising $£ 100,000$ by an extraordinary tax of 5 s. in the pound on the estates of Roman catholics and non-jurors. This ill-advised measure created dissatisfaction among classes not directly aimed at. In order to establish who were non-jurors and who were not, it was necessary to impose an oath upon all.

I R. O., MS., State Papers, Dom., G. I., bundle 5I, no. 36, Rome, December $27,1722$. 
Those who did not take it by December 25, 1723, were compelled to register their estates. An impression got about that CHAP. not to take the oaths involved forfeiture. "It was," records Speaker Onslow, "a strange as well as ridiculous sight to see people crowding to give testimony of their allegiance to a government and cursing it at the same time for giving them the trouble of so doing." As a practical outcome the sum raised fell considerably short of what had been anticipated.

When Atterbury, having left England for ever in June, 1723, set foot on the French shore at Calais, he was told that Bolingbroke had just arrived in the town on his return homewards from exile. Both Stanhope and Sunderland had been favourable to Bolingbroke. Walpole, on the other hand, from the time of his passing into opposition in the spring of 1717 , displayed strong hostility. But the favour of the Duchess of Kendal had been enlisted by a bribe of $£ 12,000$ from the purse of Bolingbroke's second wife, the Marquise de Villette, and Walpole was not the man to sacrifice court favour for the gratification of animosity. In May, 1723, the pardon passed the great seal and Bolingbroke was thereby enabled to return, though George could neither restore his forfeited estate nor reinstate him among the peers without a repeal of the act of attainder against him. To procure this was henceforth the goal of his endeavours.

John Carteret, Lord Carteret, now secretary of state for the southern department, was, to a scarcely less extent than Stanhope, a man of the highest culture and conversant with most of the European languages. Alone among the ministers he enjoyed the advantage of being able to address the king in his native German. This accomplishment also ingratiated him with Bothmer and Bernstorff and with the king's German mistresses. Conceiving himself the depositary of the traditions of Stanhope and Sunderland, and relying upon his favour with the Germans, he naturally tended to vindicate for himself an independence of Townshend and Walpole. The accession of Spain to the Quadruple alliance in February, 1720, had not cleared up all the outstanding difficulties with Great Britain. Stanhope's conditional proposal to surrender Gibraltar had taken hold of the Spanish imagination. But by the time Carteret had acceded to office this offer, which when made had not met with accept- 
CHAP. ance, had been decisively condemned by public opinion. At XVIII. first, however, the court of Spain refused to negotiate until, at least, a promise of the surrender should be made, subject to the concession of an equivalent by Spain and to the consent of parliament. It being certain that no such consent would be given, George had no scruple in expressing his willingness to make the surrender, and promising to obtain the consent of parliament on the first favourable opportunity. ${ }^{1}$ The Spanish court was probably not deceived, but the point of honour was saved. A few days later, June I3, I 72 I, a treaty with Spain was signed at Madrid. Throughout this thorny negotiation France had steadfastly supported Great Britain. The regent asserted his view that the question of Gibraltar need not affect the renewal of the treaties which had subsisted prior to the war. His determination to maintain friendly relations was further expressed by his accession to the treaty of Madrid. 2 A defensive alliance between England, France, and Spain was thereby constituted, to be kept secret from the emperor, but to avail for the exercise of pressure upon him to effect an adjustment of his outstanding difficulties with Spain. These were to be settled at a congress to be held at Cambray, at which England and France should play the part of mediators.

Carteret's desire to please the king's German favourites, especially the Countess of Darlington and her sister-in-law, the Countess Platen, induced him to lend zealous support to a projected match between the Countess Platen's daughter and the Count St. Florentin, son of the Marquis de la Vrillière, the French secretary of state. At this time (1723) George I. was at Hanover, accompanied both by Carteret and Townshend, each jealous of the other's influence. The king's mortification at a rebuff suffered in the course of the marriage negotiations was a triumph for Townshend and the Duchess of Kendal. The duchess had been interested to thwart a scheme gratifying to the ambition of Lady Darlington, and Townshend was anxious to discredit Carteret. The two combined to persuade

1 June I, 1721, [the King of Great Britain] to the King of Spain, Delaval MSS., p. I96, Hist. MSS. Comm., 1893 .

3 By another treaty of the same date. Garden, Histoire Ginerale des Traités de Paix, iii., II7. 
the king to send Horatio Walpole, younger brother of Robert, to Paris under the pretext of negotiating the accession of CHAP. Portugal to the Quadruple alliance, but really to thwart Sir Luke Schaub, the ambassador, who possessed Carteret's confidence. The recall of Schaub followed in April, 1724. Nor was this the only blow to Carteret's ambition. He urged a naval demonstration in the Baltic against Peter, a proposal gratifying to George's dislike of that sovereign, who was supporting his son-in-law the Duke of Holstein-Gottorp in claiming Schleswig which by the treaty of Fredericksborg of July, 1720 , had been guaranteed to Denmark by Great Britain and France. Townshend opposed. Though the destruction of the Russian fleet would have served the interests of Hanover, a gratuitous embroilment was not desirable for Great Britain. It illustrates the king's soundness of judgement and his loyalty to his obligations towards his kingdom that he adopted the advice of Townshend.

While, however, George rejected the spirited foreign policy of Carteret, he resolved on strengthening his position in North Germany. His daughter, Sophia Dorothea, Queen of Prussia, had planned a double marriage tie between Prussia and England: her nephew Frederick, the eldest son of the Prince of Wales, was to marry the Prussian princess royal, afterwards Margravine of Baireuth ; and her own son Frederick of Prussia, afterwards Frederick the Great, an English princess. To promote this project, she accompanied her husband, King Frederick William, to the court of Hanover at the end of June, 1723. Reluctant though he was to visit his son-in-law, the Prussian king, the anxiety inspired by the tsar's movements disposed George to pay a return visit to Berlin in the following October, of which the Margravine of Baireuth, his granddaughter, has left a lively account. The treaty of Charlottenburg between Great Britain and Prussia settled on October 12, though never ratified by George, provided for the double marriage, renewed existing treaties, and included in its scope the king's German possessions. Great expectations were entertained of this treaty. "The King of Prussia," wrote an English diplomatist, "appears in the best humour imaginable and treats our king with an affection and respect which neither the czar, nor perhaps the emperor, will be much pleased to hear 
CHAP. Of." 1 The tsar's retort was the reception of a Jacobite agent in XVIII. Petersburg and an attempt through him to engage France in a plan for a Stewart restoration. ${ }^{2}$

During the struggle between Townshend and Carteret, of which Paris was the scene, and the Platen marriage the occasion, Bolingbroke had exerted his influence at the French court in the interest of Townshend and Horatio Walpole. Townshend had in July, 1 723 , assured him of the king's goodwill, and he now looked for reward in the form of a complete rehabilitation. Walpole refused. He foresaw the difficulties for the administration which would follow Bolingbroke's readmission to the house of lords, and consented only to the restoration of his fortune, but not of his peerage. On April 20, 1725, Bolingbroke's petition was presented to parliament, praying to be restored to his family inheritance. The bill once passed, he retired for a while to country pursuits at an estate called Dawley, near Uxbridge. But whatever his professions might be, his mind was not, like that of Oxford who had died on May 21, 1724, of a cast to resign itself to exclusion from power. Against Walpole, as the opponent of his full restitution, he cherished an implacable resentment. He began to organise in and out of parliament, by pamphlets and intrigues, an opposition to the ministry. On December 5, 1726, appeared the first number of The Craftsman, in which he penned a weekly philippic against Walpole. He induced the Duchess of Kendal to lay before the king a letter of indictment against the administration with a verbal undertaking, if audience were granted him, to convince him of its truth. The king, whose character was straightforward, at once shewed it to Walpole and at his instance reluctantly consented to receive his accuser. Bolingbroke's indictment was patiently heard by George, and dismissed by him as "bagatelles".

The friction between England and Ireland both with respect. to economic and constitutional relations had long been steadily increasing. In I 79 a crisis arrived. A private litigation, Sherlock $v$. Annesley, had been decided by the Trish Court of Exchequer on February 24, 1709, in favour of the defendants, the

1 Poyntz to Delafaye, Göhrde, Monday, November 15, I723, N.S., R. O., MS., State Papers, Dom., G. I., bundle 51, no. Iog.

Ibid., bundle 56, no. 9 . 
judgement reversed by the Irish house of lords on June 19,1716 , and the first judgement confirmed on appeal to the British house CHAP. of lords. The Irish house of lords, thereupon, in an address to the king, declared its claim to be the ultimate court of appeal for Ireland. The government; however, alert to check symptoms of Irish independence, passed a bill through the British parliament denying the claim of the Irish house of lords and laying down the principle that the statutes passed by the parliament of Great Britain were binding upon the people of Ireland. ${ }^{1}$ As if to give a practical illustration of the significance of this "act for the better securing the dependency of the kingdom of Ireland," which became law in 1720 , the British parliament in the session of $1720-2 \mathrm{I}$ dealt a blow to the Irish cotton industry. By an act passed avowedly in order to encourage the English woollen and silk manufactures, the wearing in Great Britain of printed and dyed calicoes was forbidden. This, though it equally applied to British, in effect shut out Irish calicoes from the English markets. On behalf of a people quick to feel, though patient to suffer injustice, Swift in 1720 took up the challenge. ${ }^{2}$ His pamphlet, A Proposal for the Use of Irish Manufacture in Clothes and Furniture of Houses, \&c., utterly rejecting and renouncing every thing wearable that comes from England, swept like a flame through stubble. Considering the provocation, the language was moderate enough. The government took alarm. The author being unknown, a prosecution of the printer was ordered. The jury refused to convict, and proceedings were ultimately dropped in August, 1723 , by a nolle prosequi.

From this beginning dates Swift's appearance as an Irish patriot, though still behind a transparent veil of anonymity. In the same year, 1720, which saw the South Sea mania in England, his Essay on English Bubbles and his satires upon the project for a national bank of Ireland effected its rejection by the Irish legislature. Jealousy was aroused by representing

16 G. I., C. 5 .

'No explanation is given, either in Scott's Memoir of Swift or in Craik's Life or elsewhere, of the reason why Swift at this time produced his pamphlet, and the point has been obscured by the erroneous date assigned by Scott to the letter to Pope mentioning Whitshed as chief justice, which should be January 10, 1721-22. When attention is drawn to the then recent statute of the British parliament there can scarcely be much doubt of the occasion of Swit's wrath. 
CHAP. it as a device by which England in exchange for paper would XVIII. draw the gold and silver out of the country.

Experience during more than a hundred years of the proceedings of English governments justified an apprehension which might otherwise have been supposed fantastic. Elizabeth and James II. both flooded Ireland with base money, the first to impoverish the rebels, the second the protestants. The natural consequence was the efflux of gold and silver, the more rapid in that the payments due to absentee landlords and to the crown were a serious drain. The general silver currency of Ireland at the end of the second decade of the century consisted of moidores worth thirty shillings apiece. Yet England while prohibiting the export of coin to Ireland repeatedly refused to allow Ireland to set up a mint of its own and coin money of the same standard and value as England. There was some dispute as to the sufficiency of the copper coinage. Swift, in his letters, does not deny that halfpence were needed. Indeed, he estimates a coinage of $£ \mathrm{I} 0,000$ in halfpence as desirable and sufficient, while even Primate Boulter, the champion of "the English interest," and therefore of the ministry, afterwards stated that $£ \mathrm{I} 0,000$ or $£ \mathrm{I} 5,000$ would have fulfilled the demand. Such being the condition of the Irish coinage, a royal letter was sent from Kensington on June 16,1722 , commanding the English law officers to draught an indenture granting to "William Wood of Wolverhampton, in the county of Stafford, Esquire," the right to coin copper halfpence and farthings for Ireland to the value of $£ 100,800$; for which privilege Wood was to pay the comptroller of the coinage $£ 200$ yearly and $£ \mathrm{I} \infty 0$ per annum into his majesty's treasury. The patent was to run for fourteen years; a hundred tons of the whole quantity of 360 tons was to be issued the first year and twenty tons each year for the thirteen years remaining.

The patent was currently said to have been procured by Sunderland, though he died some months before the issue of the king's letter, for the benefit of the Duchess of Kendal, who sold it to Wood for $£ 10,000$. Wood set to work in the Seven Dials, at the end of 1722 or the beginning of 1723 . From London he conveyed his coin to Bristol for shipment, and before the end of 1723 had uttered seventeen thousand pounds' worth of halfpence and farthings in Ireland. The first note, of pro- 
test was sounded by the commissioners of revenue in Dublin, in a letter of August 7,1722 , to Edward Hopkins, the secretary CHAP. to the lord-lieutenant. Their complaint was against the grant of the patent on the ground that the revenue had already "suffered very much by too great a quantity of such base coin". No notice was taken of this nor of a subsequent letter. Meanwhile the coin itself was giving dissatisfaction. The patent allowed the coinage of thirty pence out of a pound of copper, whereas English halfpence were at the rate of twentythree pence to the pound. According to Swift, corroborated by Archbishop King, there were four sorts of halfpence, "three of them considerably under weight". When the Duke of Grafton, the lord-lieutenant, landed in Ireland on August 13 , 1723, he reported to Walpole that the Irish privy council had only awaited his arrival to send a representation to England, and that the matter had become "the subject of all conversations both in town and country". He concluded with a hint that it might perhaps "end in a manner disagreeable to us both".

Archbishop King, who, with Midleton, the chancellor, led the opposition within the official hierarchy, was one of the comparatively few native Irishmen in enjoyment of eminent place in their own country. Though a high churchman, he was an intrepid thinker, and his work $D_{\varepsilon}$ Origine Mali, which had excited philosophical controversy in France and Germany, still finds its place on the shelves of metaphysicians trained in the Oxford schools. Such a man commanded a consideration which no English ministry could afford to neglect. The other official leader of the opposition to the new coinage, Lord Midleton, was also Irish by birth. He had been a consistent whig, and being favourable to religious toleration had been dismissed by Harley's ministry in I 7 I from the post of chief justice of the queen's bench. In opposition to the tory government, he had been elected speaker of the Irish house of commons in 1713, and shortly after the accession of George I. had been rewarded with the chancellorship and a peerage.

The session of the Irish parliament began in September, 1723. On the 27th the commons voted six resolutions, that the patent was prejudicial alike to the revenue and to trade; that it had been obtained by misrepresentation; that the coin was inferior to the conditions imposed; that it would involve 
CHAP. a loss to the nation of 150 per cent., and that it was frauduXVIII. lently coined; finally, they laid down the principle that the right to coin ought not to be granted either to individuals or corporations. A similar address was voted by the house of lords. The addresses were sent to Carteret at Hanover to be laid before the king. Walpole was not a man easily intimidated. $\mathrm{He}$ regarded the agitation as a cabal of the chancellor, his brother Thomas, and his son St. John Brodrick, fomented by Carteret and exaggerated by the timidity of the lord-lieutenant. A letter from Carteret to Grafton, acquainting the duke that he had laid the addresses before the king, effectually disposes of the suspicion against him. ${ }^{1}$ Both Walpole and Townshend lost their tempers, not with the Irish people but with the unfortunate Grafton. To the parliament of Ireland, upon Walpole's recommendation, a pacific answer was returned, promising to inquire into and punish any frauds committed by the patentee. In the house of lords Archbishop King headed a minority who opposed an address of thanks to the king on the ground that this answer was unsatisfactory.

As the winter wore on, Wood's coinage began to rank with the other grievances of Ireland against England. Walpole, disliking and distrusting Midleton, persuaded the king, who had arrived in England on December 19, that the chancellor was at the bottom of Irish discontent, and Carteret, who had made himself the apologist of the Brodricks, had the mortification of conveying to Grafton on January 7, I 724, an intimation that his protégé's dismissal had been resolved upon. It was a presage of Carteret's own fall. On April 3, Walpole obtained the dismissal of his rival from the secretaryship of state and his appointment as lord-lieutenant in Grafton's place. It has been suggested that his nomination of Carteret to this difficult post was made with a malicious anticipation of his failure. But Carteret's character, which Chesterfield describes as "bold, enterprising, and overbearing," possessed qualities to the lack of which Walpole had imputed the failure of his predecessor. Worried by the dispatches of Grafton, which shewed the dangers attending a policy of inaction, the English ministry at last on the 9th opened an inquiry before a committee of the privy council.

1 Brit. Mus., Add. MSS., 22,254, f. 30 . 
While the inquiry in London was proceeding there was published in Dublin $A$ letter to the shop-keepers, tradesmen, CHAP. farmers and common people of Ireland, "By M. B. Drapier". With the artifice of a simple style the author held up Wood's coins to execration and ridicule. They were worth but onetweelfth of their nominal value ; they would drive all the gold and silver out of the country; a cartload would scarce pay a moderate debt ; the patent allowed Wood to coin thirty pence out of each pound of copper, and copper was worth twelve pence a pound, so that, as the Irish parliament had declared, there was a loss to Ireland of $\mathrm{I} 50$ per cent. per pound. As for the royal prerogative, it was not concerned. The patent did not oblige any one to take copper, and was, in fact, restricted by statute from doing so. The remedy, therefore, was to refuse the coin. The pamphlet instantly obtained a wide circulation and was generally and justly suspected to be from the band of Swift. On July 24 the committee of inquiry in London published the apology for the patent, penned by the skilful hand of Walpole. The committee annexed to its report the assay of the coins, bearing the great name of Sir Isaac Newton as master of the mint. According to this assay the coins proved " in weight, goodness, and fineness . . . rather exceeding the conditions of the patent than being any way defective". As the coins submitted by Wood were an issue coined after March 25,1723 , differing in pattern and, it was alleged, in weight from the issue of 1722 , of which the complaints had been made, this certificate was irrelevant. The committee concluded with the inconsistent advice that the patentee who had thus conscientiously fulfilled his share of the bargain should nevertheless be restricted to a total issue of $£ 40,000$.

In a second letter the Drapier treated the controversy as one between Wood, the London hardware man, and the parliament and people of Ireland. This prepared the way for a third letter dated August 25 and addressed "to the nobility and gentry of the people of Ireland," which recites the catalogue of Irish grievances. "Am I," the Drapier asks, "a freeman in England and do I become a slave in six hours by crossing the Channel ?" It was an echo which the whole nation could hear of language with which Archbishop King had scandalised the lord-lieutenant at the council board, " that since the king's accession, by an act of 
CHAP. the legislature of another kingdom, they werein some respects XVIII. put under slavery". Ireland was aflame. Resolutions were everywhere passed to refuse Wood's coins. The Drapier's letters were cried throughout the country. The officials shared the popular feeling. The lords justices, the chancellor, Midleton, Lord Shannon, and Speaker Conolly, the new lord-lieutenant not having arrived, refused to issue orders for the circulation of the coin. Walpole began to express doubts about pressing the matter further. The reduction of the amount authorised to $£ 40,000$ afforded no satisfaction, because $£ 40,000$ was agreed to be in excess of any possible demand. When Carteret landed at Dublin on October 23, the hawkers were crying the fourth Drapier's letter, addressed "to the whole people of Ireland". The fourth letter, in Carteret's opinion, "struck at the dependency of Ireland on the crown of Great Britain". Midleton, whose former unpopularity had been due to his assertion of this principle in the controversy between the British and Irish houses of lords, concurred that this was sedition and should be prosecuted. It was agreed at a council meeting that a proclamation should issue offering a reward of $£ 300$ for the author. Only Archbishop King and three others dissented. Harding, the printer, was arrested and thrown into prison. Through a fire of pamphlets and pasquinades from the pen of Swift and other nationalists, the government went blundering on. One grand jury returned an ignoramus to the indictment against the printer; a second, summoned by Chief Justice Whitshed with doubtful legality on November 28, carried the war into the enemy's camp by a presentment against the halfpence.

In the course of the summer the ministry had selected for the vacant archiepiscopal see of Armagh, which carried with it the primacy of all Ireland, a man who for nineteen years became the leading figure of Irish history. Hugh Boulter, Dean of Christ Church and Bishop of Bristol, was sent to Ireland in November, I724, as the representative of a policy in Church and State which should suppress Irish nationalism. But Boulter, despite his primary care for "the English interest," was capable of perceiving that the English connexion itself was in danger. Though Walpole had long had his doubts, Townshend remained obstinate. When, in December, Carteret advised 
that if the patent were cancelled, the two houses would be CHAP. amenable and would vote Wood a compensation, Townshend XVIII. angrily asked whether the king was to drive bargains with the Irish parliament. In January, 1725, Boulter was repeating Carteret's advice. It was in vain, and Carteret determined on a final effort in favour of the halfpence. Persuasion, flattery, menace were lavishly distributed. Midleton felt his position no longer tenable and resigned in May. Yet the government dared not face popular obloquy by giving Whitshed his place. Time was wearing on. The Irish parliament was to meet in September. Ministers in England would do nothing; those in Ireland could do nothing. Boulter in July, and early in August Carteret, wrote to London acknowledging failure. The business of the session could not be carried through unless Carteret were authorised to declare at its opening that the patent was cancelled. On August 26, he was able to announce to the Irish privy council that the English ministry had yielded. Wood was granted a pension on the Irish establishment of $£ 3,000$ per annum for eight years, a small part, indeed, of the gross profit contemplated by him, which has been estimated at 692,248 , but probably enough to indispose him to demand that his patroness should return his bribe. Of this, the first constitutional victory of the people of Ireland over Great Britain, Swift was the popular hero. Medals were struck in his honour. The "Drapier's head" became a common sign. Whigs and Jacobites, papists and protestants, united to acclaim the man whose pen had evoked from a country of distracted factions an effective sense of nationality.

While the tempest in Ireland was still at its height, trouble with Scotland began to add to the embarrassments of the ministry. The resistance to the imposition of the malt tax offered by the Scottish representatives in both houses in 1713 , had so far been effective that the collection of the tax had been waived. To the English squires it appeared a flagrant injustice that their country should have imposed upon it a burden of $\$ 750,000$ a year from which Scotland was exempt. With the hope, however, of avoiding a revival of the former controversy, Walpole proposed to substitute for the malt duty of sixpence a bushel a duty of threepence a bushel for Scotland, with the proviso that if the sum derived thence did not 
CHAP. reach $£ 20,000$ a surcharge to make up that amount should be XVIII. levied on the Scottish maltsters. The outcry against the union was at once revived. Riots occurred in Glasgow. In Edinburgh Walpole's manager for Scotland, the Earl of Ilay, Argyll's brother, broke up a combination of brewers. Roxburghe, a sympathiser with the malcontents, was dismissed, ${ }^{1}$ and the business of the Scottish secretary's office was divided between the two English secretaries of state, Townshend and Thomas Pelham-Holles, Duke of Newcastle, who had succeeded Carteret on April 3, I 724, as secretary of state for the southern department. By the beginning of September all resistance was over. In the meanwhile General Wade, with the assistance of loyal highlanders, ${ }^{2}$ carried out a great disarmament of rebel clans. "We have once more," wrote Walpole to Townshend on September 3, I 725, "got Scotland and Ireland quiet, if we take care to keep them so."

1 On the plea of convenience of business. R. O., MS., State Papers, Dom., G. I., bundle 64 , no. 45 .

2 This appears to have been the first occasion, at any rate since the revolution, on which highlanders were raised and drilled as regular forces in the British service. Wade reported to Henry Pelham, then secretary at war, "that the highland companies are compleat and in good order; that they encamp with the rest of the troops and improve daily in their exercise and discipline". September 3, I725, R. O., MS., State Papers, Dom., G. I., bundle 64, no. 66. See also ibid., no. 169 . They were six in number, in all 486 men. 


\section{CHAPTER XIX.}

\section{TREATIES OF VIENNA AND HANOVER.}

THE death of the industrious treaty-maker Stanhope, on February 5,1721 , left the powers of Europe constrained by obligations CHAP. which, while they created a public sentiment adverse to the violation of peace, were nevertheless acquiesced in with reluctance. Spain remained, as before, the quarter from which disturbance was most threatening. After Alberoni's fall in 1719 power passed into the hands of Elisabeth Farnese, the second wife of Philip V., whose restless ambition it was to carry into effect the investiture of her son, Don Carlos, with the Italian duchies, as stipulated by the Quadruple alliance. Peace was, indeed, purchased by treaties signed at Madrid by France, on March 27, and by both England and France on June 13, 1721, pledging them to insist upon the execution of the emperor's concessions. But Charles was not only reluctant to fulfil these agreements; he also cherished ambitions viewed with distrust and hostility by the maritime powers. By the treaty of Utrecht the inhabitants of the Spanish, now Austrian Netherlands, had lost the privileges of trade with the West Indies derived from their former dependence upon Spain. It was the loss of a right which might be utilised for the advantage of the imperial revenue, and Charles accordingly designed to recover it. As early as 1714 he had issued commissions to shipowners of Ostend with powers to trade to the East Indies. For years these commissions had been the subject of expostulations by the English and Dutch envoys at the court of Vienna, although, for lack of others, the commanders were frequently English or Dutch. It was felt by parliament that the infraction of the East India Company's charter by British "interlopers," most, if not all Jacobites, flying a foreign flag, was not to be tolerated. In VOL. IX. 
CHAP. I 7 I9 and I72I bills were passed rendering such interlopers XIX. liable to imprisonment and heavy pecuniary penalties. Upon the suggestion of the intriguer, John Ker of Kersland, the emperor retorted by incorporating in December, 1722, an Ostend East India Company, the organised competition of which at once made itself felt in England and Holland. Both powers appealed to the sixth article of the treaty of Münster of 1648 , which debarred "Castilians," which it was argued meant subjects of the Spanish crown, among them the inhabitants of the Netherlands, from the East India trade. But capital is not always a respecter of national interests, and there were signs that British investors were being attracted to this new field of profit. A statute of 1722 , therefore, forfeited their subscriptions and triple their value, one-third of the forfeitures to go to the crown and two-thirds to the East India Company; British subjects found in India without authorisation from the company were made liable to imprisonment.

With this irritation growing between the maritime powers and the emperor their plenipotentiaries arrived at Cambray early in I 722. The business was to settle the outstanding differences between Spain and the emperor. To Elisabeth Farnese the most pressing concern was the immediate investiture of Don Carlos with the succession to the duchy of Parma. Some two years were consumed in dilatory negotiations bandied to and fro between the courts as to the conditions and form of the investiture. To solicit the active aid of France and England the Count de Monteleone was accredited to Paris and London in September, 1724. Miscalculating the effect on the English temper he took occasion to demand the restitution of Gibraltar. Although Townshend had expressed his willingness to exchange that fortress for Florida or valuable commercial concessions from Spain, this was scarcely a moment, when Spain came forward as a petitioner with empty hands, to advance a peremptory demand. To Monteleone's request for aid, therefore, Newcastle returned a refusal, and Philip and Elisabeth acquired a fresh grievance against England. In this tension the political adventurer, Ripperdá, then influential at Madrid, pressed as an alternative policy the establishment of friendly relations with the emperor by double marriages between the two houses. The emperor, on his side, began to look to Spain as able to confer 
exclusive privileges on his Ostend company. In the spring of CHAP. 1725 the rejection of the Infanta as the bride of Louis XV. $\mathbf{X I X}$. exasperated Spain against France, and as England declined to undertake the office of sole mediator between Spain and Austria at Cambray, Ripperda was instructed to negotiate terms with Austria directly. By the treaty of Vienna (in three separate agreements dated April 30 and May I, 1725), Spain guaranteed the emperor's pragmatic sanction, providing for the succession of Maria Theresa to his hereditary dominions, while the emperor confirmed the concessions to Spain of the Quadruple alliance. By the second agreement Charles undertook to assist Spain by friendly representations, though not necessarily by warlike means, to obtain the restitution of Gibraltar and Minorca. By the third, a treaty of commerce, the emperor's subjects were placed on a footing superior to that of Great Britain and Holland, and the trade of the Ostend company with the East Indies and the Spanish ports was formally sanctioned.

Of these treaties only the first was published. Philip and Elisabeth received the news with elation and, as if certain of the active aid of the emperor, summarily demanded the surrender of Gibraltar in July." "Choose," cried Elisabeth to Colonel Stanhope, "between the loss of Gibraltar and that of your trade with the Indies." The reply of Townshend, then in Hanover, was "that the king thinks it not consistent either with his or the nation's honour, after the treatment both his majesty and his people have received from the court of Spain, to lay his Catholick majesty's demand of the restitution of that place before the parliament ; the late behaviour of Spain towards him and his kingdom having set him at liberty from any engagement his majesty might have been under of doing it ".2

With the announcement of the treaty of Vienna the congress of Cambray dissolved. There was a general expectation of war. Ripperdá bragged of an intended Spanish invasion of England to restore the pretender, in co-operation with a Russian fleet from the Baltic. Against a combination threatening so much mischief it naturally fell to the lot of Great Britain to construct a counter-confederacy. France excepted, the principal members

1 Newcastle Papers, Brit. Mus, Add. MSS., 32,743, f. 414 . no. 141 .

- December 3-14, 1725, R. O., MS., State Papers, Dom., G. I., bundle 64, 
CHAP. of this confederacy would necessarily be the leading protestant XIX. powers, Prussia, Sweden, Denmark, Holland, and the protestant princes of the empire. Townshend had, in fact, not waited the issue of Ripperdá's negotiations to draught an alliance with France and Prussia. ${ }^{1}$ He enlisted Frederick William by guaranteeing his succession to the duchies of Berg and Jatlich, which was the key to Prussian diplomacy. Stephen Poyntz, our envoy to Stockholm, by an expenditure of $£ 50, \infty 00$, to the mind of Walpole distressingly lavish, overpowered the Russian party in the Swedish senate. The defensive alliance was signed at Hanover on September 3, 1725, and is thence known to history as the treaty of Hanover, between Great Britain, France and Prussia, to which the adhesion of the other protestant powers was presently invited. That of the Statesgeneral was of special importance; but jealousy of English trade, tempting offers from the emperor, and the intrigues of the Spanish party delayed their accession till August, 1726.

When the treaties of Vienna and Hanover were laid before the house of commons on February IO, 1726, Shippen raised the objection that the treaty of Hanover was framed "for the defence of his majesty's dominions in Germany," contrary to the act of succession. In the absence of definite information as to the suspected plan on behalf of the pretender, the government relied for its justification, undertaken by Horatio Walpole, upon the necessity of enforcing the most-favoured-nation treatment in the Spanish dominions, which was infringed by the treaty of commerce signed between Spain and Austria at Vienna. This was, indeed, the aspect of the situation uppermost in the minds of the two brothers Walpole. The power with which Great Britain was more nearly concerned to reckon was Spain. Spanish fleets had often challenged English supremacy upon the seas; trade with Spain on both sides of the Atlantic had long held a leading place among our commercial interests. Spain was vulnerable in her ports and on the side of Portugal, whose adhesion, Robert Walpole thought, should have been secured. Townsheni, on the other hand, as secre-tary of state for the northern department, was interested in the combinations of the northern powers of which the emperor was 337,405 .

1 December, 1724, Brit. Mus., Add. MSS., 32,738, ff. 203, etc. ; 32,74I, ff. 
the moving spirit. Against the emperor the main effort in his CHAP. judgement was to be directed. Between these diverging ten$\mathbf{X I X}$. dencies of the two principal ministers the Duke of Newcastle, Townshend's colleague, maintained an uneasy neutrality.

The criticism of Shippen long remained the watchword of the opposition. By the treaty of Hanover, said Lord Chesterfield, "Hanover rode triumphant on the shoulders of England". As a matter of fact, it presented itself in a very different aspect to George I. and his Hanoverian advisers. The Ostend Company was no menace to Hanover, whereas a war to suppress it would involve the electoral state in peril of invasion. The loyalty of the King of Prussia to his engagements was always uncertain, and his defection from the alliance would involve grave risks. While Walpole was opposed to a provocative attitude towards the emperor, he was, unlike Pulteney, the champion of the "old system" of the Austrian alliance, solicitous to maintain co-operation with France. Having hitherto affected abstention from interference in foreign affairs, Walpole from this time took care that they passed through his hands. ${ }^{1}$ The influence of his brother Horatio with Fleury, the first minister of France, strengthened his position. To Townshend, then, and not to Walpole belongs the credit of the treaty of Hanover, the beneficial effects of which were presently to disclose themselves. Its immediate sequel was a tightening of the alliance between the powers against whom it was directed. By a second and secret treaty of Vienna, dated November 5, 1725, and negotiated by Ripperdá, who had remained in Austrian territory, the emperor undertook, in the event of war, to assist Spain in the recovery of Gibraltar and Minorca by force, in return for which he secured a Spanish guarantee of the Ostend Company. A general clause, promising effective help in all possible circumstances, covered the case of subsequent operations in favour of the pretender, but no mention was made of that prince. ${ }^{2}$ The contents of this treaty, of which one article provided for the dismemberment of France in the event of a successful war, though not accurately known,

'Lord Hervog's Memoirs (ed. 1884), i., 111.

2 This treaty, discovered by $M$. Syveton in the Viennese archives under the title Strictius of amplius fodws secretissimum, etc., was first printed by him in Une Cour et un A ocntwrier an svijje. sizele (1896), p. 283 ff. 
CHAP. were shrewdly suspected. Alarm was felt on both sides of the XIX. Channel. The countercheck which suggested itself to Townshend was to surround the emperor with enemies. For such a plan the ancient alliances of France with Sweden, Poland, and Turkey afforded some hope.

The first step was to assert the command of the sea and primarily of the Baltic, and incidentally to protect the duchies of Bremen and Verden. Supplies having been readily voted by parliament, Vice-Admiral Sir Charles Wager sailed from the Nore on April 17, 1726, at the head of a fleet of twenty ships of the line. On the other hand, the tsaritsa Catharine, the widow of Peter the Great, irritated by a sense of her impotence, gave in a formal adhesion to the treaty of Vienna in August. A second fleet under Sir John Jennings was dispatched in July to cruise off the coast of Spain, a measure which stirred salutary apprehensions at the court of Madrid. Even more important was the expedition entrusted in March to Vice-Admiral Hosier. The mainspring of the hostile confederacy was Spanish treasure. In fourteen months the emperor had received $3,000,000$ florins $(£ 281,258)$. He was waiting for more and the Spanish galleons with $£ 6,500,000$ sterling were expected at Cadiz in June. It was Hosier's task to prevent their sailing. This he achieved by blockading Porto Bello for six months, but the British loss through a virulent fever rendered the blockade one of the most disastrous misfortunes of our naval history. Hosier himself fell a victim to the disease at the end of August, 1727, his successor, ViceAdmiral Edward Hopsonn, on May 8, 1728. In two years 4,000 men perished.

The adhesion of Sweden to the treaty of Hanover was finally secured by a treaty of March 26,1727 , but the indisposition of France to lend hearty co-operation caused a failure of the negotiations with Poland and Turkey. Denmark, on the other hand, agreed to come in and to furnish troops on payment of a subsidy by France, and the Landgrave of Hesse and the Duke of Brunswick-Wolfenbüttel in consideration of subsidies from England. But before the negotiations with Sweden and Denmark had been concluded, the Prussian King, whether in alarm at the adhesion of Russia to the treaty of Vienna or out of resentment at George I.'s disinclination to carry out the mar- 
riage of Prince Frederick with his daughter, veered round 1 and on October 12,1726, signed the treaty of Wusterhausen with CHAP. the emperor guaranteeing the pragmatic sanction and promising 10,000 troops. Meanwhile Madrid became the centre of the coalition against England. The queen and her devout husband were filled with ardour for the extirpation of protestantism, the first step towards which was the establishment of the pretender on the throne. The purse of Colonel William Stanhope, the British minister, unlocked the door of the conspirators' designs. Admiral Camocke himself supplied information, and the Russian envoy's secretary furnished transcripts of his master's correspondence. Stanhope discovered that a party in France was actively plotting with the same object in conjunction with Ripperda, the first step to be the overthrow of the Duke of Bourbon which was to be followed by the renunciation of the treaty of Hanover. A detailed project of invasion-settled between Ripperdá and the Duke of Lirià, the son of the Duke of Berwick, also fell into Stanhope's hands. ${ }^{2}$

In April, 1726, the Duke of Wharton, who had left England to get out of the way of his creditors, appeared at Madrid. He had published a bombastic address to his "friends, countrymen, and fellow citizens," justifying his "espousing the cause of his royal master King James," with credentials ${ }^{3}$ from whom he now presented himself at the Spanish court. He is described by the British consul Benjamin Keene, as "an everlasting talker and tippler". He "declared himself the pretender's prime minister" and was welcomed by Ripperda and the queen. At Madrid he embraced the Roman catholic religion-to the prejudice of the pretender with the public at home. He was now qualified to enter into the full designs of the confederates and sketched for them a plan of operations which Ripperdá after his fall shewed to Stanhope." As early as December 27, 1725, Stanhope had reported that additions were being made to the fortifications of Cadiz ; artillery, tents, and munitions of war were in preparation; a squadron was under

2 "He desires at the bottom to be neuter and to fish on all sides to see where he can catch the most," George Tilson, under-secretary of state, to Lord Townahend, September 8, I726, R. O., MS., State Papers, Dom., G. I., bundle $69,351$. 2 Toronshend MSS., p. 196.

${ }^{3}$ Newcastle Papere, Brit. Mus., Add. MSS., 32,685, ff. 53, 55, 56.

-See Projet du Duc de Wharton, Townshewd MSS., p. 197. 
CHAP. orders. The protestations of Ripperda that his intentions were XIX. pacific deserved, he declared, no credence. On May I 4, 1726, Stanhope, returning to his house, found Ripperdá a refugee imploring his protection. The new imperial ambassador, Count Königsegg, had supplanted him in the royal favour.' Whether to ingratiate himself with his protector or to avenge his humiliation on the two courts, the fallen favourite communicated details of what he declared to be secret clauses of the treaty of Vienna for the extirpation of protestantism. By a violation of international law, he was forced from the ambassador's house and confined at Segovia, whence after two years he escaped to England.

Ripperdá's confessions to Stanhope found confirmation in a draught of the alleged secret treaty furnished to Horatio Walpole by two Sicilian abbots, refugees at Paris. The final article of this draught was for the restoration of the pretender, to be preceded by a demand from Spain for the restitution of Gibraltar. ${ }^{2}$ Although we now'know that the pretender's restoration was not explicitly a part of the secret treaty of Vienna, nevertheless the communication of the abbots so far harmonised with the disclosures of Ripperdá and the boasts of Wharton that the British government accepted it as genuine, and on January 17,1727 , acquainted parliament with its substance. Stirred by indignant patriotism, the house of commons carried the supplies demanded, amounting to nearly $£ 3,000,000$, without opposition; and augmented the army to above 26,000 men and the fleet to 20,000 seamen. $^{3}$ Lord Carpenter, the governor of Port Mahon, and Lord Portmore, the governor of Gibraltar, were ordered to their posts, and the garrison of Gibraltar

1 Historians as a rule ascribe Ripperda's disgrace to the discovery, based on Konigsegg's dispatches, that the emperor's alleged engagement to Spain had been greatly exaggerated by him and to complaints that Charles VI. had not been paid the subsidies promised, which had been stopped by Hosier's fleet. There is, however, a letter from Townshend, dated May 24, 1726, which states that it was partly due to the queen's conviction that he was betraying secrets of state to France and England. R. O., MS., State Papers, Dom., G. I., bundle 69, no. 37.

'Newcastle Papers, Brit. Mus., Add. MSS., 32,752 and 32,772, Townshend MSS., p. Irg. "Translation of the paper received from the Sicilian abbots concerning the secret treaty between the emperor and the King of Spain." The abbots said that they had been consulted by Philip. See E. Armstrong in Engl. Hist. Rev., xii. (1897), 799-800.

3 " Great is the difficulty of manning the fleet ; the volunteers are few." February 26, Portland MSS., vii., 427. 
made up to 6,000 men. Whatever the real designs of the CHAP. emperor might be, and he was probably at this time waiting XIX. upon events, public opinion in England, especially in commercial circles, was growing restive with suspense. Protracted uncertainty naturally exercised the worst effect on business. East India stock which stood at 160 on December 31, 1725, was thirty points lower on the same day of 1726 . "We must lose our trade or engage in a war" 1 was the common feeling. Pamphleteers loudly denounced the emperor and his Ostend bantling. The correspondence of 1726 constantly records general depression and the fall of stocks. In January, 1726, it was reported by the surveyors of the window tax that there were 4,300 houses empty in Westminster alone. In such circumstances public feeling not unnaturally became less favourable to the ministry. A storm, it was said, was gathering against Walpole. Adherents flocked round Pulteney. Bolingbroke, in sober intervals, proffered advice, and the forlorn band of tories began to propose their co-operation. ${ }^{2}$ Count Palm, the imperial resident, and the ministers at Vienna in correspondence with the opposition and with the Duchess of Kendal, planned the overthrow of Townshend. On March 2, 1727, Palm delivered a Latin memorial to the king, asserting that the communication to parliament as to the secret treaty of Vienna was founded on the "falsest reports". This memorial he then printed and circulated, "that the whole nation be acquainted with it". Provocative indiscretion could scarcely go further. On March 4, 1726-27, the London Gazette announced that Palm had been ordered to leave the kingdom. In the house of commons there was no dissenting voice. The manœuvre which was to ruin Townshend in public opinion left his opponents impotent.

By the spring of 1727 the confederates on either side were taking stock of the forces at their disposal. A paper drawn up by Marshal Berwick reckons the allies under the treaty of Vienna at $353,000^{3}$ men, subject to deductions for service against the Turks and Hungarians, and those under the treaty

'Portland MSS., vii., 407, December 4, 1725. See further G. B. Hertz, "England and the Ostend Company," Engl. Hist. Rev., xxii., April, rgo7.

'Portland MSS., vii., 415; p. 405, December 4, 1725; p. 430, March 10, 1725-26; p. 407, December 7, 1725.

3 This reckons the Prussians at 70,000 men, but a detailed French estimate in the Townshend MSS., p. I19, gives them at 63.932. 
CHAP. of Hanover at 299,000 men, which by contemplated additional XIX. contingents from Denmark and Sweden could be raised to 31 5,000.1 In addition, they would have absolute command of the sea, for eighteen Dutch men-of-war were promised as reinforcements to the English fleet to which were to be added contingents from France, Sweden, and Denmark. Although Spain had begun the siege of Gibraltar in February, there had been no formal declaration of war, for that would have entailed the intervention of France as an ally of Great Britain. It was alleged, therefore, that the siege was merely by way of retaliation for the blockade of the treasure fleet, the same pretext being advanced for the arrest of the South Sea ship Prince Frederick, at Vera Cruz. The veteran general the Marquis of Villadarias, who had conducted the siege in I 704, flatly declined to undertake another until Philip was master of the sea. Six men-of-war rode in the harbour and protected its supplies; the garrison numbered 6,000 men and the incompetent and boastful Conde de las Torres, at the end of four months, found the enterprise hopeless. No help was forthcoming from the emperor. In his view and that of Prince Eugene, the attempt was a sheer waste of strength. The emperor had, under the influence of Eugene, begun to reconsider his position. He determined to negotiate, obtained the unwilling concurrence of Spain ; and on May 31, 1727, the Austrian ambassador signed at Paris ${ }^{2}$ preliminaries of peace with England, France, and Holland. The emperor agreed to suspend for seven years the charter of the Ostend Company-a concession perpetuated by the second treaty of Vienna in March, 1731 - to confirm all treaties prior to the treaty of Vienna of April 30, 1725, and to refer other discussions to a general congress. The Spanish king, however, refused to ratify the agreement, and Spain remained in a state nominally of peace, but practically of war with Great Britain.

The years following Atterbury's banishment until the end

${ }^{2}$ Newcastle Papers, Brit. Mus., Add. MSS., 3275, f. 2350. In the R. O. is a memorandum in Delafaye's hand, indorsed "The Scheme in May, 1727," which estimates the Hanover allies at no more than 156,000, reckoning the French at 68,000 , the Dutch at 20,000 , and the British at 12,000 only. MS., State Papers, G. I., bundle 70 , no. $55^{\circ}$.

2 "Circonstance qui les a fait nommer 'Préliminaires de Paris " (Garden, Traités de Paix, iii., 145), though some writers call them "Preliminaries of Vienna". 
of the reign were marked in England by great tranquillity. Walpole commanded the confidence of the house of commons CHAP. and of the financial classes, while he was personally not unacceptable to the country squires, for as he had considerable estates in Norfolk and was passionately addicted to country pursuits they looked on him as one of themselves. On August 30, 1723, he was able to write to Townshend, then at Hanover, that the gossip about the factions at court and "The True Briton are the only things that cause the least disturbance here". This bi-weekly opposition paper, of which the first number appeared on June 3,1723, and which expired on February 17 in the following year, derives its chief interest from the fact that it was the creation and mouthpiece of the Duke of Wharton. It was full of the usual cant about patriotism and the degeneracy of the age. Its diatribes against corruption were, however, shortly to receive a signal illustration. The chancellor, Thomas Parker, Earl of Macclesfield, had been one of the privy councillors who had hurried to Kensington to insure the succession to the house of Hanover when Anne was on her deathbed, and, as lord chief justice of the king's bench, he had welcomed the new king at Greenwich. With these credentials of loyalty he had become from the first a favourite at court, and on March 10, 1716, was raised to the peerage as Baron Parker of Macclesfield. He ingratiated himself with George I., after the rupture with the Prince of Wales, by procuring from the great majority of the judges an opinion ${ }^{1}$ in favour of the right of the king to direct the education of his grandchildren, and on May 12, 1718, was nominated lord chancellor on the resignation of Cowper. On November 15, 1721, he was advanced to the dignities of Viscount Parker and Earl of Macclesfield. As a judge he held a high reputation and is pronounced by Lord Chancellor Campbell to have been "one of the greatest equity judges who ever sat in the court of chancery". But towards the close of 1724 public gossip was busy with irregularities imputed to the masters in chancery. There was a deficiency of $£ 82,000$ of the suitors' money entrusted to their care, and Macclesfield, who was held by public opinion to have connived 
CHAP. at the masters' misconduct, had no alternative but to resign XIX. on January 7,1725 . The report of a committee of the privy council upon the chancellor's own conduct having been laid before the house of commons, Sir George Oxenden, one of the Leicester House party, as the friends of the Prince of Wales were called, to whom he was naturally obnoxious, moved to impeach him of high crimes and misdemeanours. He was found guilty by a court of ninety-three peers, fined $£ 30,000$, the money to be applied to the relief of the injured suitors, and ordered to the Tower till it should be paid. He never reappeared in public life and died in 1732 . The new chancellor, Lord King, put an end to the possibility of the recurrence of such abuses by ordering masters in chancery forthwith to pay all sums received by them into the Bank of England.

On June 3, 1727, George left London for Hanover, after an absence of two years, with Townshend and Ilay as the ministers in attendance. On the road he was seized with a paralytic stroke and was carried unconscious to the house of his brother, the Duke of York and Bishop of Osnabrïck, where he died on June 12 in his sixty-eighth year. He was buried at Hanover on August 30. While his memory does not captivate our imaginations, justice must be done to the considerable merits which he nevertheless possessed. In him was none of the vanity which made the sense of power a personal enjoyment to the Stewarts and elevated the abuse of it to a divine right. $\mathrm{He}$ had what in a less phlegmatic man might be described as a passion for justice and a judgement exempt from extremes. Trained in an absolutism which he wielded with the moderation of a constitutional monarch, he was faithful by impulse of nature to his constitutional engagements to Great Britain. His loyalty in this respect was the safeguard of his dynasty, which could never have sustained a constant friction, still less a conflict with parliament. His qualities were exactly those which the situation required. Even his partiality for his German ministers and German dominions was kept under some degree of restraint, ${ }^{1}$ a trait generally ignored by historians. He followed with in-

1 1". . . the resolution the king has taken not to suffer his Germans to meddle in English affairs, he having forbid them to presume so much as to speak to him about them; and this he has ordered all his servants to declare to everybody to be his resolution and tells it himself to as many as come to him." Lord Sunderland to [Lord Carlisle], November 18, 1719, Carlisle MSS., p. 23. 
creasing closeness, as time went on, the counsels of his English CHAP. advisers, and where the claims upon him of Hanover and England appeared to diverge had the sense and self-restraint to follow the larger interest. To his clear perception and honest fulfilment of his duty as a constitutional sovereign Great Britain owes a debt which is often unduly minimised. 


\section{CHAPTER XX.}

ENGLAND, SPAIN, AND FRANCE.

CHAP. THE news of George I.'s death reached Walpole at Chelsea, $\mathrm{XX}$. in a dispatch from Townshend on June 14, I727. Walpole's favour with the prince had declined in proportion as it had risen with the king. He, therefore, could have felt no surprise at the coldness of his reception by the new king, who would give him no further instructions than to take directions from Sir Spencer Compton, the treasurer of his household, speaker of the house of commons, and paymaster to the army. It is an evidence of Walpole's sagacity that he was quick to descry the first beams of the rising sun. He had, while in opposition, paid assiduous court to the new queen. Wilhelmina Caroline, Princess of Brandenburg-Anspach, was now a woman of mature years, having been born on March I, I683. The queen entertained her own opinion of the relative capacity of the ex-minister and his successor. When, therefore, a difficulty arose as to the wording of the king's speech, she insinuated to the king, whom she governed by suggestion, rather than by formal advice, that business would run more smoothly if placed in the hands of Walpole, to whom Compton had found it necessary to have recourse. The civil list would have to be voted. It was imperative that the king's business should be in the hands of a minister capable of managing the house of commons. As chancellor of the exchequer Walpole had in 1721 and 1725 carried votes for the discharge of the debts of the civil list amounting in the aggregate to over $£ 1,000,000$, yet in 1727 there was again a debt of $£ 600,000$. There was also the jointure to be provided. When Compton suggested a jointure of $£ 50,000$ a year for the queen, Walpole undertook to double it, and the king's hesitation was brought to are end. 
The meeting of parliament, therefore, on June 27 found the old CHAP. ministry practically unchanged. A civil list of $£ 800,000$, inXX. cluding $£ 100,000$ for Prince Frederick, who was still a minor, besides $€ 100,000$ for the queen was voted without a division, and on August 29 parliament was dissolved. The general election added to the ministerial strength. On January 23,1728 , the king opened the new parliament.

Until the accession of George II., the opposition to the ministry, of which Townshend was still the nominal head, was heterogeneous and incoherent, swayed by personal prejudices, uninspired by fixed principles and without a common end. William Pulteney, of whose capacity and social gifts even his opponents speak in admiration, had rallied round himself the scattered followers of Carteret, whose successor as secretary of state he had aspired to become. Walpole distrusted his disposition to cabal and preferred the dull but industrious Duke of Newcastle, whose qualifications were wealth, rank, family connexions, and borough influence. So long as there were prospects of replacing Walpole by a coalition, the disaffected whigs kept aloof from the Jacobites and extreme tories. When that hope vanished, the whole opposition acted in concert. The head of the tory wing was Sir William Wyndham, and he and Pulteney were styled "the consuls of the patriots". Wyndham had been liberated from the Tower without being brought to trial and had become leader of the "Hanover tories". The principal followers of the united party of patriots were Samuel Sandys, chancellor of the exchequer in 1742-43, nicknamed "the motion maker" from the persistency of his attacks on the ministry; Sir John Barnard, a merchant with a reputation for knowledge of finance second only to that of Walpole himself; and Daniel Pulteney, who had under Anne been envoy in Denmark and was an expert in foreign affairs.

In the house of lords, Speaker Onslow tells us, "the party against him (Walpole) was very small and a speech or two from Lord Carteret and from two or three more was all he had to fear". Next to Carteret came Philip Dormer Stanhope, the famous Earl of Chesterfield. He had lived a good deal on the continent, was conversant with foreign affairs, and in 1728 was nominated ambassador at the Hague. His oratory was universally admired and his sarcasm no less dreaded. 
CHAP. Chesterfield in Fog's Journal (a continuation of Mist's), WilXX. liam Pulteney, his cousin Daniel Pulteney, and Bolingbroke in The Craftsman, Bolingbroke in The Occasional Writer, and Chesterfield again in Common Sense and other weekly papers maintained an incessant war upon Walpole's administration, upon his finance, his foreign policy, and upon the minister himself, whom they incessantly held up to execration as a monster of corruption with a vast fortune drawn from the life-blood of the nation. ${ }^{1}$ Nor did the lampoons, pamphlets, and ballads of the opposition spare the king and queen. In breadth of intelligence, as in stature, George II. was inferior to his father. While George I. cared more for principles, his son immersed himself in details. He spent hours in casting up accounts; he loved to reckon his money; his father's parsimony was in him degraded to avarice; his father's good-natured cynicism degenerated in him into petty spitefulness. But some of his father's best qualities he did inherit, his love of justice, his scrupulous regard for the limitations imposed upon his sovereignty, and his personal courage. These were the gifts essential to the situation and it was by these that he preserved his dynasty.

The death of George I. had been looked forward to by the Jacobites, though with less confidence than the death of Queen Anne, as likely to furnish an opportunity for the renewal of an attempt upon the crown. But since the failure of the rebellion of 17 I 5 , treachery, faction, and scandal had sensibly weakened their ranks. In November, 1 725, the pretender's wife Clementina withdrew to a convent. The scandal filled the courts of Europe. Lockhart, his "trustee" or agent in Scotland, wrote to him, "It is the severest stroke your affairs have got these many years". When, therefore, the critical moment had arrived, enthusiasm in his favour had cooled, alike at home and abroad. In retirement at Rome, after reconciliation with his wife, he disappears from English history. Of the pretender's supporters abroad the most prominent were Wharton and Atterbury. Atterbury formally quitted his service in June, 1727 . Wharton was commissioned as colonel of an Irish regiment in the Spanish service at the siege of Gibraltar in the spring of

1 An account of Walpole's defence of his fortune delivered in the house of commons, January 23, 1730-31, is given in the Carlisle MSS, p. 65. 
1727 ; for two years he wandered through Europe, drunken and destitute, and in 1731 died at the age of thirty-two at CHAP. the Cistercian monastery of Poblet in Spain, in the words of Pope, "the scorn and wonder of our days".

The prospect of civil war in England upon the death of George I., rendered Elisabeth Farnese at first indisposed to accede to the preliminaries of Paris. But the alarming illness of her husband aided in shaking her resolution. His death would leave her isolated not only in Europe generally but in Spain, where there was a general outcry at the sacrifice of national interests to her ambition for her family. The outcome of those reflexions was the convention of the Pardo signed on March 6, N.S., 1728 , in which the preliminaries of Paris were in substance confirmed-on the one hand, the English fleets to be withdrawn from the West Indies and the coasts of Spain; on the other, the siege of Gibraltar to be raised, the Prince Frederick to be restored, the goods of the foreign merchants to be released, and outstanding questions to be referred to the decision of a congress. In this congress, which met at Soissons on June 14, 1728, the question of Gibraltar proved a stumblingblock. Townshend, like Stanhope, entertained no objection in principle to its surrender, at least, as George I. had expressed it in a letter to the King of Spain dated April 29, 1 721 , "upon the footing of an equivalent". When this formula was objected to by Philip V., and his queen, the decision had by a subsequent letter (June 1 ) been left to parliament. But public opinion was formed. Government succeeded, indeed, in defeating by 204 to 97 votes a motion for the production of George I.'s letter, but when, at the opening of the congress of Soissons, Poyntz impressed on the ministry at home the unanimous resolution of the Spanish king and people, Townshend on June 14, 1728, replied that " the bare mention of a proposal which carried the most distant appearance of laying England under an obligation of ever parting with that place would be sufficient to put the whole nation in a flame". With this fixed resolve on either side it was impossible to make real progress.

The indisposition shewn by the emperor to guarantee possession of the Italian duchies to the Queen of Spain's sons inclined her, after months of hesitation, to give up the point of Gibraltar and agree to an alliance with France and England if

VOL. IX. 
CHAP. Spanish, instead of neutral garrisons, as provided by the terms Xx. of the Quadruple alliance, were allowed in Parma and Tuscany. The outcome of these negotiations was the treaty of Seville signed on November 9, 1729. For his success in this important diplomatic achievement, for which he was specially accredited to the court of Madrid, Colonel William Stanhope, its original projector, was advanced to the barony of Harrington. The other signatory power was France: the States-general acceded three weeks later. The treaty of Seville was satisfactory alike to England and to the Queen of Spain. The queen ruthlessly sacrificed Spanish interests. Full restoration was conceded of English commercial privileges granted in 1667, 1713, and 1716; English and French commerce was to be revived on its old footing in America; the Asiento was to be respected; Spain would withdraw privileges granted to the Ostend Company; above all, the demand for Gibraltar was waived by silence. In return for all this, the queen approached a long step towards her goal. The allies agreed that Spanish garrisons should be introduced into the duchies of Tuscany and Parma. By a secret article it was provided that if the emperor should resist the signatories, they should resort to arms for the establishment of a future balance of power in Europe.

At Vienna the news of the treaty of Seville was received with indignation. A crisis came with the death of the Duke of Parma in January, I731. The Spanish queen had the mortification of hearing that imperial troops had occupied his duchies under pretext of securing them for Don Carlos. By this time, owing to the resignation of Townshend in the previous May, a change had taken place in the views of the English ministry. Walpole was now in the ascendant. His policy was to come to terms with the emperor upon the basis of the admission of the Spanish garrisons, in exchange for a guarantee of his arrangement for the succession of his daughter Maria Theresa known as the pragmatic sanction. On March 16, 1731, the treaty publicly known as the second treaty of Vienna was signed. The installation of Don Carlos as Duke of Parma was effected by a mixed English and Spanish fleet, commanded by Admiral Sir Charles Wager, who landed the Spanish garrisons at Leghorn on October 3. 
Between France and England there had been growing up petty causes of friction which only the steady resolution CHAP. of the two powers to act in harmony had kept in the background. The advantages assigned to English trade by the transfer of the Asiento had naturally roused the jealousy of the French commercial classes. Although the French government had, under the eyes of British commissioners, demolished the fortifications, they displayed unwillingness to ruin Dunkirk as a commercial port in accordance with the terms of the treaty of Utrecht. A constant irritation was kept alive in England and reciprocated in France. ${ }^{1}$ The opportunity did not escape the watchfulness of Bolingbroke. Wyndham, his mouthpiece, moved that there had occurred a "manifest violation of the treaties". The motion, if carried, threatened the French alliance. Walpole procured an adjournment for eight days, at the end of which, on February 27, 1730, he produced an order from Louis XV. for the demolition of the works ${ }^{2}$ and defeated the motion by 270 to 149 votes, after a debate so brilliant that "Dunkirk Day" became proverbial in whig circles.

Another constant sore was the continuance of the persecution of the French protestants. The remonstrances of Qucen Anne at the time of the treaty of Utrecht had effected the release of no more than 136 Huguenot galley slaves. The ambassadors of George I. from time to time expostulated in vain with the French government. The torture chamber and the scaffold were unceasingly busy, and the galleys, the jails, and the nunneries were crammed with the victims of priestly ferocity. There were disputes about the construction of forts by the French on the Mississippi, ${ }^{3}$ and on the Canadian border, and as to the ownership of the West India islands of St. Vincent, Dominica, and St. Lucia. The neutrality of the last was decided in 1730 by arbitration, an early instance of resort to that principle for the settlement of international disputes. ${ }^{4}$

' Carlisle MSS., p. 78.

Ibid., p. 68.

'Hardwicke Papers, Brit. Mus., Add. MSS., 35.907.

- Certain minor causes of friction, overlooked by historians, are disclosed by the Domestic State Papers (R. O., MS., State Papers, Dom.), G. I., bundle 18, no. 84 (1719); ibid., bundle 33 (no number), petition of a watchmaker who had gone to Versailles where he had about seventy English workmen under him and had been bribed to return by the British ambassador (March 13, 1721-22). See also bundle 32 (no number), "An account of the last thousand pounds of his majesty's bounty to the artificers who returned," etc. (z721). 


\section{CHAPTER XXI.}

THE EXCISE BILL.

CHAP. BY 1728 the political alliance between Townshend and Walpole XXI. had long shewn signs of drawing to a close. Dissension between them began with Townshend's negotiation of the treaty of Hanover in the summer of I725. Two years before Walpole had written to Townshend: "My politics are to keep clear of all engagements" (August 3, 1723). Townshend gradually became sensible that his position in the cabinet was being weakened. During the king's absence from May to September, 1729, Caroline's reliance upon Walpole naturally increased. She dined at his house at Chelsea, and after Townshend's return, by her undisguised preference she "blew into a flame," as Horace Walpole expresses it, "the ill-blood between the two". Townshend's last success was the treaty of Seville. He had previously talked of retirement, but he made the mistake common among statesmen of believing himself indispensable and, as Lord Hervey puts it, "would neither act with Walpole nor go out". Walpole's version of his attitude and motives is characteristic: "As long as the firm was Townshend and Walpole, all went well; as soon as it became Walpole and Townshend, things went wrong". Walpole dexterously seized the occasion of one of Townshend's announcements to the king, at the end of 1729 , of his approaching resignation to procure the nomination as his successor of Lord Harrington, the negotiator of the treaty of Seville. In the spring of 1730 , when the emperor, in response to the treaty of Seville, was threatening hostile action and had secured a declaration of support from Prussia, Townshend pressed for an aggressive policy in concert with France. Walpole and fewcastle, with the support of the queen, were for first exhausting he resources of diplomacy. 
Unable to command a majority in the cabinet Townshend resigned on May 15, 1730, to acquire with the nickname of "Turmip Townshend" a fresh reputation as a reformer of agriculture.

During the early years of George II., while Walpole exercised control over domestic, and Townshend over foreign affairs, the opposition was reduced to ineffectiveness. Being without a policy it aimed at curtailing the means by which party ties were traditionally strengthened. Corruption was the "cant," as Burke says, ${ }^{1}$ of all the patriots, though it may be doubted whether under George II. it had been more flagrant than under Anne, and it is certain that more secret service money was expended before the revolution. "The charge of systematic corruption," wrote Burke, "is less applicable to Walpole, perhaps, than to any minister who ever served the crown for so great a length of time." The first of a series of attacks was directed against the expenditure of the secret service fund. Walpole succeeded in satisfying the house that the convention of the Pardo had been the outcome of part of the expenditure of $£ 250,000$, to which exception had been taken. The next assault upon the same lines was a bill for the purity of elections which went by the name of the bribery bill. It became law. ${ }^{2}$ Nevertheless, Lord Hervey records of the elections of 1734 : "Money, though it had been formerly more openly given, was never more plentifully issued than in these". 3 The third and most formidable attack was the pension bill. This became what is now known in parliamentary circles as a "hardy annual". It was first introduced into the house of commons by the indefatigable Sandys, February 16, 1730. Inasmuch as by the two statutes of 6 Anne, c. 7, and I George I., sess. 2, c. 56, no person having a pension under the crown during pleasure or for any term of years was capable of being elected or sitting, all that the bill sought to exact was a declaration under oath of conformity with the existing law. The policy adopted by Walpole of leaving to the lords the onus of throwing out the bill added another to Townshend's accumulating discontents. What the

\footnotetext{
'Works, iv., 436 (ed, 1852).

22 G. II., c. 24 .

"See Basil Williama, "The Duke of Neweratle and the Election of 1734" Engl. Hist. Rev., xii., 474, eter,
} 
CHAP. opposition failed to effect in parliament they attempted through XXI. the press, and by incessant attacks gradually wore down Walpole's popularity. The circulation of The Craftsman for a time rivalled that of The Spectator at the height of its popularity, as many as ten thousand copies being sold in one day. His brother Horatio Walpole, Lord Hervey and Bishop Hoadly were the most distinguished of Walpole's political pamphleteers. The minister was, as a rule, serenely indifferent to personal attacks, and in the licence accorded to the press contrasted favourably with his predecessors.

The arrival of the king's eldest son, Frederick, in December, I 728, and the estrangement known to subsist between him and his father, inspired Pulteney's party with the hope of a figurehead round whom to rally. Frederick, who was created Prince of Wales in the following January, was chafing under the disappointment caused by his father's evasive postponements of his marriage with the Princess Royal of Prussia, the treaty for which, though it had never been signed, had been arranged at Charlottenburg in 1723 . A nother influence disturbing the serenity of the ministry was the growing restlessness of the dissenters. In the late summer of 1730 , it appeared to their leaders that the time had come to petition parliament against the test and corporation acts. After an interview with the principal ministers at the end of 1732 , the deputies of the dissenters reported to a "general assembly" that no application to parliament was then likely to be successful, and their leaders resolved, in reliance on the ministers' goodwill, to await a more convenient season. Walpole's chief interest lay in the economic condition of the country. In the administration of his benevolent despotism at Hanover George I. had effected some ameliorations of the practice of imprisonment for debt, and it is possible that a statute "for the relief of insolvent debtors," passed in 1719, was suggested by his experience. In 1729 Townshend in the house of lords moved for a list of persons imprisoned for debt, which resulted in another act for clearing the debtors' prisons. The benefit of this measure is alleged by a contemporary news-letter to have been claimed by the astounding number of 97,248 persons. Another consequence followed. Upon an inquiry moved by the philanthropist Oglethorpe, afterwards a general, in the house of commons on Febraty 25, 
1729, disclosures were made of the state of the jails which CHAP. almost transcend belief. Starvation and torture were commonly XXI. employed by the warders to extort money from their unhappy prisoners. In the practice of these atrocities one Thomas Bambridge, warden of the Fleet prison, enjoyed an infamous preeminence. Yet, though some improvements were effected by new regulations, prisons continued to be what John Howard the philanthropist found them half a century later, a scandal to humanity. There remains to this day a monument of Oglethorpe's benevolence, the State of Georgia, founded by him as a colony in virtue of a charter granted in 1732 , to be a place of refuge for debtors on the attainment of their freedom.

In the session of 1730 the liberal tendency of Walpole's commercial policy began to be disclosed. It had been a timehonoured tradition, accepted by all nations, that colonies should be administered with exclusive regard to the advantages derivable from them by the mother country. Conformably to this principle colonial rice could be exported only to England. Carolina was now set free, subject to the navigation laws, to export rice directly to the south of Europe on payment in England of an export duty of sevenpence a hundredweight, and the experiment was sufficiently successful to justify its extension to Georgia in 1735-" a unique and remarkable instance of colonial taxation by the mother country at the suggestion of the colony itself". 1 On the other hand, Walpole withstood a specious attempt to loosen the monopoly of the East India Company which was terminable on three years' notice from Lady Day, 1733 . The charter of the old company was renewed until 1766, upon payment of $£ 200,000$ and acceptance by the company of a reduction of interest from 5 to 4 per cent. on $£ 3,200,000$ which had been advanced by it to the government.

The comparative tranquillity following the treaty of Seville afforded Walpole leisure to take a survey of the entire system of taxation. He had already, between I 721 and I 724, effected a series of readjustments of the tariff in the direction of encouraging the importation of raw materials, and, with a few exceptions, relieving of export duties such natural and manufactured products as remained subject to them. ${ }^{2}$ But his interest

' G. L. Beer, British Colonial Policy, 1754.65, New York, 1907, p. 6.

'See the king's opeech on Oct. 19, 1721, Parl. Hist., vii., 914, and A. Brisco, Economic Policy of Robert Walpole (1907), p. 130. 
CHAP. in finance was not exclusively economic. A reduction of the XXI. land tax from two shillings in the pound, to which it was lowered in 1730, while welcome to the tory squires, would afford a substantial relief to the great whig landowners, an advantage which Walpole did not affect to conceal. To supply the deficit which would be caused by a further reduction to a shilling was no easy matter. He conceived the idea of extending the system of excise, that is, to adopt his own definition, "duties payable by the retail trader upon consumption". Unfortunately excise had become associated in daily commercial life with inquisitorial administration, and traditionally with arbitrary government. The alternative means of raising revenue was by customs. But under the existing complicated system of discounts, drawbacks, and allowances, aided by false weights and false entries, the frauds upon the custom house were easy and were notorious. The repression of smuggling involved the employment of numerous revenue officers, of whom some did their duty and were beaten or killed, whilst others connived with the smugglers. Two hundred and fifty of them had suffered violence in nine years, and six had been murdered. The temptation to these breaches of law would be substantially diminished by collecting duties, not at the ports but upon inland sale. Such a change might by increase of revenue enable Walpole to abolish the land tax altogether.

The opposition was indefatigable in exciting the public mind against his proposals. A phrase of Pulteney's, "that monster, the Excise; that plan of arbitrary power," caught the public ear. Caricatures and pasquinades representing excise as a devouring dragon, a universal tax upon all commodities, especially bread and meat, ${ }^{1}$ flooded the country, among them a political ballad, "Britannia Excisa," by Pulteney. The Craftsman week by week invented hideous pictures of its effects. The essays, some of them from Pulteney's pen, bearing in a collected form the title Arguments against Excises, fed the flames of popular fury. "No slavery-no excise-no wooden shoes," the last a symbol of submission to arbitrary monarchy like that of France, became the universal cry. In

ISee B. Williams, "The Duke of Newcastle and the Election of 1734," Engl. Hist. Rcv., xii., 465 . 
vain the ministry dispersed pamphlets unmasking the impos- CHAP.

ture. It was evident that, for the present, no change could $\mathbf{X X I}$. be effected except on a limited scale. When, therefore, on March 14, 1733, Walpole introduced his reform, he disclaimed and denounced any project of a general excise. He limited his proposals to tobacco and wine, the resolutions on tobacco to be first discussed. During three weeks the opposition fought the bill stage by stage and the ministerial majorities dwindled day by day. The king was urgent in its favour. He desired to reconcile the country gentlemen to his dynasty, and his love of money was excited by the prospect of an increment in his civil list.

But Walpole had not only to face the opposition in the house of commons and the mob out of doors. A " cave," to use a modernism, was formed among the ministerialists of the upper house. The restless and intriguing Chesterfield found his opportunity. Lord Scarborough, a favourite at court and a majorgeneral, much under the influence of Chesterfield, came to Walpole two days before the second reading in the commons to announce his intention of voting against the bill in the lords. "The soldiers," he said, "had got a notion that it would raise the price of tobacco . . . and were almost as ripe for mutiny as the nation for rebellion." On the evening of this communication, April 9, Walpole, in consultation with the king and queen, decided to drop the bill. On the I Ith he moved that the bill should be read a second time on June 1 2, on which day the house, it was anticipated, would have risen for the recess. By the nation at large, as by the mob that crowded the palace of Westminster, his defeat was welcomed with a delirium of joy. That night and the next the city bells rang, the monument was illuminated, bonfires blazed in the streets, the effigies of Walpole with a blue paper ribbon of the garter and of a fat woman representing the queen, fed the flames. Cockades were worn inscribed "Liberty, Property, and no Excise". It was the triumph of passion and prejudice, excited by the interest of the numerous traders who profited by smuggling, against a scientific readjustment of taxation. The ideal at which Walpole aimed, by his proposal to levy no import duty upon goods intended for re-exportation, was not attained till more than a century afterwards. It was, in 
CHAP. his own words, "to make London a free port and by conseXXI. quence the market of the world".

The queen had received the intimation of the intention to drop the bill with a flood of tears, the king with an outburst of anger against those who had obstructed it. The minister proffered his resignation, but George answered that he and Walpole "should stand or fall together". Walpole represented that if he were to continue in office, he could no longer afford to overlook the hostile intrigues among his subordinates. In the phrase of the time, the king's servants were opposing the king's measures. "The Queen," Lord Hervey tells us, "said he was certainly in the right; that discipline was as necessary in an administration as an army; that mutiny must no more go unpunished in the one than in the other, and that refusing to march or deserting ought to be looked upon in the same light." These were, as Hervey notes, Walpole's " new maxims of government". He had already effected one great breach with tradition. Since his accession to power it was understood that the members of the administration should give assurance of general co-operation by a common recognition of the body of doctrine known as whig principles. But they were still the king's servants, not the subordinates of a premier. Walpole succeeded in impressing upon the queen and, through her, on the king the conviction that the weakness imposed on the head of a government by the toleration of independence in the ranks of the ministerial hierarchy reacted eventually upon the crown. From this time dates the responsibility of a ministry to its head, who in his turn is responsible for its policy to the sovereign. The protest of the lords of February I3, 1741 , that Walpole had "for many years acted as a sole or even a first minister" dates back to the enforcement of these " new maxims":

Two days after the postponement of the excise bill the first blow was dealt. Chesterfield was stopped on the stairs of St. James's Palace by a message from the Duke of Grafton and returned home to surrender his white staff as lord steward. Lord Clinton was dismissed from the post of lord of the bedchamber and from the lieutenancy of Devonshire, which was bestowed upon the minister's eldest son, who in 1723 had been raised to the peerage as Lord Walpole. The 
Earl of Burlington, remembered as the builder of old Burlington House, having vainly solicited Chesterfield's staff, which was CHAP. given to the Duke of Devonshire, resigned his appointments and threw himself into the ranks of the opposition. Whatever may be said for Walpole's doctrine of ministerial subordination, his intolerance of rivalry was constantly adding recruits of talent to the numbers arrayed against him. Three weeks after his defeat upon the excise bill, a motion for inquiry into the affairs of the South Sea Company, opposed by the government, was the occasion of the first ministerial defeat in the house of lords since the time of Anne. ${ }^{1}$ Among the place-holders who voted against the court were, besides Scarborough, the Dukes of Bolton and Montrose, and the Scots Earls of Stair and Marchmont. The leaders of the opposition in debate were Argyll, Chesterfield, and Carteret. The burking of investigation only suggested the suspicion of fraud. ${ }^{2}$ Against the obstructive tactics of the ministry, who were defended by Newcastle and Ilay, twenty-two lords signed what Sir Thomas Robinson affirmed to be "the most remarkable protest ever entered upon the Journals". It hinted in no obscure terms that the administration was concerned to secure the "impunity of guilt". Among the names of the protestants were Cobham, Montrose, Marchmont, and Stair.

It was now evident to $W$ alpole that the examples made in the cases of Chesterfield and Clinton had proved ineffective, and that if the administration was to be carried on, the "new maxims" would have again to be vigorously applied. On June 14, Lord Cobham, a lieutenant-general and colonel of the "King's Own regiment of Horse " (now the First or King's Dragoon Guards), in which William Pitt was then serving as a cornet, ${ }^{2}$ was dismissed his regiment, Montrose was deprived of the great seal of Scotland, and Marchmont of his place as lord clerk register. At the beginning of August the Duke of Bolton was dismissed from the governorship of the Isle of Wight, the lieutenancy of Hampshire, and the colonelcy of the Blues. Stair, whose services to the country had been conspicuous,

1 Sir T. Robinson to Lord Carlisle, May 26, 1733, Carlisle MSS., p. II7.

'Sir T. Robinson to (Lord Carlisle), June 7, 1733, ibid., p. 121.

'R. O., MS., War Office Commission Book, 1730 to 1735: "William Pitt, gent., to be cornet in Our Own regiment of Horse, February 9, 1730.38", 
CHAP. was suffered to retain his colonelcy of the Inniskilling dragoons, XXI. but was dismissed in the following April for a revolt against the ministerial management of the elections of Scotch representative peers. Early in the session of 1734 the opposition selected the dismissals as a topic for censure of the government. But no party had any real desire for a measure which would in a sense make the army independent. Shippen and the Jacobites ${ }^{1}$ regarded the attack as an invasion of the prerogative on the part of the opposition whigs. "All that was intended," according to Pulteney after the event, "was a censure upon the minister for so monstrous a piece of resentment." 2 In the commons Walpole denounced it as a proposal of "stratocracy," and roundly declared he would be "a most pitiful minister" who should be afraid to advise the cashiering of an officer in constant opposition to the government. The opposition did not even venture upon a division. In the lords the motion was defeated by 100 to 62 votes. But the expectations of the opposition chiefly rested upon a bill for the repeal of the septennial act. It was signalised by a duel of oratory between Sir William Wyndham and Walpole. In Wyndham's rhetoric in favour of triennial elections Walpole recognised and gibed at Bolingbroke's inspiration. Pulteney complained to Wyndham of his surrender to Bolingbroke's influence, and when the " patriots" found themselves discomfited at the general election of 1734 they attributed their defeat to the unpopularity attaching to association with him. In Pulteney's judgement his "very name and presence in England did hurt". Baffled in his ambitions, broken in health and fortunes, and shunned by his political friends, Bolingbroke, early in 1735 , retired once more to France. While the general election of May, 1734, raised the number of the opposition in the house of commons to 249, it strengthened the government in the lords. This result was due to Ilay's success in carrying "the king's list" of representative peers by alleged practices which provoked the futile wrath of the opposition.

${ }^{1}$ Colonel the Hon. C. Howard to Lord Carlisle, Carlisle MSS., p. 133.

2 W. Pulteney to Lord Grange, March 22, 1733-34, Earl of Mar and Kellie's MSS., p. 535, Hist. MSS. Comm., I904. 


\section{CHAPTER XXII.}

THE FALL OF WALPOLE.

EUROPE, which had enjoyed a brief period of tranquillity since the signature of the second treaty of Vienna of March I6, I 73I, CHAP. heard with alarm the news of the death of Augustus II. of Poland on February 1, 1733, N.S. The father of the Queen of France, Stanislaus, had formerly been driven from his Polish kingdom by the Austrian nominee. The king, cried the French war party, was now bound in honour to restore him. France declared war upon the emperor in October, and on November 7 a defensive alliance with Spain was concluded in profound secrecy. This was "the Family Compact" or secret treaty of the Escorial. The Family Compact of 1733 may be claimed as justifying the whig contention in the war of the Spanish succession, that the possession of the crown of Spain by a member of the house of Bourbon would prove a standing menace to Great Britain. It was plain that the maritime powers were the arbiters of the situation, and to them both France and the emperor addressed themselves. There was truth in the sarcasm of the opposition that the multiplicity of our engagements was such that to fulfil them troops should be dispatched to the support of both combatants, and they prudently abstained from committing themselves to any line of policy. ${ }^{1}$ During the spring a Spanish army swept through South Italy, meeting with but small opposition, and on May 15, 1734, Don Carlos, having taken possession of Naples, announced the cession to himself by Philip V. of the kingdom of the Two Sicilies. On March 13, the diet of Regensburg, despite the protests of the Electors of Bavaria, Cologne, and the Palatinate, declared p. 531 .

2 Pulteney to Lord Grange, December 17, 1733, Mar and Kellie MSS., 
CHAP. war against France. As Elector of Hanover George II. was XXII. now bound to act, and dispatched to the imperial army under Prince Eugene his agreed quota of 6,000 troops.

It became evident to the emperor that Walpole was the obstacle to the participation of England. A secret agent, an English Roman catholic named Strickland, Bishop of Namur, was accredited at the close of I 734 under the name of Mosley to England. He was civilly received by the king and queen, but Walpole insisted on his dismissal. The emperor had no resource left but to accept offers of mediation made by the maritime powers in the previous June, and then indignantly rejected by him. A settlement was negotiated by the French minister, Cardinal Fleury, with the emperor on the basis of their proposals, though with notable additions. Stanislaus was to have Lorraine for life; and the Duke of Lorraine, who was betrothed to the eldest archduchess Maria Theresa, was to be indemnified with the reversion of Tuscany. On the death of Stanislaus, Lorraine was to pass to France. The preliminaries were signed at Vienna on October 3, 1735. In the eyes of the nation Walpole was entitled to the credit of the boast with which in 1734 he had parried the queen's instances in favour of intervention: "Madam, there are fifty thousand men slain this year in Europe and not one Englishman". The king was persuaded, as usual, that the success of the ministerial policy, which he had strenuously opposed, was in some way due to himself. Walpole had now risen to the height of his power.

The restoration of peace on the continent gave leisure to parliament to recur to measures of social reform. Before the revolution of I 689 the habit of spirit-drinking had been chiefly confined to those classes which could afford the expensive brandies of France, English distilleries being few and insignificant. But the rupture with France which followed that event caused a prohibition to be laid upon French trade and a concurrent encouragement given to English distilling. Gradually a craving for spirits spread like a pestilence throughout the country, and the demand for cheapness was met by the invention of what De Foe describes as the "new-fashioned compound waters called Geneva". Already in 1720 .scenes such as Hogarth, five and twenty years later, engraved in "Gin-Lane," were familiar to the streets of London. In I 729 parliament resolved to inter- 
fere. An act was passed imposing a duty of $5 \mathrm{~s}$. per gallon upon "compound waters," and of $£ 20$ for a retail licence to sell gin CHAP. or compounded spirits, and forbidding the sale of brandy or other spirits about the streets. The act succeeded in diminishing the sale of gin as such, but led to the invention of a form of cheap spirit called "parliament brandy" which, as not being "compounded" within the meaning of the act, escaped the duties. A repealing act in 1733 , while continuing the prohibition of the hawking of spirits in the streets, attempted to put down dram-shops by forbidding the sale elsewhere than in "the dwelling-house of the persons so selling the same". The effect was to transform dwelling-houses into dram-shops. A carnival of drunkenness ensued. Sir Joseph Jekyll, master of the rolls, an independent whig, carried with general concurrence ${ }^{1}$ a measure reviving and extending the system of the act of 1729 . By the statute 9 George II., c. 23, a duty of 20s. a gallon was imposed on spirits and $£ 50$ was to be paid for a licence to sell them. The act, currently known as "the Gin Act," was to take effect from Michaelmas day, 1736.

The approach of Michaelmas day, on which the gin act was to come into operation, was anticipated with anxiety. Troops patrolled the streets of London and Westminster for some days before and after Michaelmas, and Jekyll's house was protected by a guard of soldiers. Unfortunately the act was defeated by its own severity. Informers and blackmailers multiplied, and the mob ducked and otherwise maltreated them. "There never was certainly," writes the Political State for September, 1737, "an Act executed with such difficulty as this against gin." The system of a heavy licence duty having failed, Carteret's ministry proposed in 1743 to lower the retail licence duty from $£ 50$ to $20 \mathrm{~s}$., by which they anticipated that the revenue would be benefited, not by the increased consumption of gin, but by a diminution of the temptation to evade the purchase of a licence. On the other hand, they proceeded to encourage the consumption by lowering the excise from 20 . to a maximum of $6 \mathrm{~d}$. and a minimum of $1 \mathrm{~d}$. a gallon according to the materials used. Great opposition was offered in both houses. The bishops, to their credit, combated it with vigour,

'Colonel the Hon. Charlea Hownd to Lord Carlisle, March 9, 1736, Carlisle MSS, p. 162. 
CHAP. as destructive not only of the people's health, but of their XXII. morals. The bill passed, but out of twenty-four protesting peers, ten wore the lawn sleeves. It was in allusion to this act that Chesterfield, not without a hit at Carteret's convivial habits, dubbed his government " the drunken administration".

During the year 1736, partly owing to the spread of drunkenness, partly to the measures taken for its suppression, and partly to economic causes, there were sundry popular disturbances throughout the country. A riot of another origin, which attracted attention even on the continent and revived the hopes of the exiled Jacobites, was that which has come down to us as the Porteous riot at Edinburgh. The origin of this was the execution on April i 4 of a smuggler named Andrew Wilson. Stones were thrown at the city guard, and its captain, John Porteous, who himself carried a musket, fired a shot into the crowd and, without any reading of the riot act, ordered the guard to fire also. At least fourteen of them fired. ${ }^{1}$ Six of the onlookers were killed and eleven wounded. Porteous was arrested and tried for murder. He was found guilty and ordered for execution on September 8 . He obtained a respite, but a mob broke into the jail on the 7 th and hanged him; after which they dispersed. ${ }^{2}$ The king's speech at the opening of the next session of parliament on February 1, 1 737, adverted to the numerous riots during the previous year. Carteret jumped at the opportunity of embarrassing the ministry in its Scottish administration. He pressed for strong measures, and Walpole found himself at issue with his own colleagues, the chancellor Hardwicke and Newcastle, who advocated the forfeiture of the charter of Edinburgh. With wise moderation, however, Walpole reduced the pains and penalties proposed to an act of two articles, one for incapacitating the Lord Provost Wilson from office, the other for inflicting upon the corporation of Edinburgh a fine of $£ 2,000$, which was assigned to the widow of Porteous.

Mention has been made of the systematic practice of smuggling, the natural consequence of high protective tariffs,

ISo the lord provost said, but upon this the evidence was conflicting, and Porteous denied having fired at all. State Trials, xii., 968.'

2 Details of these proceedings are to be found in a letter from Lord Drummore to Lord Grange, March 22, $1736-37$, Mar and Kellie MSS., p. 549, and in the letters of Lord Provost Wilson in Hist. MSS. Comm., 8th Rep., App., pp. 31t-12. 
and of Walpole's hope of repressing it by excise. Baffled in CHAP. this, he determined to sharpen the laws against smugglers, of XXII. whose exploits at this time there are numerous records in the Treasury Papers. Smuggling was made punishable by transportation for life. The appearance of the bill in the house of lords in May, 1 736, was marked by an opposition of which, since Walpole's supremacy, examples have been rare. The bill contained a clause by which a magistrate was empowered to arrest and imprison three or more persons armed with fire-arms upon information that they were intending to run goods. This clause amongst others was opposed by the chancellor, Lord Talbot, and by Lord Hardwicke, then chief justice, upon the ground that a presumption of criminal intention could not be legally made from an act innocent in itself. A revolt of the two heads of the judicature on constitutional grounds against a principal clause in a government bill would in these days be decisive of its fate. The house, however, while making concessions upon other points objected to by the two law lords, passed the offending clause by fifty-four to forty-six votes, an example, according to Hallam, of dereliction of constitutional principle " to be counted as a set-off against the advantages of a Revolution". The effect of these severities appears to have been to render the smugglers more violent. Pitched battles with customs officers, aided by soldiers, continued of frequent occurrence. In one such, near Pevensey in 1744, a hundred mounted smugglers were victorious. Another measure of social reform was an act of 1737 entrusting to the lord chamberlain the regulation of stage plays. ${ }^{1}$ That public opinion was favourable to this measure is apparent from the celerity with which it passed through parliament, the only recorded opposition to it being that of Pulteney in the commons and Chesterfield in the lords.

During the general election of 1734 the dissenters all over the country had thrown in their lot with the ministry. Two years before Walpole had given proof of his goodwill towards them, and perhaps endeavoured to pave the way for an English measure by instructing the Duke of Dorset, as lord-lieutenant of Ireland, "if it could be done, to get the test repealed".?

1 10 G. II., c. 28.

For Walpole's private feelings on the subject, see Stopford-Sachville MSS., i., 147, December 30, 1731, Hist. MSS. Comm., rga4.

VOL, IX, 
CHAP. There was a prospect of the bill for the repeal passing the Irish XXII. commons, but the certain hostility of the bishops in the Irish house of lords made an attempt hopeless. Shortly after the election, the leaders of the English dissenters approached Walpole. His private opinion, he told them, would have to give way to his duty as a minister: to provoke the clergy would be to wreck the administration. The dissenting leaders turned to the patriots. A bill for the repeal of the test act was introduced in March, 1736, but the tories opposed, and Walpole's criticism that it was "ill-timed" was justified, for it was lost by 25 I to 123 votes. The hostility of the Church to the dissenters was shewn in the course of the same session by the rejection by the lords of a bill for the relief of the Quakers, though actively supported by Walpole himself. From that time forward, he renounced all projects of change affecting the interests of the Church.

When after the secession from parliament of Wyndham and his followers in the session of 1739 , Dr. Chandler, as spokesman for the dissenters, solicited his support for the repeal of the test act, Walpole repeated his former answer that the time had not arrived." To the question, "When will the time come?" he replied, "If you require a specific answer, I will give it you in a word, 'Never'". It was the conclusion forced upon him by a mortifying experience and by the attitude of Pulteney and the dissentient whigs. When the dissenters brought in their bill on March 30, 1739, it was defeated in the house of commons by 188 to 89 votes. On the other hand, the passing of the stringent mortmain bill in 1736 appears to have been facilitated by the resentment of the laity at the oppressive conduct of the clergy in the matter of Quakers' tithes. ${ }^{2}$ The king's denunciation of the bishops as "a parcel of black, canting, hypocritical rascals" was not without its echoes. Bathurst the tory joined with Carteret the whig "patriot" in the chorus against the bench. The tide had turned since the days when the Church was a political rallying cry. Its prelates, as conservative guardians of its temporal

1 The date of this negotiation nas hitherto been left doubtful by historians, but the correspondence printed by C Jxe, Memoirs of Sir R. Walpole (ed. 1798), ii., 515, 520, suggests this as the probable occasion. I69.

'Sir Thomas Robinsọn tọ Lord Carlisle, April 24, 1736, Carlisle MSS., p. 
interests, were in conflict with the whig principles of toleration and comprehension; as nominees and supporters of whig adCHAP. ministrations, latitudinarian in their theology and often remiss in their duties, they were no longer revered by the tory laity for the sake of their office nor by the tory clergy for the sake of their doctrine.

While the repudiation of all fresh proposals for excise left the opposition without a cry for the election of 1734 , the retirement of the king's confidante, Lady Suffolk, in August of that year deprived them for a while of a centre at court round which to group themselves. The effect was to bring the Prince of Wales into greater prominence. His policy, if his conduct can be dignified with such a name, was a policy of pin-pricks. He had some fancied and some substantial grievances. The constant postponement of his marriage was a real wrong on the part of the king. A final rupture of the negotiations, which had been resumed in 1730 , was followed by the betrothal of the Prussian princess to the Margrave of Baireuth. His natural chagrin was heightened by the marriage on March 14, 1 733-34, of his sister Anne, the princess royal, to the Prince of Orange with a grant from parliament of $£ 5,000$ a year for life. The princess, the king and queen were ardent admirers of Handel, then at the head of an opera house in the Haymarket. Frederick posed as patron of Buononcini, at the head of a rival opera in Lincoln's Inn Fields. To fill this house he himself touted among the ladies of the court.1 His chief political adviser was Chesterfield. He talked "violently and publicly" against Walpole. In answer to his demand for permission to marry, the king made choice of the Princess Augusta, daughter of Frederick Duke of Saxe-Gotha, a girl of seventeen, whom George saw when at Herrenhausen in the summer of 1735. She is described by a lady of her bedchamber as being at the time of her arrival in England, "a very agreeable woman, very affable in her behaviour, a good deal of address, and her person what may be called a pretty woman ... the prince seemed vastly pleased ".?

'Lady Betty Germain to the Duke of Dorset, Jan. or Feb., 1734, StopfordSackville MSS., i., 55, Hist. MSS. Comm., 1904.

I Lady A. Irwin to Lord Carlisle, April 26, 1736, Carlisle MSS., p. 170. Hervey is more critical. Memoirs, ii., 29a. 
CHAP. XXII.

His marriage to the Princess Augusta on April 27, 1736, tranquillised resentments but for a short time. Upon the marriage the king had increased his allowance from $€ 24,000$ to $£ 50,000$. This with $£ 9,000$ from Wales and Cornwall made up a net income of something less than $£ 59,000$ a year. But as the establishment appointed for him by the king amounted to $£ 63,000$ a year, "exclusive of his own private expenses," 1 and no jointure had been allowed for the princess, he naturally complained of insufficiency of income. The idea of appealing from the niggardliness of the king to the justice of parliament is said to have been a legacy of Bolingbroke on the eve of his departure for France. Its "chief stimulators" were the younger men of the opposition, the "boys" as it became the fashion for Walpole and his friends to call them, John Russell, fourth Duke of Bedford, who in October, I73I, had married Lady Diana Spencer; his brother-in-law Charles Spencer, third Duke of Marlborough, Richard and George Grenville, their cousin George Lyttelton, and his friend William Pitt, with Chesterfield as their counsellor. Pulteney, not without hesitation, undertook to move the matter in the house of commons and Wyndham, as the leader of the tories, to support it. By dint of "closeting," " personal intercession," ${ }^{2}$ and "offering carte blanche for promissory notes of payment when he came to the crown," the prince had succeeded, shortly after the opening of the session, in securing a majority in the house of commons. On February 21,1737 , the day before that on which the question was to come before the house of commons, Walpole persuaded the king to send the prince a proposal for accommodation: the king would execute a settlement of the $£ 50,000$ hitherto paid the prince as an allowance, and would at once settle a jointure on the princess. The king was chagrined at the failure of the offer. Walpole replied to his reproaches that "he had proposed to bring the house of commons to reason by it, not the prince". His foresight was justified by the event. The motion, introduced by Pulteney, was defeated by 234 to 204 votes, but with a bad grace the king assented to a bill settling $£ 50,000$ a year on the prince, with a jointure of the same amount on the prin-

1 Lady A. Irwin to (Lord Carlisle), March 15, 1736-37, Carlisle MSS., p. 181.

${ }^{2}$ Horatio Walpole to Robert Trevor, Feb. 25, I736-37, Trevor MSS.; p. 5 (in the Earl of Buckinghamshire's MSS.), Hist. MSS. Comm., I895.• 
cess, payable only on the prince's death. Substantially, there- CHAP. fore, the king carried off the victory, since this arrangement XXII. was less than the settlement for the life of the princess demanded by the prince and the opposition.

When not at his house at Kew the prince, his income being unequal to a separate establishment in London, occupied apartments at St. James's or Kensington Palace, or wherever the court might happen to be. $\mathrm{He}$ attended the levées and drawing-rooms, dined in public with the king and queen, and observed the etiquette of the court. It was a spectral solemnity: "the king never seemed to see or know he was in the room; and the queen, though she gave him her hand on all these public occasions, never gave him one single word in public or private". On July 5, 1737, the prince announced to his mother the pregnancy of the princess. The king and queen determined that her confinement, which was expected in October, should take place at Hampton Court, where they then were resident. Great, therefore, was their irritation when on the night of Sunday, the 31 st, the princess being taken ill, the prince secretly hurried her into a coach, drove her at a gallop to St. James's, where no preparations had been made, and where she was delivered of a daughter, afterwards Duchess of Brunswick. As a public mark of the sovereign's displeasure it was determined that the prince should be ordered to leave St. James's, and the letter communicating this resolution was settled by a cabinet council on September IO. Two days later, Frederick and his family removed to Kew. The disapproval felt and expressed by many of the older members of his party threw him more into the hands of the frondeurs $d$ outrance, among whom must be reckoned both Lyttelton and Pitt.

The close of the year, 1737, was marked by the death of the queen. Her illness, which lasted from November 9 to 20 , was due to a rupture too long concealed. ${ }^{1}$ The last scenes, painted in detail by Lord Hervey and popularised by Thackeray in his Four Georges, are familiar pictures. According to Sir Robert Walpole she moulded her husband's opinions into

'Yet as early as 1734 there were rumours that she had " a sore leg which is very bad". Lady Elizabeth Compton to the Countess of Northampton, Townshend MSS., p. 244. 
CHAP. complete accord with her own. "When I give her her XXII. lesson," he told Hervey, "(she) can make him propose the very thing as his own opinion which a week before he had rejected as mine." Her political opportunities came more especially during the king's absences in Hanover, in 1729 , 1732,1735 , and $1736-37$, when, to the chagrin of the Prince of Wales, she exercised the sole regency. She indulged a fondness for theological and philosophical speculation. Her partiality for latitudinarians, such as Clarke and Whiston, is imputed to the influence of her intimate friend Lady Sundon, who does not, however, appear to have ranked with contemporaries as the queen's intellectual equal. The bench of bishops was practically of her selection, and was of marked intellectual distinction. She nominated Berkeley for preferment, though Hoadly thought him of disordered understanding and Walpole a madman. ${ }^{1}$ On her deathbed she recommended her clerk of the closet, Joseph Butler, the famous author of The Analogy. Among men of science she patronised Newton and Halley. But her chief merit as a queen was her steady support of Walpole, even against her own German prepossessions. From him she learnt and laid to heart the doctrine that the common interest of England and of the dynasty was peace. By the death of the queen the main prop of Walpole's power was removed. The opposition rejoiced at the prospect of his fall. He himself saw that the king's irritable vanity could only be managed by a woman. Madam Wallmoden, however, the reigning mistress, was no Pompadour. Walpole quickly realised the accuracy of the king's description of her, "qu'elle n'avait pas un esprit éclatant," and, though courted by Chesterfield and the opposition, she shewed herself incapable of political initiative.

When parliament met on January 24, 1738, the opposition selected the grievances against Spain arising from the right of search in American waters as the weapon with which to attack the ministry. They moved for a list of complaints made since the previous. Ist of September and examined witnesses. The public $\backslash$ were glutted with stories of British sailors imprisoned, ironed, tortured, and starved in Spanish prisons. Among the witnesses was one Robert Jenkins, master

${ }^{1}$ Lord Wilmington to Duke of Dorset, Feb. 15, 1732, Sackville MSS., i., I48, Hist. MSS. Comm., Ig04. 
of the brig Rebecca, whose vessel had been boarded by a CHAP. guarda-costa on April 9, 1731, and his ear cut off by the XXI1. captain. Jenkins produced a severed ear before a committee of the commons, which sat March 16-21, 1738, and the war that ensued has become notorious to posterity as "the war of Jenkins's ear"." In the house of commons Walpole was for the time successful in moderating the tone of the resolutions proposed, particularly in evading the question of the right of search of ships suspected of contraband trading with Spanish American ports conceded by a treaty of 1667. But he could not control the house of lords where, besides Newcastle, two members of his cabinet, Hardwicke and Harrington, were for war. Upon March 30 Carteret carried an address against the right of search. "No search," he exclaimed, "is a cry that runs from the sailor to the merchant, from the merchant to the parliament, and from parliament it ought to reach the throne."

On the whole, so long as a discreet silence was observed about theoretical rights, Spain displayed a conciliatory spirit. A preliminary negotiation was opened up in London by the Spanish envoy Geraldino (Thomas Fitzgerald), and this, under Walpole's guidance, was approaching completion. It was agreed that the claims against Spain should be appraised at $£ 200,000$. Against this sum were set-off the losses, estimated at $£ 60,000$, inflicted by Admiral Byng on the Spanish fleet at the battle of Cape Passaro in 1718, a claim acknowledged in the treaty of Seville in 1729 . The remaining $£ 140,000$ Spain proposed to pay by assignments on her American revenues, but the English ministry preferred to make an allowance of $£ 45,000$ for cash payment. The sum due from Spain was thereby reduced to $£ 95,000$. The questions of the right of search and the delimitation of Florida and Georgia were referred to a commission which was to report within eight months. This convention being sent to Madrid for ratification, Philip V. rejected it as leaving unsettled a claim of the Spanish government from the South Sea Company of $£ 68,000$ due under the conditions of the Asiento. Keene, our minister at Madrid, agreed that the $£ 68,000$ should

1 Recent researches have disproved Burke's assertion that the story told by Jenkins was a "Gable". See Sir J. K. Laughton in Engl. Hist. Rev., iv. (Oct., 1889), $74 x$. 
CHAP. be paid if it were proved to be owing. With this proviso,

XXII. which the Spanish ministry interpreted as an absolute promise, he and La Quadra, afterwards Marquis of Villarias, the Spanish minister of foreign affairs, signed the convention on January 14, I 739, N.S. On its arrival at London (January 1 5-26, 1738-39) it received the approval of the cabinet council.

A revulsion of feeling upon a measure at first sight tolerable is a common experience in politics. When parliament assembled on February I, O.S., the opposition, more anxious to evict Walpole from power than to avoid a war, overwhelmed the convention with torrents of indignation. The right of search unchallenged! the outrage on Jenkins's ear unredressed! the victory of Passaro to be penalised by the exaction of compensation! and, after all, the observance of the convention by Spain to depend, by an annexed declaration on the part of Philip V., upon the issue of the negotiations with the South Sea Company! The country was wrought into a frenzy. Lampoons and caricatures of ministers and the convention filled the town. Petitions poured into parliament denouncing it. In the lords Carteret and Chesterfield led the attack. Argyll, with vehement language against the ministers, joined them. The Prince of Wales gave his first vote in parliament with the opposition. But the ministry carried the address by 7 I to 58 votes. On March 8 the convention was debated in the commons.

In this debate William Pitt, then thirty-one years of age, first seriously impressed the political world. He was a grandson of Thomas Pitt, governor of Madras, purchaser of the great diamond which he sold to the regent Orleans for $£ 135,000$. William Pitt had been educated at Eton and at Trinity College, Oxford, and had gone the grand tour. His friend George Lyttelton, a young man of fashion, whose sister the younger Thomas Pitt had married, introduced him to his uncle Lord Cobham, and in 173 I Pitt obtained a commission in the King's Own, commonly called Cobham's, regiment of horse (King's Dragoon Guards). He took his profession seriously and later told Lord Shelburne "there was not a military book he did not read through". Cobham, after being dismissed in 1733 , became the recruiting officer of the rising talent known as the "boy patriots," and under his patronage William Pitt in 
February, 1735, succeeded his elder brother Thomas as member for the family borough of Old Sarum. Pitt's first speech in parCHAP. liament on April 29, 1736, attracted attention. The occasion being the congratulatory address to the king on the marriage of the Prince of Wales, he satirised by the extravagance of his compliments the attitude of George II. to his son. Lyttelton had already introduced him to the prince who had at once taken him into favour. The speech was recognised as a blow delivered from the enemy's camp. Walpole had not dismissed dukes to tolerate an affront from a subaltern. "We must muzzle this terrible young cornet of horse," he is reported to have exclaimed. On May 17 Pitt was dismissed the service. The dismissal not only made him a martyr; it provoked discussion among the opposition as to the policy of excluding officers altogether from a parliament in which they were only free to vote as the dependants of the ministry of the day. ${ }^{1} \mathrm{He}$ became in September, 1737, the prince's groom of the bedchamber, and his resentment against Walpole displayed itself in incessant declamation against the corruption and absolutism of the minister. His speech on the Spanish convention, if we judge by our reports of it, was an inflammatory harangue. "Mr. Pitt spoke very well, but very abusively," is the note of one of his audience. The abuse answered its purpose in discrediting Walpole, whose majority was reduced to twenty-eight.

The reduction of the ministerial majority, intelligence of the growing irritation in Spain on account of the dispatch to its coasts in May, 1738, of a squadron under Admiral Haddock, and anticipation that the obstinacy of the South Sea Company would render a collision unavoidable, combined to recommend retirement as Walpole's most politic course. George refused to accept his resignation. Walpole repeated his offer, but yielded to the king's pressure and remained at his post. That he did so was perhaps due to his knowledge that the opposition intended to secede from the house of commons. Their secession, headed by Pulteney and Wyndham, took place on March 9, 1739. It was a theatrical coup devised by Bolingbroke, who had returned to England in December, 1738 . As a manœuvre in practical politics, it was a ridiculous failure. It impressed no 
CHAP. one 1 it involved a breach of trust to the constituencies conXXII. cerned; it did not even command the approval of the whole party. Sir John Barnard, Lords Cornbury and Polwarth, Plumer and others refused to secede. The consequence was that the opposition was reduced to insignificance, while Walpole was enabled to carry through ministerial measures with unprecedented smoothness. As in all moments of respite from political pressure, he busied himself with measures for the encouragement of trade. It was in this year, I739, that when sounded by Lord Chesterfield upon a project for the taxation of America, he answered, "I have old England set against me, and do you think I will have new England likewise?" But he vindicated his refusal on the higher ground that the true policy was the developement, not the exploitation of colonial prosperity. He preferred rather to enlarge the bounds of colonial freedom by removing from the sugar colonies the restrictions upon the exportation of sugar direct to European ports south of Cape Finisterre, France having by this policy almost absorbed the sugar trade of Southern Europe. ${ }^{2}$

The factious character of the opposition exhibited itself in their attitude upon the vote for the army. In February, I 738, while driving the country into war, they opposed the vote for I 7,400 men proposed by the ministry, Shippen moving a reduction to 12,000 men. It was a relief to Walpole, therefore, when in the session of 1739 the secession of the opposition facilitated the passage through the commons of a treaty with Denmark engaging the services of 6,000 men for a subsidy of $£ 70,000$ a year. The treaty rescued Denmark from the grasp of France, which had already secured Sweden. It was a first step in the new "northern system" of England which looked to the two ancient adversaries of Sweden, Denmark and Russia, to counterpoise the influence of France in the Baltic. When on May 23 the plenipotentiaries met to exchange ratifications of the convention with Spain, the Spaniards demanded the withdrawal of Haddock's squadron from their coasts, and declared the revocation of the Asiento and their intention to seize the South Sea Companies' effects as an indemnification for the $£ 68,000$ they claimed. As if to exclude the possibility

${ }^{1}$ Horatio Walpole to Robert Trevor, May 8-19, 1739, Trevor MSS., p. 30.

2N. A. Brisco, Economic Policy of Robert Walpole, 1907, p. 164: 
of an accommodation, they added a general assertion of the CHAP. right of search. Of this claim Keene had been directed to XXII. exact an explicit renunciation, a sign that the policy of Walpole was no longer authoritative in the ministry. War was now unavoidable and both sides made active preparations. ${ }^{1}$ At the beginning of July Haddock in the Mediterranean was strongly reinforced. A fleet for the defence of the coasts was equipped under the command of Admiral Sir John Norris. By the end of the summer, the effective force of the navy was estimated at 28,870 seamen and 84 ships of war carrying 3,996 guns, exclusive of fireships and transports.

Although war had not yet been formally declared, the English ministry determined to strike in the West Indies, and on July 19, Vice-Admiral Edward Vernon received instructions "to destroy the Spanish settlements and to distress their shipping". Vernon had sat in parliament as a member of the whig opposition, had signalised himself by the acrimony of his invective, and had boasted that with six ships he could destroy Porto Bello, the port in which the guarda-costas, the Spanish revenue vessels, were fitted out. Arriving off Porto Bello on November 20, with six ships, Vernon found the Spaniards unprepared, and on the 2 Ist, after a hot cannonade, captured the place by assault. Although active hostilities were thus being carried on, war had not been declared. At last the formalities of diplomacy being exhausted, the declaration of war was issued in London on October 23. It was received with transports of enthusiasm: "a war with Spain was a war of plunder". The first-fruits were soon tasted. By the end of the month the news reached London that Haddock's squadron had captured two treasure ships from the Caraccas, each of the estimated value of $£ 100,000$. Walpole alone kept his head. "They now ring the bells," he exclaimed with bitterness, " they will soon wring their hands." It is now known ${ }^{2}$ that he was aware of the Family Compact and that Spain would be joined

'Mr. Armstrong, who insists on the indisposition of the Spaniards to go to war, saye that "till within a month of the declaration of war, October, 1739, no serious preparations were made in Spain". Elisabeth Farnese (1892), p. 355. But Horatio Walpole writing to Robert Trevor on June 8-19, announces the re ceipt of a dispatch from Keene, and says: "Spain is preparing all the ships they can get together to offend and defend ". Trovor MSS., p. 33.

Sir J. R. Seeley in Engl. Hist. Rev., i. (Jan., 1886), 86. 
CHAP. by France. The obvious counterpoise was to be found in XXII. Prussia, and Prussia might, in Horatio Walpole's opinion, have been gained by the support of England to its claim to the disputed succession of Berg and Jülich. Here, indeed, Hanoverian antipathies stood in the way of British interests. When Frederick II. came to the Prussian throne in 1740 , the question was still unsettled, and Walpole, Newcastle, and Hardwicke were urgent with the king to offer a guarantee as the price of the Prussian alliance. ${ }^{1}$ Unfortunately, there were outstanding bickerings with Hanover over the succession to East Friesland, which Horatio Walpole recommended should be ceded by $\mathrm{Hanover}^{2}$ and conflicting claims in Mecklenburg. Meanwhile, the marriage of the eldest daughter of Louis XV. with Don Philip, the younger son of Philip V. and Elisabeth Farnese, gave fresh force to the Family Compact.

Parliament met earlier than usual, on November 1 5, 1739. The seceders, being now alive to the futility of their demonstration, returned to the house of commons, and Pulteney vindicated their action, declaring it justified by the declaration of war, an acceptance of the policy they had represented. Though the address was carried in both houses, the course of the session revealed the growing weakness of Walpole's position. One rebuff followed another. He was harassed by gout and the stone, which left him but intermittent vigour and disturbed the balance of his naturally placid temper. "All agree Sir Robert cannot live," wrote Pope in 1740. A supply of $£ 4,000,000$ for the war was granted with alacrity, the land tax being again raised to four shillings in the pound; but official returns shewed that no more than 21,500 seamen had been procurable for the navy during 1739 . In April, 1740, only twenty out of the thirty ships reserved to guard the Channel were manned. In the hope of filling the gaps, the admiralty laid an embargo upon all shipping excepting coasters. It was clear, however, to Walpole that the time had arrived when makeshift expedients should be replaced by a regular system. The problem was not of a kind new to him. As

${ }^{1}$ Newcastle to Harrington, September II, 1740, R. O., MS., State Papers, G. II., bundle 5,220, no. 48 ; $c f$. Horatio Walpole to Robert Trevor, September 23-October 4, 1740, Trevor MSS., p. 54 .

Ibid., p. 50, June 7-18, 1740 . 
secretary at war in 1708 he had been responsible for the act 1 empowering parish officers to search for and impress vagrants CHAP. and paupers for service as soldiers and marines. For the sea service more effective material was needed than could be raised from the random sweepings of the country-side. ${ }^{2}$ A committee of the house of commons reported in favour of establishing a general register of all seafaring men. Admiral Sir Charles Wager, the first lord of the admiralty, Walpole's constant supporter, brought in a bill to carry out this recommendation on February 5. The opposition rose in arms. The plan was French; it smacked of slavery. Against it Pitt hurled all his thunders-"the prettiest words," said Winnington, "and the worst language he had ever heard ". All that the ministry could carry was a futile resolution "that a voluntary register would be of great utility to the kingdom". The conduct of the opposition was the more unpatriotic in that it convinced the war party in France that the supply of seamen would run short and English naval supremacy be overthrown. ${ }^{3}$

In the middle of March the news arrived of Vernon's capture of Porto Bello. It was not enough to exalt this somewhat minor success into a great national victory. It was converted into party capital. The two houses of parliament voted thanks ; congratulatory addresses poured in upon the king; medals were struck showing Vernon's head with the legend: " $\mathrm{He}$ took Porto Bello with six ships". In this legend lay the sting which the opposition, who claimed the hero of the hour as their peculiar property, applied to Walpole. Admiral Hosier in 1726-27, at the head of twenty ships, had ventured no further than to establish a blockade of Porto Bello which had cost the country, besides the life of the admiral himself, the lives of 4,000 men. The inference was clear. The naval strength of the country had been sapped by Walpole's pusillanimity. The ministry resolved to insure superiority at sea. Information having reached them that the French squadrons at Toulon and Brest had sailed for America, ${ }^{4}$ they dispatched

I7 Anne, c. 2.

Circular for impressment of seamen from the lords of the council to the lords lieutenant, June 15, 1739, Hist. MSS. Comm., 6th Rep., App., p. 474.

Neweastle to Harrington, September I9, 1740, R. O., MS., State Papers, Dom., G. II., bundle 52, no. 55 .

- This explanation, hitherto unknown, of what has sometimes been represented as an aimless profusion of etrength, is contained in a draught letter from Newcastle 
CHAP. at the end of October an auxiliary fleet under Rear-Admiral XXII. Sir Chaloner Ogle, consisting of the vast number of I I 5 ships, thirty-three of them of the line, with I 5,000 sailors and 9,000 to 10,000 soldiers on board. On January 7, 1741, Ogle joined Vernon at Port Royal, in Jamaica, where a council of war decided upon the reduction of Cartagena, the strongest place in Spanish America. General Wentworth, who succeeded on Lord Cathcart's death to the command of the troops, having first delayed and then mismanaged an assault on April 9, settled down to a siege. By the 24th his effective force had dwindled to 3,200 men, the remnant that had survived the fire of the enemy and the more searching deadliness of the climate. Smollett has left a description of the misery, of which he was an eye-witness, endured by the wounded and sick.1 It was determined to withdraw. A half-hearted attempt was next made in July by Wentworth on Santiago in Cuba. At the end of the year, after twelve months of failure and disease, the expedition returned to Jamaica. With the public at home exultation had been followed by depression. On September I 8, I740, a small squadron of six ships had been dispatched to the Pacific under Commodore George Anson. So lavish were the preparations for the support of Vernon that Anson's squadron could only be manned with difficulty. Its forces for land service consisted of 500 worn-out Chelsea pensioners and undrilled marines. For three years it disappeared from sight. Anxiety for its fate added to the disappointment over Vernon's failure.

On October 20, I 740, the Emperor Charles VI. died and by virtue of the pragmatic sanction his daughter Maria Theresa succeeded to his dominions. Eight days later followed the death of Anne of Russia, Austria's most powerful ally. After rapid military preparations, Frederick II. threw a Prussian army into the Austrian province of Silesia. The entire continental system constructed by England as a barrier against French aggressions had fallen to pieces in a few weeks. In this critical conjuncture of events, in which Great Britain

to the lord president (Wilmington) of September 9, r740. The letter states that Vernon had already ten sail of the line with him and that the addition of the thirtythree now dispatched would give a total of forty-three as against the combined Spanish and French forces of thirty-nine. R. O., MS., State Papers, Dom., G. II., bundle 52 .

'Roderick Random, chap. xxxiv. 
found itself hampered by a war with Spain and bound by its guarantee of the pragmatic sanction to face a probable coaliCHAP. tion arrayed against Austria, an opportunity offered itself for the first personal attack upon Walpole. This attack was led on February 13, 1741, by Carteret in the lords and by Sandys in the commons. After arraigning the whole policy of Walpole, domestic as well as foreign, a motion was made for an address to the crown to remove him "from His Majesty's presence and counsels for ever". Pelham and Henry Fox were Walpole's chief apologists, but the most masterly defence was that of the minister himself. He defended himself against the invidious charge, formulated afterwards by the pen of Bolingbroke in the protest of the defeated minority of the peers, that he had made himself "a sole or even a first minister". As in this connexion the ominous name of Strafford was mentioned, such an accusation was at that epoch of constitutional developement one of grave moment. In the house of lords, where the Prince of Wales was present but did not vote, the motion was defeated by eighty-one to fifty-four votes. In the commons Shippen, at the head of thirty-four Jacobites, walked out of the house, so that the opposition, who had been handing round lists of the incoming ministry, found themselves defeated by 290 to 106 votes. The defection of Shippen did not, indeed, decide the battle, but in Chesterfield's phrase, " it broke the opposition to pieces". Recent discoveries of letters ${ }^{1}$ establish that since 1734 Walpole had been playing off the Jacobites against the rest of the opposition by an indirect correspondence with the pretender, carried on with the cognizance of the king.

Notwithstanding majorities in parliament, in the country at large the ministry was falling into increasing unpopularity. Maria Theresa having summoned the king as elector to support her against Prussia and France, he repaired to Hanover in May, despite Walpole's remonstrances, and in September, in a fit of alarm, without consulting the cabinet in London, hastily negotiated a treaty for the neutrality of the electorate, a step possibly necessary but involving him in a torrent of obloquy. Parliament was dissolved on April 27, 1741. In the new

1 Hodghin MSS., p. 235, Hist. MSS. Comm., 1897. See also the author's article "Wapole, Sir Robert," in the Dict. Nat. Biog. 
CHAP. parliament Dodington estimated the opposition as but sixteen XXII. short of the ministerialists. During the interval before the session began the tide of Walpole's unpopularity still shewed signs of rising. From abroad came the ill news of Cartagena in October and the failure of the enterprise against Cuba. Losses of merchantmen captured by Spanish vessels of war were constantly reported. Bankruptcies were of "daily" occurrence, if we may accept the rhetoric of William Murray, who in 1738 had distinguished himself by his speech in the house of commons upon the merchants' petition concerning the Spanish depredations. In the beginning of December Haddock was compelled by the inferiority of his force to retire before a Spanish and French fleet to Port Mahon and another naval failure was added to the debit of the ministry. But the decisive blow to Walpole's credit was the news of the treaty for the neutrality of Hanover, though in this he had been compelled to a reluctant acquiescence in an accomplished fact.

The new parliament met on December I, I74I. The turn of the balance between the two parties would be determined by the results of the trials of election petitions. On December I 7 ministerialists returned for Bossiney were unseated by six votes and five days later those for Westminster by four (220 to 2 I6). The victories of the opposition were celebrated by bonfires all over the town. Unless some diversion could be effected, it was plain that the ministry was doomed. Modern usage might demand resignation; but resignation which now, at the worst, means retirement was likely, as Horace Walpole said, to mean the Tower, and he tells us that, when defeat came, people hired windows in the city to see the fallen minister pass by. It is mere pedantry to apply modern conventions to a time when a man's fortune and perhaps his life were at stake. On January 21, 1742, Pulteney delivered his long-expected attack, by moving to refer to a secret committee the papers relating to the war. Walpole replied with astonishing vigour and effect, and was supported by Pelham, Winnington, and Yonge. The ministry was victorious, with the assistance of two deserters from the tories, by 253 to 250 votes. On the 28 th upon a point arising out of the Chippenham election petition, it was placed in a minority of one. The final struggle over that election was to take place on February 2 , 
and on Sunday, January 31, Walpole made up his mind to resign. Rumours had apparently got about, for on the division CHAP. the ministry was beaten by 241 to 225 . On February 9 Walpole was created Earl of Orford, and on the IIth he resigned all his offices. But so notorious was the confidence reposed in him by the king that neither party regarded him as an extinct force in politics. "All cry out," wrote Horace Walpole, "that he is still minister behind the curtain."

The new Earl of Orford's first care was to paralyse the opposition. He advised the king to offer Pulteney the headship of the administration on condition that he should not be impeached. Pulteney replied that he was " not a man of blood". But Pulteney made three mistakes. He had failed to learn the lesson which Walpole first taught the nation, that the seat of power was the house of commons; he assumed that he could air the disinterestedness of his "patriotism" by refusing office, and yet by a seat in the cabinet retain a guiding hand upon the helm of government; and he yielded to the king's wish to make as few changes as possible in the ministry. Among a numerous party hungry for their share of the spoils, such a concession was certain to produce heart-burnings. His nominations were the Earl of Wilmington as first lord of the treasury, Sandys as chancellor of the exchequer, Carteret as secretary for the northern department in the place of Harrington, who was to be president of the council, and a few other minor officials; Gibbon, a tory, the father of the historian, had a seat at the treasury, and Sir John Hynde Cotton, a Jacobite, on the board of admiralty. The real head of the administration was Carteret, who, after Walpole, possessed the king's confidence. Carteret's mind, like Pulteney's, had no place for personal rancour. But smaller men hoped to win a name by driving on measures against Walpole, and the tories, in resentment at their exclusion, joined in a persecution likely to embarrass the new ministry. A motion by Lord Limerick for an inquiry "into the conduct of Robert Earl of Orford during the last ten years," was carried by 252 to 245 votes, and a secret committee of twenty-one was appointed by ballot, of whom not more than two were supporters of the fallen minister. Limerick himself was elected chairman.

Flushed with expectations of startling disclosures and VOL. IX. 
CHAP. conscious of the necessity of substantiating their oft-repeated XXII. charges of peculation and corruption, the committee of secrecy entered with ardour upon their inquiry. The outcome of their investigations was insignificant-some alleged promises of places to voters and financial assistance to candidates at two or three contested elections; a charge of conspiracy to defraud, because the contractors who undertook to furnish the pay to the troops in the expedition against Cartagena gained 14 per cent.; an expenditure of secret service money computed at a million and a half in ten years; the subsidising of newspapers to the extent of $£ 50,000$ in ten years, a practice which had been long maintained by successive administrations. A conclusion so lame and impotent provoked a reaction of opinion in favour of Orford. When in the autumn session an endeavour was made to revive the inquiry, even the eloquence of Pitt, who had been foremost in his animosity, failed to carry the house with him, and the motion was rejected on December I by 253 to 186 . In proportion as the credit of Orford was raised, the credit of Pulteney fell. At the end of the session he made up his mind to go to the upper house, and on July 16 was created Earl of Bath. Some promotions of his friends followed, the most important among them being the substitution of Lord Gower, a tory, for Lord Hervey, as lord privy seal. Orford welcomed his old opponent in the house of lords with, "You and $I$ are now two as insignificant men as any in England". Pulteney's acceptance of a peerage, said to have been pressed upon him by the king at Orford's instance, seemed to the people to give the lie to his repeated professions of disinterestedness. He was bespattered with virulent abuse and derided in a succession of witty vers de societt from the facile pen of Hanbury Williams. 


\section{CHAPTER XXIII.}

THE CARTERET ADMINISTRATION.

AT the accession of Carteret to the direction of foreign affairs, a change of the fortune of war in favour of Maria Theresa was CHAP. in full progress, but an Austrian defeat at Chotusitz, on May 17, 1742, promised a renewal of the French ascendancy in Germany and Bohemia. The haughty spirit of Maria Theresa now stooped to consider the surrender of Silesia, while prudence prescribed to Frederick contentment with his acquisitions under the guarantee of Great Britain and the States-general. Under Carteret's instructions a settlement was effected by the treaty of Breslau, of which the preliminaries were signed on June I I. The treaty restored Great Britain to credit as a mediator in continental politics, and conferred on Carteret the reputation of being the most brilliant foreign minister in Europe. In the meanwhile the rival ambitions of Elisabeth Farnese and Charles Emanuel of Sardinia to carve kingdoms out of the Austrian possessions in Italy were working apace. The failure of Admiral Haddock, in face of the threatening attitude of a French fleet, to prevent the transport of troops from Spain had been followed in December, 1741 , by the landing of 14,000 Spaniards on Genoese territory. Don Carlos had already welcomed a Spanish army at Naples.

The complete ascendancy of Spain in Italy was as dangerous to Charles Emanuel as that of France in Germany to Frederick of Prussia. In March, 1742, his position was strengthened by the dispatch of an English fleet to the Mediterranean under the command of Vice-Admiral Mathews, who was also accredited to him as plenipotentiary. The accession of Sardinia to the cause of Maria Theresa would enable England to strike a blow at Spain in the north of Italy, while 
CHAP. the Spanish dependency of Naples lay open to her fleet. xxIII. Carteret's promise of a subsidy of $£ 200,000$ determined Charles Emanuel. He signed at Turin a convention with Austria on February I, I 742, marched an army of 30,000 men into Lombardy and united with the Austrian General Traun. A change came over the Spanish fortunes in Italy. While Mathews was blockading the French and Spanish fleets in Toulon, he detached Commodore Martin in command of three ships of the line, two frigates, and four bomb vessels, to compel the King of Naples to sign a convention withdrawing his troops from the Spanish army. On August 9, 1742, under threat of a bombardment at the expiration of half an hour's grace, Don Carlos yielded. ${ }^{1}$ In that half-hour England had dissipated Elisabeth Farnese's dream of a kingdom of Lombardy for her younger son, Don Philip.

At the close of the year I741, Maria Theresa's envoy demanded, in fulfilment of treaty obligations, the dispatch of troops for the protection of the Austrian Netherlands against the French. For this the king and nation were equally zealous; the king because it promised additional security to Hanover, and because he was bound to enforce the pragmatic sanction, the nation at large out of sympathy with the young Queen of Hungary. It was determined that I 6,000 British troops should be embarked for Flanders, to join the auxiliary corps of Hessians and Hanoverians. Argyll, who had been reinstated by the new ministry, having resigned, Stair was nominated commander-in-chief and was accredited in March, 1742, to the States-general with the task of persuading them to furnish a contingent of troops. The total force which, it was anticipated, would be at the disposal of the maritime powers consisted of 14,000 Austrians, 20,000 Dutch, 6,000 subsidised Hessians, I 6,000 Hanoverians, and I6,000 British-in all 72,000 men. The rest of the year was wasted in waiting for the Dutch contingent. The British army remained in its headquarters at Ghent "idle, unemployed, and quarrelling with the inhabitants".

The assumption sedulously inculcated by the opposition

${ }^{1}$ So Sir J. K. Laughton in the Dict. Nat. Biog., art. "Martin, William". Luigi Bossi, however, in his Istoria d'Italia (1823), xix., 21I, states it at two hours, adding however, "tratto quindi dalla tasca l'oriuolo, comincio a contarne $i$ minuti," which makes the half-hour the more probable. 
writers at this period, that the connexion with Hanover was disadvantageous to Great Britain, was derived rather from CHAP. patriotic sentiment than from a just estimate of the political situation. But it did impress British public opinion with the conviction that British resources were being sacrificed to alien policy. Great, therefore, was the dismay of Carteret and Newcastle when the king announced to them his intention to disband 16,000 of his Hanoverian troops on account of the expense. The Dutch were still hesitating. Such a withdrawal was certain to increase their timidity. The cabinet, therefore, unanimously decided that the 16,000 Hanoverians should be taken into pay as from August 31,1742 . In the meanwhile the mission of Stair to the States-general had proved a failure. In October Carteret took over the negotiations. Within a week he obtained from the Dutch an undertaking to join England in the payment of subsidies to the Queen of Hungary and to furnish 20,000 troops towards the campaign. It was a triumph to set off against the odium in which the ministry was involved by the transaction relating to the 16,000 Hanoverians. "Hanover," writes Horace Walpole, "is the word given out for this winter." There was a shower of pamphlets denouncing what one of them calls "the Hanover rudder". Of these the most famous were The Case of the Hanover Troops, attributed by Horace Walpole to the co-operation of Pitt, Lyttelton, and Dodington, and effectively answered by Horatio Walpole in The Interest of Great Britain Steadily Pursued. In spite of the unpopularity of the government's action, the weakness of the opposition in the commons was shewn by a minority of 193 to 260 ministerialists (December 10). George meanwhile strengthened himself by two prudent alliances. A treaty with Prussia, signed at Westminster on November I 8, 1742, by which each sovereign guaranteed the other's territories, protected Hanover against a French raid; and a treaty with Russia stipulated that the empress should furnish 12,000 troops and Great Britain twelve men-of-war, if either should be attacked by a fresh enemy in the war between Russia and Sweden or between England and Spain. France, the secret instigator of Sweden as of Spain, was the enemy aimed at.

Parliament rose on April 21, 1743, and on the 27th George, greedy of glory, embarked for the continent. Stair's army had 
CHAP. begun marching eastwards in February ${ }^{1}$ with the object of xXIII. cutting off the French from their Bavarian allies. In the middle of May Stair fixed his camp at Aschaffenburg, where there was a bridge over the Main. Here he was joined by the king, the young Duke of Cumberland, and Carteret. His forces consisted of some 30,000 men, but reinforcements were expected of 6,000 Hanoverians, whom George, by way of appeasing the storm in England, had freshly raised at his own expense, and 6,000 Hessians released from garrisoning the barrier fortresses. He was threatened by a French army of 50,000 men under Marshal Noailles, who had superseded Belleisle. Stair's force, which went by the name of "the pragmatic army," was the victim of divided counsels. His supplies were cut off by the enemy's cavalry; the English and Hanoverians were bickering ; discipline was daily slackening. He proposed to the Duke of A renberg, the commander of the 20,000 Austrian auxiliaries, with whom he was on bad terms, to give battle; but the Austrian refused, and Noailles, hoping to starve the allies out, abstained from attack. It was resolved to fall back down the river to Hanau, the rendezvous of the Hessians and Hanoverians, by the road on the right bank of the Main about sixteen English miles. Half-way lay the village of Dettingen which the French, having thrown two bridges across the Main at Seligenstadt, occupied with 30,000 of their best troops under the command of Noailles' nephew, the Duke de Gramont. In front of Dettingen lay a ravine and morass. It was the intention of Noailles to harass the retreating allies with his artillery from the other bank of the river, to trap them in Dettingen, and, himself seizing Aschaffenburg, to prevent their escape to the rear: Dettingen was to prove a British Sedan.

The allied army left its camp early on June 27 , the king with the British being in the rear, where the attack was expected. At eight o'clock in the morning the advanced guard reached the outskirts of Dettingen, only to find the village occupied by the French. A halt was called. During six hours the two armies watched one another, the allied army being drawn up in five lines, three of foot and two of horse. The French artillery at the distance of 200 to 300 yards on the other side of the river poured an incessant fire upon the allies'

${ }^{1}$ Russell-Astley MSS., p. 223, Hist. MSS. Comm., 19ọo, 
left flank. At last Gramont's patience gave way. He abandoned an impregnable position, commanding a defile through CHAP. which the allies would have to pass, crossed the boggy ravine, and threw himself upon the allied army drawn up in the plain, thereby paralysing the action of the French artillery on the opposite bank. The French cavalry broke the dragoons in front of the allies' left, but were thrown into disorder by the second line of infantry. For the last time a king of Great Britain was seen at the head of his troops. George, who had hastened to the front of his right wing, dismounted from his charger, which had become unmanageable, and on foot, sword in hand, led the British and Hanoverian infantry. The French foot failed to retrieve the rout of the horse. Broken by a charge of the British infantry, they took to flight, many being drowned in trying to cross the river. At the end of four hours the field remained in possession of the allies, who had lost 2,38I men; the French losses being more than double that number. The Duke of Cumberland was wounded in the leg, and his courage as colonel of the First Foot Guards (Grenadiers) is attested by Wolfe, the hero of Quebec, who was present. As it was of the first consequence to reach Hanau, the men being without food, it was necessary for the victorious army to abandon its wounded to the care of the enemy.

Stair, finding the expected reinforcements at Hanau, pressed the king to cross the Main and intercept the retreat of the French upon the Rhine; or in the alternative, to hurry the army to Flanders, thence to carry out his plan of invading France. To his mortification no notice of his advice was taken, ${ }^{1}$ though it was supported by General Ligonier, who at the head of Ligonier's Black Horse, now the 7th Dragoon Guards, had distinguished himself in the action. A period of inactivity ensued, broken only by the ravages of dysentery and by incessant bickerings between the English and Hanoverians, who were accused of enjoying the king's partiality, notwithstanding indifferent behaviour during the battle. Fortunately for the allies, Noailles was in no situation to retrieve his defeat. The

1 This is attributed by Lieut.-Colonel Russell of the First Foot Guards, after a conversation with Stair, to Carteret's anxiety to avoid a war with France. RussellAstley MSS., p. 262. Noailles had humoured this fiction of peace between the two countries by releasing and giving money to English prisoners taken a few days before Dettingen. Ibid., p. 243. 
CHAP. result of the campaign was that the French, greatly weakened, XXIII. were driven out of Germany.

Carteret, in continuous attendance on the king, had been busy with diplomacy. Charles Emanuel had manfully fulfilled his part under the convention of Turin, but Maria Theresa had failed to discharge her reciprocal obligations. England called upon her to satisfy Sardinia by a cession of territory in Italy. By way of rendering the advice more palatable, Carteret at Worms and Sir Thomas Robinson at Vienna engaged their country to considerable sacrifices. England undertook to maintain a strong squadron in the Mediterranean and to contribute an annual subsidy to Sardinia of $£ 200,000$ during the war. The queen on her part, while protesting to Carteret that the dismemberment of the Austrian territory in Italy was not the same thing as the execution of the guarantee of the pragmatic sanction, reluctantly granted the concessions demanded. This treaty of September I 3, between the three powers, known as the treaty of Worms, was followed by a declaration of war by Sardinia against France and led to that tightening of the alliance between France and Spain called the treaty of Fontainebleau or the second Family Compact of October 25. This compact, of which the preamble recites that it is based upon that of the Escorial, now known as the first Family Compact (November 7, 1 733), contemplated a declaration of war by France against England. In that event the recovery of Gibraltar was to be a principal objective of the allies, and no treaty of peace was to be signed which should not include it; France was also bound to assist Spain to recover Minorca; both powers were to compel the English to suppress the colony of Georgia, and the King of Spain undertook not to renew the Asiento in favour of England. As against this country, it was on the part of France an undertaking to revive Spain's naval power, on the part of Spain a promise of commercial privileges to France, contingently on the accomplishment by France of its promises. 1

With the conclusion of the treaties of Worms and Fontaine-

1 The treaty was betrayed to the English ministry during its negotiation (August, 1740) by an informer known as I01, whom Coxe in Memoirs of Sir $R$. Walpole, iii., 457, identifies with the French envoy the Abbe de Bussy. Newcastle to Harrington, August I2, 1740, R. O., MS., State Papers, Dom., G. II., bundle 52, no. Io. See also 28 to Bussy's treachery, A. Waddington, Louis $X V$. et lo renversement des Alliances (1896), p. Ior, 
bleau the war assumed a new aspect. So far, Great Britain had figured as the auxiliary of Austria, and the army victorious CHAP. at Dettingen, of which the largest part was directly in British pay, was nothing more than "the pragmatic army". The Family Compact brought France into the contest as a principal against a league of which Great Britain was the head. The entire range of their conflicting interests was thenceforth involved. In North America, in India, ${ }^{1}$ on the sea throughout the world there had begun between France and England a struggle for supremacy. In England the news of Dettingen aroused an excitement out of proportion to the merits of a victory due rather to the folly of the opposing general than to the skill of our own. There was, however, solid ground of satisfaction in the steadiness of the British troops. Bonfires and illuminations hailed the day immortalised by Handel's "Dettingen Te Deum". The king's courage and that of the young Duke of Cumberland were the theme of universal praise. But the subsequent inactivity of the army, the bitter feeling between the British and the Hanoverian troops, the alleged partiality of the king for his countrymen, and the resignations in disgust of Stair and of his second in command, the Duke of Marlborough, combined to dissipate these favourable impressions. "The distinction this winter," wrote Bishop Sherlock on October 8, "is to be Hanoverians and Englishmen." 2 A great revulsion of feeling as to the war rapidly arose. There was a sense that England had already expended more than her share in blood and treasure; and that instead of being an auxiliary, she was becoming a principal.

Within the cabinet the old colleagues of Orford, Newcastle and Hardwicke, largely prompted by him, held these views. Their party was strengthened in July by the death of Lord Wilmington, which threw open the post of first lord of the treasury. On Orford's .recommendation the king appointed Newcastle's brother, Henry Pelham. A struggle between Carteret and the Pelhams supported by Orford was thenceforth in-

1 In Hardwicke Papers, Brit. Mus., Add. MSS., 35,906, f. 180 , is to be found a memorandum of an agreement, negotiated at Paris between the French and English East India Companies in $\mathbf{1 7 4 2}$, for preserving the peace between the two nationalities in the East Indiea, notwithstanding a state of war between them in Europe.

MSS. of C. P. Weston-Underwood, Hist. MSS. Comm., roth Rep., App., p. 278 , 
CHAP. evitable. The ministry was gradually reinforced with Orford's XXIII. friends. Henry Fox, who upon the fall of Walpole had resigned his office of surveyor-general of works, was made a lord of the treasury. In December Sandys, whom the king disliked, was promoted to the peerage and resigned the chancellorship of the exchequer, which was taken together with the treasury by Pelham. In the same month Lord Cholmondeley, Orford's son-in-law, replaced the tory Lord Gower as lord privy seal. Thomas Winnington, on Orford's recommendation, succeeded Pelham as paymaster-general of the forces, an accession of a politician of first-rate talent.

The misfortunes of a conflict in which Great Britain, under the pretext of being an auxiliary, ${ }^{3}$ had played a leading part, had naturally incensed public opinion in France. The march against Noailles would have justified a declaration of war. In I 742 Captain Richard Norris, to Fleury's indignation, had violated French territory by destroying five Spanish galleys in the Bay of St. Tropez. Towards the close of I 743, not many weeks after the signature of the second Family Compact, the English fleet in the Mediterranean had driven into the harbour of Toulon a Spanish squadron of twelve vessels. As they were unable to get out, the Spanish court applied to Louis XV. for a convoy, which received orders only to act on the defensive. On February 22, I 744, the van and centre of the English fleet,

${ }^{1}$ George tenaciously adhered to the fiction that he was, as Elector of Hanover, in command of a "pragmatic army" to oppose the assumption of the imperial dignity by the Elector of Bavaria as Charles VII., and not as King of Great Britain at the head of a British army, Great Britain being, from a diplomatic point of view, at peace with France. The very interesting letters of Lt.-Colonel Russell, in the Kussell-Astley MSS., bring this point out, and it explains much which in England led to hostile criticism and brought great unpopularity on the king. For example, George went into action at Dettingen wearing the Hanoverian yellow sash, which gave mortal offence in England. The protest of the peers of January 31 , 1744 , denounces " the Hanoverian guards having for some days done duty upon His Majesty at Aschaffenburg, which we look upon as the highest dishonour to his Majesty and this Nation," whereas a letter in answer to one of Colonel Russell's points out that this was because "he was there as Elector of Hanover, not as King, and so to be attended by his Hanover people". Ibid., p. 27r. Nevertheless, that the king did shew a marked preference for the Hanoverians, which was resented at the time by the English officers, does also appear. Ilid., pp. 259, 260. The refusal of the king in September to attack the French lines near Worms, notwithstanding the wishes of the Austrian commanders, "who want us by all means to be engaged in a French war," is also remarked by Colonel Russell. Ibid., p. $28 \mathrm{~g}$. This attitude must have been due to English influence and was the more absurd in view of the treaty for the neutrality of Hanover, 
under the command of Admiral Mathews, came up with the allies, who had stolen out of Toulon three days before. The CHAP. total number of the English ships was twenty-nine; that of the French fifteen and of the Spaniards twelve. In command of the English rear was Vice-Admiral Lestock, between whom and Mathews a bitter feud existed. Mathews had been for some time out of active service; he appears to have lost his head and issued contradictory signals. Lestock never came into action and the result of the engagement was indecisive, though Mathews retreated. The action off Toulon, sometimes called the battle of Hyères, remains famous as evidence of the indiscipline into which the English navy had fallen during the long peace. The house of commons voted an address for bringing the culprits to trial. Lestock was acquitted on June 3 , 1746, upon his technical defence that he could not obey the signal to engage without disobeying the signal, which was also Aying, to form line. Mathews was dismissed the service in 1747 , for retreating before an inferior enemy. Eleven out of the twenty-nine captains were put on their trial, of whom two only were acquitted. Two officers emerged with distinction from the general discredit. The one was Captain Edward Hawke, afterwards the celebrated admiral, who ventured to disregard the signal for line of battle, ran out of the line to close with the enemy, and took a Spanish ship of sixty guns, the sole prize of the day. The other was James Cornewall, captain of the Marlborough of 90 guns, who fell in the action, deserted by Mathews in his retreat. His valour is immortalised in Westminster Abbey by a huge monument erected by parliament to his memory.

The French government had not waited for this collision to satisfy its grievances against Great Britain. Amelot, the minister for foreign affairs, took up negotiations begun by Fleury in 1740 with the Jacobite exiles in Paris and with their leaders in Scotland and England. From them he received the usual assurances of success. In the western counties of England and in Warwickshire and Staffordshire the gentry were for them to a man. In London they could count on 196 out of the 236 common councilmen. Of the peers seventy were reckoned Jacobites, among them being Bedford, Stanhope, 
CHAP. Chesterfield, and Waldegrave. 1 Two captains of line-of-battle XXIII. ships in the Downs were expected to join a Jacobite attempt.

Charles Edward, commonly known as the young pretender, had been born in Rome on December 31, 1720. His education had been scrappy and without definite supervision, being sometimes consigned to Jesuit priests, sometimes to protestant tutors, sometimes to old Jacobite soldiers. We have his portrait sketched by Horace Mann, who saw him as he passed through Florence- " above the middle height and very thin; his face rather long .... the forehead very broad, the eyes fairly large-blue but without sparkle; the mouth large with the lips slightly curled, and the chin more sharp than rounded". He had the charm of youth and was free from his father's stiff and ungracious manner. He had had a slight experience of war, having in 1734 served with credit in the Spanish army at the siege of Gaeta. As the domestic scandals attaching to the old pretender impaired his popularity in Scotland and England, the hopes of the Jacobites centred in the young prince. Ten thousand veterans were concentrated at Dunkirk under the command of Marshal de Saxe, illegitimate son of Augustus II. Elector of Saxony and King of Poland, then esteemed the ablest officer in the French service and, what was of importance, a protestant. At the end of I 743 preparations were sufficiently advanced for notice to be sent to Rome. Once more James put his name to a proclamation addressed to the people of Great Britain. His son received a commission as regent. On the same day, December 23, he nominated Lord Lovat Duke of Fraser and lieutenant of the counties north of Spey. The restless Lovat had, from violent denunciations of the union, ${ }^{2}$ passed to intrigue with the Jacobites, who had unfurled the banner of repeal.

In a message to parliament on February 15, 1744, the king announced the expected invasion. The apprehension acted, as always, like a charm upon political dissensions. Stair and Marlborough forgot their grievances and tendered their services. Stair was reappointed commander-in-chief. The moment for an invasion had, indeed, been well chosen. Accord-

1 The list is in J. Colin, Louis XV. et les Facobites (rgor), p. 31.

${ }^{2}$ Lord Lovat to Lord Grange, October 12, 1736, Earl of Mar and Kellic's MSS., p. 547, 
ing to Horatio Walpole, not more than 7,000 regular troops CHAP. were available to repel the invading force. Charles, in the XXIII. meanwhile, proceeded to Dunkirk, where a flotilla of transports was ready. On January 26, O.S., Admiral de Roquefeuil at the head of a fleet of twenty-two ships, sailed out of Brest. His instructions were that, notwithstanding there had been no declaration of war, he should either destroy or hold the English fleet, after luring it towards the Isle of Wight, while the transports under Saxe, who was to land as near London as possible, carried the troops across from Dunkirk. On February 1 7/28, Admiral Sir John Norris, having sailed with a considerably superior force to intercept some French ships reported off the coast of Kent, met Roquefeuil's fleet off Dungeness. A hurricane was blowing and the English admiral postponed an engagement till the morning; but the French ships, driven before the gale, escaped under cover of darkness. Of the transports twelve were lost, seven with all on board. "Those which escaped made their way back to Dunkirk. There was now no longer room for the pretence of amity, and on March 4/ 5 Louis XV. declared war. He complained, not unreasonably, of the violation of the convention of Hanover of October, I74I, by the British expedition to Germany and of the blockade of Toulon. The English counter-declaration of March 29, O.S., alleged the violation of the pragmatic sanction, the aid afforded by the French to the Spanish privateers in the West Indies, the violation of treaties by the construction of new works at Dunkirk and the attempted invasion of England.

On April 3, the king announced to parliament the declaration of war. Three days afterwards the opposition took an opportunity of demonstrating their freedom from Jacobitism. Correspondence with the pretender's sons was made high treason and the English penalties of unlimited forfeiture in such a case, abolished on the union with Scotland, were revived. ${ }^{1}$ The command-in-chief was entrusted to a dependant of the Pelhams, Field-Marshal Wade, then seventy-three years of age and in failing health. Paralysed by dissensions, the allies could agree upon no other course than to advance in the beginning of June from Brussels to Oudenarde, where they relapsed into inaction. When reinforced by the 6,000 Dutch troops which,

117 O. II., c. 39 ; and $f f .7$ Anne, c. 21. 
CHAP. in fulfilment of treaty obligations, had been dispatched to EngXXIII. land to repel the French invasion and returned early in July, their whole force amounted to 65,000 men, ${ }^{2}$ while as it was necessary to withdraw a large number of French troops to defend Alsace against the Austrians, Saxe was left with only 45,000 men. On August 10, however, Frederick of Prussia again declared for France. The emergency compelled the Austrians to retreat from Alsace. The French were then able to reinforce Saxe who, while evading a decisive action, cut off the supplies of the allied army, and harassed their communications. Wade, broken in health and spirits, resigned, and was succeeded by the hero of Dettingen, Sir John Ligonier. To wind up the catalogue of misfortunes, the finest ship in the navy, the Victory, with Admiral Sir John Balchen in command and an unusual number of aristocratic cadets on board, was lost at sea on October 4. On the other hand, June had witnessed the return of Commodore Anson after an absence of nearly four years. His adventures read like a romance. He had lost five out of six ships and four-fifths of his crews-misfortunes forgotten in his capture of the Acapulco galleon on June 20,1743 , with $£ 500,000$ in specie, which was conveyed in waggons from Portsmouth to London amid popular rejoicings.

Carteret's popularity, never very great, had now vanished, yet George's reliance upon him remained unshaken. Alone among the ministers he kept an eye upon the interests of Hanover. A memorial was drawn up by the chancellor Hardwicke attacking his policy upon two fundamental points; its failure to detach Prussia from the French, and its inability to prevail on the States-general to execute their treaty obligations and come forward as principals in the war. The time, it urged, had arrived for a peace with France. The memorial was presented by Newcastle on November I. George dispatched urgent messages to Orford, then at Houghton, to come up to London and advise upon the situation. Orford's advice was against Carteret, who by the death of his mother on October 18, I 744, had succeeded to the title of Earl Granville. It was possibly the last advice Orford ever gave the king: he died on March 18 following. The minister so often charged with peculation left a mortgaged estate and debts of $£ 40,000$.

${ }^{1}$ Russell-Astley MSS., p. 326.

2 Lieut.-Col. Russell, ibid., p. 334. 
Nothing remained for Granville but resignation (November 24, 1744). A junta of nine, including "the Cobham squadron" CHAP. and some tories, now "put the dagger to the throat" of the Pelhams. They must, it was plain, construct a new "broad bottom ministry," a catchword coined by Argyll at the formation of the Carteret ministry of 1742. This clashed with the personal antipathies of the king, always vivacious and outspoken. Harrington had proved himself pliant enough. He succeeded Granville. But Chesterfield and Pitt, the two critics whom it was most important to disarm by office, were alike odious to George for their sneers at Hanover and their attacks on a Hanoverian policy. Chesterfield was too great to be denied. His diplomatic talents were needed to persuade the Dutch to a more effective co-operation in the war. $\mathrm{He}$ was accredited ambassador extraordinary to the Hague. His dignity was further gratified by the lieutenancy of Ireland which, while it gave him cabinet rank, removed him from contact with the king. The tories were singularly destitute of talent, yet their claims to recognition had to be met. Sir John Hynde Cotton was appointed treasurer of the chamber; a contemporary caricature represents him, a tall and corpulent man, as thrust by the ministry down the king's throat. Lord Gower succeeded Lord Cholmondeley as lord privy seal. But so unpopular with the rank and file of the tories had the dynasty now become that offers of posts to other members of the party were refused because the Jacobites, by whose votes they were in parliament, would have rejected their candidatures for reelection. Gower's compliance so exasperated them that Doctor Johnson told Boswell he was only prevented by the discretion of his printer from giving "Gower" as a synonym for "renegade". There remained the prince's party, for whom the disapproval of their master was less compulsive than the bait of office. George Lyttelton, his secretary, accepted a commissionership of the treasury and was instantly dismissed by the prince. Dodington became treasurer of the navy; George Grenville, Cobham's nephew, a lord of the admiralty. Pitt held aloof, as one with whom the ministers would have to reckon. A secretaryship of state or the war office was the least that would satisfy him. In the new ministry the leading figure was Newcastle. To his intrigues the overthrow of Gran- 
CHAP. ville was primarily due, and he shewed resentment because XXIII. at Orford's instigation, his brother indicated some pretension to be at the head of affairs. Modern historians, reproducing the gibes of Horace Walpole, have dwelt upon the peculiarities of speech and manner ridiculed by his contemporaries. But his long tenure of power justifies the verdict of Lord Shelburne that he " rather cajoled than imposed on mankind, passing for a man of less understanding than he was". Undoubtedly he was not a directive genius, and was incapable at a crisis, but his political influence was enormous, by reason of his sedulous attention to the business of patronage.

It was upon the evasion of their obligations by the Dutch and the reckless growth of British expenditure that the attack on Granville had fastened. There was, however, a Dutch point of view, ably and, indeed, sympathetically set forth by Robert Trevor, our ambassador at the Hague. ${ }^{1}$ The king, they urged, could not justly expect them to declare war against France so long as he, in his capacity of elector, remained neutral. Notwithstanding the persuasions of Chesterfield, therefore, they insisted on continuing to take part in the war as auxiliaries only, though with fixed quotas of troops, ships, and subsidies. The king's persistency was at first invincible. Though Granville was no longer in office, the ministers found themselves unable to initiate a change of policy, even could they have agreed upon one. "We must not," feebly protested Newcastle to his brother Henry Pelham, "because we seem to be in, forget all we said to keep Lord Granville out." In the matter of the Hanoverian troops the factiousness of the attacks upon Granville was now revealed. For the sake of appearance, they were dismissed the British service, but by an arrangement with the Queen of Hungary they were at once received into Austrian pay, and the money was provided by raising the queen's subsidy from $£ 300,000$ to $£ 500,000$. It was a transparent trick which deceived no one, saved from Granville's rhetoric and sarcasm only by the "two or three bottles" a night which were sapping his energies. In the year following, when the popular clamour had been forgotten, 1 8,000 Hanoverians again passed directly into British pay. The representations by Trevor and Chester-

${ }^{1}$ Robert Trevor ta Henry Pelham, November 30, 1744, Trevor MSS., pp. 103-8. 
field from the Hague of the hopelessness of expecting the Dutch to embark heartily in the war so long as the neutrality of CHAP. Hanover was maintained, at last had their effect. Shortly before the end of the session George consented to a declaration abandoning the neutrality of Hanover and, in his character of elector, entering as a principal into the war.

As commander-in-chief for the campaign of 1745 , George, after some hesitation, nominated his younger son Cumberland, who received the revived rank of captain-general of the British forces on March 7, 1745. His colleagues in joint command were Count Königsegg, a veteran of seventy-two, half crippled by gout, nominated to lead the Austrian troops in the Netherlands, and the commander of the Dutch army, the Prince of Waldeck, a young man of his own age. William Augustus, Duke of Cumberland, had enjoyed the advantage denied to his father and elder brother of having been born in England (1.721). He had been trained for the navy but disliked its hardships. The credit he gained at Dettingen inspired him with a belief in his military capacity. He was promoted lieutenant-general and, to the annoyance of his officers, became "outrageously and shockingly military," 1 in a word, a martinet. Two qualities of a general he possessed to a high degree, intrepidity in attack and coolness in a reverse. His disposition was impulsive, at times generous, at times brutal. At the head of the French army was Marshal Saxe, the most scientific soldier of the age. When, towards the end of April, Saxe reviewed his troops near Maubeuge, they numbered 69,000 infantry and 25,600 cavalry, more than double the number of the allies and with the advantage of being a homogeneous force. He first diverted the attention of the allies by a feint at Mons, but his real objective was Tournay, one of Vauban's finest fortresses, held by a Dutch force of 7,000 men. The allied army advancing to its relief numbered 46,800 men, of whom 16,900 were British and 4,450 Hanoverians. Their artillery consisted of eighty guns, of which the heaviest were six-pounders.

Saxe having masked Tournay with 21,000 men, had already selected his field of battle, a cultivated plain traversed by the highway five miles south-west of that city. The key of his

1 Lieut.-Colonel Russell to his wife, October 27, 1743, Russell-Astley MSS., p. 299.

VOL. IX. 
CHAP. position was the village of Fontenoy in its midst. Separated XXIII. from this on the east by a ridge 620 yards wide lay a wood known as the Barri wood. Between this wood and Fontenoy over the ridge ran the Mons road northwards, along which the impracticable nature of the other approaches would compel the allies to advance. To hold this road was, therefore, Saxe's main object. It was the expressed belief of Saxe and the experience of the English at Dettingen as elsewhere ${ }^{1}$ that French infantry could not be trusted to stand against an advance in line. He therefore strengthened his position by a chain of redoubts mounted with artillery. The main part of his army, numbering 66,000 men, was drawn up across the Mons road, protected against an advance in front by a hollow way full of brushwood and trees. West of him lay the Schelde, the passage across which had been secured at Calonne and Vaulx by two bridges of boats. The hamlet of Antoin between Fontenoy and the Schelde was, like Fontenoy itself, strongly fortified. Louis XV. and the dauphin had arrived on the field amid the acclamations of the troops and passed the night of May 10 at Calonne on the western side of the river.

On the morning of the 11 th the allies took up their position in the form of a horse-shoe, the frog being occupied by the French at Fontenoy with Antoin on their right, the wood of Barri on their left. This wood and its redoubt, held by the regiment d'Eu, were to be taken by the I 2 th and I 3 th Foot and the 42 nd Highlanders, or Black Watch, a regiment of the whig clans formed by Wade in 1725 , with the brigade of guards under Brigadier Ingoldsby on their left. The space between these and Fontenoy was occupied by British and Hanoverian infantry. Against Fontenoy the Dutch infantry were massed, with 2,000 Austrians on their left. The cavalry of both sides was in the rear. Ingoldsby hesitated in his attack, and the Dutch assault on Fontenoy was repulsed. The only chance of success lay in the advance over the ridge between Fontenoy and the redoubt d'Eu. Marching up it in two lines with Cumberland at their head, amid a destructive fire on either flank, the British and Hanoverian infantry found themselves within fifty paces of the French army. It was at this moment that an incident took place which Voltaire has made famous. Lieu- 
tenant-Colonel Lord Charles Hay, of the first Guards (the Grenadiers), stepped to the front and saluted the French houseCHAP. XXIII. hold infantry opposite his battalion. Taking out a flask he drank to their health, adding: "We are the English Guards and hope you will stand till we come up to you, and not swim the Schelde as you did the Main at Dettingen". ${ }^{1} \mathrm{He}$ then called for three cheers from his men. The salute and cheers were returned; the English advanced and at thirty paces the French fire rang out. After two repulses, the British, still exposed to a fierce cross-fire, found themselies masters of the enemy's position. Saxe in vain endeavoured to retrieve the repulse of his infantry by successive charges of cavalry. The garrison of Fontenoy had expended their ammunition and the marshal sent word to Louis XV. to retreat across the Schelde.

Cumberland's troops were at that time, I.3O P.M., in three sides of a square with oblique fronts caused by the falling. back of both his flanks before the enfilading fire. Saxe concentrated the fire of a battery of four cannon upon the advancing British. Under cover of this fire, seeing that the Dutch on his right flank shewed no disposition to renew their attack, Saxe withdrew the troops opposed to them to reinforce his centre. A convergent advance was now made by the French. The Irish brigade, consisting of six regiments of infantry, stationed in reserve on their left flank, threw itself upon the British right which was being swept by a storm of grape. The reinforced French infantry of the centre again advanced, exchanging volley for volley, and were followed by a charge of the entire French household cavalry. The troops near Fontenoy charged the British left. His own cavalry which Cumberland had, too late, ordered forward, had become entangled with a mass of

'Voltaire's version is well known: "My Lord Charles Hai, capitaine aux Gardes Anglaises, cria: Messieurs des Gardes-Francaises, tirez. Le Comte d'Auteroche leur dit a voix haute: Messieurs, nous ne tirons jamais les premiers, tirez vous memes. Les Anglais firent un feu roulant." Sizcle de Louis XV." ch. xv. (ed. 3775). Carlyle, however, discovered a letter from Lord Charles, written about three weeks after the battle, giving the account adopted in the text. Frederick the Great, bk. xv., ch. viii., p. Irg (ed. 1864). It is, of course, pos. sible that the French misunderstood Lord Charles and seplied as Voltaire reports. According to Colonel Townshend (Life of first Marquis Townshend, p. 62) the French guards were under orders to reserve their fire. The advantage of reserving fire is explained by a writer in Notes and Qmerics, 8th Ser., ii., 433. Ligonier's official account says "we received their fire". 
CHAP. Dutch and Austrian fugitives and unable to act effectively. XXIII. Before these combined attacks the British and Hanoverians fell slowly back, overwhelmed by superior numbers. A general retreat was conducted in admirable order under cover of the cavalry, though the French captured about forty guns, the contractors who had horsed them having fled with the teams at the first check. During the night the allied army trudged wearily thirteen miles to Ath on the road to Brussels. The orderliness of the retreat is attested by the figures of the slain, it being remembered that the allies had conducted assaults upon intrenched positions. While they lost 7,545 officers and men, of whom only 1,544 were Dutch, the loss of the French was 7,1 37. The author of the Traite des Legions, ${ }^{1}$ sometimes supposed to have been Saxe himself, extols the steadiness of the British infantry.

While France abandoned itself to a frenzy of rejoicing, and Voltaire sang the pæan of victory in the poem "Fontenoy," Saxe pressed the siege of Tournay vigorously. The French were reinforced to nearly 100,000 men, and in Königsegg's belief were "more than twice as strong as the allies". The capitulation of the town, and on June 20 of the citadel of Tournay, set this great army free. Ghent, despite an effort of Cumberland to relieve it, surrendered in the middle of July with immense stores and munitions of war. Oudenarde speedily followed. On August 24 Ostend, the naval base of the British, was after a bombardment surrendered by the Austrian General Chanclos, and Nieuport fell on September 5. Flanders lay at the feet of France. A fortnight later urgent orders were received by Cumberland in his headquarters at Vilvorde to detach from his attenuated army of 30,000 troops ten of the best battalions under Ligonier, some 7,500 men, to join Wade at Newcastle for service against "the Young Pretender". At the end of October Cumberland himself returned home, and the 6,000 Hessians, all that was left of the British contingent, embarked for Leith in mid-December.

Elsewhere on the continent fortune had been unfavourable to the Austrian cause. Maria Theresa, "pursuing her Silesia madness," ${ }^{2}$ had sent a combined army of Austrians and Sax-

$14^{\text {th }}$ ed., 1737 . p. 132.

2 Horatio Walpole to Robert Trevor, October 25, O.S., 1745, Trevor MSS., 
ons into that province which was defeated by Frederick on June 3, N.S., at Hohenfriedberg, and compelled to retreat into CHAP. Bohemia. This victory, following hard upon Fontenoy, inspired the English cabinet with the idea of working on the Prussian king's jealousy of French predominance in Germany to persuade him to re-enter their alliance. Frederick shewed himself ready to come to terms, and a preliminary convention was concluded at Hanover on August 26 by which Great Britain guaranteed Silesia to Prussia. By the treaty of Dresden on December 25, forced upon her by a threat of the British ministry to withdraw her subsidies, Maria Theresa sullenly accepted the terms of the convention of Hanover. Frederick, in return, acknowledged the election of her husband Francis of Lorraine and Tuscany as emperor, and became thereby, as a prince of the empire, committed to a defence of his imperial rights.

In Italy, as elsewhere, the war had gone ill for Great Britain's allies. The Genoese determined to enter into an alliance with France and Spain. In virtue of a treaty signed at Aranjuez on May 7,1745 , they sent 10,000 troops to the Spanish army in Italy. Among the terms of the treaty were the support of the establishment of Elisabeth Farnese's younger son, Don Philip, in north Italy in return for an extension of Genoese territory. This was an occasion on which Sardinia looked to England to make its power felt in the war in Italy. Vice-Admiral Rowley, who had been left in command in the Mediterranean upon the recall of Lestock and Mathews, had under him a fleet of thirty-five ships of the line, and was entrusted with the duty of preventing the landing of additional Spanish troops in Italy or the junction of the Spanish fleet of sixteen ships ${ }^{1}$ at Cartagena with the French Brest fleet then cruising to the west of Gibraltar. After being joined in May by Rear-Admiral Medley with seven line-of-battle ships and a frigate, Rowley was strong enough to detach Commodore Cooper with six ships of the line and a frigate for hostilities against Genoa. Cooper bombarded that city without effect, but did much destruction at San Remo and Finale. ${ }^{2}$ Thence he sailed to Corsica, drove the Genoese garrison out of Bastia,

'Dw Cane MSS., pp. 48, 53, Hist. MSS. Comm., rgo5.

L. Bossi, Istoria d'Italia (1823), xix., 247. Apparently about September. Gent. Mag., 1745, p. 559. 
CHAP. and reduced the greater part of the island to submission to the xxIII. King of Sardinia. On the mainland, however, the combined forces of the Bourbon powers, Spain, France, and Naples, swept all before them.

Amid the prevailing gloom in England, one gleam of satisfaction shone forth. It will be remembered that in the negotiations preliminary to the treaty of Utrecht, Torcy had been energetic in refusing to abandon the North American fisheries. These were protected by Louisbourg on the island of Cape Breton commanding the mouth of the St. Lawrence, which remained in the possession of France. On the armament and fortification of this stronghold the French government was estimated to have expended $£ \mathrm{I}, 000,000$ sterling, for Louisbourg boasted the title of the Dunkirk of North America. It was a standing menace to the New England colonies and the avenue of communication of the French settlements in America and Canada with France. The capture of Louisbourg by Commodore Peter Warren on June 27, aided by 4,000 colonial troops, was felt to be a landmark in English history. 1 It was not merely a turn in the tide of misfortune. Help had come from an unlooked-for quarter, and the colonies, hitherto a burden, had revealed a new source of strength. Warren was promoted rear-admiral, Pepperell, the colonists' elected commander, received a baronetcy, and in 1748 parliament voted $£ 255$,000 to reimburse their expenditure.

1 "Our new acquisition of Cape Breton is become the darling object of the whole nation; it is ten times more so than ever Gibraltar was." The Earl of Chesterfield to Robert Trevor, August 13, 1745, Trevor MSS., p. 127. 


\section{CHAPTER XXIV.}

\section{THE REBELLION OF 1745 .}

AFTER the abandonment of the projected invasion of 1744, CHAP. Prince Charles remained at Paris, the centre of a small knot of XXIV. Jacobite conspirators. The French court had become alive to the fact that the assurances of the Jacobites as to the disposition of the English people, the unpopularity of the dynasty, and the strength of the navy were untrustworthy. ${ }^{1}$ Chavigny, the French envoy to the Emperor Charles VII., wrote begging Louis XV. to get rid of "that phantom of a pretender" and summed up the Jacobites as "bons à rien, sinon pour se précipiter et ceux qui se concertent avec eux".2 The failure of 1744 is the key to the neglect of an opportunity under the more promising circumstances of 1745 . Prince Charles, however, remained sanguine. He procured a small brig of twenty guns named the $D u$ Teillay, lying at Nantes, on board of which he shipped such arms and munitions of war as, by borrowing and pawning, he had been able to get togetherI,500 muskets, I,000 broadswords, twenty small field-pieces, "two of which a mule may carry," and some ammunition, beside 7,000 louis d'or. He secretly embarked on June 22, narrowly escaped capture by an English man - of - war, touched at Erisca in the Hebrides, and finally cast anchor at Loch-na-Nuagh, between Moidart and Arisaig, where he landed with seven companions known to Jacobites as the "Seven men of Moidart". When on August 19, O.S., his standard of "white, blue and red silk" was unfurled in the vale of Glenfinnian, it was joined by Lochiel, 600 Camerons, 250 Stewarts of Appin, and 450 of the clan Macdonald. A list sent by

'Colin, Louis $X V$. at les Facobites, Pp. $117 \cdot 124$.

2 Duke de Broglie, Frédíric II. of Lowis XV., 1742-44 (Paris, 1885), ii., 212. 
CHAP. Cumberland to the Duke of Newcastle of the fighting strength XXIV. of the clans reckons them in all at 19,800 men; but from that number large deductions must be made, representing those loyal to the Hanoverian dynasty. These included the greater part of the Grants, who numbered 800 in all; the Sutherland Highlanders, 700 ; the Rosses, I00; the Monroes, 300; the Mackays, 500 ; above all, the Campbells of Argyll and Breadalbane, 4,000; while the Frasers, 600, the Gordons, I,000, and the men of Atholl, 2,000, were doubtful.

The affairs of Scotland at this time were administered by the Marquis of Tweeddale, the secretary of state resident in London. The commander-in-chief was Sir John Cope, who had held the command in Flanders in 1742 . The troops in Scotland numbered about 3,000 men. On the day that Charles raised his standard at Glenfinnan, Cope marched out of Edinburgh for Fort Augustus at the head of I,500 foot, the 44th, 46th, and 47th regiments, and Gardiner's (I $3^{\text {th }}$ ) and Hamilton's (1 $4^{\text {th) }}$ regiments of dragoons, which last he left behind at Stirling for the protection of the lowlands. Upon the news that the Jacobite army, reported to outnumber his own, barred his road a few miles south of Fort Augustus, Cope, whose troops were ill-armed and largely raw recruits, turned aside to Inverness, there to gather reinforcements from the Campbells and other whig clans. Charles at once struck southwards for Perth. At Perth he was met by Lord George Murray, a soldier of proved capacity, who had been "out" in I 7 I5, had fought at Glenshiel in I7 I9, and had since seen active service in the Sardinian army. Lord George had many of the gifts of a great leader of men. But he was blunt, imperious, and provocative, contemptuous of Drummond, the young titular Duke of Perth, to whom Charles gave equal rank as lieutenant-general, and bitterly hostile to Secretary Murray and Charles's Irish adviser, Sir Thomas Sheridan. Like all the Stewarts, the only capacity which Charles understood was the capacity of pleasing him, and he listened with readiness to those who threw suspicion on the fidelity of the man most fitted to render him service. In person he offered a brilliant contrast to his father whose very aspect, thirty years before, had dispirited his followers. By general consent, he had the art of winning men. His figure was tall, athletic, and graceful. 
He made himself one with his men, sleeping like them wrapt in his plaid, leading them through the rivers, and delighting CHAP. them with the few Gaelic phrases he had learnt. Versed in all the social accomplishments of the day, he was everywhere popular with women.

Meanwhile Cope, hearing of the prince's descent on the lowlands and knowing the unprotected condition of the capital, marched for Aberdeen, and there embarked his troops. This news reached Perth on September 7, and on the II th Charles and his army set out for Edinburgh. On the morning of Sunday the 15 th the fire-bell of the capital sounded the alarm. The highland army was but a march from the city. It was determined to make a stand at Corstorphine, a distance of three miles, where Gardiner's dragoons had taken post. Hamilton's regiment rode in from Leith; a hastily enrolled body of volunteers marched with it through the streets, only to vanish, like a morning mist, when it reached the gates. The dragoons, therefore, marched on alone. On Monday morning they and such of the town guard as had marched out were drawn up at the north end of the Colt bridge, which crosses the Water of Leith some two miles from Corstorphine. On the approach of a reconnoitring party of mounted officers and the discharge of their pistols, they wheeled about in sudden panic and fled to Leith. Thence, upon a fresh alarm, they galloped to Dunbar, and the "Canter of Coltbrigg" became a byword in the history of the British army.

No means of effective resistance remained. The magistrates were convened by the lord provost and voted to surrender. Next morning, the 17 th, the citizens discovered that the highlanders were in possession of Edinburgh. Later in the day the heralds, under compulsion, proclaimed King James VIII. at the cross, and Prince Charles entered the city on horseback amid the enthusiasm of the populace. That night he gave a grand ball at Holyrood House. On the 19th the news was brought in that Cope had landed at Dunbar and was advancing to the relief of the capital. His force consisted of 2,000 infantry, the heroes of the "Canter of Coltbrigg," six cannon, of which five were served by nine naval gunners, 200 of Lord Loudoun's Campbells, and a handful of lowland volunteers, among them the Earl of Home-about 2,300 men in all. 
CHAP. On the morning of the 2oth the highland army, numbering XXIV. about 2,500 , with one iron gun used for signalling, set out to meet him.

Cope had vindicated his claim to generalship by the position he had taken up behind a morass intersected by ditches and inclosures. On the $2 \mathrm{Ist}$, under cover of the morning mist, the highlanders in three divisions stole towards Cope's army which, ii expectation of a surprise, had "stood all night under arms".' They were already within 400 yards of his guns when they were descried advancing from the east instead, as Cope was expecting, from the west. There was but just time to re-form with the infantry in the centre, Hamilton's dragoons on the left flank and Gardiner's supporting the artillery on the right, when the highlanders rushed upon the guns like an avalanche. Unused to this mode of fighting, the naval gunners fled. Gardiner's dragoons followed "without either receiving or firing one shot". Hamilton's, attacked by the Macdonalds on the prince's right wing, held their ground "less than thirty seconds". The hundred infantry told off to support the guns fired two volleys, and were then ridden down by the fugitive horsemen. In less than five minutes the foot in the centre found themselves unsupported. They delivered three volleys before the highlanders, parrying their bayonet-thrusts with their targets, were among them, sword in hand. Only the Loudoun Campbells, who formed the baggage-guard, stood fast and were made prisoners of war. The rest of Cope's army were cut down or captured in flight, fewer than 200 of the infantry escaping. He collected rather than rallied 450 of his broken dragoons and rode with them to Coldstream, and on the following morning to Berwick, where he was received by Lord Mark Ker with the sarcasm that " He believed he was the first general in Europe who had brought the first tidings of his own defeat". Among those killed none was more lamented than Colonel James Gardiner, the first military methodist of rank, an officer with the highest reputation for courage and integrity, whose memory was enshrined by the nonconformist hymnwriter Philip Doddridge as the exemplar of a Christian soldier. Of the highland army not more than thirty were killed and

1 "Narrative of the battle of Preston Pans" (by the officer commanding the royalist artillery) in Hardwicke Papers, vol. dxli., Brit. Mus., Add. MSS., 35,889. 
seventy wounded. The young prince behaved with characteristic humanity. He stayed the slaughter and was careful that CHAP. succour should be rendered to the wounded.

The battle received the name of Prestonpans, from the village in the rear of Cope's army, though to the Jacobites it was known as Gladsmuir. In London it created astonishment rather than consternation. The English Jacobites, mindful of 1715, preferred to wait upon events. On the other hand, the whig nobility were raising their tenants. The bishops issued charges exhorting their dioceses to loyalty and to the defence of the protestant religion. On October 29 Wade, with the bulk of the troops from Flanders and the Dutch contingent, had reached Newcastle and was at the head of nearly 10,000 men. Ligonier, with thirteen regiments, was in the midlands. A third army under the king and Lord Stair, consisting of the guards, the trained bands of London, and the militia, was forming at Finchley, an incident immortalised by Hogarth. In London itself, which the Jacobites had the year before represented to the court of Versailles as seething with disaffection, Horace Walpole records that the aversion to the rebels was "amazing". The weavers not only offered the king $1, \infty 00$ men, but the whole body of the law formed themselves into a little army under the command of Lord Chief Justice Willes to guard the royal family. Society generally assumed the defeat of the invaders. On November 28, the day the rebels entered Manchester, Ligonier, then at Lichfield, was writing advice to his friends to buy government stock. ${ }^{1}$

The prince was now master of all Scotland, except the highland forts, the country of some of the whig clans north of Inverness, and the castles of Stirling and Edinburgh. The tax collectors were called upon to hand over the sums in their hands; the goods impounded for customs at Leith and other parts were sold; forced loans were levied and $£ 5,000$ extorted from the unfriendly city of Glasgow, whilst some sympathisers, too timid to take arms, contributed voluntary subscriptions. Yet money was scarce. The highland rank and file were paid sixpence a day, the gentlemen a shilling; but early in October highland officers were clamouring at Holyrood for arrears due to them. Supplies were beginning to dribble in. The arrival

'C. F. Weston-Underwood MSS., p. 287, Hist. MSS. Comm., roth Rep., App. (1). 
CHAP. from France of an envoy, whom Charles ceremoniously received XXIV. as an ambassador, produced a marked impression. To recruit in Scotland, to await fresh supplies there, and to allow the French to organise an effective diversion in concert with the English Jacobites was the prevailing advice of his principal officers. Meanwhile a close blockade of Edinburgh castle was maintained.

On leaving France, Charles had dispatched an apology for his secret departure to Louis XV. and a request for aid. Preparations were begun at Dunkirk, where the Irish brigade still lay, and the pretender's second son Henry, titular Duke of York, was sent thither to take command of an expedition destined for a landing in the south of England. But it was apparent that the French would not attempt an invasion of England so long as the English Jacobites were inactive, and that these would not stir so long as Charles remained north of the border. The prince, therefore, when his council raised objections to an advance, declared that he would go to England "though he should go alone". Their reluctant consent being thus extorted, it was agreed, on Lord George Murray's suggestion, that the army should make for Carlisle. By taking this route they would avoid the army of Wade, which occupied Newcastle in order to protect the supply of coal to London. On October 31, Charles set out from Holyrood. Difficulties began from the first. The highland rank and file had no appetite for an adventure into England. Their numbers at starting were about 6,000 men, of whom under 300 were cavalry $;^{1}$ but they were so thinned by desertions on crossing the border that before reaching Carlisle they had lost at least I,, 00 men. On November I7, Charles made a triumphal entry into that city, the capture of which had cost him one man killed and one wounded. Fortunately for the reigning dynasty its safety did not rest solely upon the sluggish and war-worn veteran, Wade. Ligonier's force was already in Staf-

${ }^{1}$ Lord Stanhope says " 500 ," but the detailed list of the highland army given in the Life of the Duke of Cumberland, 1767, reckons the contingents of horse as follows: Lords Elcho and Balmerino, 120; Lord Pitsligo, 80; Lord Kilmarnock, 60. Total 260. This more nearly accords with the Lord Justice Clerk's intelligence (State Papers, Scotland, November 2, 1745). He estimates the cavalry at 300 , but puts the numbers of the other forces higher than most writers, viz. : infantry, 6,280; volunteers, $1, \infty 00$. 
fordshire with orders to prevent the invaders from entering North Wales, where the Jacobite squires were believed to be CHAP. numerous.

While the prospects of the government daily improved, those of Charles, despite his easy success at Carlisle, began to. decline. The towns of Glasgow, Paisley, and Dumfries had declared for King George; Perth and Dundee had celebrated his birthday and fired upon their Jacobite garrisons; Edinburgh had witnessed the re-entry of the law officers of the crown, and its Jacobite enthusiasm had vanished on a view of the two cavalry regiments detached by Wade for their escort. Leaving a garrison of 200 men in Carlisle, the Jacobite army resumed its march southwards on the 20th, reduced by desertions to less than 4,500 men. They marched through Preston and Wigan to Manchester, which they entered late on the 28th and were received with popular rejoicing. The church bells rang, the town was illuminated, bonfires blazed, the white cockades, the Jacobite badges as distinguished from the black cockade of Hanover, were everywhere visible; numbers thronged to kiss the prince's hand. Yet the substantial results were pitiful, notwithstanding that the recruiting officers promised a five-guinea bounty, of which one shilling was paid down. About 200 volunteers were enlisted in two days. These, with the handful that had joined on the march, were embodied by the name of "the Manchester regiment," under the command of a Roman catholic gentleman, Francis Towneley, who held a colonel's commission in the French army.

Meanwhile, on the official pretext that Ligonier's health had given way, the Duke of Cumberland had on November 22, at Lichfield, taken over the command of his troops. The duke pushed forward north-west to Stone, thereby leaving open the road to London by way of Derby, which the highland army

'This is accepted as fact by Mr. P. H. Skrine in his Fontenoy (1906), but, to judge from Ligonier's activity, it cannot have had much foundation. Horace Walpole says (November 22) that when Carlisle was captured by the rebels he was supposed to be at Preston, whither Colonel Durand sent a dispatch to him, but that he was at the time playing whist with Lord Harrington at Petersham. In the following week he was to march to the midlands as Cumberland's second in command (ibid.), and that he did so may be inferred from a letter of his dated "Litchfield, November 28, 1745," in MSS. of C. F. Weston-Underteood, p. 288. On December 6, according to Tindal, he was marching from the duke's main army on Meriden Common, near Coventry, to Lichfield. 
CHAP. entered on December 4. Less than I 30 miles lay between the XXIV. prince and London. December 6 , the day on which this news reached the capital, was long remembered as "Black Friday". Shops were shut. A run was made on the Bank of England," which is said to have saved itself by paying out in sixpences, in order to gain time. For a day there was, as Fielding wrote in the True Patriot, a " terror scarce to be credited" in London. Charles eagerly anticipated his entry into the capital. Intelligence was brought him at Derby that the French were already moving. Bitter was his chagrin, therefore, when on the morning after their arrival at Derby, Lord George Murray and his officers, acquainted him with their unanimous opinion in favour of retreat. No English person of note had joined them. The people of the counties most favourable to their cause had stood aloof. The Welsh Jacobites were contenting themselves with promises. The French had not stirred. Nothing remained but a retreat upon the reinforcements gathered at Perth and Montrose. On the night of December 5, Charles consented to retire to Scotland.

It has been maintained that, had his wishes prevailed and an advance been made upon London, he would have effected a restoration. This conclusion appears to rest upon the propositions, firstly, that London was Jacobite in its sympathies, secondly, that the French transports would succeed in evading the English fleets, and lastly, that the army before London would not be capable of withstanding half its numbers, supported by no more than thirteen small cannon, ${ }^{1}$ until Cumberland could come up. Upon the first point, the evidence is conflicting. A secret letter ${ }^{2}$ dated London, October $2 \mathrm{I}$, and transmitted to Rome by the Jacobite titular Lord Sempill, promised a rising in the city. But Sempill and his correspondents had proved in 1744 so absolutely unveracious as to have become a by-word at the French court. ${ }^{3}$ Horace Walpole has testified to the fecling among the weavers and the professional classes of London, and there is no reason to suppose that the weavers, descendants of French refugees though they largely

1 At Derby they were in possession of thirteen pieces of cannon, see Letter of Thomas Drake, R. O., MS., State Papers, Dom., G. II., December 7, 1745.

'Stanhope, History (2nd ed., 1839 ), iii., $413 \mathrm{n}$.

'Colin, Louis XV. et les Facobites, p. 124. 
were, differed from the rest of the working classes. The London mob had, in fact, gradually ceased to be Jacobite, since "Church CHAP. and Queen" had ceased to be a toast. The prisoners of 1745 no longer met with the applause that greeted the prisoners of 171 5. When a Dunkirk privateer Le Soleil, bound for Montrose, with twenty French officers and the brother and son of the beheaded Earl of Derwentwater, was captured in the last week of November, the prisoners were brought to London. The belief was that the earl's son was Prince Henry. "The mob," writes Horace Walpole, "persuaded of his being the youngest pretender, could scarcely be restrained from tearing him to pieces all the way on the road and at his arrival." 1 As for the men of business, Henshaw, a navy agent, writes a month later, " His (' the Pretender's') little army might have been eaten up here (London), where nine men in ten were resolved to expose themselves to all hazards in opposition to him ".2

Nor were there any substantial expectations from France. The English government was on its guard, and the French, as in the previous year, had missed the critical opportunity. Their preparations were yet incomplete when Martin returned from the Mediterranean with his squadron, and other men-ofwar convoying vessels from the East Indies and America also arrived, making a reinforcement to the home fleet of seventeen line-of-battle ships. There were, in addition, twenty-six line-ofbattle ships between Plymouth and the Nore. A system of intelligence by means of small ships, sloops, cutters, yachts, etc., to watch movements on the French coast had been organised by Admiral Vernon. Byng was cruising with a squadron off the east coast of Scotland. Apart from the weather, the balance of force was far more adverse to the French than it had been when Norris's hastily equipped fleet had proved too strong for De Roquefeuil. Little need be added to what has been said of the magnitude of the task which would have confronted the prince's army on approaching the capital. The London Jacobites were unarmed; while muskets had been furnished to the whig

1 Contrast the sympathy of the London mob in May, 1716: "All the ladyes and mob eryed and weepd and cryed that the Almighty would preserve us (the prisoners) against all our enimies". Alex. Menzies to Lady_, MSS. of Sir R. Mensies, p. 703, Hist. MSS. Comm., 6th Rep., App.

'James Henshaw to Vice-Admiral Medley, January 7, O.S., 1746, Du Cane MSS., p. 85, Hist. MSS. Comm., rgos. 
CHAP. volunteers, and they, with a preponderantly loyal population XXIV. at their back, would certainly not have submitted without a struggle to a force which, even after a victory, would not have numbered more than 4,000 effective men. A battle, a day's street fighting, and Cumberland would have been upon the weary invaders with his 10,000 veterans, and in two or three days would have been reinforced by Wade. Lord George Murray and the prince's council were right. Failing the French, success was hopeless. The succour which the French had furnished, small as it was, had been partly cut off and had arrived too late. On November 22, Lord John Drummond had landed at Montrose with about 800 men of the "Royal Ecossais" regiment in the French service and a small detachment from the Irish brigade under Major-General Stapleton, ${ }^{1}$ but the most part of the Duke de Fitzjames's regiment of horse was captured.

Early in the morning of the 6th, the retreat of the highland army from Derby began. The clansmen, whose predatory instincts had hitherto been kept in check, indulged in plunder and violence in the villages through which they passed. As a natural consequence, the country people exchanged their attitude of curious indifference for resentment and reprisal. Sick and stragglers were made prisoners or killed. Manchester, erewhile so friendly, confronted their vanguard with a furious mob, which hampered their rear as they marched away. The prince, indignant at this unlooked-for change, demanded a fine of $£ 5,000$ from the town. At Wigan an attempt was made to shoot him. The news of the retreat reached Cumberland the same day at Meriden Moor, near Coventry, about fifty miles from Derby, whither he had fallen back from Stone for the defence of the capital. He at once set out in pursuit at the head of his cavalry, leaving Ligonier in command of the main

\footnotetext{
1 The statement of the Duke de Broglie in Maurice de Saxe et le Marquis d'Argenson (1891), i., 13, that 3,000 men in all of the Royal Scots and Fitzjames's regiments reached Scotland does not seem accurate. Lord John Drummond's command at Culloden, apart from the clansmen, appears to have consisted of only 400, which included a Perthshire squadron of horse. The pickets of the Irish brigade numbered 400. Set Plan of Culloden in Colonel Townshend's Life of the Marquis Townshend, p. 95. Of three privateers which sailed from Dunkirk with troops at the same time, two, one of them with Drummond's men, got to Scotland, the other two were taken. A fourth was captured a few days later. J. Entick, Naval History (1757), p. 808 ; London Gaxette, Nov. 30, 1745.
} 
army at Coventry. It is eloquent of the sentiments of the midlands, a notably disaffected district, according to the praters CHAP. at Versailles, that the neighbouring gentry voluntarily supplied him with a thousand horses on which to mount his infantry. A thousand of Wade's cavalry under General Oglethorpe joined him at Preston. At Clifton, three miles from Penrith, mounted volunteers endeavoured to cut off Lord George Murray and the rebel rear-guard. Here Cumberland's advance guard of mounted infantry came up on December I 8 , but were driven off with a loss of a hundred men.1 Carlisle was reached by the rebels on the morning of the 19 th. It was, perhaps, rather with the object of encouraging the French by the news that a fortified city of England was still in the occupation of the Jacobites than because of any hope of permanently defending it that the "Manchester regiment," now numbering about a hundred men, a few French and Irish, and 250 lowlanders were left as a garrison, too weak to hold it many days against the duke's army and a hostile population within the walls. On the 3oth the rebels hung out the white flag. No terms were granted them, except that they should not be put to military execution.

Charles himself had recrossed the border on the 2oth and on the 26th entered Glasgow, the termination of a march of some 500 miles in fifty-six days, many of which were days of halt. Glasgow, hostile to him from the first, had, during his absence in England, levied troops against him. He now punished it by requisitions of necessaries for his soldiers amounting to $£ 10,000$, a sum repaid to the city as compensation by a vote of parliament in 1749. His forces at this time amounted to about 3,600 foot and 500 horse. At Glasgow a pistol was snapped at him. It is noteworthy, in view of the controversy which followed Culloden, that, on this as on other

'Stanhope, followed by Mr. Skrine (Fontenoy, p. 29r), attributes the relaxation of the pursuit to this check which, since Cumberland's main force was not engaged, is in itself improbable. It happens, however, to have synchronised with the arrival of a dispatch dated December 12 from the Duke of Newcastle, acquainting Cumberland that a French invasion was expected, and requesting him to reinforce Wade and return to London immediately with the rest of his troops. This order was followed, as Newcastle's custom was, by a counter-order on the next day; but the delay which it had caused and the celerity of the rebels account for the cessation of the purwuit. Fitsherbert MSS., p. 175. Cf. the Duke of Richmond to the Duke of Newcastle, 15 and 24 Dec., 1745, Newcastle Papers, Brit. Mus., Add. MSS., 32,705, fi. $435,458$. 
CHAP. like occasions, Charles shewed excessive good nature, refusing XXIV. to inflict any punishment upon the offender. The wisdom of a retreat was now apparent. Reinforcements which could not have fought their way through by land became available. The prince with his French, Irish, and highlanders had under his command nearly 9,000 men, the largest number he had yet mustered. On January 3, 1746, he left Glasgow, resolved to undertake the siege of Stirling Castle. Cumberland, upon a fresh rumour of the imminence of a French invasion, received another summons to London, whither he returned immediately after the surrender of Carlisle. At the same time Marshal Wade, long since incapacitated by ill-health, resigned his command.

Cumberland was prone to favouritism, too often of men who reflected the worst sides of his own character. Among these was General Hawley, a smart cavalry officer but notorious, in that by no means squeamish age, for brutality. $\mathrm{He}$ was selected by Cumberland to take over Wade's army and act as commander-in-chief in Scotland. His force was composed of three mounted regiments, Cobham's (now the King's dragoon guards), Hamilton's and Gardiner's, ${ }^{1}$ with eleven regiments of foot and the Glasgow militia. Marching out of Edinburgh on January 13, he arrived on the 16th at Falkirk. When joined by I,000 Argyll Campbells, his army mustered 8,000 men. Upon Hawley's approach Prince Charles left I,000 men to maintain the blockade of Stirling Castle and drew up his army on the field of Bannockburn in expectation of an attack. The English army encamped in front of Falkirk, five miles distant; nor did it shew any sign of movement on the morning of the 17 th. Hawley was not insusceptible to feminine charms, and the Countess of Kilmarnock, a Roman catholic and an ardent Jacobite who had persuaded her husband, a ruined spendthrift with a grievance against the government, to join the rebels, had invited him to become a

'See R. Burnett's letter to James —_, January 19, 1745, Capt. Stewart's MSS., p. 144, Hist. MSS. Comm., roth Rep., App. Mr. Fortescue in his Hist. of the British Army says that the three regiments of dragoons were the 9 th, $13^{\text {th }}$ and ${ }_{4} 4_{\text {th }}$; but Burnett expressly tells us that his account was " a collection of my own and several others' letters". He is confirmed by the letter of General Cholmondeley who was present, in the Weston-Underwood MSS., p. 440, and by a contemporary plan of the battle published by Mr. C. S. Terry, The Rising of 1745, p. 124. See also ibid., Lockhart Papers, ii., 500, and Home's History, pp. 127, I69. 
guest at Callendar House, some little distance from the camp. While the general was there, Prince Charles, probably in CHAP. concert with the countess, made his dispositions for attack. Masking his intentions by a feint, Lord George Murray led his troops towards a rugged upland called Falkirk Muir on the south-west of that town. Hawley, who had been sent for, galloped into camp. He at once ordered his three regiments of dragoons who were posted on his left, to ride full speed and occupy the upland before the highlanders could reach it, and the infantry to follow. Two of Hawley's dragoon regiments were those which had disgraced themselves both at Coltbrigg and at Prestonpans. One of these, Hamilton's, did not belie its reputation. ${ }^{1}$ The dragoons gained the summit and charged the highlanders who received them with a well-directed fire. Hamilton's men wheeled about and threw both the rest of the cavalry and the infantry behind them into confusion. Before the foot had time to recover themselves, the Macdonalds, the prince's right wing, were among them with their broadswords. Hawley in vain tried to rally them. The left and centre broke and fled; their second line "without firing a shot".

The English right wing under General Huske was more fortunate. Between them and the enemy ran a ravine, a natural obstacle to the highlanders' charge. Three English foot regiments, Price's ( $4^{\text {th }}$ ), Barrett's (4th), and Ligonier's (48th Foot), by their steady fire repulsed the clansmen, and Cobham's horse, who had rallied, drove them to flight. The strange spectacle was seen of two-thircls of the English army and one-third of the highlanders at the same time in full retreat. Neither side was in a position to take advantage of its success. Huske's troops protected their beaten comrades from pursuit, but the prince remained in possession of the field and of seven of Hawley's ten guns which had stuck in a morass and could neither be used nor extricated. Three standards,

1"Lord Cobham's dragoons on our right, Gardiner's (now Legonier's) and Hamilton's on the left. These last ran away (as they always will) on the first attack." R. Burnett to James _-, January 19, 2745, MSS. of Captain Stcwart of Llandyssil, p. 144. They appear to have been raised in Ireland, for an Edinburgh correspondent, Robert Wightman, in an undated letter to Edward Weston, speaks of "the cowardice of the Iriah dragoons, who fied outright as soon as they were fired upon". Weston-Underwood MSS., p. 286. See also the letter of J. S. Mackenzie, Hawley's aide-de-camp, in Trevor MSS., p. 139. 
CHAP. his ammunition, baggage, and tents also fell into the enemy's XXIV. hands. Under three hundred English dead were left on the field and a hundred surrendered as prisoners. The highlanders only admitted a loss of forty. On the 18 th the streets of Edinburgh were crowded by Hawley's dispirited and rain-sodden troops. He gratified his fury at defeat by a series of military executions.

The cry was raised for the nation's favourite general. Travelling night and day Cumberland reached Holyrood early on the 3oth. In thirty hours he was in the saddle, marching to relieve the garrison of Stirling. Hawley was retained in command of the cavalry, consisting of three dragoon regiments, Cobham's, Lord Mark Ker's (I I th Hussars), and the Duke of Kingston's light dragoons (since disbanded). Despite bitter expostulations from Charles, Lord George Murray and the leading chieftains insisted on a retreat, and on February I the rebel army spiked its heavy cannon, blew up its powder magazine, and set out on its march northwards. Charles occupied Inverness on February I8. Fort George surrendered three days later. Fort Augustus opened its gates to Drummond's regiment and a party of French engineers. Though Fort William held out against Keppoch and Lochiel, the spirits of the rebels rose. Following their track but at a far slower rate of progress, Cumberland reached Aberdeen on the 27th. There he remained awaiting the arrival of supplies. When, at the end of March, he was ready to resume the offensive, he was detained by the swollen state of the Spey, and it was not until April 8 that he set out to attack Inverness. His army numbered fifteen line battalions of 7,200 men, the three dragoon regiments of 900 sabres, and 600 Argyll Campbells, well provided with all necessaries; while a naval force accompanied it along the coast. It was now far otherwise with the rebels. The prince's slender treasury was exhausted. His men were receiving payment in meal ; and often short even of that, were compelled to roam the country for subsistence. The distrust among the leaders increased with the pressure of misfortune. They were divided between the prince and the Irish party on the one hand, and Lord George Murray and the Scottish party on the other.

News was brought on April I 5 to the highland camp on 
Culloden Muir that the English had halted at Nairn, and were carousing in honour of Cumberland's birthday. It was deterCHAP. mined to surprise the duke's camp by a night attack. Famished and wearied, the highland army moved forward slowly. Day was already dawning when they found themselves still an hour's march distant. The English drums were heard beating to arms. The attempt at a surprise had failed. Lord George Murray ordered a retreat, and the army, jaded and hungry, returned to its original position, many of the men hurrying off to Inverness to seek for food. At seven in the morning, three hours after their return, scouts announced that Cumberland's cavalry were but two miles distant. Roused from their brief rest, the insurgents were drawn up for battle in two lines, the first consisting of the clansmen. The second line was of four battalions of 500 men each, the left flank composed of Drummond's troops in the French service and the right of General Stapleton's pickets of the Irish brigade, the main body being lowlanders. On the left of the Irish foot were posted 150 troopers of Fitzjames's Irish horse. Eight hundred men formed the reserve. A detachment held an inclosure which covered their right flank. They were computed in all at 8,350 men. Cumberland's army, 7,649 combatants, of which 1,100 were cavalry, was marshalled in three lines of infantry, with two pieces of cannon between every two battalions of the first line. The duke had utilised his leisure at Aberdeen in the invention of a drill to countervail the superiority of the target and broadsword to the bayonet. The foot soldier was to direct his weapon not against the man opposite him, but against the assailant of his right-hand man; by which the opposing sword man would be attacked under his unprotected arm. A storm of rain and snow was driving in the faces of the insurgent army.

The battle began with exchanges of cannon shot in which the English artillery inflicted heavy losses upon the clansmen who soon shewed signs of wavering. Without waiting for the word of command, the clan Maclntosh, which had never been in action, rushed on the English centre and were followed by the whole right wing of the highland army. They broke through the front rank, but Cumberland, in anticipation of this, had drawn up his second line three deep, which poured a 
CHAP. murderous discharge into them. Before they could recover, the XXIV. English infantry charged and the whole right and centre of the insurgent army gave way. Their left, consisting of the three Macdonald clans, had from the first remained motionless. The men were sullen at not being posted on the right wing, a privilege they claimed to have enjoyed since the battle of Bannockburn. They now fell back in good order on to their second line. At this crisis, a breach having been made by the Argyll highlanders in the wall of the inclosure protecting the rebel right, Lord Mark Ker's and Cobham's dragoons, led by Hawley and Bland, threatened the rebels in the rear, while a simultaneous charge was made by the Duke of Kingston's light dragoons upon their left flank. So completely did these two bodies of cavalry clear the ground that they met behind the first line of the rebels. The highlanders broke and fled. Their example was followed by the lowland and French troops composing their second line, who never came into action at all. A handful of highlanders of the second line kept together, and Inarching with colours flying and bands playing made its way to Ruthven in Badenoch. Charles, though eager to charge the enemy, was forced from the field by Sheridan and O'Sullivan. A thousand of the rebels were slain. A thousand were taken prisoners. Fourteen stands of colours, 2,300 firelocks and all their cannon, baggage, and papers were captured. Lords Kilmarnock and Balmerino were taken. The royalist loss in killed and wounded was not more than 310 men.

The carnage which followed the battle on that and the succeeding days reflects indelible disgrace upon the royalist troops and their general. The general orders issued on the day after the battle ordering a search party to " search all cottages in the neighbourhood for rebels" concluded: "The officers and men will take notice that the publick orders given yesterday were to give us no quarter," an infamous suggestion from a commanding officer after resistance had ceased. By way of justification, a general order was alleged to have been issued by the instructions of Prince Charles containing a paragraph: "It is his royal highness' positive orders . . . to give no quarter to the Elector's troops on any account whatsoever". It is to be observed that this document bears no signature, and its 
authenticity was always denied by the Jacobites. Further, it is wholly inconsistent with the character and behaviour of CHAP. Charles, who had himself intervened to stop the slaughter at Prestonpans and had on all occasions manifested great concern for the enemy's wounded. Odious as Cumberland's character was in some respects, and prejudiced though he was against the Jacobites, he was not deliberately dishonourable. The conclusion seems to be that such an order had been draughted by some person, but never approved by the prince and probably never promulgated.'

During the six months following Culloden Charles was a hunted fugitive, passing through hair-breadth escapes, and shielded by the fidelity of simple peasants. Not until September 20 did he succeed in boarding at Loch-na-Nuagh a small French vessel sent to bring him off. Nine days later he landed in safety at Roscoff in Brittany. One by one the clans submitted to overwhelming force and surrendered their arms. By the end of the summer only a few scattered bands had failed to make submission. The fortunes of the house of Stewart were for ever ruined. Cumberland was acclaimed as the saviour of the country. In gratitude for his services, the commons voted him a pension of $£ 25,000$, bringing his income up to $£ 40,000$ a year. The city guilds vied one with another in offers of the freedom of their crafts. Even after his return to London he was still "for the utmost severity"; and as the news of the cruelties committed in Scotland filtered through to the public, a reaction of opinion manifested itself. When, in July, it was proposed to make him free of one of the city companies, an alderman said aloud, "Then let it be of the butchers," and "Billy the Butcher" was the nickname by which he was thenceforth known.

When military licence had exhausted itself, the law, which

' See James Bradshaw's declaration, November 20, 1746, Trevor MSS., p. 478. Horace Walpole writes: "The duke said publicly at his levee that the latter (Kilmarnock) proposed murdering the English prisoners". Tindal, an apologist of the government, writing during Cumberiand's lifetime, stigmatises the story as "absolutely false". A writer to the Athemawm of March Ir, 1899 , affirms that three copies of the orders, all in Lord George Murray's hand, have been ex. amined by him and that none contains the alleged paragraph. See Duke of Athole's MSS., p. 74. Hist. MSS. Comm., r8gr, where also are Cumberland's own orders, dated Feb. 20, to give no quarter, 
CHAP. it had displaced, proceeded to take its course. In accordance XXIV. with an act of parliament ${ }^{1}$ framed on the precedent of 1716 , the rank and file of the Scottish rebels taken in arms were removed to England for trial. It being impossible to discriminate between degrees of guilt where all appeared equally concerned, they were permitted to cast lots, one in twenty to be hanged, the rest to be transported. Among the first to suffer were the officers of "the Manchester regiment," at their head Colonel Towneley, who was hanged at Kennington Common near London. At Carlisle, York, Brampton, and Penrith, executions took place accompanied by the hideous penalties of drawing and quartering. The total number of sufferers was seventy-seven. Among them was Charles Radcliffe, brother of the Earl of Derwentwater, who had been condemned in I 716 , but escaped. As he had been captured upon a French vessel bound for Scotland with supplies for the insurgents and was, therefore, for the second time, taken in an act of rebellion against the established government, it is difficult to see that any substantial injustice was done. " "He had the favour," a contemporary records, "of being beheaded" on December 8, I 746. The sufferers almost invariably met their death with firmness and with a declaration of allegiance to the exiled family. Some of the leaders however forgot their "honour in their craving for life". Macdonald of Barrisdale struck a bargain with Cumberland by which the betrayal of Charles should be the price of pardon. Eneas Macdonald, one of the "seven men of Moidart" whose heart was never in the adventure, and John Murray of Broughton, the prince's secretary of state, purchased their lives by the betrayal of their associates.

Among the prisoners were the three Scottish peers, the Earls of Cromartie and Kilmarnock and Lord Balmerino. They were tried by their peers in Westminster Hall. Balmerino had held a military commission under both George I. and George II.; had resigned it to take part in the rebellion of 1715 , had escaped to France, had procured a pardon and returned to rebel a second time. He was unanimously found guilty by $\mathrm{I} 35$ peers. The two earls pleaded guilty. Kilmar-

1 Ig G. II., C. 9 (1746).

"Hallam considers it "impossible not to reprobate" his execution upon his former sentence. Const. Hist., iii., $3^{12}$ n. (ed. 1832). 
nock and Balmerino were cast for death, the latter disdaining to sue for mercy. On August 18, amid a vast crowd of specCHAP. XXIV. tators, they were beheaded on Tower Hill, Balmerino with his last breath praying for King James. Kilmarnock, alone of the seventy-seven sufferers for the rebellion, repented his action and acknowledged the justice of his fate. Three days before the execution of Kilmarnock and Balmerino, Simon Fraser, Lord Lovat, was brought to the Tower. As he had not appeared openly in arms and had been profuse in assurances of loyalty, the government, though convinced of his guilt, had no overt acts on which to found an indictment by a grand jury as in the case of the other lords. It was, therefore, determined to proceed by way of impeachment by the house of commons. The evidence laid before the house was produced by the prince's ex-secretary, Murray of Broughton, in the shape of a letter from the secretary of Lovat recommending Lovat's son as having been sent by his father at the head of the clan Fraser to fight for Prince Charles. The capture of Lovat's secretary, Robert Fraser, to whom the letter had been dictated, completed the chain of evidence, and the motion of impeachment passed the house of commons unanimously on December II. The evidence tendered at the trial before the lords referred to Lovat's conduct before, during, and after the rebellion. Defence he had none, other than attacks upon the witnesses against him and complaints that some of his own had failed to appear. $\mathrm{He}$ was found guilty, sentenced to death, and beheaded on Tower Hill on April 9, 1747, solacing his last moments with the Horatian eulogy of a dying patriot.

The incidents of the rebellion and, in particular, the trial of Lovat furnished illustrations of the manner in which the feudal rights of the highland chieftains clashed with the power of the crown. By a bill introduced by the Chancellor Hardwicke into the house of lords on February 17 , all "heritable jurisdictions" were abolished, but as pecuniary emoluments were associated with them, provision was made for compensation to the amount of $£_{152,000}$. A second outcome of Lovat's trial was an act extending to cases of impeachment of treason the right to be defended by counsel, already granted by 7 W. III., c. 3, to cases of indictment for treason. 
CHAP. Two other statutes were consequences of the rebellion; the XXIV. first, a disarming act, attached heavy pecuniary penalties to the retention or concealment of arms, the alternative being compulsion to serve in the army in America. By the same statute the wearing of highland dress by any except officers and soldiers was made punishable with six months' imprisonment for a first, and seven years' transportation for a second offence. This statute was declared by Dr. Johnson, who visited the highlands in 1773, to have been "universally obeyed". The second was an act of indemnity for those involved in the late rebellion, from which, however, eighty names were excepted. The estates forfeited by attainted traitors were applied to the encouragement of Scottish agriculture, manufactures, and fisheries. Schools were established, the linen industry and stocking weaving taught, ${ }^{1}$ and the population trained to peaceful pursuits. Culloden thus marked the end of one system and the beginning of another. From its consequences arose the Scotland of to-day.

1 Reports of commissioners and trustees for fisheries and manufactures in Scotland (1757-60), Brit. Mus., Add. MSS., 35,89I, ff. 6r, 74; 25 G. II., c. 4I. 


\section{CHAPTER XXV.}

THE PELHAM ADMINISTRATION.

LFss than a month after the defeat of the royal army at Falkirk a ministerial crisis arose. The king had never cordially CHAP. acquiesced in the ascendancy of the Pelhams and specially disliked the Duke of Newcastle, who was "not fit," he declared, "for a chamberlain to a petty court in Germany". He resented their growing disinclination for the war, arising out of the popular disgust on account of its ill success and of the inefficiency of the Dutch troops. Both George and the Pelhams began to look round for aid. On February 5, 1746, Newcastle submitted to the king proposals for strengthening the ministry by the inclusion of Cobham's friends, among them Pitt as secretary at war. The king perused the list without objection till he came to Pitt's name, and then rejected the whole. He turned to Lord Bath who counselled resistance. George offered him the treasury, and Granville a secretaryship of state, and entrusted them with the task of organising a ministry. A general resignation of offices followed, and Bath and Granville discovered that they could not fill the vacancies. On the I th, after two days' tenure of office, Bath resigned. The Pelhams were now in a position to insist on their own terms. The king must no longer run counter to them nor look for advice elsewhere than to his official counsellors. Pitt must be given office. On the 14th, Granville resigned the seals; the crisis was over and the supremacy of the Pelhams was established. Upon one point, however, the king remained obdurate. He would not concede to Pitt a place in the cabinet. Pitt, with profuse professions, declared himself conformable to the king's will and accepted the valuable sinecure of joint vice-treasurer of Ireland.

In less than three months Pitt's compliance was rewarded. 
CHAP. Winnington, paymaster of the forces, unexpectedly died, and XxV. on May 6 Pitt was advanced to his lucrative office. The value of his adhesion to the ministry had speedily revealed itself. Subsidies of $£ 400,000$ for 50,000 Austrians, $£ 300,000$ for the King of Sardinia, and $£ 310,000$ for 18,000 Hanoverians were carried in one day by 255 to 122 votes. Pitt himself unblushingly advocated the measures he had before denounced. A ballad, "The Unembarrassed Countenance," satirised the celerity of his conversion. The less his change commended itself to the public, the more favourably did it impress the king. Upon his appointment as paymaster of the forces he was sworn of the privy council; but the much-coveted place of secretary at war, now resigned by Sir William Yonge, was bestowed upon Henry Fox. Fox was a characteristic example of the political adventurer, of no elevation of sentiment or principle, with an ambition to fill lucrative posts, dexterous in the enlistment of dependants and in the transaction of public business. One advantage he had over Pitt; he suffered from no infirmities to isolate him from mankind. His good humour and good nature secured him troops of private friends.

Notwithstanding the usage that armies should remain quiescent in winter quarters, Saxe resolved to avail himself of the impotence to which the withdrawal of British troops had consigned the allies in the Netherlands. In May the reflux of troops from Scotland set in with the return of the 6,000 Hessian mercenaries. Ligonier with six British infantry regiments and four of cavalry joined them towards the end of June. Still inferior in strength, the allies passively watched the progress of French conquest. The two first-class fortresses of Mons and Namur fell without a blow. Autumn drew on, the army had been weakened by sickness, and their highest ambition was to secure Liege for winter quarters. Saxe at the head of 120,000 men resolved to dislodge them. On October I I he defeated them in a battle in the neighbourhood of the city, and they retreated in order towards Maestricht, saved by the approach of night from close pursuit. Their loss was 4,500 to 5,000 men, about 1,000 more than the French. The practical result of what is known in history as the battle of Roucoux, was that the army was driven to take up winter quarters in Flanders. 
The public satisfaction at the capture of Louisbourg and CHAP. the warlike temper of the American colonists recommended XXV. to the ministry a scheme for an attack on Quebec and the reduction of Canada. The New England colonies agreed to raise troops to the number of 10,000 men. At the beginning of May, 1746, a strong squadron was being fitted out at Portsmouth, but preparations were so much behindhand that when ready it was too late in the season to set sail. It became necessary, as Horatio Walpole, an intimate friend of Pelham, wrote, " to save appearances, that the vast charges of our naval armament this year may not seem to have been flung away". Lorient in the south-west of Brittany, the storehouse of the French East India Company, containing, it was believed, magazines of fabulous wealth, was to be attacked. The expedition consisted of sixteen ships of the line, eight frigates, and thirty transports under Lestock who had been honourably acquitted upon his quarrel with Mathews. In command of the land forces, 5,000 infantry, was General Sinclair. The fleet anchored on September 17 in the bay of Pouldu, ten miles from Lorient; large reinforcements entered the town, and Sinclair, judging that there was no chance of success, determined to abandon the enterprise. After destroying some forts the expedition returned ingloriously to England in the middle of October.

In 1745 the anxiety of the Dutch for the re-establishment of peace had led to a conference opened at Breda on September 30, 1746, at which Lord Sandwich was the representative of Great Britain. Events were working for peace in other directions. In Italy the allied army of Austrians and Sardinians gained a decisive victory at Piacenza on June 17. This blow to the ambition of Elisabeth Farnese was followed on July 9 by the death of her husband Philip V. and the total eclipse of her power. Ferdinand VI. at once withdrew the Spanish troops from Italy and made overtures through the court of Lisbon to England. Italy being cleared of the enemy, the allied Austrians and Sardinians resolved to take the offensive by an invasion of Provence with the cooperation of the English fleet, an enterprise in which Admiral Byng's inertness first disclosed itself ${ }^{1}$ and which ended in a fruitless blockade of Genoa in 1747.2

I See Du Cane MSS., xix., 173, 174. IJbid., pp. 165, 171, 174, 180, 185, 186, 191. 
CHAP.

The return of Harrington to office after the crisis of XXV.

February, 1746, had been effected by the influence of Pelham, much against the inclination of the king, who resented his resignation. Sensible of this, Harrington again resigned on October 29, and the king nominated Lord Chesterfield as his successor. His brilliant administration of Ireland and his maintenance of that kingdom in absolute quiet during the rebellion had overcome the king's aversion. It was indispensable to effect an understanding with the Dutch, and Chesterfield, who had gained their confidence during his missions in I 728 and 1744, was the only English statesman capable of doing so. Harrington was appointed to Ireland in his place. When the allied army concentrated at Breda in February, I 747, it proved, as usual, deficient in its promised quotas. Cumberland was once more nominated commander-in-chief; the Prince of Waldeck was at the head of the Dutch and Marshal Batthyani of the Austrian contingent. The French were now determined on a campaign in Holland, though without a formal declaration of war. By the middle of May the country on the left bank of the Schelde was in their hands.

On June 22, Louis XV. having arrived at Brussels, Saxe marched upon Maestricht. This strong city commanded the course of the Meuse and gave access to the United Provinces. Cumberland's army of 90,000 men advancing to its relief came upon Saxe with 125,000 men, blocking the road by the occupation of the heights of Herdeeren. The order of battle was formed on July 2, the Austrians on the right, the Dutch in the centre, the British, Hanoverians, and Hessians on the left. The village of Laffeldt, the key of the position, was tenaciously held by the British and German infantry and only taken by sheer force of numbers after six unavailing attacks. The Dutch cavalry, ordered by Cumberland to create a diversion by charging from the centre, fled before the French carabineers, riding down two battalions of British, one of Hessian, and two of Hanoverian infantry, posted in reserve. The allied army was then pierced in the centre and only the desperate valour of Ligonier, who headed a charge of three dragoon regiments upon the pursuing cavalry, in which he captured five standards, saved it from total rout. The 27,000 Austrians of the right wing, held in position by the French 
left, scarcely fired a shot. The allies lost 5,680 killed and wounded, of whom more than a third were British, and 2,000 CHAP. prisoners, among them Ligonier, who had been unhorsed in his charge. The French loss, as Saxe told Ligonier, was 1,500 officers and 9,000 men. In the opinion of the public at home, though the defeat was largely attributable to the misbehaviour of the Dutch, a want of generalship was shewn by Cumberland, as at Fontenoy, in his neglect to employ so large a part of his army. In September the French took Bergen-op-Zoom by storm. The armies shortly afterwards retired to winter quarters, the British at Amsterdam and Rotterdam.

Though the campaign in the Netherlands was an unbroken series of disappointments, some compensation was found in the fruit of the increased energy at sea promised in the king's speech at the opening of the session on November 18, 1746. Vice-Admiral Anson was at this time under the Duke of Bedford, as first lord, the working chief of the admiralty. At the head of thirteen ${ }^{1}$ sail of the line, with Rear-Admiral Warren, who in 1745 had forced the harbour of Louisbourg, as his second in command, Anson attacked a French fleet of nine lineof-battle ships and eight Indiamen, carrying reinforcements and supplies to the East Indies and Canada off Cape Finisterre on May 3-14, 1747. Six French ships of the line and four Indiamen were captured. Anson was rewarded with a peerage and Warren with the Order of the Bath. This success was followed on October 25 by an action off Belleisle in which Hawke, at the head of fourteen ships of the line, defeated nine French ships of the line with a convoy of 250 vessels for the West Indies. Six French ships were taken, but the commander saved his convoy. These two actions ruined the French fighting navy, the victory of Anson contributing in no small degree to the establishment of British supremacy in India. ${ }^{2}$

At this time the governor of French India was Joseph Dupleix, whose far-seeing design it was first, with the assistance of Indian princes to expel the British, and afterwards to

I See Gent. Mag., 1747. p. 247.

"This was fully appreciated at the time. See "Representation of the Secret Committee of the East India Company to the Duke of Newcastle," April 24, 1747. Brit. Mus., Add. MSS., f. 176. "The news from Anson will be the preservation of our East India Company," Colonel Ruswell to his wife, May 30, 1747, Russell. Astly MSS., p. 362. 
CHAP. reduce the country to submission to France. He had fortiXXV. fied Pondicherry, the seat of his government, but the white troops under his command were no more than 436 in number. At his persuasion, therefore, upon the appearance of an English squadron off Pondicherry in July, I 745, the Nawáb of the Carnatic forbade the English governor of Madras to attack any of the French possessions on the Coromandel coast, at the same time guaranteeing the English against attacks from the French. Alarmed by this warning, the English desisted from their intended operations. The French, however, under La Bourdonnais, the energetic governor of the Isle of France, besieged and took Fort St. George, Madras, in September, I746. The news of the fall of Madras excited great irritation in England. On November 1, 1747, Admiral Boscawen sailed from Portsmouth with six ships of the line and other vessels, and picking up reinforcements on his way appeared in August, 1748, off the Coromandel coast at the head of the largest fleet till then seen in eastern waters. He also carried a total of 3,700 European troops ${ }^{1}$ whom he had a general's commission to command. With these forces he undertook the siege of Pondicherry, but was compelled to abandon the enterprise on October I 4. In the following year intelligence was brought to India of the conclusion of peace by the treaty of Aix-la-Chapelle of April 30, 1748. Dupleix, to his disappointment, found himself constrained by its provisions to surrender Madras, its fortifications strengthened by his industry, in exchange for Louisbourg. The struggle in India, while it had proved favourable to the French, nevertheless exercised a prejudicial effect upon their interest, for the Indian princes beheld the nation apparently victorious compelled to abandon its conquest to the nation which commanded the sea.

Parliament was dissolved on June I 8, I 747. Notwithstanding public dissatisfaction with the fortune of war on the continent, the shock of the recent invasion still made itself felt. The ministry triumphed throughout the country. Nevertheless there was a strong undercurrent of feeling in favour of ending the war." The ministry itself was an assemblage of unconnected

${ }^{1}$ His troops, under the name of "The Independent Company," were recruited from the enlistment of rebels in Carlisle jail who had not come within the general pardon of the previous session. R. O., MS., State Papers, Dom., G. II., bundle ror, no. ro.

'Bishop Sherlock to Weston, Dec. I I, I747, Weston-Underwood MS6., p. 299. 
units. Pelham complained: "He did not know where the government lived ; that there was none". Newcastle's flatterers, among CHAP. them the chancellor and Horatio Walpole, addressed him as "in a manner the Prime " [Minister], and as a consequence, the two brothers were so antagonistic that they only exchanged views through Andrew Stone, the duke's private secretary. Newcastle excepted, who "lived by the smiles in the closet," the feeling of the ministers was for peace. Overtures had already been made by Saxe through Ligonier. Saxe communicated to him for his government's information that Louis XV. was weary of the war and ready to grant generous terms. These it was determined to refer to a congress of the powers to be held forthwith at Aix-la-Chapelle. But upon the opening of parliament on November I 2, the war party were gratified by the preparations for carrying on the struggle attested by the rise of the estimates to $£ 13,000,000$. The allies hoped to begin the next campaign in the Netherlands with I 80,000 men.

Cumberland, again elate with hopes of victory, left England for Holland in the middle of February, 1748. His departure synchronised with the resignation by Chesterfield of his office of secretary of state. Chesterfield was an advocate of peace, ${ }^{1}$ and it was remarked at the time that his acceptance of office was inconsistent with his professions. His place as secretary for the northern department was taken by Newcastle, upon whose recommendation the Duke of Bedford succeeded as secretary for the southern department. The dreams of Cumberland, the king, and Newcastle of coming conquest did not long outlast Cumberland's arrival in Holland. The entire allied army at Roermond on April I I numbered only 35,000 men, and Cumberland was at last driven to the conclusion that " $a$ tolerable peace is absolutely necessary," to which the king and Newcastle yielded a reluctant assent. While Saxe, at the head of 105,000 men, prepared to attack Maestricht, the congress had opened at Aix-la-Chapelle. On April 30, preliminaries were signed by the British and French plenipotentiaries. Conquests were to be reciprocally restored and former treaties revived. Don Philip was to be provided with the duchies' of Parma and Guastalla and the city of Piacenza. Finale was to 146, 149 .

' Earl of Chesterfield to Robert Trevor, Aug. 13, 1745, Trcoor MSS., pp. 127, VOL, IX. 
CHAP. be restored to Genoa. Except Piacenza and Finale, the cessions XXV. made to the King of Sardinia by the treaty of Worms were to be confirmed. The Asiento treaty, four years of its term of thirty being unexpired at the outset of the war with Spain, was to be renewed for four years in favour of British subjects. France was again to guarantee the protestant succession. Silesia and Glatz were to be confirmed to Prussia. The pragmatic sanction was to be guaranteed, but so also, much to the empress-queen's disgust, was the Barrier treaty. These terms roused indignation at Turin and Vienna. The sacrifices made by France in the midst of a career of conquest were dimly recognised by Louis XV. who, indifferent to aught but the pleasures of Versailles, preferred "to treat as a king and not as a tradesman ". The judgement of the French public summarised itself in the proverb, "Bête comme la paix". The question of the right of search, out of which the war had arisen, was passed over in silence. The fruit of years of expenditure of blood and treasure was the status quo ante bellum.

Upon his return to France after so many adventures, Prince Charles was for a brief space the hero of the day. But to the prince's repeated solicitations for the assistance of 18,000 or 20,000 men towards a renewed invasion of Scotland, before the measures for the pacification of the highlands could take effect, Louis turned a deaf ear. When after the signature of the treaty of Aix-la-Chapelle, Louis urged him to leave the country, he treated the message with contempt. On December 9, he was given three days within which to quit Paris. On the second day after, as he was entering the opera house, he was arrested. A few days later he was released on condition that he should leave France. He withdrew to the papal territory of Avignon. On February 28, I 749, he rode out of Avignon with one attendant, Henry Goring, and for the next five years wandered in stealth. In 1750 he visited England," disguised, and "in the new church in the Strand"

1 In R. O., MS., State Papers, Dom., G. II., bundle I I 4, no. 33, are some depositions taken on August 23 and 24, I750, before Lord Stanhope, to the effect that the young pretender had lodged " on Saturday night last with Mrs. Isabel Sherriff at Star Court in the Minories". The evidence shews that a person, probably a Jacobite exile, was obtaining food and lodging by personating the prince. Charles kept notes of his visit, from which it appears that he left Antwerp.on September I2, and arrived at London on the 16th. See A. Lang, Pickle the Spy (1897), p. 105. 
made a profession of embracing Anglicanism, a step of which CHAP. Pelham had expressed apprehension as not improbable two XXV. years before. But it was too late. His character, declining with drink and debauchery, rendered him no longer the idol of his party nor the terror of the house of Hanover.

The Prince of Wales had, for a time, been discouraged by the defeat of his nominees at the recent general election. A new party was now forming round him after, as Horace Walpole sardonically expresses it, "the Pelhams had bought off every man of parts in his train ". Dodington, a typical placehunter, acted as the chief wire-puller. Policy was directed by the restless Bolingbroke. On May I, I 749, a meeting of the prince's friends, tories and Jacobites, at which the Jacobite Duke of Beaufort took the chair, proclaimed the success of these efforts and the cohesion of the new party. It was Bolingbroke's task to frame a programme and devise the catchword. The Spirit of Patriotism and The Illea of a Patriot $K$ ing, the titles of his expository treatises published in 1749 , declared war against the party system and against the corruption on which it relied. The evils should be remedied when the prince's hands held the reins of power. Purity, integrity, economy, should be the order of the day, and those should be esteemed the "king's friends." to whatever party they might have belonged, who rallied to this political reformation.

Since the restoration the navy had chiefly been governed until 1749 by an act of the reign of Charles II. But frequent instances of disobedience to orders and the general slackness of the service led in that year to the introduction of an amending and consolidating bill which became an act commonly known as "the articles of the navy"." The general tendency of this measure was to sharpen the penalties upon convicted officers. In the case of the army, which since i 715 had been governed by articles of war authorised in the statute I G. I., c. 9, an endeavour was made in 1747 by Fox, under the inspiration of Cumberland, to make half-pay officers subject to the mutiny act, a measure so unpopular that, though then passed,

He was reported by Lord Abemarle, British ambassador in Paris, as having been at Nottingham in May, 1754. Lord Lansdowne's MSS., p. 141, Hist. MSS. Comm., 3 rd Rep., App.

' 22 G. II., c. 33 . 
CHAP. it was excluded from the mutiny act of 1749 . In 1748 an $\mathrm{XXV}$. oath of secrecy was imposed on courts-martial, except when dispensed with by acts of parliament.

With the return of peace Pelham hastened to effect the economies he desired, especially the reduction of the interest on the debt of $£ 78,000,000$ from 4 to 3 per cent. He next proposed sweeping reductions in the services. Lord Barrington, representing the admiralty, moved the reduction of the navy to I0,000 men. Despite the opposition of Nugent, speaking for the prince's party, and of Sir Peter Warren on behalf of the navy, this extensive reduction was agreed to without a division on November 27, 1749. The army was fixed at nearly 19,000 men. Since the conclusion of peace the total discharges from the navy exceeded 40,000 and from the army 20,000 men. By these reductions the estimates for 1750 , apart from the interest $(£ 3,000,000)$ on the national debt, were lowered to less than $£ 3,000,000$. The consequences of the disbandments were speedily apparent. "You will hear little news from England," wrote Horace Walpole on January 31, I750, "but of robberies; the numbers of disbanded soldiers and sailors have all taken to the road or rather to the street; people are almost afraid of stirring after it is dark." Executions multiplied. In the session of 1751 , in response to a paragraph in the king's speech, the house of commons appointed a committee of inquiry into the best means of repressing crime. The outcome was a sharpening of the penal laws against criminal combinations and other offences. ${ }^{1}$ But as such remedies failed to touch the causes, so they were ineffective to suppress these social disorders. A more fruitful suggestion was that of the philanthropic Captain Thomas Coram, who in 174I had established the Foundling Hospital, that provision might be made for those thrown out of employment in the colony of Nova Scotia. The settlement, formed with the assistance of government in October, I 749, took the name of Halifax, and numbered at that time 350 houses.

During the king's stay at Hanover in the summer of 1750 his attention had chiefly been devoted to Electoral interests. His traditional sympathies with Austria and his dislike of his nephew Frederick II. rendered him anxious to conciliate Maria 
Theresa, as well as to check the advance of Prussia towards the hegemony of Germany. In order to prevent a contest of claims CHAP. to the imperial throne when a vacancy should occur, he proposed to secure the dignity to the Habsburg family by the election as King of the Romans of the son of the Emperor Francis and of the queen-empress, the Archduke Joseph, then in his tenth year. Prussia was notoriously hostile to the plan; but the scheme of George, warmly supported by Newcastle, was to procure the assent of eight of the electors, which would leave Prussia isolated. Pelham, however, foreseeing the dissolution of his own schemes of economy in a shower of German subsidies, refused to do more than to guarantee the Elector of Bavaria alone the sum of $£ 20,000$, to which Holland added $£ 10,000$ for six years. The condition was that the elector should maintain 6,000 infantry at the disposal of the maritime powers, which were thus able to shew an ostensible equivalent for what was really the purchase of his vote.

When parliament opened on January I 7, I 75I, a variety of vexatious matters of foreign policy were occupying the public mind. Several questions concerning commercial relations with Spain had been left at Aix-la-Chapelle for subsequent negotiation. This had been entrusted to Benjamin Keene, the author of the convention of January, 1739. That convention had been rejected at the stage at which the claims due from Spain had been agreed to at $£ 95,000$, while the Spanish king claimed $£ 68,000$ from the South Sea Company. Great, therefore, was the disgust in England with the outcome of Keene's new negotiation. By a treaty signed at Madrid on October 3, I 750 , Great Britain surrendered the South Sea Company's Asiento rights, the company receiving within three months $£ 100,000$ as compensation, and all claims by the crown of Spain against the company being waived. On the other hand, in recognition of the greater losses of Spain at sea during the war, the other British claims were cancelled. Pitt, who twelve years before had thundered for "no search," now changed his tone. Eager to succeed to Bedford's post, he who had abused the convention of 1739 as "nothing but a stipulation for national ignominy," applauded the less favourable treaty of 1750 . He had, he acknowledged, supported the address moved by Wyndham on November 27, 1739, praying the king not to make peace with 
CHAP. Spain until the right of search had been relinquished. "I am XXV. now," he said, "ten years older, and have had time to consider things more coolly." The Spanish war, by these admissions of one of its leading advocates, left matters as they were before it began.

Another cloud in the political horizon was the state of our relations with France. Port Royal in Acadia or, as it was called by the British, Nova Scotia, having been captured by General Nicholson in 1710 , the province had been formally transferred by France under the treaty of Utrecht. A wrangle, which lasted from I 750 to I 755, was being conducted in Paris between the commissioners of France and England as to the boundaries of the Acadia conceded by the treaty. It needed little foresight to see that the two countries were again drifting towards war. Yet while to please the king and Cumberland, Pelham carried on February 4, I 75 I, a vote of 18,850 soldiers, he maintained the economy of his administration by a reduction of the navy from 10,000 to 8,000 men. The greatest dissatisfaction was excited by this change. Its object, it was asserted by the tories, was the establishment of a military despotism. Newcastle disapproved it, and Pitt, still studious of Newcastle's patronage, vehemently condemned it, once again exasperating the king. The reduction was carried by a majority of 167 to 107 upon the assurances of Pelham that the country had nothing to fear from the naval power of France.

Another attempt to check the plague of spirit drinking, passed in the session of $175 \mathrm{I}$, owes its parentage to Nugent, a prominent member of the Leicester House party, but its inspiration to Henry Fielding, novelist and police magistrate, who in An Inquiry into the Causes of the Late Increase of Robbers, etc., published in January of that year, had denounced intemperance as a source of crime. All the ill consequences that its opponents had predicted from the relaxations introduced by the Gin act of 1743 had come to pass. Though the legislature, in 1744, had attempted to strengthen the act by another declaring a licence forfeited if its holder embarked in other than the victualling trade, 1 in 1747 it had undone what little good this restriction might have effected by granting to distillers $£ 5$ retail licences for "off" consumption. The 
distillers then employed agents for the sale of spirits. In CHAP. addition to this, the law was so openly broken, that notwithXXV. standing the reduction in the cost of licences, upwards of 4,000 persons were convicted in London in 1749 of selling spirituous liquors without a licence, and I 7,000 surreptitious gin shops were said to be in existence. Hogarth's "Gin Lane," published in February, 1751, confirmed the impression produced by Fielding. By Nugent's bill, which without much discussion passed into an act, commonly known as "the tippling act," the distillers' licences were abolished, unlicensed retailing was prohibited, and illegal retailing was made punishable on a second offence with whipping and on a third with transportation. Two years later the act 26 George II., c. I 3, restricted the liberty of magistrates to issue licences, placed public-houses under stringent regulations, and established a liquor law which survived with beneficial effects till the consolidating act of 1828 .

One other social reform of this session, which has lasted until the present day, calls for mention. Chesterfield introduced into the house of lords a measure recommended by Lord Macclesfield, son of the ex-chancellor and the most eminent astronomical expert of the day, substituting the Gregorian for the Julian calendar. The bill, thenceforth known as "Chesterfield's act," ${ }^{1}$ was carried without a division, March $18,175 \mathrm{I}$. To effect its purpose, the day after September 2, 1752, was reckoned the I 4 th, an omission of eleven days. Polite society readily accepted a reform introduced under such auspices; but the pious shuddered at the profanity of tampering with saints' days, and the commonalty grudged that their lives should be shortened by acts of parliament. The death of Macclesfield's coadjutor, James Bradley, the astronomer-royal, in 1762 , was recognised as a tardy visitation upon impiety, while at the Oxfordshire election of 1 754, at which Macclesfield's eldest son, Lord Parker, was a candidate, the mob clamoured for the eleven days of which they had been robbed by his father.

In the course of the session of 1751 an event occurred which confounded the expectations of political aspirants and, by cutting away the foundation of the opposition, gave the ministry a fresh lease of power. On March 20 Frederick,

$$
124 \text { G. II., c. } 23 .
$$


CHAP. Prince of Wales died of pleurisy. His eldest son, Prince XXV. George, was but ten years old. It was necessary that a council of regency, against the event of the king's death, should at once be constituted. The first care of the Pelhams was to guard Prince George, now created Prince of Wales, against the influence of those disaffected to themselves. The prince was made the subject of contention and intrigue, while his mother, anxious for his morals, denied him the companionship of children of his own age, other than that of his brother Edward. He was kept in a strict seclusion, likely to render him, in the event of his early succession, a docile pupil of the regent. Who this regent should be and what should be the regent's powers pressed for an immediate settlement. The choice was limited to the Princess of Wales and Cumberland. A struggle between their supporters ended in favour of the princess, who in public affairs was to be guided by a council consisting of the duke and certain great officers of state.

Though the Pelhams carried their scheme of a regency, they weakened the security of their tenure of office by increasing the hostility of Cumberland. George was unwilling to strengthen the hands of the brothers by giving office to the party of the late prince. The Pelhams' alternative resource, therefore, was to carry the war into the enemy's country and to force Bedford, who had attached himself to Cumberland, to resign. George was easily persuaded to dismiss Sandwich who had succeeded Bedford as first lord of the admiralty in February, I 748, and had also allied himself with the duke against the Pelhams. His post was transferred to Anson. As the Pelhams had foreseen, Bedford, indignant at this usage of his friend, resigned the seals two days later, June 14, 1751. Among the changes of place which followed none more surprised the political world than the return of Lord Granville to office as president of the council in place of the lord-lieutenant of Ireland, the Duke of Dorset. The selection was one which justified Newcastle's underrated sagacity. It reconciled the king to the loss of Bedford and enlisted the one powerful critic who might have headed an opposition to the Hanoverian policy. There remained the secretaryship for the southern department vacated by Bedford. If Pitt supposed that Newcastle's gratitude for sedulous support would induce the duke to force him 
upon the king, he was soon undeceived by the nomination of CHAP. Lord Holdernesse. Robert d'Arcy, the fourth Earl of HolderXXV. nesse, had served a diplomatic apprenticeship as ambassador to Venice, 1 744-46, and plenipotentiary at the Hague, 1749-51, but was in intelligence a mere clerk, little likely to run counter to either the king or the duke. Whatever resentment Pitt may have felt, he had no opportunity of gratifying it. His own popularity had vanished with his official obsequiousness to the Pelhams.

The busy pen of Newcastle was set free by the close of the session on June 25, 175I, to resume the negotiations for the election of a King of the Romans. Granville, not without incurring the suspicion of the Pelhams of a desire to outstrip them in the king's favour, zealously promoted the scheme. Sir Charles Hanbury Williams effected a treaty with the King of Poland as Elector of Saxony on September 13, for the payment of $£ 48,000$ a year for four years, two-thirds by Great Britain, the remaining third by Holland, nominally for the engagement of 6,000 troops to be furnished should occasion arise, substantially for his vote in the electoral college in favour of the Archduke Joseph. Pelham was too weak to run counter to his brother and the king, and it fell to him to recommend the Saxon subsidy to the house of commons on January 22, 1752. Horace Walpole's facetious suggestion for an advertisement, "Lost, an Opposition," was illustrated by the fact that, even with so strong a case, a minority of no more than fifty-four could be mustered against 236 for the subsidy. The opposition was sensibly weakened by the death of their inspirer Bolingbroke on December I 2, I 75 I, quickly followed by that of the leader of the Jacobite section, Sir John Hynde Cotton. It was not due to opposition protests but to the exertions of the French to strengthen their navy, that Pelham determined to restore the naval establishment to 10,000 men. While political life in the British parliament was drifting into stagnation, a movement began in Ireland which succeeded in the course of fifty years in transforming the relations of that country to England. The Irish parliament in 1749 and 1753 asserted a right to appropriate its surplus revenue. The king, however, on the advice of the Irish law officers insisted that this was an invasion of the prerogative, and in 1754 directed 
CHAP. the appropriation of a surplus of $£ 77,000$, though in accordXXV. ance with an appropriation bill passed by the Irish parliament. The opposition of "the patriots" was bought off by places and pensions, and Lord Charlemont, destined to fame in the following reign, has left it on record that the spectacle of their venality first caused him to "form in his mind some vague ideas of a future possibility of emancipating his country".

${ }^{1}$ Charlemont MSS., i., 8. 


\section{CHAPTER XXVI.}

PITT.

WHILE affairs in Europe generally wore a tranquil aspect at the beginning of 1753 , the relations between Great Britain and Prussia were approaching a dangerous state of tension. On November 23, 1 752, an announcement was made by Frederick II. of his intention to detain the last instalment of the repayment of the Silesian loan of $£ 250,000$ due to English creditors. This money had been borrowed in January, 1735, by the Emperor Charles VI. upon the security of the revenues arising from the duchies of Upper and Lower Silesia, since annexed by Prussia, the capital to be repaid in instalments of which the last was due in 1745. By the treaty of Breslau in 1742 , and that of Dresden in 1745, Frederick agreed to take over these obligations, which for some years he continued to discharge. He now stopped $£ 30,000$, out of $€ 45,000$ due, and applied it as compensation to Prussian shipowners whose vessels had been seized in October, $1745,{ }^{1}$ by English cruisers for carrying contraband of war.

The irritation caused in England by Frederick's demands and by his appointment in August, $175 \mathrm{I}$, of the Jacobite Earl Marischal Keith as his ambassador to Paris contributed to bring about the execution of Dr. Archibald Cameron, younger brother of Lochiel, who had escaped after Culloden to France. News reached England from the Austrian minister Kaunitz and from a Jacobite informer, known to the English ministry as "Pickle the Spy," and now proved to have been the exiled "Young

'So Carlyle (Frederick the Great, bk. xxvi., chap. xiii.) from Prussian authorities, but the Duke of Neweastle's letter to the secretary of the Prussian embassy, dated February 8, 1753, declares that no seizures took place till a year after the last payment of the Silesian loan was due, i.e., till 1746. See Gent. Mag., 1753, p. 83 f. 
CHAP. Glengarry," 1 that Frederick was tampering with the Jacobites. XXVI. Between Glengarry and Cameron a feud had long existed, and Glengarry now betrayed to the English ministry that Archibald Cameron was about to return to Scotland as an emissary of Prussia to concert a fresh rising. ${ }^{2}$ Two sloops of war were stationed to intercept Cameron. He was arrested on March 20,1753 , arraigned on the act of attainder for his share in the rebellion of 1745 , and hanged. His personal qualities stirred public commiseration, but the circumstances which are now known to have led to his death, a renewed attempt against the public peace by an attainted rebel acting in the interest of a foreign power, absolve ministers from the discredit of a "wanton atrocity" imputed to them by Lord Campbell and suggested by Carlyle.

The session of 1753 was proceeding with the languor natural where an opposition is insignificant both in numbers and talent, when two questions of domestic interest were introduced which divided not only society but the ministry itself. For some years the court of chancery and the house of lords had been scandalised by suits to establish or annul the validity of clandestine marriages. "Fleet marriages" had become a by-word, yet 2,954 were proved to have been celebrated in four months. The bill, known as Hardwicke's marriage act, remains, to the credit of the chancellor, the substantive act regulating marriage to the present day. All marriages celebrated irregularly were declared void. It is difficult for later generations which have experienced the salutary working of this wise measure to understand the outburst of hostility provoked by it.

An unsuccessful attempt made in I75 I with Pelham's support to encourage the immigration of foreign protestants was finally dropped, but in the session of 1753 he assented to an analogous measure in favour of the naturalisation of the Jews. Unfortunately for the cause of toleration, the parliament of I 747 was nearing its end, and the opponents of the ministry were casting about for a useful cry for the approaching general election. The Jews' naturalisation act furnished one. The

\footnotetext{
${ }^{2}$ Chief of the Glengarry branch of the Macdonalds. A. Lang, Pickle the Spy, 1897.

2 Mr. Lang has disposed of Carlyle's view that this was a delusion of the English ministry. Pickle the Spy, pp. 195-77.
} 
whole race of Jews was to be naturalised and would presently buy up the fee-simple of the country. The print-shops were full CHAP. of caricatures of the Jews; anti-Jewish ballads became the vogue. "A man of dark complexion," wrote a member of parliament," "is scarce safe in the streets." "No Jews: Christianity and the Constitution" became a popular cry. The affront offered to Christianity furnished texts to the tory clergy. Hayter, Bishop of Norwich, who had been zealous for the bill, was publicly insulted in his diocese. Pelham had no thought of repeating Godolphin's blunder of collision with the pulpit. On November 15, 1753, parliament met, and on the same day the Duke of Newcastle moved to repeal the act "as a point of political policy". In the house of commons the fear of the electors lay heavy on the whigs, and the act of repeal was the first enrolled in the session of 1753-54.

To lovers of the grandiose, like Granville, or to dilettanti politicians like Horace Walpole, who complained "the house of commons is become a mere quarter sessions, where nothing is transacted but turnpikes and poor rates," the ministerial achievements of Henry Pelham were humdrum and insignificant. His personality was, indeed, not one to inspire enthusiasm, but neither did it excite animosity. Caricatures of him there were, but he was satirised with less virulence than any of his predecessors. Leaving details of diplomacy to his brother Newcastle, by whom, according to Fox, "he was always drawn and generally dragged," he used his influence for peace because his interest lay in economic and domestic reform. A series of measures attests the sedulous solicitude of Pelham as well as of Lord Halifax, the president of the board of trade, for the commercial advantage of the country. Upon the suggestion of Henry Fielding, the police of London was in 1753 reformed by the establishment of a "Bow Street foot patrol". So effective did this small body prove that by 1757 , according to Brown, the author of the Estimate, "the reigning evil of street robberies had been almost totally suppressed," and the "Bow Street runners," as they were commonly called, became celebrated as detectives. This improvement is ascribed by Sir John Fielding, the brother of the novelist and his successor at Bow Street, to the Duke of Newcastle. At the same time

'Robert Ord to Lond Carliale, July 87, 1753, Carlisle MSS., p. 207. 
CHAP. some check was applied to the increase of criminals by training XXVI. destitute boys for the navy. The criminal law and its administration however still remained blundering and sanguinary. The most permanent monument of Pelham's administration was the foundation in 1753 of the British Museum. While his success exceeded that of Walpole in managing the house of commons, the circumstances of his ministry rendered his task infinitely easier. Nor did he shrink from Walpole's methods of securing loyalty by a lavish distribution of the spoils of office.

Although Pelham had been for some months ailing, his death on March 6, I 754, plunged the ministry into confusion. "I shall now," exclaimed George, on hearing the news, "have no more peace." The two great offices of first lord of the treasury and chancellor of the exchequer fell vacant. The treasury Newcastle determined to reserve to himself. Fox was to be offered the secretaryship of the southern province, to be vacated by the transfer of Holdernesse to the northern. To the chagrin of Fox, when the secretaryship of state with the leadership of the commons was offered him he was told by Newcastle that he would have nothing to do with the secret service money, nor yet with the ministerial nominations to seats, nor with the management of the approaching general election, which were to be reserved to the duke. Fox refused place shorn of power and preferred to remain secretary at war. Sir Thomas Robinson, the real author, as coadjutor to Sandwich, of the peace of Aix-la-Chapelle, accepted the secretaryship declined by Fox. The temper of Pitt towards the new leader of the commons relieved itself in the exclamation: "The duke might as well have sent us his jackboot to lead us".

At the moment of Pelham's death Pitt was at Bath. If Hardwicke may be believed, the king refused to listen to his pleas for the promotion of Pitt. Under cover of offering such compensation as was in his power, but really, it was suspected, to break up the Leicester House party by enlisting its members with the government, Newcastle distributed some places among them. Lyttelton accepted the post of cofferer of the household; George Grenville the treasurership of the navy vacated by the advancernent to the chancellorship of the exchequer of Henry Bilson Legge. This was a fresh mortification 
to Pitt. With a bitterness at heart which the prospect of a seat from Newcastle at the approaching election compelled CHAP. him to dissemble, Pitt began to lay his plans for future satisfaction. Newcastle was now, in effect, as Horace Walpole calls him, "universal minister". The chancellor Hardwicke was rewarded for his fidelity with advancement to an earldom; the attorney-general, Sir Dudley Ryder, was promoted chief-justice of the king's bench, and Murray succeeded Ryder. On April 8, the parliament of 1747 was dissolved. If we may believe Horace Walpole, " there never was such established bribery or so profuse," but only forty-two places in England were contested. Upon the first party division in the following November the government majority was 151. The occasion was a petition against the return of William Pitt, member for Newcastle's borough of Seaford.

The tranquillity prevailing upon the continent of Europe after. the peace of Aix-la-Chapelle found no counterpart in India, where the rivals for supremacy, the English and French, had, at the moment of the conclusion of the treaty, gathered forces for the continuance of their struggle, not indeed as principals, but as auxiliaries to native princes. Until the end of 1 751 , the growth of French influence bid fair to absorb the whole of the Carnatic. The succession to this province was in dispute between two rival Nawábs, but Mohammed Ali, the candidate supported by the British, had been reduced to Trichinopoli, which was invested by Chunda Sahib, the French nominee, with a large force. Clive, a young writer in the East India Company's service, who had already displayed military capacity, perceived that Trichinopoli could only be saved by a diversion. His surprise of Arcot on August 31, 175 I, and subsequent defence produced an immense revulsion of feeling among the native princes, and marks a turning-point in the history of India. On March 28, 1752, Colonel Stringer Lawrence, "the father of the Indian army," marched to the relief of Trichinopoli, with Clive as second in command. They succeeded in beating off reinforcements sent by Dupleix, and on June 13, the French general, Law, and Chunda Sahib surrendered with 800 French soldiers, 2,000 sepoys, and 3,000 to 4,000 cavalry. So crushing a blow left the British and their candidate, the Nawab Mohammed Ali, masters of the Carnatic; 
CHAP. only Pondicherry and a few settlements remained to the French. XXVI. But French influence was still dominant in the Deccan, where the talented soldier and diplomatist Bussy controlled the policy of the Nizam. Dupleix was recalled, and a provisional treaty, signed by his successor Godeheu on January I I, 1755 , conceded to the British the main points in contest and accepted their candidate Mohammed Ali as Nawáb of the Carnatic. The work of Dupleix in the Carnatic was undone.

As in India, so in America, the peace of Aix-la-Chapelle was but the prelude to the final struggle between England and France for the mastery of the continent. France was mistress alike of the great waterways of the St. Lawrence in the north and the Mississippi in the south, and of the vast territory, the hinterland of the English littoral, lying between Montreal and New Orleans. The strategical points of importance were the southern coasts of the great lakes and the valley of the Ohio. On the other hand, the range of the Alleghanies, the western boundary of the English colonies, was a barrier easily surmounted. Once crossed, the approach was clear to the Ohio and the chain between the French northern and southern settlements severed. A French expedition in 1753 constructed a fortified post near the south-east shore of Lake Erie called Fort Lebœuf. Hearing this news, the British government ordered Dinwiddie, the lieutenant-governor of Virginia, to stop the enterprise, if necessary, by force. Dinwiddie selected George Washington, a name destined to world-wide renown, at that time borne by a young surveyor who also acted as major and adjutant-general of the Virginia militia. Washington's orders were to send a summons to the French at Fort Lebcuf to withdraw. His mission proved fruitless. The assembly of Virginia thereupon, in 1754 , voted $£ 10,000$ for the construction of a fort at the fork of the Ohio, where Pittsburg now stands, conformably with instructions from the home government. But a French force came down the Alleghany on April 17, compelled the Virginians to withdraw, and demolished the works, subsequently reconstructing them on a larger scale under the name of Fort Duquesne. Henceforth the French and English were actually, though not professedly, at war. Strong reinforcements were dispatched to Fort Duquesne. Washington, besieged in an intrenched 
camp at " the Great Meadows," capitulated with the honours of war and was suffered to retreat across the Alleghanies. The CHAP. hostilities of 1754 had ended disastrously for the British.

Before the meeting of parliament in the autumn of 1754 , it had been decided to send two regiments of regular troops to the Ohio valley, and at Christmas, General Braddock, a favourite of the Duke of Cumberland, was dispatched to Virginia with the $44^{\text {th }}$ and $4^{8 \text { th }}$ regiments of the line. Braddock was an officer of the type of Hawley, intrepid but brutal, a contemner of all combatants not drilled after the fashion set by the martinets. In France a counter-expedition to that of Braddock was organised. At the end of April, 1755, a fleet of eighteen ships conveying 3,000 troops under Baron Diskau, an officer of Marshal Saxe, set sail from Brest for Canada.

Braddock's operations had been prescribed by Cumberland. The French were to be simultaneously attacked at four points. Braddock himself, with the two regiments of regulars, was to land at Hampton in Virginia, and march against Fort Duquesne; two regiments of colonials were to take Fort Niagara, which commanded the passage between Iakes Ontario and Erie; Crown Point, the key of Lake Champlain, was to be seized by New Englanders, another body of whom were to capture Fort Beauséjour, which the French had erected to command the road between the Nova Scotia peninsula and the mainland. On July 9 Braddock with 1,373 officers and privates, crossed the Monongahela river within a few miles of Fort Duquesne. As he advanced through the forest, with insufficient precautions against surprise, he was attacked by the French aided by their Indian allies, about 900 in all. Unaccustomed to forest fighting, Braddock, despite the advice of Washington, now his aide-de-camp, kept his soldiers in close formation, while the enemy fired at them from behind the shelter of the trees. After two hours and a half of fighting their defeat was complete. ${ }^{1}$ Of eighty-six officers sixty-three

' See a letter by Lady Anson, constructed out of dispatches from Washington and Captain Orme, another aide-de-camp of Braddock, dated August 23, 1755. Newcastle Papers, Brit. Mus, Add. MSS., 35,376, f. 127 . According to this account, "Washington alone of the general's family escaped unwounded tho" he behaved gallantly, having two horses killed and four bullets thro' his coat". From this letter it appears that Lord Anson's advice had been to organise American regiments for the war.

VOL. IX. 
CHAP. were killed or wounded, and two-thirds of the privates. XXVI. Braddock himself, who had five horses killed under him, was shot through the shoulder and lung, and died four days later. All the artillery in advance was lost. Colonel Dunbar, the commander of the rear-guard, fell back in a panic on Fort Cumberland, after destroying his cannon and stores. From thence, though there was no pursuit, he hurried to Philadelphia, leaving the frontier unprotected.

In two other directions the English scheme of operations was successfully carried out. The New England militia captured Fort Beausejour in June, and the destruction of a smaller fort, Gaspereau at Baye Verte, gave the English the command of the whole of Nova Scotia. The expedition against Crown Point, which threatened the northern colonies, was entrusted to William Johnson, an Irishman by birth, influential among the Iroquois confederacy. Diskau, who had garrisoned Crown Point with 3,500 men, advanced early in September with some picked troops and Indians against Johnson's camp at Lake St. Sacrement, named by Johnson Lake George, but was defeated and taken prisoner. The news reached England at the end of October, and was welcomed the more as the depression caused by Braddock's defeat had been acute. The objective of Crown Point had, indeed, not been attained, but Oswego and the colony of New York had been saved from a French invasion. Johnson, who was wounded in the action, was rewarded by a baronetcy and a grant from parliament of $£ 5,000$. There remained the fourth enterprise, the attempt upon Fort Niagara, the capture of which would sever the chain of forts between Canada and the west. The command of this expedition was entrusted to William Shirley, governor of Massachusetts. Unfortunately, Shirley was on bad terms with Johnson, who would not co-operate with him, and the French forces were too considerable to be attacked. The American campaign of 1755 had, on the whole, been adverse to England. Johnson had not followed up his victory, Shirley and Braddock had failed, only the contested portion of Nova Scotia had been conquered. Braddock's defeat encouraged organised incursions of the Indians under French direction across the frontiers of Virginia, Maryland, and Pennsylvania.

Beyond general professions Pitt had given no pledges to 
Newcastle as the price of his return at the general election of CHAP. April, 1754, for the duke's borough of Aldborough. Repeated Xxivi. disappointments had proved to him that he had nothing further to hope for from the ministry, that his sole prospect of rising was upon its ruins. He found a ready ally in Fox, still embittered by the conditions Newcastle had sought to impose upon him, yet doubtful whether he had done wisely to reject them. In a few days after the meeting of parliament in November, 1754, the storm burst. In a speech upon an election petition Pitt implored the house to beware lest it should "degenerate into a little assembly serving no other purpose than to register the arbitrary edicts of one too powerful subject". The significance of the allusion was seized. It was a declaration of war. But as Newcastle could only be assailed indirectly, his representative in the commons, Sir Thomas Robinson, was selected as a vicarious sacrifice. Robinson, pompous, flustered and irascible, was unable, even with Murray's assistance and the general sympathy of the house, to cope with the sarcasm of Fox and the invective of Pitt. It became obvious to Newcastle that the confederate assailants must be separated. When, in April, I 755, a demand by Fox of a seat in the cabinet was conceded by the king, Pitt felt himself isolated. He intimated to Fox that their understanding was at an end. $\mathrm{He}$ was, indeed, casting his lines elsewhere. On the 27 th, the day before the king, despite all remonstrances, left for Hanover, Pitt sent old Horatio Walpole to Newcastle to demand an explicit promise of the secretaryship of state at the first vacancy. The duke shuffled. From that day Pitt paid his court to the Princess of Wales and her son. This association involved him in antagonism to Cumberland and still further estranged him from Fox, whom the princess disliked as Cumberland's strongest ally. Upon the king's departure the war party was in the ascendant, Cumberland being now for the first time a member of the regency of sixteen, among whom, in virtue of his cabinet rank, Fox was also included.

During the spring of 1755 warlike preparations proceeded busily on both sides of the Channel. Parliament voted a supply of $£ 1,000,000$. When the French fleet carrying Baron Diskau and his troops was ready to start, Vice-Admiral Boscawen, with eleven ships of the line and one frigate, was 
CHAP. ordered to intercept it. The preponderance of numbers was XXVI. with the eighteen vessels of the French fleet, but of these eight were only lightly armed as transports. Boscawen put to sea first on April 27, with orders which were concealed from the French ambassador in London, the Duke de Mirepoix, to attack reinforcements for Canada. Boscawen's fleet sighted the French ships off the mouth of the St. Lawrence river on June 7 , but a fog came on, and only two were captured. It was a provocation that could have but one sequel. Mirepoix was recalled from London on July 22, and orders were issued from Paris to reconstruct the seaward fortifications of Dunkirk in breach of the treaty. Nevertheless France, behindhand in her preparations, behaved with studious restraint. English merchant vessels were suffered to ply unmolested in her ports, and the English frigate Blandford, on board of which Sir Thomas Lyttelton was proceeding to his government of South Carolina, being taken by a French frigate, was released in August. Nevertheless the admiralty issued letters of marque and reprisal. French trade afloat was everywhere destroyed by English cruisers, and before Christmas, 1755, 300 French merchant ships and 6,000 French sailors were carried into English ports. France, as yet too weak at sea to retaliate, filled the courts of Europe, not without reason, with denunciations of English piracy and robbery. Even in London, according to the dispatches of the Prussian envoy, disapproval was expressed of such proceedings.

The persistence of the king in visiting Hanover in this critical condition of affairs arose from his anxiety for the Electorate, and his sense of a greater freedom of action when beyond the immediate control of his English ministers. He entered into a treaty with Hesse-Cassel by which 8,000 troops were to pass into the service of Great Britain upon payment of a subsidy. More ambitious was the Russian convention for 55,000 men and $£ 100,000$ for the protection of the Electorate, the negotiation of which was not finally concluded till November. The nation was already sick of subsidies, but Newcastle's tenure of power depended upon his gratifying the king. Fearful lest the house of commons, stirred by the thunders of Pitt, should revolt, the duke resolved upon another effort to gain him. To a request that he would support the 
ministry, Pitt answered by denouncing subsidies. Hanover could not be defended by subsidies. Hanover should be CHAP. defended by the empire and, if invaded, its restitution should be macie a condition of peace. At an interview on September 2, Pitt addressed himself to a constitutional question, already raised by Fox with his cognisance. Newcastle, ever fearful of a rival, had persuaded the king "to have no minister at the head of the house of commons". Pitt boldly challenged the principle. He refused to be bought by an offer, made with the king's reluctant permission, of a seat in the cabinet. The utmost he would concede was to vote for the Hessian subsidy, as the duke urged that the king's honour was already pledged to it. For other subsidies, whether Saxon, Bavarian, or Russian, he would never vote. Since an interview Pitt had had with Hardwicke on August 9, the situation of Newcastle, as Pitt very well knew, had become more critical. Legge, the chancellor of the exchequer, had for some time past followed Pitt in cultivating the good graces of the Princess of Wales. The council of regency had signed the Hessian subsidy treaty, without examination and as a matter of course, on the intimation by Newcastle that it was at the king's command. To the general astonishment, when the necessary treasury warrants were laid before Legge, he peremptorily refused his signature.

In his desperation Newcastle turned to Fox, who had always regretted his former refusal of promotion. Fox, as a champion of the war party, was in principle favourable to subsidies. He therefore accepted Newcastle's proposals, and in November obtained what the king had before refused to grant," "not only the lead but the power of the house of commons" with the secretaryship of state for the southern province in place of Robinson. Pitt now found himself and his group isolated and could look for support only to his allies of Leicester House, where Fox, as "Cumberland's minister," was in disfavour with the princess. The intermediary who came forward to organise the new opposition was the princess's favourite, Lord Bute, a man with a taste for amateur acting, "a good person, fine legs, and a theatrical air of the greatest importance, but no substantial acquirements". The Leicester

\footnotetext{
I See Fox to the King, April 25, 1755, Chatham Correspondence, i., 128,
} 
CHAP. House party thenceforth consisted of Legge, Lord Egmont, Sir XXVI. George Lee, the Duke of Devonshire, and Dodington, reinforced by Pitt and his followers.

The session of parliament which opened on November 13 , I 755, at so grave a crisis of affairs, was distinguished by the brilliancy of its debates, recorded by the accomplished pen of Horace Walpole. In the commons an address was moved by Lord Hillsborough, pledging the house " to assist His Majesty against insults and attacks that may be made upon any of $\mathrm{His}$ Majesty's dominions, though not belonging to the Crown of Great Britain ". It was the language of the act of settlement and directly challenged the issue of Hanover. Pitt, determined upon a final rupture both with the ministry and the court, attacked the policy of the government on the ground that it was directed to the defence of the Electorate. "He surpassed himself," writes the enthusiastic Horace Walpole, "and then I need not tell you that he surpassed Cicero and Demosthenes." But the address was carried by 3 I I to I05 votes. A few days later, Pitt, Legge, and George Grenville were dismissed and James Grenville resigned his place on the board of trade. Dodington had, as usual, played false. On December I 7 he received the treasurership of the navy. Another old friend of Pitt, Sir George Lyttelton, also reaped the reward of desertion and was appointed chancellor of the exchequer, the final breach of his "historic friendship" with Pitt. One further incident of this debate remains to be mentioned; a speech which "was at once perfection" by William Gerard Hamilton, thereafter known as "Single-speech Hamilton" from his subsequent failure to redeem the brilliant promise of his first effort.

Opposed though Pitt was to a lavishing of promiscuous subsidies, he realised the necessity, in view of a struggle with France, of increasing the military resources of the country, and on December 5 advocated an augmentation of the army by I 5,000 men. On March 12, 1756, Colonel George Townshend, afterwards field-marshal, introduced into the house of commons a scheme for the reorganisation of the militia as a defence against invasion. His idea was to substitute for a levy en masse a regularly trained army of reserve, numbering 61,000 men, drilled twice a week and reviewed quarterly by 
the lords-lieutenants of their counties. Pitt as a soldier knew the value of military discipline and warmly supported the CHAP. proposal. But ancient prejudice was strong. Though Pitt's advocacy was successful in securing the passage of the bill through the commons, it was thrown out by the lords. "It would," declared Newcastle, who led the opposition to it, "tend more to make this a military country and government than any scheme I have yet heard of." Indeed, a scheme which proposed by a training of three years to pass 240,000 men through the ranks in twelve years out of a population of under $7,500,000^{1}$ merited such a description. The ministry, however, at the end of the year obtained a second augmentation, raising the army in Great Britain to 40,000 , and the Irish parliament voted an establishment of 12,000 men.

The provocations offered by England at sea since the summer of 1755, which France had been unable to resent, made war imminent. In January, 1756, the French minister of foreign affairs, Rouille, formally notified it as the alternative to immediate redress. ${ }^{2}$ Yet, with the exception of Prussia, there was no first-class power upon whom England could count. The position of Frederick was at the moment one of extreme delicacy. In January, 1753, he had been placed in possession of a copy of the secret articles of a treaty between Russia and Austria, dated May 22-June 2, I746, for the restitution of Silesia to Austria and the partition of the Prussian kingdom. He determined, after some hesitation, to enter into alliance with England. By the convention of Westminster, signed on January 16, 1756, Prussia and England agreed to unite to resist the invasion of Germany by foreign powers. A settlement was made of the outstanding grievance of the Silesian loan. The great object of George II. was now attained, Hanover was placed under a Prussian protectorate. France was isolated. For a while she hesitated. She cared nothing for Silesia. The ministers of Louis XV. knew that in the impoverished condition of the country they could "not support the war both at sea and at land". They intended,

\footnotetext{
${ }^{1}$ Malthus estimated it as 7,721,000 in England and Wales in 1780. Essay on Population, 2 vols, 6th ed., 1826, i., 435.

Duke of Newestle to Duke of Devonshire, January 10, 1756, Newcastle Papers, Brit. Mus., Add. MSS., 32,862, f. 58.
} 
CHAP. therefore, "to confine the war to their marine and North XXVI. America". But the bait of compensation in Flanders and Brabant held out to them by the Austrian ambassador Stahremberg, led them into the first steps of a policy fatal to the real interests of their country. By the treaty of Versailles of May I, 1756, the traditions of French diplomacy were revolutionised and an alliance entered into with Austria.

Pending these negotiations, the French made vigorous preparations for a naval war. Newcastle was well served with intelligence. Among the Newcastle papers are transcripts of the official dispatches of Bunge, the Swedish minister at Paris, and letters of the most confidential character from an anonymous informer." The French naval estimates for 1756 exceeded the $£ 3,000,000$ estimated for England. Dispatches of Bunge of February 6 and 20 disclosed that transports were being collected under the supervision of Marshal Belleisle for an invasion of England. On January 26 the informer sent intelligence that the "Court had a design on Port Mahon". "An offer," wrote the spy from Versailles on February 22, " hath been actually made the Court of Madrid to take Port Mahon at our own expense, to assist them in the siege of Gibraltar, and to guarantee both these places to the Crown of Spain. . . . The Toulon Squadron is fitting out with great expedition and will be employed in convoying our troops to Minorca, if the Court of Madrid come into our measures." The same news came on the $4^{\text {th }}$ from the British consul at Genoa, and in March warnings as to preparations for an invasion of England and Ireland as well as for an attack on Minorca were repeated. ${ }^{4}$ The West Indies and America were also to be attacked, and attempts were to be made on Guernsey and Jersey and an invasion of Sussex simulated in order to "make England keep a number of her ships at home": Similar

'Secret information to Newcastle, Newcastle to Devonshire, January 2, 1756, Newcastle Papers, Brit. Mus., Add. MSS., 32,862, f. 5.

2 Intelligence from Paris on August 25, I756, ibid., 32,867, f. 42, and Fontainebleau, October 20, 1756, ibid., 32,868, f. 392.

${ }^{3}$ Ibid., f. 184, March $4,1756$.

1" The Cardinal (de Bernis) told me at Rome in 1771 that the cabals ran so high against him at Court that the only struggle there was how to give the most certain intelligence to England of the design against Minorca on purpose that it might fail." Ld. Shelburne in Fitzmaurice's Life of Shelburne, i., 80.

- Newcastle Papers, Brit. Mus., Add, MSS., 32,863, f. 59. 
intelligence as to Minorca reached Fox, as secretary for the CHAP. south, from Madrid about the same time.1

XXVI.

On March 23, 1756, a message from the king announced the imminence of an invasion and that the 8,000 Hessians stipulated under the Hessian treaty had been summoned. Both houses addressed the king to send over a body of Hanoverians. The convention of Westminster was laid before the house of commons on May $I I$, and a vote taken of $£ 1,000,000$ for general war purposes. But there was a general sense that the country was drifting into war unprepared. Pitt, always at:entive to popular feeling, violently denounced the ministry on this account. Newcastle, indeed, had refused to believe it must be war, but Cumberland and his satellite Fox, who were for driving things to extremes, had, as early as Christmas, 1755, pressed for the dispatch of a squadron to Minorca. There were, however, difficulties for .which ministers were not wholly to blame. Popular jealousy of freedom had stood in the way of systematic recruitment of the navy. The sailing of Admiral John Byng, who had been nominated to the command, was delayed a few days, while the last 200 men were being brought in by the press-gangs. The crews thus got together were held cheap by the French. The Duke de Mirepoix bragged to Newcastle "that thirty of his master's ships would amuse eighty of ours". Nor was the spirit of the officers always such as to compensate for the doubtful quality of the crews. Anson, first lord of the admiralty, wrote on June 6, 1756 , not of Byng but of Boscawen, an officer with a fighting reputation, "I don't know how it comes to pass, that unless our commanders-in-chief have a very great superiority of the enemy, they never think themselves safe". 2 To use a current expression, the sea service was "slack". It responded, indeed, to the general tone. "I want," exclaimed Pitt, "to call this country out of that enervate state that 20,000 men from France could shake it." The last commander capable of this feat was Byng, whom his operations on the southern coast of France in 1747 had already proved wanting in enterprise and energy. ${ }^{3}$ But he had solicited

' Keene to Fox, March 22, 1756, Neweastle Papers, Brit, Mus., Add. MSS., 32,863, f. 434 .

Ibid., 32,865, f. 221.

"Du Cane MSS., Introd, xviii., xix. 
CHAP. the appointment and his family connexions secured it for XXVI. him.

Byng's instructions were, in the event of an attack by the French on Minorca, to take a battalion of troops on board at Gibraltar and to throw them and the Royal Fusiliers, whom he carried with him, into Port Mahon, "and to use all possible means in your power for its relief". On April Io, four days after he had set sail, the Marshal Duke de Richelieu left Toulon with 16,000 men in transports under escort of twelve men-of-war commanded by Admiral de la Galissonière. On the 2oth they disembarked at Minorca, a small English squadron under Commodore Edgcumbe, which lay at Port Mahon, retiring to Gibraltar. The harbour at Port Mahon was defended by the castle of St. Philip, an elaborate and formidable fortification. But the garrison was inadequate, consisting of the Welsh Fusiliers and the 4th, 24th and 34th regiments, in all some 2,800 men under a veteran soldier, General Blakeney, who was ill in bed. At Gibraltar Byng heard from Edgcumbe of the French descent, but disobeyed his instructions to embark a battalion, concurring with the opinion ${ }^{1}$ of the governor, General Fowke, and a council of war that to do so would be unduly to deplete the garrison at Gibraltar, which consisted of four regiments. With Edgcumbe's reinforcement his fleet now numbered thirteen sail of the line and three frigates, ${ }^{2}$ and with these on May 8 he weighed for Port Mahon, which he reached on the 19th. "I found it," he wrote, "too strongly invested by I,700 men to be able to land even a letter to the castle, had I time, for that day we fell in with the French fleet of twelve large ships of the line and five frigates, all very heavy ships." 3 On the 2oth the French van was attacked by Rear-Admiral West who was leading, and "a running fight" took place. ${ }^{4}$ Byng failed to come up to his support. After an action in which the English fleet lost forty-two killed and

1 So expressly stated by Fowke in his dispatch to Fox of June 2, 1756, Newcastle Papers, Brit. Mus., Add. MSS., 32,865, f. 177, though Stanhope represents Byng to have been at issue with Fowke on the subject.

${ }^{2}$ Anson to Newcastle, May 31, I756, ibid., f. 159. Also Admiralty Warrant read at trial. Trial of Byng, p. 4 .

${ }^{3}$ R. O., MS., State Papers, Foreign, Spain, 152.

"Admiral Byng to Sir B. Keene, "Ramillies," off Mahon, May 25. Byng is confirmed by Lieutenant Basset, who was his flag-lieutenant. Ibid, 
168 wounded and the French thirty-eight killed and 184 CHAP. wounded," the French fleet got away, sailing "three feet to XXVI. our one".2 Byng was, in fact, a prey to despondency: "Between you and I," he wrote to Keene, "they are too strong for us ". He returned to Gibraltar. On June 28 the garrison of Fort St. Philip capitulated with the honours of war and were transported to Gibraltar.

War had been declared by England on May 18, and by France on June 9, and the loss of Port Mahon was the first fruit. When anxious inquiries had been made of Fox as to the sufficiency of the force, Anson "took it upon himself that Byng's squadron would beat anything the French had". Either the ministry or Byng was culpable. Newcastle's pusillanimous soul was racked with the apprehension "that the opposition will endeavour (if possible) to fling it singly upon me"." The chancellor must speak to his son-in-law Lord Anson "for the immediate trial and condemnation of Admiral Byng if, as I think, there can be no doubt, he deserves it".s The public had long been nervous. It was now in "extreme consternation," a state of mind which naturally seeks for a scapegoat. The ministry were conscious that Minorca might be followed by Gibraltar. The safest policy in Newcastle's eyes was to fan the rising flame against Byng. An abstract was published of Byng's dispatch, carefully omitting points that might tell against the ministry. The impression left was of an incapable commander blinded by self-complacence. Byng and West had reached Portsmouth on July 26 in close arrest, Hawke and Admiral Saunders having been dispatched to Gibraltar with five sail of the line to supersede them. West was presently released, having by common consent behaved with gallantry, and was graciously received at court. Byng's house and park in Hertfordshire were with difficulty saved from the attack of a mob, and he was in many places burnt in effigy. Ballads and caricatures at the expense of the ministry were everywhere to be heard and seen. At Greenwich Newcastle was pelted by a crowd.

In North America, during the winter of $1755-56$, though

' R. O., MS., State Papers, Foreign, Spain, 152, Letter of De la Galissonière.

Ibid., Byng's letter. Ibid.

- To Hardwicke, July 19, 1756, Newcastle Papers, Brit. Mus., Add. MSS., 32,866, f. 220.

Ibid, 
CHAP. war had not been formally declared, intermittent hostilities had XXVI. been carried on. With the spring both sides prepared for action upon a larger scale. But influences were already at work against the original intention of France to concentrate her attention upon maritime warfare. The empress-queen had won Madame de Pompadour by addressing her in an autograph letter as "Ma chère cousine," and the mistress's gratitude and satisfaction knew no bounds. D'Argenson, the minister for war, the courtiers, avid of military glory, and Marshal Belleisle, who might "be said to govern," 1 were anxious that the army should play the leading part. Above all, the combination with Austria against protestant Prussia and England recommended itself to Louis as a new crusade for the faith, zeal for which would cancel the adverse spiritual scores debited against him during a life of debauchery. Thus it came to pass that, although by the defensive treaty of Versailles of May I, 1756, only 24,000 men were promised, by the second treaty of Versailles of May I, I 757, as many as 105,000 were to be furnished by France, besides 4,000 Bavarians and 6,000 Würtembergers to be taken into French pay. On the other hand, the reinforcements for Canada dispatched in April, I 756, under the Marquis of Montcalm numbered only I,200 troops. The total number of the French regular forces in Canada then approached 3,000, reinforced by 2,400 men in March, 1757. Besides these, there were 1 5,000 militia and an indefinite horde of Indian allies.

At the end of July, the Earl of Loudoun, an incompetent and irascible general, took over the command of the British forces. Montcalm was already moving. His objective was Fort Oswego and Fort Ontario, on the east side of Lake Ontario, the natural base of operations against Forts Frontenac and Niagara. The French captured the forts with I 3 cannon and large supplies, and were thus assured of their communications from the river St. Lawrence to the upper Ohio. In the prevailing irritation the news of the loss of Oswego in August, which reached London on September 30, seemed a final blow to the credit of the ministry. The anxiety naturally felt by Newcastle as to the winter session of parliament was quickened

${ }^{1}$ Secret intelligence, Paris, August 25, 1756, Newcastle Papers, Brit. Mus," Add, MSS., 32,867 , f. 42 . 
into apprehension in consequence of the death in June, after CHAP. little more than two years' tenure of office, of Sir Dudley Ryder, XXVI. lord chief justice of England. Murray demanded his place. Newcastle protested that he could not be spared from the commons, but Murray threatened resignation. The duke had no choice. He lost his ablest supporter in the commons, ${ }^{1}$ and Murray, as Baron Mansfield, passed to the house of lords.

In the middle of October Newcastle was taken aback when Fox intimated his intention to retire. Seeing that the king resented his desertion, Newcastle hinted at Pitt. "But Mr. Pitt," said the king, "won't do my German business." 2 On the next day, however, he quoted Lord Hyde as having said, "Pitt is a man that when once he has taken a part, will go through with it, steadily, honourably, and more ably than Fox". 3 The hint was followed up by the king's mistress, Lady Yarmouth, "saying good things of Pitt". Pitt on his side paid his firșt visit to Lady Yarmouth (October 21), and afterwards cemented the alliance with a public eulogy of her virtues in the house of commons. It is probable that he desired to convey a hint to the king that he was not irreconcilable about Hanover, for Newcastle wrote that "the conduct of the war by sea and land was the thing he found fault with". As to coming into the ministry, his final determination, he told Hardwicke, was not to serve with Newcastle. ${ }^{5}$ It was probably at this crisis, in vindication of the resolute stand taken by him, that he exclaimed to his ally, the Duke of Devonshire: "My Lord, I am sure I can save this country, and nobody else can". And yet Pitt's following in the house of commons was reckoned as no more than sixteen, while Newcastle was master of many legions-a striking lesson of the effect of moral force in politics!

With the aid of Granville's good offices, the Duke of

'Newcastle to the Attorney-General (Murray), May 30, 1756: “No ten men can be brought to supply your place," etc. Newcastle Papers, Brit. Mus., Add. MSS., 32,865, f. 143 .

'Same to same, October 14,1756 , ibid., f. 28r. See also Lord Hardwicke to Colonel Yorke, October 3r, r756, Hardwicke Papers, Brit. Mus., Add. MSS., 35,357, f. 66.

${ }^{3}$ Newcastle to the Lord Chancellor, October 15, 1756, Newcastle Papers, Brit. Mus., Add. A!SS., 32,868, f. 306.

"Ibid., f. $3^{80}$. His visit only served to annoy the king. "Mr. Pitt," he exclaimed to the chancellor, "shall not go to that channel any more. She does not meddle and shall not meddle." Lord Hardwicke to Colonel Yorke, October 31, 1756, Hardwicke Papera, Brit. Mus., Add. MSS., 35,357, f. 66.

- Conference with Mr. Pitt, October 24, 1756, ibid., 35,870, f. 263. 
CHAP. Devonshire, lord-lieutenant of Ireland, who enjoyed the goodXXVI. will of all parties, came forward as intermediary. The duke himself undertook the treasury. As first lord of the admiralty Pitt nominated Lord Temple; George Grenville as treasurer of the navy, in place of Dodington, and James Grenville, formerly Prince Frederick's secretary, as a lord of the treasury -all three his own brothers-in-law. But his adherents were too few to fill all the places in the government and several members of the late ministry remained, Granville, the lord president, Halifax at the board of trade, and Lord Barrington, Fox's successor, as secretary at war. By this section the Duke of Bedford, one of Cumberland's party, was nominated lord-lieutenant of Ireland and Charles Yorke, son of the late chancellor, solicitor-general. Upon the point of Holdernesse's secretaryship for the northern department Pitt had to give way. Hanover should not, George was resolved, be abandoned to Pitt's tender mercies. On November I I Newcastle and Fox resigned, Hardwicke a week later. The great seal was put in commission. Seldom has an administration acceded to power with less apparent strength. The house of commons was practically divided between the followers of Newcastle and those of Fox. But to Pitt, who had advised no blunders and been implicated in no miscarriage, the nation in its extremity turned.

The ministry now coming into office presents to the eyes of the student of constitutionalism an example of the transition from a system under which all the ministers were alike servants of the crown to that at which, by a change quite recent, the prime minister has had assigned him a definite place in the constitution. When the great place of lord treasurer, answering most nearly to the modern conception of prime minister, was delegated to a body of commissioners, the head of that body was not, as was seen in the cases of Stanhope and Townshend, necessarily the mainspring of affairs. In the administration of November, 1756, the Duke of Devonshire, chiefly by his rank in the peerage and secondarily as first lord of the treasury, enjoyed a certain official primacy, and George II. may perhaps have contemplated reverting through him to what Fox condemned as "governing without any communication of power to a commoner".1 But outside court circles the recognised

${ }^{1} \mathrm{H}$. Fox to Lord Digby, September, 21, 1756, Digby MSS., p. 220, Hist. MSS. Comm., 1895 . 
head of the government was Pitt. One instance will suffice. In 1758, when Newcastle, the "universal minister" of 1754, was CHAP. again at the head of the treasury, a medal was struck to commemorate the capture of Louisbourg. The legend round the edge was "William Pitt administering". And yet Pitt was no more than secretary for what George regarded as the less important department of foreign affairs. To Holdernesse belonged the whole continent exclusive of Italy, Spain, and Portugal, France being at war. Fortunately for England, Pitt's province included her interests beyond the Atlantic and in India, the value of which his mind had grasped. Moreover, as concert was necessary between the two secretaries, the stronger intellect exercised a natural control over the entire foreign policy, while in case of differences an appeal lay to the king and the cabinet.1

Pitt's study of military affairs had convinced him of the ministerial misconduct of the war, and it was to the management of the war, particularly by sea, that he addressed his energy, and he therefore placed Temple, who would work with him, at the admiralty. As the drama unfolded itself in America and India, the rôle of the navy was increasingly appreciated. A change came over the spirit of English naval officers, whether owing to the inspiration of Pitt or the fate of Byng. On the morrow of Byng's failure, Fox, as secretary for the south, discussed with the Spanish ambassador the possibility of exchanging Gibraltar for Port Mahon. ${ }^{2}$ Newcastle was as resolute in his opposition as he knew how to be. England, he suggested to Fox, had better indemnify herself by taking Corsica from the Genoese, ${ }^{3}$ who had always supported France. "But," he added, "I own my chief dependence is in North America, and to regain Port Mahon by operations there. Conquest in North America is our point." On the other hand, the governor, Lord Tyrawly, reported to Pitt on February 1, 1757, that Gibraltar was a source of expense, as ill-adapted as the Eddystone for the

' For instance, Holdernesse writes to Newcastle that the king has commanded him "to go to him (Pitt) in the country with the Duke of Devonshire . . . to settle the several points of busineas depending in my office ". November 22, 1756, Newcastle Papers, Brit. Mus, Add. MSS., 32,869, f. 120.

Ibid.

s Newcastle to Fox, July 24, r756, ibid., 32,866, f. 265. 
CHAP. repair of a fleet. This consideration obscured its strategic XXVI. value as controlling the straits and interposing an obstacle to the junctions of the two divisions of the French or Spanish fleets. Pitt adopted Tyrawly's view, took no pains to improve its defensiveness, and at this time regarded it as a pawn in the game of negotiation for the restitution of Port Mahon. From the expressions of Newcastle above quoted, it will be seen that the idea of exerting the national energies chiefly in North America was not, as seems sometimes to be supposed, peculiar to Pitt. Newcastle's weakness lay, not in lack of ideas, but in incapacity for sustained purpose, and he would inevitably have succumbed to the pressure of the court in favour of a continental war. Newcastle, as well as Wade and Cumberland, had recognised the usefulness of the highlanders as soldiers. ${ }^{1}$ It was Pitt who extended their employment from the whig clans to those recently in rebellion. In answer to remonstrances by Hardwicke, he said "it would be a drain and not many of them would return ".2 Two battalions, numbering in all 2,000 men, were enlisted for service in America.

Not until February 17, 1757, did Pitt, who had been incapacitated by gout during his ten weeks of office, take his seat as a minister in the house of commons. "It could not fail of being remarked," notes Horace Walpole, "that he dated his administration with a demand of money for Hanover." A message from the king asked for $£ 200,000$ for an "army of observation" to enable him to fulfil his agreement with the King of Prussia, under the convention of Westminster, "for the security of the Empire against the irruption of foreign armies". As the proposal before the house was to carry into effect a treaty made by the previous administration, it met with no opposition from the dependants of Newcastle or the followers of Fox. The militia bill, announced in the king's speech, one of the conditions precedent to Pitt's acceptance of office, was again brought forward by George Townshend. The suspicion was general that it was designed to entrap recruits for the regular army. The tory party, consistently with its

${ }^{1}$ Newcastle to the Duke of Devonshire, January ro, r756, Newcastle Papers, Brit. Mus., Add. MSS., 32,862, f. 58, and see p. 320, n. 2 supra.

2 Hardwicke to Newcastle, December 6, 1756, ibid., 32,869, f. 253. 
attitude since the revolution, vehemently opposed it. In the lords, the opposition succeeded in cutting it down by oneCHAP. half, to 32,000 men for England and Wales, in which form it became law. After the harvest, when the first steps were taken to carry it into force, riots broke out in the counties of Surrey, Kent, Leicester, Hertford, Bedford, Nottingham, and York.

On December 28, 1756, the court-martial on Admiral Byng held its first sitting. It consisted of twelve officers under the presidency of Vice-Admiral Thomas Smith. The main charges were that Byng had not done his utmost to destroy the French fleet, to assist the ships engaged, nor to relieve St. Philip's castle. Upon this third charge a substantial defence could scarcely be made. Upon the other two Byng justified himself by the case of Admiral Mathews : the signal for the line being hoisted, any other course than that taken by him would have increased the disorder of the fleet. This piece of naval pedantry did not commend itself to his judges. By the twelfth of the naval articles of warl "Whoever through cowardice, negligence, or disaffection shall not do his utmost during an engagement shall suffer death". On January 27, 1757, the court acquitted Byng of cowardice or disaffection, but unanimously found that he did not do his utmost " to relieve St. Philip's castle, nor to take, seize, and destroy the French ships and to assist his van". Of negligence it said nothing. In accordance with the twelfth article he was ordered to be shot, but on the ground that his misconduct did not arise from cowardice or disaffection, the court unanimously recommended him to mercy. Public opinion was divided. The mass of the people, the real authors of the overthrow of Newcastle's ministry, were violent against Byng. It is to the credit of Pitt that in what he felt to be justice to Byng he had the courage to withstand both the king and the popular outcry. At a cabinet council on February 26 Pitt told the king that the house of commons wished to have Byng pardoned, but he was met by the memorable retort: "Sir, you have taught me to look for the sense of my subjects in another place than the house of commons". George was deaf to all petitions. He was convinced, as was the majority of the nation,

$$
122 \text { G. II., c. } 33 .
$$

VOL IX. 
CHAP. that an example would have to be made, and certain it is that, had XXVI. Byng's policy of avoiding doubtful engagements been suffered, England's superior naval strength would have been neutralised. On March I 4, upon the quarter-deck of the Monarque in Portsmouth harbour, the admiral intrepidly met his doom.

The formation and equipment of the "army of observation" were taken in hand in February. At the instance of the King of Prussia, who hoped that British troops might serve with him, the post was offered to Cumberland. The duke made his acceptance conditional upon Pitt's dismissal from office. Pitt's influence, both with the king and with the general public, had suffered by his intervention on behalf of Byng. On March 7, the king, since Newcastle had refused to move, invited Fox to form an administration. Not a word was said to Pitt. The first blow was the dismissal of Temple from the admiralty. On April 5 Lord Winchilsea kissed hands for his post. Pitt received his dismissal on the next day, and this was followed by the resignation of Legge and the Grenvilles. Secure of success, Cumberland had on April I started for Germany.

It was enough for the nation that Pitt had been turned out of office to gratify the widely detested Duke of Cumberland. The cities of London, Bath, Worcester, Chester, Exeter, and other places voted him and Legge their freedoms. As Horace Walpole puts it, "for some weeks it rained gold boxes". Pitt, on the other hand, had learnt that he could not maintain himself in office except by a coalition which would enable him to command the house of commons. This consideration pointed imperatively to an alliance with Newcastle, who had apparently taken no steps to supplant him. For nearly three months after the dismissal of Pitt, the country was without a government. Newcastle was "arbiter of England". He hesitated at an alliance with Pitt which would consign himself to insignificance. The king, thereupon, resolved with the help of Fox to form a ministry himself, with Lord Waldegrave as the nominal chief, supported by Holdernesse, Winchilsea, Bedford, Granville, and other friends of Cumberland. Waldegrave declined, and Chesterfield, under the inspiration of Leicester House, undertook to smooth matters between Newcastle and Pitt. The admiralty was the chief difficulty. After some bargaining a compromise was 
arrived at. Anson was nominated first lord, but Pitt was to CHAP. write the instructions to the admirals, to be countersigned XXVI. by three lords of the admiralty. As Hardwicke declined office, Sir Robert Henley, attorney-general, was made lord keeper, and Pitt's friend and schoolfellow, Charles Pratt, promoted to Henley's place. Holdernesse, who had tendered his resignation, was reinstated as northern, while Pitt again received the seals as southern secretary. On June 29 the new ministry kissed hands. It was at a moment of darkened prospects. Five days earlier the news had arrived of the disastrous defeat of Frederick by the Austrians at Kolin in Bohemia. About the same time came tidings of the peril to the British settlements in Bengal and of the atrocity known to history as "the Black Hole of Calcutta". 


\section{CHAPTER XXVII.}

\section{DEFEAT AND VICTORY.}

CHAP. Ali VARDI, the Nawáb of Bengal, having died in April, 1756, XXVII. had been succeeded by his grand-nephew, Suraj-ud-Daulah, a youth of nineteen. The new nawáb, who cherished a hatred to the English, marched upon Calcutta with an army of 50,000 men. The settlement was defended by 264 soldiers, of whom only 174 were Europeans, and 250 residents. Fifteen hundred native matchlock-men were also hired. By the fifth day the nawáb's artillery had rendered the place untenable. The governor, Drake, against whom the nawáb nurtured peculiar resentment, escaped with some others in boats. The rest, to the number of 146 persons, were thrust on the night of June 20 into a room eighteen feet by fourteen with only two small grated windows and those opening on to a covered arcade. The scene that followed has been described by two of the survivors. Suffice it to say that on the following morning only twenty-three were taken out alive, of whom several shortly succumbed. The tragedy of "the Black Hole of Calcutta" added to the public gloom, which since the dismissal of Pitt had again set in. The moment was one of those at which discouragement deepens into panic and panic into despair. Some effort must be made shewing immediate results. Pitt determined upon an attempt on Rochefort under General Sir John Mordaunt. On September 23, 1757, the fleet under Hawke silenced the fort on the isle of Aix and took 600 prisoners and thirty-six guns. But Mordaunt doubted the practicability of an attack on Rochefort and on October 3 the expedition ingloriously returned to Portsmouth. At the end of April Cumberland had concentrated his " army of observation," numbering $40,000 \mathrm{men}$, at Bielefeld in order to cover Han- 
over. Opposed to him was Marshal d'Estrées, at the head of CHAP. an army double in numbers with which on July 24 he attacked XXviI. the duke at Hastenbeck. The result of the action which, had Cumberland been a general of skill, he would have converted into a victory, was his precipitate retreat across the Elbe, abandoning the Electorate to the French.

By the second treaty of Versailles of May I, 1757, France had joined Russia and Austria in the conspiracy for the partition of Prussia, and Russian troops were beginning their march westwards. Their invasion of Prussia would, under the convention of Westminster, compel England to attack them. While relations with Russia and the prospects of alliance with Spain, which Pitt hoped to negotiate by the cession of Gibraltar for Port Mahon, were still uncertain, Cumberland had withdrawn, it is said, at the suggestion of King George, ${ }^{1}$ to the shelter of the guns of the fortress of Stade, where he hoped to receive reinforcements from England. Richelieu, who had superseded d'Estrées, penned him in between the Elbe and the Weser. But he was now met by a diplomatic difficulty. Cumberland was encamped in the duchy of Bremen and by the treaty of June 15-26, 1715, Denmark had guaranteed Bremen and Verden to the Elector of Hanover, undertaking in case of need to enforce its guarantee within six weeks by an army of 8,000 men. Frederick V. had hitherto maintained a scrupulous neutrality. He could now only avoid involving himself in the war by effecting some sort of pacification between the belligerent forces, to which he was urged by his father-in-law, King George. ${ }^{2}$ The mission was confided to Count Lynar, the Danish governor of Oldenburg. The pacification known as the convention of Kloster-Zeven, was concluded on September 8. Its stipulations were that Cumberland, with half the Hanoverians, should retire beyond the Elbe, that the other half should be interned and the rest of the German troops disbanded, and that the French should remain in occupation of the duchies of Bremen and Verden except Stade until the conclusion of peace. On the part of the

'So it is stated in an anonymous contemporary justification of Cumberland in R. O., MS., State Papers, Dom., G. II., bundle 138, no. 22, where it is also said that the duke "thought endeavouring to join the King of Prussia would be much more preferable".

Ibid. 
CHAP. French the convention in the circumstances was afterwards XXVII. justly declared by Napoleon "inexplicable". That it should have been received with an outburst of indignation in England may in part be imputed to Cumberland's unpopularity, since British interests were not directly involved. The king, untruly alleging that Cumberland had no power to conclude it, repudiated the convention, and Richelieu having marched away without waiting to enforce its execution, it remained inoperative. Cumberland, insulted by his father and the object of general censure on the part of a public ignorant of the circumstances, abstained from a defence which would have reflected on the king, and resigned all his appointments. His army of observation was placed under Prince Ferdinand, brother of the Duke of Brunswick-Wolfenbüttel, and a general in the Prussian service.

The exasperation in England at these failures was intense. A court-martial on Mordaunt condemned the project of the expedition, and by Mordaunt's acquittal Pitt sustained a mortifying rebuff. Affairs in America proved no more prosperous than those in Europe. The commander-in-chief, the Earl of Loudoun, abandoned in August a contemplated attempt upon Louisbourg, for which place, however, Vice-Admiral Holburne sailed with twenty ships of the line, intending to challenge the French fleet to an action. After weeks of fruitless cruising the English fleet was caught by a hurricane. One ship was lost on the rocks ; nine were dismasted; others threw their guns overboard. Unable to keep the sea, Holburne sailed for England, arriving on November 8 . All that he had accomplished had been the capture on his outward voyage of five French ships carrying I,000 soldiers. Meanwhile Montcalm attacked Fort William Henry, which guarded the southern end of Lake George. After a siege of five days the garrison capitulated. Despite the exertions of Montcalm, a hideous massacre by the Indians of some hundreds of prisoners, men, women, and children, took place. In the middle of October the news reached England. It was another of a quick succession of disastrous tidings-the Black Hole of Calcutta, the defeats of Kolin and Hastenbeck, the occupation of Ostend and Nieuport by the French, the convention of Kloster-Zeven, the failure of the attempt on Rochefort, the rejection of overtures 
by Spain, the failure and loss before Louisbourg. Only one compensating gain was to be recorded. The news arrived CHAP. on September 3 of the reduction on March 23 by Clive, in concert with Admiral Watson, of the French settlement of Chandernagore on the Hooghley.

Between June and November, constant appeals were made by Frederick to the ministry. Instead of soldiers, Pitt offered him a subsidy. In return for $£ 670,000$, to be expended in the common cause, Prussia agreed that neither ally should conclude peace with either of the belligerents separately. George undertook to maintain 5,000 men as elector and 50,000 at the expense of England. The financial burden thus put upon England, in addition to the subsidy, was $£ 1,800, \infty 00$. Great as this was, it was voted by the commons with but one dissentient voice on April 20. The "army of observation" was to be converted, as Pitt said, into an army of operation. There being no more hope of seeing a British army attached to his own, Frederick suggested that useful diversions might be made upon the French coasts. Pitt gladly adopted a means of proving that England was not a useless ally. In May, I758, an armament was concentrated in the Isle of Wight of 14,000 soldiers and 6,000 marines with fifteen ships of the line and some frigates. To clear the Channel, Hawke, with twenty ships of the line, cruised before Brest. The land forces were placed under the command of the Duke of Marlborough, a popular officer though without talent. The late chief secretary for Ireland, Lord George Sackville, was next in rank. Commodore Howe directed the transports, an appointment which led to the temporary resignation of Hawke. Pitt thereupon offered the command of the sea-going fleet to Anson, under whom Hawke consented to serve. The expedition anchored on June 5 in the bay of Cancale, near St. Malo, and after pillaging that village and attempting Cherbourg returned on July I to St. Helen's Bay, in the east of the Isle of Wight.

The lesson learnt from the failures of Rochefort and St. Malo, contrasted with the brilliant victory over the French gained by Prince Ferdinand at Krefeld on June 23, produced an effect on public opinion which Pitt could not ignore. Even Leicester House was persuaded, as Bute wrote, that at last " the 
CHAP. most peevish person will be brought to assent to the assistXXVII. ance of Prince Ferdinand's army". Pitt consented to dispatch I0,000 men to Germany. The Duke of Marlborough and Lord George Sackville at once asked for commands, Lord George roundly refusing to "go a-buccaneering again". Marlborough was nominated to the chief command, Sackville being next in rank. They disembarked at Emden with 8,500 men and joined Ferdinand on August I5. For a second Cherbourg expedition, General Bligh, commander-in-chief in Ireland, was nominated. The fleet arrived before Cherbourg on August 7, and found that the French had profited by the interval to throw up earthworks held by some 3,000 men. But the numbers of the British were overwhelming, the forts were weak, ${ }^{1}$ and the town was taken with little resistance. Considerable stores and many guns were captured. The harbour-basin and forts at Cherbourg were demolished, and after a few trivial skirmishes the troops re-embarked and landed at Portland. This success prompted a renewal of the attempt upon St. Malo, which was repulsed at St. Cast with a loss of I,000 British killed or wounded on September I I. These expeditions kept France in alarm and prevented her from using her full strength against Frederick.

Pitt's main object was America, and for the campaign there of 1758 he had a threefold plan. Firstly, a fleet was to cooperate with a land force in the capture of Louisbourg as a preliminary to that of Quebec; secondly, an expedition was to attack Canada from the south, and, thirdly, the French communications were to be severed by the reduction of Fort Duquesne on the Ohio. For the first enterprise he selected General Jeffery Amherst, who had seen much service in Germany, with Brigadier James Wolfe as second in command; General James Abercromby, next in rank to Loudoun, who was recalled, was appointed is lead the second, and the third was committed to Brigadier Iohn Forbes, a regular officer popular with the colonial troops Boscawen in command of the fleet was to be ready to leave England in February, and Halifax was to be the rendezvous. To anticipate the dispatch of reinforcements to Louisbourg, Admiral Sir Charles

${ }^{3}$ Narrative of the second attack on Cherbourg, Stopford-Sackville MSS., i., $293-96$. 
Hardy sailed early in January with orders to blockade the harbour. On February 28 Admiral Osborn off Carthagena CHAP. dispersed and captured three French ships which had sailed from Toulon to reinforce the fleet under Admiral de La Clue destined for America, then lying in Carthagena harbour. Another squadron of seven ships of the line and three frigates under Hawke on April 4 attacked a fleet of transports fitted out for Louisbourg in Rochefort harbour, driving them ashore or rendering them unserviceable.

Boscawen's force consisted of twenty-three ships of the line, eighteen frigates and fire-ships, as well as transports with I 1,600 regulars and 500 provincial rangers. Louisbourg was defended by fewer than 4,000 French regular troops besides militia and Indians. The attacking force had been swollen by reinforcements from New England to a nominal 15,000 men much enfeebled by scurvy and want of fresh meat. ${ }^{1}$ Two feigned attacks were made near the town; but the actual disembarkation was about a third of a mile to the westward, under the orders of Brigadier Wolfe. This officer, now thirtyone years old, was one of the few, as he himself tells us, who regarded his profession as a serious business. His conduct at Laffeldt had won him the personal thanks of the Duke of Cumberland, and at twenty-two he was lieutenant-colonel of the 2oth foot. His eagerness to attack Rochefort attracted the notice of Hawke who commended him to the king. "Mad, is he?" said George to Newcastle, "then I hope he will bite some others of my generals." The siege was pressed without intermission, and on July 27 the garrison surrendered as prisoners of war. The key of Canada was in British hands.

Abercromby for his attack on Canada by way of Lake Champlain had collected an army of over 1 5,000 men, of whom 6,000 were regular and 9,000 provincial troops. Amply provided with boats by the foresight of Pitt, he embarked on Lake feorge on July 5 for the capture of Ticonderoga, a strong fort at the junction of the two lakes, with a garrison of 3,600 men. Without waiting for his artillery, which had been landed and would have swept away the newly constructed

1 Wolfe to Lord G. Sackville, Halifax, February $11,175^{8}$, Hist. MSS. Comm., 9th Rep., App., p. 75. 
CHAP. abatis, he threw his troops against the fort. From noon XXVII. till nightfall successive assaults were repulsed, I,944 being killed and wounded on the British side, while the garrison lost no more than 377. With so superior a force as Abercromby had, and with the assistance of artillery, it would have been easy to retrieve the defeat. But the general lost his head. On the following day, the 9 th, he ordered a retreat and the combination of Pitt for the conquest of Canada was shattered. The one success of Abercromby's campaign was achieved by a New England officer, Bradstreet, who with a force of 3,000 men, nearly all provincials, took the important French post of Fort Frontenac on August 26. The last of the three campaigns by Pitt for this year, that against Fort Duquesne, was greatly forwarded by Bradstreet's success. At Fort Frontenac Bradstreet found the stores intended for Fort Duquesne, and by his capture there of nine armed vessels, the French naval force on Lake Ontario, he deprived the enemy of the means of reinforcing its garrison. The occupation by Forbes of Fort Duquesne, which was replaced in the following year by a newly constructed Fort Pitt, transferred "the key of the great west" to British hands, and by robbing the French of their prestige, insured the frontier population against the continuance of Indian attacks.

After prolonged depression in England, broken in June by the news of the capture of Fort Louis on the Senegal, a reaction of enthusiasm set in when in the middle of August the surrenders of Louisbourg and Cherbourg became known. When parliament opened on November 23 it found Pitt in a position of supremacy never reached even by Walpole. He was free to carry out his plans on a grand scale, confident in the resources of his country and of the approaching exhaustion of France. The total sums voted rose from $£ 10,486,000$ to $£ 12,749,000$, of which $£ \mathrm{I} c, 000,000$ was for the war. ${ }^{1}$ Pitt's ascendancy, enforced as it was by his autocratic bearing, began to provoke the jealousy of his colleagues. On the other hand, the tories, having neither leader nor hopes of office, rallied to his support. Prominent in their ranks was Alderman William Beckford, a Jamaica planter of inmense wealth, member for the city of London. Beckford urged a naval expedition against the ${ }^{1}$ Sinclair, Hist. of the Revenue (3rd ed, I803), ii., 76. 
French colonies in the West Indies, especially the two queens of the Antilles, Martinique and Guadeloupe. In October, the CHAP. force which had lately suffered the disaster at St. Cast was ordered by Pitt upon this service. Six battalions of infantry, 800 marines, and some artillery were placed under the command of General Hopson, a veteran officer of infirm health. The descent on Martinique was repulsed, but after several months of fighting Guadeloupe surrendered on May I, $1759 .^{1}$ France had, at last, become alarmed by the situation across the Atlantic and by the destruction of its colonial trade.

To Choiseul, leader of the war party, who had displaced Bernis as foreign minister, there remained but one chance of dealing the enemy a mortal blow. He determined to carry into effect the former project of Marshal Belleisle for an invasion of England. The mere threat, it was thought, would starve supplies and reinforcements to the British in Canada. At the - beginning of 1759 , flat-bottomed boats, each to carry 300 to 500 men, were built at Havre, Brest, Rochefort, and Dunkirk for the conveyance of 50,000 troops. Another expedition was to land 12,000 men in Scotland. Squadrons were fitted out at Toulon and Brest for the protection of the transports. Pitt did not finch. He resolved to brave risk at home rather than to incur the sacrifice of his successes abroad. He hastened naval preparations to reinforce our troops in India and Canada, while blockading the French fleets in harbour. On February 17 fifteen ships of the line and ten frigates sailed under Admiral Charles Saunders for the St. Lawrence. To Boscawen was assigned the task of blockading Toulon with fourteen ships of the line, to prevent the junction of the fleet under Admiral de La Clue, lying in that harbour, with the fleet at Brest. The Brest fleet was to be watched by Hawke, who was given the command of the western fleet of twenty-four ships of the line with Torbay as their base. Hawke arranged

'Great discrepancies exist as to the circumstances of the abandonment of the descent on Martinique. Cf. General Hopson's dispatch in Pitt's Correspondence with Colonial Govermors (1906), ii., 20; Entick, Hist. of the Late War (1763), iv., 144: "Candid Reflections on the Expedition to Martinico," by J. J., a lieutenant in the navy, Gent. Mag., 2759, p. 206, and Ruville, William Pitt (1905), ii., 259, n. (Engl. transl., ii., 235, 236). This last version, which is from a French source, differs from the others and is not in accord with the account accepted by $M$. R. Waddington in his Guerre de Sept Ans, iii., 355 . 
CHAP. a chain of frigates jwhich swept the Channel, ready to report XXVII. any egress from Brest. A few first-raters guarded the mouth of the Thames. Means were even found for the dispatch to Bombay in May of four ships of the line under Rear-Admiral Cornish as convoy for the East India merchantmen and reinforcement for Vice-Admiral Pocock.

Preparations were complete, yet still invasion tarried, and Anson advised Pitt to anticipate it by offensive movements. At the beginning of July Rear-Admiral George Brydges Rodney, with a squadron of four fifty-gun ships, five frigates, and six bomb vessels, bombarded Havre, where a large number of the flat-bottomed boats were assembled, but met with doubtful success. The first blow to the hope of invasion was dealt by Boscawen. La Clue's fleet of ten of the line and two fifties escaped from Toulon on August 1 7. Pursued by Boscawen, the rearmost was destroyed, and $\mathrm{La}$ Clue, with four ships, made for the waters of Lagos Bay where, in violation of the neutrality of Portugal, two of them were captured and two destroyed. Five which ran into Cadiz harbour were blockaded by a detached squadron under Vice-Admiral Brodrick; only two in all escaped to the open sea. This disaster destroyed the hope of a successful invasion of England upon a grand scale, though Choiseul still projected an invasion of Scotland with I 5,000 or 20,000 men and of a minor attempt upon Ireland.

The confidence felt in Prince Ferdinand's military capacity relieved the king and ministry from a sense of responsibility for the movements of the British contingent of his army. 1 But there were irritating bickerings about relative rank. Upon the death of Marlborough on October 20, I 758, his command was transferred to Lord George Sackville. Defeated at Bergen in April, Ferdinand had cautiously retired before the French armies. But when on July 9, I759, the French occupied Minden, no course remained, if Hanover were to be saved, but to risk an engagement. Ferdinand's force numbered 52,000, of whom 10,000 were British; that of the French, including Broglie's corps which joined Contades just as the allies appeared on the scene, ${ }^{2} 62,000$ men "in a position too strong to

${ }^{1}$ Lord Holdernesse to Lord George Sackville, July 3, I759, StopfordSackville MSS., p. 56.

${ }^{2}$ Lord George Sackville to Lord Holdernesse, Oberstadt, July 18, 1759, Brit. Mus., Add. MSS., 35,893, f. 208. 
be forced" to the south of Minden, with their right resting upon the river Weser, their left protected by a morass, and a chain of CHAP. hills in their rear. To dislodge them, Ferdinand dispatched the hereditary Prince of Brunswick with 7,000 men to cut the enemy's communications, and on the 3 I st learnt that the prince was behind the French rear-guard. Contades was forced either to attack Ferdinand or to retreat towards his base at Cassel. $\mathrm{He}$ decided for attack and in the early morning his army advanced on to the plain before Minden. Ferdinand, adroitly invited the direction of the French assault. He had thrown forward his left wing under General Wangenheim, posting it in an intrenched camp at Todtenhausen, three miles from the main body of the army, from which position he could observe the French movements. ${ }^{1}$ The plan of Contades, as Ferdinand had anticipated, was to detach Broglie with a force sufficient to crush Wangenheim, to thrust his cavalry into the gap, and turn the left centre of the allies. Early on August I, Ferdinand had moved his troops to the support of Wangenheim, ${ }^{2}$ and when the morning mist lifted, Broglie saw the main army marching to its positions in front of him.

The allies by taking the offensive disconcerted the plans of Contades. The Hanoverian general, Spörcken, advanced at the head of the six English battalions-the I 2th, 20th, 23rd, 25th, 37 th and 51 st of the line, which still bear "Minden" on their colours, followed by three of Hanoverians. Marching steadily in two lines some 12,000 yards across the plain, they were swept by a cross-fire of thirty-six cannon on the one, and thirty on the other flank. Yet without even "paying the compliment of forming squares, " as a French writer complains, they received the charges of three successive lines of French cavalry, numbering 7,560 sabres, with a fire at twenty-five yards' distance which turned the enemy into a mass of fugitives. As the infantry were first about to advance ${ }^{3}$ Ferdinand dispatched a German

1 This circumstance is overlooked by historians who insist on the boldness of the manceuvre. See "Estorp's Narrative" in Hardwicke Papers, Brit. Mus., Add. MSS., 35,893, f. 210.

' See R. Waddington, Ln Guerre de Sept Aus, iii., 53.

" "To sustain the infantry which was going to be engaged," is the evidence of Captain Winschingrode, the first aide-de-camp dispatched, taken before the court-martial. The Trial of Lord George Sackville, p. 11. Nevertheless, Stanhope, followed by all other writers I have consulted, represents the first order to have been sent after the first repulse of the French cavalry. 
CHAP. aide-de-camp to Lord George Sackville, who commanded fourXXVII. teen British and ten Hanoverian squadrons of cavalry on his right wing, numbering 3,330 sabres, to move "the cavalry" forward towards the left in support. Sackville professed not to understand the orders and, though they were subsequently repeated by two British aides-de-camp, remained motionless. The delay enabled the French army, which in military opinion might have been pulverised, ${ }^{1}$ to make good its retreat through the inclosures of Minden where cavalry were useless. The French, however, lost over 7,000 killed, wounded, and prisoners, besides forty-three guns and seventeen colours. Of the allied loss of 2,600 the British infantry sustained one-half.

Minden was a victory of the "thin red line" of the English infantry. The inaction of Lord George Sackville during the struggle of the English infantry, notwithstanding that, as Prince Ferdinand reminded him, ${ }^{2}$ he was commander-in-chief of the whole British contingent, is one of the mysteries of history. Sackville had been wounded at Fontenoy where, according to the Duke of Cumberland, no lenient judge, he had "shewn his courage". ${ }^{3}$ The simplest explanation of his conduct is probably the truest, that he was a man whose courage fluctuated and on this occasion failed him altogether, his initial indisposition to act being strengthened by dislike of Ferdinand and reliance on his own influence with Leicester House to protect him against complaints. Ferdinand behaved with selfrestraint ; but in his general orders thanking the troops omitted Sackville's name, while he paid a compliment to the Marquis of Granby who led the second line. ${ }^{4}$ He wrote to King George requesting Sackville's recall. ${ }^{5}$ The king, however, who had in the first instance objected to the appointment of Sackville, had already acted, and a dispatch from Holdernesse ${ }^{6}$ crossed Ferdinand's letter. Meanwhile, London had blazed with bonfires and Granby had become "the mob's hero". As for Sackville, Horace Walpole tells us, "Admiral Byng was not more

1 So also Waddington, Guerre de Sept Ans, iii., 60.

2 Prince Ferdinand to Lord George Sackville, Minden, August 3, 1759, Stopford-Sackville MSS., p. 313 .

${ }^{3}$ De La Warre MSS., p. 282, Hist. MSS. Comm., 4th Rep., App.

- Hardwicke Papers, Brit. Mus, Add. MSS., 35,893, f. 216.

'August 13, 1759, ibid., f. 227.r.

'August 14, 1759, Hist. MSS. Comm., 3rd Rep., Appo, p. 134: 
unpopular". At his request a court-martial was promised, and in the meantime he published an Address to the English Public CHAP. asking for a suspension of judgement. The charge against him was disobedience to orders. He defended himself with ability, but was overbearing to the witnesses and dictatorial to the court. On April 5, 1760, he was found guilty and declared "unfit to serve His Majesty in any military capacity whatever".

At the close of the year I 758 Pitt was energetically making preparations for a fresh campaign in America. There were to be two lines of attack on Canada; the main one under Admiral Saunders and Wolfe, now a major-general, against Quebec by way of the St. Lawrence, the other along the route prescribed to Abercromby against Quebec or Montreal, entrusted to Amherst. In contrast with the unity of direction given to operations by Pitt were the personal rivalries distracting the cabinet of Versailles. After an interesting sketch of its component personalities, Newcastle's spy summarises the outcome of their "intrigues and cabals". "What is resolved one day," he reports, "is changed the next." But the dominant influence remained with Madame de Pompadour and her pro-Austrian continental policy, artfully stimulated by the empress-queen, who continued to write "her such letters as are suited to flatter her pride and vanity".1 For Canada France could spare no more than three or four hundred recruits and sixty engineers and gunners, with supplies sufficient for a campaign. These, in seventeen vessels convoyed by three frigates, reached Quebec in May.

On June 26th, 1759, after a three weeks' passage up the river, the English fleet cast anchor off the isle of Orleans, opposite the village of Beauport, an outlying defence below Quebec. It consisted of twenty-two ships of the line, thirteen frigates, and numerous transports and river craft. The troops on board numbered 8,635 men. On the other side was a force numerically superior, behind intrenchments singularly aided by nature. About Quebec the bank of the river was precipitous, while below, earthworks had been thrown up from the falls of the Montmorency, almost opposite the British warships, to the river St. Charles near the city. The defenders in all consisted

1 Versailles, February zo, 1760, Neweastle Papers, Brit. Mus., Add. MSS., 32,902, f. 290. 
CHAP. of 1 5,000 men, ${ }^{1}$ of whom 5,000 were regulars and the rest XXVII. colonial militia. To these may be added a varying crowd of auxiliary Indians, of doubtful value in actual warfare, perhaps on the average 1,000 in number. Despite his superiority in numbers, the policy of Montcalm was to act on the defensive. While the command of the sea and the river would enable the British to make good their losses, it would prevent the approach of succour to the French. If the defence were protracted, the autumn rains and the winter frosts would do their work, and the colony be freed by the forces of nature from Admiral Saunders as it had been from Admiral Walker in I7II. No resistance was, therefore, offered to the occupation of favourable positions by Wolfe.

After several abortive engagements, Wolfe on August 5 dispatched Brigadier Murray with I,200 men in boats up the river to embark on the ships of Admiral Holmes, second in command to Saunders, whose squadron lay above the town. This manœuvre contributed largely to his eventual success. Montcalm's second in command, Bougainville, with 1,500 troops was detached from the main force at Beauport to watch Murray's movements. Murray's troops were comfortably housed on the ships of Admiral Holmes, which were allowed to float up and down with the tide. This involved an incessant marching and countermarching on the part of Bougainville's force which exhausted their energies, while it did not prevent occasional raids. Wolfe's feeble constitution, however, began to succumb before disappointment and anxiety. Autumn was approaching; the admirals were anxious to be out of the river before the equinoctial gales; the success of the expedition appeared to be becoming daily more remote. On the 29th Wolfe, then rallying from illness, addressed a letter to his three brigadiers, Monckton, George Townshend, and Murray, suggesting an assault on Quebec by one of three routes, all of them from the side of Beauport. The brigadiers proposed instead an attack above the town, which would cut off Montcalm from supplies by way of Montreal as well as from communication with the French forces opposed to Amherst, who was

'At the time of Wolfe's arrival about 11,500 , reinforced during the campaign by Canadian volunteers. R. Waddington, La Guerre de Sept Ans, iii., 274, 3 ro. 
believed to be advancing. Wolfe determined to adopt their plan in principle, but he reserved to himself a discretion as to CHAP. details which improved its effectiveness. They had recommended a landing-place on the north shore twelve miles above Quebec. There he would have at once encountered the detachment of Bougainville, a conflict with which would have weakened his chances of forcing his way into Quebec.1 He reconnoitred the north shore himself, rejected the landing-place of the brigadiers, and fixed upon Foulon, a steep hill about a mile and a half from the town.

On September 3 Wolfe evacuated his camp on the Montmorency and transported his troops to Pointe Levis and the Isle of Orleans. Four days later four thousand of them had been secretly embarked on Admiral Holmes's ships. On the night of the 1 2 th while Wolfe was preparing the real attack, Saunders lying in the Basin of Quebec, directed a fierce bombardment against Beauport, below the city, and threatened a landing. Montcalm massed his troops there to meet him. Holmes's squadron sailed towards Pointe aux Trembles to draw Bougainville westward. The device was successful and distracted the attention of the French. As Wolfe's procession of boats in the early morning of the I $3^{\text {th }}$ moved silently down the St. Lawrence, the general relieved the tension of his mind by reciting in a low voice to the officers around him Gray's Elegy in a Country Churchyard. "I would rather," he ended, "be the author of that poem than take Quebec." The rapidity of the tide carried the boats to a steep ascent below the intended landing-place. ${ }^{2}$ Here they found no sentries. Twenty-four volunteers who led the way scaled the heights and surprised the small post at the top of the path from the intended landing-place who had preferred their tents to sentry-duty. The

This point is of importance in view of the controversy which has arisen as to whom the capture of Quebec was to be credited. While Stanhope has wrongly attributed "the honour of that first thought to Wolfe alone," Warburton, Conguest of Canada (p. 322), followed by Lieutenant-Colonel Townshend, Mili: lary Life of the First Marquess, speaks of "the remarkable plan which Wolfe unteservedly adopted ". "The Correspondence between Wolfe and his Brigadiers," published by Doughty (Siege of Quebec, vi., 59,60), justifies the apportionment of the credit adopted in the text. See further Brigadier Murray's criticism of Wolfe in Townshend MSS., p. 316, Hist. MSS. Comm., Inth Rep., App., pt. iv.

-General Townshend to W. Pitt, September 20, 1759, ibid., p. 324, Hist. MSS. Comm., Ith Rep., App., pl. iv.

VOL. IX. 
CHAP. rest of the troops as they landed rapidly followed. Wolfe drew XXVII. up his men in two lines facing towards Quebec. Monckton commanded on the right; Wolfe himself was in the centre, and on his left Murray. The total force which landed was about 4,000 men, but as the third battalion of Royal Americans, afterwards the 6oth Rifles, were posted to guard the landing-place and parties of light infantry were detached for other duties, the total fighting line was reduced to about 3,100 .

A little before 9 A.M. on September I 3 th the two armies advanced towards each other. The French were formed in a single long line opposite the British, five regiments of regulars in the centre, with colonial militia at the wings, their numbers variously estimated at from 3,500 to 7,520 men. Both generals, Montcalm on horseback, passed down the front of their troops. The French rushed in some disorder down the slope on the ridge of which they were posted, firing as they advanced. No reply was made until they were within thirty yards. The British then delivered a volley with such deliberation and precision that the French recoiled. Before they could recover, a second volley followed, and they broke and fled, pursued by the British bayonets. At the moment of ordering the charge, Wolfe, already twice wounded, was struck by a bullet in the breast and sank to the ground. He was told that the French were running. "Now," said he, with a smile, "I die contented," and so died.1 Soon after his fall Monckton was severely wounded. The British troops continued their advance until arrested by the French artillery fire from the ramparts. Townshend, who had succeeded to the command, had scarcely ${ }^{2}$ reformed his battalions, which had been disordered by the pursuit, when Bougainville with 900 troops appeared in their rear, coming from Cap Rouge, but did not venture an attack. Townshend then intrenched his position, which was at once supplied by Saunders with a number of twenty-four pounders.

Montcalm was mortally wounded and died on the following morning. V'audreuil, the governor-general, abandoned his camp at Beauport in disorderly flight and on the 17 th De Ramsay, the commandant of the city, capitulated. On the

${ }^{1}$ See a discussion of his last words in Doughty's Siege of Quebec, iii., 208-16.

2 Notes dated September 13 in Townshend MSS., p. 323 ; also General Townshend to Pitt, September 20, r759, ibid., p. 325. 
afternoon of the next day Townshend' took possession of Quebec. The victory of Wolfe was a successful "forlorn CHAP. XXVII. hope," only rendered possible by the steadiness of the British infantry and by the co-operation of the fleet, which distracted and misled the enemy. The news reached London on October 16. Two days earlier had arrived a despondent dispatch from Wolfe dated September 2, which the government had ordered to be published in the Gazette, as if to prepare the public mind for a disappointment. In the same Gasette appeared the announcement of success. Horace Walpole has described in graphic phrase the swift vicissitudes of feeling. "They" (the people) "despaired-they triumphed-and they wept-for Wolfe had fallen in the hour of victory." On December $2 \mathrm{I}$ the house of commons voted a monument in Westminster Abbey to the general who in one campaign had acquired a continent for the British crown.

During the winter of 1758-59 Amherst, the commander-inchief in North America, made New York his headquarters and his correspondence with Pitt proves the diligence of his preparations. His first step was, in conformity with Pitt's instructions, to provide for the reduction of Fort Niagara and thereby to secure the control of Lake Ontario. On July 24, the fort surrendered to a detachment under General Prideaux. Its capture, as Pitt had foreseen, left the French interior posts in helpless isolation. Amherst, with an army composed of regulars and provincials, about $I I, 000$ in number, embarked on Lake George on July 21 ; he occupied Ticonderoga and Crown Point, but finding his advance impeded by the storms of October, he retreated to Crown Point and occupied himself in the reconstruction of its defences.

Saunders left Quebec soon after the middle of October, 1759. As he lay becalmed in the entrance of the Channel on November 18, news was brought him that Hawke had put to sea from Torbay four days before in search of the

1 A literary controversy arose in 1760 as to the share of Townshend in the victory, the merit of which was injudiciously claimed for him by his friends, and he was attacked in a pamphlet entitled A Letter to an Honourable Brigadier General. This elicited a reply from "An officer," by some supposed to ha ve been "Junius ". Townshend's own dispatches raise no undue claims, but it was known that he had been guilty of eatirieal reflexion on his commander which had been resented by Wolfe. 
CHAP. French fleet, which was reported to have sailed out of Brest. XXVII. He at once ordered the transports he was convoying to make the best of their way to Portsmouth, and himself in the Vanguard (64) with General Townshend on board, accompanied by the Devonshire (64), put about to join Hawke, whose fleet was said to be numerically inferior to the French. But before Saunders could come up with him Hawke had achieved a victory which the American naval historian, Captain Mahan, describes as "the Trafalgar of this war". Notwithstanding the destruction of La Clue's Toulon fleet by Boscawen in August, the French preparations for invasion had been kept on foot, though Scotland was substituted as the main objective, with a diversion upon the coast of Ireland. But the persistence and method of Hawke's blockade of the French coast, "a revolution in naval strategy," had made egress from Brest impossible. In the first week of November came a westerly gale so severe that Hawke, unable to keep the sea, put into Torbay. The favourable direction of the wind and the absence of the English fleet enabled the French squadron under Bompart, on its way home after the failure of an attempt to relieve Guadeloupe, to make Brest.

The French admiral commanding-in-chief, the Marshal de Conflans, thus reinforced, judged the occasion opportune to slip out of Brest, pick up I 8,000 troops concentrated at the Morbihan and transport them to Scotland. Accordingly, he sailed southwards ${ }^{1}$ on November 14, and at daybreak of the 2oth came in sight of a small squadron of four fifty-gun ships and four frigates under Commodore Robert Duff, cruising off the Morbihan coast. Duff was being chased by the French, when Hawke's fleet suddenly appeared to windward, numbering twenty-three sail of the line as against twenty-one of the

1 Captain Mahan's statement (Influence of Sea Power upon History, 5th ed., p. 300 ) that, as the outcome of a controversy between the French admiral and the French minister of marine, the admiral was ordered to bring the English to an engagement and thereby clear the Channel for the transports is, as he acknowledges, scarcely to be reconciled with the admiral's "subsequent course". The explanation of the direction taken by Conflans to the Morbihan given by M. Henri Martin (Histoire de France, $x v ., j 46$ ) is that he went there to pick up the troops, which had been concentrated there by the Duke d'Aiguillon instead of at Brest because of the friction between the two commanders. This explanation is consistent with Conflans' movements. M. R. Waddington (La Guerre de Sept Ans, iii., 369) follows Martin. 
French. Conflans determined to lure the English fleet into Quiberon Bay and there to take up the windward position so CHAP. as to expose them to the risk of being driven on to the reefs and shoals nearer the shore by the westerly gale fast rising to a tempest. Hawke, to his surprise, ${ }^{1}$ did not finch from the risk. Before the French fleet could take up its position, Hawke caught up the rearmost ships and closed with them, "under conditions of exceptional interest and grandeur from the gale of wind, the heavy sea, the lee shore, the headlong speed, shortened canvas, and the great number of ships engaged ".2 Five French ships were taken or sunk, seven threw their guns and stores overboard and ran up the Vilaine, where four of them broke their backs. Nine escaped southwards, some to Rochefort, some to the Loire where they were blockaded. The English lost but two ships, which ran upon a shoal. Choiseul's plan for the invasion of England was at an end. In one year England had added to its navy twenty-seven French ships of the line and thirty-one French frigates. At sea she was now supreme. For the greatest naval victory since the Armada Hawke received the thanks of the house of commons on January 28 , I 760 , and a pension of $£ 2,000$ a year for the lives of himself and his two sons. That his reward was not more munificent was attributed to personal dislike on the part of Pitt and Anson.

The subsidiary expedition planned by Choiseul, a descent upon Ireland to divide the British forces, suffered still more complete destruction. With three ships and 600 men. Thurot, an experienced and enterprising officer, landed on February 21 , 1760, at Carrickfergus, a little town with ruinous walls. The garrison, four companies of the 62nd regiment, short of powder and provisions, surrendered after a brief resistance. Upon news that the Duke of Bedford with a considerable force was advancing against him, Thurot re-embarked with his booty and a few prisoners on the 26th. It happened that Captain Elliot, with three frigates had sought shelter from the weather at Kinsale. He at once put to sea, found Thurot on the 28th, and after a fight of an hour and a half captured the three

'See Conflans' dispatch, La Guerre de Sept Ans., iii., 370.

'Captain A. T. Mahan, The Infuence of Sea Power upon History, 5th ed, p. 303. 
CHAP. French ships, Thurot being killed in the action. This victory XXVII. was the complement of Quiberon Bay and the extinction of the last hope of Choiseul.

This year 1759, "the great year" as it was called, was the zenith of Pitt's career, and of his genius the fruit. His ardent prosecution of military studies in youth had not been thrown away. He had created a British welt-politik. He did not need to ask, like Newcastle, where Annapolis was, nor to learn, in a flurry of amazement, that Cape Breton was an island. Where he had exercised unfettered discretion, as in his selection of Amherst, Wolfe, and Saunders, his judgement of men had not erred. He had planned the campaigns, organised the co-operation of the services, supervised the provision of equipment, and given their orders to generals, admirals, and ambassadors alike. Above all, he had inspired them with his own heroic soul. There was no place under Pitt for a Rooke or a Byng. "Nobody," said Colonel Isaac Barré of him, "ever entered his closet who did not come out of it a braver man." $\mathrm{His}$ ministry was an autocracy of genius. "The great commoner," as he was called, "was the first Englishman of his time, and he had made England the first country in the world." In this hour of triumph, though his resolution was, as Horace Walpole expresses it, to lay France "on her back," he was forced once more to listen to overtures for peace. Charles III., the new King of Spain, late of Naples, ordered his ambassador D'Abreu to declare that he could not regard with indifference the disturbance by English conquests of the equilibrium adjusted in America by the peace of Utrecht. Language of this sort was thrown away on Pitt. On December 13 he intimated in polite phrases that as he had respected Spain's neutrality, Spain had no concern with England's victories in America.

The unprecedented sum of $£$ I 2,761,000 1 had been raised for 1759. The forces in the service of Great Britain had numbered 91,000 . In 1760 , it was Pitt's intention that, including 18,000 militia, I 75,000 men should be receiving British pay, while the supplies granted during the session of I 759-60 rose to $£ I 5,500,000$. This budget, which no other minister could have carried, was voted with unanimity. Pitt's profusion was, indeed, a calculated profusion. "Our distress," 
wrote the spy from Versailles on February I, I 760 , " has daily increased for some months past and it is next to impossible to CHAP. find out the funds to carry on the war another year." 1 Upon this theme, as justifying lavish expenditure, Pitt enlarged to the house of commons. France, he declared, was "more like a dying than a living monarchy". On its side the French government had taken the opportunity of Lord Howe's presence in France to arrange an exchange of prisaners, to entrust him with a memorandum dated November 30, 1759, proposing secret negotiations. It was an attempt to entrap an English ministry into a second "Mat's peace". But Pitt had already given proof of his intention not to desert his ally, now in extreme straits. He had assured Frederick through Mitchell, the British ambassador, "No peace of Utrecht will again stain the annals of England". Five days prior to the memorandum addressed to Howe, Pitt had, in conjunction with Knyphausen, issued a declaration to the representatives of the belligerent powers at the Hague, announcing the readiness of the Kings of England and Prussia to send plenipotentiaries to a congress. Choiseul, nevertheless, renewed his proposals in various forms, but with the same result, and during the first five months of I 760 a succession of futile efforts was made to overcome the firmness of Pitt.

Early in May negotiations were broken off and resort was once more had to arms, the French putting 140,000 men into the field and the allies, with the British contingent of 32,000 under Lord Granby, numbering 92,000 in all. ${ }^{2}$ In this disparity of force Ferdinand was condemned to a generally defensive policy. He suffered a defeat at Korbach on July I 0 , 1760 , when the British artillery of the right wing was captured, ${ }^{3}$ but sixty days later the hereditary prince surprised a French brigade at Emsdorf, taking 2,600 prisoners and eight cannon. The hero of this affair was George Augustus Eliott, afterwards better known as Lord Heathfield, who commanded a regiment of light dragoons (now I 5 th hussars) raised in England in no. 136 .

'Brit. Mus., Add. MSS., 32,902, f. 11 ; see also R. O., MS., "German States,"

2 Probably on paper, but see an official letter from Newcastle to Granby, June 15, 1760, Rutland MSS., ii, 216, Hist. MSS. Comm., 1891. A letter of Newcastle, dated May 6, anticipates that the number will be 95,000. Ibid., p. 209.

${ }^{3}$ Granby to Ligonier, July 14,1760 , ibid., P. 219. 
CHAP. 1759 in imitation of the Prussian hussars. The battle of XXVII. Warburg, fought on July 3I, was largely a British battle, decided by a charge of the heavy cavalry under Granby, which resulted in the French being driven across the Diemel with a loss of I,500 men and ten guns. Nevertheless, the allies were unable to do more than maintain themselves in the field, a not inconsiderable achievement in view of their numerical weakness, and of importance as contributing to the increasing exhaustion of France. Further east, the campaign of I 760 continued the series of Prussian misfortunes, until Frederick's victories at Liegnitz on August 15 and at Torgau on November 3, relieved him for a while from the pressure of the Russians and Austrians. But nine days before Torgau, George II. had died, and the power of Frederick's constant ally, Pitt, was already beginning to wane.

During the winter of $1759-60$ Pitt renewed preparations for the next American campaign with the energy he had displayed twelve months before. To Amherst was assigned the attack on Montreal, the operations being left to his own judgement. The French at Montreal were conscious that the next campaign would decide the fate of Canada. The British garrison of Quebec was, they well knew, in evil plight. By April, 1760, when the winter was breaking, the 6,400 men who had been left under General Murray's command in October had dwindled to some 3,900 effectives. On April 26, Lévis, the French commander-in-chief, disembarked a force of 8,000-9,000 men at Pointe aux Trembles and marched on Quebec. Murray had no choice but to fight. "The place," as he wrote, "is not tenable against an army in possession of the heights" (of Abraham). ${ }^{2}$ On the morning of April 28, Murray marched from Quebec with 3,000 troops in two columns, and near the village of Sainte-Foy came in sight of the vanguard of the French crosing the plateau above Wolfe's landing-place. He was driven back with a loss of upwards of 1,000 , that of Lévis being returned as 800 . Quebec was now besieged. On May 9 a frigate appeared, the precursor of a squadron under Commodore Swanton, and brought the news that the rest of the force was in the St. Lawrence. On the night of the I6th the

'Colonel Home's MSS., pp. 123-28, Hist. MSS. Comm., Ig02.

${ }^{2}$ Townshend, Life of the Marquess Townshend, p. 276. 
French beat a hasty retreat. Two days later ${ }^{1}$ a squadron under Lord Colville anchored before Quebec. The reinforcements and supplies so ardently expected by the French were dispatched too late, and were intercepted on July 14 by Commodore Byron on the north coast of New Brunswick. This success cut off the last hope of the French at Montreal of offering an effective resistance to the forces converging upon the capital, for Colville's fleet was now blockading the mouth of the St. Lawrence.

The winter and spring of $1759-60$ had afforded Amherst time to mature his plans. Montreal was to be attacked by three columns simultaneously. Murray was to ascend the river from Quebec. Brigadier Haviland, starting from Crown Point, was to follow the old route by Lake Champlain, Amherst himself to lead the main body from Lake Ontario down the St. Lawrence. On the evening of September 7, the three columns lay outside the walls of Montreal. Against the united army numbering 17,000 men resistance was impossible. After twenty-four hours of negotiation Vaudreuil had no choice but to yield to Amherst's terms, which the British general resolutely refused to modify. On September 8 the capitulation was signed. Religion and property were guaranteed. The French troops and officers were to lay down their arms, and be conveyed to France on undertaking not to serve again during the war. Canada and all its dependencies passed to the British crown.

When the news reached Madras in August, 1756 , of the outrage of the Black Hole of Calcutta, perpetrated on the previous June 20, Clive, then governor of Fort St: David's, shipped his troops, the British 29th regiment ("Primus in Indis"), I,200 sepoys and some artillery to Calcutta, routed the native army and compelled the nawáb to come to terms. The nawáb signed a treaty on February 9, 1757, restoring Calcutta to the British. and promising compensation for their losses. Three days later he signed a second treaty of offensive and defensive alliance. At the very moment of his success Clive found himself exposed to a new peril. News reached Bengal of the declaration of

1 The r8th. The date has been variously stated. Horace Walpole, confusing Lord Colville's with Swanton's squadron, states it as May 9; Kingsford, History of Carada (1890), iv., 373, as the 17 th. It is now fixed by Colville's dispatch to Pitt of May 24, printed in Pitt's Correspondence, ii., 290 (1906). 
CHAP. war between England and France. The treacherous disXXVII. position of the nawáb was notorious, and at the neighbouring settlement of Chandernagore on the Hooghley the French maintained a military force of 500 Europeans and 700 sepoys, a constant menace to Calcutta. After an attack by land and water, Chandernagore capitulated to Admiral Watson and Clive on March 23. But the nawáb was tired of temporising. He marched to Plassey, about seventy miles north of Calcutta, having first sent a letter of defiance to Clive. Clive's position was perilous. His force consisted of 750 British soldiers, fifty sailors, 2,100 sepoys and ten field-pieces; the nawáb's of 35,000 infantry, I 8,000 horse, and fifty guns; but the foot were badly armed, some of them only with bows and arrows. A party of forty to fifty French from Chandernagore with four field-pieces was its most efficient element. At a cost of seven British and sixteen sepoys killed and thirteen wounded Clive's victory of Plassey on June 23 established British supremacy in Bengal. Clive recognised as nawáb Mír Jafar, his enemy's commander-in-chief, whose treachery had contributed to his success.

Unexampled as the exploit of Clive had been, the supremacy of the British in India was as yet by no means assured. The design of the French ministry to take up the work of Dupleix and sweep the British out of Southern India, appeared on the very morrow of Plassey in a fair way to be accomplished. On May 2, I 757, a fresh armament left Port Lorient for the East Indies. At the head of the land force, numbering some I,200 men, was Count de Lally Tollendal, son of Sir Gerard Lally, an Irish Jacobite refugee. He arrived at Pondicherry after a difficult voyage of nearly twelve months at the end of April, 1758. The junction of Admiral Pocock, who had succeeded to Watson's command, with Commodore Steevens, who with eight ships had wintered in Bombay, had taken place at Madras in March. The forces being about equal, two naval actions followed, in which the French sustained so much damage that the French admiral, D'Aché, was compelled to retire to the Isle of France to refit (September 2). Supremacy at sea proved for the English an effective set-off to the superiority of the French by land. It rendered difficult Lally's execution of the instructions of the French East India Company to uproot the British settlements on the coast. He deter. 
mined, therefore, to concentrate all available forces and when the English fieet should be compelled by the monsoon to CHAP. sail away, to make an attempt on Madras.

It was a critical moment in Bengal. Clive's nominee, Mir Jafar, the new nawáb, was already in cifficulties with an exhausted treasury, disaffected nobles, and an invasion of his northern frontier threatened by Shah Alam, a rebellious son of the King of Delhi. On the other hand, the government of Madras was pressing for the return of Clive and the Madras troops. In the teeth of the opposition of the council at Calcutta, Clive decided to dispatch a detachment to attack the French in the Northern Circars, a district contiguous to Bengal, which would serve to divert their operations in the Madras presidency. For this task he selected Colonel Francis Forde, "one of the great Indian soldiers of the century". Forde on April 7, 1759, with a force of barely 900 men, took Masulipatam by storm and made prisoners 500 French soldiers and 2,100 sepoys. This brilliant exploit was followed by an offer of alliance on the part of the Nizam of the Deccan; French influence in the Deccan was destroyed and the Northern Circars, a territory of 17,000 square miles, was transferred by him from the French to the English East India Company. On October 16, 1 758, Pocock sailed from Madras for his winter station at Bombay. The issue now lay between the land forces on either side. Lally with 3,266 French and 4,000 Indian troops on December 12 encamped before Madras. Fort St. George, also known as the White Town, to distinguish it from the Black Town or native quarter, was held by the veteran Colonel Stringer I awrence, at the head of 1,758 British and 2,400 native soldiers. For fifty-four days the French batteries maintained an incessant fire. On February 16, 1759, Pocock's fleet returned from Bombay, and anchored before the city. The relief of Madras was the first success of the year of victories, 1759 . Thenceforth the balance in the Carnatic inclined in favour of the British.

In February, 1759, came the expected invasion of the territory of the Nawáb of Bengal by Shah Alam, with an army of 30,000 men. Clive collected such forces as he could muster which, owing to the absence of Colonel Forde's command, numbered no more than 450 Europeans and 2,500 sepoys. 
CHAP. With these he marched to the relief of Patna, besieged by XXVII. Shah Alam's troops. The name of "Sabut Jung," "Daring in War," by which Clive was known among the natives, sufficed to put the invader to flight on the appearance of the British advance guard on April 4. Not long after his return to Calcutta, Clive was confronted with a difficulty involving European international relations. Prior to the invasion by Shah Alam of the nawáb's territories, Mír Jafar's restless and intriguing son Miran, who cherished a dislike of the English, suggested the introduction of the Dutch by way of counterpoise to English influence. Irritation prevailed in England because the Statesgeneral refused to join in alliance against France, and in Holland on account of the confiscation of Dutch vessels carrying alleged contraband of war. An outbreak of hostilities was probable. In October, I 759, seven Dutch ships disembarked 1,400 troops, half Dutch and half Malays, near the Dutch settlement of Chinsurah. At Clive's orders they were attacked and routed by Forde and their ships taken by Commodore Wilson.

Had a man of less promptness and intrepidity than Clive been in command, Bengal might have been lost to the company. With the expulsion of the French and the defeat of the Dutch Clive felt his work in Bengal completed. In three years, and at the age of thirty-five, he had forced Suraj-ud-Daulah to evacuate Calcutta, and at Plassey had avenged "the Black Hole" ; had added a large tract of land near Calcutta and rich revenues to the possessions of the company; had driven the French from their concession in the Northern Circars and thereby from the whole Deccan; had excluded all rivals from the dominion he had acquired, and had established a virtual sovereignty over Bengal. His health was impaired. He was ambitious to receive his reward in England; and to exert the influence in home politics which his wealth had acquired for him. In Engiand he was received with enthusiasm in July, 1760. He had proved himself the greatest English general since Marlborough, and his victories impressed both king and people the more that they followed upon a long succession of defeats.

Elate with the news of Plassey, Pitt in December, 1757 , had, during the debate on the mutiny bill, acclaimed Clive as a "heaven-born" general. His imagination was fired by the 
brilliant daring of Clive's achievements, and from this time he had spared no pains in furnishing reinforcements. The French, CHAP. XXVII. on the other hand, were active in increasing their naval force in the Indian seas, and Count d'Aché, having been joined in the Isle of France by three ships of the line, appeared at the end of August, 1759, off the Coromandel coasts with a fleet of eleven ships. Pocock was awaiting him with nine small ships of the line, his force being inferior by 192 guns and 2,365 men. The battle of September 10, off Tranquebar, though bloody, was indecisive, but it was followed by the final retreat of D'Aché, leaving Pocock master of the sea and the French in India hopeless of help. The ill success of Lally served to increase the discords and difficulties of the French army. His native soldiers shewed themselves ready to desert, and their example infected even his regular troops. Taking advantage of this, Eyre Coote on November 30 attacked the important fortress of Wandiwash, which surrendered after a few days' siege. In an attempt to recover it Lally sustained a crushing defeat by Coote on January 22, 1760 . Bussy, Lally's principal officer, was taken prisoner. The battle of Wandiwash decided the fate of the Carnatic and thereby of India. Pondicherry was soon the last place of importance left to the French. An iron ring closed round the city; supplies had run out. Nothing remained but surrender. On January 16,1761 , Pondicherry was surrendered to Coote. In the following month the French possessions on the west coast followed, and the French power was expelled from India.

On October 25, 1760 , ere the surrender of Pondicherry had sealed the transfer of India to the British, George II. died suddenly at Kensington, of rupture of the ventricle of the heart, at the age of seventy-seven. His end came at a dramatic moment, tidings of victories, successive as the news of Job's misfortunes, casting a parting glory upon his life. On September 22, Admiral Pocock, who had driven the French from the Indian coasts, anchored in the Downs, bringing with him the news of the decisive battle of Wandiwash. Nine days before the king died, the lord mayor and corporation presented him an address of congratulation on the completion of the conquest of Canada. Saunders in the new world, Boscawen in the Mediterranean, and Hawke in the Channel were masters of the sea. Success 
CHAP. so brilliant extinguished such unpopularity in the nation at XXVII. large as may have been entailed on the king by his Hanoverian leanings. The public recognised, as did those nearest to him, like Lord Waldegrave, that, despite his prejudice in favour of the absolute government to which till past the age of thirty he had been accustomed, he remained in practice steadily faithful to the limitations imposed upon him by the British constitution. He offered, it is true, an obstinate resistance where his personal dislikes were aroused, as to the admission of Pitt to cabinet office; but when Hanover was not in peril, he was free from a disposition, like that of Anne and Louis XV., to intrigue against his own ministers. What he surrendered in initiative he gained in influence, and the relations of the sovereign to the ministry were, at the close of his reign, nearer those obtaining under Queen Victoria than was the case with his grandson and successor. The effectiveness of the influence which, while abstaining from insistence on prerogative, he contrived to exercise, is illustrated by the concessions of Pitt to his Hanoverian policy. When George II. died the secular struggle between the crown and a political party seemed, with the extinction of Jacobitism, to have been laid at rest. 


\section{CHAPTER XXVIII.}

\section{LITERATURE AND MANNERS.}

THE Revolution stirred the national life in all departments. CHAP. It impressed a political stamp upon social and literary activity Xxviri. during the two generations following it, so that the parties of poets and philosophers were as well known as those of their patrons. At the death of William III. freedom of discussion reigned in the coffee-house and the club, and a spirit of reform had begun to test social and literary traditions. The reign of Anne, during which this renascence acquired a marked extension, was a brilliant period of the Augustan age of English literature. It was, indeed, the achievement of Addison to found a school of taste upon classical models ; but the developement of his literary form by poets and essayists submissive to his canons continued throughout the reigns so dissociated in popular thought from literary distinction as those of Anne's two successors.

While Addison gave literature its form, John Locke, who died in 1704, inspired its spirit. He exercised over the thinkers of the first half of the eighteenth century much the same influence that Darwin and Herbert Spencer exercised over those of the end of the nineteenth. His "common sense philosophy" was applied to social and literary questions as widely as the doctrine of evolution is now. It was reinforced in the purely literary sphere by classicism, which aimed at realising the doctrine of Boileau, the critic most in vogue, Tout doit tendre au bon sens. The kernel of Locke's philosophy -that all our knowledge is derived from experience-fitted in also with the active investigation of natural phenomena which marked what Whewell calls " the inductive epoch of Newton ". John Flamsteed, the first astronomer-royal (d. 1719), Edmund 
CHAP. Halley (d. I742), the student of tides, comets, and eclipses, XXVIII. James Bradley (d. 1762), the discoverer of the nutation of the earth's axis, above all, Sir Isaac Newton himself (d. 1727), gave England the leading place in astronomical science.

In the region of pure speculation Locke held the field in the sense that subsequent philosophic thought was either in developement of, or antagonism to his system. Bishop Berkeley (d. I 753) inferred from Locke's doctrine of "ideas" the nonexistence of " matter," while David Hume (d. 1776) carried destructive analysis a step further by attacking the substantial existence of mind. David Hartley, in his Observations on Man (1 749), first brought into prominence the part played by the law of association in mental processes. In moral philosophy Locke was, to employ a later designation, a utilitarian, while Bishop Butler (d. 1752), the author of The Analogy, opposed Locke's negation of " innate ideas" by assigning " conscience" as the innate principle of authority. In The Fable of the Bees, or Private Vices Public Benefits, Bernard Mandeville (d. I 733), in a series of cynical paradoxes, attacked Locke's doctrine that "God has by an inseparable connexion joined Virtue and Public Happiness together". Vehement condemnations followed, alike from critics such as John Dennis, the dramatist (d. 1734), theologians, as William Law, and moralists, as Francis Hutcheson (d. I 747), whose System of Moral Philosophy borrowed its doctrine of the "moral sense" from the school of Shaftesbury. David Hume, whose Enquiry Concerning the Principles of Morals was published in $175 \mathrm{I}$, introduced "the experimental method of reasoning into moral subjects".

The theologians, like the philosophers, derived from Locke. "The reasonableness of Christianity," upon which he wrote a treatise, was the key-word of the orthodox preachers of the school of Tillotson. On the other hand, Locke rated Church authority bit lightly, and was nebulous or reticent upon dogma. In this he was followed by Hoadly, Bishop of Bangor and afterwards of Winchester, "the object," says Gibbon, " of Whig idolatry and Tory abhorrence," but unquestionably the most prominent prelate of his time. The Bangorian Contro versy, in which Hoadly minimised ecclesiastical authority, and A Plain Account of the Lord's Supper, in which he rationalised the Christian mysteries, convulsed religious England. His 
chief opponent was William Law (d. 1761), the author of The Serious Call (1728), a non-juror and a mystical high churchCHAP. man. Another school of thought, that of the Deists, which flourished during the first half of the eighteenth century, was traced by friends and foes alike to Locke's writings. The earliest of the school, John Toland, an Irishman, published in 1696, the year after Locke's treatise on the Reasonableness of Christianity, a book, Christianity not Mysterious, which Bishop Stillingfleet declared to be a legitimate deduction from Locke's premisses. A friend of Locke, Anthony Collins, published in 1712 a Discourse on Freethinking, which provoked a satirical tract from Swift, and argumentative answers from Whiston, Berkeley, and Richard Bentley, the last under the name of "Phileleutherus Lipsiensis". A fresh controversy arose upon his publication in 1724 of $A$ Discourse on the Grounds and Reasons of the Christian Religion, in which Thomas Sherlock, afterwards Bishop of London, Zachary Pearce, afterwards Bishop of Rochester, and Samuel Clarke, the metaphysician and a friend of Queen Caroline, were Collins's opponents. Another Deist, of a family intimate with Locke, was Anthony Ashley Cooper, third Earl of Shaftesbury, whose Characteristicks appeared in 1713 . Matthew Tindal's Christianity as Old as the Creation, published in 1730 , proposed as the constructive substitute offered by Deism for popular Christianity " the religion of nature". This book produced a hundred and fifteen answers, the most notable of which was the Defence of Revealed Religion (1732), by John Conybeare, afterwards Bishop of Bristol, pronounced by Bishop Warburton to be one of the best reasoned books in the world.

To the school of Deistical thinkers belonged Bolingbroke (d. 1751), though his Philosophical Works were not published till 1754. "He was," said Dr. Johnson, " a scoundrel for charging a blunderbuss against religion and morality, and a coward because he had no resolution to fire it off himself." After the appearance of Tindal's book the controversy declined, but not before it had given birth to three apologetic works, of which one is read and the others remembered to the present day. Alciphron, or the Minute Philosopher (1732), by George Berkeley, the metaphysician, afterwards Bishop of Cloyne, was a satirical polemic against Deism in general. The Analogy

VOL. IX. 
CHAP. of Religion (1736), by Joseph Butler, afterwards Bishop of XXVIII. Bristol and Durham successively, traversed the doctrine of the perfection of revelation in nature set up by the Deists against the revelation of religion. In 1737 appeared the first part of the Divine Legation of Moses, by William Warburton, afterwards Bishop of Gloucester, the significance of which in the history of this controversy is its substitution of an historic method for abstract speculative theology. In this connexion may be mentioned the treatise on Miracles, by Conyers Middleton, published in 1748 .

Scarcely less supreme than the influence of Locke on speculation was that of Addison over the lighter literature of the day. Addison entered the field of English letters saturated with the writings of the Latin poets, and with a reputation for elegant scholarship which lent authority to his literary judgements in a society in which classical " correctness" commanded a more assured applause than poetic inspiration. The intellectual atmosphere of the coffee-house and the club, in which current ideas crystallised into shape, was uncongenial to imaginative extravagance. It was an age when critics like Lord Mulgrave, afterwards Duke of Buckinghamshire (d. 1721), author of an Essay on Poetry, and Colley Cibber (d. I757), actor and dramatist, rewrote Shakespeare to suit the modern restraint. The merit of such essays, according to Lord Lansdown's poetical Essay on Unnatural Flights in Poetry, was that

They gave us patterns and they set us bounds.

These ideals, and more than these ideals, Addison satisfied. His heroic couplets ran on smoother lines than those of his contemporaries; his inspiration was fresher and less reminiscent. Dryden eulogised him; Halifax, the patron of rising talent, introduced him to the literary whigs, and Godolphin commissioned him to immortalise in verse the triumphs of Marlborough and the ministry. The Campaign, the poem in which he commemorated Blenheim, discarded the fashion of a servile imitation of Homer ; called men and places by their real names, and thrilled the country by the noble lines referring to that impressive national disaster, the great storm of 1703 . Addison became the literary fashion. Amid a "little senate" of wits and men of letters at Button's, and in the pages of the Tatler and Spectator, he directed the taste of the day. From his populari- 
sation of the heroic metre flowed divergent streams of poetry. Alexander Pope brought to perfection the characteristics of CHAP. compression and epigrammatic antithesis. His imitators were so numerous, and many of them so facile, that Cowper afterwards complained that he had "made Poetry a mere mechanic art"-a complaint expressed by Steele when Pope was as yet little known (Tatler, No. 3). But the superiority of Pope over his followers in glitter and point, in mordancy of satire and exquisiteness of finish, proves his achievement to have been much more than this. His earliest experiment in pastorals was, indeed, compared by Addison's "senate" unfavourably with the Pastorals (1709) of Ambrose Philips. But The Rape of the Lock, among mock-heroics, the verses upon Addison as Atticus in satire, and the Essay on Man, as an example of ethical and didactic poetry, were from the first acknowledged to be unrivalled in the classical schools of poetry.

The Splendid Shilling (1703) of John Philips is a brilliant example of the mock-heroic, which introduced the author to the favour of the tory leaders, by whom he was commissioned to write Blenheim as the tory counterblast to The Campaign. Jonathan Swift's City Shower; John Gay's Trivia, or the Art of Walking the Streets of London (1716), and William Shenstone's Schoolmistress (1742), characterised by Johnson as "a delightful performance," are in the same vein. Between the mock-heroic and burlesque is but a fine line. Pope, jealous of Ambrose Philips's Pastorals, suggested to Gay to ridicule them in The Shepherd's Week (I 7 I4), "rustic life with the gilt off". More than twenty years afterwards the pastoral revived in the blank verse of William Somervile's Chase (1735) and John Dyer's Fleece (1757), of which last a contemporary critic aptly prophesied that its author would be " buried in woollen". Burlesque found fresh food in the fashionable tragedies, ridiculed by Henry Fielding's Tragedy of Tragedies, the Life and Death of Tom Thumb the Great (1730), and in Henry Carey's Chrononhotonthologos (1734).

Among satirists in verse Swift was unique. He was no imitator of Pope's style, still less of his methods. His octosyllabic verse glides easily from his pen; his nightly rest was undisturbed by the labour of manufacturing epigram. His model, if any, was Butler, the author of Hudibras. In his 
CHAP. Imitations of Horace his humour is pleasant enough; but as XXVIII. he grew in years and infirmities it became misanthropic and brutal. Of the school of Pope was Richard Savage, whose satire The Bastard (1728) was an attack upon the Countess of Macclesfield whom, probably without ground, he claimed to be his mother. Of The Love of Fame, seven satires, of Edward Young, better known as the author of Night Thoughts, the fifth and sixth On Women (1727-28) are thought, as representations of feminine types, to have been little inferior to Pope's satires upon feminine persons.

From what has been said, it will be seen that ethical discussion largely absorbed public interest. The heroic couplet lent itself readily to this as to other purposes. Sir Richard Blackmore, physician to Queen Anne, produced (I7I2) a ponderous poem, Creation, commended by Addison (Spectator, No. 339) and by Johnson. Early in his career (I 7 I 3) Pope, in his Windsor Forest, had earned the applause of the tories by extolling the peace of Utrecht, and had pilloried his literary enemies in the Dunciad (1712). But when the tory party had ceased to have an effective existence, and he was himself the acknowledged head of English poetry, he succumbed to the didactic disposition of the time. As he says of himself he

\section{Stooped to Truth and moralised his song.}

At the instance of Bolingbroke, who wrote out in prose a large part of the thesis, Pope produced (1733-34) his Essay on Man, which, whatever may be said of its philosophical reasonings, ranks as a classic in didactic poetry. Its Deistic argument evoked from Edward Young, who was a clergyman, a poem in blank verse, The Complaint, or Night Thoughts on Life, Death, and Immortality (1742). Mark Akenside, in his Pleasures of Imagination, in blank verse (1744), belongs to the same school of thought as Pope. Among poets contemplative of Nature rather than argumentative as to its ethical significance, was Thomas Parnell, the author of The Hermit, published by Pope in I72I, after Parnell's death. James Thomson's Seasons (I 726-30), ir. blank verse, is still popular. In thought, the poem belongs to the Deistic school; in inspiration, as the poem of an observer of nature, to the Georgics of Virgil, of which Cyder (I 708), a blank verse poem by John Philips, was the most skilful imitation. 
The study of classical models naturally led to translations in verse. Nicholas Rowe, dramatist and poet-laureate, transCHAP. lated Lucan into heroic couplets (published in 1718), and though, like Dryden and Pope, he adopted the method of paraphrase, his work abounds in dramatic vigour. So far was paraphrase, involving eighteenth-century modes of thought and eighteenth-century epigram, carried by Pope in his lliad $(1715-20)$ that the great scholar Bentley said of it-" A pretty poem, Mr. Pope, but you must not call it Homer". Half of the Odyssey (1725-26) was the work of two assistants, William Broome and Elijah Fenton, the latter the author of the tragedy Mariamne. These two were so successful in catching Pope's method and manner that their work is scarcely distinguishable from his. Parnell translated into the same heroic metre the so-called Homeric Batrachomuomachia and the late Latin Pervigilium Veneris (published in 1721). A lyrical translation of some of Pindar's odes was published by Ambrose Philips, and another (1749) by Gilbert West. Lyrical poetry had, under the domination of classicism, maintained a fitful existence, just as natural hair, as an eccentricity, competed here and there with the wig. The Scottish national spirit kept alive, in the songs of Allan Ramsay's Gentle Shepherd (1725), the metres natural to the Scottish vernacular. His poems are strongly suggestive of Burns. This return to Nature reappears in Gay's Sweet William's Farewell to Black-eyed Susan, and, still more, in Shenstone's pathetic ballad of Jemmy Dazeson. The odes of William Collins (1746 and 1749), and of Thomas Gray, the author of the famous Elegy, were developements of the romantic movement. Among the authors of purely political ballads, which were generally of inferior literary merit, William Pulteney takes a high place. His ballad, The Honest Jury, on the acquittal in 1729 of the printer of The Craftsman, for seditious libel, "was once among the most popular in the language".

To a variety of lyrical poetry of the nature of vers de societt, known as " the familiar style," belong the poems of Matthew Prior (published 1709), summed up by a modern critic as being " as easy as Swift and as polished as Pope". Two poets of this school were Pope's literary godfathers- 
CHAP. XXVIII.
Granville the polite, And knowing Walsh would tell me I could write.

George Granville, afterwards Lord Lansdown, a tory poet, hymned James II.'s " mighty mind," while William Walsh, whose verse at times recalls Pope and at times Prior, in a happy imitation of Horace extolled "the great Nassau". A knack of epigram was part of the equipment of a fine gentleman, and as social life furnished the inspiration of so many poets, epigrammatists abounded. Prior and Pope were the most felicitous; but two less well known are Sir William Browne and Joseph Trapp, the first professor of poetry at Oxford. Their rival epigrams upon the occasion of the presentation by George I. in I 7 I 4 of Bishop Moore's library to the University of Cambridge are familiar to the members of the two universities. Original epic poetry, judged by its present oblivion, was a failure. Its most ambitious examples were Alfred, by Blackmore (1723), and Richard Glover's Leonidas (I 737), the success of which last was due rather to its usefulness as a manifesto of the whig opposition to Walpole than to its poetic merits. At the opposite pole to vers de societe in the occasions inspiring, and in the emotions aroused by it was the new hymnology. It had its rise among the nonconformist congregations whose musical devotion was unsatisfied by the metrical versions of the Psalms generally used in the Established Church. Isaac Watts, the author of a collection of religious poems, Horae Lyricae (1 706), published in 1707 the first volume of his Hymns, which aroused the enthusiasm of the religious world, and many of them are in use at the present day. With the new Oxford movement of methodism under the Wesleys and George Whitefield the use of hymns began to spread. John and Charles Wesley published twenty-three collections of hymns, to which both brothers contributed, between 1737 and 1786. Many of them survive.

In a society so busied with politics political satire appeared in every form and political references were everywhere looked for. The declamations of the fashionable tragedies were interrupted by the applause of audiences in search of allusions to current events. At the first representation of Addison's Cato (April 14, 1 213) the theatre was crowded by friends of the rival politicians, who clapped and hissed for the honour of 
their party, and not for the merits of the play.1 Booth, the CHAP. actor of Cato's part, was publicly presented with a purse of guineas by Bolingbroke for sentiments for the reward of which the whigs, who also claimed them, presently collected subscriptions. Gay's Beggars' Opera (1 728) was full of political allusions. In 1739 Gustarus Vasa, a play in the interest of the opposition by Henry Brooke, author of The Fool of Quality (1766), was prohibited in London, Walpole being pilloried in it as the tyrannical Danish vicegerent. Of political romances Dr. John Arbuthnot's History of John Bull is the most famous, as possibly the creation of a name and character which has been adopted as a national type. It is, in fact, a tory apology for the peace of Utrecht. Arbuthnot was the mainstay of the Martinus Scriblerus Club, an association of which Swift, Gay, Parnell, Pope, Congreve, Bishop Atterbury, and Lord Oxford were members, for the "composition of joint-stock satire". But with the death of Queen Anne the club came to an end, and the contribution of Arbuthnot with the assistance of Pope, The Memoirs of Martinus Scriblerus, ridiculing contemporary pedants, was first printed by Pope in I741. Swift's Gulliver's Travels and his cognate satires were chiefly at the expense of humanity in general, according to the King of Brobdingnag, "the most pernicious race of little odious vermin that nature ever suffered to crawl upon the face of the earth". Satire is the essential quality of Swift's humour. Addison's gentler satire of a social kind yet remains the salt of the essays of the Tatler and the Spectator. The taste for pictorial satire, especially illustrated by doggerel verse upon persons and questions of the day, grew with great rapidity. The catalogues of prints and drawings in the British Museum describe 169 such under Anne, 207 under George I., and as many as I,93I under George II. In this connexion William Hogarth, the unrelenting painter of realism, may be mentioned. His caricatures contain numerous portraits of celebrities of the day.

During the first half of the century the drama was upon the decline. Jeremy Collier's attack in 1698 , in the Short View of the Immorality and Profanemess of the English Stage, had scared the respectable middle class. Vanbrugh and Con-

1 George Berkeley to Sir J. Percival, April 16, 1713, Egmont MSS., p. 288. Lord Castlecomer to the same, April 28, 1713, ibid., p. 246. 
CHAP. greve defended themselves with but indifferent success. When, XXVIII. further, Queen Anne issued a proclamation, dated January 17 , 1703-4, forbidding women to wear a mask at the theatre, an affectation, at least, of a sense of decorum slowly set in, though Vanbrugh's Confederacy, produced in the following year, has been described as a play "the lowest in point of morality to which English comedy ever sank". The new taste for adaptations from French tragedians, like Edmund Smith's Phaedra and Hippolytus (1707), and Ambrose Philips's Distrest Mother (17 I 2), contributed towards improvement, but the critics of the Spectator were better pleased than were popular audiences with "sentiments worthy those of the highest figure". Steele's practice as a writer of comedy squared with his principles, and The Lying Lover (1703), which contained an indictment of duelling, was, as he complained, "damned for its piety". Colley Cibber's comedies were also on a higher level. Nevertheless, in 1719, Arthur Bedford, a clergyman, published $A$ Serious Remonstrance, containing seven thousand impious or immoral sentiments culled from plays of the previous four years. This onslaught was followed by William Law's Absolute Unlawefulness of the Stage Entertainment (1726), answered by the critic John Dennis. It was doubtless in response to a purified public taste that Lillo produced the History of George Barnzell in 1731 , a type of domestic drama, followed by Edward Moore's Gamester (1 753 ).

With the awakened sense of religion due to the evangelical labours of Whitefield and the Wesleys came a spirit of selfabasement which, applied to public affairs, took the form of social pessimism. John Wesley himself, in his Further Appeal to Men of Reason and Religion (1745), drew a despondent picture of contemporary society, its vices and its corruption. As public disasters multiplied at the outset of the Seven Years' War, the impression thus made was deepened, and Dr. John Brown's Estimate of the Manners and Principles of the Times (1757) won wide popularity, its thesis being, to adopt Burke's description of it, that "a frivolous effeminacy was become the national character". This temper of gloom reproduced itself in poetry, and Robert Blair's blank-verse poem, The Grave (1743), was "the first and best of a whole series of mortuary poems".

Italian opera was first introduced in January, 1705, by the 
English composer, Thomas Clayton. The principal actors CHAP. being Italian sang their parts in their own language, the other XXvii. performers in English. Addison, whose Rosamond Clayton set to music in 1707, with failure as the outcome, describes in No. 29 of the Spectator the amusement of English audiences at the innovation of " recitative," accustomed as they had been to alternations of song and speech, as generally in Purcell's operas. The personal rivalries traditional on the operatic stage were represented by hostile demonstrations between the adherents of Catherine Tofts ("British Tofts") and Margharita de l'Epine ("the Tawny Tuscan"). First-rate English singers were scarce. The first English vocalist after Catherine Tofts was Anastasia Robinson, who in 1724 became the wife of the celebrated Earl of Peterborough. The brilliant success of Handel's Rinaldo in 1711 , the first of thirty-five operas composed by him for the English stage, and the favour shewn to the opera by the Hanoverian family, led to the foundation of the Royal Academy of Music in 1720 . This was an attempt to maintain an Italian opera permanently in London, Handel being placed at its head. In 1728 it proved a failure. Handel being patronised by George II., a rival composer, Buononcini, was supported by Frederick Prince of Wales. But until Handel's death in 1759 he remained, in general estimation, supreme as an operatic composer.

It has been said that as dramatic composition declines, the personality of the actor rises in importance. The change in things dramatic which the first half of the eighteenth century witnessed is as probably due to the extension of literary interest, especially in aristocratic circles, and the consequent increased social importance of the actors themselves. Thomas Betterton, "the best actor in the world," according to Pepys, a man of unblemished character, the friend of Tillotson, as of Pope, was honoured by burial in the cloisters of Westminster Abbey (1710). While extolled for the variety of his talents by all his contemporaries, he excelled, if we may believe Colley Cibber, in a gift of rhythmical declamation that carried an audience through "sounding periods, signifying roundly nothing". The school which he founded, well suited to the fashionable tragedies of the day, eventually gave way to the natural manner of David Garrick (d. 1779). Betterton's pupil, 
CHAP. Mrs. Bracegirdle, another example of a decorous life, and, like XXVIII. Betterton, buried in the abbey cloisters, achieved her most brilliant triumphs in the comedies of Congreve. As an actress of tragedy, Mrs. Barry, teacher of elocution to Queen Anne. was generally accorded the first place, but she belonged to the older school, being the mistress of the profligate Rochester With the death of the queen, times again changed. Anne Oldfield, the mistress in succession of Arthur Maynwaring and General Churchill, became in Cibber's comedy of The Careless Husband, played in 1704 , the leading exponent of the woman of fashion in the character of Lady Betty Modish. Caressed in life by the aristocracy, and even by Queen Caroline herself, she was, at death, buried at the foot of Congreve's monument in Westminster Abbey (1730). Lavinia Fenton, the original Polly Peachum of The Beggars' Opera, became the mistress, and afterwards wife, of the Duke of Bolton. Betterton's pupil, Barton Booth-Pope's "well-mouth'd Booth"-is now best remembered as the actor applauded by both parties in the rôle of Cato, as a reward for which Queen Anne ordered Colley Cibber, Doggett, and Wilks-the last an actor eulogised by Steele in the Tatler (No. I 82)-to admit him a partner in the management of Drury Lane Theatre. The leading tragic actress in succession to Mrs. Barry was Mary Porter. In the judgement of Dr. Johnson, "Mrs. Porter, in the vehemence of rage, and Mrs. Clive, in the sprightliness of humour," were unequalled. The Irish actress, Margaret Woffington (d. 1760), appears to have excelled in both tragedy and comedy alike, being compared both with Mrs. Oldfield and Mrs. Porter. James Quin (d. I 766), the last of Betterton's artificial school, has left a name for caustic wit. With him may be coupled Samuel Foote (d. 1777), a comedian who disarmed even the dislike of Dr. Johnson.

Another section of the public which did not frequent the playhouse, and which took but a distant interest in Mrs. Manley's society scandals, such as The New Atalantis (1 709), eagerly read the realistic tales of Daniel De Foe, of which Robinson Crusoe, published in 1719, is the most celebrated. These extinguished the waning interest in the high-flown romances written upon French models. Robinson Crusoe went through four editions in the year of its publication. 
Swift's Gulliver's Travels, primarily a satire, is also a story of CHAP. incident. The novel of character, perhaps suggested by the XXVill. characters painted by Addison's skilful brush of the friends of Sir Roger de Coverley, and indicative, as Lord Morley of Blackburn has suggested, of the coming social revolution, first appeared in Samuel Richardson's Pamela in 1740. The fine sentiments of Richardson's model characters hit the public taste, though moderns are disposed to echo D'Alembert's sarcasm on his prolixity, "La Nature est bonne a imiter, mais non pas jusqu'd l'ennui". Robust natures, like Fielding's, regarded Richardson's sentimentalism with aversion, and Fielding's first novel, Joseph Andrews, which appeared in 1742, was written in ridicule of Pamela. But Richardson's second novel, Clarissa Harlowe (1748), and his third, Sir Charles Grandison, were even more popular than his first, the last in particular becoming the vogue in France through the extravagant eulogies of Diderot and Marmontel. He was rhapsodised about in Germany. He appealed to women; the coarser realism of Fielding, to men. Both, however, were didactic in intention, Fielding's plea for his coarseness being that he has "endeavoured to laugh mankind out of their favourite follies and vices ". His most popular work, Tom Jones, was published in 1749, and the claim that it is not "inconsistent with the strictest rules of decency " illustrates the change of standard since the author's day. To this school, but broader in humour and less artistic in construction, and approaching the "picaresque," belong the novels of Smollett, of which the earliest, Roderick Random, appeared in 1748 .

The most characteristic literature of the century, and that which first supplanted the aristocratic patron by the reading public, was the periodical essay. Of this, the earliest example was De Foe's Review, published twice a week, which added to political observations "Advices from the Scandal Club". The first number appeared during his imprisonment, on February 17, 1704, and it continued till June 11, 1713. The Tatler, the creation of Richard Steele, at first added news to the essay, but as Addison's share increased, the news gradually disappeared, and political were supplanted by social and artistic discussions. Its opening number was issued on April 12, 1 709. It was not in the first instance a political paper, but professed to get its 
CHAP. gossip from White's, Wills's, the Grecian, and the St. James's XXVIII. coffee-houses, the rendezvous respectively of wits and beaux, poets, men of letters, and the diplomatic world. Unfortunately for Steele, the Tatler had published certain satirical papers upon Harley, shortly before his appointment to office. The change of ministry cost Steele his place as gazetteer, and, it is said, but for the friendly intervention of Swift, would probably have cost him the post of commissioner of stamps, worth $£ 300$ a year. At any rate, the Tatler abruptly ceased on January 2, I 7 II.

On March I the Spectator appeared, professing " an exact neutrality between the Whigs and Tories". By the time its tenth number was issued, its circulation was 3,000 a day. Addison wrote 274 numbers; and Steele 236. Eustace Budgell, Addison's cousin and secretary; John Hughes, author of the tragedy, The Siege of Damascus; Laurence Eusden, who succeeded Rowe as poet-laureate in 1718 , and a few others, also contributed. But Addison's was the pen which brought the Spectator popularity. The coffee-houses had furnished opportunities for conversation, whereas, through lack of general culture, wholesome material was scanty. It was this defect which Addison set himself to supply. "I shall be ambitious," he wrote in the tenth number, " to have it said of me that I have brought philosophy out of closets and libraries, schools and colleges, to dwell in clubs and assemblies, at tea-tables and in coffee-houses." He seriously endeavoured, by the use of the weapon of gentle irony, to improve the social tone, so that Taine somewhat contemptuously dismisses the Tatler, Spectator, and Guardian, which last followed the Spectator in March, I713, as "mere lay sermons". Yet they hit the taste of the reading public, among whom women, attracted by Addison's playful satires upon their sex, numerously enrolled themselves. Addison's success produced imitations. Sir Richard Blackmore and John Hughes edified the public with The Lay Monk (November 16, 171 3, to February 1 5, 1714). In March, 1718, Ambrose Philips started The Freethinker, a name not connoting theological heterodoxy, to which Hugh Boulter, afterwards Archbishop of Armagh, and Gilbert Burnet, the son of the bishop, were contributors. Scurrilous essays, such as Mrs. Manley's Female Tatter (July 8, 1709), also made their 
appearance. The Rambler, started by Dr. Johnson in 1750, is the best known of a fresh group of essay sheets. It lacked CHAP. the lighter humour of Addison, and, as Johnson himself admitted, in its pages " the severity of dictatorial instruction has been too seldom relieved". Its original circulation was small, but it introduced Johnson to the world as a serious moralist, and the appetite for "lay sermons" had grown so keen that ten editions passed through the press in his life-time. On the extinction of the Rambler, in 1752 , John Hawkesworth, who in 1744 had succeeded Johnson as the compiler of parliamentary debates for the Gentleman's Magazine, started The Adventurer, which ran for two years.

The daily newspaper first made its appearance on March 12, 1702, in the form of The Daily Courant. Four years later followed The Evening Post. De Foe's Review (1 704-1 3) made journalism a power in the state. In 1709 eighteen papers were published in London. The earliest inspired ministerial paper was The Examiner, which appeared on August 3, I 710. It was edited by Dr. William King, of Balliol College, Oxford, assisted by Prior, Atterbury, and Freind. From November 2, 1710 , to June 14,1711, it was written by Swift. In its turn it called into being, on September 14, 1710, its rival, The Whig Examiner, from the pen of Addison. This, after a short life of three numbers, was followed by The Medley, mainly by Arthur Maynwaring, with the help of Steele, the whig wit and physician Dr. Samuel Garth, and Oldmixon; Maynwaring's patroness, the Duchess of Marlborough, supplying inspiration. On October 6, 1713, Steele published The Englishman, a paper committed to whig politics. The insinuations of this paper, and of his pamphlet The Crisis, in which Addison and Hoadly had a share, that the tory ministry was endangering the protestant succession, led to Steele's expulsion from the house of commons, on March 18, 1714. The Whig Flying Post, conducted by George Ridpath, was another thorn in Bolingbroke's side. After the accession of George I., Mist's Weekly Jourmal became the organ of the Jacobites and the High-Flyers, De Foe anticipating the modern leading article by "Letters Introductory". In 1715 and 1716 Addison held | up Jacobitism to ridicule in The Freeholder. The most formidable opposition ongan was The Craftsman, mentioned else- 
CHAP. where.1 After the retirement of Walpole, Fielding's True XXVIII. Patriot, in I 745-46, and his satirical The Jacobite Journal, in I 747-48, were written to discredit the pretender and his partisans. When, in i 756, Pitt was in power, he was attacked by The Test, to reply to which The Con-Test was edited by Philip Francis, the translator of Horace and Demosthenes.

The success of the essayists and the multiplication of newspapers led to a change in the position of the author. At the accession of Anne the general method of publication was the enlistment of subscribers under a nobleman whose interest was secured by the prospect of a fulsome dedication. Halifax was the typical patron of the day, satirised by Pope as "Fullblown Bufo, puffd by every quill". Nor was the author's hoped-for remuneration confined to the proceeds of the subscriptions of a select circle of readers. It was almost a duty incumbent upon the belauded patron to see him rewarded at the public charge. Addison, Stepney, the ambassador to the emperor, who, like Addison, had floated into fashion upon Latin verse, Vanbrugh, Congreve, Nicholas Rowe, Budgell, John Hughes, Ambrose Philips, Tickell, Mallet, and many others, looked to official place for their main subsistence. The lively writer of comedies, George Farquhar, was an officer in the army. With a growing circle of readers the patron became less indispensable, and the publisher came forward as the middleman between the public and the author. Lintot bought Pope's Iliad and Odyssey. De Foe sold Robinson Crusoe to John Taylor who, after having made a large sum by it, sold his publishing business in 1724 to the first Thomas Longman. Pope's earliest published poems appeared in Jacob Tonson's Miscellany. Robert Dodsley, founder of the Annual Régister (1758) was both publisher and author. Authorship, like publishing, became a calling. Hack-writers and translators depended upon the publisher for a livelihood, and, if Pope's lampoons upon the piratical publisher, Edmund Curll, may be believed, lay in garrets, two in a bed. Men with literary tastes, like James Thomson, drifted up to London to earn a living. Unfortunately the class of necessitous authors and the decline of the ambition of patronage conspired towards the middle 
of the century to make literature unfashionable. As late as 178 I, Dr. Johnson praised Lord Carlisle for " not disdaining" literary fame.

One form of literature, of which examples are rare, was reserved for persons of social distinction. French society in the seventeenth century, notably the Marchioness de Sevigne, had set the fashion. The writing of letters intended for publication was a post obit advertisement of the social importance, the taste, and the popularity of the author. Lord Chesterfield, himself the writer of letters still read as an example of eighteenth century worldly wisdom, desired the acquisition of the art by his son. Lady Mary Wortley Montagu's vivacious pictures of her life were preserved in copies taken by her friends. Of all the letter-writers of the period Horace Walpole remains the most popular, but is rivalled by his friend and schoolfellow, the poet Gray.

Letter-writing was fostered by the grand tour which, as the century advanced, became an indispensable part of a gentleman's education. It thinned the universities, where learning was at a discount, and aroused the dislike of conservative minds. The tory fox-hunter in Addison's Freeholder said " he did not know what travelling was good for but to teach a man ... to to jabber French and to talk against passive obedience". It also exercised a reflex action upon taste. The Alps or the wild landscapes of Salvator Rosa gradually revolutionised taste, and as the century advanced made the old-fashioned formal garden seem prim and tame. Formalism had been carried to grotesqueness, and, as Horace Walpole tells us, London and Wise, the gardeners to Queen Anne and George 1., "had stocked our gardens with giants, animals, monsters, coats of arms, and mottoes in yew, box and holly". Wise's successor in 1720 , Bridgman, abandoned " the geometric style," and became the pioneer of reversion to nature. By borrowing from the military art the device of the sunk fence in place of the wall, he contrived the "opener vista" praised by Pope, embracing the surrounding country. His methods were developed by William Kent, painter, furniture designer, architect, and " the father of landscape gardening," who popularised temples and grottoes as giving an Italian air to scenery. Of the garders of this style those of Stowe are the most famous, contrasted 
CHAP. by Pope with the old-fashioned tastelessness of the Duke of XXVIII. Chandos's at Canons. Pope himself was an expert in landscape gardening, and his five acres at Twickenham were so metamorphosed as to afford a vista of lawns " surrounded with impenetrable woods". Kent's method was followed by Launcelot Brown, generally known as "Capability" Brown, whose excellence lay in bringing out the effects of undulating landscape. The prevalence of Italian taste in matters of art generally was marked by the establishment of the Society of Dilettanti in I732. A fashion arose of collecting Italian pictures. In this Sir Robert Walpole shewed an example, his gallery costing him at least $£ 30,000$. Foreign, especially Italian, artists, some of whose works survive, were imported by wealthy noblemen for the decoration of their mansions. Two of them have been handed down to fame by Pope's description of the chapel at Canons :-

On painted ceilings you devoutly stare

Where sprawl the saints of Verrio or Laguerre.

Their rival, Sir James Thornhill, painted the dome of St. Paul's and the great hall of Greenwich Hospital. Thornhill was also a capable portrait painter. His son-in-law, William Hogarth, was an original genius, best known by his realistic pictures of contemporary life which, conformably to the didactic temper of the times, carry a moral with them. Charles Jervas, an Irishman, was a fashionable portrait painter, though Kneller ridiculed his drawing. The first portrait painter of the day was undoubtedly Sir Godfrey Kneller (d. 1723), a German by birth. His chief rival was a Swede, Michael Dahl (d. I 743). Jonathan Richardson succeeded these in favour, a writer upon the theory of his art as well as a skilful, if cold, artist. His pupil, George Knapton, was the first portrait painter of the Society of Dilettanti. Thomas Hudson was the master of Sir Joshua Reynolds, who soon after the middle of the century was beginning to assert his supremacy, though as late as 1760 the portraits of Allan Ramsay, the son of the poet, were preferred. Thomas Gainsborough was at this time better known as a landscape painter, in which branch of the art Richard Wilson, as early as 1750, was acquiring a reputation in Italy. The first public exhibition in London by British artists of their own works was held in 1760 . 
Of the sculptors of the period, the most famous were from the Low Countries domiciled in England. The earliest CHAP. in date and first in celebrity was Grinling Gibbons, generally known to fame by the unsurpassed excellence of the woodcarving with which he has adorned so many English mansions and churches. Gibbons, who lived till 1720 , was also a statuary, his best-known work being the statue of James II. in front of the Admiralty. James Gibbs, the architect, was much employed upon funeral monuments. His designs are heavy and tasteless, the best known of them being the monument in Westminster Abbey to John Holles, Duke of Newcastle. Many of his designs were executed by Francis Bird, a sculptor employed by Wren on the statuary decorating St. Paul's. Bird's own monument of Sir Clowdisley Shovell in the abbey was not unfairly called by Pope "the bathos of sculpture". Rysbrack, a Fleming, who came to England in 1720 , by the introduction of a simpler taste and by the excellence of his statuary, greatly improved this class of art. Two other Flemish sculptors, Delvoux and Scheemakers, were also much in vogue, especially for statuary in gardens. Scheemakers, among many other monuments, executed that of Shakespeare from Kent's design, and the bust of Dryden in Westminster Abbey. Their supremacy began to be challenged about 1738 by the French sculptor Roubiliac, who executed the tomb of John Campbell, second Duke of Argyll, also in the abbey. Much of Roubiliac's work is to be seen at Trinity College, Cambridge. Joseph Wilton, who sent busts to the first exhibition of British artists, and Joseph Nollekens, arrived at fame about the close of this period.

The period witnessed the death of the greatest of English architects, Sir Christopher Wren. But though he lived until 1723, Wren's work substantially belongs to the previous century. The fashionable architect of Queen Anne's reign was Sir John Vanbrugh (d. 1726), who had been educated in France, and had been in turn an officer in the army, a prisoner in the Bastille, and a successful dramatist. $H$ is architecture merits the sarcasm of the well-known epigram of Abel Evans,

\section{Lie heavy on him, Earth, for he}

Laid many a heavy load on thee,

but Castle Howard, his best work, evoked from Horace WalVOL. IX. 
CHAP. pole, no favourable critic, the epithet "sublime". He built XXVIII. many other "Brobdingnagian mansions" for the nobility of his day, of which the most famous is Blenheim Palace. As a subordinate of Wren and Vanbrugh, and afterwards as an independent architect, Nicholas Hawksmoor (d. 1736) was much employed, especially upon churches, being surveyor of the new churches which parliament voted for London in 1711 . He was also one of the earliest to introduce modern Gothic, of which the twin towers of All Souls College, Oxford, are a specimen. James Gibbs (d. I 754 ), another of the architects employed upon the parliamentary churches, adorned London with St. Mary-le-Strand, and Oxford with the Radcliffe Library. Among British architects of the century Gibbs stands next after Wren. The accomplished Richard Boyle, Earl of Burlington (d. 1753), had studied architecture in Italy, and repreduced in London and at Chiswick Palladian mansions of which the external taste and the internal inconvenience provoked the gibes of Chesterfield. Sir William Chambers, the architect in 1775 of Somerset House, was coming into vogue at the close of the period.

At a time when classical scholarship, of which Richard Bentley was the most eminent representative, was part of the equipment of a gentleman, the collection and study of antiquities naturally enlisted sympathy. William Stukeley, who took a part in the foundation of the Society of Antiquaries in 1718, left upon his death in 1765 a collection not only of antiquities but of fossils. To coins and medals Maurice Johnson (d. 1755) added plants. But these collectors of natural objects were before their age. Addison, in the Tatler (No. 216), derides them as virtuosi, and insinuates (No. 221) that to be a fellow of the Royal Society was to be a little mad. Dr. John Woodward, the geologist, and his collections became the butt of the wits, of Gay, who in 1717 ridiculed them in a farce, in which Pope and Arbuthnot were believed to have had a hand, called Three Hours after Marriage, and of Arbuthnot, who jeered at his "knicknackatory". When, upon the death of Sir Hans Sloane in 1753 , Horace Walpole found himself a trustee of Sloane's botanical and other collections, which formed the nucleus of the British Museum, he ridiculed them as "embryos and cockleshells". He himself was ardently devoted to the acquisition of bric-d-brac by way of decoration for his "little 
Gothic castle" at Strawberry Hill. Classical archaeology, such as that which occupied the Society of Dilettanti, was an CHAP. evidence of culture; the pursuit of science an eccentricity. Nevertheless, the act for the establishment of the British Museum, passed in 1753, indicates that outside the circle of fashion scientific research was beginning to command appreciation. Sloane and Woodward seem to have been the only scientific collectors among the physicians of the day. Dr. Radcliffe and Dr. Arbuthnot were bon-vivants; Garth was a wit and a poet; Blackmore a poet but not a wit. Freind, Mead, and William Heberden the elder (d. 1801) wrote treatises on medical subjects, and were eminent classical scholars.

Scholarship was well represented upon the bench of bishops, among whom were men of great attainments, especially such as owed their appointments to the discernment of the philosophic Queen Caroline, who told Sale the Orientalist that she read Butler's Analogy every morning at breakfast. She loved to encourage debates in her presence between Bishops Berkeley, Sherlock, and Secker against Hoadly, supported by Samuel Clarke. Of Anne's bishops the most considerable was William Wake of Lincoln, afterwards primate, whose correspondence on Gallicanism with the theologians of the Sorbonne made him famous throughout Europe. William Fleetwood, Bishop of St. Asaph and afterwards of Ely, is still known as the author of the history of prices called Chronicon Pretiosum; George Bull, Bishop of St. David's, had in 1685 received the thanks of the Gallican Church for his Defensio Fidei Nicaenae. Atterbury was pronounced by the learned nonconformist hymnwriter, Philip Doddridge, "the glory of English orators". Thomas Wilson is still remembered as the organiser of a High Church theocracy in the Isle of Man. William Nicolson, Bishop of Carlisle, was a student of Runic as well as of astronomy. Two men of great learning were nominated bishops under George I. : Edmund Gibson, Bishop of Lincoln, and afterwards of London, who went by the nickname of "Walpole's Pope," was the author of the Codex Juris Ecclesiastici Anglicani(1711), and John Potter, Bishop of Oxford, afterwards primate, was distinguished for classical scholarship and archaology. To these may be added White Kennett, Bishop of Peterborough, an antiquary and a historian. The revivalism of Whitefield and the 
CHAP. Wesleys was a protest against the subordination of religious XXVIII. instinct to intellectual and other secular interests.

In commerce and industry the first sixty years of the eighteenth century was not a period of rapid developement. Constant war absorbed the interest and diminished the resources of the nation. The iron manufacture was stagnant, the woollen trade was slowly improving. Paper manufacture and the silk industry were stimulated by the immigration of French artisans, and by the invention in 1719 of Sir T. Lombe's machine for silk-throwing. The export of cotton goods increased, doubtless with the extension of the East India Company's operations. Calico-printing developed to such an extent as to excite the jealousy of the woollen manufacturers. The Society of Arts was founded in London in 1754 for the encouragement of technical skill. A considerable advance was made in agriculture during the reign of George II., partly as a consequence of a revived activity in inclosing; partly through the improvements introduced by Lord Townshend after his retirement from office in the cultivation of his Norfolk estates. By the practice of marling, and by the four-course system of husbandry, "Turnip Townshend" increased the rental value of the land tenfold. A bounty on the export of wheat when the price was below $48 \mathrm{~s}$. encouraged cereal cultivation. But all trade was much impeded by the founderous condition of the roads, which did not improve till after the general turnpike act of 1755 . Goods were, in consequence, largely carried on the backs of packhorses, and though the nobility had carriages, and numerous servants to pull them out of the ruts, the gentry frequently travelled on horseback and their wives behind them on pillions. Public coaches, often known as "flying coaches," became more common during the reign of George I., but they could not make more than about five miles an hour, and were commonly drawn by six horses with postillions. "Stagewaggons" travelled at a less perilous speed, and at a lower price, accomplishing the distance between Lancashire and London in ten days during summer and eleven in winter. A journey without accident was scarcely expected. To the risk of being upset was added the risk of being plundered. It was the golden age of the highwaymen, of whom the best known to fame, Richard Turpin, was executed at York in 1739. 
The age was one in which men's callings were marked by their costume. Physicians carried a gold- or silver-headed CHAP. stick, and a muff to conserve the temperature of their hands. Barristers, like Counsellor Silvertongue in Hogarth's Marriage a la Mode, wore "the long robe" in the streets and clergymen their gown. The two were only distinguishable from behind by the absence of powder from the clerical wig, except in the case of military chaplains, who in this followed the mode of officers. The Spectator complains that young clergymen were parading the town in the scarves of doctors of divinity, to which noblemen's chaplains were also entitled, an innovation ridiculed by the poet Savage in The Progress of a Divine. The scarf, nevertheless, became commonly adopted. An analogous change complained of in the Tatler was the assumption by tradesmen of the laced hats, swords, and wigs tied with ribbon, worn by the gentry. A man's character might be discerned from his wig. In an amusing poem of Shenistone, The Extent of Cookery, the hero when a hard student, wears "a plain brown bob"; when a rising politician, his own hair in a bag; when a judge, "a full-bottom ". Hogarth divides wigs into five orders. Swift complained of paying three guineas for a wig; a beau would pay forty. The wire frames of the head-dresses of the ladies of Anne's reign, called "commodes," fell, according to the Spectator, by a change of fashion, two feet in height. Hoops, varying in shape more than in size, maintained themselves, despite ridicule, throughout the period; as did lace shirts and ruffles among men. The cost even of men's dress was very great. In 1746 Vice-Admiral Medley paid $£_{51}$ 5s. Id. and $£ 73$ 8s. for two embroidered waistcoats. ${ }^{1}$. Umbrellas were carried by women only, until, in 1756, Jonas Hanway, the philanthropist, broke through the rule. The dangers of the streets of London, their filthy state, the streams from the gutter-spouts, the pestilential "kennel," the scanty light from the lanterns and oil lamps at night were much the same in 1760 as when Gay wrote Trivia in 1716. But these inconveniences were trifling compared to the risk of being tormented by brawling men of fashion called "Mohocks" and "Hawkubites," or robbed and murdered by the footpads, who molested unfrequented thoroughfares. The severity of

'Lady Ducane's MSS., p. 117, Hist. NSS. Comm., 1905. 
CHAP. the penal law acted as a premium upon murder. In London XXVIII. alone 242 criminals were hanged at Tyburn between 1701 and I 7 I 3. Women were strangled and their bodies burnt for petit treason, that is, the murder of husbands, and coining. Men and women were put in the pillory, especially for seditious libel, and were sometimes killed by the ill-usage of the mob. The discipline in the navy and army, always severe, became incredibly harsh with the introduction of German methods during the Seven Years' War.

Manners were at once more formal and more intimate than to-day. Men kissed each other. Rigby writes to the Duke of Bedford on September 4, I 758: "I had kisses both from the Duke of Newcastle and Mr. Pitt, of congratulation upon ... the King of Prussia's victory". Sons and daughters, even when of mature years, knelt both in public and in private for their parents' blessing. Towards women men's demeanour ranged from ceremoniousness to brutality - a variety of conduct frequently consequent on wine-bibbing. "The people of England take all their liberty out in insulting pretty women," wrote Horace Walpole (June 23, I 759), when Lady Coventry, better remembered as Maria Gunning, one of two beautiful sisters, and Lady Waldegrave, next to her esteemed the handsomest woman in England, were mobbed by the crowd in the park. The king, hearing of it, ordered two sergeants of the guards and twelve guardsmen to attend their walks; nevertheless, as Charles Jenkinson, the future Earl of Liverpool, recounts in a lively letter, three days later "some impertinent things were still uttered, and some of Fielding's men that attended took up the most troublesome". Sports and amusements remained much the same throughout the century, and are described in the next volume. 


\title{
APPENDIX I.
}

\section{ON AUTHORITIES.}

\author{
ANNE.
}

I. Contemporary Writers on Generat Affairs.-Narcissus LUT- APP. I. TRELL's Brief Historical Narration of State Affairs from September, 1678,10 April, 1714 (6 vols., Clarendon Press, 1857 ) is a contemporary diary of public events, not always to be relied on for accuracy, much being extracted from newspapers, but with a good deal of valuable miscellaneous information. Bishop GILBERT BURNET'S History of His Own Times (6 vols., Clarendon Press, 1823) is carried down to the year 1713 . Burnet is somewhat unduly depreciated by Ranke, who, however, concedes to him a desire to be truthful. He was a strong whig, and his version of incidents should be compared with other accounts; but he played a leading part in whig politics, and is a first-rate authority where he speaks of matters in which he was himself actively engaged. Jonathan Swift's Memorial on the Change of Ministry (1 710 ) and History of the Last Four Years of Queen Anne are of value, as the author was the confidant of Harley, St. John, and other leading tories. But as they were not written until some years after the events, they must be corrected by his Journal to Stella (September 2, 17 10, to June 6, 17 13), which narrates his first impressions. His pamphlets in justification of Harley's policy on The Conduct of the Allies ( 1711 ) and Some Remarks on the Barrier Treaty are of the first importance. BolingBRoke's account of many of the same events in his Letter on the State of Parties at the Accession of George 1., is even more outspoken than Swift's, specially in his attacks on Harley. ABEL BoYkR's Annals of Queen Anne (1703-13), which in 1713 was renamed The Political State of Great Britain, is a valuable chronicle of events as they occurred, in the nature of the later Annual Register, and includes an account of debates in parliament. It forms the basis of his folio History of Qween Anne (1722). JOHN OldmixON, a vehement whig controver- 
APP. I. sialist, brought out a history of the reign in 1739 , but, like Swift, was too pronounced a partisan for his statements to be received without caution. Nicholas Tindal's continuation of Rapin's History to 1727 appeared in $\mathbf{1 7 4 4 - 4 5}$, and is a careful and impartial collection of facts and documents indispensable to historians. Political Ballads, edited by W. Walker Wilkins (2 vols., 1860), covers the three reigns. GEORGE LockharT of Carnwath, the leading Jacobite agent in Scotland during the reigns of Anne and George I., wrote Memoirs of the Affairs of Scotland from the queen's accession to the union in 1707 , and his Commentarys continues the history of the reign till its end. It is of the highest value for the history of the Jacobite movement, as is also his Register of Letters (see sub George I.) (2 vols., 1817). Evelyn's Diary continues to February, 1 706, but for the last four years contains but scanty entries. The State Trials record the proceedings against Oxford and others involved in the treaty of Utrecht. D. DE FoE, History of the Union between England and Scotland ( 1787 ). As a secret agent of the English ministry to report on the proceedings for a union, De Foe had unrivalled opportunities, and his book is the chief authority on the subject.

II. Contemporary Correspondence.-Correspondence of the Duke of Shrewsbury to 1707, edited by Archdeacon Coxe, 1821 , is of inferior importance for this queen's reign, though it contains some letters of Marlborough. The Letters and Dispatches of the Duke of Marlborough, edited by Sir George Murray ( 5 vols., 1 845 ), are probably the work of his secretaries, and chiefly useful for details of movements. Correspondance diplomatique et militaire $d u d u c$ de Marlborough, du Grand Pensionnaire Heinsius, etc., edited by G. G. Vreede (I vol., Amsterdam, I850), is an important collection of original letters in English and French between January, 1706, and April, 1707. The Private Correspondence of Sarah, Duchess of Marlborough (2 vols., 1838 ), and Letters of Sarah, Duchess of Marlborough (1875). The dislikes of the duchess are so acute that ill-natured statements concerning other people are to be received with caution. Two large quarto volumes of The Letters and Correspondence of BolingBROKE, while Secretary of State (1 798), extend from October, 17 ro, to the queen's death. Swirt's Journal to Stella (September 2, 1 710 , to June $6, \times 7 \times 3$ ) is a diary of political and social events (Works, edit. $x 883$, vols. ii. and iii.). PoPE's correspondence is in Elwis's Pope (vols. ii.-v.). Original Papers, edited by James Macpherson (2 vols., 1 775), contain correspondence between England and France and the Jacobites on the one hand and the court of the Elector of 
Hanover on the other, during the closing years of the reign; some APP. I. of the papers are said by Coxe to be "garbled"; see also the English Historical Review, xiii., 534 (1898). Coxe's Memoirs of Sir R. Walpole (1 798, vol. ii., pp. $1-46$ ) contains correspondence of this period. Epistolary Correspondence of Sir $R$. Steele was edited by J. Nichols (2 vols., 1809). Among the Additional Manuscripts in the British Museum are many letters of statesmen of the period, as Godolphin, Nottingham, etc. The Wentworth Papers ( 1883 ) contain the correspondence of LORD STRAFFord, one of the plenipotentiaries for the treaty of Utrecht, and afterwards one of the leaders of the tory party from 1705 to 1739 . A small number of important letters belonging to this reign are to be found in volume ii. of HARDwICKR.'s Miscellaneous State Papers (2 vols., 1 778). For Scottish affairs The Culloden Papers (1 815 ) contain letters down to 1747 ; M'Cormick's State Papers and Letters addressed to William Carstares (1774), papers of PATRICK, EARL OF Marchmont (1706-12), in Marchmont Papers (1871, vol. iii.), and Annals, etc., of the First Earl of Stair (1875) should also be consulted. J. M. Kemble's State Papers and Correspondence (1857), though largely occupied with continental politics, contains letters to and from eminent English politicians during this reign and that of George I., especially correspondence of Caroline of Anspach with Leibniz.

The Historical Manuscripts Commission has published many volumes of correspondence, of which the most important are, MSS. of Duke of Buccleuch, containing the correspondence of G. Stepney, ambassador at Vienna, and of Sir L. Blackwell, envoy at Florence; also of the Duke of Shrewsbury; also some interesting papers on Canada and the American colonies. The MSS. of Mrs. Frankland-Russell-Astley (1900) contain newsletters from G. de Lamberty, in the English diplomatic service at the Hague, to Lord Cutts, and other correspondence of Cutts. The MSS. of the Marquis of Bath (vol. i., 1904) are most important for the correspondence of Godolphin, Harley, Rivers, St. John, Marlborough, Shrewsbury, and the queen, etc.; of EARL CowPER (vol. iii., 1889) for letters on the campaign of 1704; of the Earl of Dartmouth (vol. i., 1887) for home affairs; of the Duke of Athole (1 vol., 1891) for Marlborough's campaigns; of T. J. Hare for Marlborough's campaigns; of J. E. Hodgkin (1897) for Report on State of Gaols, 1702-19; of the Earl of Mar and Kellie for the correspondence of James, sixth Earl of Mar, Secretary of State for Scotland, the letters relating to the union being of firstrate importance; of the Earl of Marchmont (1894) for letters on the union. The MSS. of the Duke of Portland, vol. ii. (1893), are 
APP. I. especially interesting at the time of the fall of the Godolphin ministry; volumes iv. (1897), v. (1899), contain Harley's correspondence, especially the letters of Daniel De Foe, his secret agent in Scotland at the time of the union, and his reports on the state of public opinion in England in 1704, accounts of some of Marlborough's battles, and many letters of great value. Volume viii. contains letters on Scottish affairs; as do also the MSS. of the Countess of Seafield (1894) and of J. J. Hope-Johnstone (1897). The MSS. of Lord Townshend ( 1887 ) contain correspondence of Lord Townshend while ambassador at the Hague, I 709-II, and letters of James Craggs when attached to the army in Spain, and of Horatio Walpole.

III. Contemporary Memoirs.- The Memoirs of John Ker of Kersland, in three parts ( 1726$)$, give an account of the intrigues of a professing Jacobite in Godolphin's pay. Ker, who claims to have suggested to the emperor the foundation of the "Ostend Company," much overrated his own importance. The Duchess of MarLBOROUGH's Account of Her Conduct, edited in 1742 by Nathaniel Hook, is a passionate vindication of herself. DE LA CoLonie's Chronicles of an Old Campaigner, I692-I7I7 (translation 1904), throw a light on the part played by the Bavarians during Marlborough's campaigns. The Mémoires de Villars (1705-11), lxix. of the Petitot collection, and the Mémoires de Berwick (1702-9), lxv., lxvi., give the French version of the war. BolingBroke's Works (edit. 1754) are largely concerned with the reign of George II. $A$ Metrical Account of the IVar in Flanders, by JoHN ScotT (Scottish History Society, vol. iii., I 901 ), is justly described by Boswell as written with "attention and genius too". The Letters and Works of Lady Mary Wortley Montagu (vol. i., 1709-14) are full of amusing gossip of court and society. The Military Memoirs of Captain Carleton, much relied on by Stanhope and other writers, are shewn by Colonel Parnell (War of Succession in Spain, Appendix C, p. 316) to be largely a fiction, probably inspired by Peterborough.

IV. Contemporary Pamphlets.-The Somers Collection of Tracts (vols. xii., xiii., $18(5)$ ). Swift's numerous pamphlets are to be found in the edition of his collected works. Some of the most important pamphlets are mentioned in the text. Mr. F. Madan has printed a bibliography of those on the Sacheverell case. The best-known pamphleteers, in an age of pamphleteering, were De Foe, Walpole, Bolingbroke, and, among divines, Atterbury and Hoadly. For Ireland, there is $A$ Collection of Tracts and Treatises (2 vols., 186r).

V. Collections of Documents.-F. Mignet, Negaciations Relatives 
d la Succession d Espagne sous Louis XIV. (4 vols., 1835-42); APP. 1. Garden, Histoire Gentrale des Traités de Paix (vols. ii.-iv.); Memoires Militaires relatifs d la Succession d' Espagne sous Louis XIV., Documents Inedits, edited by General Pelet (Paris, 1835-62). The Statutes of Anne are in The Statutes of the Realm (1822, vols. viii. and ix.). J. E. Thorold Rogers, $A$ Complete Collection of the Protests of the Lords (vol. i., 1624-1741; vol. ii., 1741-1825). Recueil des Traites et Conventions conclus par la Russie avec les Puissances Etrangeres (tome ix., $x$.): Trait's avec 1 Angleterre, $1710-1801$ (Petersburg, 1892). G. DE LAMBerTy, Mémoires pour Servir à 6 Histoire du xvisime siècle contenant les Nigociations, Traitts, etc. (14 vols., Amsterdam, 1735-40). Parliamentary History (vol. vi.), the speeches are, perhaps, more trustworthy during this reign, before the jealousy of the house of commons had been excited against reports, than they became a generation later.

VI. Later Histories. - In 1798 appeared Thomas Somerville's History of Great Britain during the Reign of Queen Anne. The author made use of many papers from the Buccleuch, Hardwicke, Townshend, and Orford collections, as well as of original records in Scotland. The result is a solid and valuable piece of work, comparable to those of Coxe. Die Feldzïge des Prinzen Eugen von Savoyen are published by the Austrian War Office, in which Marlborough is represented as playing a secondary part. There is a detailed Histoire Militaire du Regne de Louis le Grand, by the Marouis DE QUincy (7 vols., 1726). 'The period is covered by LoRD Stanhope's Reign of Queen Anne (1870), a well-written and, on the whole, trustworthy work, though occasionally discursive. His History of the War of the Succession in Spain, like that of Carl von Noorden, is to some extent vitiated by his acceptance as genuine of Carleton's Memoirs. Colonel the Hon. A. Parnell's War of Succession in Spain (1888) is the most complete account of the campaigns in the Peninsula. Ranke's History of England Principaliy in the Seventeenth Century (Eng. trans., 1875) (vol. v.) gives a philosophic view of the general political situation. J. H. Burton's Reign of Queen Anne (3 vols.) is of slight importance, except on Scottish affairs. F. W. WroN's History of Great Britain during the Reign of Qween Anne (2 vols., $1876)$ is a laborious compilation, founded on printed books, and written before most of the publications of the Historical MSS. Commission. Wolfgang Michael's Englische Geschichle im 18. Jahrhundert (vol. i. to 1718), a solid and valuable piece of work. C. voN NoORDEN, Europäische Geschichte im 18. Jahrhundert (3 vols., 1870-82), is the best general history of the period 1702-10. 
APP. I. OnNo Klopp's Fall das Hauses Stuart, etc. (14 vols., 1875-88), contains Anne's reign in volumes x.-xiv., and is a very detailed and meritorious work. F. Salomon's Geschichte des letzten Ministeriums Annas (r894) is an able apology for the tory ministry. For W. E. H. LEcky's History of England in the Eighteenth Century, see appendix to the next volume. J. S. Corbert, England in the Mediterranean (vol. ii. for 1702-13). The best ecclesiastical historians are Abbey and Overton, The English Church in the Eighteenth Century (1896); and for Anne, W. H. Hutton, in volume vi. of Stephens and Hunt's History of the English Church (1903). LeSLie STePhen's History of English Thought in the Eighteenth Century (2 vols., ' 1876 ) is learned and able. OtTocar Weber, Die Friede von Utrecht (1891), is a work of research. A. LEGRELLE, La Diplomatie Française et la Succession d'Espagne, volumes iv.-vi. cover the years I 700-25, a learned work of much detail. A. T. Mahan's Influence of Sea Power upon History, 1660-1783, may be consulted for the whole of the period. J. Entick, New Naval History (1757), contains many documents of value to the naval historian, and ends with the execution of Admiral Byng in 1757. Hon. J. W. Fortescue's History of the British Army (1899, part i.) covers the period. E. PorRITT, The Unreformed House of Commons (2 vols., I 903), is a complete account of the composition of the house of commons in the three kingdoms and of the variety of elective franchises during the whole period. Hallam's Constitutional History of England also embraces these three reigns. Ashton's Social Life in the Reign of Anne (1882) abounds with curious pictures of manners. H. R. Fox BOuRNe, English Newspapers, has much information for the whole period.

For Ireland, see LECKY throughout this period (1 702-60), but with his work should be read T. DunBar INGRAm's Critical Examination of Irish History (vol. i., 1900). On the same lines as Lecky is Two Centuries of Irish History (1888, part i.), by Dr. W. K. Sullivan. F. Plowden's History of Ireland (2 vols., 1809) is a heavy but useful work. An elaborate study of the financial and commercial affairs of Ireland has recently (1903) been published by Miss A. E. Murray; see also The Commercial Restraints of Ireland, by Hely Hutchinson (reprinted in 1882), and $A$ Collection of Tracts and Treatises (2 vols., Dublin, 1861). FROUDE's The English in Ireland in the Eighteenth Century (vol. i.) is a vivid exposition of the incompatibility of the Irish national character with English constitutional forms.

VII. Biographies, -The Life of Sidney, Earl of Godolphin, K.G., 
by the Hon. Hugh Ellot (1888), is a political study founded APP. I. upon original correspondence, yet not very rich in detail. Coxe's Memoirs of Marlborough remains the best biography of that great general: the first part of his Memoirs of Sir $R$. Walpole should also be cunsulted. Miss Strickland's life of Anne in her Lives of the Qucens of England $(1848)$ shews research, but is not critical. Of the various Lives of Bolingbroke, T. MACKNIGHT's (1863) remains by far the best. R. HARRop's Bolingbroke (1884) is, as its sub-title indicates, "a political study and criticism" of merit. C. von NoORDEN in his Historische Vorträge ( $\left.188_{4}\right)$ includes Bolingbroke among other studies of the period. JoHN Forster's Life of Swift is well written, but is unfinished, ending with 1711 ; Sir Henry Craik's Life (1882) remains the best. Harley's biography, with an adequate use of original MSS., is still to be written; Mr. E. S. Roscoe is the author of a biographical sketch (I vol., I 902). J. Campbell's Lives of the British Admirals, and the excellent series of Lives of great seamen by Sir J. K. Laughton in the Dictionary of National Biography are throughout the period worth consulting. 'The same may be said of the Lives of the Chancellors and Chief Justices, by Lord Campbell. For ecclesiastical biographies see C. J. ABвey, The English Church and Its Bishops (1700-1800). For a vindication of the union with Scotland against Lockhart's aspersions, see The Defence of Patrick, Earl of Marchmont, by G. H. Rose, in introduction to the Marchmont Papers (3 vols., i 831). J. M. Graham's Annals and Correspondence of the First and Second Earls of Stair ( 2 vols., 1875 ) gives an account of the part played by the first earl in promoting the union of Scotland with England, and by the second while serving under Marlborough.

\section{GEORGE I.}

1. Contemporary Writers on General Affairs.-BOLIngBroke's State of Parties, etc. BoYer's Political State (1711-40). Nicholas TINDAL's Continuation, see p. 504 (1714-27). Scottish History from Contemporary Writers, No. iv., The Chevalier de St. George, edited by C. S. Terry (1901), a useful collection of evidence as to the Jacobite schemes prior to 1715 , and the rebellion itself. Many contemporary letters, etc., are to be found in the volumes published by the Scottish History Society.

II. Contemporary Correspondence. $\rightarrow$ Register of Letters 'nvixt the King (the Old Pretender) and George Lockhart of Carnwath, containing also a short Account of Public Affairs from 1716 to 1728 . See also p. 504. Letters of Lady Mary Wortley Montagu, $1714-27$ (2 rols., 186 I). 
APP. I. Historical Manuscripts Commission: MSS. of Duke of Athole (1891), a few letters and papers on the rebellion of 1715 ; of the Earl of Carlisle (1897), on the same subject, the South Sea Company, etc.; of the Earl of Dartmouth (vol. i.), letters from Lord Oxford; of LADY DU CANE (1905), throwing light on the naval administration. Hodgkin MSS., collection of Jacobite correspondence (1 7 1 4-34). MSS. of the Earl of Mar and Kellie (1904), correspondence during the rebellion of I $_{71}$, when Lord Mar was the pretender's commanderin-chief in Scotland. Portland MSS., volume v. (1899) contains correspondence of Harley, Earl of Oxford, and in particular Auditor Edward Harley's Memoirs of the Harley Family, especially of Robert Harley, First Earl of Oxford, and other valuable matter. Volume vi. contains some interesting accounts of the debates in Parliament on the impeachment of Macclesfield in 1725. Earl of Marchmont's MSS. (1894), letters on the rebellion of I7 15 . Earl of Onslow's MSS. (1895), some most important papers by Speaker Onslow, reviewing political history from 1714 to 1727 . J. J. Hope-Johnstone's MSS. (1897), correspondence of the Marquis of Annandale on the rebellion of 17 1 5. Townshend MSS. (1887), letters of Bolingbroke while in Paris, of Sir R. Walpole, and Jacobite letters, 1 703-2 7.

III. Contemporary Memoirs.-Diary of Lord Chancellor Cowper (1833), not very full but of high authority. Diary of Mary Countess Cowper (I 7 1 4-20).

IV. Contemporary Pamphlets. - The Somers Collection of Tracts, volume xiii. (1815). Numerous pamphlets, especially by $\operatorname{Sir} R$. Walpole, Bishop Hoadly, Horatio Walpole, and many others.

V. Collections of Documents.-See sub Anne, v., Parliamentary History, volumes vii.-viii. (see p. 506).

VI. Later Historians.-For RANKE, History of England (vol. v.), Stanhope, Lecky, W. Michael, Froude, Plowden, Ingram and MurRay (see sub Anne, vi., p. 507, supra). A. W. WARD, Great Britain and Hanover (1899), a valuable study of the political consequences of the union between the kingdom and the electorate. Papers in the English Historical Review for 1900-I on "The Foreign Policy of England under Walpole," by Basil Williams, and on the "Baltic Policy," by J. F. Chance, ibid., 1901-8. Both these series are full studies of their subjects, drawn from MS. sources. OtTocar Weber, Die Quadrupe!:-Allianz von 1718 (1887), a learned monograph. On the same subject is L. WIESENER, Le Regent, l Abbe Dubois et les Anglais, d'apres les sources Britanniques (3 vols.; 1 891, 1893, 1899), 1 7 14-23, a thorough piece of work, with abundant references. Syveton, Une Cour et un Aventurier au $\mathrm{XVIII}^{e}$ sìcle: 
Le Baron de Ripperda (Paris, 1896), valuable for the treaties of Vienna APP. 1. of 1725 , and the policy of the Emperor Charles VI. and of Philip V. towards England. With this may be coupled E. Armstrong's Elisabeth Farmese (1892), a brilliant study. A. Hassall's Balance of Power, 1715-89 (1896), is a compendious but able review of international relations in Europe, especially as illustrating the decline of French ascendancy. ThOMAS WRIGHT, Caricature History of the Georges, illustrates the reigns generally from the point of view of the opposition. John Ashton, The Fleet ; its River, Prison, and Marriages (1888), and the History of English Lotteries (1893), give features of social life in the reigns of George I. and II.

VII. Biographies.-W. Coxe, Memoirs of Horatio, Lord Walpole ( 2 vols., 1820 ), from $1678-1757$, is a solid work giving an account of the principal diplomatic negotiations of the reigns of George $I$. and II., in which Walpole, who represented Great Britain in Holland and France at various times between 1709 and 1739 , took an active part. The same author's Memoirs of Sir $R$. Walpole, with the corrospondence, is a standard work. ROBERT CAMPBELl, Life of John, Second Duke of Argyll (1 745), is a volume of hero-worship. A. BallanTYNE, Life of Carteret, $1690-1763$ (1887), is well written and full of matter. A. W. WARD, The Electress Sophia and the Hanoverian Succession (1903), is of high authority. R. Nisbet Bain, Charles XII. (New York, 1895), gives a lucid account of the attempt to form an alliance to counteract the Quadruple alliance. A good deal of information about George I.'s wife is contained, notwithstanding its title, in W. H. WILKINs's The Love of an Uncrowned Queen (2 vols., and edit., 1900). For the second Earl of Stair's famous embassy to France, and subsequent career as commander-in-chief, see Annals and Correspondence of the Earls of Stair (see above, p. 505). C. S. KING, W. King, a Great Archbishop of Dublin, 1650-1729 (1906), is valuable for Irish affairs.

\section{GEORGE II.}

I. Contemporary Writers on General Affairs.-Lord Hervey's Memoirs of the Reign of George II. are of the first importance down to the queen's death in 1737. He was for many years at court in close friendship with the queen and Walpole. HoraCE WALPOLE, Memoirs of the Reign of George 1I. (3 vols., 1846), open at 1751 , and are the principal authority for that part of the period. He was animated by a violent dislike of all who were instrumental in the overthrow of his father, Sir Robert. While Hervey presents us with the opinions 
APP. I. of the court and the ministries, Horace Walpole pictures affairs from the point of view of society and the house of commons. The Memoirs were prepared for publication during his later life, and are sometimes inaccurate in details, as at times appears from the same author's Letters (Oxford, 1903), which should be read with them. Volumes i.-iv. embrace this period. Scottish History from Contemporary Writers, No. iii.; The Last Jacobite Rising, 1745, with a Biblio. graphy of Jacobite History, 1689-1 788, by C. S. Terry (1903). The Works of Sir Charles Hanbury Williams (3 vols., 1822) include a collection of witty poetical satires from 1739-57.

II. Contemporary Correspondence.-Of the first five volumes of Elwin's edition of the Letters of the Poet Alexander Pope, volumes i. and ii. to page 96 belong to the reigns of Anne and George I., the rest to the reign of George II. This correspondence was with the principal literary and political personages of the day, Pope ranging himself with the opposition to Walpole inspired by Bolingbroke. With due allowance for the writer's prejudices, the letters are full of material, especially for social and literary history. HoRACE WalPole's Letters. Papers of Alexander, Second Earl of Marchmont (1733-40), the correspondence of Scottish peers in opposition to Walpole. The correspondence of the third Earl of Marchmont, who was intimate with Pope and Bolingbroke (1739-50), is also published in volume ii. of the Marchmont Papers (3 vols., 1831). A. Bısset, Memoirs and Papers of Sir Andrew Mitchell, K.B. (2 vols., $185^{\circ}$ ), contain the diplomatic correspondence of our ambassador with Frederick the Great during the Seven Years' War, and are of the highest value for that period. The Grenville Papers (vol. i., 1852) have an importance as the correspondence of the circle with which Pitt was associated. The Correspondence of John, Fourth Duke of Bedford (vols. i. and ii., r 842-43), political, and full of matter, specially as regards Ireland. The Chatham Correspondence (vols. i. and ii., I 838) between $174^{1-60}$ of first-rate importance. Chesterfield's Letters, edit. J. Bradshaw ( 3 vols., 1892 ), valuable rather for their social than for their political information. This is also true of the Letters to and from Henrietta (Howard), Countess of Suffolk (2 vols., I824), who was on terms of friendship with the leading literary men and politicians of the day. The letters of Charlotte Clayton, Lady Sundon, who once proposed to Walpole that he and she should govern the kingdom togethar, are published in Mrs. Thomson's Memoirs of Lady Sundon (2 vols., 1847). The Letters of $C$. de Saussure, translated under the title of $A$ Foreign View of England in the Reigns of George I. and George II. (1902), give interesting 
pictures of manners. Primate Boulter's Letters, $1724-48$ (2 vols., APP. I. 1769); are of the first importance for Irish affairs.

Reports of Hist. MSS. Comm. of MSS. of Duke of Athole (189r), a few letters and papers on the rebellion of 1745 ; of Mrs. Frankland-Russell-Astley (1900), letters on the campaigns of Dettingen and Fontenoy; of the Earl' of Buckinghamshire (1895), including the Trevor MSS., the very valuable correspondence of the first Lord Trevor, minister at the Hague from 1735 to 1746 ; of the Earl of Carlisle (1897), letters on the differences between Frederick, Prince of Wales, and the King, and on proceedings in the house of commons; of the Earl of Charlemont (189r, vol. i., 1745-83); contains a memoir by him of his political life, $1755-83$, and papers on the French landing at Carrickfergus in 1760 , and on the condition of the Irish catholics, etc.; of Lady du Cane (1905), correspondence of Admiral Medley, very interesting for naval affairs, with letters from Admiral Hosier during the blockade of Porto Bello in I 726, correspondence on naval affairs during 1745 , letters from Admiral 'John Byng during operations in the Mediterranean, and captured dispatches throwing light on the state of the French navy; of Sir William Fitzherbert (1893), letters on the rebellion of 1745. Hodgkin MSS: (1900), letters on the rebellion of 1745 . Colonel Home's MSS. (1902), letters on campaign of 1759.60 ; Lord Kenyon's (1894), on the rebellions of 1715 and 1745; Earl of Mar and Kellie's (1904), correspondence of Lord Grange with Pulteney, Angyll, and other leading men; Duke of Rutland's (vol. ii., r 889); correspondence of the Marquis of Granby during his campaigns in 1747 and 1759-62 ; Mrs. Stopford-Sackville's (vol. i., 1904), a few letters of Lord George Sackville, Henry Fox, Pitt, Primate Stone, the Duke of Newcastle, etc., more particularly valuable for Irish history. The Stuart Papers (vol. i., 1902 ; vol. ii., 1904; vol. iii., 1907). Some of these letters and papers have been already published, but the entire mass is now being catalogued and printed together, affording a complete view of the Jacobite conspiracies from the flight of James II. The third volume carries the reader down to February, 1717. Tounshend MSS. (1887); letters on American affairs, $1700-$ 40, and letters of General George Townshend, 1759. The Newcastle and Hardwicke Papers fill many volumes of the Additional MSS. in the British Museum.

III. Contemporary Memoirs.-Diary of .Hugh, Earl of Marchmont, $1744-48$, is valuable for Bolingbroke's communications to him : Marchmont was also intimate with Chesterfield, Stair, and the principal Scottish peers (Marchmont Papers, vol. i., 1831). R. GLover's VOL. IX. 
APP. I. Memoirs (1742-57) contribute somewhat to our knowledge, though much more may be gleaned from The Diary of George Bubb Dodington (Lord Melcombe) (1809). Memoirs (1 754-58), by JAMES, EARL of Waldegrave (1821), scanty but trustworthy. Kalm's Visit to England, translated by Joseph Lucas (1892), is the account by a Swedish botanist of his travels in 1748 , a large part of it consisting of scientific observations.

IV. Contemporary Pamphlets.-These are too numerous to mention in detail. The most eminent pamphleteers were Swift, Lord Hervey, Sir R. Walpole, Bolingbroke, Hoadly, and Horatio Walpole.

V. Collections of Documents. - See above, p. 506. Parliamentary History (vols. viii.-xv.). The speeches, as has been explained elsewhere, are not to be relied on as conveying anything beyond general impressions. The public documents are authoritative.

VI. Later Historians.-See above, p. 5 Iо. J. Colin, Louis XV. et les Jacobites, 1743-44 (1901), an account from French archives of the attempted invasion of England. Die Nordische Frage in den Jahren I 746-51, by J. R. DANielson (1888), a valuable work, drawn more particularly from Russian, Danish, Swedish, and British archives. W. Oncken, Das Zeitalter Friedrichs des Grossen (2 vols., 1881-82), an exhaustive survey of European politics between 1701 and the Seven Years' War, which may be read with T. Carlyle's History of Frederick II., vii.-ix. To the same period belongs M. RICHARD Waddington, Louis $X V$. et le Renversement des Alliances, 1754-56 (1896), a history of the diplomatic preliminaries of the Seven Years' IVar, followed by La Guerre de Sept Ans (4 vols.), the most authoritative account of the war. The DUKE DE Broglie's Histoire de la Politique Exterieure de Louis $X V$., $1741-56$, in ten volumes (1883-99), may also be consulted with advantage. The last volume of Coxe's History of the House of Austria deals with this period. His Memoirs of the Administration of H. Pelham (2 vols., 1829) is a posthumous publication, but, like all this author's work, learned and trustworthy. Julian CoRbetr, England in the Seven Years' War (2 vols., 1907), is an admirable study of Pitt's strategy. F. $\mathrm{H}$. SkRINe, Fontenoy (1906), is a detailed account of the British campaigns in the war of the Austrian succession, $1741-48$, and is full of useful information.

Much yet remains to be done on the history of finance of the period. Sir John Sinclair's History of the Public Revenue (3 vols., 1803) is the best authority. In commercial matters, N. A. BRisco, The Economic Policy of Robert Walpole (New York, 1907), has brought together the leading measures of Walpole. 
T. Wright, Caricature History of the Georges (1868), illustrates APP. I. public opinion on current politics. J. Ashron, see George I., vi., supra. For Literature, etc., see chapter xxviii., p. 5 I I.

On naval and military history, Mahan and Fortescue, see volume x., page 467. JoHn ENTick, New Naval History, 1757, a laborious compilation; also his General History of the Late War (5 vols., $1763-64$ ).

For Indian, transatlantic and colonial affairs generally, R. ORME, History of the Military Transactions of the British Nation in Indostan from the Year 1745 (1763), praised by Macaulay as "one of the most authentic and finely written in our language". J. Malcolm, Life of Clive (1836), the recognised biography of Clive. A. Zimmermann, Die Europäische Kolonien (1896-1901), gives a compendious survey. The Hon. M. Elphinstone's Rise of British Ponver in the East (ed. 1887) is a good summary of Indian history. James MıLl, History of British India (5th edit., 9 vols., 1858), remains a standard work. Bryan EDwards, History of the British Colonies in the West Indies (5 vols., 1849), is a leading authority.

For America, W. Kingsford's History of Canada (1 888-90), vols. ii. to iv., covers the whole period. F. Parkman, France and England in North America, in 9 volumes (ed. 1874-93), is a work well written, impartial, and founded on original authorities. G. L. BEER, British Colonial Policy, 1754-65 (New York, 1907), is chiefly drawn from the papers in the Public Record Office, London, and is a valuable addition to knowledge. A. Dougrty, The Siege of Quebec and the Battle of the Plains of Abraham (6 vols.), is an exhaustive study of Wolfe's campaign. The Correspondence of $W$. Pitt with Colonial $\checkmark$ Governors (New York, 2 vols., 1 906) is most valuable for the conquest of Canada, etc.

VII. Biographies.-G. HARRIS, Life of Lord Chancellor Hardwicke ( 3 vols., 1847 ), full of original matter; so also is J. Holliday's Life of William Murray, Earl of Mansfield (1 vol., 1797). W. ERnst, Life of Lord Chesterfield ( 1893 ), draws a good deal from the Newcastle Papers. Coxe's Memoirs of Sir $R$. Walpole, with his correspondence, continues till the minister's death in 1745. C. Nugent's Memoir of Robert, Earl Nugent (1741-60), gives some insight into the political circle of Dodington and Glover. To the same group belonged GeORGE, LoRd Lytrelton, whose Memoirs and Correspondence were published by Sir R. J. Phillimore in 1845 . Thackeray's History of $W$. Pitt, Earl of Chatham (2 vols., 1827) contains much information and numerous documents. An exhaustive 
APP. 1. biography was published in German by A. von Ruville in 1905 (English translation, 1907): Colonel Townshend's Military Life of George, First Marquess Townshend (1901) gives valuable particulars of the American campaigns of 1759-60. LORD FitzMaurice's Life of Shelburne, wolume i. contains some interesting political matter; A. C. Ewald's Life and Times of Charles Stuart, the Young Pretender (2 vols., 1875), remains the standard biography. Prosper Cultru, Dupleix, etc. (1901), supplies information largely from unpublished French sources. MaCaulay's Essays on Chatham, Clive, etc., are well known. The Dictionary of National Biography will repay consultation.

In conclusion, I desire to record my obligations to the officials of the Record Office for the facilities granted by them for the perusal of documents not as yet finally catalogued; and to Mr. A. D. L. Cary, archivist of the War Office, for aid in research upon the military career of Pitt. Still more am I indebted to the laborious exertions of Miss Margaret Cotter Morison, who has kindly rendered the most valuable assistance by the perusal and transcription of great numbers of MSS:, both in the Record Office, the British Museum, and elsewhere, as well as in the construction of this bibliography. 


\section{APPENDIX II.}

ADMINISTRATIONS, I 702-1760.

ANNE.

APP. II.

\section{GODOLPHIN, 1702.}

Lord Treasurer

Lord President of Couwcil

Lord Privy Seal

Chancellor of Exchequer

Lord Chancellor

Secretary of Statc (Northern Dept.).

Secretary of State (Southern Dept.).

Lord-Licutenant of Ireland 1710. Legge, Ld. Dartmouth, succ. June 15.

became Ld. Cbancellor, May, 1707.

Daniel Finch, E. of Nottingham; Robert Harley, succ. 1704 ; Hon. Henry Boyle, succ. 1708 ; Henry St. John, succ. 1710.

Sir Chas. Hedges; Chas. Spencer, E. of as. Butler, D. of Ormonde; Thos. Herbert, E. of Pembroke, succ. 1707 ; Thos. Wharton, E. of Wharton, succ. 17 10.

Secretary for Scolland . . . Jas, Douglas, D. of Queensberry.

Lord High Admiral . . . . Pr. George of Denmark; Thos. Herbert, E. of Pembroke, succ. 1708.

Secretary at War . . . . Henry St. John, to Feb., I 708 ; Robert Walpole, succ. 1708, dismissed Sept., I7ro; Geo. Granville, succ. Sept., 1710.

\section{ROBERT HARLEY, 1710.}

First Lord of Truasury - . . John Poulett, E. Poulett, Aug. 10, 1710. Chancellor of Excheguer : . : Robert Harley, Aug. 10, 1710.

Lord President . . . . . Lawrence Hyde, E. of Rochester, Sept. 21, Lord Keeper . . . Sir Thos.

Lord keeper . . - Sir Thos. Trevor; Sis

Secretary of State (Northern Dept) . Henry St. John. 
APP. 11. Secretary of State (Southern Dept.) . Wm. Legge, Ld. Dartmouth.

Lord Privy Seal . - . . John Holles, D. of Newcastle, d. July, I7II.

Lord-Lieutenant of Ireland ～. Jas. Butler, D. of Ormonde.

First Lord of Admiralty . . . . Sir John Leake.

Treasurer of Navy . . . . Robt. Walpole, dismissed Jan., 1711.

III. ROBERT HARLEY, EARL OF OXFORD AND MORTIMER, I7II.

Lord Treasurer . Robt. Harley, E. of Oxford, etc., May 29, I7II; Charles Talbot, D. of Shrewsbury, July 30,1714 .

Chancellor of Exchequer . . . Robt. Benson, June, I7II.

Lord President. . . . . John Sheffield, D. of Buckinghamshire, June, I7II.

Lord Keeper . . . . . . Sir Simon Harcourt.

Lord Chancellor . . . . Sir Simon Harcourt, Ld. Harcourt, April 7, 1713.

Secretary of State (Northern Dept.) . Henry St. John (cr. Visc. Bolingbroke, 1712).

Secretary of State (Southern Dept.) . Wm. Legge, E. of Dartmouth; Wm.

Lord Privy Seal Bromley, succ. Aug., 1713.

. . . John Robinson, Bishop of Bristol, April 23, I7I I; Wm. Legge, E. of Dartmouth, succ. Aug., I713.

Lord-Lientenant of Irelard - . Jas. Butler, D. of Ormonde ; Chas. Talbot, D. of Shrewsbury, succ. Sept., I7r3.

First Lord of Admiralty . . . Sir John Leake ; Thomas Wentworth, E. of Strafford, succ. I712.

\section{GEORGE I.}

I. CHARLES TOWNSHEND, VISCOUNT TOWNSHEND, SEPtember, I7I4.

First Lord of Treasury - . - Chas. Montagu, E. of Halifax, d. I715; Chas. Howard, E. of Carlisle, succ. May, I715 ; Robt. Walpole, succ. Oct., 1715.

Lord Chancellor . . . . Wm. Cowper, Ld. Cowper.

Lord President $\quad$ - . . . Daniel Finch, E. of Nottingham; Lionel Cranfield Sackville, E. of Dorset, succ. Jan., 1715; Wm. Cavendish, D. of Devonshire, succ. July, I7I6.

Lord Privy Seal . . . . 'Thos. Wharton, M. of Wharton, d. I7I5;

Chas. Spencer, E. of Sunderland, succ. Aug., 1715; Evelyn Pierrepont, D. of Kingston, succ. Dec, 1716.

First Lord of Admiralty . . . Edward Russell, E. of Orford.

Secretary of State (Southern Dept.) . Jas. Stanhope.

Secretary of State (Northern Dept.). Chas. Townshend, Visc. Townshend.

Lord-Lieutenant of Ireland . . Chas. Spencer, E. of Sunderland; Chas. Townshend, Visc. Townshend, succ. I7r6.

Secretary for Scotland . . . Jas. Graham, D. of Montrose ; John Ker, D. of Roxburghe, succ. I716.

Captain-General . . . John Churchill, D. of Marlborough.

Paymaster-General of Forces : Robt. Walpole; Hen. F. Clinton, E. of Lincoln, succ. Oct., r7t5. 
Fint Lord of Treaswry and Chancel-

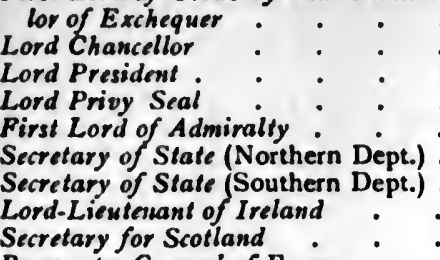

James, Lord Stanhope.

William, Ld. Cowper.

Chas. Spencer, E. of Sunderland.

Evelyn Pierrepont, D. of Kingston.

Jas. Berkeley, E. of Berkeley.

Chas, Spencer, E. of Sunderland.

Joseph Addison.

Chas. Powlett, D. of Bolton.

- John Ker, D. of Roxburghe.

Paymaster-General of Forces . . Hen. Clinton, E. of Lincoln.

III. JAMES STANHOPE, LORD STANHOPE, MARCH, I7I8.

First Lord of Treasury . . . Chas. Spencer, E. of Sunderland.

Chancellor of Exchequer . . . John Aislabie.

Lord Chancellor - . . . Thos. Parker, Lord Parker.

Lord President . . . . - Chas, Spencer, E. of Sunderland; Evelyn Pierrepont, D. of Kingston, Feb, 1719 ; Chas. Townshend, Visc. Townshend, June, 1720.

Lord Privy Seal . . . . Hen. Grey, D of Kent; Evelyn Pierrepont, D. of Kingston, June, 1720.

First Lord of Admiralty . - . Jas. Berkeley, E. of Berkeley.

Secretary of State (Northern Dept.) - Jas. Stanhope, E. Stanhope.

Secretary of State (Southern Dept.) . Jas. Craggs.

Lord-Lieutenant of Ireland - - Chas. Powlett, D. of Bolton.

Secretary for Scotland . - . John Ker, D. of Roxburghe.

Paymaster-General of Forces - $\quad$ Henry Clinton, E. of Lincoln; Robert Walpole, 1720.

\section{ROBERT WALPOLE, 1721 .}

First Lord of Treasury and Chancellor of Exchequer.

Lord Chancellor : : : :

Perker, E. of Macclesfield ; Sir

Lord President . Peter King, Ld. King, succ. I725.

succ. 1725.
Lord Privy Seal $\quad$ - . Evelyn Pierrepont, D. of Kingston, d. 1726 ; Thos. Trevor, Ld. Trevor, succ. March, 1726.

First Lord of Admiralty - . - Jas. Berkeley, E. of Berkeley.

Secretary of State (Northern Dept.). Chas. Townshend, Visc. Townshend.

Secretary of State (Southern Dept.). John Carteret, Ld. Carteret; Thos. Pelham Holles, D. of Newcastle, succ. 1724.

Lord-Lieutomant of Ireland - . Chas. Fitzroy, D. of Grafton; John Carteret, Ld. Carteret, succ. 1724.

Secretary for Scolland : . . John Ker, D. of Roxburghe, resigned 1725 .

Paymaster-General of Forces : " Chas. Cornwallis, Ld. Cornwallis, d. I722: Hon. Spencer Compton (cr. E. of Wilmington, I730).

Secretary at War

- Geo. Treby ; Henry Pelham, succ. 1724. 
I. SIR ROBERT WALPOLE, I727, TO FEBRUARY, 1742.

First Lord of Treasury and Chancellor of Exchequer. . . . Lord President.

Lord Privy.Seal

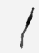

Lord Chancellor

-

First Lord of Admiralty .'

Secretary of State (Southern Dept.). Secretary of State (Northern Dept.) .- Chas.

Lord-Lieutenant of Ireland

Secretary for Scotland

Paymaster-General of Forces
Sir Robt. Walpole.

Wm. Cavendish, D. of Devonshire; Thos. Trevor, Ld. Trevor, succ. May, $173^{\circ}$; Hon. Spencer Compton, E. of Wilmington, succ. Dec. 3I, 1730.

Thos. Trevor, Ld. Trevor ; Hon. Spencer Compton, E. of Wilmington, suce. May, I730; Wm. Cavendish, D. of Devonshire, succ. June, 173r; Henry Lowther, Visc. Lonsdale, succ. May, 1733; Fr. Godolphin, E. of Godolphin, succ. May, I735; John Hervey, Ld. Hervey, succ. April, 1740.

Sir Peter King, Ld. King; Hon. Chas. Talbot, succ. Nov., 1733 ; Sir Philip Yorke, Ld. Hardwicke, succ. Feb., 1737.

Sir Geo. Byng, Visc. Torrington; Sir Chas. Wager, succ. Jan., 1733.

Thos. Pelham Holles, D. of Newcastle.

Chas. Townshend, Visc. 'Townshend; Wm. Stanhope, Ld. Harrington, succ. June, I730.

John Carteret, Ld. Carteret ; Lionel Cranfield Sackville, D. of Dorset, succ. Sept., 173I; Wm. Cavendish, D. of Devonshire, succ. 1737 .

Thos. P. Holles, D. of Newcastle; Chas. Douglas, E. of Selkirk, succ. x73r.

Hon. Sir Spencer Compton (cr. E. of Wilmington, 1730); Hon. Henry Pelham, succ. $x 730$.

\section{JOHN CARTERET, LORD CARTERET, FEBRUARY, 1742.}

First Lard of Treasury . . . Hon. Spencer Compton, E. of Wilmington, d. 1743; Henry Pelham, succ.

Chancellor of Exchequer - . . A Samuel Sandys; Henry Pelham, succ. Aug., 1743.

Lord President . . . . . Wm. Stanhope, E. of Harrington.

Lord Privy Seal . : $\quad$ - John Leveson Gower, Ld. Gower, till Dec. Io, 1743; Geo. Cholmondeley, E. of Cholmondeley, succ. Dec., I743.

Lord Chancellor Philip Yorke, Ld. Hardwicke.

Secretary of State (Southern Dept.) : Thos. Pelham Holles, D. of Newcastle.

Secretary of State (Northern Dept.) : John Carteret, Ld. Carteret (became E.

First Lord of Admiralty .. $\quad$. Daniel Finch, E. of Winchilsea.

Lord-Lieutenant of Ireland - . Wm. Cavendish, D. of Devonshire.

Secretary for Scotland . . . John Hay, M. of Tweeddale.

Paymaster-General of Forces : : Hon. Henry Pelham; Thos. Winnington, succ. 1743 . 
111. THE PELHAMS, NovemarR, 1744.

APP. II.

First Lord of Treasury and Chancellor of Exchequer. . .

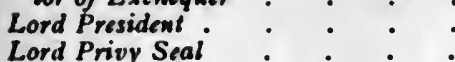

Lord Chancellor . . . .

Secretary of State (Northern Dept.).

Secretary of State (Southern Dept.) .

First Lord of Admiralty.

Lord-Lientenant of Ireland : : Secretary for Scotland . . - John Hay, M. of Tweeddale.

Paymaster-General of Forces : - Thos. Winnington, d. April 23, 1746;

Wm. Pitt, May 6, 1746 .

Hon. Henry Pelham.

Lionel Cranfield Sackville, D. of Dorset.

John Leveson Gower, Ld. Gower.

Philip Yorke, Ld. Hardwicke.

Wm. Stanhope, E. of Harrington.

Thos. Pelham Holles, D. of Newcastle.

John Russell, D. of Bedford.

Wm. Cavendish, D. of Devonshire; $\mathrm{Ph}$. Dormer Stanhope, E. of Chesterfield,

\section{William PULTENEY, EARL OF BATH, Frbruary 10-12, 1746.}

In February, 1746, Pelham and his friends tendered their resignation to the king, whereupon the Earl of Bath, guided by Granville, undertook the formation of a ministry, which expired, however, in two days while yet incomplete: The members actually appointed were as follows:-

First Lord of Treasury - . . Wm. Pulteney, E. of Bath.

Secretary of State - . . . John Carteret, E. Granville.

Lord Privy Scal : . . - Hen. Howard, E. of Cárlisle.

First Lord of Admiralty : $\quad$ - $\quad$ - Daniel Finch, E. of Winchilsea.

\section{PELHAM MINISTRY AGAIN, Frbruary, 1746.}

First Lord of Treasury and Chancellor of Exchequer

Lord President.

Lord Prioy Seal

Lord Chancellor

Secretary of Stale (Northern Dept.) .

Secretary of State (Southern Dept.)

First Lord of Admiralty

Lord.Licutenant of Iroland

Secretary for Scotland Paymaster.General of Forces
Hon. Henry Pelham, d. March 6, 1754.

Lionel Cranfield Sackville, D. of Dorset ; John Carteret, E. Granville, succ. 1751 . John Leveson Gower, Ld! Gower.

Philip Yorke, Ld. Hardwicke.

Wm. Stanhope, E. of Harrington, Feb. 14, 1746; Philip Dormer Stanhope, E. of Chesterfield, Nov. 4, 1746: Thos. Pelham Holles, D. of Newcastle, succ. Feb. 6, 1748.

Thos. Pelham Holles, D. of Newcastle, till Feb. 6, 1748; John Russell, D. of Bedford, Feb. 12, 1748 , till June 13. 1751 ; Robt. Darcy, E. of Holdernesse, succ. June 21,1751 .

John Russell, D. of Bedford, till Feb. 6, $174^{8}$; Johñ Montagu, E. of Sandwich, succ. 1748; Geo. Anson, Ld. Anson, succ. 1751 .

Phil. Dormer Stanhope, E. of Chester. field, Dec., 1744; Wm. Stanhope, E. of Harrington, succ. Sept., 1747; Lionel Cranfield Sackville, D. of Dorset, succ. Sept., 175r.

Office not fllled up.

William Pitt. 
APP. II. VI. THOMAS PELHAM HOLLES, DUKE OF NEWCASTLE, APRIL, 1754 .

First Lord of Treasury - . - Thos. Pelham Holles, D. of Newcastle.

Chancellor of Exchequer . . . Hon. Henry Bilson Legge; Sir Geo.

Lord President . . . . . John Carteret, E. Granville. Lyttelton, succ. Nov., 1755.

Lord Privy Seal . . . . John Leveson Gower, E. Gower, d. 1754; Chas. Spencer, D. of Marlborough, succ. Jan., 1755; Granville Leveson Gower, E. Gower, succ. Dec., 1755.

Lord Chancellor Phil. Yorke, E. of Hardwickc.

Secretary of State (Northern Dept.) Robt. Darcy, E. of Holdernesse.

Secretary of State (Southern Dept.) . Sir Thos. Robinson, till Nov. 15, 1755 ;

First Lord of Admiralty Henry Fox, succ. Nov. 15, 1755.

. . Geo. Anson, Ld. Anson.

Lord-Lieutenant of Ireland . . Lionel Cranfield Sackville, D. of Dorset; Wm. Cavendish, M. of Hartington, succ. 1755 .

Paymaster-General of Forces . Wm. Pitt; Henry Vane, E. of Darlington, succ. 1755.

Secretary at War . . . . Henry Fox, till Nov. 15, 1755; William Wildman Barrington, Visc. from Nov., 1755 .

VII. WILLIAM PITT, November, 1756.

First Lord of Treasury . - . Wm. Cavendish, D. of Devonshire.

Chancellor of Exchequer . - . Hon. Henry Bilson Legge.

Lord President . . : : - John Carteret, E. Granville.

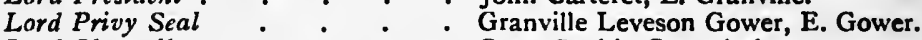

Lord Chancellor . . . . Great Seal in Commission.

Secretary of State (Northern Dept.) . Robt. Darcy, E. of Holdernesse.

Secretary of State (Southern Dept.) . Wm. Pitt.

First Lord of Admiralty . - . Richard Grenville, E. Temple.

Lord-Lieutenant of Ireland - John Russell, D. of Bedford.

Paymaster-General of Forces - . Thos. Hay, Visc. Dupplin.

\section{PITT'S COALITION MINISTRY, JUNE I9, 1757.}

First Lord of Treasury

Chancellor of Exchequer.

Lord President.

Lord Privy Seal

Lord Keeper

Lord Chamberlain : • • .

Secretary of State (Southern Dept.) :

Secretary of State (Northern Dept.) .

First Lord of Admiralty .

Lord-Lieutenant of Ireland

Paymaster-General of Forces

Secretary at War

President of Board of Trade and Plantations. . . .
Thos. Pelham Holles, D. of Newcastle.

Hon. Henry Bilson Legge.

John Carteret, E. Granville.

Richard Grenville, E. Temple.

Sir Robt. Henley.

Wm. Cavendish, D. of Devonshire.

Wm. Pitt.

Robt. Darcy, E. of Holdernesse.

Geo. Anson, Ld. Anson.

John Russell, D. of Bedford.

Henry Fox.

William Wildman Barrington, Visc. Barrington.

George Montague, E. of Halifax. 


\section{INDEX.}

Abbeville, 158.

Abercromby, General, 456; attacks Ticonderoga, 458; is repulsed, 459. Aberdeen, 102, 246, 260, 261.

Aberlady, $25 \mathrm{r}$.

Abingdon, Earl of (Montagu Bertie), 223. Acadia. See Nova Scotia.

Adderstone, 250.

Addison, Joseph, 68, 131; Irish secretary, r39; and Sacheverell, I64; patronised by Godolphin, 177; and George I., 237 ; secretary of state, 279 ; retires, 281, 289, 295; defends the peerage bill, 292; quarrels with Steele, 293; influence of, on literature, 479, 482, 487, 489, 492, 493.

Administrations, lists of, app. ii., 517-522.

Adriatic, the, 19, I12.

Africa, trade to, 94.

African Company, roo, ror, 108.

Agueda river, 64 .

Aire, 158, n. 1 .

Aislabie, John, chancellor of the exchequer, 289, 293; and South Sea stock, 294, 297; resigns, 300; his trial, $301,302$.

Aix-la-Chapelle, treaty of (1748), 416, 417-418, 431, 432.

Alberoni, Cardinal, adverse to the pretender, 27I; favours George I., 273 ; and the Quadruple alliance, 280, 281 ; and the battle of Cape Passaro, 282; attempts invasion of England, 283 ; its failure; 284; dismissed, 285, 321 .

Albuquerque, capture of, 85 .

Albuquerque, Duke of, Viceroy of Mexico, I4.

Alicante, $109,12 \mathrm{r}$.

Almanza, 110; battle of, 110, 111, 112, $120,130,156$.

Almenara, battle of, I56.

Almonde, Admiral Van, $14,19$.

Alps, the, 155, 264.

Alsace, designs of Leopold I. on, II, 58, 75, 80; campaign in, I15; projected invasion of, I55: Austrians threaterl, 382.

Niea, Spain, 20.

Ait-Ranstadt, treaty of, 113,114 .
Amerdingen, 52.

America, North, $287,265,308$; clashing of French and English interests in, $377,432-434,435-436,444,454,457-$ 458.

America, South, 338 .

Amherst, General Jeffery, commanderin-chief of British forces in North America, 456, 467, 472- +73 .

Amsterdam, its trade, 26 ; feeling in, 78 , 79, 194 .

Andalusians, the, $53,22$.

Anderlecht, Is 6.

Anglesey, Earl of (John Annesley), 69 ; a leader of the Hanover tories, 214, 219, 223.

Anjou, Duke of. See Philip V.

Anne, Empress of Russia, death of, 366 .

Anne of Austria, 123 .

Anne, princess royal, afterwards. of Orange, 355.

Anne, Queen, her accession, I, 93, 94, 177 ; her prepossessions and appearance, 2; declaration 28 to crown of Spain, 22; devotion to her husband, 27, 28; dislikes Sunderland, 29. 46; supports the bill against occasional conformity, 32 ; under tory influence, 34 i disapproves the second occasional conformity bill, 36,$37 ;$ and the whigs, 67; and the high churchmen, 69; and the Duchess of Marlborough, 70 ; succession to, 95; in parliament, 106, 107: her obstinacy, 123; overcome, 124; appoints two tory bish. ops, 125 ; and Mrs. Masham, 126, 127 ; grants audiences to Harley, 13r; writes to Joseph I., I3I ; supports Harley, 132; accepts Harley's resignation, 133; supports the Bank of England, 137; refuses Somers office, 138; complains of Sunderland, 139; orders tents for Protestant refugees, 141; act of grace of, 143; bribes Somers, 160 and n. I; resists appointment of Orford, $16 x$; rupture of with the Duchess of Marlborough, 162,163 ; at the trial of Sacheverell, 167,168 ; on divine right, 168 and 
n. I makes Shrewsbury chamberlain, Arniston, 184 .

I70; dismisses Sunderland, I7x ; and Arran, Earl of, chancellor of Oxford, Godolphin, 172; Harley's advice to, 174 ; change of feeling as to the pretenders, 175; dismisses the Duchess of Marlborough from office, I79; grant of allowances by, 192 ; opposes dissolution of union with Scotland, 202 ; prejudice as to Prior, 204; acknowledgment of her title by the treaty of Utrecht, 205 ; illness of, $2 \mathrm{II}$; asks Ormonde to mediate between ministers, 216 ; dislikes Bolingbroke, 217 ; shields him and Lady Masham from inquiry, 2Ig; dismisses Oxford, 219 ; her last illness, 220 ; her death, 22I, 274, 33I; and character, 222; Marlborough and, 224; her will, 225 ; sat in council, 23I; the pretender and, 135,232 ; intercedes for Huguenots, 264, 339; corruption under, 341 ; authorities on, app. i., 503-509.

Annesley, Arthur, 29.

Anson, Commodore (later Vice-Admiral), his services, $366,382,415,45 I$; on Admiral Boscawen, 44I; on Admiral Byng, 443, and Admiral Hawke, 455. Anspach, 228.

Antwerp, 15, 76, 81.

Aragon disaffected to Philip V., 21, 65, $85,87,90$, I10, 120; cortes of, 149, I57.

Aranjuez, treaty of, 389 .

Architects of the eighteenth century, 497-498.

Arcot, $43 \mathrm{r}$.

Ardoch, 257.

Arenberg, Duke of, 374 .

Argyll. second Duke of (John Campbell), a whig, 95, roo; hostile to Marlborough, I79; at Barcelona, 189 ; in the lords, 200, 214, 215; appears at Anne's last council, 220; commanderin-chief in Scotland, 229, 247; selects whig officers, 243 ; advances against Scottish rebels, 25I; commands at Sheriff Muir, 255.258; pursues the rebels, 260-26r ; recalled, 262 ; dismissed, 270, 271 ; influences Prince George, $27 \mathrm{I}$; protests against standing army, 290; appointed lord steward, 298; not involved in the South Sea Company, 299; his brother Lord Ilay, 320; opposes Walpole, 347.

Armagh, Archbishopric of, 318.

Army, discarding the, by Ormonde, 21 I ; by Marlborough, 243; vote for the, 290 ; and the excise bill, 345 ; dismissal of afficers of, 347,348 . 249.

Arras, 158.

"Articles of the Navy," 419.

Asfeldt, General d', Spanish general, I 20.

Ashby $v$. White. See Aylesbury.

Asiento, the, 187, 194, 205, 210,216 , 219,220 ; new treaty, 273, 293, 294, $338,359,362,376,418$.

Aston, Salop, 169 .

Athlone, Earl of (Godert de Ginkel), 8, Io.

Atholl, Marquis of, afterwards Duke of (John Murray), 38, r05, 134, 246, 247, 255.

Atterbury, Dr. Francis, afterwards Bishop of Rochester, chaplain to Queen Anne, 169; a violent tory, 174; Bishop of Rochester, 208; a suspected Jacobite, 220; a friend of Bolingbroke, 222; does homage to George I., 232; opposes the septennial bill, 268; in correspondence with the pretender, 289 ; in conspiracy, 305; his eminence, 306; banished, 307, 309, 330, 336 .

Aubach, General, 76.

Augsburg, 52.

Augusta, Princess of Saxe-Gotha. See Wales, Princess of.

Austria, its army, 7,8 ; threatened by Bavaria, I6, 48; the Dutch and, 83 ; house of, 140; and Spain, 186; and Savoy, 213; commercial treaty of Vienna with Spain, 324; alliance of, with France, 440, 444 .

Austrian generals, 114 .

Austrian party in Spain, 21, 120.

Austrians, the, in Spain, 23, I09, Ir2.

Authorship, standing of, during eighteenth century, 494-495.

Auvergne, Prince d', 153 .

Avignon, the pretender goes to, 264, $265,270$.

Aylesbury election, the, $4 \mathrm{I}, 67$.

Aylesford, Earl of (Heneage Finch), 267.

Badajoz, 85, 87, 156.

Baden, Louis, Margrave of, imperial general, I7, 48, 50, 51, 58, 59, 80; death of, II4.

Baden, Margravate of, $48,75$.

Badenoch, 26r.

Baireuth, Margrave of (Christian), II4.

Baireuth, Margrave of (Frederick), 355.

Baireuth, Margravine of (Wilhelmina), 31. , 327, 355.

Baireuth, Prince of, 55.

"Army ofobservation, the," 450,452-456. I Balearic Isles, 78. 
Balmerino, Balmerinoch, Lord (Arthur Elphinstone), $193 \mathrm{n}$. I ; trial and death of 408,409 .

Baltic, the, and Russia, 145, 285, 311; and Sweden, 274, 275, 285, 286, 287 ; trade in, 308; Russian fleet from, 323 ; the command of, 326.

Bambridge, Thomas, 343.

Bangor, Bishop of. See Hoadly.

Bank of England, 30; run on, 137; advances to Godolphin, 155; fall of stock of, 175,$184 ;$ supports govern. ment, 244, 288; a whig institution, 293 ; in rivalry with the South Sea Company, 293, 294, 295, 297, 298; Walpole's scheme and the, 299; plot to seize the, 307 ; chancery funds and the, 332.

Bara, John, a spy, 132.

Barbary, coast of, 20.

Barbary, state of, 19 .

Barcelona, relief of, $8 \mathrm{x}$; siege of, 86 , $87,88,89$; court of, 112 ; city of, $-121,146,149,157,158,189,215$.

Bar-le-Duc, 225.

Barnard, Sir John, 335, 362.

Barrier, the, 6, 82, 83, 84, $121,146,147$, 148; negotiations of the treaty for, 149, 150; Barrier treaty condemned by parliament, r94; Tournay added to, 205, 237 ; Townshend's conduct of the Barrier treaty, 229; Cadogan's Barrier treaty, 260.

Barrington, Viscount (William Wildman Barrington Shute), secretary at war, 446.

Barrisdale, Macdonald of, a traitor, 408.

Barry, Blizabeth, actress, 3:

Bassce, La, French lines at, 158.

Bath, 249.

Bath and Wells, Bishop of (Richard Kidder), $2 x$.

Bathurst, Lord (Allen Bathurst), 354.

Bavaria, Elector of (Charles Albert), supports France against the empire, 349.

Bavaria, Elector of (Max Emanuel), 7 ; seizes UIm, II; designs on Vienna; $15,16,48,49$; at Blenheim, 55, 58 ; writes to Marlborough, 84 ; besieges Brussels, II9; and the peace negotiations, 203.

Bavaria, Elector of, subsidised, 420.

Bavaria, Electress of, 59 .

Bavaria, raided by Marlborough, 52, 57 .

Bavarian army, the, $8,50,51,52,55$, $58,76,77,80,8 x, 754$.

Baxter, Richard, 44:

Bay, Marquis de, Spanish general, 120, 156.

Beaufort, Duke of, 4 rg.
Beaumont, Basil, rear-admiral, drowned in the great storm, 21.

Beckford, Alderman, and West Indies, 458-459.

Bedford, John Russell, fourth Duke of, $356,417,424,446,469$.

Bedmar, Marquis de, Spanish general, 15.

Belgian troops, 83.

Belgium, fortified towns of, 82 ; English administration of, 83 ; Dutch and, 150.

Belhaven, Lord (John Hamilton), roo, I04.

Bellasis, Sir Henry, general, 13.

Belleisle, battle of, 415.

Belleisle, Marshal, 440, 444.

Benbow, John, vice-admiral, 14.

Benson, Robert, afterwards Lord Bingley, chancellor of the exchequer, 215 .

Berkeley, Bishop, and Queen Caroline, $35^{8}$; his works, $4^{80}, 4^{81}$.

Berkeley, Earl of (James Berkeley), admiral, 221, 279.

Berkshire, 176 .

Berlin, 59, 79, 286.

Bernstorff, Baron A. G. von, 229, 230, 231, 272, 274, 275, 297, 309 .

Berwick, Duke of (James Fitzjames), in Portugal, 62, 63, 64, 88; retreats, 89; occupies Madrid, 9I; superseded by Orleans, 109, Iro; in the Netherlands, I18, I19; and the Jacobites, 129; at Cambray, 158; baffles Daun, 159; commands against Victor Amadeus, 189; his plan of restoration, $2 \mathrm{rr}$; and Marlborough, 224, 245, 25I; the pretender and, 236; Bolingbroke and, $24 \mathrm{r}$; on the pretender, 246; deserts the pretender, 262; blames the pretender, 263; his son, 327 ; his military estimates, 329.

Berwick, North, 251.

Bethune, $158 \mathrm{n}$. 1 .

Betterton, Thomas, actor, $489,490$.

Binckes, Dr. William, preacher, 5 ; made Dean of Lichfield, 35.

Birmingham, riots in, 238 .

Biron, Duc de (Chasles-Armand de Gontaut), French general, I17.

Bishops, the, 264, 352, 354.

Black Forest, the, 50,58 .

"Black Friday," 398.

"Black Hole of Calcutta," 45r, 452.

Black Prince, the, 270.

Blackall, Offspring, Bishop of Exeter, 125.

Blackheath, $x+1$.

Blackwell, Sir Lambert, British minister at Florence, $2 \mathrm{r}$.

Blandford, Marquis of (John Churchill), Marlborough's con, 15. 
Blandford, Marquis of, Marlborough created, ro.

Blathwayt, William, secretary at war, 45.

Blenheim (Blindheim), battle of, 47, 54, $55,56,57,59,65,66,80,87.97,1 \times 6$, 307.

Blenheim, palace of, 44 n. $4,65,223$.

Bligh, General, 456 .

Blunt, Sir John, South Sea director, 300.

Bolingbroke, Lord. See St. John, Henry.

Bologna, 285.

Bolton, Duke of (Charles Powlett), 233, 279, 347.

Bonet, Friedrich, Prussian minister in London, 131, 230.

Bonn, taken by Marlborough, 15, 50 ; Dutch demand, 150.

Boscawen, Admiral, sails for India, 416; meets French fleet, 435-436; his North American flect, 456-457; blockades Toulon, 459; destroys De la Clue's fleet, 460 ; general successes, 477.

Bothmer, Count H. C. von, Hanoverian envoy, 178, 190, 194, 224, 225, 230, 23I, 245, 272, 278, 309.

Bouchain, 188, 199, 200.

Boufflers, Louis Françoise Duc de, Marshal of France, 15, 16, 119; at Malplaquet, 154 .

Bougainville, General, at Quebec, 464 466.

Boulter, Dr. Hugh, Archbishop of Armagh, 314, 318, 319.

Bourbon army, I12, II5, 120.

Bourbon, Duke of, French minister, 327.

Bourbon, house of, 22, 87, 186, 191, 349.

"Bow Street runners," 429.

Boyle, Henry, afterwards Lord Carleton, chancellor of the exchequer and secretary of state, $x 33,138,151,16 x$, 163,171 ; dismissed, 174 .

Boyne, battle of the, 28 .

Brabant, 8, 9, 80, 8I; the states of, 83 ; Marlborough master of, 119 .

Bracegirdle, Mrs., 49a.

Braddock, General, in Virginia, 433 ; defeat and death of, 434 .

Bradley, James, 423, 480.

Bradstreet, General, success of, in Canada, 458.

Braemar, 246.

Brampton, 252.

Brandenburg-Anspach, 334.

Brechin, 246.

Bréda, conference of, 413 .

Breisach, 50.

Bremen, Duchy of, 249, 272, 280, 283, 286, 289, 326, 453 .
Breslau, treaty of, 371, 427.

Brest, 59.

Bridgewater, Duke of (Scroop Egerton), 295.

Bridgnorth, 169.

Brihuega, capture of, 157.

Brinsden, John, Bolingbroke's secretary, 262.

Bristol, 232, 248, 249, 314.

Bristol, bishops of. See Smalridge, Robinson, Boulter, Butler.

British Museum, foundation of, $43^{\circ}, 498$, 499.

British, the, success of, in India, $43 \mathrm{I}$ 432 ; struggles of, in North America, 432 et sqq.

Brittany, i18.

Brodrick, Alan. See Midleton.

Brodrick, St. John, 316.

Brodrick, Thomas, 294, 299, 30r, 302, 3 I6.

Broglie, Marshal, 460-462.

Bromley, William, 29, I39; Speaker, I78, I91, 220, 230.

Brougham, Lord (Henry Brougham), 276 n. 3.

Broughton, Murray of, 392 ; turns informer, 408, 409 .

Bruges, 8, 15, I16, 118, 119, 150, 199, 237.

Brunswick-Luneburg, 50; troops of, 55 .

Brunswick-Wolfenbüttel, duchy of, 8 .

Brunswick-Wolfenbuttel, Duke of, 326.

Brussels, 77, I16, 118 .

Brutus, 300.

Bubb, George. See Dodington.

Buckinghamshire, Duke of (John Sheffield) $4,67,69, \times 28$; lord president, $183,194,204,220$; introduces the peerage bill, 293.

Bucklebury, Berks, 176.

Bunge, M., Swedish Minister at Paris, 440.

Buononcini, 355, 489 .

Burgundy, Duke of (Louis), grandson of Louis XIV., 17, 115, 116, $117,196$.

Burke, Edmund, 165,341 .

Burlington, Earl of (Richard Boyle), 346.

Burnet, Gilbert, Bishop of Salisbury, 3, $9,25,30,32,4 x, 45,49,70,141,165$, 182, 193, 223; death of, 238.

Bussy, General, 432, 477.

Bute, Lord, of Leicester House party, 457 ; on the success of the "army of observation," 455-456.

Butler, Bishop (of Durham), and Queen Caroline, 358, 480.

Buys, William, 79, 195, 196.

Byng, Hon. John, Admiral, 359, 399, 447 ; his lack of enterprise, $413,44^{10}$ 
412; arrest of, 443 ; court-martial on, 449; execution of, $45 a$

Byng, Sir George, afterwards Viscount Torrington, admiral, 60, 136, 162, 249, 277, 281, 282, 285.

Cadiz, Angla-Dutch expedition against, II, 12, 22; Rooke projects an attack on, 60; French fleet at, 64 ; England and, $78,86,92,214$; Ormonde sails from, 283 ; galleons 2t, 326 ; preparations 2t, 327.

Cadogan, William, general, afterwards earl, 117, 118, 178, 243,260, 261 ; commander-in-chief in Scotland, 262 ; plenipotentiary at Hanover, 271 ; commander-in-chief, 307.

Cagliari, 120, 283.

Calais, 128, 158, 309 .

Calcutta, fall of, 452.

Callenburg, Dutch admiral, 6x.

Cambray, 188; congress of, 310,322 ; dissolution of congress of, 323 .

Cambridge, Duke of. See George II.

Cambridge, University of, 29.

Cambron (Hainault), 123 .

Cameron, Dr. Archibald, execution of, 427-428.

Cameronians, the, 135 .

Camisards, the. See Cevennes.

Camocke, George, 239, 281, 282, 283, 327.

Campbell, the clan, 247.

Campbell, Lord (John Campbell), chancellor, $33 x$.

Canada, progress of French in, 6, 339 ; expedition against, 182 ; becomes British, 473. See also America, North.

Canterbury, Archbishops of, Gilbert Sheldon, 166; Thomas Tenison, 4, 32, 44 n. I, 70, 101, 106, 107, 232; William Wake, $218,308$.

" Canter of Coltbrigg," the, 393.

Cardona, Spanish viceroy, Iog.

Cardona, town of, 189.

Cardonnel, Adam, secretary-at-war, dismissed, 178, 192.

Carleton, George, captain, 86 n. I.

Carleton, Lord. See Boyle, Henry.

Carlisle, city of, 98, 265; Prince Charles Edward in, 396.

Carlisle, Earl of (Charles Howard), 248.

Carlos, Don, Prince of Spain, afterwards King of Naples and Charles III. of Spain, 280, 28I, 32I, 322, $338,371,372,470$; occupies Naples, 349.

Carlyle, Thomas, cited, 428.

Carnatic, the, 416, 431-432, 477.

Carnwath, 100, 103, 247.
Carnwath, Earl of (Sir Robert Dalzell), 250, 266.

Carolina, its tobacco, 6, 343.

Carolina, North, 142.

Casoline of Anspach, Princess of Wales, afterwards queen, 228 ; favours Wal, pole, $334,340,345,346$; character and death of, 357-358.

Carpenter, George, general, afterwards Lord, at Almanza, III ; commanderin-chief in England, 251; overtakes rebels, 252; at Preston, 258, 267; commander-in-chief in Scotland, 271 ; governor of Port Mahon, 328.

Cartagena, siege of, $366,368,370$.

Carteret, John, Lord (later Earl Gran. ville), negotiates with Sweden, 286 ; and Denmark, 287 ; secretary of state for southern department, 304, 309, $310,311,320$; rivalry with Townshend, 312 ; appointed lord-lieutenant, 316, 318 ; recommends concessions to Irish feeling, 319; Pulteney and, 335 ; leads opposition, 347 ; and the liquor trade, $35 \mathrm{r}, 352$; denounces the bishops, 354; against "right of search," 359 ; and S'panish convention, 360; attacks Walpole, 367; secretary for the northern department, 369, 371 ; his diplomacy, 376 . 377 ; his policy impugned, $382-384$; resigns the seals, $4 \mathrm{Ir}$; returns to office, 424,425 .

Castile, $21,85,87,91,148,157$.

Castilians, the, I12; meaning of term, 322.

Caswall, Sir George, 302.

Catalans, the, 21, 86, 112, 189, 206, 214, 215.

Catalonia, 21, 65, 87,88, 109, 110,120 , $129,156,189,283$.

Cateau-Cambrésis, 199.

Catherine I., Empress of Russia, 326.

Catholics. See Roman.

Catinat, Nicolas de C. de la Fauconnerie, marshal of France, II ; superseded by Villars, 16.

Celle, 227.

Cette, 158.

Ceuta, 60 .

Cevennes, insurrection in the, 20, 36, 155, 159.

Chamillart, French minister for war, 84 , 13 2,135 .

Chance, J. F., 287 n. 1.

Chandler, Dr. Samuel, 354.

Chandos, Duke of (James Brydges), 295.

Channel lslands, the, 249.

Charlemont, James, first Earl of, 426.

Charleroi, 12, 82. 
Charles, Archduke of Austria (afterwards the Emperor Charles VI.), candidate for the crown of Spain, II ; proclaimed as Charles IIf. of Spain, 20, 22; lands in England, 23; proclaimed at Gibraltar, 6o, 78, 83 ; at Barcelona, $86,87,88$; proclaimed at Madrid,. 89, 90, 92 ; complains of Peterborough, IIO; in Catalonia, I12, 120, 121, 129; and General Stanhope, 146 ; and the Spanish Netherlands, 147; and Spain, 148, 149; enters Saragossa, 156; occupies Madrid, 157; and England, 185; succeeds Joseph I. as emperor, 186; sends Eugene on a mission, 193; commissions envoys to Utrecht, 196; and the Catalans, 214; and Stanhope, 230; Barrier treaty with Dutch, 26o; overtures of Stanhope to, 272; his treaty with George I., 273, 275; at war with Turkey, 282; signs treaty with Hanover and Saxony, 285 ; and Prussia, 3II; creates an Ostend company, 321, 322; concludes treaty of Vienna with Spain, 323; Great Britain's relations to, 325 ; engages in secret treaty with Spain, 325 ; in treaty with Prussia, 327; makes peace with Great Britain, 330; reluctance to guarantee the Italian duchies, 337, 338; allied with Prussia, 340; attacked by France, 349 ; intrigues against Walpole, 350 ; death of, 366 ; and Silesian loan, 427.

Charles Edward, Prince (the young pretender), description of, 380 ; Dunkirk, 381 ; in Paris, 39r ; in Scotland, $39 r-392$ et sqq.; he enters Carlisle, 396 ; failing fortunes, $397-398$; the retreat, 400 ; enters Glasgow, 401 ; at Falkirk Muir, 402-404; at Culloden Muir, 405-406; a fugitive, 407; his wanderings, 4 18-419.

Charles Emanuel, King of Sardinia, his ambitions, 371,372 ; and convention of Turin, 376 .

Charles I., his execution, 5, 260.

Charles II. of England, 42, 72, 200, 237, $239,260$.

Charles II. of Spain, 82, $150,273$.

Charles III. of Spain. See Charles, Archduke.

Charles V., the emperor, II.

Charles VI. See Charles, Archduke.

Charles XII. of Sweden, 8, 112, 113 II 4 ; his hostility to George I., 249, 273,274 ; his ambaseadors arrested, 275,276 ; in correspondence with
Alberoni, 28r ; death of, 283 ; its consequences, 285 .

Charlottenburg, treaty of, 311 .

Chateau-Regnault, Marquis de (Francois-Louis-Rousselet), vice-admiral of France, 13.

Chavigny, M. de, on the Jacobites, 39r.

Chelsea, 340.

Cherbourg, surrender of, $45^{8}$.

Chester, 254.

Chester, Bishop of, Sir William Dawes, 125.

Chesterfield, Earl of (Philip Dormer Stanhope), 316, 325, 335, 345, 346, $347,352,353,355$; and Spanisb convention, 360; and Walpole's colonial policy, 362 ; on Shippen's defection, 367 ; Lord-Lieutenant of Ireland, 383 ; success of, in Ireland, $4 I_{4} ;$ an advocate of peace, $417 ;$ and the Gregorian calendar, 423; acts as intermediary, 450; his letters, 495 ; mentioned, $356,384,385$.

Chetwynd, William Richard, afterwards Viscount, III.

Child's Bank, r37.

Choiseul, French minister, determines to invade Great Britain, 459,460 ; makes overtures to Pitt, $47 \mathrm{I}$; failure of his schemes, 469, 470 .

Cholmondeley, Earl of (Hugh Chol. mondeley), $133,378$.

Chotusitz, battle of, 371 .

Chunda Sahib, 43r.

Church of England, 2, 29, 68, 69, 106, 139, 166, 169, 217, 221, 233, 239, 244, $259,264,308,354$.

Church of Ireland. See Ireland.

Church of Scotland, 104, 106, 259.

Churchill, Arabella, 63.

Churchill, Charles, General, Io, 54, 55, 56.

Churchill, George, admiral, 125, 128, 133 .

Churchill, John. See Marlborough.

Cibber, Colley, 482; 488, 489.

Cifuentes, Count of, 87,120 .

Cinque Ports, $21 \mathrm{r}$.

Ciudad Rodrigo, 88.

Clans, disaffected, 391-392; loyal, 392.

Clarendon, first Earl of (Edward Hyde), chancellor, 3 .

Clarendon, third Earl of (Edward Hyde), 216.

Clarke, John, alias Alexander Valiere, a spy, 132.

Clarke, Dr. Samuel, philosopher, 227, 358,481 .

Clayton, Thomas, 489 .

Clement XI. See Popes.

Clementina Sobieski, wife of the pretender, 284, 285, 336. 
Clinton, Lord (Hugh Fortescue), 346, Cowper, William, afterwards Lord 347.

Clive, Robert, later Lord Clive, rise of, 431; reduces Chandernagore, 455: retakes Calcutta, 473 ; Chandernagore and Plassy, 474; difficult position of, 475; he routs the Dutch forces, 476 ; and returns to England, 476; Pitt on, $476-477$.

"Cobham Squadron, the," $3^{82 .}$

Cobham, Viscount (Sir Richard Temple), 347,360 .

Coblenz, 5o.

Coehoorn, Menno Van, Dutch general, I5I.

Colbert, Jean-Baptiste, Marquis de Seignelay, French minister, 5 .

Collins, Anthony, $4^{8 r}$.

Cologne, Elector of, 7, 8, 154, 349.

Colville, Admiral Lord, blockades the St. Lawrence, 473.

Commerce and industry in the eighteenth century, 500.

Commercy, 242, 264.

Common Sense, newspaper, 336.

Compton, Hon. Henry, Bishop of London, 236.

Compton, Hon. Sir Spencer, afterwards Earl of Wilmington, 253, 301, 334 ; first lord of the treasury, 369 ; death of, 377 .

Conflans, Marshal de, 468-469.

Congreve, William, poet and dramatist, 233.

Conolly, William, Speaker of Irish house of commons, 318 .

Contades, Marshal, lirench commander at Minden, 360-362.

Conybeare, John, 481 .

Cooper, Anthony Ashley, third Earl Shaftesbury, $4^{81}$.

Cooper, Commodore, $3^{89}$.

Coote, Eyre, defeats Lally Tollendal, 477.

Copenhagen, 276, 286.

Cope, Sir John, commander-in-chief in Scotland, 392, 393; defeat of, 394395.

Coram, Captain Thomas, and the Foundling Hospital, 420.

Cornewall, Capt. James, death of, 379.

Cornish boroughs, their venality, 210 and n. 3 .

Cornwall, 250, 259, 284.

Corsica, 389-390.

Corunna, Rooke to take, 12 ; mentioned, 283.

Costume and manners in the eighteenth century, sor-502.

Cotton, Sir John Hynde, 369, 383, 425.

Courtray, 82, 151 .

Chancellor, 45, 68, 101, 122; made a peer, I24; opposes Marlborough's demand of a patent for life, 162 ; and Mrs. Masham, 163; on Harley, 173 ; and the war, 19r; and the Duchess of Marlborough, 222; chancellor, 229, 266, 279; resigns, 290, 331 ; opposes the peerage bill, 292, 293 ; and suspension of Habeus Corpus, 307.

Craftsman, The, newspaper, 3:2, 336, 342, 344, 493-494.

Cromartie, George, third Earl of, executed, 408-409.

Cromwell, Oliver, 43, r4o.

Craggs, James, the elder, 297, 300; his death, zor.

Craggs, James, the younger, 149,221 ; secretary at war, 279 ; secretary of state, 28 $x, 283,289,298,300$; his death, 3or, 304 .

Croisic, De, French minister, ISI.

Crowe, Mitford, 214.

Cuba, 368.

Culloden Muir, battle of, 405-407, 410, 427.

Cumberland, 252.

Cumberland, Duke of (Prince George of Denmark). See George.

Cumberland, Duke of (Prince William Augustus), British commander-inchief, 385 ; at Fontenoy, 386-388 ; returns to England, 388 ; supersedes General Ligonier, 397 ; pursues Prince Charles, 400-401; recalled to London, 402; resumes pursuit of the rebels, 404-405; his severity, 406-407; at Bréda, $4 \mathrm{I}_{4}$; his want of generalship, 415: wishes for peace, 417 ; hostility of, to Pelham, $424 ;$ procures dismissal of Pitt, 450; defeated at Hastenbeck, 453; unpopularity of, 434; referred to, $435,44 \mathrm{r}$.

Cutts, Lord (John Cutts), General, 9, 55, $56,66$.

D'Ache, French admiral, 474, 477.

D'Alegre, Bavarian general, 77 .

Danes, the, $55,153,275,277,286,287$.

Danube, river, II, 48, 49, 50, 5I, 52, 53 , $54,56,57,96$.

Daptheim, 54 .

D'Árco, Bavarian general, 52.

Darien company, 134 .

Darlington, Countess of (Charlotte Sophia von Kielmansegg), 227. 3 ro.

Dartmouth, Lord (William Legge), afterwards Earl of, 165; secretary of state, 17I, 176, 203, 204; dismissed, 209.

VOL. IX. 
Daun, Count, imperialist general, 155 , I58, 159.

Dauphiné, 158.

Davenant, Charles, 17, 36.

Dawes, Sir William, Bishop of Chester, afterwards Archbishop of York, 125.

Dawley, 312.

Deal, 306.

De Foe, Daniel, 3I, I03, 105, 134 n. 4, $164,185,200,207,218,350,490-491$.

de la Clue, French admiral, 457, 459, 460.

Demer, river, 76.

Denain, 200.

Dendermonde, $8 \mathrm{r}$.

Denmark, 274; treaty with Sweden, 287 ; Schleswig and, $3 \mathrm{II}$; treaty of Hanover and, 324,326 ; contingent of, 330 ; treaty with, 362 .

Denmark, Frederick IV. of, 8, 272, 286.

Denmark, Frederick V. and George II. of, 453 .

Denmark, Prince George of. See George.

Derby, I64.

Derry, 74.

Derwentwater, Earl of (James Radcliffe), 250 ; beheaded, 266.

d'Estrées, Marshal, 453.

Dettingen, battle of, $374-375,377,385$ 387 .

Devonshire, 250, 346.

Devonshire, first Duke of (William Cavendish), 42.

Devonshire, second Duke of (William Cavendish), r38, 229, $271,297$.

Devonshire, third Duke (William Caven. dish), 347 .

Devonshire, fourth Duke of (William Cavendish), $43^{8}$; as intermediary, $44^{6}$.

Dillingen, 52, 54 .

Dillon, Arthur, French general, 269, 305, 306.

Dinwiddie, governor of Virginia, 432.

Diskau, Baron, French commander opposed to General Braddock, 433-435.

Dissenters, English, 30, 3I, 7I ; betrayal of, 190; Bolingbroke and the, 21 7, 218, 221 ; Oxford and, 218; at Preston, 264 ; favoured by Stanhope, 290 ; partial relief of, 29r; Walpole and the, 353,354 .

Dissenters, Irish, 72, 74, 353 .

Dissenters, Scottish, 201.

Doddridge, Philip, 394 .

Dodington, George Bubb (later Lord Melcombe), negotiates commercial treaty with Spain, 273; mentioned, $281,383,419,438$.

Dolben, Dr. John, Archbishop of York, 166.

Dominica, island of, 339 .

Donan Castle, 284.

Donauwörth, 51, 52, 53.

Dorset, Duke of (Lionel Cranfield Sackville), 353.

Dorset, Earl of (Charles Sackville), I77.

Douay, 158, 187, 199, 200.

Drake, Dr. James, 68.

Drapier letters, the, 317,318 .

Dresden, treaty of (1745), 389, 427.

Drummond, James, titular marquis, 255.

Drummond, Lord John, lands at Montrose, 400 .

Drummond, Robert, merchant-captain, Ioo.

Dublin, 142, $214,317$.

Dublin, Archbishop of, William King, 74,143 ; leads opposition to Wood's halfpence, $315,317-319$.

Dublin, St. Patrick's Cathedral, 28.

Dublin, Trinity College, 74 .

Dubois, Abbé, afterwards Cardinal, agent of the Regent Orleans, 277; warns Stanhope of Spanish invasion, 283.

Ducasse, French admiral, ${ }_{4}, 42$.

Dumfries, 252.

Dunblane, 25I, 255, 258.

Dundas, Robert, of Arniston, 184.

Dundee, 246, 260.

Dundee, Viscount (John Graham of Claverhouse), 102.

Dunkirk, 82, 96, 128; preparations at, 135,136 ; dismantlement of, demanded, $147,149,187$; surrendered to England, I99; dismantlement agreed to, 206; not carried out, 213, 234; pretender embarks at, 259; Louis XIV. and, 272 ; the Regent Orleans and, 277; continued maintenance of, 339; a Jacobite base, 381, 396.

Dupleix, Joseph, governor of French India, his schemes, 415.416; his work undone, 43I-432.

Dupplin, Viscount (George Henry Hay), 248.

Dutch, field-deputies, 9, 10, 16, 48, 77, 78, 84 .

Dutch fleet at $\mathrm{Cadiz}, \mathrm{I2}$; its unreadiness, 18, 19; under Shovell, 19, 20; off Malaga, 6r ; at Gibraltar, 64 ; in West Indies, 85 ; at Barcelona, 88; under Byng, 136 ; under treaty of Hanover, 330.

Dutch generals, 9, 13, 16, 49, 63, 76 and $\mathrm{n} . \mathrm{I}, 77,85,86,109,15 \mathrm{I}, \mathrm{I} 88$.

Dutch government, the, and Maria Theresa, 372-373; evasion of obligations by, 384 ; Indian experiment of, 476. 
Dutch merchants in London, 137.

Dutch Republic, the, 156.

Dutch, the. See also Holland, StatesGeneral. Treaty with, 14; Marlborough and, 49, 75, 78, 82; and the Barrier, 82, 83, 84 ; French overtures to, 84 ; indignant with Joseph 1., 115; and the Spanish Netherlands, 116 ; and a French invasion, 135; war party, 145; demand cession of seven towns, 147; and Spain, 148; and Townshend, 148, 149; and British trade, 149; and the Barrier treaty, 150, 151; and France, 186; and "Mat's Peace," 187: Marlborough's services to, 188 ; libelled by the "representation," 194, 195 ; indignation of, at Ormonde's desertion, 199; and the commercial treaty with France, 208 ; form the Triple alliance, 278 ; and the Quadruple alliance, 280; and the Ostend Company, $32 x$.

Dutch troops at Cadiz, 12 ; in Germany, 50 ; at Blenheim, 55, 59; in Portugal, 63,85 ; in Italy, 79; at Ramillies, 80, $8 \mathrm{I}$; 2t Barcelona, 86; in west of Spain, 88 ; in east of Spain, 110 ; at Malplaquet, 153,154 ; in the Thames, 260; in Scotland, 262, 284.

East India Company, 30, 100; Walpole and the, 299; and the Ostend Company, 321, 322 ; renewal of its charter, 343.

East India Company of Scotland, roo.

East Indies, the, and the Ostend Company, 321.

Ebro, river, 89.

Eckeren, defeat of Dutch general Opdam at, 16.

Edgcumbe, Commodore, 442.

Edinburgh, 96, 102-106, 108, 201, 243, 246, 251, 255, 320, 352; Prince Charles Edward in, 393.

Edinburgh castle, 135 .

Egmont, Lord, 438.

Ehingen, 50.

Elbe, river, 272.

Elisabeth Famese, Queen of Spain. See Farnese.

Elizabeth, Queen of England, 314.

Elliot, Captain, defeats Thurot of Irish coast, $469-470$.

Elvas, Portugal, 63.

Emperor :-

Charles VI. See Charles Archduke of Austria.

Francis 1. See Lorraine, Francis, Duke of.

Leopold I., 7, II, 18, 22; renounces Spain, 22, 23; writes to Queen Anne, 49.
Emperor (cont.) :Joseph I., felicitated by Marlborough, 79,83 ; makes a treaty with France, Iog, Ir2; and Charles XII., IrJ. 114: letter of Anne to, 131, 145 ; and the Barrier treaty, 151 ; remiss with reinforcements, 158; death of, 183, 186.

Empire, the, condition of, 7; declares war against France, IX; disorganisa. tion of, 48 ; princes of, 150 ; continues at war with France, 205 i interests of, sacrificed, 206; and Savoy, 213; George I.'s attitude to, 226; George II. and, 350 .

England, poor rates burdened by immigrants, 142; Highland army enters, 252; indifferent to pretender. 254: commercial depression in, 329; tranquillity in, $33 \mathrm{I}$.

Erle, Thomas, general, 188.

Erskine, Colonel, 104.

Escorial, treaty of. See Family com. pact.

Estrées, Jean d', Vice-Admiral of France, 61.

Eton, 19r.

Eugene, Prince of Savoy, imperialist general, 19; concerts plan of campaign with Marlborough, 49; first meeting with Marlborough, 5I; marches to join Marlborough, 52-54; at Blenheim, 55-58; wins the battle of Turin, $79 ;$ a friend of Guiscard, $9 \mathrm{r}$; besieges Toulon, $\mathrm{III} \mathrm{II}_{4}$; visits Hanover, I15; joins Marlborough, I16; besieges Lille, 118 , I19; Anne's request as to, 132; approached by Peter the Great, 45 ; on the terms of peace, 148; at Malplaquet, 152, 153 ; his plan of campaign, 157; leaves Marlborough, 187, 188; opposed to Marshal Harcourt, 189; arrives in London, 193, 194; generalissimo of the allies, 197; his opinion of Ormonde, 198 ; on the Scottish rebellion, 265; commands the imperial army, 350.

Europe, strongest fort in, 152 ; balance of power in, 338 .

Evelyn, John, 21.

Examiner, The, newspaper, 178, 182, 493.

Excise bill, the, 344, 345 .

Exeter, Bishop of (Offspring Blackali), 125.

Eyne, 117.

Pagel, Dutch general, 63, 85.

Falkirk, 255.

Falkirk Muir, battle of, 402-404.

"Pamily compact, The first," 349, 363 ; "second tamily compact," 376-378. 
Farnese, Elisabeth, second wife of Philip V. of Spain, 280, 364, 389; her ambition, 321, 322; grievance against England, 322, 323; abandons Gibraltar, 337 ; and the treaty of Seville, $33^{8}$; ambition of, 371,372 ; eclipse of her power, 413.

Fénelon, Archbishop of Cambray (François de Salignac de la Mothe), 115.

Ferdinand, Prince, commander-in-chief of the "army of observation," 454456 ; British confidence in, 460 ; at battle of Minden, 460-462; defeated at Korbach, $47 \mathrm{I}$.

Ferdinand VI., makes overtures to England, $4^{\mathrm{r}} 3$.

Fergusson, Robert, " the plotter," 38 .

Fetteresso, 260.

Fielding, Henry, and the liquor trade, 422,423 ; and "Bow Street runners," 429; his literary style, 49r.

Filmer, Sir Robert, writer, 105.

Finch, Lord (Daniel Finch), afterwards Earl of Winchelsea, 450.

Finchley, militia muster at, 395.

Findlater, Earl of. See Seafield.

Finisterre, battle of, 4 r5.

Finisterre, cape, 284.

Fitzgerald, Thomas (Geraldino), 359.

Flamsteed, John, 479.

Flanders, French lines in, $15,81,82$; states of, 83 ; French army in, 115 ; war in, 129, 135; French, 150, 158; recall of troops from, 221 ; at the feet of France, 388 .

"Fleet marriages, the," 428.

Fleming, Hon. Charles, Jacobite, 136.

Fletcher, Andrew, of Saltoun, 94, roo.

Fleury, Cardinal, 325, 350, 378, 379.

Florence, court of, 21 .

Florida, 322.

Floyd, David, Jacobite, 262.

Fog's journal, 336.

Fontenoy, battle of, 386-388.

Forbes, Brigadier John, 456, $45^{8}$.

Forbin, Claude de, French admiral, 136.

Forde, Colonel Francis, Indian service of, 475,476 .

Fornelles, castle of, 121.

Forster, Thomas, junior, 248, 250; rebel commander, 252; surrenders, 253 ; escapes, 265.

Fort William, 246.

Forth, Firth of, 100, 136, 247, 251.

Fontainebleau, treaty of, 376 .

Fox, Henry, first Lord Holland, defends Walpole, $37^{\circ}$; secretary at war, 412 ; relations of, with Newcastle, 430 , and Pitt, 435 ; favourable to subsidies, 437 ; threatens to retire, 445 ; and Gibraltar question, 447 ; invited to form administration, 450; a lord of the treasury, 378 ; secretary of state, $4 \mathrm{r} 9,44 \mathrm{r}$.

France, declaration of war against, 5 ; its army, 8 ; and Alsace, II ; projected invasion of south of, 18; Dutch trade with, 26; law of inheritance in, 73 ; misfortunes of, $8 \mathrm{r}$; projected invasion of $91,92,155,158,181,182,187$; apprehended invasion by, 97, 103; trade of with Scotland, 107; treaty between Austria and, rog; and Venice, Ir2; concessions demanded from, 121 ; exhaustion of, 145,146 ; to retain Strasburg, $\mathrm{I}_{47}$; its trade with Holland, $\mathrm{I}_{4} 8$; rupture of negotiations by, 149 ; and the Dutch demands, 150; recalls its troops from Spain, 156; union of with Spain, 185 ; Spanish commercial privileges to, 187 ; its first commander, 188 ; succession to, 196 ; peace with 205 ; treaty of commerce with, 206, 207; Bolingbroke favours alliance with, 225 ; Robethon a refugee from, 230 ; and the overtures for peace, 235 ; and Dunkirk, 240; Ormonde lands in, 244 ; Jacobites escape to, 262 ; hostility of William III. to, 226; warned by George $1 ., 265$; its woollen manufacture, 273 ; pretender to leave, 277 ; comes into the Quadruple alliance (1718), 280; crippled by the Missisippi scheme, 287; defensive alliance with England and Spain (r72r), 3ro, 321; philosophy in, 315; alienated from Spain, 323; joins in the treaty of Hanover, 324 ; proposed dismem. berment of, 325 ; and the treaty of Hanover, $326,327,330$; joins in treaty of Seville (1729), 338; growing friction with Great Britain, 339 ; declares war against Charles VI., 349 ; acquires the reversion of Lorraine, 350 ; and "family compact," $363-364$, 377 ; and Maria Theresa, 372 ; grievances of, against Great Britain, 378 ; fails the Jacobites, $398-400$; influence of, in India, 431-432; clashes with English interests in North America, 432-434; isolation of, 439 ; alliance of, with Austria, $44^{\circ}$; changed intentions of, 444 ; joins Russia and Austria against Prussia, 453.

Francis of Lorraine and Tuscany, husband of Maria Theresa, acknowledged emperor by Prussia, 389 .

Franconia, 16, 53 .

Franquenies, 80, 81 .

Fraser, Simon, of Beaufort, afterwards Lord Lovat. See Lovat.

Fraser, the clan, 262. 
Frederick Augustus, Elector of Saxony, King of Poland, I13.

Frederick I. of Prussia, etc. See Prussia.

Frederick IV. of Denmark, etc. See Denmark.

Frederick, Prince, afterwards Prince of Wales, 228 ; and a Prussian marriage, $311,326,327$; vote of money for, 335; created Prince of Wales, 342 ; becomes active in politics, 355 ; $\mathrm{pa}$ tronises Pitt, 361 ; death of, 424 .

Frederick William I. of Prussia. See Prussia.

Fredericksborg, treaty of, $28 \mathrm{z}, 3 \mathrm{Ir}$.

Freind, Dr. John, writer, 129.

French East India Company, 474.

French fleet, 59, 61, 88, 112, 136, 137.

French Protestants, 32, 14 I.

French wines, consumption of, 24.

Gaeta, siege of, 380 .

Gainsborough, Thomas, 496.

Galway, Earl of (Henri de Massue de Ruvigny), British general, $63,85,88$, $89,90,92,109,110 ;$ at Almanza, 110, III ; ambassador at Lisbon, 120, 129, 179.

Gardening, landscape, rise of, 495-496.

Gardiner, Colonel James, killed, 394.

Garrard, Sir Samuel, r64.

Garrick, David, 489.

Gassion, Jean, alias Ogilvie, spy, 134 n. I.

Gaultier, Gautier, the abbé, 174, 175, $186,187,211,212,217$.

Gell, servant to Marlborough, 10.

Genappe, 77.

General elections, (1702) 25 ; (1705) 84 ; (1708) 138; (1710) 174; (1713) 210; (1715) 232, 233; (1722) 306; (1727) 335 ; (1734) 384 ; (174I) 368 ; (1747) $416 ;(1753) 429$.

Geno2, 90, 110, 112, 129, 389, 413.

Genoese, envoy at Madrid, $2 \mathrm{I}$; policy of the, 389-390.

George I. (George Lewis, Elector of Hanover), 70; imperialist commander-in-chief, 114, 155; and the tory party, I44; resigns command, $158 ;$ and Harley's ministry, 178, 183 ; opposed to the peace preliminaries, 190; supports Marlborough, 192; declines invitation of whigs, 203; continues at war with France, 205; favours the whigs, 212 ; indifferent to Oxford's overtures, $2 I_{4}$; and Schutz, 216; becomes next in succession to the crown, 217 ; his visit as prince to England, 222; his accession, 223; loan offered to by
Marlborough, 224 ; his life, 226 ; his character, 227, 228 ; enters London, 229 ; indifferent to the succession, 231: unpopularity of, 237, 238; Bolingbroke and, 24I, 242; oaths of allegiance to, 243 ; overtures of the Duke of Orleans to, 244 ; clans loyal to, 247; hostility of Charles XII. to, 249 ; speech to parliament, 264, 265 ; quarrels with the Prince of Wales, 270; reconciled, 27I ; purchases Bremen and Verden, 272, 274, 275; arrests Swedish ambassador, 275, 276; apprehensive of Russia, 277; jealous of the Prince of Wales, 278 ; disputes with Walpole, 278, 279; anxious for investiture of the duchies, 28o; and Sir G. Byng. $28 x, 282$; parliament and, 284 ; dislike for Peter the Great, 285, 3II ; and the pacification of the north, 286, 287; scheme for alienating Hanover, 290, 304 n. I; favours the peerage bill, 292 ; appoints lords regent, 296; and the South Sea Company, 297; returns to England, 298 ; libels on, 304 ; plot to seize, 307: Lord Macclesfield a favourite of, 331 ; death and character of, 332, 333. 334 ; compact with George II., 336 ; clemency, 308 ; pardons $\mathrm{BO}$ lingbroke, 309; and the Platen marriage, 310; against Carteret's foreign policy, 3II ; supports Walpole against Bolingbroke, 312; creates Alan Brodrick a peer, 315 ; and the treaty of Hanover, 325 ; his friction with Prussia, 326, 327; on the surrender of Gibraltar, 337; and the French Protestants, 339; and the marriage of Prince Frederick, 342 ; authorities on, App. 1., 509-511.

George 11. (George Augustus, Duke of Cambridge, Electoral Prince of Hanover, afterwards Elector) at Oudenarde, $I 17$ and n. I, 228; demand for writ of summons of, 216 ; Prince of Wales, 228, 233, 238, 27I, 278 ; affronts the Duke of Newcastle, 289 ; retires to Leicester House, 290; forms a party, 29I, 297; plot to seize, 307 ; his friends impeach Macclesfield, 332 ; his accession, 334, 335; compared with George I., 336; early years of, 341; supports the excise bill, 346 ; supports the empire against France, 350; for relief to dissenters, 354: chooses wife for Prince of Wales, 355 ; relations of, with Frederick, Prince of Wales, $356-357$; influence over, of Queen Caroline, 357-358 ; 
attitude of, towards Walpole, $36 \mathrm{r}$; and Maria Theresa, 367,372 ; the Hanoverian troops, 373; he heads his troops, 375 ; attitude of, towards Carteret, 382 ; and the Pelhams, 4II ; attitude of, towards Pitt, 4 I2, 445, 446; his electoral policy, 420-42I, 436, 439 ; on Pelham's death, 430 ; and convention of Westminster, 448 ; on Admiral Byng, 449-450; he resolves to form a Ministry, 450-45 ; death of, 472, 477 ; character of, 478 ; authorities on, App. I., 5II-5I6.

George of Denmark, Prince, lord high admiral, I9; provision for, 27, 40; and occasional conformity, 32, 62, 123 ; his council, $125,128,130$; and the queen, 133 ; dislikes Solners, 138 ; his death, $139,16 r$.

George, Prince of Wales, afterwards George III., 2, 424 .

George William of Celle, 227.

Georgia, colony of, 343,376 .

German ministers of George I., 332 and n. $r$.

German princes, 158, 205, 226, $31 \mathrm{r}$.

German troops at Blenheim, 5I, 55, 56.

Germany, enlistment of troops in, 15 ; French in, 48; war in, 114 ; philosophy in, 315 ; king's dominions in, 324 .

Gerona, II2.

Gertruydenberg, conferences at, 157 , I59, 170, 186, 187, 206.

Gheet, the Great, 76,80 .

Gheet, the Little, 76, 80 .

Ghent, $8,116,118$, 119, 199, 237 ; surrender of, 388 .

Gibbons, Grinling, sculptor, 497.

Gibbs, James, architect, 497, 498.

Gibraltar, Rooke ordered to take, 12; taken, $60,61,62$; besieged by Spaniards, 64; England and, 78; Marshal Tessé at, 85 ; negotiations as to, $\mathrm{r} 87$; troops from, $\mathrm{r} 89$; to be held, I95; formal cession of, 206 ; Stanhope ready to surrender, 28I, 309 ; Spain demands, 322, 323, 328 ; alliance to recover, 325,328 ; besieged by Spain, 330, 336; siege abandoned, 337 ; demand for, waived, 338 ; question of, $376,44^{2}, 443,447^{-}$ $44^{8}$.

Gibraltar, Straits of, rg.

Gin act, the, 350, 35r.

Gladsmuir. See Prestonpans.

Glasgow, 104, 255, 320; attitude of, towards the young pretender, 395 .

Glencoe, Massacre of, 103.

Glenfinnan, 391, 392.
Glenshiel, battle of, 284 .

Gloucestershire, address from, 27.

Godolphin, Sidney, Lord (afterwards Earl of), I, 2 ; lord treasurer, 3 ; for war, 4 ; and whigs, $26,67,68$; action on the occasional conformity bill, 37; and Scottish plot, 39; as financier, 40, 45; and Nottingham, 42 ; and a middle party, 43, 44; and St. John, 46 ; on Rooke's victory, 62 ; on Lord Galway, 63; the High Church party and, 66 ; and the war, 69 ; indifference to religious questions, 73 ; on Dutch credit, 84 ; Shovell and, $92 ;$ and the Scots, $95,96,97 ;$ and the commons, 99 ; selects commissioners for union, I0I, I07; plans invasion of S. France, III ; resolute for war, 115 ; his success, I22; recommends Sunderland, 123 ; created an earl, 124; and the junta, 125; and Harley, 126, 127; and the first parliament of Great Britain, I28; attacked by Rochester, 129 ; betrayed by St. John, I30; and Harley, I3I. 133 ; Ker of Kersland and, 135 ; and Jacobite prisoners, 137; supports Somers, 138 ; offers resignation, 139 ; compromises with whigs, 140; his correspondence with St. Germain's, I43; borrows from the bank, 155; and the junta, 160; friction with the queen, $16 \mathrm{r}$; and Mrs. Masham, 163 ; nicknamed Volpone, 165 ; at Newmarket, 170; deceived by Shrewsbury, 171 ; is dismissed, 172, 175; alienation of Somers from, I73; patron of Addison, 177 ; Peterborough and, 179 ; accused of conspiracy, 194; protest against ministerial action, 199 ; Anne's affection for, 222; death of, 223.

Gordon, 246.

Gordon, Alexander, Jacobite general, 255, 26 r.

Gordon, Duchess of (Elizabeth Gordon), 184.

Gordon, Duke of (George Gordon), 246, 255.

Görz, Baron, Swedish minister, 275, $276,283,285$.

Görz, Baron von Schlitz-, Hanoverian minister, 226.

Gothenburg, 249, 277.

Gower, Lord, privy seal, 370,383 .

Grafton, Duke of (Charles Fitzroy), $307,315,316,346$.

Gramont, Duke de, at battle of Dettingen, 374-375.

Granby, Marquis of, "the mob's hero," 462 ; commander of the British con- 
tingent under Prince Ferdinand, 471: at Warburg, 472.

Grant, the clan, 262.

Grantham, Earl of (Henry Nassau Auverquerque), 28.

Gray, Thomas, 48 .

Graydon, John, vice-admiral, 18, $4 x$.

Great Britain, commercial interests of, 5; sympathises with Cevennois, 20; poor rates, 142 ; Protestant refugees in, 141, 142; contemplated union with Ireland, 143; Holland and, 146; demands Newfoundland, $147 ;$ and the evacuation of Spain, 155 ; feeling in, 196 ; Jacobites in, 239, 249 ; estranged from France, 240; discontent in, 241 ; grievances against Sweden, 274; Alberoni plans invasion of, 281,283 ; preparations against invasion, 284 ; crippled by the South Sea bubble, 287 ; Ireland and, 313, 314; protests against the Ostend Company, 322 ; trade of and the treaty of Vienna, 323 ; concludes treaty of Hanover (1725), 323, 324; debt of to George 1., 333; alliance with France and Spain (treaty of Seville), 337, 338; growing friction between France and, 339.

Green, Thomas, merchant-captain, 100.

Greenrig, 250.

Greenshields, 20 r.

Greenwich, 228, 229, 331.

Greg, William, betrays state documents, I31, 132, 133.

Gregorian Calendar, the, 423.

Grenville, George, 356, 383, 430 ; treasurer of the navy, 446 .

Grenville, James, 446.

Grenville, Richard. See Temple, Earl.

Griffin, Lord (Edward Griffin), 136.

Gross Heppach, 51.

Guadalaxara, 89, go.

Guadarrama Mountains, 89.

Guardian, The, 213.

Gudina, 156.

Guelderland, Spanish, or Upper, 16, 147, 150, 151.

Guelders taken by Marlborough, I6.

Guernsey, Lord (Heneage Finch), 267.

Guienne, $9 x$.

Guinea Company, the French, 187.

Guiscard, Marquis de, 91,92 and $n . I_{1}$ $181,184,235$.

Gunning, Maria (Lady Coventry), 502.

Gustavis Adolphus, King of Sweden, II3.

Gyllenborg, Count, Swedish ambassador, 275, 276, 279.

Habeas Corpus Act, 243, 247, 307.
Habsburg, house of. See also Austria, 18, 186.

Haddock, Admiral, in war with Spain, $36 x-363,368,371$.

Hague, receipt of news of William III.'s death at the, 3; Archduke Charles arrives at, 23; Marlborough arrives at, $49,75,78,79,91$; leaves, 113 , 157, 178; Petkum minister at the, 119 ; letter of Marlborough from, 123 ; Marlborough at, I70; British envoy at, 186; Chesterfield at, 335.

Hainault, 82 .

Haine, river, 152.

Halifax, Lord, afterwards Earl of (Charles Montagu), omitted from the privy council, 4i charged with irregularities in accounts, 34 ; disposition, 36 ; financial talent, 40 , 122 ; one of the junta, 67, 83, 92, 122; and Marlborough, 125, 160, 161; Sir James Montagu, brother of, 133 ; patron of Prior, 177; opposes Oxford's ministry, $19 \mathrm{I}$; and the demands of France, 196; denounces "the restraining orders," I99; opposed to the commercial treaty with France, 207 ; created an earl, 229 ; death of, $238,248$.

Hallam, Henry, historian, 353.

Halley, Edmund, 480.

Hamburg, 272.

Hamilton, fourth Duke of Uames Hamilton), 94, 103, 105, 106, ז36, 204 ; killed in a duel, 205.

Hamilton, general, in Swedish service, 249.

Hamilton, Sir David, physician, 179.

Hamilton, William Gerard, "single speech Hamilton," 438.

Hampshire, 347.

Hampton Court, 278.

Hanau, 374, 375 .

Handel, George Frederick, 355; the Dettingen Te Deum, 377 ; George II.'s favourite, 489 .

Hanmer, Sir Thomas, his "representation," 194 ; deserts the Jacobites, 207 ; votes against the commercial treaty with France, 208 ; on Marlborough's retirement ; 223 n. I ; speaker, 225 : refuses office, 230; displaced from speakership, 233; defends Schism Act, $29 \mathrm{I}$.

Hanover, 216, 224, 310, 316, 323, 331, 332.

Hanover, court of, 217, 225, 277, 285 , 311.

Hanover, Elector of, Ernest Augustus, 226. See also George I. and George II. 
Hanover, Electorate of, joins the grand alliance, 7 ; house of, $40,70,106,150$; Marlborough and Eugene visit, II 5 ; English resident at, 183 ; Prince Frederick at, 228 ; jealous of Prussia, 230; visits to, 27 I ; nervous of Russia, 273 ; and Sweden, 274, 275, 286, 287; and Prussia, 286; Craggs at, 301 ; George I. visits, 308; relations of, to Prussia, $31 \mathrm{I}$; and to the empire, 325 ; interests of, 333,350 ; interests of, opposed to British, $36_{4}$; the treaty of neutrality, 367,368 ; British attitude towards, $372-373,377$; the neutrality violated, $38 \mathrm{I}$; and abandoned, 385 ; Pitt's attitude towards, $437,43^{8}$; it is abandoned to France, 453 .

Hanover, house of, $216,222,28 \mathrm{o}, 33 \mathrm{I}$.

Hanover tories, the, 17I, 208, 214, 215 , $219,223,270$.

Hanover, treaty of, 324, 325, 327, 329, 340.

Hanoverian residents. See Bothmer, Schütz, Kreienberg.

Hanoverian troops, at Malplaquet, 153 ; in English pay, 226; at Vienna, 226.

Harcourt, Henri, Duc d', marshal of France, 189.

Harcourt, Sir Simon, attorney-general, afterwards lord, 130, 133, 139, 168, r74; lord keeper, 177, 179, I94 ; allied with Bolingbroke, 209; chancellor, 209,220 ; at trial of Oxford, 288 ; excluded from act of grace, 289 ; leads tories in lords, 302.

Harding, printer, 318.

Hardwicke, Earl of (Philip Yorke), chief justice, afterwards chancellor, 352, 353; against war, 377; attacks Carteret's policy, 382 ; his " heritable jurisdictions" bill, 409; his "marriage act," 428 ; for war, 359 ; created an earl, 430 ; resigns chancellorship, 446 ; opposes enlistment of Highlanders, 448.

Hardy, Sir Charles, Admiral, 456-457.

Hare, Dr. Francis, afterwards Bishop of Chichester, 177.

Harley, Edward, auditor of the exchequer, 172, 180, 181, 184, $210,295$.

Harley, Robert (afterwards Earl of Oxford), 2 ; speaker, 25, 40 ; releases De Foe, 32 ; moderation of, 36, 42, 43, 44 ; and St. John, 46; and the tories, 66 ; and the war, 69 ; selects commissioners for union, ror ; and De Foe, ro3; his correspondents in Scotland, 104, 106; secretly advises Anne, 123, 124, 125, 126; and Mrs. Masham, 126, 127; betrays Godolphin, 130; has audiences of the queen, I3I ; Marlborough denounces, 132 ; and Greg, 132; resigns, 133 , 134,138 ; his intrigues, 160, 162; nicknamed Janus, 165; supports Sacheverell, 166, 169; his method with the queen, $x 70$; intrigues with Mrs. Masham, I72; chancellor of the exchequer, 173; his ministry, 174; overtures to Marlborough, I75; and the press, I77; and the clergy, I78; and the extreme tories, 180,181 ; stabbed by Guiscard, 182, 183, 235 ; created Earl of Oxford, etc., 183 ; difficulties of, 184 ; and the South Sea company, 185 ; negotiates with France, 186; approaches Marlborough, r89, 190; Plunkett and, I94; and the Asiento, 195 ; and the succession to France, 197; and St. John, I98; denies separate negotiations, 199; inspirer of De Foe, 200; opposes dissolution of union with Scotland, 202 ; intrigues against $\mathrm{Bol}$ ingbroke, 203; supports the treaty of commerce with France, 207 ; approaches the Hanover tories, 208; increasing weakness, 209; deserted by Lady Masham, 210, 216; his advice to the pretender, 211, 212; and the Elector of Hanover, 214 ; consents to purge the army of whigs, 216 ; favours the Hanoverian succession, 217 ; embarrassed by the schism bill, 218 ; promotes an inquiry into Bolingbroke's conduct, 219 ; dismissed, 219 ; charges Bolingbroke with corruption, 220; hopes from George I., 222 ; and Marlborough, 223, 224; reception of by George I., 229; does homage, 232 ; allusion to, 233; impeached of high treason, 235, 236; sent to the tower, 237; popular with Jacobites, 238; his son-in-law arrested, 248 ; Lechmere and, 269; his trial, 288; and acquittal, 289 ; opposes mutiny bill, 290 ; his creation of peers, $29 \mathrm{I}$; opposes the peerage bill, 292 ; and the South Sea company, 293; his secretary, 303; death of, 312; his ministry, 315 .

Harley, Thomas, envoy to Hanover, $216,224,289$.

Harrington. See Stanhope, William. Hartley, David, 480.

Harwich, 49.

Haversham, Lord (Sir John Thompson), $69,97$.

Havre, vessels for the pretender at, 242, 249.

Hawke, Admiral, bravery of, 379; at Belleisle, 415 ; victorious at Quiberon, 
467-469; successful service of, $457,459,477$.

Hawles, Sir John, 168.

Hawley, General, succeeds Marshal Wade, 402; defeated at Falkirk Muir, 403-404; retained in command of cavalry, 404 .

Hay, Lord Charles, his salutation to the French infantry, $387 \mathrm{n}$. 1 .

Hearne, Thomas, antiquary, 93, 164.

Heathfield, Lord (George Augustus Eliott), at Emsdorf, 47 I.

Hedges, Sir Charles, secretary of state, $4,62,90,92,123$; dismissed, 124 .

Heinsius, Antoine, grand pensionary of Holland, 6; proposes the Archduke Charles for the crown of Spain, II ; concerts a "great design " with Marl. borough, 15, 16, 49, 57; France negotiates with, 69; and England, 78, 83,91 ; letter from Marlborough to, 135; Peter the Great and, 145; Torcy on, 147 ; and Torcy, 148 ; and England, 149, 150.

Helchen, 82.

Henley, Sir Robert, $45 \mathrm{r}$.

Hennequin, Dutch diplomatist, 85 n. I.

Henry IV., king, 168 .

Henry VII., king, I68.

Henshaw, James, cited, 399.

Herrenhausen, 226, 355. See also Hanover, court.

Hervey, Lord (John Hervey), afterwards Earl of Bristol, created a peer, 35.

Hervey, Lord (John Hervey), author of the memoirs, 280, 340,34 $1,34^{2}, 346$, $357-35^{8}, 370$.

Hesse-Cassel, 50, 55, 152, $154,326$.

Hesse-Darmstadt, George, Prince of, 12, $13,59,60,64,86,87$.

Hessians, troops, 55.

Heurne, $116,117$.

High Church party, the, 31, 65, 66, 67, $71,141,164,168,200,208,217,232$, 236, 306, 315 .

Hill, Abigail, afterwards Mrs. and Lady Masham. See Masham.

Hill, John, colonel, afterwards majorgeneral, 162, 163, 182, $189,199$.

Hill, Richard, diplomatist, 36, 178.

Hillsborough, Lord, 438.

Hoadly, Dr. Benjamin, Bishop of Bangor, afterwards of Winchester, 291, $342,480$.

Hoare, Sir Robert, banker, 137 n. I.

Hobbes, Thomas, philosopher, 105.

Hochstådt, 52, 54, 57.

Hoffmąnn, J. P., Prussian envoy, 238, 253 n. 2.

Hogarth, William, 350, 395, 423,487, 496.
Hohenfriedberg, battle of, 389 .

Holburne, Vice-Admiral, 454.

Holdernesse, Robert D'Arcy, fourth Earl of, secretary for the southern depart. ment $425,446,447$; reinstated, 451.

Holland, sympathy in for the Cevennois, 20; Archduke Charles in, 23 ; extra. ordinary mission from, 26; Marlborough embarks for, 59 ; feeling in, 78 ; trade of, 107 ; states of, 117 n. $x$, $146,186,194,205$; interests of sacrificed, 206; escape of Jacobites to, 262; Swedish ambassador to, 276 ; protests against the imperial Ostend Company, 322; accedes to treaty of Hanover, 324 ; treaty of peace between emperor and, 330 .

Holstein-Gottorp, Duke of, 8,311 .

Holt, Sir John, chief justice of the queen's bench, ror.

Holywell, Marlborough's house, 224.

Home, Earl of (Alexander Home), 247, 393.

Honywood, Philip, brigadier, 178.

Hooke, Nathaniel, Jacobite, 134 :

Hopkins, Edward, 3 r4.

Hopsonn, Sir Thomas, vice-admiral, 14.

Hopsonn, Edward, vice-admiral, 326.

Hosier, Francis, vice-admiral, 326 ; admiral, at Porto Bello, 365.

How, John Grubham, 27, 41.

Howe, Commodore Sir William, later fifth Viscount, 455.

Hudson's Bay, $187,206$.

Huguenot merchants, 137 .

Huguenots, 110, 206, 264, 339.

Hull, town of, 98 .

Hume, David, ${ }_{4} 80$.

Hungary, 226.

Hungary, insurrection in, $7,16,48,57$, 329.

Huntly, Marquis of (Alexander Gordon), $246,255,258$.

Huske, General, 403.

Huxelles, Marquis d', French diplomatist, 196.

Huy, fortress of, 16, 76, 150.

Hyde. See Rochester.

Hyères, battle of, 378-379.

Iberville, d', French ambassador, 212, 221, 234.

Ilay, Earl of (Archibald Campbell), afterwards third Duke of Argyli, 270, 320, 332 ; supports Walpole, 347,348 .

Illbesheim, convention of, 59 .

India, 322 ; French and British interests in, $377,431-432,473$ et sqq.

Indies. See West.

Ingoldsby, Brigadier, at Fontenoy, 386. 
Ingolstadt, 53 .

Innsbruck, 284.

Inverary, 251.

Inverness, 246, 260, 262, 284 .

Ireland, affairs of, $71,72,74$; troops in, I05; German Protestants in, 142, 143; Wharton's administration, 143 ; nationalist party, 143; Phipps, chancellor of, I68, 213 ; Ormonde, lordlieutenant of, 174; pretender and, 184; troops from, 189; Sunderland, lord-lieutenant of, 229 ; Brodrick, chancellor of, 229; Church of, and the pretender, 239, 259; additional troops for, 265 ; friction with England, 312, 313; its currency, 314 ; and Wood's halfpence, 3I4-3Ig.

Ireland, lords-lieutenant of. See Rochester, Ormonde, Pembroke, Wharton, Sunderland, Townshend, Bolton, Grafton, Carteret, Dorset, Chester. field, Harrington.

Irish brigade, the (in the French service), 56.

Irish cavalry (in the French service), 250.

Irish Jacobites, 3 Ig.

Irish officers (in the French service), 265.

Irish privy council, 3 Ig.

Irish tenants, 142.

Irish trade, 99, 143, 313.

Irish troops (in the Spanish service), $283,336$.

Irish whigs, 3 Ig.

Irwin, Lord, 298.

Italian opera, introduction of, into England, 488-489.

Italy, Austrian troops for, 8 ; imperial possessions in, 16; French army in, 48 ; proposed campaign in, 59 ; Prussian troops in, 79; lost to France, 80 ; Peterborough goes to, $9 \mathrm{I}$; French garrisons in, $109, \mathrm{II}_{4}$; grand alliance and, II2; the Italian duchies, Ir3; compensation proposed to France in, 197 ; the succession to the duchies, 280, 281, 321, 322, 337, 338; Spaniards invade south, 349 ; relations of, with Spain, 37 I.

Jackson, British minister to Sweden, 276.

Jacobites, the, 37; and the Scottish plot, 38, 93, 94, 96; and Scotland, 103, 104, 105, 106, 108; and Oudenarde, I17, I18; and Almanza, 129; and Greg's case, 133; in Scotland, $\mathrm{I}_{36}$; and the bank, I37; after Malplaquet, I55; and Sacheverell, I68; and Harley's ministry, 175, 176, 180; favour dissolution of union with Scot- land, 202 ; deserted by Hanmer, 207 ; increased influence of, at court, $2 \mathrm{II}$ : a Jacobite envoy, 215; Lady Masham and the, 2r6; suspected, 220; and the accession of George I., 224, 225 ; excite riots, 232 ; confounded with the tories, 233; overtures to Bolingbroke, 234; and Oxford, 236, 238; and Roman catholics, 239; incapacity of for organisation, 242; precautions against, 243; in Paris, 244, 245; in London, 246; arrests of in Scotland, 247 ; in Newcastle, 250 ; brought to London, 255 ; and Scottish prisoners, 265 ; oppose the septennial bill, 269; General Dillon, 269; and George I.'s visit to Hanover, 270; and Sweden, 276,277 ; revival of activity among, 305 ; agent of, in Petersburg, 312 ; and Ostend company, 321 ; views of, on the dismissal of officers, 348 ; and the Porteous riots, 352; Walpole and, 367 ; mentioned, $380-381,383,391$, 408, 427-428.

Jamaica, I4, 42, 86.

James I. (VI. of Scotland), 93, 314.

James II., 3 ; his widow, 38 ; his illegitimate son, the Duke of Berwick, 62 ; his obstinacy, I23, I65 ; his expulsion, $168,17 \mathrm{r}$; his grants, 200 ; his heirs, 213.

Janus, nickname of Harley, 165 .

Jedburgh, 252.

Jekyll, Sir Joseph, master of the rolls, 45,218 ; and the South Sea directors, 299 ; and the liquor law, 351.

Jenkins, Robert, his ear and the Spanish war, 358-359, 360.

Jennings, or Jenyns, Sir John, I26.

Jennings, Sir John, admiral, 326.

Jersey, Countess of (Barbara Villiers), 234.

Jersey, Earl of (Edward Villiers), of the Church party, 4 ; Jacobite, 42, 175 , 176 ; dismissed, 45 ; struck off privy council, 124 ; his death, 183 .

Jesuits, the, 193 .

Jews, 137 ; feeling against, 428-429.

Johnson, Dr. Samuel, cited, 383,410 , 493.

Johnson, Sir William, 434.

Jonson, Ben, 165.

Joseph, Archduke, and George II., 42I, 425.

Junta, the, $67,68,71, .122,124,125$, $138,139,160,161,170$.

Junta, the Hanoverian, $230,278$.

Karlskrona, 277.

Kaunitz, Austrian minister, 427.

Keene, Benjamin, 327. 
Keene, Sir Benjamin, minister at Madrid, 359-360, 363 and note, 421 .

\section{Kehl, 17.}

Keith, Marshal, 247.

Kelly, Rev. George, 305, 306, 307.

Kelso, 251.

Kendal, Duchess of (Ermengarde Melusina von der Schulenburg), 227,301, 309, 310, 312, 314, 329.

Kenmure, Viscount (William Gordon), 250 ; beheaded, 266.

Kent, county of, 73,244 .

Kent, Earl, afterwards Marquis and Duke of (Henry Grey), 45, 170.

Kent, William, 495.

KeT, John, of Kersland, $135,322$.

Ker. Lord Mark, on Sir John Cope's defeat, 394.

Kerpen, river, 53, 54.

Kerry, county of, 142.

Kessel, river, $53,54$.

Kidder, Dr. Richard, Bishop of Bath and Wells, 21.

Kielmansegg. See Darlington, Countess of.

Kildrummy, castle of, 246.

Kilmarnock, Countess of, 402.

Kilmarnock, fourth Earl of (William Boyd), trial and execution of, 408 . 409.

Kilsyth, 255.

King, Sir Peter, afterwards Lord, chancellor, 45, 218, 322.

King, William. See Dublin, Archbishops of.

Kinnoull, Earl of (Thomas Hay), 247.

Kintail, 284.

Kloster-Zeven, convention of, 453, 454 .

Kneller, Sir Godfrey, painter, 2, 496.

Knight, Robert, South Sea Company's cashier, 299, 300.

Kolin, battle of, $45 r, 454$.

Königsegg, Count, 328, 385, 388.

Königsmarck, Count, 227.

Krefeld, battle of, 455 .

Kreienberg, Hanoverian resident, 184 , 223, 225.

La Bourdonnais, 4 I6.

La Quadra, afterwards Marquis of Villarias, 360 .

Lagos, Portugal, $13,60$.

La Mothe, Comte de, French general, $15,118$.

Lancashire, proposed descent on, 250; rebels in, 253, 254, 255; troops in, 253 ; executions in, 265.

Lancaster, 254.

Landau, fortress of, $11,17,59,75$.

Langholm, 252.

Languedoc, insurrection in, 19, 20, 9I ; proposed kingdom of, 12 ; diversion in, 158.

Laniere, 153.

Lansdown, Lord (George Granville), 210,235 ; secretary at war, 248.

Lauderdale, Duke of (John Maitland), 102.

Lauingen, 58.

Launsheim, 5 .

Law, General, 43 I.

Law, John, 294.

Law, William, $480,48 \mathrm{r}$.

Lawless, Patrick, 215.

Lawrence, Colonel Stringer, at Trichinopoly, 431 ; in Fort St. George, 475.

Lawrence, St., river, 6.

Layer, Christopher, 306 ; trial of, 307 ; execution, 308.

Leake, Sir John, admiral, 6o, 6r, 62, 64; besieges Barcelona, 86 ; relieves Barcelona, 88; occupies Sardinia, 120 ; at Port Mahon, 121; a lord of the admiralty, 162 ; first lord, 174 .

Lech, river, 53 .

Lechmere, Nicholas, afterwards Lord, $218,269$.

Lee, Sir George, 438.

Leeds, second Duke of (Peregrine Osborne), admiral, 245.

Légal, French general, 87, 89.

Legge, Henry Bilson, chancellor of the exchequer, 430 ; and subsidies, 437 ; of Leicester House party, 438 ; resignation of, 450.

Leghorn, 19, 338.

Leibniz, Gottfried Wilhelm, philosopher, 227.

Leicester House, Prince and Princess of Wales retire to, 290; the prince's party at, $297,332,430,437,438$.

Leinster, Duke of Schomberg and. See Schomberg.

Leipzig, 113 .

Leith, 136, 251.

Leominster, 302.

Lerida, 156.

Lestock, Admiral, and Admiral Mathews, $379,413$.

Lévis, General, repulsed at Quebec, 472.

Lewarde, 187.

Lewis, Erasmus, Oxford's secretary, 303.

L'Hermitage, secret political agent, 131 .

Lichfield, 142.

Liechtenstein, Antony, prince of, 23, rog.

Lizge, 10, 16, 76, 150.

Liegnitz, battle of, 472 .

Ligonier, General, afterwards Earl, 375, $382,388,395,396-397,412,414-415$, 417.

Lille, siege of, $118,119,121$; cession of demanded, $147,158$. 
Limburg, taken by Marlborough, 16 .

Limerick, county, 142.

Limerick, Lord, attacks Walpole's administration, 369-370.

Linlithgow, 255.

Linlithgow, Earl of (George Livingstone), 26r n. 4 .

Linz, 48 .

Liquor trade, the, and parliament, 350 , $351,352$.

Liria, Duke of (James Francis Fitzjames), 327.

Lisbon, 20, 23, 59, 61, 62, 63, 64, 86, $88,92,112$.

Literature of the eighteenth century:Religious and speculative, 479-482, 488.

Poetry and satire, $482-487$.

Dramatic, $487-488$.

Tales and romances, 490 .

Essays and journals, 491-494.

Newspapers, 493.

Epistolary, 495.

Liverpool, 254.

Lloyd, Robert, of Aston, Salop, r69.

Locke, John, ro4 ; influence of his philosophical writings, $479,480,48 r, 482$.

Lockhart, James, of Carnwath, Jacobite, 100, 103, 201, 202, 223, 247, 336.

London, 99, I36, 137, I4 I, I42, 145, $157,174,178,187,194,195,203,212$, 224. 229, 236, 238, 239, 244, 246, 247 , $248,254,264,265,271,275,276,280$, 294, 295, 302, 305, 3I4, 3I7, 3I9, 322, $332,346,350,35 \mathrm{I}$.

Bank of England, see Bank.

Burlington House, 347.

Charing Cross, 306.

Cockpit, the, IoI, I82, 220.

Cornhill, 295.

Exchange, the Royal, r6g.

Fleet prison, 343 .

Goldsmiths' Hall, 99.

Grub street, 182 .

Haymarket, 355 .

Holborn, St. Andrew's, 170.

Hyde Park, 205.

Kensington Palace, 220, 3r4, $33 \mathrm{r}$.

Leicester House, see sub Leicester.

Lincoln's Inn Fields, 355.

Newgate prison, $67,182,255,265,304$.

St. James's Palace, 95, 240, 290, 305, 346.

St. Paul's, 77, 88, 164.

Seven Dials, 314.

Strand, the, 167.

Temple, the, I67.

Temple Bar, 308.

Tower, the, 136, 162, 192, 194, 237, $249,255,267,288,289,290,302$, $305,306,307,308$.
London (cont.) -

Tower Hill, 266, 302.

Tyburn, 308.

Westminster Abbey, 225, 301, 305, 306.

Westminster Hall, 167, 288, 289 .

Westminster Palace, 99,345 .

Whitehall, ror, 18I, 182 .

London Assurance Company, 295.

London Gazette, The, 329.

London, loyalty of, 398-399.

Longman, Thomas, founder of the publishing house of Longman, 494.

Lonsdale, Viscount (Henry Lowther), 252, 298.

Lords, House of, alien peers in, 28 ; and the occasional conformity bill, 32,33 ; quarrel with the Commons, 39,40 ; appeal to the public, 40 ; its resolution as to Spain, 140 ; inquiry into Peninsular campaigns, 179; swamped with twelve new peers, r93; examines Arthur Moore, 219; tries the rebel lords, 266; paramount in parliament, 289; the opposition in the, 335 ; throw out the pension bill, $34 \mathrm{I}$; defeat of ministers in, 347.

L'Orient, attack on, 413.

Lorraine, Duke of, Francis Stephen, afterwards Grand Duke of Tuscany and Emperor, 350.

Lorraine, Duke of, Leopold Joseph, 264.

Lorraine, the pretender in, 215, 217, 225, 239, 250 ; expelled from, 264 ; Stanislaus of Poland and, 350 .

Loudoun Campbells, the, at Prestonpans, 393, 394.

Loudoun, fourth Earl of (John Campbell), commanding in Canada, 444, 454 ; recalled, 456.

Louis XIV., 6; aids the Hungarian insurgents, $7 ;$ is supported by the Elector of Bavaria, 7; his grandson, 17, 18; and Fraser (Lord Lovat), 38 ; mentioned, $57,59,62,64,76,80,84$; and Spain, 87, 121; his persecutions, 91, I13, 146; attempts to bribe Marlborough, 147; Philip V. and, $\mathrm{I}_{4} 8$; and the States-General, 149 ; and the Barrier treaty, 150; saying of, 151 ; and peace, 186, 197, 205, 212; Marlborough and, 224; and the accession of George I., 225; and Lord Stair, 240; raises money for the pretender, 242 ; death of, 244,246 ; and the Huguenots, 264; and Dunkirk, 272 ; consequences of death of, 273.

Louis XV., 197, 244, 282, 323, 339; his queen, $349 ;$ the marriage of his daughter, 364 ; he declares war against England, 381 ; at Calonne, $386,3^{87}$; 
relations of, with Prince Charles, 396 ; his campaign in Holland, 414 ; weary of war, 417 ; character of, 418.

Louisbourg, capture and importance of, $390,413,456,457,45^{8}$.

Louvain, 76.

Lovat, Lord (Simon Fraser), 38, 247 , 260,262 ; and the young pretender, 380 ; trial and execution of, 409.

Lowndes, William, 2 rg.

Lutzingen, 55.

Luxembourg, 82.

Lynar, Count, 453.

Lynn, 213.

Lyons, 155.

Lyttelton, George (later, first Lord Lyttelton), 356, 357, 360, 36r, 383. $430,438$.

Lyttelton, Sir Thomas, 436 .

Macaulay, Lord (Thomas Babington Macaulay), historian, I60.

Maccartney, George, general, 178, 205.

Macclesfield, second Earl of (George Parker), and Gregorian Calendar, 423.

Macdonald, Eneas, 408.

MacIntosh, Brigadier, Jacobite, 25I, 265.

Maclntosh, the clan, $25 \mathrm{x}$.

Maclean, Sir John, 39 ; before the privy council, 39; pensioned, 40; arrested and discharged, 136; Government spy, 248 and $n .2$.

Madagascar, 100.

Madras, 416, 475.

Madrid, 21, 85, 87; occupied by the Anglo-Portuguese army, 89, 9o, Io9. I Io ; march on, 156, 157; occupied by the British and Austrian army, 157; Asiento treaty signed at, 205, 218; James Stanhope at, 230; Paul Methuen at, 273; Ormonde and the pretender at, 283, 284; Alberoni banished from, 285; treaty of (I72r), 310, 321 ; Ripperdá at, 322 ; court of, $326,327,338$; treaty of (1750), 421.

Maestricht, 8, 10, 50; battle of, 414-415.

Mahan, Captain, American naval historian, 468.

Mahomet, George I. 's page, 23 r.

Maine, Duchess of, 283 .

Maine, Duke of, his plot, 282, 283.

Maintenon, Madame de, wife of Louis XIV., 264.

Mainz, Elector of, 57.

Malaga, battle off, 6r, 62, 65 .

Malplaquet, 152; battle of, 153, 154, 240.

Manchester, city of, Jacobites in, 397 ; change of feeling in, 400 .
Manchester, Earl of (Charles Montagu), secretary of state, 4 .

"Manchester Regiment, the," 397, 40r, 408.

Mandeville, Bernard, 480.

Manley, Mrs. Mary de la Riviere, authoress, her New Allantis, r62.

Mann, Horace, 380.

Mann, Robert, I9r.

Mansell, Sir Thomas, afterwards Lord, $45,133$.

Mantua, I8, 109.

Mar, Earl of (John Erskine), ro3; secretary for Scotland, 208; suspected of Jacobitism, 220; dismissed, 229 ; turns Jacobite, 245; proclaims the pretender, 246; his influence, 247 ; inactivity of, 248,250, 25I; his dispatches, 250; advances to Sheriff Muir, 255 ; commands Jacobites at battle, 256, 257 ; created a duke by the pretender, 260; escapes to France, 261 ; at Avignon, 269.

Marchmont, first Earl of (Sir Patrick Hume), 95, I01, 104, 347 .

Marchmont, second Earl of. See Polwarth.

Mardyck, 240, 277.

Margate, 298.

Maria Theresa, Queen of Hungary, afterwards Empress, 323, 338; accession of, 366 ; she summons George II., 367 ; political fortunes of, $37 \mathrm{I}$ 372 ; relations of, with France, 372 ; and convention of Turin, 376 ; and the Hanoverian troops, 384 ; her "Silesian madness," $388-389$; correspondence of, with Mme. de Pompadour, 444, 463 .

Marischal, the Earl (George Keith), $246,260,283,284$.

Marlborough, third Duke of (Charles Spencer): resigns his command, 377 ; re-offers his services, 380 ; requests command under Prince Ferdinand, 456 ; dies, 460 ; mentioned, 356.

Marlborough, Countess of, afterwards Duchess, Queen Anne's favourite, I, 2 ; declines a duchy, to; influence with Anne, 35, 70; Godolphin and, 66; Peterborough and, 86 ; supports Sunderland, 123; suspects Harley, 124; and Abigail Hill, 126; a friend of Robert Walpole, 133; quarrels with the queen, 139; Marlborough to, 155; suspects Somers of venality, 161; favours appointment of Orford to admiralty, 162 ; attacks on, 162 ; and Mrs. Masham, 163; alienation of Somers from, 173 ; Harley's overtures to, 175 ; St. John and, 178; attacked 
in The Examintr, 178 ; writes to the queen, I79; her character of the queen, 222 ; death of, 304.

Marlborough, Earl of, afterwards Duke of (John Churchill), his military talents, I ; his political views, $I$; made captaingeneral, 3 ; envoy to Holland, 3,6 ; for war, 4 ; joins the army in the Netherlands, 9 ; escapes capture, Io; returns to England and is created duke, ro; his second campaign, 15 ; is censured by the Dutch, I6; protests to the StatesGeneral, I6; parliamentary congratulations to, 25 ; friends of, vote with whigs, 26 ; thanksgiving for successes of, 26 ; and the whigs, 34 ; hostility of tories, 35; works against the second occasional conformity bill but votes for it, 37 ; and the Scottish plot, 39, 4I ; and Nottingham, 42 ; and a middle party, 43 ; and St. John, 46 ; his plans for $1704,48,49,50$; meets Eugene, $5 \mathrm{I}$; storms the Schellenberg, 52; his movements, 53; marches to join Eugene, 54 ; at Blenheim, $55,56,57$; after Blenheim, $5^{8}$, 59 ; returns to England, 59 ; consulted as to Gibraltar,62; Woodstock granted to, 65 ; and the Duke of Buckingham, 67 ; and the whigs, 68 ; on Spain, 69 ; and a campaign on the Moselle, 75,76 ; in the Netherlands, 76,77 ; at Vienna and Berlin, etc., 79; in Brabant, 80 ; at Ramillies, $80,8 \mathrm{I}$; captures Courtray, 82 ; nominated governor of the Netherlands, 83 ; and the Dutch, 84,85 ; and Peterborough, 88 ; and Guiscard, 91 ; returns to London (I704), 99 ; advice on Spain, IO9, III ; visits Charles XII., II3; his campaign in $1707, I_{4}$; and the Elector George, II 5 ; at Oudenarde, II6, II7; proposes to march on Paris, I 8 ; captures Lille, 119 ; his opinion of Galway, r2o; and Godolphin, I22 ; and Sunderland, 123 ; pension to, 124 ; and the junta, I25; Harley and, I26; and St. John, 127; and the first parliament of Great Britain, I28; attacked by tories, I29; betrayed by Harley and St. John, r30; denounces Harley, I32; supported by Admiral Churchill, 133 ; and Jacobite prisoners, r36; supports the Bank of England, 137 ; Anne appeals to, 138 ; his correspondence with St. Germain's, r43; organises campaign for 1709 , and the preliminaries of peace, $I_{4} 6, I_{47}, 1_{4} 8$; on Dunkirk, 149; refuses to sign Barrier treaty, I50; reassures Prussia, I5I ; besieges Tournay, I52; at $\mathrm{Mal}$ - plaquet, I53, I54, I55; plan of campaign of, 157 ; takes Douay, $15^{8}$; alienates Lord Halifax, I60, I6I; asks for a patent for life, I62 ; denounces Mrs. Masham, r63 ; Shrewsbury and, 170, I7I ; emperor opposes dismissal of, I72; Addison's panegyric on, I77; returns to London, $r 78$; ill-health of, 179 ; supports Galway in the Lords, 179 ; tories and, I80; opposes Villars, I87; penetrates the French lines, I88; overtures to by Oxford, I89, I90; secures the defeat of Oxford's ministry, I9I; dismissed the army, I92, I93; accused of a conspiracy, 194; consequence of his dismissal, 200; Hanmer and, 207; omitted from the regency, 223 ; well received by George I., 229; as a statesman, 230, 245; inactivity of, 248, 25I ; Argyll and, 255 ; fails the pretender, 262 ; discards the army, 243 ; distrusted by Stanhope, 248, 251 ; Argyll and, 255; fails the pretender, 262; resigns captaingeneralship, 300; death of, 304 ; former officers of, 307 .

Marsin, Count de (Ferdinand), marshal of France, I7, 50, 5I, 55, 56, 75, 80.

Martin, Commodore, 372.

Mary of Modena, ex-queen, 38, 224, 239, 240.

Mary II., her death, I.

Masham, Mrs., afterwards Lady, ı26, 138 ; triumphant, I39; her intrigues, $160,162,172,175$; her brother, 182 ; supports Bolingbroke, 210; is bribed by him, 2I9; her character of the queen, 222.

Masham, Samuel, afterwards Lord, 193.

"Mat's Peace," I87.

Mathews, Admiral, in Mediterranean, 371-372; off Toulon, 379 ; and Admiral Lestock, 379, 4 I3.

Maubeuge, 188 .

Maynwaring, Arthur, auditor of the exchequer, I8o.

Mead, Dr. Richard, physician, 308.

Mechlin, 8.

Mecklenburg, 273, 275.

Medina, Sir Solomon, 192.

Mediterranean, the command of the, I2, $20,62,65,78,121,129,187,477$; France and Venice in the, II2.

Mehaigne, river, 15, 16, 80.

Meldert, 77, I I4.

Menin, 82, I5 r.

Mercy, Count, imperialist general, I55.

Meredyth, Thomas, general, 178 .

Merioneth, 45 .

Mesnager, French diplomatist, I87. Messina, 28r. 
Methuen, John, ex-lord chancellor of Ireland, envoy to Portugal, 23, 92.

Methuen, Paul, envoy to Portugal, 22, 60,85 , 112 ; acting secretary of state, 27x, 279 ; envoy to Madrid, 273.

Methuen treaty, 23, 207.

Metz, 80.

Meuse, river, 9, 15, 16, 49, 76, 150.

Mexico, 14.

Midleton, Viscount (Alan' Brodrick), chancellor of Ireland, 229, 301, 3r5, 316,318 ; resigns, 319.

Milan, Spanish troops in, 8; Victor Amadeus and, 18; treaty of, rog.

Militia bill, the, $438,439,448,449$.

Minas, Marquis das, Portuguese general, $63,87,88,89$.

Minden, battle of, $460-462$.

Minorca, projected attempt on, 90,120 , $12 \mathrm{r}$; cession of, 149, 150, 189, 206 ; alliance for the recovery of, 325,376 ; loss of, 440-443.

Mirepoix, Duke de, 436.

Mir Jafar, Nawáb of Bengal, 474, 475.

Mississippi, the, river, 339 .

Mississippi scheme, the, 204, 205.

Mist, Nathaniel, printer, 304.

Moffat, 250.

Mohammed Ali, 43i-432.

Mohocks, the, 194 .

Mohun, Lord (Charles Mohun), 205.

"Moidart, Seven men of," 391 .

Monckton, Brigadier, at Quebec, 464 ; wounded, 466.

Mons, 82, I19, 152; fall of, 412.

Montagu, Edward Wortley, I4I.

Montagu, Lady Mary Wortiey, 141, 248, 495.

Montagu, Sir James, solicitor-general, 133.

Montcalm, Marquis of, sets out for Canada, 444: success of, 454 ; besieged in Quebec, 464-466; death, 466.

Monteleone, Count de, Spanish envoy, 322.

Montespan, Madame de, 59.

Monthermer, Marquis of, afterwards Duke of Montagu (Ralph Montagu), 97.

Montjuich, fort, 87.

Montpellier, 159.

Montreal, fall of, 473.

Montrose, 260.

Montrose, Duke of (James Graham), 229, 347.

Moore, Arthur, 182, 207, 219, 289.

Moravia, 48.

Mordaunt, General Sir John, 452 ; court-martialed, 454.

Moreau, French banker, 182.
Morley, Mr. and Mrs. (Prince George and Queen Anne), 123, 126, 170.

Mortimer, Earl. See Harley, Robert.

Morton, Thomas, 145.

Moselle, river, projected campaign on the, $16,49,50,75,115$.

Mosley, name assumed by Strickland, qu. vid.

Munich, 52, 59.

Munster, Duchess of. See Kendal, Duchess of.

Münster, treaty of, 150.

Murray, Brigadier James, in Canadian war, $464,466,472-473$.

Murray, Lord George, advises Prince Charles Edward, 392, 396, 398, 400, 401, 404, 405.

Murray, William, created Lord Mansfield, 445.

Musgrave, Sir Christopher, ro.

Mustapha, George I.'s page, 231 .

Mutiny Act (I712), 221; (1718), 290; (1747), 419; (1748), 420 ; (1749), 420.

Nairne, Lord (Lord William Murray), 266.

Namur, 76, 80, 82, 350 ; fall of, 412.

Naples, Leopold I.'s designs on, II, 18, 19, 23 ; Joseph I, and, 109, 113; Louis XIV. and, 147 ; Sir G. Byng's fleet at, 28r ; Charles (Don Carlos) King, 37 I-372.

National debt, the, 288, 293, 294.

Navarre, 89 , 121 .

Navy, whigs dismissed from the, 203.

Neapolitan troops, 86,87 .

Nebel, river, 54 .

Neckar, river, 50.

Netherlands, the, 8 ; reinforcements for, 15; defence of, 49; Marlborough marches from, 50; the French in, 75, 76 ; Marlborough in, 77, 80; Spanish, $82,83,115,121,145,147,150$; French army in, I5I ; British army in, 192; Ormonde in, 197; Austrian governor of, 283 ; and trade with West Indies, 321 ; British army in, 372, 412.

Nettuno, 283.

Newcastle, Duke of (John Holles), 62, $67,133,137,138,171,173$; death of, 183.

Newcastle, Duke of (Thomas Pelham Holles), affronted by the Prince of Wales, 289 ; joint-secretary for Scotland and secretary of state for the southern department, 320; refuses to concede Gibraltar, 322; neutral between Walpole and Townshend, 325 ; preferred by Walpole to Pulteney, 335 ; supports Wal pole against Townshend, 340; and against the 
opposition, 347 ; differs from Walpole on the Porteous riot, 352 ; views of, on the war, 377 ; characteristics of, 383-384; relations of, with George II., $4 \mathrm{II}, 4 \mathrm{I7}$; and the reductions in the navy, 422 ; and Archduke Joseph, 425 ; and "Bow Street runners," 429; "universal minister," 430-43I ; relations of, with $P i t t, 435,445,450-$ $45 \mathrm{I}$; the question of subsidies, $436-$ 437 ; on militia scheme, 439 ; his intelligence department, 440; attitude of, towards Admiral Byng, 443 ; and Port Mahon, 447; weakness of, 448; mentioned, 392.

Newcastle, town of, $98,249,250,253$.

Newmarket, 170 .

New England, 6.

New Forest, the, 21 .

Newfoundland, 18, 147, 187, 206.

Newgate, prison of. See London.

Newton, Sir Isaac, 317, 480 .

New York, I42.

Neynoe, Philip, 306, 307.

Nice, 59.

Nicholson, Francis, general, 189 .

Nieuport, 82, 136 .

Nimeguen, 9 .

Nithsdale, Countess of (Winifred Herbert), 267.

Nithsdale, Earl of (William Maxwell), rebels, 250; impeached, 266 ; escapes, 266, 267.

Noailles, Duke de (Anne Jules), Marshal of France, 120, 157, 374, 375, 378.

Nonconformists. See Dissenters.

Non-jurors, 40, 22 r, 305, 308.

Nore, the, 287,326 .

Norfolk, 33I.

Norken, river, II6, II7.

Normandy, I 18.

Norris, Captain Richard, 378.

Norris, Sir John, admiral, $158,274,275$, $284,286,287,363,38$ r.

North American Fisheries, the, 187, 390.

North and Grey, Lord (William North), $306,307,308$.

North Sea, the, 48.

Northumberland, 250, $25 \mathrm{I}$.

Norway, 262, 283.

Norwich, Hayter, Bishop of, and the Jews, 429.

Nottingham, Earl of (Daniel Finch), of the Church party, 4 ; called "Dismal," 4 ; made secretary of state, 4,31 ; dismisses whig officials, 35, 36; and the Scottish plot, 38, 39; resigns, 42 ; his intrigues, $43,66,69,72$; his influence on Church appointments, 73 ; letter from, 94 n. I ; leads opposition, 97,
107; dismissed from privy council, 124 ; attacks the admiralty, 128; and also Marlborough, 129; deserts the tories, 190, 195, 200; leads the Hanover tories, 2I4, 223 ; relations to the dissenters, 218 ; president of the council, 229, 230; pleads for the rebel prisoners, 266 ; dismissed, 267 , $27 \mathrm{I}$; in opposition, 268.

Nottingham, town of, r3I.

Nova Scotia, 189, 205, 206, 420, 422.

Noyelles, Dutch general, Io9.

Nugent, Lord (Thomas Nugent), 13, 250.

Nugent, Robert, later Earl Nugent, and the drink trade, 422-423.

Nystad, treaty of, 287 .

Oberglauheim, 55, 56 .

Occasional conformity bill, 30, 31, 32, 33 ; second, 36 ; rejected by the lords, 37 ; accepted by the whigs, I90; repealed, 291.

Occasional Writer, the, newspaper, 336. October club, the, 180, 183, 207.

Ogilvie, Captain John, a spy, 84 n. I, 134 n. I.

Ogle, Rear-Admiral Sir Chaloner, 366.

Oglethorpe, James Edward, general, 342, 343.

Oldfield, Anne, 490.

Oldmixon, John, 3.

Old Sarum, borough of, $36 \mathrm{r}$.

Onslow, Arthur, Speaker, 27, 292, 300, 305, 308, 335 .

Onslow, Sir Richard, Speaker, afterwards Lord Onslow, 140, 269.

Opdam, Dutch general, defeat of, 16.

Orange, Prince of (John William Frison), at Malplaquet, 153, 154.

Orange, Prince of. See William III.

Orange, Prince of (William IV.), 355.

Orford, Earl of (Edward Russeli), 42, $67,122,125,160,161,166,174,229$, 279.

Orkney, Earl of (Lord George Hamilton), general, $55 \mathrm{n}$. I, 57 ; at Malplaquet, I53, 154 .

Orkneys, the, 262.

Orleans, Anne of, Duchess of Savoy, 213.

Orleans, Duc d' (Philippe), general, afterwards Regent of France, 79, I09, Iro, 120; intrigues with Stanhope, 121, 140; Regent of France, 244, 246-263; releases Huguenot prisoners, 264; impressed by the collapse of the Jacobite rebellion, 265; and Philip V., 273; makes overtures to George I., 277, 280; Alberoni's plot against, 282; declares war against Spain, 283. 
Ormonde, Duke of (James Butler), commands army againat Cadiz, 12, 13. 60 n.; lands at Vigo, 14; thanksgiving for, 26; lord-lieutenant of Ireland, 27, 72, 214; and Rooke, 86; appointed captain-general, 197 ; his onders, 198; proclaims an armistice, 199; and Hanmer, 207; "discards the army," 211 ; Anne and, 216 ; suspected of Jacobitism, 220; his desertion of the allies, 226 ; dismissed, 229 ; riot in bonour of, 232 ; Stanhope on, 233; his popularity, 236,238 ; in the Netherlands, 237 ; projected attempt on England, $24 \mathrm{I}$; his flight, 244, 249; and Marlborough, 245 ; expected attempt by, 246 ; his secretary, 248; at St. Malo, 250; the pretender and, 250 ; expected in Lancashire, 252 ; to make an attempt on England, 259; his failures, 262 ; price on head of, 264 ; to lead a Spanish invasion, 281, 283; in conspiracy, 305, 307.

Orrery, Earl of (Charles Boyle), 186, $306,307,308$.

Osborn, Admiral, 457.

Osnabrück, 332.

Ostend Company, the imperial, 321 , $322,323,325,329,330,338$.

Ostend, importance of, 15 ; siege of, 82 , I16, I18.

Oudenarde, 116, 117 ; battle of, 116,117 , I18, 119, 228, 308 ; surrender of, 388 .

Ouwerkerk, Dutch general, 49, 50, 77, 82.

Oxburgh, Colonel, Jacobite, 253.

Oxenden, Sir George, 332.

Oxford, city of, 238 .

Oxfordshire, 170.

Oxford, University of, 29, 65, 164, 169, $178,244,249,315$; Christ Church, $3 r 8$.

Painters of the eighteenth century, 496.

Palatinate, the Rhenish, 79, I4I, 349.

Palatines, the, 141, 142, 143, 167.

Palm, Count, 329.

Panmure, Earl of (James Maule), 246, 255.

Parda, the convention of the, 337, 341.

Paris, 157, 177, 182, 186, 188, 200, 204, 225, 230, 234, 24x, 244, 245, 248, 269, 276, 282, 285, 295, 311, 312, 322, 328, 330, 337.

Parker, Sir Thomas, afterwards Earl of Macclesfield, and chancellor, 168 ; appointed chancellor, 290, 331; im. peached, 332.

Parliament, English (afterwards British), last of William III., meets, 2 ; Anne's first, 25 ; opening of session, 36 ; dissolution of, 67 ; and Irish parliament, 73 ; and Scots, 98.

Parliament of Great Britain, opening of the first, 127; of 1710,178 ; and the preliminaries, 190; eleven prorogations of, 205; of 1715,233 ; and the pretender, 242, 243 ; and Sweden, 276 ; and the South Sea Company, 293-303; of 1722, 306; relations to the Irish parliament, 313 ; and the liquor trade, $350,351,35^{\circ}$.

Parliament, Scots, 38, 93, 94, 95, 98, 102, 103, 104, 105, 106, 107, 134 ; restoration of, promised by pretender, 259.

Parliament, the Irish, 72, 73 ; encourage Palatine immigrants, 142 ; and devolution of land, 143 ; and Bolingbroke. 2r4; and the pretender, 264; and the South Sea Bubble, 298 ; session of 1723,315 ; and Wood's halfpence, 3 Ig.

Parma, duchy of, 280, 322, $33^{8}$.

Parma, Duke of, 338.

Parnell, Thomas, poet, 177.

Passajes, 284.

Passaro, battle of Cape, 282, 359, 360.

Passarovits, peace of, 282.

Paul, Joshua, captain, 25 I.

Peace and war, act anent (Scotland), 95.

Peerage bill, the, 291, 292, 293.

Pelham, Henry, secretary at war, 320 n. 2 ; defends Walpole, 367,368 ; first lord of the treasury, 377 ; his economies, 420, 422; his administration, 425, 429; and the Jews, 428-429; his death, 430 .

Pembroke, Earl of (Thomas Herbert), lord president, 132, 138; lord-lieutenant of Ireland, 138; lord high admiral, 139 ; attacked by the junta, 161.

Penn, William, Quaker, I42.

Penrith, 252.

Penterriedter, Christoph Freiherr von, imperial ambassador, 281.

Pepper, John, general, 249.

Pepperell, Sir William, 390.

Perth, 247, 25I, 255, 260, 264.

Perth, Dummond, titular Duke of, 392.

Perth, titular Duke of (James Drummond), 255.

Peter the Great, 145, 275 ; his dislike of George I., 285; and Prussia, 286 ; ravages Sweden, 286; withdraws, 287 ; refuses George I.'s mediation, 287 ; Carteret and, 3 II ; favours Jacobites, 3II; his widow, Catherine I., 326.

VOL. IX. 
Peterborough, Earl of (Charles Mordaunt), 85, 86; in joint command with Shovell, 86 and $n . I$; at Mont. juich, 87 ; and Leake, 88 ; at Valencia, 89, 92, Iro; recalled to England, 129; the New Atlantis and, 162 ; the tories and, 167,179 ; and the Catalans, 214; torns Jacobite, 245.

Peterhead, 259, 26r.

Petkum, Edzard Adolf, German diplomatist, $119,146$.

Pevensey, 353.

Philip, Don of Spain, 389, 417.

Philip 11., King of Spain, 85 .

Philip V., Bourbon King of Spain (Duke of Anjou), 12, 19, 22, 57, 69, 85, 86, 87 ; evacuates Spain, 88, II I, I2I; Torcy on, 146 ; preliminaries as to, 148 ; refuses to abandon Spain, 155 ; defeated, 156 ; joined by Vendôme, 157 ; demands of, at Utrecht, 196; proposed renunciation by, 197, 205; his cruelty, 215; lends money to the pretender, 242 ; ambitious of the French crown, 244, 245; hostile to George I., 273; and the Regent Orleans, 277 ; seizes Sardinia, 280, 28I ; plot to make him regent of France, 203 ; and the pretender, 284; accedes to the Quadruple alliance, 285 ; his second wife, 321 ; his irritation on account of Gibraltar, 322, 323, 330, 337 ; cedes the two Sicilies to Don Carlos, 349 ; and South Sea Company, 359-360; the marriage of his son, 364 ; his death, 4I3.

Philip V., wives of. See Savoy and Farnese.

Philips, John, 483.

Phipps, Sir Constantine, afterwards chancellor of Ireland, $168,213,214$; dismissed, 229 ; defends Atterbury, 307.

Piacenza, battle of, 413.

Piacenza, Duchy of, 280.

Picardy, 118, 158.

"Pickle the Spy," 427, 428.

Piedmontese army, 16, 17, 18, 158.

Piper, Count, Swedish minister, 1 r3.

Pitt diamond, the, 360 .

Pitt, William, afterwards first Earl of Chatham, 347 and n. 3 ; and Prince of Wales's allowance, 356, 357 ; his speech on Spanish convention, $360-36 x$; against registration of seamen, 365 ; attitude of, towards Walpole, 370 ; the king's attitude towards, $383,411-412$; contrasted with Fox, 412; and treaty of Madrid, 42I; attitude of, towards Newcastle, 422,
424-425, 430-431; new policy of, 434435 ; against subeidies, 437 ; and militia scheme, 438-439; says that the country is unprepared for war, $44 \mathrm{I}$; moral force of, 445 ; the nation turns to him, 446-447; attitude of, towards rebel highlanders, 448 ; and Byng, 449-450; dismissed from office, 450 ; reinstated, $45 \mathrm{I}$; relations of, with Frederick II., 455 ; interest of, in North American campaign, 456, 463 , 472 ; general ascendancy of, $458-459$; he assumes the offensive against France, 460; military skill of, 470 ; will not desert Prussia, 471 ; on Clive, 476-477.

Pitt, William, the younger, 241.

Placentia, Newfoundland, 18.

Plassey, battle of, 474,476 .

Platen, Countess, 301, 3 I0, 312.

Plunkett, Plunket, John, 193, 194, 305, 307, 308.

Plymouth, 14, 249.

Poblet, monastery of, 337 .

Pocock, Admiral, in Indian waters, 460 , 474, 477.

Pointis, French rear-admiral, 64 .

Poland, designs of Prussia on, 59 ; Frederick Augustus renounces in favour of Stanislaus, 113; at war with Charles XII. of Sweden, 274; John Sobieski, late king of, 284 ; Sweden and, 286; and the treaty of Hanover, 326 ; death of Augustus of Poland, 349.

Polwarth, Lord (Alexander HumeCampbell), minister to Denmark, afterwards seeond Earl of Marchmont, 276.

Pompadour, Mme. de, under the infuence of Maria Theresa, 444, 463.

Pondicherry, siege of, 416 ; surrender of, 477.

Pont de Vendin, 158.

Ponte Vedra, 12.

Pope, Alexander, poet, 288, 30r, 337 ; literary style of, and works, 483,484 , 485 ; his gardens, 495 .

Pope, Clement XI., 264.

Porteous, John, 352.

Porteous riot, the, 352.

Porter, Mary, actress, 490.

Portland, Duke of (William Henry Bentinck), 298.

Portland, Earl of (William Bentinck), 28,29 ; letter of, $39,40,83$; grants to, 200 .

Port Mahon, 60, 12a, $449,187,189$, 195, 328 ; loss of, 442-443; value of, versus Gibraltar, 447-448.

Port Royal, Jamaica, I4.

Port St. Mary, Spain, I3. 
Portmore, Earl of (David Colyear), 328. Porto Bello, Admiral Hosier at, 326 ; Admiral Vernon captures, 363, 365.

Portamouth, 23, 26, 92.

Portugal, desirous of neutrality, II ; emers the grand alliance, 22; and France, 62, 63, 87, 9r, I10; change of feeling in, 112; British army in, 120, 130, 189 ; and the Amazon river, 205 ; the Methuen treaty with, 23, 207; and the Quadruple alliance, 31 ; Spain and, 324 .

Portugal, King of, Pedro II., 22, 23, 60 ; John V., 148.

Portuguese fleet, 64 .

Portuguese generals, 63, 88, 89, 90.

Portuguese troops, 23, 63, 64, 85, 87, 89, $110,112,156$.

Portuguese wine, consumption of, 24.

Pouleth, Earl (John Poulett), 17 r, 173, $183,212$.

Poyntz, Stephen, envoy to Stockholm, 324.

"Pragmatic army, the," 374, 377.

Pragmatic Sanction, the, 323, 327, 338 .

Pratt, Chas., 451.

Pratt, Sir John, chief justice and chan. cellor of the exchequer, 300 .

Preston, surrender of rebels at, 253, 254; dissenters at, 264; prisoners taken at, 265.

Prestonpans, battle of, 394-395.

Pretender, the old (James Edward), 7, $69,99,117,134$; his proclamation, 135; sails for Scotland, 136; Anne denounces, 137 ; his attempt, 139,140 , 144,146 ; to be banished from France, 147; at Cambray, $15^{8}$; his birth, I68; plans for restoration of, 175 ; Plunkett and, 194; Bolingbroke and, 203 ; Oxford and, 204, $21 \mathrm{I}$; circular letters from, 212 ; in Lorraine, 215 ; declines to conform, 217 ; the whigs and, 221 ; Marlborough and, 224 ; excluded from France, 225 ; declaration of, 232, 233 ; London mob and, 237 ; character of, 239 ; his religious designs, 240 ; projected attempt on Scothand, $24 \mathrm{I}$; and Bolingbroke, 24I; overtures of Marlborough to, 245 ; proclaimed 28 James III., 246; dejection of, 249 ; goes to St. Malo, 250, 259; arrives in Scotland, 260; re-embarks for France, $26 \mathrm{r}$; his fallure, 262 ; dismisses Bolingbroke, 263 ; takes refuge at Avignon, 264; his expulsion demanded, 270, 277 ; Alberoni plans combination in support of, 281; goes to Madrid, 283 ; marriage of, 284,285 ; the South Sea Bubble and, $305 ;$ and Atterbury's conspiracy, 305, 308; declara. tion by, 308 ; Spain and, 323, 327, 328 ; at Rome, 336.

Price, Sir Robert, baron of the exchequer, 2 ro.

Prié, Marquis de, 283.

Prince's party, the. See Leicester House.

Prior, Matthew, poet and diplomatist, $124,177,182,186,187,19 x, 204,225$, $234,235,240,289,485$.

Protestant succession, the, 150, 155 , I68, I83, I90, 205, 2I5, 232.

Protestantism, proposed extirpation of, 327, 328.

Protestants, persecution of, 113,264 , 339: immigration of foreign, 141 , 167 and $n .1,206$; naturalisation of for eign, $141,200$.

Provence, 189.

Prussia, Frederick 11. of, declares for France, 382 ; comes to terms with Great Britain, $3^{89}$; the Silesian loan, 427 ; and the Jacobites, 428 ; delicate position of, 439 ; defeat of, at Kolin, 45I; relations of, with Pitt, 455 ; Leignitz and Torgau, 472 ; referred to, $364,366,37 x$.

Prussia, Hanoverian jealousy of, 230; treaty with ( 7 r 9 ), 286 ; negotiations with (1723), 311 ; accedes to treaty of Hanover (3725), 324; allied with Charles VI., 340; alliance of, with Great Britain, 364, 373.

Prussia, King of, Frederick I., 7, 9, 59, 79. I4I ; his grievances, 145,148 , 151 , 205.

Prussia, King of, Frederick 11. ("the Great "), 3rr.

Prussia, King of (Frederick William I.), $227,274,275,286,31$ I, 323-327.

Prussia, Princess Royal of, afterwards Margravine of Baireuth, 311, 327, 342.

Prussia, Queen of (Sophia Dorothea), 3 II.

Prussian troops, 50, 153, 154 .

Public accounts, commissioners of, 33 , 42.

Publication, methods of, in eighteenth century, 494.

Pulteney, Daniel, 335, 336.

Pulteney, William (afterwards Earl of Bath), denounces "the restraining orders," 199; secretary at war, 248; dismissed, 279 ; for the Austrian alliance, 325 ; growing popularity of, 329, 335 : a leader of the opposition, 336, 342 ; denounces the excise bill, 344 ; on the dismissal of officers, $34^{8}$; opposes regulation of plays, 353 ; Opposes repeal of Test Act, $354 ;$ and Prince of Wales's allowance, 356 ; secession of, $36 \mathrm{r}$; he vindicates secession, 364; 
attacks Walpole's administration, Riosecco, Duke of, $2 x$. 368; his mistakes, 369; created Earl Ripperdá, Duke de, prime minister of of Bath, 370 ; fails to form a ministry, $4 \mathrm{Ir}$.

Quadruple alliance, the (1718), 280, 281, 284, 285, 3Ir.

Quakers, I42, 354 .

Quebec, General Nicholson's designs against, 189, 220; siege of, by General Wolfe, $463-467$; attacked by General Lévis, $472-473$.

Queensberry, Duke of (James Douglas), high commissioner, $3^{8}$; dismissed, 40; for the Union, 94 ; vetoes the act of security, 95 ; and the Scottish plot, 96 ; privy seal, 100; his talent, 103, 106; secretary for Scotland, 161 .

Quesnoy, Le, 154, 188, r98.

Quiberon Bay, battle of, 469.

Radcliffe, Charles, execution of, 408 .

Rain, 54.

Rakoczy, Francis, Hungarian insurgent, $7,48$.

Rambler, The, 493.

Ramillies, battle of, $80,8 r, 82,85,88$, 115, I 16, 174 .

Ranelagh, Earl of (Richard Jones), 33-34.

Rapparees, Irish, 13 .

Recruiting the army, $\mathbf{r}_{40}$.

Reductions in army and navy, 420.

Regency Act, 70 .

Regensburg, diet of, declares war against France, I r, 349, $35^{\circ}$.

Regiments, British-Stanhope's, 63 ; Stewart's, 63 ; Churchill's, 8r n. I ; Mordaunt's, 8r n. I; Grenadier Guards, 25r ; Scots Greys, 256; king's own regiment of horse (King's Dragoon Guards), 347 and n. 3; The Blues, 347 ; Inniskilling Dragoons, 348 ; Hamilton's Dragoons, 394, 396; Cobham's Horse (Ist Dragoon Guards), 403, 406; Ker's, 406; 4th Foot, 403 ; I4th, $403 ; 4^{8 \text { th, }} 403$; 12th, $46 \mathrm{r}$; 20th, 46r ; 23rd, 46r ; 25th, $46 \mathrm{r}$; 37 th, $46 \mathrm{r}$; 5 rst, $46 \mathrm{r}$; 6oth, 466 .

Regium Donum, the, 72 .

Renauld, Ormonde's cook, 244.

Reval, 287.

Reynolds, Sir Joshua, 496.

Rhine, the, $8,9,15,16,17,48,50,75$, $\mathrm{rr}_{4}, \mathrm{rr} 5, \mathrm{rrg}, \mathrm{r} 55, \mathrm{r} 57, \mathrm{r}_{58}, \mathrm{r}_{7}, \mathrm{r} 89$.

Ribble, river, 253.

Richards, John, major-general, 86 n. I.

Richardson, Samuel, $49 \mathrm{r}$.

Richelieu, Cardinal, 453.

Richmond, Surrey, 244.

"Right of search" claimed by Spain, $35^{8}$ et sqq., 422. Spain, concludes treaty of Vienna (1725), 323, 324; threatens England, 323; negotiates a secret treaty of Vienna, 325; his intrigues in France, 327 ; his hostile preparations, 327; his fall, 328.

Rivers, Earl (Richard Savage), 29, 9r, 92, rog, I ro, I62, $17 \mathrm{r}$.

Robethon, Jean de, 229, 23 r.

Robinson, Anastasia, 489.

Robinson, Dr. John, Bishop of Bristol and afterwards of London, $\mathrm{Ir}_{3}, \mathrm{r}_{3}$; opens conferences at Utrecht, 196, r99, 234 ; Bishop of London, 236.

Robinson, Sir Thomas, 347, 376, 430, 435.

Rochester, Bishop of. See Atterbury.

Rochester, Earl of (Laurence Hyde), uncle to Queen Anne, 3 ; lord-lieutenant of Ireland, 3 ; a Jacobite, 4 ; resigns the lord-lieutenancy, $27,35,47$, $66,69,71,72$; leads opposition, 97 ; dismissed from privy council, 124; attacks the admiralty, 128 ; supports Peterborough, r29; approached by Harley, 139,174 ; and the queen, 176 , 183.

Rochford, Earl of (William NassauZulestein), 28.

Rocoux, battle of, 412 .

Roermond, 9.

Rollo, Lord (Robert Rollo), 258.

Roman catholic persecutions of protestants, 141.

Roman catholics, the, in England, disarmed, 98 ; and the Abbe Gaultier, 175 ; associated with the whigs, 182 ; the Duchess of Gordon, 184 ; disarmed, 22I ; their religious designs, 239; join rebels, 253 ; $\operatorname{tax}$ on, 308 ; bishop of, and George II., 350.

Roman catholics, the, in Ireland, 72, 74 ; devolution of land of, 143 .

Roman Church and the pretender, 239, $240,264$.

Rome, 264, 283, 307, 336.

Ronquillo, Spanish general, 63.

Rooke, Sir George, admiral, inquiry into conduct of, ro; sails from Spithead, 12; unpopular, 13 ; in bed at battle of Vigo, 14 ; supported by the tories, I8; commands channel fleet, 19 ; escorts Archduke Charles to Lisbon, 23 ; member for Portsmouth, 26 ; thanksgiving for victory of, 26 ; lords? vote on, 27 ; commons and, 4r; Marlborough and, 59; takes Gibraltar, 60, 62 ; in battle off Malaga, $6 r, 62$; his return to England, 64 ; commons ad- 
dress queen on, 65 ; and Ormonde, 86 ; struck off privy council, 123, 167.

Roquefeuil, Admiral de, his fleet, $3^{81}$.

Rosas, 283.

Roselaere, 82 .

Ross-shire, 284.

Rota, Spain, 13.

Rothbury, 250, 25 I.

Rothweil, 50.

Rotterdam, 141 .

Roussillon, 88, 109, 157.

Rowe, Nicholas, poet laureate, 177.

Rowley, Vice-Admiral, $3^{89}$.

Roxburghe, Duke of (John Ker), 223, 299 ; dismissed, 320.

Royal Exchange company, 295.

Russia, the Swedes march against, 114 ; in the Baltic, 145; at war with Sweden, 274 ; its fleet, 277 ; Alberoni and, 281, 283. 285; and Prussia, 286; dominant in Northern Europe, 287; contemplated alliance with Spain against England, 323, 327; British treaty with, 373 .

Russian ambassador, the, 146.

Russian troops, 273, 275.

Ryder, Sir Dudley, death of, 445.

Ryswick, peace of, II.

Sacheverell, Dr. Henry, Fellow of Magdalen College, Oxford, 3r, 164 , $165,167,168,169,174,175,2 \times 3$, 230, 232.

Sackville, Lord George, 455, 456 ; succeeds Marlborough in command, 460 ; strange conduct of, 462 ; court-martialed, 463 .

Saint Alban's, 224.

Saint Christopher, island of, 206.

Saint Florentin. Count, 3 ro.

Saint-George, Chevalier de. See Pretender.

Saint-Germain's, court of, 38,39, 94, 103. 134, 135, 143, 234, 263.

Saint Helen's, Isle of Wight, 19.

Saintonge, 91 .

Saint Philip's castle. See Port Mahon.

Saint Venant, 158 n. $x$.

Saint Vincent, island of, 339.

St. John, Henry, afterwards Viscount Bolingbroke, 29; commissioner of public accounts, $33,41,44$ n. $I$; secretary at war, 45, 46, 9r, 92, 124, 130,131 ; resigns, 133,138 ; description of the pretender, 136 ; relations to Harley, I39; supports Sacheverell, 169; secretary of state, 174, 176; patronises Swif, 177; allied with the clergy, 178; and with the squires, $18 \mathrm{I}$; rivalry with Harley, I82; his wife, 176, 182 ; charged with pecula. tion, 183 ; and the Habsburgs, 186 ; urges expedition against Canada, 189 ; designs against Marlborough, 190; antagonism of to R. Walpole, r91; attacks the Dutch, 194; and Gibraltar and Port Mahon, 195; begins secret negotiations, 196 ; and "the restraining orders," 197, 198; supreme in the commons, 200; created Vis. count Bolingbroke, 202; on Oxford's action, 204 ; draughts ultimatum to France, 205; his concessions censured, 206, 207; defeat of his treaty of commerce, 207, 208; conciliates Lady Masham, 2 ro; increased influence with the queen, 211 ; the Elector George and, 212 ; and Dunkirk, 213 ; and the Irish parliament, 214 ; and the Catalans, 215 ; bribes Lady Masham, 216; his reasons for the schism bill, 217, 218; and the Spanish commercial treaty, 2rg; charged with corruption, $22 \mathrm{~b}$; his intentions, 221 ; and George I., 222 ; dismissed, 225; his foreign policy, 225 ; his mistaken view of George I., 227 ; does homage to George I., 232 ; last speech in the lords, 233; his alarm, 234; flight of, 235, 236 ; Oxford's charge against, 237; his description of the pretender, 239 ; watched by Stair, $24 \mathrm{I}$; the pretender's secretary of state, 242; and the army, 242; interview with Duke of Leeds, 245 ; remains at Paris, 249 ; draughts a proclamation for the pretender, 259 and n. 2 ; dismissed, 263 ; political foresight of, 273 ; his peerage, 289 ; Atterbury's alleged proposal to, 306 ; is pardoned, 309 ; restored to his estates, 312 ; his intrigues, 329 ; writes in The Craftsman, $326 ;$ inspires the opposition, 339, 348; and Prince of Wales, 356,429 ; returns to England, 361; death, 425; philosophical works of, $48 \mathrm{r}$.

St. John, Sir Henry, Viscount St. John, 271.

St. Lawrence, river, 189 .

St. Lucia, island of, 339 .

St. Malo, 250, 259, 455, 456.

Salisbury, Bishop of (Gilbert Burnet). See Burnet.

Salop, I69.

Sambre, river, 152.

Sandwich, John, fourth Earl of, at Breda, 413; dismissed, 424.

Sandys, Samuel, afterwards Lord, chancellor of the exchequer, $335,34 \mathrm{I}$; attacks Walpole's policy, 367 ; made 
chancellor of the exchequer, 369 ; made a peer, 378 .

San Sebastian, 284.

Santa Catalina, 13.

Saragossa, 9o; battle and capture of, $156,157$.

Sardinia, 120; a kingdom, 28o, 371, 376; evacuated by Spaniards, 285 .

Sart, 153 .

Saunders, Admiral, 443, 459, 463, 466 468, 477 .

Savoy, Duchy of, I7, r24.

Savoy, Duke of (Victor Amadeus II.), his army, 8 ; his connexions, 17 ; joins the grand alliance, 18, 20; envoy to, 36, I78; effect of Blenheim on, 57, 59, 87; and Peterborough, 9o; and Eugene, III; and the emperor, 145 ; and the maritime powers, $\mathrm{I}_{4} 8$; to invade France, 155 ; and "Mat's Peace," 187; opposed to Berwick, 189 ; claims to Spain, 197 ; and the peace, 203, 205; King of Sicily, 206; Bolingbroke and, 213, 225 ; King of Sardinia, 280.

Savoy, Eugene, Prince of. See Eugene.

Savoy, Marie Adelaide of, Duchess of Burgundy, 17.

Savoy, Marie-Louise-Gabrielle of, wife of Philip V. of Spain, 17.

Saxe, Marshal de, and Prince Charles Edward, 380, 381, 382 ; commanderin-chief of the French army, 385, et sqq.; at siege of Tournay, 388 ; and battle of Rocoux, 412; and Maestricht, 4I4-4I5; his overtures for peace, 4 I7.

Saxe-Gotha, 79 .

Saxe-Gotha, Duke of (Frederick), 355.

Saxony, Elector of (Frederick Augustus), I13; treaty with Hanover, etc., 285.

Scandinavian kingdoms, the, 145 . See also Denmark, Norway and Sweden.

Scarbrough, Earl of (Richard Lumley), 345.

Schaub, Sir Luke, ambassador at Paris, 3 II.

Schelde, river, 49, 82, II6, II9, I50, 152, 188.

Schellenberg, the, 52, 53 .

Schenek, Fort, 7 .

Schism act, the, 217, 218, 22I; repealed, 291.

Schleswig-Holstein, Duke of, IIg, I46, $3 I 1$.

Scholarship in the eighteenth century, 499-500.

Schomberg, Duke of (Meinhart Schomberg), $28,63$.

Schrobenhausen, 53.

Schittz, Baron, Hanoverian envoy, 212, 216.
Scientific research in the eighteenth contury, 498-499.

Scilly Isles, I I2, I42, 249.

Scone, palace of, 260 .

Scot, John, writer, II 7 n. I.

Scotland, Jacobites in, 37 ; succession to crown of, $38,40,93$; commissioners for union with, 94 ; succession to, 95, 99 ; highlands of, 96 , ro3; apprehended invasion of, 97 ; and English trade, 98, 99; feeling in, Ioo; commissioners for union, 100 , IOI; negotiations for union, IOI-IO4; Church of, 104, 106; treaty of union, 106 ; act of union, 107, 124; discontent in, 108; peers of, and whigs, 129 ; disaffection in, 134, 135; attempted invasion of, $136,137,144$; peers of, bribed, 193 ; disturbances in, 201 ; and the malt tax, 202 ; secretaryship for, 209 ; peers support the tory ministry, 2 IO; highland clans, 215 ; Montrose secretary of state for, 229 ; representative peers of (1715), 233; projected rising in, 236; Jacobites in, 239 ; pretender in, 240; discontent in, 24I; precautions against Jacobites in, 243 ; outbreak of rebellion in, 245-262 ; Cadogan, commanderin-chief in, 262; prisoners removed from, 265; expected invasion of by Charles XII., 277; attempt by Spaniards, 283 ; and naval supplies, 308 ; discontent in, at the malt tax, 319 ; managed by Lord Ilay, 320 ; secretaryship of state for, abolished, 320 ; great seal of, 347 ; administration of, 392 ; Prince Charles retreats to, 401 ; devastation of, 407; improvements in, 4 ro.

Scots' brigade, the (in the Dutch service), 117.

Scottish officers (in the French service), 265.

Scottish plot, the, 38-4I, 96.

Scottish presbyterians, 72 .

Scottish trade, 98, 99, 107, 410.

Sculptors of the eighteenth century, 497.

Seafield, Earl of (James Ogilvy), afterwards Earl of Findlater, chancellor of Scotland, 106, 202, 209.

Seaforth, Earl of (Kenneth M'Kenzie), $255,258,284$.

Security, act of (Scotland), 95, 97.

Sefelingen, 58 .

Segovia, 328.

Sejanus, 300 .

Selle, river, 188.

Sempill, Lord, secret letters of, 398.

Sensée, river, 188. 
Septennial act, the, 267, 268, 269, 270 ; bill to repeal, $34^{8}$.

Seton palace, 251.

Setulement, act of, 270.

Seville, treaty of (1729), 338, 340,343, 359.

Seymour, Sir Edward, comptroller of the household to Anne, 3 ; made a privy councillor, 4 ; motion against alien peers, 29; unpopularity of, 34, 4I ; dismissed, 42, 45, 47.

Shah Alam, invades Bengal, 475, 476.

Shannon, Viscount (Richard Boyle), 318.

Sharp, Dr. John, Archbishop of York, 4 .

Sheridan, Sir Thomas, 392.

Sheriffmuir, battle of, 255, 256, 257, 260.

Sherlock $v$. Annesley, case of, 312.

Sherlock, Bishop, cited, 377 .

Shippen, William, 226, 24I; sent to the Tower, 290; defends Schism act, 29I ; opposes treaty of Hanover, 324, 325 ; and the cashiering of officers, 348 ; and Walpole, 367 .

Ships, names of: Torbay, 14 ; Worcester, 100; The Prince Frederick, 330, 337; The Marlborough, 379; The Victory, 382.

Shirley, William, governor of Massachusetts, 434.

Shovell, Sir Clowdisley, admiral, 14 ; commander-in-chief in the Mediterranean, 19. 20; returns to England, $2 I, 23,4 I, 59,60,6 I$; in joint-command with Peterborough, 86; and Guiscard, 92 ; in south of France, III, II2, I20; and the Catalans, $21_{4}$.

Shrewsbury, Duke of (Charles Talbot), I8 n. I, 21, 139, 170, 171, 174, 205 , 214, 220, 221, 223, 229, 245, 268, 289.

Shrewsbury, town of, 169 .

Sicilian abbots, 328.

Sicilies, kingdom of the Two, 349.

Sicily, 23, 206, 213,272; surrendered to Charles VI., 280; projected invasion of, by Spain, 281; Cape Passaro in, 282; Spanish army in, 285; evacuated, 285.

Silesia, 48, 113, 389, 439 ; Silesian loan, the, 427,439 .

Sinclair, General, 413.

Sinclair, the Master of, 258.

Slangenbourg, Dutch general, 77, 78.

Sloane, Sir Hans, 498.

Smalridge, George, Bishop of Bristol, 169.

Smith, John, speaker, 68, 10I; chancellor of the exchequer, 133, 173.

Smollett, Tobias George, 366, $49 x$.

Smuggling, 352, 353.

Sobieaki, Clementina, 284
Sobieski, John, 284.

Soissons, congress of, 337 .

Somers, Lord (John Somers), omitted from the privy council, 4,29 ; his representation, 39, 40,67, 97, 98, 122, 138 ; lord president, $140,143,147$; bribed by Anne, 160 and n. I, 17r, 173; attitude towards Mrs. Masham, 223 ; on the prosecution of Sacheverell, 165 ; dismissed, 174 ; opposes the commercial treaty with France, 207 ; at the queen's last council, 221 ; relations to the queen, 222 ; death of, 238.

Somerset, Duke of (Charles Seymour), $34,42,132,137,138,171,173,183$, 229, 225, $229,268$.

Sophia Dorothea, Queen of George I., $227,228$.

Sophia, Electress of Hanover, 69, 70, $79,17 x, 203,216$; death of, $217,226$.

Southampton, 167 n. $1,249$.

Southesk, Earl of (James Carnegic), 26r n. 4 .

South Sea Bubble, the, 287, 293-303.

South Sea Company, expels A. Moore, 182,219 ; its origin, 185 ; its new Asiento treaty, 273 ; advances $£ 2,000,000$ to Government, 288 ; its plan for dealing with the National Debt, 293, 294; rise of its stock, 295, 296; fall of its stock, 297, 298; its corrupt action, 300, 303 ; ship of, 330 ; and quarrel with Spain, 359-36o, 36I, 362 ; rights of, surrendered, 421 .

Spain, declaration of war against, 5 ; as a market for England, 5 ; its colonial ports, 5; candidature of Archduke Charles for crown of, II; projected invasion of, 18; Dutch trade with, 26 ; effect of Blenheim in, 57 ; French army in, 64 ; effect of relief of Gibraltar on, 65 ; Marlborough's views as to, 69; French driven out of, 8I; and the Barrier, 82; Austrian party in, 85; Anglo-Portuguese army in west of, 88, 92, 112 ; French successes in, 114, 115, 120; Orleans and the crown of, 12I; campaign in, 124; and the house of Bourbon, 129 ; and the house of commons, 130; tory party against war in, 139, 189; resolution of house of lords as to, I40, I9I ; the Netherlands and, 147; French troops to compel evacuation of, 148,159 ; British policy in, 149,155 ; Galway in west of, 156 ; inquiry into campaigns in, 179; and the South Sea Company, 185; and union with Austria, I86; dcmand of for Philip V., $x 96$; signature of treaty of peace 
with, 205, 206; variation made in commercial treaty with, 210; evacuation of, by the Archduke Charles, 215; Bolingbroke projects an alliance with, 225; commercial treaty with, 273; warlike preparations of, 280 , 281; war declared against, 282, 283; and Sweden and Russia, 285; and Gibraltar, 309; treaty with (I72I), 3ro; warlike disposition of, 321 ; its differences with the emperor, 322 ; concluded by treaty of Vienna, 323 ; antagonism of, to Great Britain, 324 ; concludes a secret treaty with Austria, 325, 328; English cruisers off coast of, 326 ; besieges Gibraltar, 330 ; unpopularity of Elisabeth Farnese in, 337 ; concessions by, in treaty of Seville, 338 ; secret treaty of the Escorial with France (first family compact), 349 ; British quarrel with, $35^{8}$ et sqq.; convention with, 362 ; war with, declared, 363 ; interest of, in Italy, 37r.

Spanheim, Prussian envoy, 222.

Spanish America, Spanish Indies, rзo, I 48, 187, 196, 206.

Spanish fleet, the, 280, 281, 282, 283, $284,338$.

Spanish generals, 15, 63.

Spanish treaty of commerce, 205, 210, $218,219,338$.

Spanish troops, 86, 88, 9 I, I Io, I56, I57, $281,283,284,285,338,349$.

Sparre, Spaar, Baron, 276.

Spectator, The, 492.

Spinola, Ambrogio, Marquis of, Italian general, 82.

Spithead, 12, 281, 284.

Staffordshire, riots in, 238, 242, 314 .

Stahremberg, Count von, Austrian fieldmarshal, 156, 157, 189.

Stahrenberg, M., Austrian minister, 440.

Stair, first Earl of (John Dalrymple), 103, 104, 105; death of, ro6.

Stair, second Earl of, ambassador to Paris, 234; protests as to Dunkirk, 240; his activity, 24I, 242, 244, 245, $248,249,25 \mathrm{I}, 263,265,270$; opposes Walpole, 347 ; dismissed, 348 ; his mission to the States-General, 372373 ; fortunes of his army, 373-376; resignation of, 377 ; reappointed commander-in-chief, 380 .

Stanhope, Charles, 3or.

Stanhope, fifth Earl (Philip Henry Stanhope), historian, 86 n. I ; 257 n. I.

Stanhope, James, general, afterwards Viscount Mahon, and first Earl Stanhope, envoy to the archduke in Spain, 90 , 109, 129, 146; takes Port Mahon,
I2I; the younger Craggs and, I49: successful campaign of, 156 ; taken prisoner, 157; opposes the treaty of commerce with France, $207 ;$ and the schism bill, 217; leader in the commons, 229; secretary of state (southern department), 230, 233, 234, 235, 238, $24 I, 243,248,25 I, 265,269$; accompanies George I. abroad, 271 ; plans a renewal of the war, 272 ; and Spain, 273 ; and Russia, 275; and Sweden, 276; negotiates with Dubois, 277 ; accusation against Townshend, 278 ; recommends the peerage bill, 292 ; secretary of state (northern department), 293 ; dominant in the ministry, 279; negotiates the Quadruple alliance, 280; his overtures to Alberoni, 281; visits Paris, 285 ; and the northern question, 287 ; his death, 287 ; friction of with Walpole, 288 ; created a peer, 289 ; favours the dissenters, 290,291 ; reconstructs ministry, 297, 298; not involved in South Sea Bubble, 299 ; his death, 300, 302, 321 ; and Bolingbroke, 309 ; and Gibraltar, 337.

Stanhope, Colonel William, afterwards Earl of Harrington, 323, 327 ; shelters Ripperdá, 328; negotiates treaty of Seville, 338, 340; and Spanish war, 359 ; succeeds Granville, 383 ; lordlieutenant of Ireland, $4 \mathrm{I} 4$.

Stanislaus, King of Poland, $\mathrm{I}_{3}, 349$, 350.

Stapleton, General, and the Irish brigade, 400,405 .

States-General, the, $49,50,77,79,81$, $84,85,91,145,146,147,148,1_{49}$, 190, I99, 221, 260, 272, 276, 283.

Steele, Sir Richard, writer, 213,269 , 491, 492 ; opposes the peerage bill, 292 ; Addison's quarrel with, 293.

Steinheim, 58.

Stella (Johnson), 177 .

Stephanswerth, 9 .

Stepney, George, ambassador to the emperor, 7,8 n. 1,18 and $n n .1,2$; 19 , 65,83 .

Stettin, 274.

Stewart, house of, 94, 103, 265, 332.

Stirling, 104, 247, 25I, 255, 257, 260, 262.

Stockholm, 286, 287, 324 .

Stollhofen, lines of, $48,51,52, I_{4}$.

Strafford, Earl of (Thomas Wentworth), at conference at Utrecht, 196; his papers seized, 234; impeached, 236, 237 ; pardoned, 289.

Stralsund, 275.

Strasburg, 147.

Strickland, Thomas John Francis, Bishop of Namur, 350, 
Stuttgart, 51.

Suabia, 16.

Succession, act of (English), 95, 16 $\mathrm{r}_{\text {, }}$ $164,324,325$.

Suffolk, Countess of (Henrietta Howard), 355.

Sunderland, Earl of (Charles Spencer), son-in-law of Marlborough, 28 ; opposes grant to Prince George, 29; wrecks the commissioners of public accounts bill, 42 ; disliked by the queen, 46 ; one of the junta, 67 ; envoy to Vienna, 79; secretary of state, 110, 121, 122, 123, 124, 139, 143 , $144,160,161,162,163,166$; dismissed, 171, 172 ; opposes dissolution of union with Scotland, 202; Anne's dislike of, 222 ; lord-lieutenant of Ireland, 229; and Gyllenborg, 276; lord privy seal and secretary of state, 279 ; and the dissenters, $29 \mathrm{I}$; recommends the peerage bill, 292 ; first lord of the treasury, 293, 297; and Walpole, 293; and the South Sea Company, 300, 301, 302; acquitted, 302 ; retires, 304 ; and Bolingbroke, 309 ; procures Wood's patent, 314.

Sunderland, Earl of (Robert Spencer), 268.

Sundon, Lady, $35^{8}$.

Suraj-ud-Daulah, Nawáb of Bengal, 452; and Clive, 474.

Sutherland, Earl of (John Gordon), 247, 260.

Sutton, Sir Robert, 282.

Sweden, 7, 8, 113,183,262, 273, 326 ; at war with Hanover, 274; naval demonstration against, 275; Gyllenborg sent back to, 276; fresh naval demonstration against, 277; suspected designs of, 279; proposed combination of, with Spain, 28I ; and Russia, 283, 285; concludes treaty with Great Britain, 286; and with Prussia, 287; accedes to the treaty of Hanover, 324, 326; contingent of, 330.

Swedish troops, 113, 249.

Swift, Jonathan, Dean of St. Patrick's, 108 ; describes Mrs. Masham, 127; view of Harley, 131 ; on Barrier treaty, 150; his writings, 160; on the queen, 162 ; Somers's statement to, 165 ; and the "Tale of 2 Tub," I77 ; attacks the Duchess of Marlborough, 178; on Peterborough, 179; attacks Marlborough, I80; enlogises Harley, 182, 183; his Conduct of the Allies, 185 ; on Marlborough's dismissal, 193; his History of the Four Last Years, 194; approves of taxes on newspapers,
201 ; on Lord Oxford, 209 ; description of the queen's illness, 2 II ; Anne's dislike of, 222; anticipates Oxford's return to office, 224; his writings, 232, 313; on Irish currency, 314 ; on Wood's halfpence, 315 ; publishes the Drapier's letters, 317,318 ; popularity of, in Ireland, 319 ; literary style of, $483.484,487$.

Syveton, Gabriel, 325 n. 2.

Tack, the, 37, 42, 66, 68.

Taisniere, 153.

Talbot, Lord (Charles Talbot), chancellor, 353 .

Tallard, Camille d'Hostun, Comte de, marshal of France, 17, 48, 50, 5 I, 55, $56,59,131$.

Tatler, The, 49x-492.

Tavier, 80, 81 .

Temple, Earl (Richard Grenville), 356 ; first lord of the admiralty, 446, 447; dismissed from office, 450.

Terbank, I15.

Tessé, Marquis de Froulay de, marshal of France, $64,85,87,88$, III.

Tetuan, 60.

Thackeray, William Makepeace, mentioned, 357.

Thames, river, 100, 107, 193, 260, 277, 307.

Thomson, James, 484 .

Thurot, invades Ireland, 469 ; is killed. 470.

Tindal, Mattbew, $48 \mathrm{x}$.

Tindal, Nicholas, historian, $257 \mathrm{n}$. I.

Toland, John, writer, $185,48 \mathrm{r}$.

Tollendal, Count Lally de, in India, $474,475,477$.

Torbay, 92, 250.

Torcy, Marquis de (Jean Baptiste Colbert), French foreign minister, 38 , $85,119,146,147,148,149,174,175$, 186, 187, 194, 197, 198, 223 n. I, 234.

Torgau, battle of, 472 .

Torres, Count de las, 330.

Torrington,Lord. See Byng, Sir George.

Tortosa, I12.

Tory party, or Church party, 2 ; opposed to continental war, 4, I8; support Rooke against Marlborough, 18 ; attitude towards the war, 24; and the dissenters, 30, 3I; influence over the queen, 34 ; bring in a second occasional conformity bill, 36 ; and St. John, 45 ; and Harley, 46; and Rooke, 62 ; policy of, 65, 66; and Queen Anne, 69 ; and ministry, 78; and Scotland, 98; support Peterborough, 129; reformed, 139 ; and the army, 140; and 
St. Germain's, 144 ; and taxation, I63; and the prosecution of Sacheverell, $166, x 67$; and Harley, 174 ; support the queen, 176 ; attack Godolphin, 180; hatred of Marlborough, I90; divided as to Marlborough's dismissal, I93; and the press, 201 ; divided on the treaty of commerce with France, 207 ; alarm at the queen's illness, 2 rr ; desert the pretender, 212 ; continental policy of, 212; Bolingbroke's lament over, 222; aloof trom Townshend's ministry, 230; confounded with the Jacobites, 233; discontent of, 238 ; its leaders in the lords, 302 ; state of the, 335 ; oppose repeal of Test Act, 354 ; support Prince Frederick, 356, 4I9; secede from parliament, 36r; desertion of, by Lord Gower, 383 ; impotent in the Commons, 446 ; oppose the Militia bill, 448,449 .

Toulon, operations against, $12,20,59$; French fleet retreats to, $61,62,64$; England and, 65, XII, II4; failure of operations against, $x 79$.

Toulouse, Count of, French admiral, $61,62,88$.

Tournay, 152, 153, 154, 157, 199, 205, $237,385$.

Towneley, Colonel Francis, and the "Manchester Regiment," 397; executed, 408.

Townshend, Colonel George (afterwards Brigadier), his militia scheme, $43^{8}$ 439,448 ; opposed, 449 ; at siege of Quebec, 464, 466, 467 .

Townshend, Viscount (Charles Townshend), 29; plenipotentiary to the Hague, $147,148,149,150,151$; resolution of commons against, 194 ; forms a ministry, 229; and Lord Strafford, 234 ; and Prior, 235; public estimate of, 238 ; his energy, 248 ; and Hanover, 272 ; and Stanhope, 275, 277, 278; dismissed, 279 ; lord-lieutenant of Ireland, 279; approached by Stanhope, 297 ; secretary of state for northern department, 304; directs foreign affairs, 308, 309; in rivalry with Carteret, 3 IO, 311, 312 ; supported by Bolingbroke, 312 ; against concessions on Wood's halfpence, 318,319 ; administers Scotland, 320; willing to exchange Gibraltar, 322, 337 ; refusal to do so, 323; draughts treaty of Hanover (1725), 324, 325, 326; plan for his overthrow, 329 ; Walpole's report to, 33I ; remains head of ministry, 335 ; friction with Walpole, $34^{\circ}$; resigns, $338,34 \mathrm{I}$; his inquiry into the debtors' acts, 342 .
Traum, General, 372.

Travendal, treaty of $(1700), 286$.

Treves, $59,74,75,76$.

Trevor, Robert, minister at the Hague, 384.

Trevor, Sir Thomas (afterwards Lord), chief justice of the common pleas, ror; leader of tories in lords, 302.

Trichinopoly, $43 \mathrm{I}$.

Triennial act, the, $267,268$.

Triple alliance, the $(x 7 \times 7), 278,280$.

Trouille, river, 152.

True Briton, The, newspaper, $33 \mathrm{x}$.

Tullibardine, Marquis of (William Murray), 247, 255, 284.

Turin, 79, 80, 90; defeat of French at, I09; convention of, 372,376 .

Turkey, 273, 326.

Turks, the, campaigns of George $I$. against, 23I; the Austrian forces against, 329 .

Tuscany, Duchy of, 280, 338.

Tuscany, Grand Duke of (Cosmo de' Medici III.), 19, 20.

Tweed, river, 106.

Tweeddale, second Marquis of (John Hay), 95, 96, 99, xoo.

Tweeddale, John, fourth Marquis of, secretary for Scotland, 392.

Tyrawly, Lord, on question of Gibraltar, 447-448.

Ulm, imperial city of, seized by Max Emanuel, Elector of Bavaria, $\mathrm{xx}, 4^{8}$, $51,58$.

Ulster, $7 x$.

United Provinces, the, 82, 178 .

Unterglaubeim, 54,55 .

Utrecht, treaty of, the preliminaries, $186,187,194$; conferences opened, 196, 197, 199; signature of, 205; the treaty of commerce, 206, 218, 219; and the Catalans, 2r4; Louis XIV. and the, 225; and Dunkirk, 234; Bishop Robinson and, 236, 237 ; Philip V. and, 245 ; Dutch troops and, 260 ; Huquenots and, 264, 339; Philip V. accepts, 285; and the South Sea Company, 293; and the Austrian Netherlands, 32I ; mentioned, 339, 390.

Utrecht, university of, 122.

Uxbridge, 312.

Valencia, city of, 86, 89, 90, $9 x, 109$.

Valencia, province of, $20,85,87,88,92$, Iro, 120.

Valenciennes, $152,154$.

Valenza, siege of, 85 .

Valiere, Alexander, alias Clarke, a spy, 132. 
Vauban, Seigneur de (Sebastien le Prestre), marshal of France, 151.

Velasco, Spanisb governor, 87.

Vendóme, Louis. Joseph, Duc de, French general, 82, 115, 116-119, 157, 189.

Venice, neutrality of, 20, I12.

Venloo, capture of, 9.

Vera Crux, 330.

Verden, Duchy of, 249,272, 280, 283, $286,287,326$.

Vernon, Admiral, at Porto Bello, 363, 365 ; at Port Royal, 366; his system of intelligence, 399.

Versailles, court of, 22, 75, 132, 134 , 148,240 ; treaty of (1756), 440, 444; second treaty of $(\mathbf{1 7 5 7}), 444,453$.

Victor Amadeus II. See Savoy.

Victory, loss of the, 382 .

Vienna and William III.'s death, 3; negotiations with, II; menaced by French and Bavarians, 15, 17, 20; and by Hungarians, 48 ; saved by Blen. heim, 57; Marlborough at, 79; court of, $83,84,9 x, 113,114, x_{32}$; Eugene at, 145: Stanhope at, 230, 248; treaty with Hanover at, 285 ; court of, and the Ostend Company, 321 ; treaty of, 323,324 ; secret treaty of, 325,326 , 328,329 ; second treaty of $(1731), 338$, 349: preliminaries of, 350 .

Vigne, La, 235.

Vigo, Rooke ordered to take, 12 ; French and Spanisb fleets reach, 13; battle at, 14, 18, 19; news of, 26.

Villadarias, Marquis of, Spanish general, $12,64,330$.

Villa Viciosa, 157.

Villars, Duc de (Charles-Louis-Hector), marshal of France, II; supersedes Catinat, 16; resigns, 17 ; in Lorraine, 75 ; on the Rhine, 80 , 114 ; in the Netherlands, 151, 152 ; at Malplaquet, 153, 154; fails to relieve Douay, 158; opposed to Marlborough, 187; outmanceuvsed, 188; opposed to Ormonde, 197, 198; victorious at Denain, 200; and Ormonde, 233.

Villena, fortress of, 110 .

Villeroy, Duc de (François de Neufville), manhal of France, 15, 17, 50, 58; in the Netherlands, 75, 76, 80, 81; superseded, 82; surprises Stollhofen, II 4.

Villette, Marquise de, Bolingbroke's wife, 309 .

Villingen, 50.

Virginia, its tobacco, 6.

Vollkra, imperial ambaseador, 272.

Volpone, 865 .

Voltaire, cited, $386,387,388$.

Vrillizte, Marquis de 12, 370.
Waal, river, 9.

Wade, George, general, afterwards field-marshal, 320, 381, 382, 395, 396, 402.

Wager, Sir Charles, vice-admiral, 326, 338, 365.

Wake, William. See Canterbury.

Waldeck, Prince of, $385,414$.

Waldegrave, Lord, on George II., 478.

Wales, Augusta Princess of, her marriage, 355,356 ; birth of her first child, 357 ; antipathies of, 435.

Wales, Frederick Prince of, his marriage, 356 ; domestic affairs of, 357 ; and Spanish convention, 360 ; his new party, 419; death of, 423-424.

Wales, George, Prince of (son of Frederick), and the Pelhams, 424.

Wales, George, Prince of, son of George I. See George II.

Wales, Prince of. See Pretender.

Walker, Sir Hovenden, rear-admiral, 189.

Wallmoden, Mme., and Walpole, 358.

Walloon, congregation in Londop, 32.

Walpole, Horace, son of Sir Robert, 179 n. I, 340; cited, 368, 369, 373, $384,395,398-399,420,425,431,438$, 448,450 ; his letters, 495.

Walpole, Horatio, afterivards Lord Walpole of Wolverton, $90 \mathrm{n} .1,277$, 363 and n., 364 ; sent to Paris, 311 ; defends treaty of Hanover, 324 ; his influence with Fleury, 325 ; ambassa. dor at Paris, 328 ; as a pamphleteer, 342 ; on the naval preparations, 413 ; and Pitt, 435.

Walpole, Lord (Robert Walpole), afterwards second Earl of Orford, 346.

Walpole, Robert, afterwards Earl of Orford, 29; secretary at war, 133. 138, 140; against Mrs. Masham, I63; Harley and, 173; dismissed from treasurership of navy, 180; charged with peculation, 19I; sent to the Tower, 192; returned for Lynn, $2 \times 3$; opposes the schism bill, 218; allied with the Duchess of Kendal, 227; paymaster of the forces, 229 ; autho. rity on finance of, 230 ; talks Latin to George I., 231 ; suggests a proclama. tion, 232; impeaches Bolingbroke, 235 ; his position, 238; first lord of the treasury and chancellor of the exchequer, 248 ; odious to the Hanoverian junta, 278; resigns office, 279 ; attacks Stanhope's ministry, 282 ; his scheme for reduction of the national debt, 288; his factious opposition, 189-291; opposes the peerage bill, 292, 293; his advice to the Prince of Wales, 295; his prediction, 297; ap- 
pointed paymaster of the forces, 298 ; and the South Sea Bubble, 297, 299 ; manages the exchequer, 300 ; vindicates Charles Stanhope, 30r ; and Sunderland, 302 ; nicknamed "the Screen," 303 ; appointed chancellor of the exchequer, 304 ; controls domestic affairs, 308 ; opposes Bolingbroke's return, 309,312 ; procures Carteret's dismissal, 316 ; and the treaty of Hanover, 324; defends Wood's halfpence, 317 ; for concession to Irish feeling, 318 ; and the Scottish malt tax, 319,320 ; for alliance with Portugal, 324; for cooperation with France, 325; unpopularity of, 329 ; popular with the squires, 330; and the accession of George 11., 334; distrusts Pulteney, 335 ; dominates the ministry, 338; his “ Dunkirk day," 339 ; friction with Townshend, $34^{\circ}$; attacks by opposition on, 34I; his domestic policy, $34^{2}$; his commercial policy, 343 ; his excise bill, 344,345 ; proffers resignation, 346 ; his " new maxims," 346 , 347 ; denounces "stratocracy," 348 ; maintains peace, $35^{\circ}$; his measures for the repression of smuggling, 353 ; reasons for opposing repea! of test acts, 354; Prince of Wales opposed to, 355 ; on Prince of Wales's allowance, 356; and Queen Caroline, 357358 ; attitude of towards Spanish war, 359-36o; relation of, with Pitt, 36I ; his colonial policy, 362 ; on Admiral Haddock's victory, 363 ; in bad health, 364 ; and naval affairs, $364-365$; a motion against, 367 ; created Earl of Orford, and resignation of office, 369 ; committee of secrecy on, $369-370$; death of, $382-383$; his administration compared with Henry Pelham's, 430 ; his pictures, 496 .

Wandiwash, battle of, 477 .

Wangenheim, General, 461.

Warburg, battle of, 472 .

Warren, Commodore Peter, afterwards Rear-Admiral, at Louisbourg, 390; at Finisterre, 4 I5.

Washington, George, rise of, 432, 433.

Watts, Isaac, 486.

Weavers, London, loyalty of the, 395 .

Webb, John Richmond, general, I18, I 19, $203,308$.

Wells, Somerset, 21.

Welsh Copper Company, the, 295.

Wentworth, General, and Cartagena, 366.

Wernitz, river, 53 .

Weser, river, 272,
Wesley, John, $486,488$.

West Indies, expedition projected against, 12; Spanish treasure ships from, 14, 69; Dutch squadron in, 85 ; trade of, 99 ; resolution of lords as to, I29; English trade in, 146; Philip V. and the, $146,1_{4} 8$; England and the, 15I ; Spain and, 19I ; bankrupt peers and, 298; British trade with threatened, 323 ; English fleets to be withdrawn from, 337 ; France and England in, 339; expedition against, 458-459.

West, Rear-Admiral, 442, 443.

Westminster, city of, $295,303,329,35$. Westminster, convention of, 439, 44I, $448,453$.

Westminster, treaty of (February, 17 16), between Great Britain and the StatesGeneral, 272; (May, I716), between the emperor and George 1., 273, 275, 280.

Westmorland, 252.

Wharton, Duke of (Philip Wharton), attacks Stanhope, 300 ; at Madrid, 327,328 ; founds The True Briton, 331 ; in Spanish service, 336 ; death of, 337 .

Wharton, Lord (Thomas Wharton), afterwards earl and marquis of, 29, $32,43,67,70$, 122 ; created earl, 124 ; attacks the admiralty, 128 ; lord-lieutenant of Ireland, 139, 143 ; encourages German protestants, 142; and Sacheverell's prosecution, 166 ; dismissed, 174; his jest, 193; supports the alien peers, 200; and the queen's illness, $2 \mathrm{II}$; Anne's dislike of, 222 ; nominated lord privy seal, 229 ; death of, 238; Stanhope's eulogy of, 300.

Whetham, Thomas, general, 247, 25I ; at Sheriff Muir, 256, 257 and n. r, 258.

Whigs, the, issue a black list, 25 ; their leaders, 29 ; intellectually superior, 41 ; and Sunderland, 46 ; increased influence of, 67 ; and the Electress Sophia, 70 ; and the war, 84 ; press for Sunderland's promotion, 123 ; and Godolphin, 125; and the Dutch, 129; and Greg's case, 132 ; and the attempted invasion, 137, 138 ; command a majority, 139; control ministry, 140; and the war in the Peninsula, 156, 157; and Godolphin, 160; appealed to, by Marlborough, 162 ; and the prosecution of Sacheverell, 165-167; and finance, 172 ; Harley and the, 173,182 ; offer to support an occasional conformity bill, 19o; denounce "the restraining orders," rg9; favour naturalisa- 
tion of protestant refugees, 14I, 200; attacks on by tories in commons, 201 ; invite the Elector of Hanover, 203 ; denounce the treaty of Utrecht, $206,207,210$; and the queen's illness, 211 ; and Dunkirk, 213 ; overtures of, to the Hanover tories, 214 ; preparations of, against the pretender, 22I; their majority in the parliament of 1715, 233 ; deaths of leaders of, 238 ; form the government, 267 ; ascendancy of, 280 .

Whiston, William, 358, 48r.

Whitshed, William, chief-justice of Ireland, 318, 319.

Whitworth, Sir Charles, afterwards Lord Whitworth, envoy to Berlin, 286.

Widdrington, Lord (William Widdrington), 250, 252, 253; impeachment of, 266.

Wigan, 253, 254.

Wight, Isle of, 19, 306, 347.

Wightman, Joseph, general, 256, 257, 284 .

Wigtoun, Earl of (John Fleming), 247.

Willes, Lord Chief Justice, 395.

William III., his relations to the Princess Anne, I ; the news of his death at Vienna and the Hague, 3 ; his influence over Heinsius, 6 ; his conventions with the allies, 8 ; entertains Prince George of Hesse-Darmstadt, 12 ; last parliament of, 45,68 ; dissolved, 25 ; reflection on memory of, 25 ; whigs and, 26 ; tories and, 27 ; grants of, 29 ; employed De Foe, 31 ; domestic policy of, 36,40 ; and the Harleys, 43; his toleration act, $7 \mathrm{r}$, $90 \mathrm{n} . \mathrm{I}$; and Scotland, 93, 95, 103 ; and Somers, 122 ; and the revolution, 166,168 ; his reign, 180; his great officers, 183 ; and subsidies to the allies, 192; his grants to favourites, 206; his foreign policy, 226; court of, 230.

Williams, Sir Charles Hanbury, 370; and King of Poland, 425.

Wills, Charles (afterwards Sir Charles), general, 156, 253, 254, 267.

Wilmington, Earl of. See Compton, Spencer.

Wilson, Alexander, lord provost of Edinburgh, 352.

Wilson, Andrew, 352.

Wiltshire, 176.

Winchilsea, Earl of. See Finch, Lord.

Winnington, Thomas, 365, 368, 378.
Wintoun, Earl of (George Seton), 250, 267.

Wishart, James, captain (afterwards admiral), 13, 2 rs.

Withers, Henry, general, I53, 154.

Wittelsbach, family of, 7 .

Woffington, Margaret, actress, 490.

Wolfe, James, General, 375, 456, 457, 463; takes Quebec, 464-466; dies, 466.

Wolverhampton, 354 .

Wood, William, 314, 316, 317, 318, 319.

Wootton Bassett (Wilts), 45.

Worcestershire, riots in, 238.

Worms, treaty of, 376.

Wratislaw, Count, imperial minister, 84.

Wren, Sir Christopher, 497.

Wright, Sir Nathan, lord-keeper, $25 \mathrm{n}$. I, 68.

Wirtemberg, Duchy of, 53, 114 .

Würtemberg, Duke of, 17 .

Whirtemberg, Prince of, 55 .

Wusterhausen, treaty of (r726), 327.

Wyndham, Sir William, secretary at war, 203 ; supports treaty of commerce with France, 207 ; chancellor of the exchequer, 208; brings in the schism bill, 218 ; first lord of the treasury, 220 ; Bolingbroke to, 242 ; arrest of, 248, 249; defends schism act, 29I; allied with Pulteney, 335 ; inspired by Bolingbroke, 339 ; advocates repeal of the septennial act, 348 ; secedes from Parliament, 354; and Prince of Wales's allowance, 356 ; secession of, $36 \mathrm{r}$.

Wynendaele, victory of, $118,203$.

Yarmouth, Lady, sides with Pitt, 445.

Yonge, Sir William, 368, 412.

York, archbishops of :-

Dr. John Sharp, 4, ror.

Sir William Dawes. See Chester, Bishop of.

John Dolben, 166.

York Building Company, the, 296.

York, Duke of (Ernest Augustus, Duke of Brunswick-Lilneburg), 332.

York, titular Duke of (Henry Stewart), 396.

Yorke, Charles, solicitor-general, 446.

Young, Edward, 484.

"Young Glengarry," 427-428.

Ypres, 82.

Yssche, river, 77.

Zusam, river, 53. 
$\ldots$

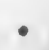

$\dot{y}$ 
















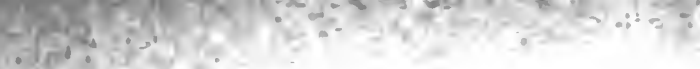

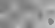

$x^{2}=$

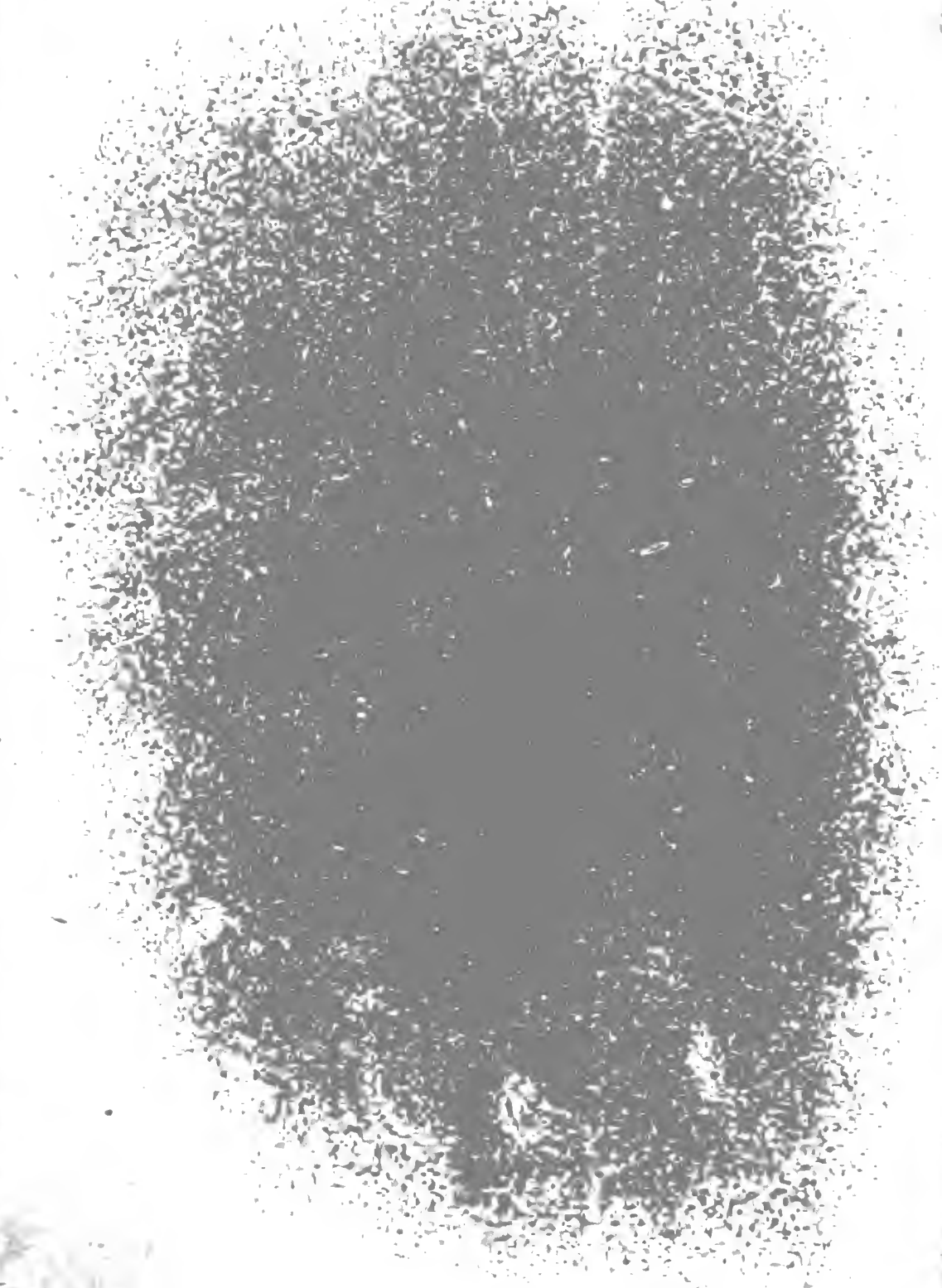




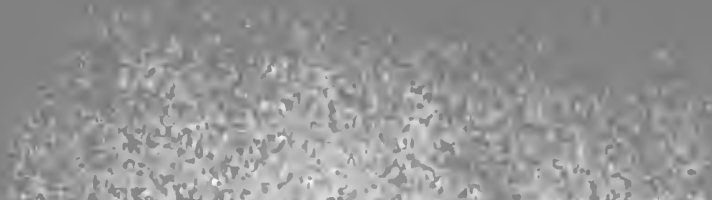

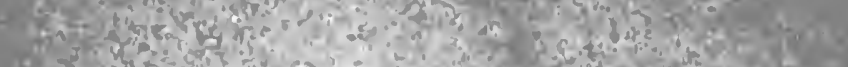
4h. $x$ x

C.

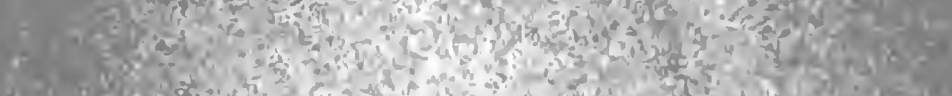

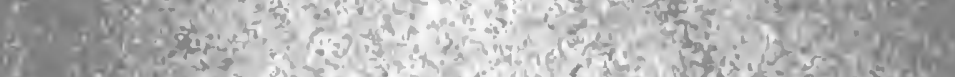

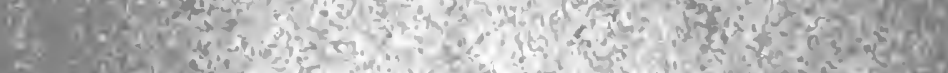

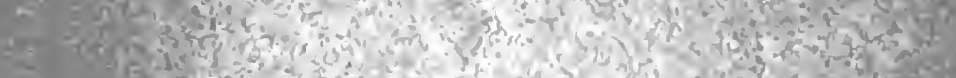

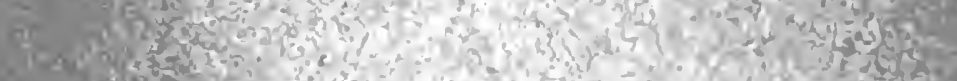

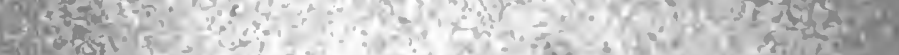

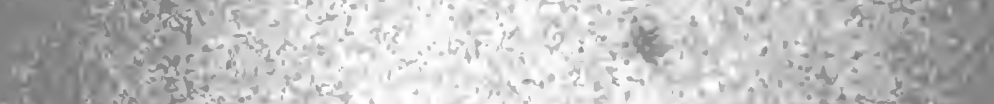

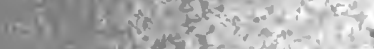

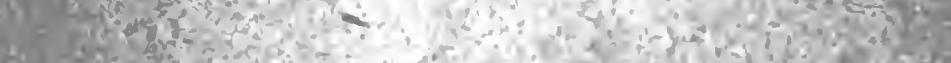

6. 5 .

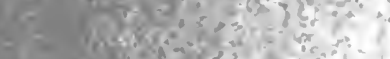

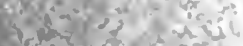

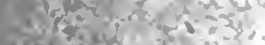

Wo

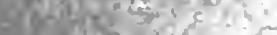

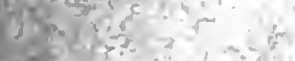

$x=\sin i \sin$

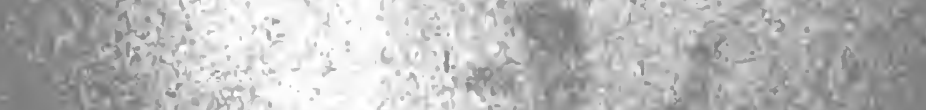

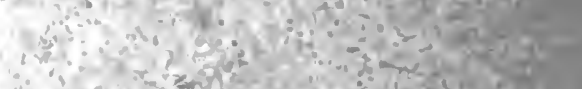

in

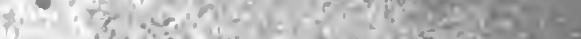

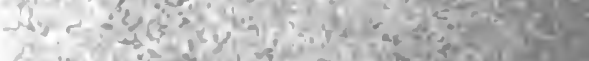

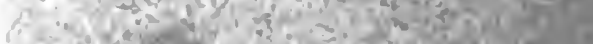

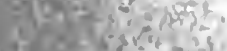

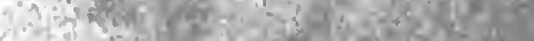

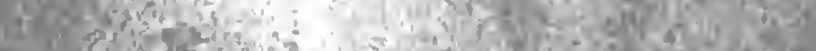

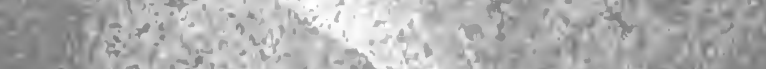

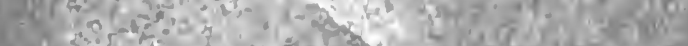

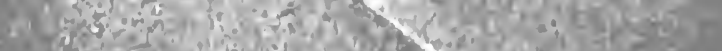

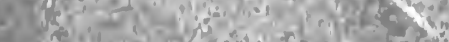

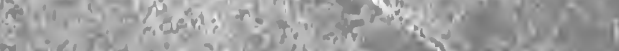

w of

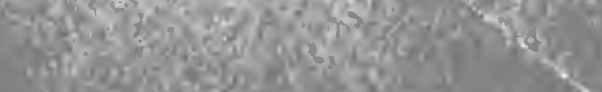

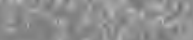

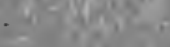

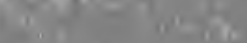




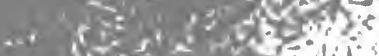

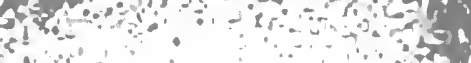

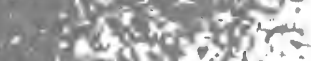

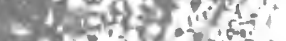

ces ${ }^{\prime}-3 \rightarrow-0$

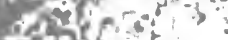

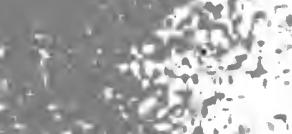

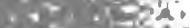

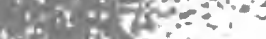

tot.8.

ing in:

Whe

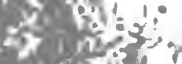

congis:

102

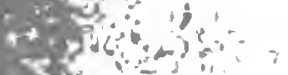

in,

$+\pi$ \%

tis 28

atsis

tant?

is 98 olforis

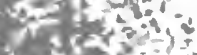

ton

$+\frac{5}{5} ;=5$

10.2.

is

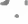

$\because+3 v i d$

$\therefore$ 


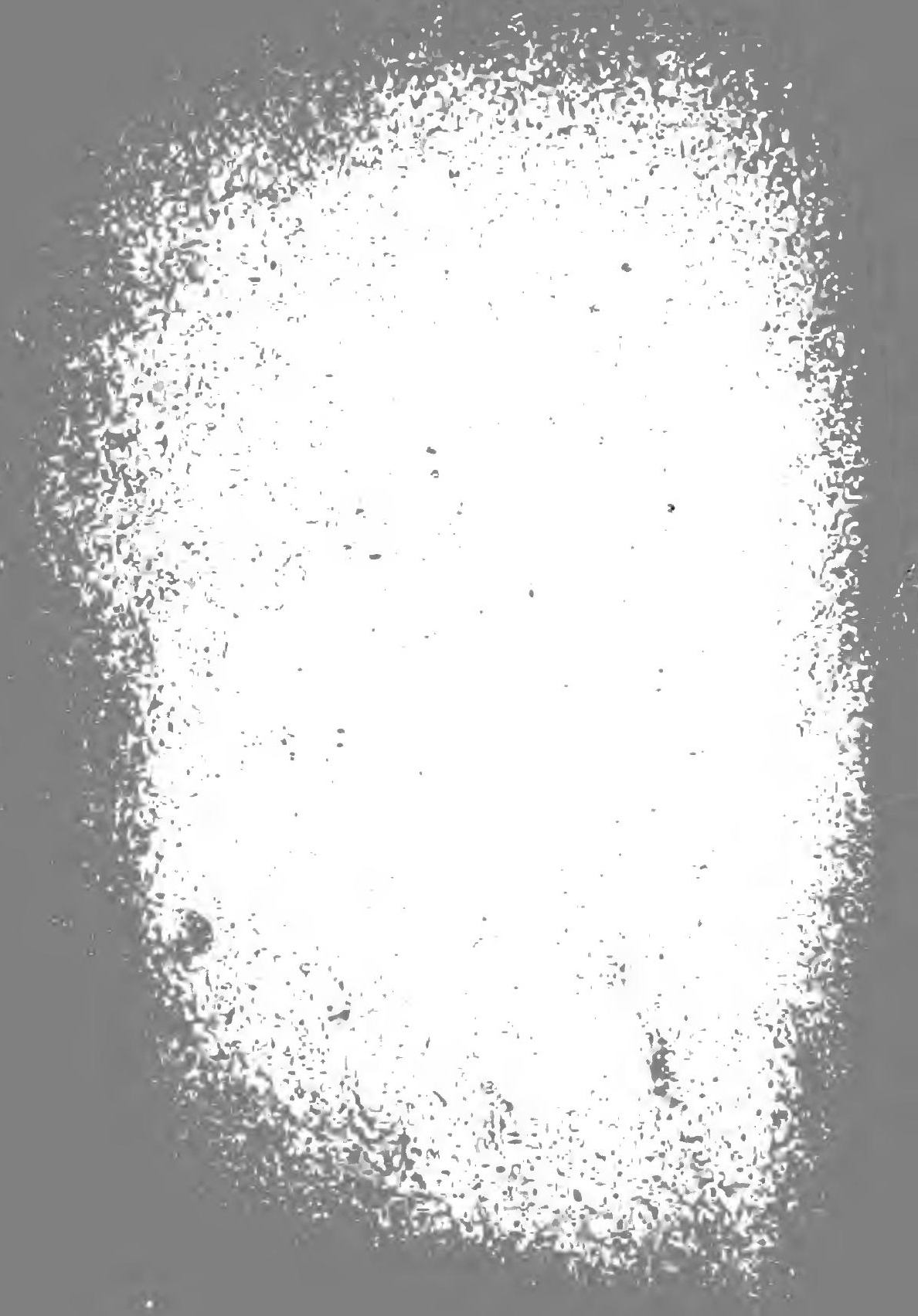




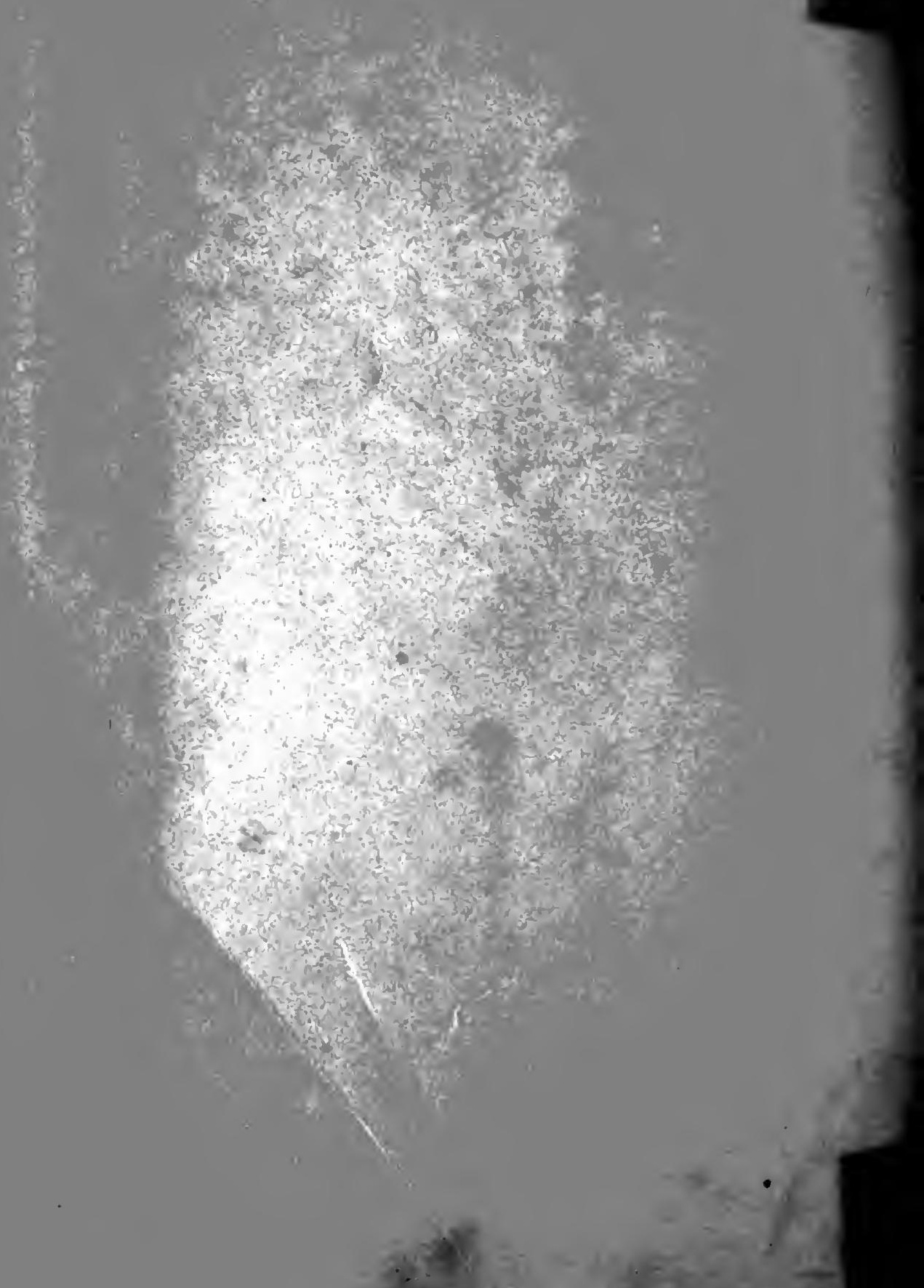




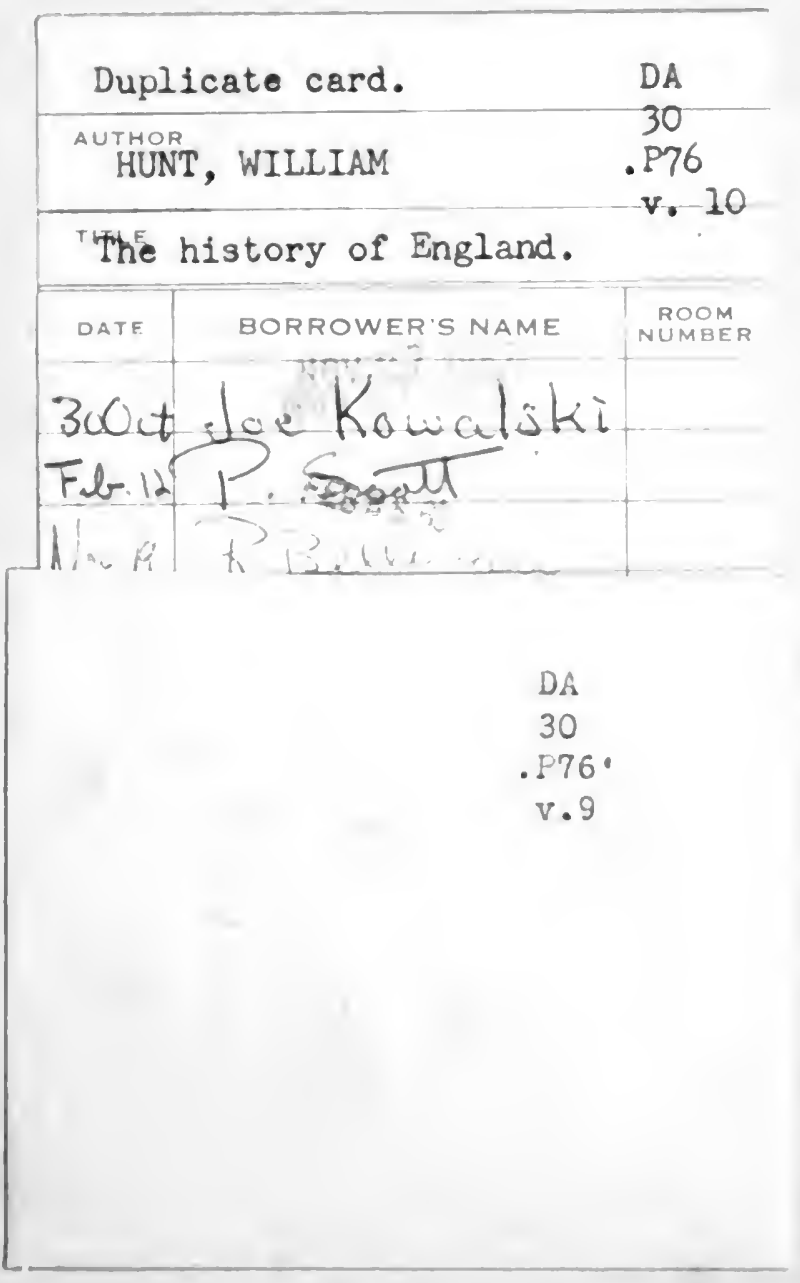




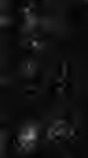

$x_{x \rightarrow 3}+:$

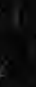
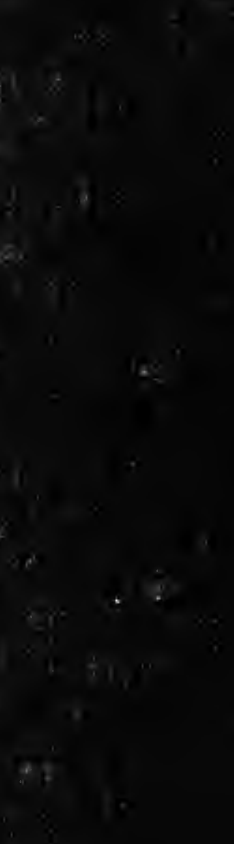

$x$ 